WHC-EP-0468-3

UC-721

\title{
Facility Effluent Monitoring Plan for the Plutonium Uranium Extraction Facility
}

D. L. Wiegend

Date Published

September 1994

Prepared for the U.S. Department of Energy Office of Environmental Restoration and Waste Management

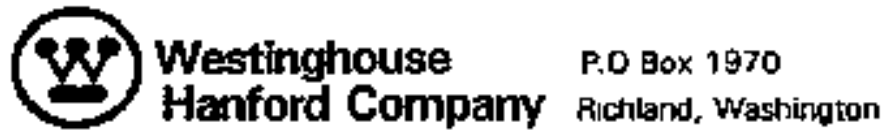

Henford Operotions and Enoineenng Contracter far the

U.S. Department of Eneroy under Contraot DE-ACD8-87fiL10930

Approved for Public Release 


\section{EEGAL DISCLAMIER}

This repert was propered ts in aceourt of work sponsored by en equshey of the United States GoverimemL. Neilher the United States Goverrondent nor sny ageney thoreof, nor any of

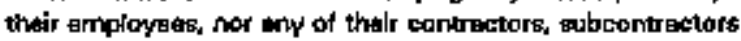
or thatr amplopeass mekes any warrency, expross of implied,

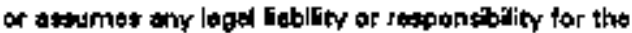
accuracy, complateness, or any third party's ubs or the results of such we of any information, apparalus, product, or process dreckested, or represents that its use wauld not infringe

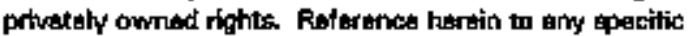
corrmercial product, procese, or service by trade name. trademerk, menufacturer, or otherwise, does not noessarily constitute or imply its endorsement, recommendation, or favdring by the United States Goverrment or any dogncy thereof or its contrectore or esbcontractore. The vieuse and opincions of turthora exprossted herein do not nocegsenty stale or retlact thoese of the Unitud States Govermment or any spency thereot.

Thls report has been reproduoed from the best weilebate oopy. Avallablo in pepor oapy and miorotiohe.

Avalable to the U.S. Depertment of Energy

and its oontractors from

Offlet of Saientific and Toxhnical trommation

P.O. Box 32

Dak Fidoe, TN 37831

(6)15) 576-8401

Available to the public from tha U.S. Depertrment of Commerce Nationel Tecturical information Sorvice

5285 Port Rayel Road

Springlield, VA 22161

1705) 497.4550

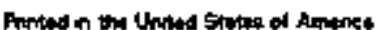

DISCLM-1.CHF $\{1-81\}$ 


\section{DISClaIMER}

Portions of this document may be illegible in electronic image products. Images are produced from the best available original document. 
P]utonium-Uranfun Extraction PIant

Prepared by:

Approved by:

Approved by:

Approved by:

Approved by:

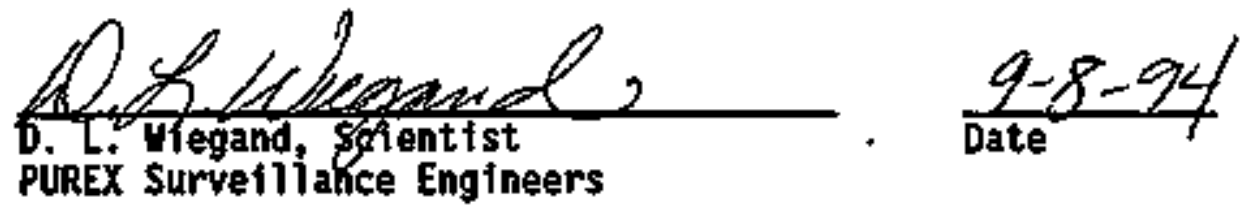

C.D. Go.lam

c. D. Vollan, Manager

$\frac{9 / 8 / 94}{\text { Date }}$

PURFX Surveillance Engineers

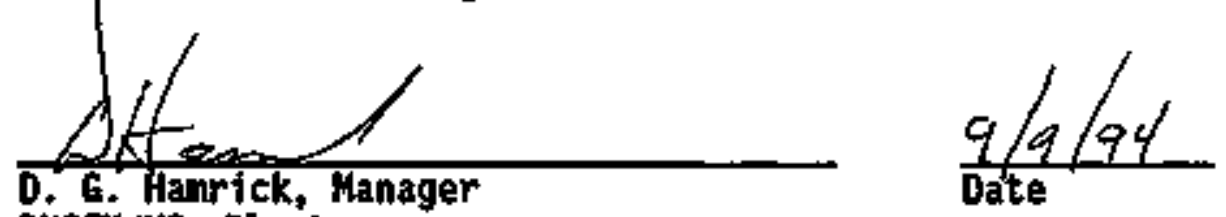
PUREX $/ \mathrm{NO}_{3}$ Plant

Date

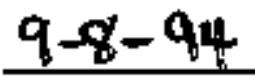

D. 2 Cayre1, Hanager

Date Envirominental Policy

Approved by:

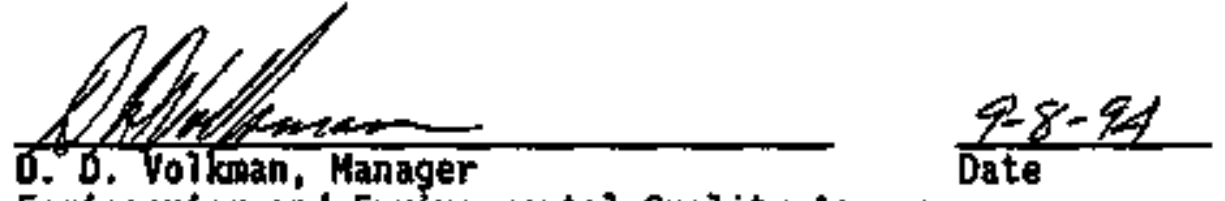
Engineering and Environmental Quality Assurance

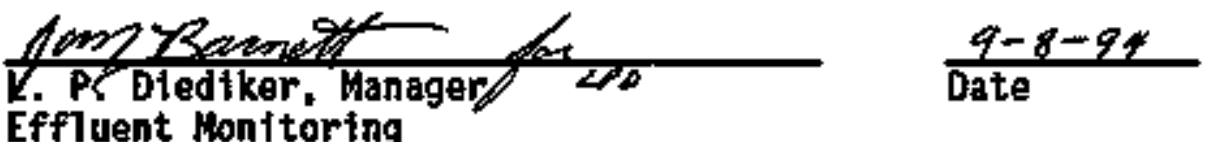




\section{INFORMATION RELEASE REQUEST PUBLIC DOCUMENT CHANGE/REVISION \\ (Short Form No. 1)}

1. Base Documeint to Number: WHC-EP-0468-2

2. Base Oocument Title:

Facility Effiuent Nonitoring Plan for the Plutonium Uranium Extraction Facility

3. Change/Revision Number: WHC-EP-0469-3

4. Change/Revision Date: 09/08/94

5. Unclassified Catagory: * UC - 721

6. Budget \& Reporting Code:* BRR -

1 verify this change/revision to the base document indicated above:

- Complies with the provisions of WHC-CM-3-4

- Contains no Limited-Use information

- Contains no classified or Applied Technology references

- Does not change the intent or meaning of the base document

- And, the base document itself is approved for public release.

7. Pesponsible Manager: C.D. WOLLAN
MSIN:
$56-17$
Telephone Number:
373-1587

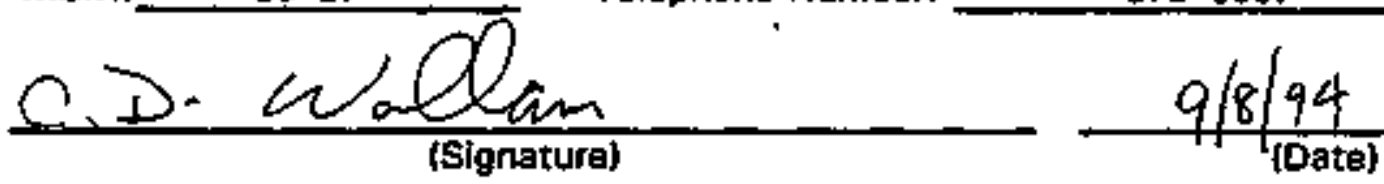

8. Information Release Administration Specialist: **
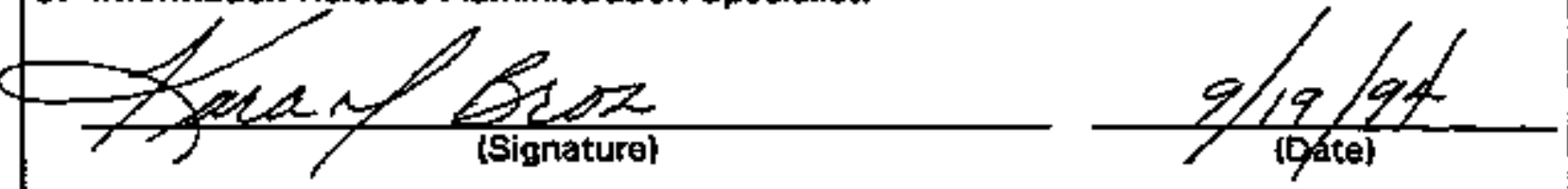

- Required only for full revisions transmitted to OSTI.

* "Required only for full revisions. 
FACILITY EFFLUERT MOHITORIHG PLAM FOR THE PLUTOHILA URANIUN EXTRACTIOH FACILITY

\section{ABSTRACT}

A facility effluent monitoring plan is required by the U.S. Department of Energy in DOE Onder 5400.1* for any operations that involve hazardous materials and radioactive substances that could impact employee or public safety or the environment. This document is prepared using the specific guidelines Identified in A Guide for Preparing Hanford Site Facility Effluent Monitoring Plans, WIC-EP-0438-01*t. This facility effluent monitoring plan assesses effluent monitoring systeros and evaluates whether they are adequate to ensure the public hest th and safety as specified in applicable federal, state, and local requirewents.

This facllty effluent monttoring plon shall ensure long-range integrity of the effluent monitoring systems by requiring on update whenever a new process or operation introduces new hazardous materials or significant radfoactive materials. This documant must be reviewed annually even if there are no operational changes, and it must be updated at a minimus of overy three years.

*General Environmental Protection Program, DOE Onder 5400.1, U.S. Departinent of Energy, Washington, D.C., 1988. +*A Guide for Preparing Hanford Site Facility Effluent Monitoring Plans, WHC-EP-0438-01, Westinghouse Hanford Cospany, RIchland, Washington, 1992. 
WHC-EP-0468-3

This page intentionally left blank. 


\section{COKTENS}

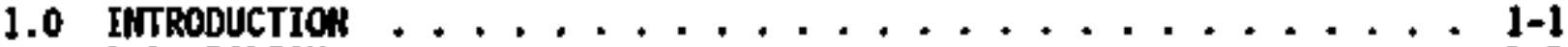

1.1 POLICY . . . . . . . . . . . . . . . . . . . 1 . 1

1.2 PURPOSE .......................... 1-1

1.3 SCOPE .......................... 1-1

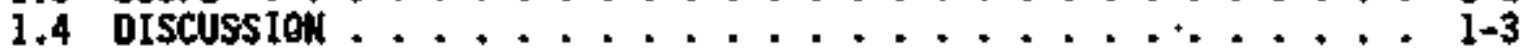

2.0 FACILITY DESCRIPTIOH .................... 2-1

2.1 BRIEF FACILITY PHYSICAL LAYOUT . .............. 2-1

2.1.1 The 202-A Butlding ................. 2-1

2.1.2 203-A Pumphouse and Tank Farm . . . . . . . . . . 2-2

2.1.3 211-A Pumphouse and Tank Farm . . . . . . . . . . . 2-2

2.1.4 206-A Acid Fractionator Bujlding . . . . . . . . . 2-2

2.1.5 The 293-A Building ................. 2-2

2.1.6 Effluent-Honitoring Buildings ............ 2-3

2.1.7 Tank 216-A-5 Calcium Carbonate Neutralization

Tank ...................... 2-3

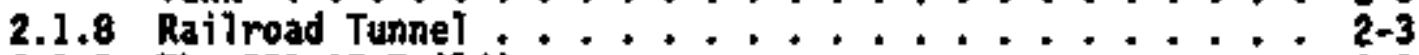

2.1.9 The 291-AE Butlding ................. 2-3

2.2 BRIEF PROCESS DESCRIPTIOH ................ 2-3

2.2.1 Present and Future Activities......... 2-4

2.3 IDENTIFICATION/CHARACTERIZATION OF POTENTIAL SOURCE

TERHS .......................... 2-5

2.3.1 Gaseous Effluents.................. 2-5

2.3.2 Liquid Effluents ................. 2-6

3.0 APPLICABLE REGULATIOHS . . . . . . . . . . . . . . . .

3.1 U.S DEPARTHEHT OF EHERGY ORDERS .............. 3-1

3.1.1 U.S. Department of Energy Order 5400.1 . . . . . . . 3-1

3.1 .2 U.S. Departinent of Energy Order 5400.5 ....... . 3-1

3.2 FEDERAL REgULATIONS .................... 3-1

3.2.1 Environmental Protection Agency Regulations on

Wationa] Emission Standards for Hazardous Air

Pollutants 40 Code of Federa7 Regulations $61 \ldots$. . . 3-1

3.2.2 Reportable Quantities 40 Code of Federal

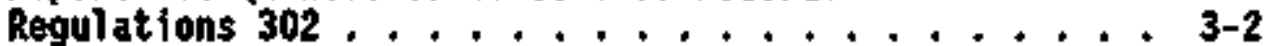

3.3 STATE REgILATIOHS . . . . . . .

3,3.1 Washington State Ambient Air Quality Standard and
Emission Limits for Radionuclides WAC-173-480 . . . 3-3

3.3.2 Groundwater Protection ............... 3-3

3.3.3 Dangerous Waste Regulations.............. 3-3

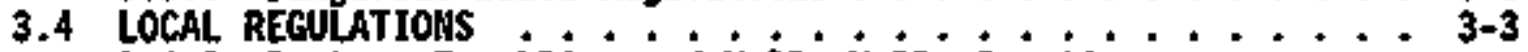

3.4.1 Benton, Franklin, and Walla Halla Countjes

Air Pollution Control Authorjty ............ 3-3

3.5 AIR EMISSIOHS .................... 3-4

3.6 LIQUID EFFLUEHTS..................... 3-5

4.0 IDEHTIFICATIOH/CHARACTERIZATIOH OF EFFLUEHT STREAMS . . . . . . . . 4-1

4.1 IDENT IFICATIOH/CHARACTERIZATIOH OF SOURCE TERAS

CONTRIBUTION TO EACH AIR EFFLUENT STREAH. .......... 4-1

4.1.1 Routine Operations ................ 4-3

4.1.2 Upset Operating Conditions ............ 4-3

4.1.3 Oispersion Nodeling ................. 4-4 


\section{CONTENTS (continued)}

\subsection{IDENTIF ICATION/CHARACTERIZATION OF SOURCE TERMS \\ COHTRIBUTING TO EACH LIqUID EFFLUENT STREAM $\ldots \ldots \ldots \ldots$ \\ 4.2.1 Routine Operating Conditions ........... 4-6 \\ 4.2.2. Upset. Operating Conditions ........... 4-10 \\ 4.2.3 Waste Water Discharge Criteria . . . . . . . . 4-11}

5.0 EFFLUERT POINT OF OISCHARGE DESCRIPTION ........... 5-1

5.1 AIR EFFLUEATS $\ldots \ldots \ldots \ldots \ldots \ldots \ldots \ldots \ldots$

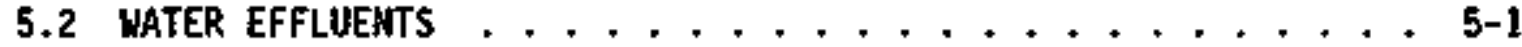

6.0 EFFLUENT MONITORIMG/SAMPLING SYSTEM DESIGN CRITERIA . . . . . 6-1

6.1 MEN FACILITIES ..................... 6-1

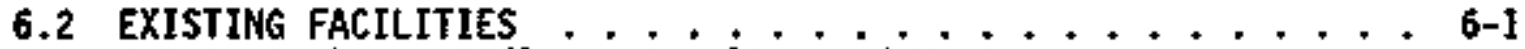

6.2.I Atrborne Effluent Samping and Monitaring System . . . 6-1

6.2.2 Liquid Effluent Sampling and Monitoring System
Design Criteria .................. 6-4

7.0 CHARACTERIZATIOH OF CURRENT EFFLUENT MONITORING SYSTEM $\ldots \ldots$. .

7.1 AIR EFFLUENT MONITORING SYSTEM DESCRIPTION AND

SPECIFICATIONS ............... 7-1

7.1.1 Monitoring/Sampling Requirements and Criteria . . . . 7-1

7.1.2 Existing Air Effluent Monitoring/5ampling System . . . 7-2

7.1 .3 Remaining Stacks .............. 7-3

7.1.4 Air Effluent Samoling Program ........... 7-3

7.2 LIQUID EFFLUENT MONITORING SYSTEM DESCRIPTION AND
SPECIFICATIONS . . . . 7

7.2.1 Monitoring/Sampling Requirements ......... 7-4

7.2.2 CSL Effluent Monitoring/Sampling System ....... 7-5

7.2.3 Liquid Effluents Monitoring Program ....... 7-5

7.2.4 Liquid Effluent Sampling Program .......... 7-6

8.0 HISTORICAL MONITORING/SAMPLING DATA FOR EFFLUENT STREAMS . . . 8-1

8.1 aIR EFFLUENTS $\ldots \ldots \ldots . \ldots . \ldots$ 8-1 . . . . . . . .

8.1.1 Normal Canditions ............... 8-1

8.1 .2 Upset Condttions .............. 8-2

8.2 LIQUIO EFFLUENTS .................. 8-2

8.2.1 Normal Conditions . . . . . . . . . . . . . . 8-2

8.2.2 Upset Conditions ................ 8-2

9.0 SAMPLE ANALYSIS ................... . . . .

9.1 ANALYTICAL LABORATORY AND PROCEDURES ............ . .

9.2 SAMPLE AND DATA CHAIN OF CUSTODY ............ 9-4

10.0 NOTIFICATION AND REPORTING REQUIREMENTS .......... 10-1 10.1 OCCURRENCE CATEGORIZATION, NOTIFICATIOH, ARD REPORTING ... 10-I

10.1.1 0ccurrence Identification and Immediate Response ... 10-I

10.1 .2 Occurrence Categorization .............10-1 


\section{COHTEkTS (conttnued)}

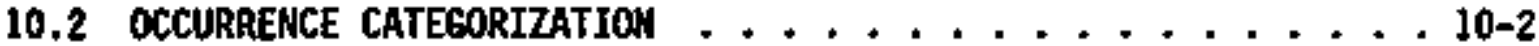

10.2.1 Radioactive Releases ............ 10-2

10.2.2 Release of Hazardous Substances/Regulated

Pollutants $/ 011 \ldots \ldots$ 10-3

10.2.3 Discovery of Hazardous Material Contamination

Due to DOE Operations ................ 10-4

10.2.4 Agreement/Compl iance Activities . . . . . .... 10-5

10.2.5 Ecologjcal Resources .............. 10-5

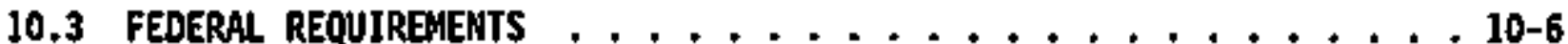

10.3.1 Resource Conservation and Recovery Act of 1976 ... 10-6

10.3.2 Comprehensive Environmental Response, Compensation and Liability Act of 1980 . . . . . . . . . 10-6

10.3.3 National Emission Standards for Hazardous Air PotJutants ........................ 10-6

10.4 STATE REQUIREMEMTS ................... . . . . . . . . .

10.4.1 Generator Reporting ............... 10-6

10.4.2 Facility Reporting .............. 10-6

10.5 U.S. DEPARTMENT OF ENERGY REQUIREMENTS ....... 10-7

10.5.1 U.S. Department of Energy Order 5400.1, Chapter II General Environmental Protection Program Notification and Reports ......... 10-7

10.5.2 U. S. Department of Energy Order 5484.1 Environmental Protection, Safety and Health Protection Information Reporting Requirements ............. 10-7

11.0 INTERFACE WITH THE OPERATIONAL ENIRONENTAL MONITORING

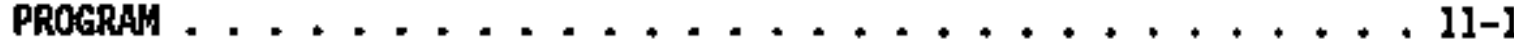

11.1 DESCRIPTION ........................ . . . . .

11.2 PURPOSE $\ldots \ldots \ldots \ldots \ldots \ldots \ldots \ldots \ldots \ldots \ldots \ldots$

11.3 BASIS .......................... . . . . . .

11.4 MEDIA SAMPLED AMd AMLLYYSES PERFORMED ............. 11-3

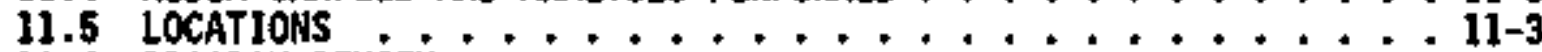

I1.6 PROGRAM REVIEM . ...................... . . . . . .

11.7 SAMPLER DESIGN ....................... 11-4

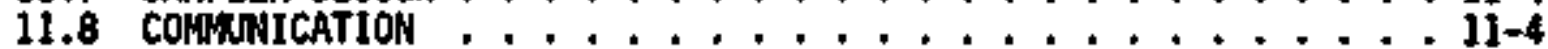

11.9 REPORTS ............................... II-4

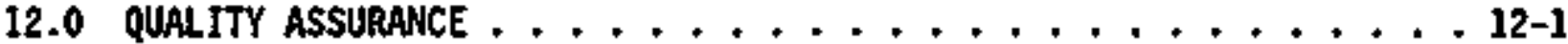

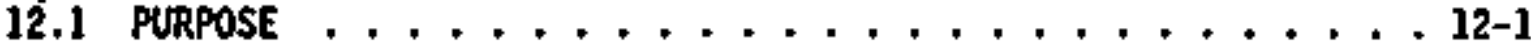

12.2 OBJECTIVE ......................... 12-1

12.3 REQUIREMENTS ........................ 12-1

13.0 internal and external Plan ReView . . . . . . . . . . 13-1

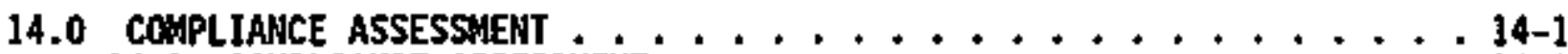

14.1 COMPLIANCE ASSESSHEMT . . . . . . . . . 14-1

14.1.1 Comparison of Instrument Specifications with

Required Standard ........... 14-1

14.1.2 Comparison of Instrument Specifications with

Monitoring Criteria . . . . . . . . . . . 14-1 


\section{coirtents (continued)}

14.1.3 Conparison of Instrument Specifications with Effiuent Characteristics ............ 14-1

14.1.4 Comparison of Projected Effluent Characteristics with Historical Data .............. 14-2

14.1.5 Compartson of Effluent Monitoring Capabiilties

14.2 EXEMPTIONS . . . . . . 14-2

14.3 SYSTEM UPGRADES REQUIRED FOR COMPLIAMCE $\ldots \ldots \ldots \ldots \ldots$

14.4 CLEAN AIR ACT REQUIREMEHTS . . . . . .......... 14-2

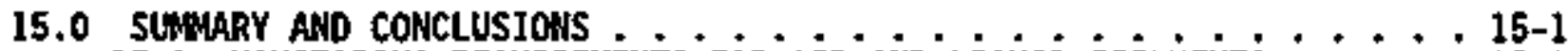

15.1 MONITORING REQUIREMEHTS FOR AIR AMD LIQUID EFFLUENTS . . . . 15-1

15.1.1 Monjtoring Requiroments for Radioactive Constituents in Ajr Effluents .................. 15-1

15.1.2 Monjtoring Requirements for Radioactive Constituents in Liquid Effluent .................. 15-1

15.2 SAMPLING REQUIREMERTS FOR AIR AND LIQUID EFFLUENTS . . . 15-1

15.2.1 Sampling Requirenents for Radioact fve Constituents

in Air Effiluents . . . . . . . . . 15-1

15.2.2 Samp ing Requirements for Liquid Effivents . . . 15-1

15.3 SYSTEKS UPGRADES FOR AIR MOHITORIHG AND LIQUID SAMPLIMG $\ldots .15-2$

15.3.1 Systems Upgrades for Air Monjtoring/Samp] tng . . . 15-2

15.3.2 Systems Upgrades for Liquid Sampling ........ 15-2

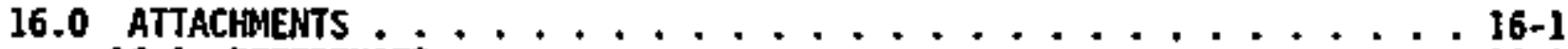

16.1 REFERENCES . . . . . . . . . . . . . . 16-1 


\section{LIST OF FIGURES}

2-1 Location of the Plutioniun-Urantum Extraction Plant at the Hanford Site ...................... 2-8

2-2 The Plutonfum-Uranium Extraction Plant Plot Plan . . . . . 2-9

2-3 The $202-A$ Butiding . . . . . . . . . . . . . 2-10

2-4 The Plutonium-Uranium Extraction Plant Liquid Effluents .... 2-11

4-1 CSL schematic Flow Diagram ................ . 4-12

4-2 CSL Flow Dfagram .................... 4-13

5-1 P1utonium-Uranium Extraction Plant Exhaust Stacks ....... 5-2

$5-2$ B Pond location ....................... 5-3 
WHC-EP-0468-3

\section{LIST OF TABLES}

3-1 Applicable Regulations and Standards ... . . . . . . 3-6

3-2 Groundwater Qua]ity Criteria ............. . . . . . 10

4-1 Pluton fum-Uranium Extraction Plants Stack Exhaust Data . . . . 4-14

4-2 CAP-88 Unit Dose Factors for the Offsite Hypothet 1ca] Waximally Exposed Individual Affected by Radionucl toe Air Emissions from the Hanford Site in $1993 \ldots \ldots \ldots$ 4-15

4-3 Individual Radionuclide Doses to Haximally Exposed Individual for 1993 from 291-A-1. . . . . . . . . . . . . . 4-16

4-4 Individual Radionuclide Doses to Maximally Exposed Individual for 1993 from $296-A-1 \ldots \ldots$. . . . . . . . . . . . . . . . .

4-5 Doses to the Maximally Exposed Individua] From Routine Releases During Transition to Shutdown ................ 4-17

4-6 Potential Doses to the Maxima71y Exposed Individual fron An Unmitigated Release ................... 4-18

4-7 Potential Indivtdual Radionuclide Doses to the Maximally Exposed Individual from An Unmitigated Release. ............ 4-18

4-8 Sumary of PUREX Plant Liquid Effluent Qualities . . . . . . 4-19

4-9 List of Plutonium-Uranium Extraction Plant Chemicals . . . . . 4-22

7-1 Radioactive Sampling Requirements for Plutonfum-Uranium Extraction Plant During Transition to Shutdown ............ 7-7

7-2 Monitoring/Sampling and Analys1s Program for A1r Effluents . . . 7-8

7-3 Chemical Sewer korwal Operating Parameters ......... . 7-9

7-4 Sampling and Analysis Program for Chemical Sewer Stream . . . . . 7-10

8-1a Final 1990 Radionuclide Airborne Releases from 291-A-1 (A552), 200 East Area ................... 8-3

8-1b Radionuclide Air Emissions in 1991 from 291-A-1 (A552), 200 East Area 


\section{LIST OF TABLES (continued)}

8-1c Radionuclide Air Emissions in 1992 from 291-A-1 (A552),

200 East Area . . . . . . . . . . . . . 8-5

8-1d Radionuclide Air Emissions in 1993 from 291-A-1 (A552),.

200 East Area .................... 8-6

8-1e Radionuclide Air Emissions in 1990 from 296-A-1 (A540), 200 East Area . . . . . . . . . . . . . . . 8-7

8-If Radionuc7ide Air Emissions in 1991 from 296-A-1 (A540), 200 East Area .................... 8-7

8-Ig Radionuclide Air Emissions in 1992 from 296-A-1 (A540), 200 East Area . . . . . . . . . . . . 8-8

8-Ih Radionuclide Air Emissions in 1993 from 296-A-1 (A540), 200 East Area . . . . . . . . . . . . . 8-8

8-2a Plutonium-Uranium Extraction Chenical Sewer (CSL) to 216-B-3 Pond, 200 East Area $(H 118)$ in $1990 \ldots \ldots$. . . . . . . . . . . 8-9

8-2b Plutonium-Uranium Extraction Chealical Sewer (CSL) to 216-B-3 Pond,

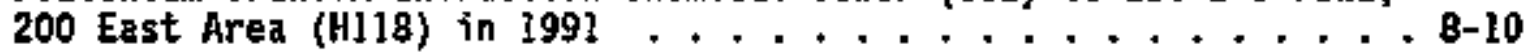

8-2c Radionuclides in Plutonium-Uraniun Extraction Plant Chemical Sewer Discharge (CSL) to 216-6-3 Pond, 200 East Area (H118) in 1992.

8-2d Radionuclides in Plutonium-Uranium Extraction Plant Chemical Sewer Discharge (CSL) to 216-B-3 Pond, 200 East Area (H118)

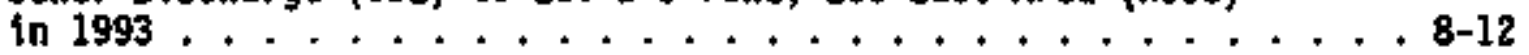

14-1 Natfonal Emission Standards for Hazardous Air Pol]utants Requirements ..................... 14-3

14-2 Matfonal Enission Standards for Hazardous A1r Pollutants Requirements ................. 14-109 
WHC-EP-0468-3

This page intentionally left b7ank. 


\section{LIST OF TERHS}

\begin{tabular}{|c|c|c|}
\hline 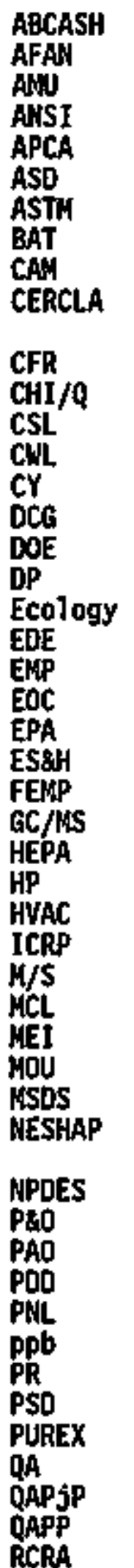 & • & 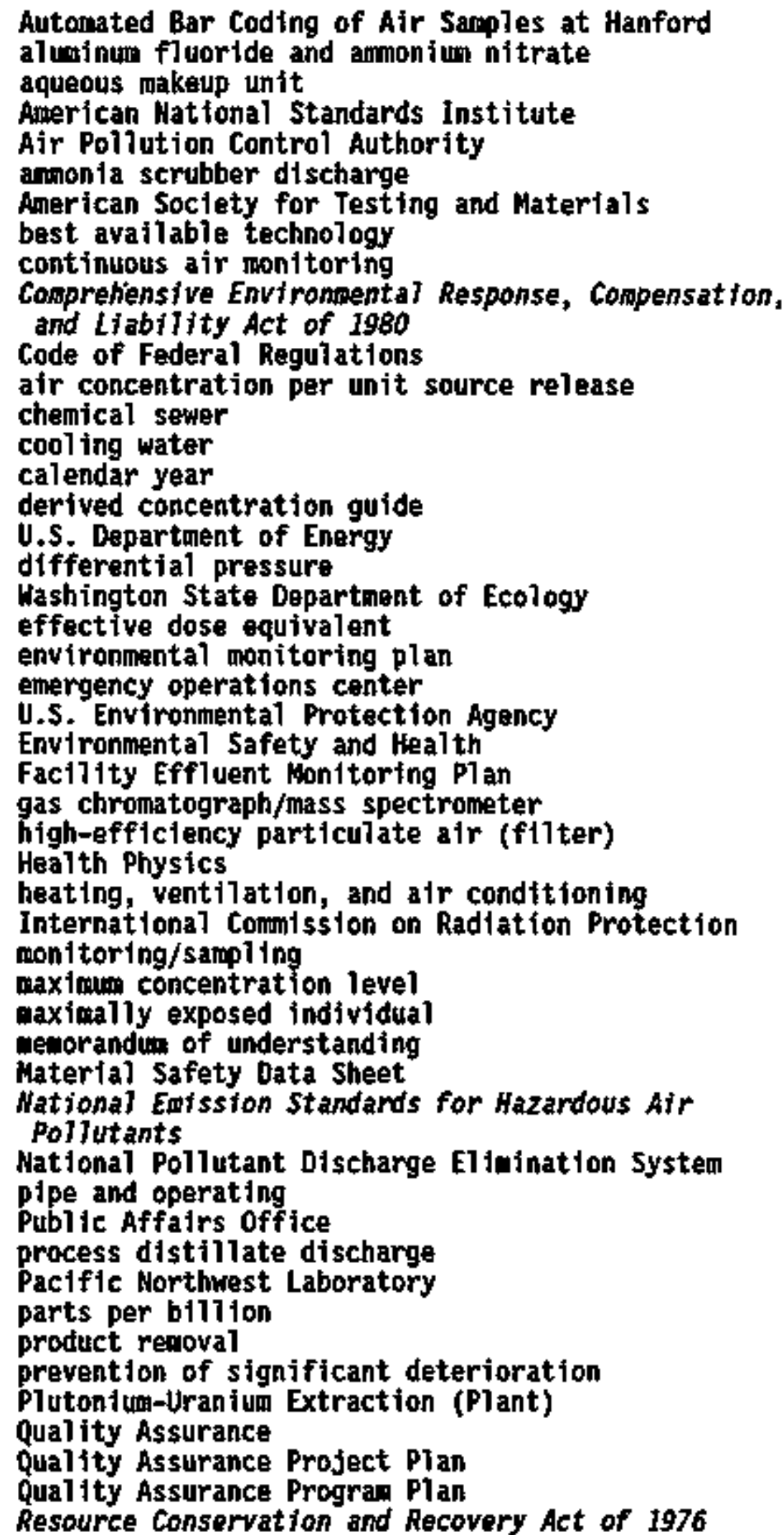 \\
\hline
\end{tabular}




\section{LIST OF TERAS (continued)}

RL

SALDS

SAP

SARA

SCO

SOWA

SQA

TEDF

TLD

TSD

U/UPW

UNH

10

USt

HAC

HHC

HPCA
U.S. Department of Energy, Richland Operations office State Approved Land Disposal Structure

Sampling Analysis Plan

Superfund Amendants and Reauthorfzation Act of 1986

stean condensate

Safe Drinking Nater Act

software quajity assurance

Treated Effluent Disposal Facility

thermal Juminescent dosineter

treatment, storage, and disposal

$\mathrm{UO}_{3} \mathrm{~J}$ Plant Waste Water

urany nitrate hexahydrate

uranju trioxide

United States Code

Washington State Administrative Code

Westinghouse Hanford Company

Water Pollution Control Act 
WHC-EP-0468-3

METRIC CONVERSIOY CHART

\begin{tabular}{|c|c|c|}
\hline \multicolumn{3}{|c|}{ INTO METRIC } \\
\hline If you know & Multiply by & To get \\
\hline \multicolumn{3}{|c|}{ Length } \\
\hline inches & 2.54 & centimeters \\
\hline feet & 30.48 & contimeters \\
\hline miles & 1.6093 & k11 ometers \\
\hline \multicolumn{3}{|c|}{ Yolume } \\
\hline gations & 3.786 & 1 iters \\
\hline cubic faet & 0.02832 & cubic meters \\
\hline \multicolumn{3}{|c|}{ Temperature } \\
\hline Fahrenheit & $\begin{array}{l}\text { Subtract } 32 \text { then } \\
\text { multiply by } 5 / 9 \text { ths }\end{array}$ & Celsius \\
\hline \multicolumn{3}{|c|}{ Pressure } \\
\hline inches water & 1.87 & $\mathrm{mmltg}$ \\
\hline \multicolumn{3}{|c|}{ OUT OF METRIC } \\
\hline \multicolumn{3}{|c|}{ Length } \\
\hline centimeters & 0.3937 & inches \\
\hline meters & 3.28 & foet \\
\hline kilometers & 1.6093 & miles \\
\hline \multicolumn{3}{|c|}{ Volume } \\
\hline mtlliliters & $1.247 \times 10^{+3}$ & cubic feet \\
\hline 11ters & 0.264 & galtons \\
\hline cubic meters & 35.31 & cubic feet \\
\hline \multicolumn{3}{|c|}{ Temperature } \\
\hline Celsius & $\begin{array}{l}\text { Multiply by } 9 / 5 \text { ths, then } \\
\text { add } 32\end{array}$ & Fahrenheit \\
\hline \multicolumn{3}{|c|}{ Netght } \\
\hline graus & 28.35 & ounces \\
\hline
\end{tabular}


WHC-EP-0468-3

This page intent tonally left blank. 


\subsection{INTRODUCTION}

The U.S. Department of Energy (DOE) Order 5400.1 (DOE 1991a) requires that a Facility Effluent Monitoring Plan (FENP) be prepared for each DOE facility that has gaseous and/or 1 iquid effluents. Only effluents that release significant pollutants or hazardous materials are included in this order; sanjtary sewer and exhausts fron air heating or cooling equipment are exempt.

The Plutonlum-Uraniw Extraction (PUREX) Plant is transitioning into a shutdown mode. No fuel processing activities are occurring and the majority of the tanks have been emptjed. One waste water discharge and eleven air exhaust stacks are active. One previous air discharge, six wall exhausters, and four previous waste water discharges have been el iminated.

\subsection{POLICY}

It is the policy of DOE and Kestinghouse Hanford Company (UAC) to conduct effluent monitoring that is adequate to determine whether the public and environment are adequately protected during DOE operations and whether operations are in compliance with DOE and other appl lcable federal, state, and local radioactive and nonradioactive hazardous materials standards and requirements. It is also the policy of DOE and DOE contractors to ensure that effluent monitoring programs meet high standards of quality and credibility.

\subsection{PURPOSE}

This plan fulf171s the requirements in DOE 5400.1 (COE 1991a) for a FEMP to exist for each site, facility, or process that uses, generates, releases, or wanages significant pollutants or radfoactfve or hazardous materials that could affect public and employee safety and the environment. This document is specificaily intended to meet this requirement for the PUREX facility on the Hanford Site.

The purpose of the FEmP is to assess and document information used to determine if the monjtoring, samp] ing, and controls are sufficient to protect the public and the environiment and to assess whether these systems are in compliance with all federal, state, and local requirements and regulations.

\subsection{SCOPE}

This document includes progras plans for monitoring and characterizing radioactive and nonradjoactive hazardous materials discharged in DOE facility effluents. This plan includes complete documentation for both gaseous and Tiquid effluent monitoring systems for both radioactive and nonradioactive hazardous pollutants that could be discharged under routine and/or upset conditions. 
Specific sections that detail how the faup is implenented and structured follow. They compose the scope of this document.

Section

scope

2.0

This brtef facility description summarizes the processes that produce the effluents and couples then with a listing of effluents.

3.0

DOE orders and federal and state regulations that establ ish FEAP requirements, as we11 as discharge criterla, are provided.

4.0 Each gaseous and liquid effluent is characterized. Routine and upset conditions are described. The discharge criteria are developed and listed.

5.0 A description of each effluent's discharge point is provided.

6.0 The design criteria for the nonitoring/sampling (M/S) systom are 1 isted for both air and water effluents.

7.0 Instrument descriptions and specifications of the effluent monitoring system are provided.

8.0 Appropriate historical $\mathrm{H} / \mathrm{S}$ data are sumarized.

9.0 Analytical requirements are listed and coupled with saapling and sample handling procedures.

10.0 Hotification and reporting requirements for routine and envirommenta] occurrence reports and procedural changes are listed.

11.0 This section provides the interface of the FEMP with the operational environmental surveitiance program.

12.0 The Quality Assurance (QA) $\mathrm{plan}$ governing the field activities, laboratory analysis, and recordkeeping is stated. Audits are covered.

13.0 Internal and external FEMP review requirements are provided.

14.0 Comp tance assessment is summarized. Two point-bypoint evaluations of the Mational Emission Standards for Hazardous Air Pollutants (NESHAPs) are included.

15.0 A sumary is provided and conclusions are listed.

16.0 References. 


\section{4 olscussion}

The characterization of the radioactive and nonradioactive constituents in each effiuent stream coupled to the regulatory framework provides the underlying rationale for the $\mathrm{M} / \mathrm{S}$ prograns. The method of characterization discussed in this plan identifies potentia] pollutants in their individual effluents. Characterization parameters are based on process knowledge and chemical and equipment use. An accurate description of the effluents point of discharge is reguired for enission wodeling and location of end-of-the-pipe $M / S$ stations. Both normal and upset conditions (either projected or actuaj) are characterized.

As stated in federal regulations (40 Code of Federal Regulations [CFR] 61, Subpart K) (EPA 1991a), when determining the potential dose from an effluent, the emission controls between the point of generation and the discharge point are not to be considered. The enission controls are to be considered when assessing the types and amounts of a pollutant actualiy released at the discharge point.

The effluent monitoring system must have the appropriate design criteria and technical specifications to fully characterize the effluent streans. A combination of continuous sensing, continuous or periodic sanpling, and parameter specific monitoring may be used.

Proper sampling, analysis, and data recording of all effiuent monitoring efforts provide defensible documentat ion that all appropriate discharge criteria are being met at the point of discharge.

Characterization of 11 quid waste pollutants is required by 40 CFR 261.3(b) (EPA 1989a). Other regulations, such as 40 CFR 61, Subpart H (EPA 1991a), provide guidance on the adequacy of gaseous effluent monitoring. However, all potential pollutants should be characterized for two reasons (1) to assess the preventive capabilities of engineered and admintstrative barriers and the consequences of an upset release due to fallure of one of these barriers, and (2) to verify that the $\mathrm{M} / \mathrm{S}$ programs address a 77 pertinent constituents at the point of discharge. 
WHC-EP-0468-3

This page intentionally left blank. 


\subsection{FACILITY DESCRIPTIOH}

This section presents a brief facllity and process description of the PUREX Plant. These descriptions include the following:

- Location and physical layout of the process factlity

- General description of the present, past, and future activities of the process

- Identity of the waste streams.

Section 4.0, Identification/Characterization of Effluent Streams, provides further specific infornation on the gaseous and liquid effluents.

\subsection{BRIEF FACILITY PHYSICAL LAYOUT}

The PUREX P1ant is a collection of buildings and facilities located in the 200 East Area of the Hanford $S i$ te, in the south-central region of Washington State (Figure 2-1). Figure 2-2 is a plot p7an for the PUREX Plant. The matn building, 202-A (Figure 2-3), is a heavily shlelded, reinforcedconcrete structure known as a canyon building. This building contains the main equipment used in the PUREX process.

Principal building and structures which have the greatest connection to gaseous and liquid effiluents, are described in the following sections.

\subsubsection{The 202-A Bujlding}

The 202-A Building, in which the fuels were reprocessed, is a reinforcedconcrete structure $1,005 \mathrm{ft}$ long, $119 \mathrm{ft}$ wide at its maximum, and $100 \mathrm{ft}$ high, with about $40 \mathrm{ft}$ of this height below grade. The building consists of three main structural components (i) a thick-wa) led, concrete canyon in which the equipment for radioactive processing is contained; (2) the pipe and operating (PRO), sample, and storage galleries; and (3) a steel-and-transite annex that houses offices, process control rooms, laboratories, and the building services. The basic features and arrangement are shown by the cut-away perspective view in Figure 2-3. The portion of the canyon below grade is subdivided into a row of process equipment cells paralleled by a ventilation air tunnel and a pipe tunnel through which intercell solution transfers are made. The air tunnel exhausts the ventilation air from the cells to the main ventilation filters and stack.

Running nearly the full length of the canyon butiding, above the cells and pipe trench, is a craneway for three gantry-type maintenance cranes. These cranes are used to handle cell cover blocks, remotely renlove and replace process cell equipment, and charge irradiated fuei into the dissolvers.

The galleries contain service piping to the cells, samplers for obtaining process samples, and electrical switchgear. 
The service section, next to the gallertes, consists of two separate annexes. The larger annex contains the maintenance shops, offtces, lunchrooth, locker roow, radiation zone entry lobby (SWP lobby), blowar room, a switchgear room, compressor room, central control roow, and the aqueous makeup unit (ANU) area. The smaller annex contains the analytical laboratory, the headend control room, and a switchgear room.

\subsubsection{3-A Pumphouse and Tank Farm}

The 203-A Pumphouse contains instruments for measuring the volunes of solutions contained in the 203-A tank farm, and pumps and piping to receive and transfer the solutions in the tank farm. The tank farm stores aqueous uranium solutions and recycled nitric acid froe the Uranium Trioxide (v0, ) Plant. The tank farm includes sampling equipment, as well as loading and unloading equipment for the tank trucks and cars used to transfer solutions between the PUREX Plant and the UO, Plant. This area is called out in Figure 2-2 as the 203-A Storage Area.

\subsubsection{1-A Pumphouse and Tank Farm}

The 211-A Pumphouse is Tocated in the midst of the 211-A Tank Farm. The pumphouse contains pumps used to transfer the chemicals stored in the tank farm. The pumphouse also contains ion-exchange coltuns and ancillary equipment previously used to produce demfineralized water from sanjtary (potable) water. The 211-A Tank Farm stored bulk uncontaminated liquidd chewicals for use in the PUREX process. The chemicals stored included 57 wt* nitric acid, 93 wt\% sulfuric acid, 50 wt\% sodium hydroxide, 45 wt\% potassium hydroxide, as well as demineralized water, normal paraffin hydrocarbon, tributyl phosphate, aluminum nitrate, and an aqueous mixture of amronium fluoride and ammoniul nitrate. All of the bulk chemicals except sodium hydroxide have been removed. This area is called out in Figure 2-2 as the 2l1-A Demineralizer Building.

\subsubsection{6-A Acid Fractionator Building}

The 206-A Building is a reinforced concrete structure located adjacent to the 202-A Bul7ding. It houses the vacuum fractionator and associated equipment. The vacuum fractionator concentrated recovered nitric acid. The heat transfer piping in the vacuum fractionator was a major contributor to the PUREX Plant Chemical Sewer (CSL) waste stream during operation. During shutdown conditions there is no discharge from the fractlonator to the CSL. This building is called out in Figure 2-2 as the 206-A fractionator.

\subsubsection{The 293-A Butlding}

The 293-A Building houses the backup facility, which removed nitrogen oxides from the dissolver off-gas streas converting them to nitric acjd. The nitric acid was then recycled into the PUREX process via the 206-A Building. This process does not operate during shutdown conditions. 


\subsubsection{Effluent-Nontitoring Buildings}

Several small bujldings and other enclosures contain equipment needed to monitor various 1 iquid and gaseous offluent streans. The 295-XX Butldings house $N / S$ equipront for the waste water streans. The 292-XX Bufldings house W/S equipeent for the gaseous effluent streans. Additional stack sampling equipment is located in small enclosures (cabinets) near the exhaust stacks.

\subsubsection{Tank 216-A-5 Calcium Carborato Meutralization Tank}

This tank contains calcium carbonate (crushed limestone), which ensures that the Process Distillate Discharge (PDD) would not exceed the $2.0 \mathrm{pH} 1 \mathrm{imit}$ if upstream neutralization systems did not perform as expected. This tank, like the PDD, is not in service during transition to shutdown. Re-use of this tank or the PDD are not anticipated.

\subsubsection{Raflroad Tunnel}

The rattroad tunnel received irradiated fuel and large pieces of equipment that have been transported to PUREX via railcars. The railroad tunnel enters the north side of the east end of Butlding 202-A, continues through the buflding, then exits on the south side of the buifding where it. connects to the storage tunnels. The storage tunnels are two parallel, earthcovered tunnels that contain railroad tracks. The storage tunnels are isolated from the railroad tunnel by water ftllable doors. The tunnels contajn failed equipment (loaded on rajroad cars) that is contaninated with high levels of radioactivity or too bulky for immediate burial. Storage of the equipment allows the radioactivity to decay to less dangerous levels. During transition to shutdow, PUREX will not receive railcar futel shipnents, however, a]uminun clad fuel and a few fuel slugs from the dissolver ceit floors may be shipped out of PtIREX via rallears.

\subsubsection{The 291-AE Building}

Butlding 291-AE is an above-grade concrete structure which houses the No. $4 \mathrm{htgh}$ efficiency particulate atr (HEPA) fliter systen. The Ho 4 filter consists of 10 paraliel banks of two-stage, HEPA filters for final filtration of the canyon exhaust systen. Instrumentation to detect pressure drop across each stage and gamma radiation at the first stage is part of the filter systein.

\subsection{BRIEF PROCESS DESCRIPTIOH}

The PUREX Plant separates useab]e actinides fron fisston products in irradiated nuclear fuel. Briefly, the process consists of dissolving the fuel and then separating the actinides using liquid-liquid solvent extraction. The driving forces for the separations consist of concentration changes, teaperature changes, and cherical additions. The PUREX Plant has been the source of five 7 iquid effluent streams, which are mostly by-products of the 
chemical separation processes. These liquid effluent streams are the Chemical Sewer (CSL), the Steam Condensate (SCD), the Process Distillate Discharge (PDD), the Amonia Scrubber Discharge (ASD), and the Cooling Water (CWL) streains. The PUREX Plant has been the source of 11 principal gaseous effiuent streams that resulted from the control of process vapors/gases and potential contamination. of the 11 PUREX stacks, only 10 discharge at any one time; see Section 4.1.1, Stacks 296-A-5A and 296-A-5B. There are also stx minor gaseous effluent streams that result from building ventilation of noncontaminated, normally occupled areas. Approximately 50 exhaust points are exempt from regulation, such as lavatory, office, and lunch room exhausts.

One of the stacks, 296-A-24, was deactivated in early 1990, leaving 10 principal streams. The six wall exhausters (296-A-33 through 296-A-38) were b]anked off in early 1993, eliminating these minor effluent streans. During the transition to shutdown, the renaining gaseous effluents will continue. Continuous air flow through the process areas will ensure control of trace quantities of contamination. Of the five liquid effluent streans, the ASD, PDD, SCD, and CHL have been eljminated. Residual flow through the heat exchange equipwent and heating, ventilation, and ajr conditioning (HVAC) systems will maintain some discharge (prinarily butiding heating and cooling) from the CSL, but at a reduced rate.

\subsubsection{Present and Future Activities}

PUREX is continuing activities in the transition to shutdown to place the facility in a safe and enviromentally secure configuration. Some of the major activities included in this transition are the consolidation of the ventilation systens, contaminated acid disposal, fuel disposition, canyon flushing, contaminated solvent disposal, operation of the Fil concentrator, and $\mathrm{N}-\mathrm{Ce}$ il cleanout.

PUREX recovered approxinately 200,000 gallons of low specific activity nitric acjd from NOX absorption in the PUREX process and from the $1993 \mathrm{CO}_{3}$ campaign. As part of deactivation activities, PUREX plans to ship the acid to British Nuclear Fuels Ltd (BNFL) in England for use in their nuclear reprocessing program.

Approximately 3.4 HTU of irradiated fuel elenents will be shipped to $K$ Basin per the PUREX/V03 Project Management Plan (UHC-SP-I0IID).

Elimination of the fire foam system was made possible by the removal of approximately 21,000 gallons of slightly contaninated PUREX solvent from the 202-A building.

Work is ongoing in the Plutonfun Oxide Conversion Facility (H-Cell) disassembling and decontaminating process equipment housed within the gloveboxes. Equipment and piping will be removed by bagging out through gloveports and the gloveboxes will be decontaminated and a fixative agent applied to the surfaces.

Approximately 250,000 gallons of low-level non-dangerous waste remain at the PUREX plant with approximately 100,000 gallons of waste being generated from flushes of the canyon vessels and piping. Wost of this low-jevel nondangerous waste will be used as a dilution medium for the disposal of the 
metal solution in tanks DS and E6; the meta1 solution was recovered from transition-to-standby cleanout activities. The remaining waste may be evaporated by the Fll concentrator.

PUREX will also consolidate the four ventilation systens into one by cascading afr from one ventilation systen to another. This will reduce the voluma of air discharged and the number of stack nonitoring stations needed following PUREX deactivation. Final discharge of all air will be through the main stack via the canyon.

\subsection{IDEKTIFICATION/CHARACTERIZATIOH \\ OF POTEMTIAL SOURCE TERUS}

Source terms for effluents from the PUREX PIant depend on the building or process they originate from and whether the plant is operating or in shutdown mode. This document has been written to address the current shutdown status of PUREX.

\subsubsection{Gaseous Effluents}

The contributors to a gaseous effluent are linked by physical location and are not related to a specific process. The PUREX Plant has 10 sources of major alr effluents with the potential to release radioactive and nonradioactive constituents. The six minor wall exhausters were blanked off in the Spring of 1993 .

The PUREX main exhaust stack (291-A-1) exhausts the offgas from a number of sources:

- Vapor from the dissolvers when they are operating

- Vent gases from the nitric acid absorber (T-XB) when dtssolvers are operating

- Vent gases from the condenser on the nitric acjd absorber E-F5 when operat Ing

- Gases from the vessel vent system when operating

- Gases from the condenser vent system when operating

- Building ventilation air.

The Product Removal (PR) Room Stack (296-A-1) exhausts air from the following areas:

- PR room and hoods

- N celt hoods

- Q cell

- PR corridor

- Hot shop lobby. 
Stack 296-A-2 exhausts sampler hoods fron the west end of the sample gall lery.

Stack 296-A-3 exhausts sampler hoods fron the east end of the sample gat lery.

Stacks 296-A-5A and 296-A-5B, at the west and east laboratory do not operate concurrently; only one is operational at any given time. These stacks exhaust the PUREX analytical jaboratory and are considered to be a single release point in this document.

The 296-A-6 stack exhausts roon air from the east end of the sample gallery and from $\mathrm{U}$ cell.

The 296-A-7 Stack exhausts rocm air from the west end of the sample gatTery and from $R$ cell.

The 296-A-8 Stack exhausts room air from the west end of the P80 gallery, including the white room.

The 296-A-10 Stack exhausts room air from the Ho. 2 storage tunnel. This tunnel contains used equipment, as discussed in Section 2.1.8.

The 296-A-14 Stack exhausts room air fron the 293-A backup facility. This building contains two absorption colums for nitric acid recovery fron the dissolver offgases.

Fuel decladding operations resulted in the formation of gaseous ammonta in certain D-Cell, E-Ce11, and F-Cell vessels. The 296-A-24 5tack provided filtered exhaust for these vessels. This stack is no longer operating.

\subsubsection{Liquid Effluents}

Removal of the protective cladding fran the fuel, the first step in fuel dissolution, produces large quantities of gaseous amonia. Th1s amonia is scrubbed from the off-gas with water to prevent the release of antonia to the air and to alleviate the explosion hazard that the armonla would otherwise present. The resulting ammonia solution, contaninated with radtonuclides from the fuel, is then botled. The radionuclides are concentrated in the bottons, which are sent to UGS. Before 1987, the resulting annsonia-bearing condensate stream was released as the ASD. In the current shutdown mode, the ASD strean does not exist and is mentioned as historical fact only.

Concentration changes within the PUREX process solutions are provided by dilution with water or acid and by renoval of water and sometimes nitric acid by boiling. Chemical additions to the process solutions add water, which must be removed in the concentration stages. Although nost of the water that is boiled out of solutions is reused in dilution stages, there is sane excess water that requires disposal. This water is the source of the PDD. Because PUREX is in a shutdown mode and not processing, the PDD stream does not exist and is mentioned as historical fact only. 
Boiling process solutions and condensing the resulting vapors require the use of stean and cooling water. These processes produce steam condensate and warm water as effluents. Changing the temperatures of process solutions to drive the separations produces more steam condensate and warm water. This steam condensate and warm water constitute most of the liquid effluents from PUREX, mamely the CWL, SCD, and most of the CSL strean. The CWL and SCD have been b]anked off'and the remaining contributors rerouted to the CSL.

Ventilation, heating, water services, and roon drainage contribute to the rewainder of the CSL. Roon drainage consists of waste water from shower roons, water coolers, housekeeping, atr compressors, steam, water, and occasional chemical leaks. To minimize the potential for chemical leaks during transttion to shutdown, nonessential chemical headers have been emptied. Most chenicals which are not needed for shutdown have been or are being removed from the plant. Condensed noncontact heating steam to operate the F-11 concentrator will be routed to the CSL via the 216-A-42 Retention Basin.

Figure 2-4 shows the PUREX Plant 11quid effluent system. Within the operating history of PUREX, the varjous waste water streams have been discharged to several ponds and cribs as follows.

$\begin{array}{ll}\text { Stream } & \text { Discharged to } \\ \text { POD } & 216-A-5,216-A-10, \text { and } 216-A-45 \text { Cribs } \\ \text { SCD } & 216-A-30 \text { and } 216-A-37-2 \text { Cribs, occasionally } \\ & 216-B-3 \text { Pond } \\ \text { ASD } & 216-A-36 B \text { Crib, UGS } \\ \text { CSL, CHL } & 216-B-3 C \text { and } 216-B-3 \text { Ponds, CWL sometimes to } \\ & 216-A-25 \text { Gable Mt. Pond }\end{array}$

During the existing shutdown mode, the PDO, ASD, SCD, and CWL waste streans are el ininated. The potential for contamination via the CSL waste strean will be el iminated after the recommended best available technology (BAT) to control effluent quality is implemented in accordance with DOE order 5400.5 (OOE 1990a). The BAT for the CSL includes eventua] routing to the Treated Effluent Bisposal Fact1ity (TEDF). 


\section{Figure 2-1. Location of the Plutoniun-Uranium Extraction} Plant at the Hanford Site.

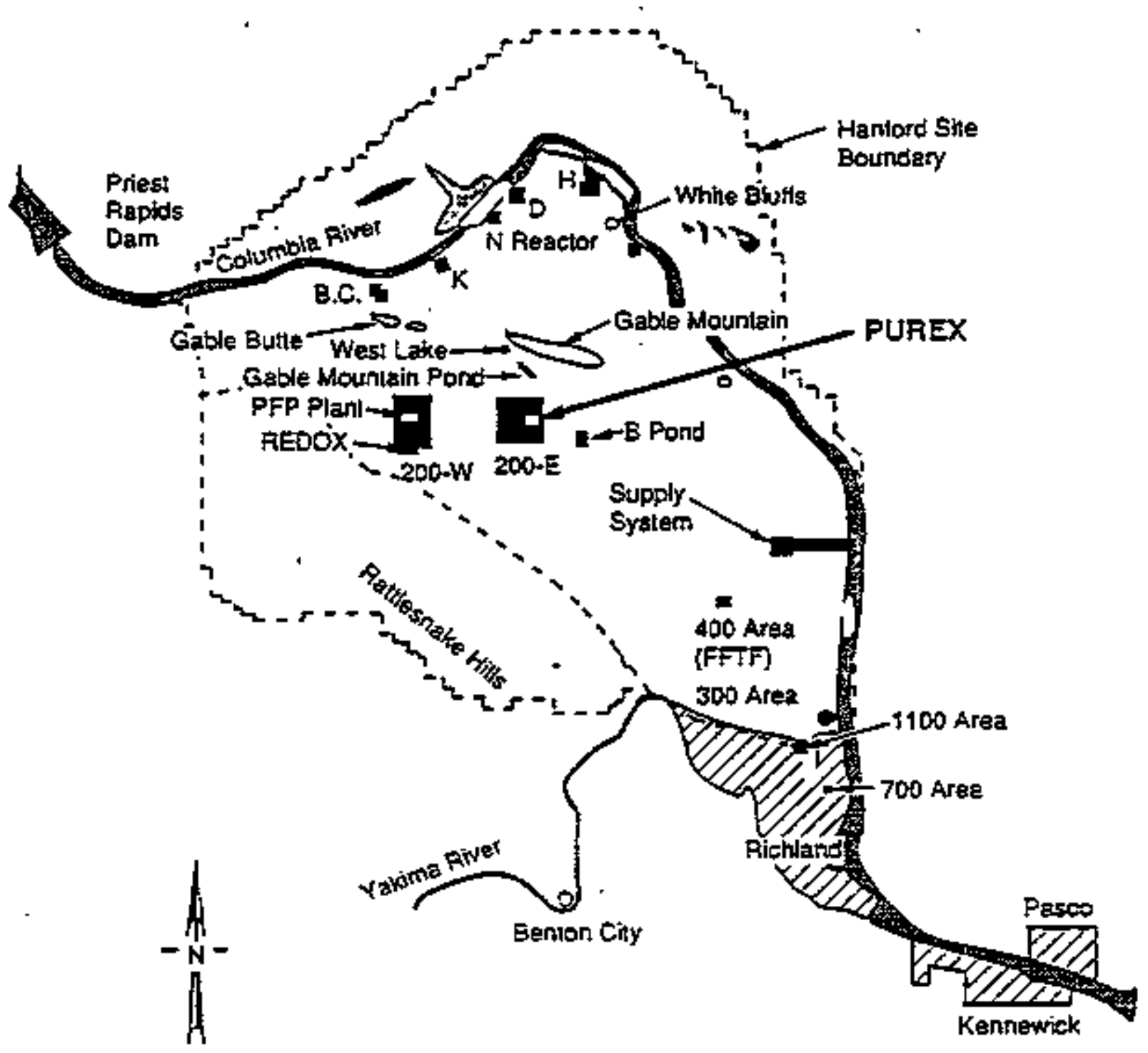

$28905055.72 \mathrm{M}$ 
WHC-EP-0468-3

Figure 2-2. The Plutonfulu-Liraniua Extraction Plant Plot Plan.

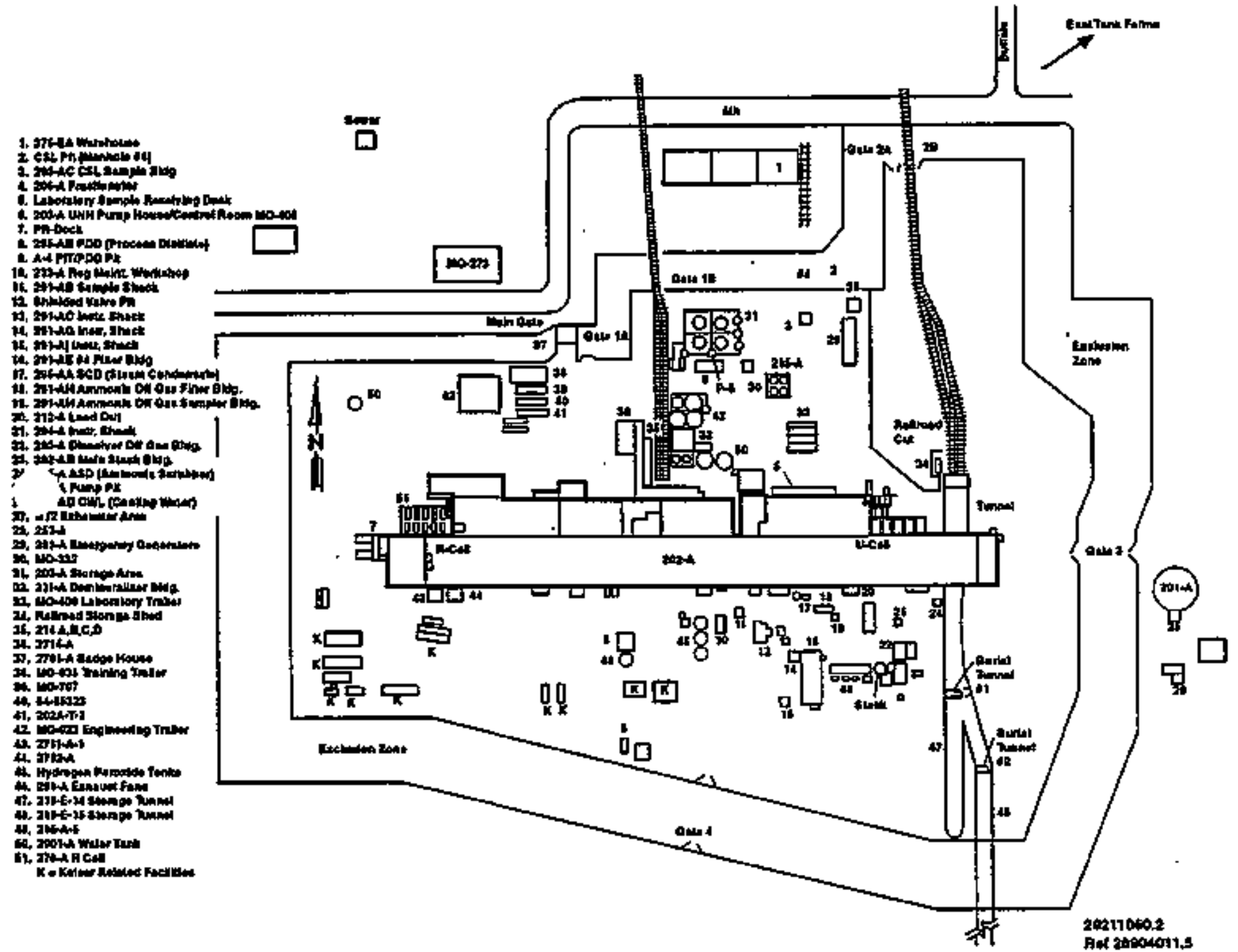


Figure 2-3. The 202-A Bujlding.

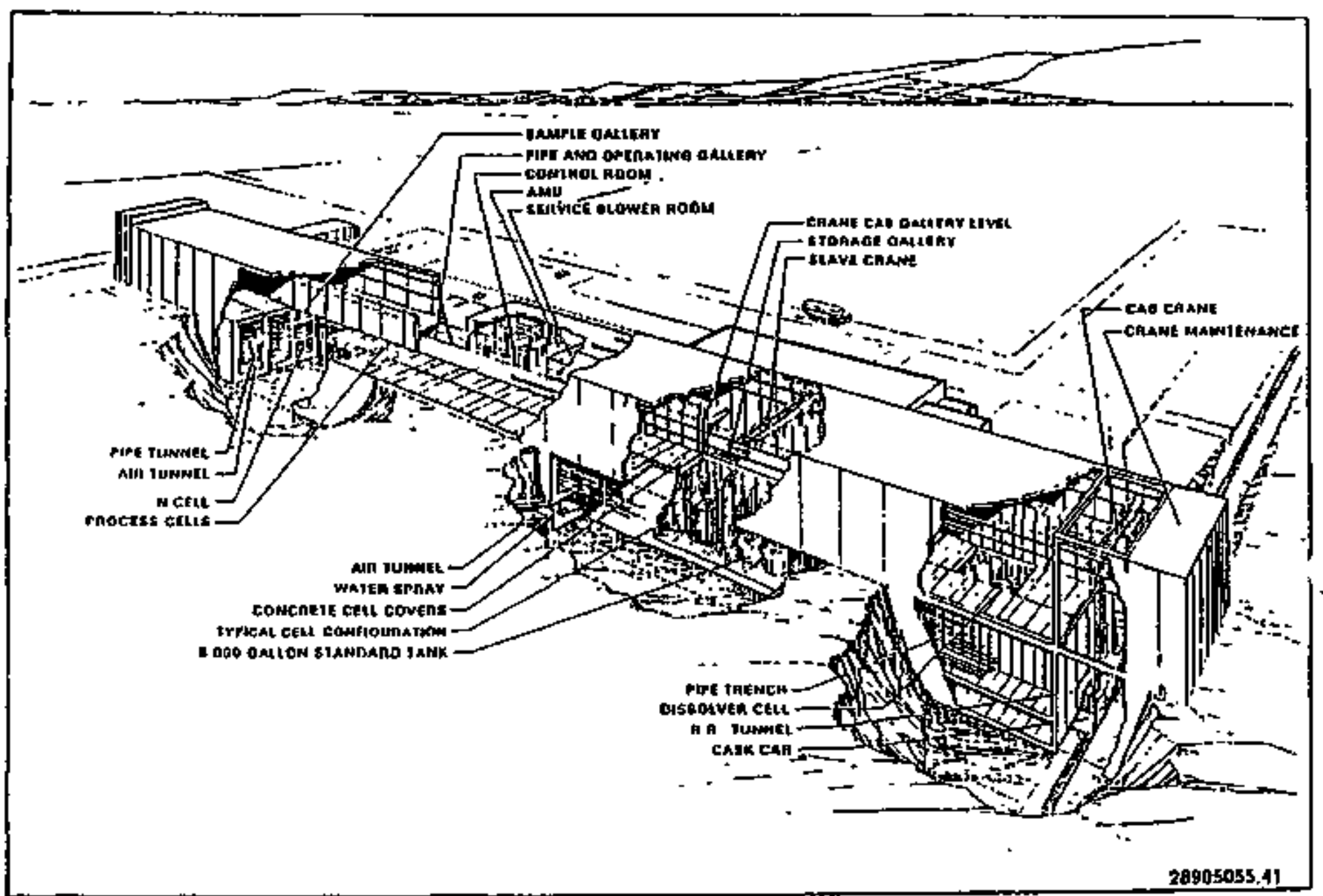


WHC-EP-0468-3

Figure 2-4. The Plutonium-Uranium Extraction Plant Liquid Effluents.

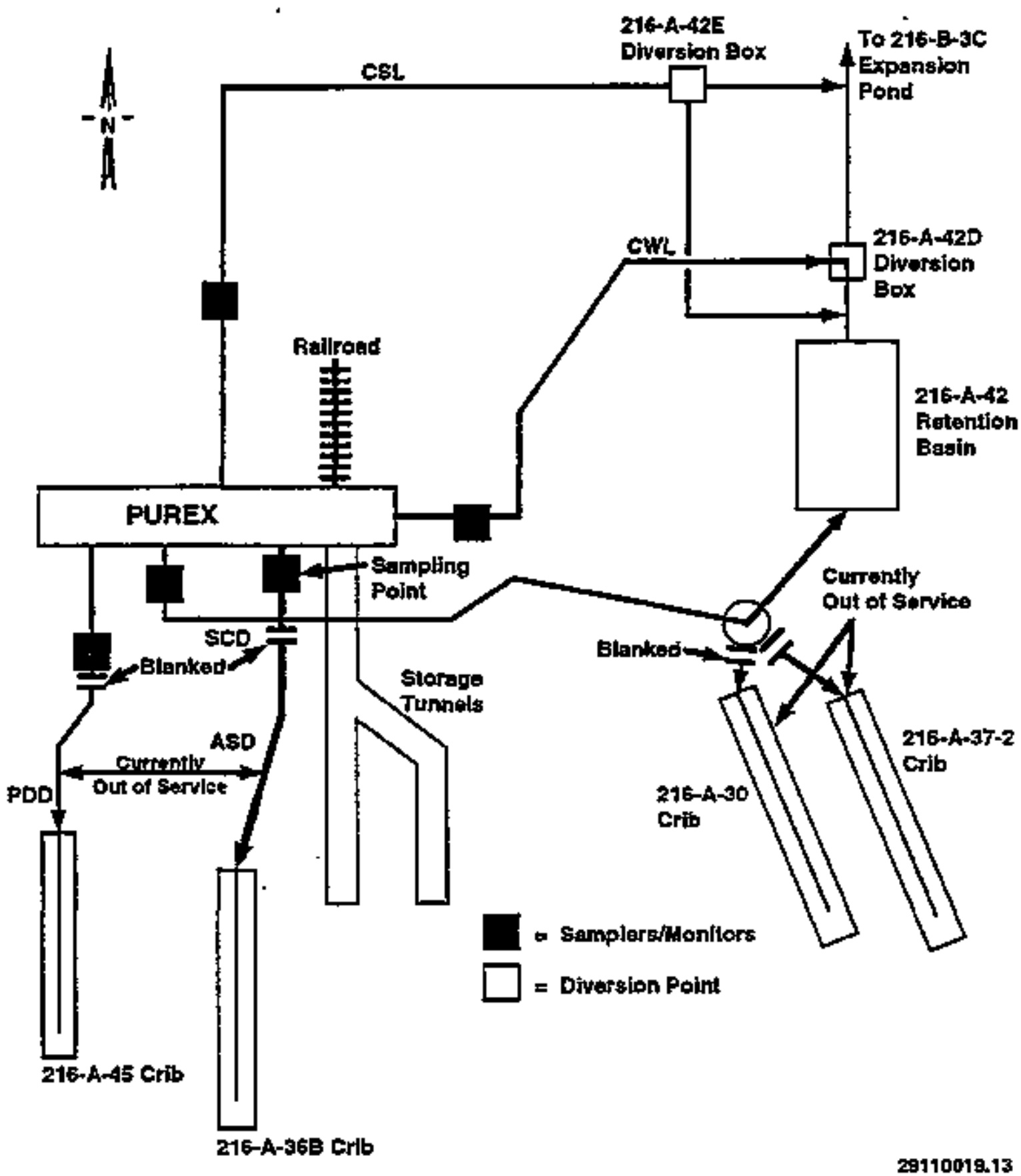


WHC-EP-046B-3

This page intentionally left blank. 


\subsection{APPLICABLE REGULATIONS}

Conditions and requirements for monitoring existing or potential reieases of radioactive and other chemicals to the environient are contained in DOE orders and federal, state, and local laws and regulations. Table 3-1 gives a brief summary of the reguiations and standards applicable to this FEMP.

\subsection{U.S DEPARTIENT OF ENERGY ORDERS}

\subsubsection{U.S. Department of Energy Order 5400.1}

The DOE Order 5400.1, General Envirommental Protection Prograw (DOE 1991a), requires a written environmenta] monitoring plan for each site, faclitity, or process that uses, generates, releases, or manages significant pollutants or hazardous materials. The plan must include the rationale and design criteria for the monjtorjng program, as well as describe the extent and frequency of the monitoring analysis. The plan a 150 mast contain Quality Assurance (QA) requirements, prograw implementation procedures, directions for preparation and inplementation of reports, and directions for identification and discussion of effluent monitoring and environmental surveillance.

The effluent monitoring portion of the plan must verify compliance with applicable regulations and DoE orders. It also should evaluate the effect lveness of treatment; identify potential environinental problems; evaluate the need for remedial action or witigation measures; support permit revision and/or reissuance; and detect, characterize, and report unplanned releases.

\subsubsection{U.S. Department of Energy Order 5400.5}

The DOE Order 5400.5 (DOE 1990a) requires a monitoring plan that complies with the requirements of DoE Order 5400.1. Compliance with the requirements of gOE Order 5400.5 may be demonstrated based on calculations from monitoring and surveillance programs information.

\subsection{FEDERAL REGULATTOHS}

\subsubsection{Environmental Protection Agency Regulations on Wational Enission Standards for Hazardous Air Pollutants 40 Code of Federal Regulations 61}

Subpart H, Nationa? Emission Standards for Emisslons of Radionuclides Other Than Radon from Department of Energy Facilities," establishes exposure limits and monitoring requirements. The exposure limits, for members of the public, from radionuci ide emissions is an effective dose equivalent (EDE) not to exceed $10 \mathrm{mrem} / \mathrm{yr}$. Compliance with this standard is measured by calculating the highest EDE where a person resides or abides using an EPA-approved method. 
Entssions of radionuclides must be measured at all release points that have a potential to discharge radionuclides into the air in quantities that could cause an EDE in excess of 1 percent of the standard. Effluent streams shall be directly wonitored continuously with an in-line detector or representative samples of the effluent stream shall be withdrawn continudusly from the sampling site following the guidance presented in American National Standards Institute (ANSI) KI3.1 (ANSI 1969). The requirements for continuous saeapling are applicable to batch processes when the unit is in operation. Perlodic sampling (grab samples) may be used only with EPA's prior approval. Such approval may be granted in cases where continuous sapilting is not. practica] and radionuclide enission rates are relatively constant. In such cases, grab samples shall be collected with sufficient frequency to provide a representative sample of the enissions.

To determine whether a release point is subject to enission measurement requiferents, it is necessary to evaluate the potential for radionuclide. emissions for that release point. In evaluating the potential of a release point to discharge radionuclides into the air, the estimated radionuclide release rates shall be based on the discharge of the effluent stream that would result if all pollution control equipment did not exist, but the faciljty operations were otherwise normal.

If the EDE caused by a11 emissions is less than I percent of the standard, the facility is exempt from the EPA monitoring requirements. All radionucijides that could contribute greater than 10 percent of the potential EDE for a release polnt shall be measured individualiy. With prior EPA approval, DOE may determine these enissions through alternative procedures. For other release polnts that have a potential to release radionuclides into the air, periodic confirmatory measurements shall be nade to verify low emissions.

\subsubsection{Reportable Quantities 40 Code of Federa] Regulations 302}

The regulations in 40 CFR 302 (EPA 199Ib) designate hazardous substances and fdentify reportab]e quantities and notification requirenents for releases of these hazardous substances under the Comprehensive Environmental Response, Compensation, and Liablitity ACt (CERCLA) of 1980 and the Safe Drinking Water Act, as amended.

Any unpermitted release of any of these designated hazardous substances must be reported. Therefore, if the possibility exists for a facility to release any of the designated substances, waste streams must be monitored for their presence and monitoring practices must be provided in a FEAP. 
WHC-EP-0468-3

\subsection{STATE REQULATIONS}

\subsubsection{Washington State Ambient Air Quality Standard and Enission Limits for Radionuclides WhC-173-480}

A7though the standard for Mashington (WAC 1986) establishes a 25 mrem/yr effect lve dose equivalent for public exposure to radionuclide emissions, facilities must comply with the most restrictive of federal, state or local law. Therefore, the exposure 1 imit that oust be complied with is $10 \mathrm{mrem} / \mathrm{yr}$; however, compliance is calculated at the point of maximum annual air concentration in an unrestricted area where any member of the public may be located (fence boundary).

\subsubsection{Groundwater Protection}

Radionuclides are defined as hazardous air pollutants, so they also will be construed to be hazardous in liquid effluent, without any specific listing of individua] radionuclides as a hazardous substance under water pollution control 1aws.

The Water Quality Standards for Groundwaters of the State of Washington (WAC 1987) protect groundwater to the level of drinking water standards. Thesese standards linit exposures to gross a]pha, gross beta, trititum, ${ }^{50} \mathrm{Sr}$, and $226,{ }^{228} \mathrm{Ra}$ (Table 3-2). For radionuclides that are not specifically 3 isted, exposures are 1 imited by the federal standard to an effective dose equivalent not to exceed $4 \mathrm{mren} / \mathrm{yr}$.

\subsubsection{Dangerous Waste Regulations}

Any release of a dangerous waste or hazardous substance [as designated by Washington (State) Administration Code (WAC) (UAC 1991a)] to the environment, except permitted releases, must be reported. Waste streams that have the potential to contain dangerous waste constituents must be monitored accordingly.

\subsection{LOCAL REGULATIOHS}

\subsubsection{Benton, Franklin, and Nalla Nalla counties Air Pollution Control Authority}

The local air pollution control authority has jurisdiction over all air exissions except radionuclide emissions in the Benton, Franklin, and Walla Walla county areas, including the Hanford 5tte. Currently, there are no local standards more restrictive than the prevfously mentloned state and federal linits; therefore state and federal standards apply. 
WHC-EP-0468-3

\subsection{AIR EnISSIOHS}

The DOE Order 5400.5 (DOE 1990a) provides requirements for the monitoring of radjoactive and nonradioactive afrborne effluents from DOE facilities at the Hanford Site. This order states that DOE-controlled facilities must comply with 40 CFR 61 (EPA 1991a).

Additional EPA requirements on hazardous substances are contained in 40 CFR Part 302.A. This regulation provides information on reportable quantities of nonradloactive hazardous substances. Unlisted hazardous substances destgnated by 40 CFR Part 302.4 are regulated in accordance with the EPA toxicity of the contaminant.

In Washington State, airborne effluents are regulated by the Departanent of Ecology through regulations in the WAC, Titie 173. Chapters 173-400 through 173-490, as amended, pursuant to the Washington Clean Air Act (RCH, Title 70, Public Health and Safety Chapter 94, as amended). General regulations for air pollution sources are presented in WAC 173-400, including emission standards for sources emitting hazardous air pollutants found in MAC 173-400-075.

The NAC 246-247, Radiation Protection Air Exissions (WAC 1991b), specifies new source review, notification, registration, and peraiting requirenents associated with any source of radioactive air emissions in Hashington State, including those on the Hanford Stte. One requirement listed in WAC 246-247 is the semiannual (twice yearly) reporting of emissions from each registered stack or vent on site. By agreement with the Washington State Department of Health, only annual reporting is required.

The NAC 173-480, Ambient Radionuelides (WAC 1991c), defines maximum allowable levels for radionuclides in the ambient air and defines required levels for control of emissions.

While both the WAC 246-247 and 173-480 1ist outdated maximum EDE standards, each contains a caveat stating that wore stringent federal standards take precedence over the EOE standard speciffed by the WAC. Therefore, each effectively endorses the 10 mrem/yr EDE standard of 40 CFR 61 , Subpart $H$.

In Washington State, airborne effluents are regulated by the Washington Clean Air Act of 1967. General regulations for air pollution sources are presented in WAC 173-400, including eaission standards for sources emitting hazardous air pol]utants in WAC 173-400-075. Hew sources for toxic air poltutants are presented in WAC 173-460. State regulations pertaining specifically to radioactive ajrborne effluents are found in WAC 246-247 and WAC 173-480, and are more restrjctive in wost cases than the Federal requjrements.

Regulations, including DOE orders, state that DOE facilities must comply with the requirements set forth in the Mational Erission Standards for Hazardous Air Pollutants (NESHAP), Other regulations [e.9., 40 CFR 52, "Approval and Promulgation of Implementation P1ans" (EPA 1991c); and DOE Orders 5400.1 (DOE 1991a), 5400.5 (DOE 1990a), DOE/EH-0173T (DOE 1991b), and 5484.1 (DOE 1983) state that DOE facilities must comply with the applicable requirements set forth in the Clear Air Act. 
NHC-EP-0468-3

\subsection{LIQUID EFFLUEHTS}

Requirenents 7 imfting the exposure of the pub]ic to radioactive materials frow DOE-controlled activities through the drinking water pathway are presented in DDE Order 5400.5, Chapter II, Paragraph 1.d. The radiological criterla of the pubjic community drinking water standards of 40 CFR Part 141, "Hational Interim Primary Drinking Nater Regulations" (EPA 1991d), are applicable to Stean and Water Utilities Operation 200 East and West Operations as the providers of potable water to the site under the Safe Orinking Water Act. It is the poi icy of DOE to provide an equivalent jevel of protection for all persons consuning water from a drinking water supply operated by, or for, the DOE. These systems shall not cause any persons consuming the water to receive an EDE greater than $4 \mathrm{mrem} / \mathrm{yr}$, excluding naturally occurring radionucildes. In addition, DOE facility operators shall ensure that the 1 iguid effluents from DOE activities shall not cause private or public drinking water systems downstream of the facility discharge to exceed the drinking water radiological limits of 40 CFR Part 141.

Depending on where a liquid effluent (waste water) is discharged, certain regulations apply. These regulations are implemented through issuance of permits by federal, state, and/or local agencies. It is the responsibility of the facility, through the Richiand Operations office (RL), to apply for the permit appropriate to the effluent being discharged. Before applying for any permits, the applicant nust knou the source of waste water discharges and where the waste water is being discharged to. The following regulations apply based on where the waste water is discharged.

1. The 40 CFR 261 (4) (b) (6) (EPA 1991b) provides a hazardous waste exclusion for fly ash, bottom ash, slag waste, and flue gas enissions control waste generated primarily from combustion of gas or other fossil fuel.

2. Washington State controls discharges to groundwater and surface water of the state, under WAC 173-216 (WAC 1991d), and issues peralts for such discharges. A permit of this type would be necessary for any discharges to land that could infi]trate to groundwater.

Each type of discharge permit identified will typically contain discharge 1 imitations and monitoring requirements. However, the limitations and monitoring requirements will vary depending on the source and type of waste water being discharged. For instance, discharges to a publicly owned treatment works will be subject to pretreatment standards based on the product ton process that generated the waste water for those processes categorized by the EPA. Categorical processes are identified in 40 CFR 401-471 (EPA 1991e). Specific limjtations, monitoring, and reporting requirements have been promulgated for each categorical process. In addition to EPA's requirements, the state and local waste water treatment agencies may inpose additional linitations, monitoring, and reporting requirements. 


\begin{tabular}{|c|c|c|c|c|c|c|}
\hline Ageney/orliginator & Regulation no. & HA & HL & An & $\mathbf{R L}$ & Sunnory/Apot laction \\
\hline \multirow{6}{*}{$\begin{array}{l}\text { W.s. Oeppartwent of } \\
\text { Energr (pos), } \\
\text { Washingtom, o.c. }\end{array}$} & 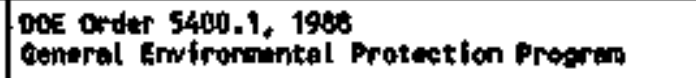 & $\mathbf{x}$ & $x$ & $\mathbf{x}$ & $\mathbf{x}$ & Outl ines effluent monit or ins requil tenente \\
\hline & $\begin{array}{l}\text { Dote Drder } 5400.5,1990 \\
\text { Rediation Protection of the Publ it and } \\
\text { Erwitrontent }\end{array}$ & & & $\mathbf{x}$ & $\mathbf{x}$ & 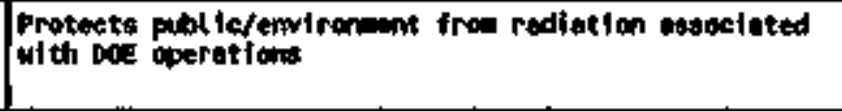 \\
\hline & 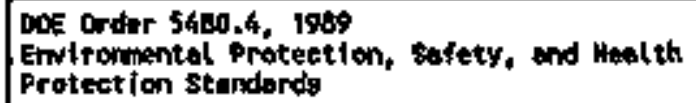 & $\mathbf{k}$ & $\mathbf{x}$ & $x$ & $\mathbf{x}$ & 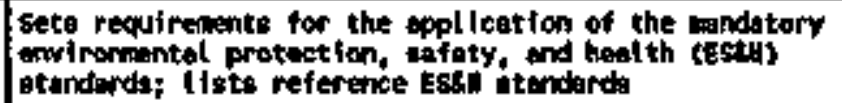 \\
\hline & 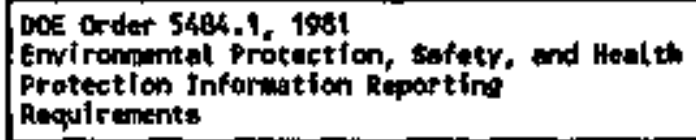 & $\mathbf{K}$ & $\mathbf{x}$ & $\mathbf{x}$ & $\mathbf{x}$ & 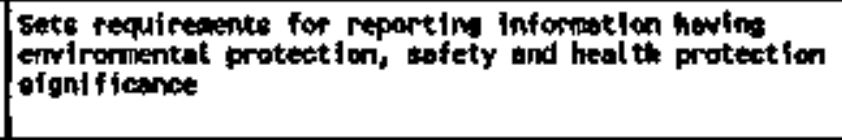 \\
\hline & 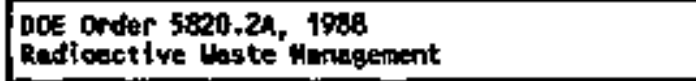 & $\mathbf{x}$ & $\mathbf{x}$ & $x$ & $\mathbf{x}$ & Seta rodioect ive waste manepenent requifrement" \\
\hline & 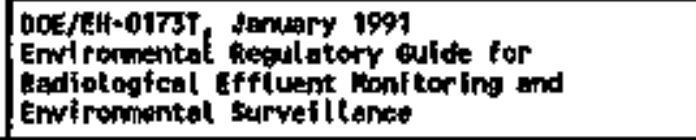 & & & $x$ & $x$ & Prowfdes gutidance for effluent salpling and aonitoring. \\
\hline \multirow[t]{6}{*}{ 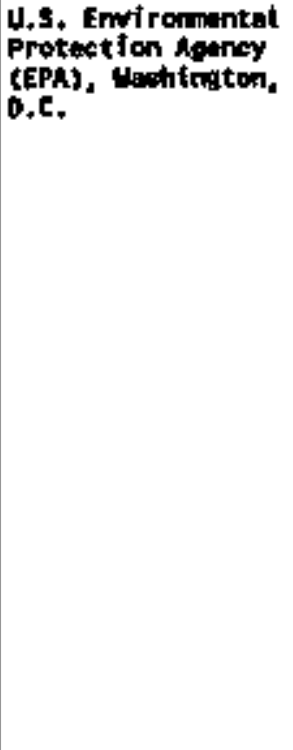 } & 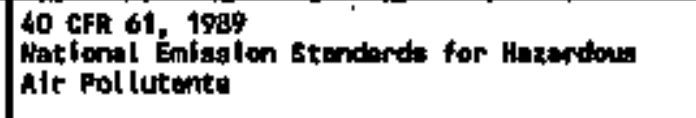 & $\mathbf{x}$ & & $x$ & & 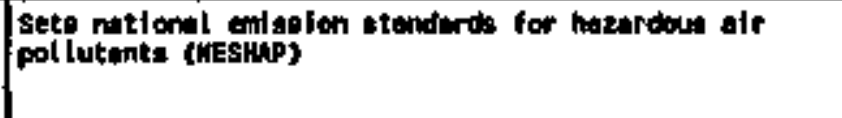 \\
\hline & $\begin{array}{l}40 \text { Cfr } 61.1989 \\
\text { abpert } \\
\text { emeral Provisions }\end{array}$ & $\mathbf{x}$ & & & & Regulates hazerdows pol lutente \\
\hline & 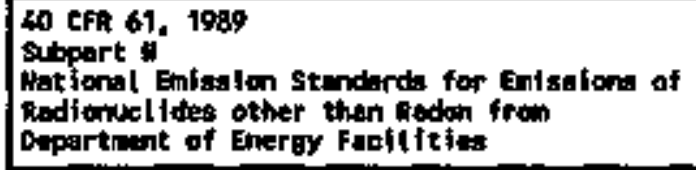 & & & $x$ & & 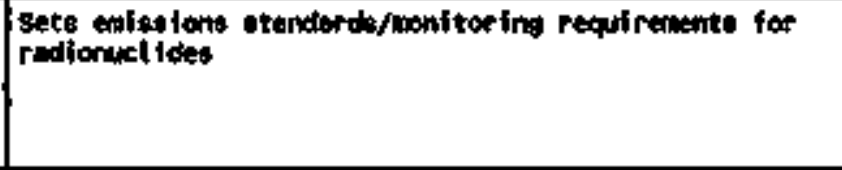 \\
\hline & $\begin{array}{l}40 \text { Cfk } 70 \\
\text { stete Operating Pevinis Prositan }\end{array}$ & k & & $x$ & & 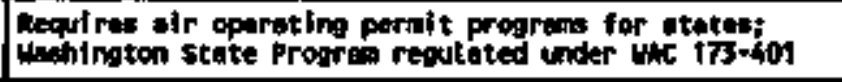 \\
\hline & 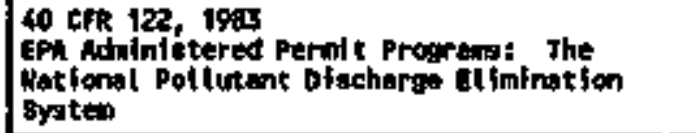 & & $\mathbf{x}$ & & & Coverna relesule of nonfedfoective (Iquids \\
\hline & 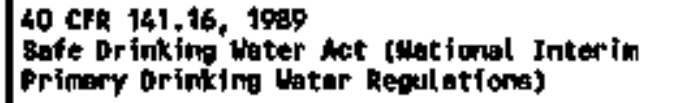 & & $x$ & & $x$ & sets mextanen conturinent lovele fn peblic water svatuma \\
\hline
\end{tabular}




\begin{tabular}{|c|c|c|c|c|c|c|}
\hline hency/oriotinator & Reeutution no. & *n & HL & $\mathbf{R A}$ & Rit. & Brrary/application \\
\hline \multirow[t]{5}{*}{ Eph (cont'd) } & 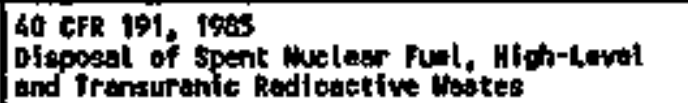 & & & & $\bar{x}$ & 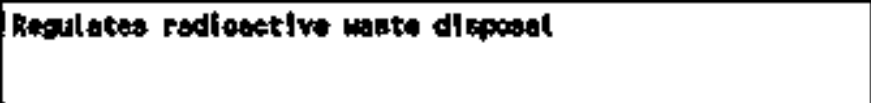 \\
\hline & 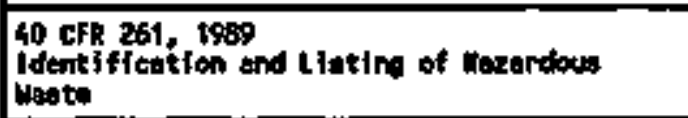 & & $\bar{x}$ & & & 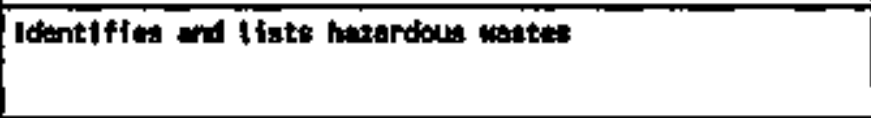 \\
\hline & 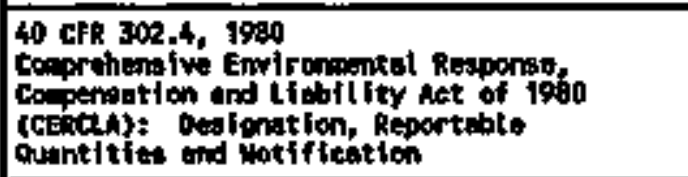 & $\bar{x}$ & $\mathbf{x}$ & $\mathbf{x}$ & $\bar{x}$ & 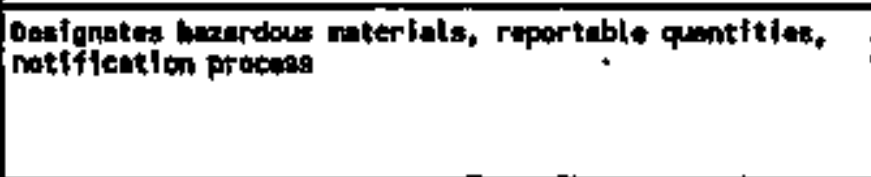 \\
\hline & 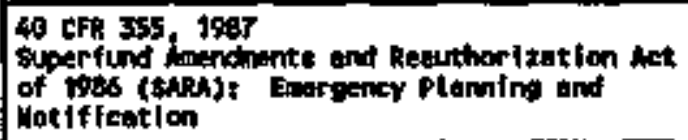 & $\mathbf{x}$ & $\mathbf{x}$ & & & 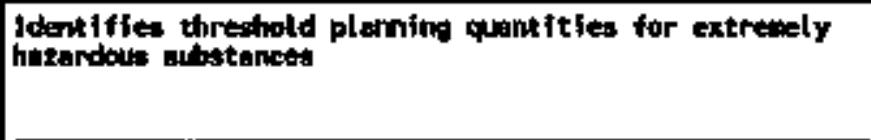 \\
\hline & $\begin{array}{l}40 \text { CFR } 403+471 \text { 1990 } \\
\text { Effluent euldel ines standerds }\end{array}$ & & $x$ & & & 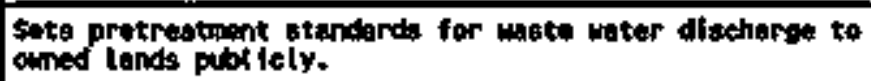 \\
\hline \multirow{2}{*}{ 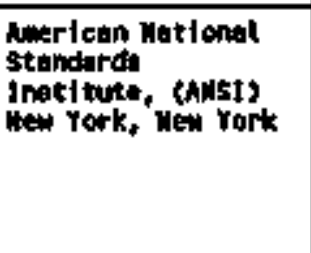 } & 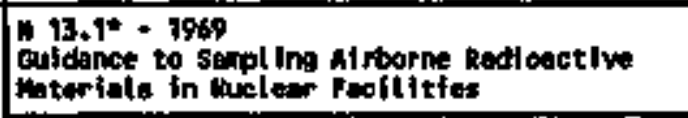 & & & $x$ & & Sets standard for effluent aonitoring ayotens \\
\hline & 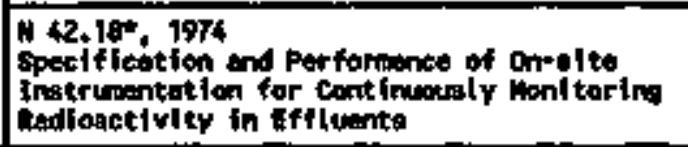 & & & $\bar{x}$ & $\bar{x}$ & 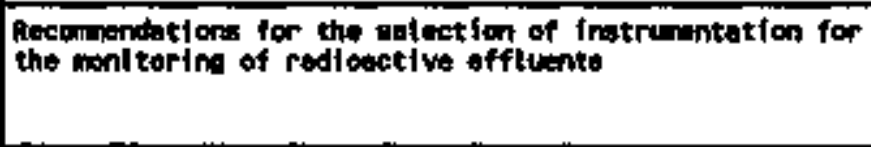 \\
\hline \multirow{6}{*}{$\begin{array}{l}\text { Wouhington state } \\
\text { Departinent of } \\
\text { Ecology, (Ecology) } \\
\text { olvipia, Weshington }\end{array}$} & 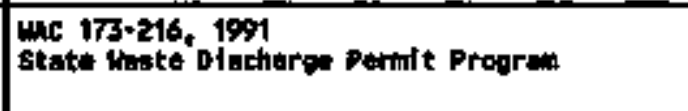 & & $x$ & & & Covertis discheroted to ground and surfece whters \\
\hline & 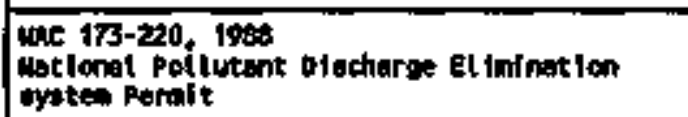 & & $x$ & & $\bar{x}$ & $\begin{array}{l}\text { Governs waste water of acharped to nevigoble woterwore; } \\
\text { controle woEs pernite process }\end{array}$ \\
\hline & 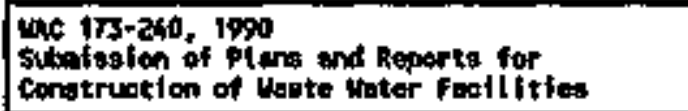 & & $\mathbf{x}$ & & & Controle release of montediouctive liquiti \\
\hline & 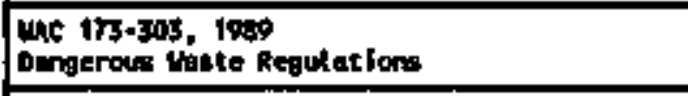 & & $\bar{x}$ & & & 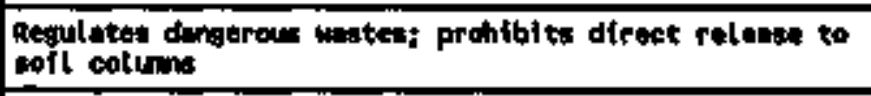 \\
\hline & $\begin{array}{l}\text { Whe } 173-400,1976 \\
\text { Generat Regulatione for Air Podlution } \\
\text { Sources }\end{array}$ & $\mathbf{x}$ & & & & Bete enferiona stundarda for hazandous ale potlutenks \\
\hline & $\begin{array}{l}\text { Whe 173-401 } \\
\text { Afr Opersetog Peralt Progren }\end{array}$ & $\bar{x}$ & & $x$ & & 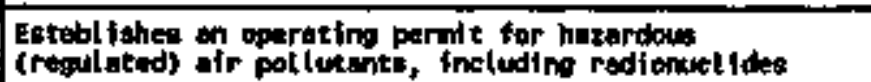 \\
\hline
\end{tabular}




\begin{tabular}{|c|c|c|c|c|c|c|}
\hline Mency/ortalnetor & Regulation no. & 唤 & II. & $\mathbf{R A}$ & 忮 & 8umery/Applteation \\
\hline \multirow[t]{2}{*}{ Ecoloor (Cont'd) } & $\begin{array}{l}\text { wac } 173-460,1991 \\
\text { Control for wen sources of Taxie Alr } \\
\text { Podtutents }\end{array}$ & $\mathbf{x}$ & & & & 5eto atendards for new sources of taps \\
\hline & 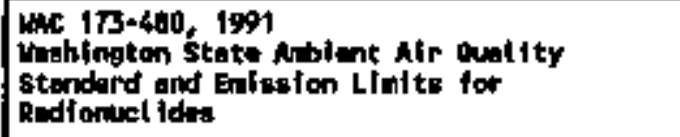 & $\mathbf{x}$ & & $\mathbf{x}$ & & 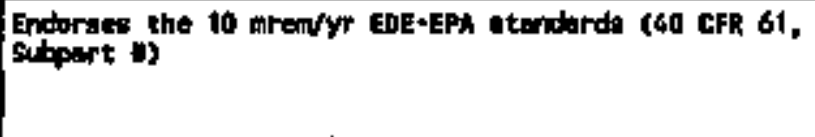 \\
\hline 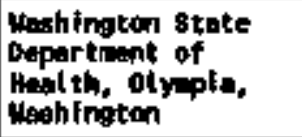 & $\begin{array}{l}\operatorname{lac} 246-247,1991 \\
\text { Redietion Protection - A1r Eniagiona }\end{array}$ & $\mathbf{x}$ & & $\mathbf{x}$ & & 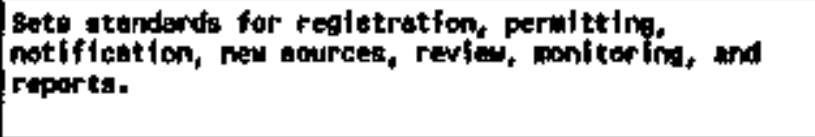 \\
\hline 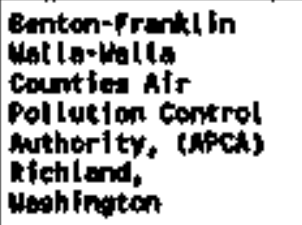 & teneral Regulation BD-7/Proposed Regulation & $\mathbf{x}$ & & & & Regulates afr qualfy \\
\hline \multicolumn{7}{|c|}{ 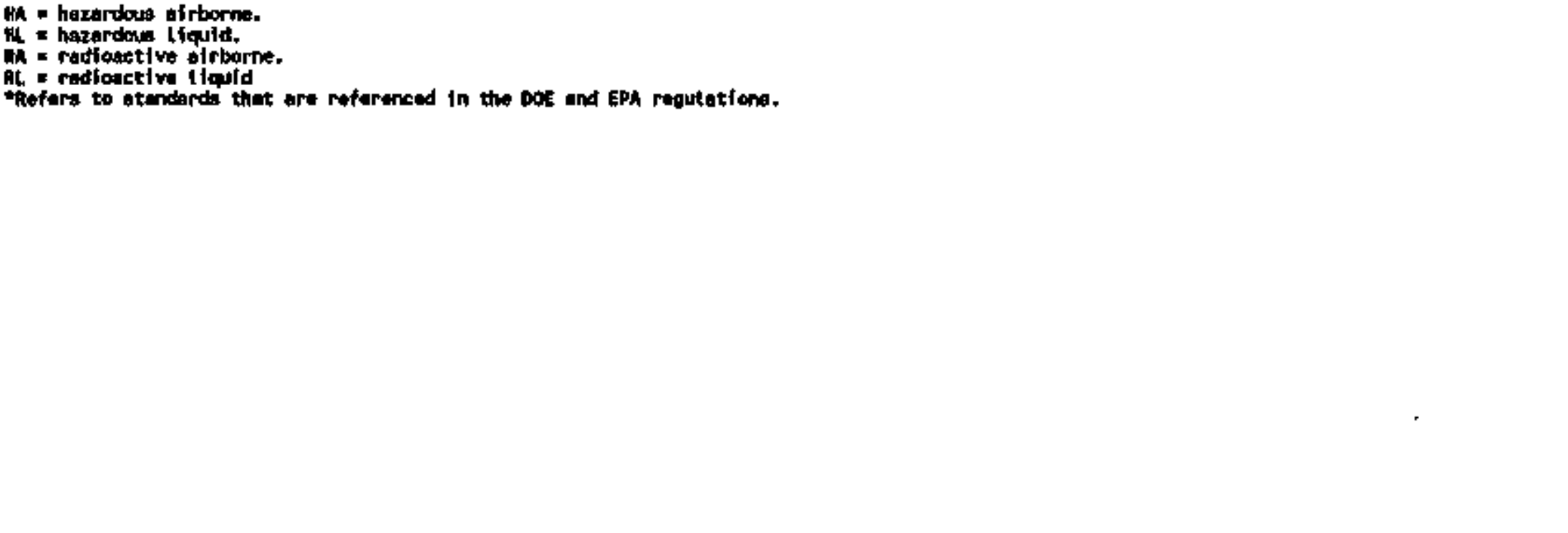 } \\
\hline
\end{tabular}


D1scharges to a navigable waterway al so will be subject to certain standards based on the industrial process that generated the waste water; certain additional 1 imitations are typically imposed in the Hational Pollutant Discharge Ei imination System (MPOES) permit. In ail cases, the specific pollutants to be ctonitored and the frequency of monttoring and reporting will be based on the applicable regulations and the language of the permit. 
Table 3-2. Groundwater Quality Criteria. (5 sheets) Contarlinant criterion

\begin{tabular}{|c|c|c|}
\hline Contasinant & \multicolumn{2}{|c|}{ Criterion } \\
\hline \multicolumn{3}{|c|}{ 1. Primary and Secondary Contaminants and Radionuclides } \\
\hline \multicolumn{3}{|c|}{ A. Primary Contaminants } \\
\hline Barjuma & 1.0 & $\mathrm{mg} / \mathrm{L}$ \\
\hline Cadmium" & 0.01 & $\mathrm{mg} / \mathrm{L}$ \\
\hline Chromitum" & 0.05 & $\mathrm{mg} / \mathrm{L}$ \\
\hline Lead" & 0.05 & $\overline{m g} / \mathrm{L}$ \\
\hline Mercury" & 0.002 & $\mathrm{mg} / \mathrm{L}$ \\
\hline Selen 1 un" & 0.01 & $\mathrm{mg} / \mathrm{L}$ \\
\hline Silver ${ }^{\mathrm{a}}$ & 0.05 & $\mathrm{mg} / \mathrm{L}$ \\
\hline Fluoride & 4 & $\mathrm{mg} / \mathrm{L}$ \\
\hline Nitrate (as $\mathrm{N}$ ) & 10 & $\mathrm{mg} / \mathrm{L}$ \\
\hline Endrin & 0.0002 & $\mathrm{mgg} / \mathrm{L}$ \\
\hline Kethoxych7or & 0.1 & $\mathrm{mg} / \mathrm{L}$ \\
\hline 1,1,1-Trich]oroethane & 0.20 & $\overline{m g} / \mathrm{L}$ \\
\hline $2-40$ & 0.10 & $m g / L$ \\
\hline $2,4,5-\mathrm{TP}$ Silvex & 0.01 & $\mathrm{mg} / \mathrm{L}$ \\
\hline Total Coliform Bacteria & $1 / 100$ & m \\
\hline \multicolumn{3}{|c|}{ B. Secondary Contaminants } \\
\hline Copper" & 1.0 & $\overline{\mathrm{mg}} / \mathrm{L}$ \\
\hline Iron" & 0.30 & $m g / L$ \\
\hline Manganese & 0.05 & $\mathrm{mg} / \mathrm{L}$ \\
\hline Z1nc & 5.0 & $\mathrm{mg} / \mathrm{L}$ \\
\hline Chloride & 250 & $\mathrm{mg} / \mathrm{L}$ \\
\hline Sulfate & 250 & $\mathrm{mg} / \mathrm{L}$ \\
\hline Total Dissolved Solids & 500 & $\mathrm{mg} / \mathrm{L}$ \\
\hline Foaming Agents & 0.5 & $\operatorname{mg} / \mathrm{l}$ \\
\hline $\mathrm{pH}$ & $6.5-8.5$ & \\
\hline Corrosivity & noncorrosive & \\
\hline
\end{tabular}


Table 3-2. Groundwater Qual ity Criterla. (5 sheets)

\begin{tabular}{|c|c|c|}
\hline Contaminant & \multicolumn{2}{|c|}{ Criterion } \\
\hline \multicolumn{3}{|c|}{ B. Secondary Contaminants (Cont'd) } \\
\hline Color & 15 color units & \\
\hline Odor & $\begin{array}{l}3 \text { threshold } \\
\text { odor units }\end{array}$ & \\
\hline \multicolumn{3}{|c|}{ C. Radionuclides } \\
\hline Gross Alpha Particle Activity & 15 & $\overline{\mathrm{pCi}} / \mathrm{L}$ \\
\hline \multicolumn{3}{|c|}{ Gross Beta Particle Radioactivity } \\
\hline Gross Beta Activity & 50 & $\mathrm{pCi} / \mathrm{L}$ \\
\hline Tritium & 20,000 & $\mathrm{pCj} / \mathrm{L}$ \\
\hline Stront fitm-90 & 8 & $\mathrm{pCi} / \mathrm{L}$ \\
\hline Radium $226 \& 228$ & 5 & $\mathrm{pCl} / \mathrm{L}$ \\
\hline Radium-226 & 3 & $\mathrm{DC} 1 / \mathrm{L}$ \\
\hline \multicolumn{3}{|c|}{ II. Carcinogens } \\
\hline Acryl amide & 0.02 & $\mu g / L$ \\
\hline Acrylonitrile & 0.07 & $\mu g / L$ \\
\hline Aldrin & 0.005 & $\mu g / L$ \\
\hline Antline & 14 & $\mu g / L$ \\
\hline Aramite & 3 & $\mu g / L$ \\
\hline Arsenic" & 0.05 & $\overline{\mu g / L}$ \\
\hline Azobenzene & 0.7 & $\mu / \mathrm{g} / \mathrm{L}$ \\
\hline Genzene & 1.0 & $\mu \mathrm{g} / \mathrm{L}$ \\
\hline Benzidine & 0.0004 & $\mu \mathrm{g} / 1$ \\
\hline Benzo (a)pyrene & 0.008 & $\mu \mathrm{g} / \mathrm{L}$ \\
\hline Benzotrichloride & 0.007 & $\mu g / L$ \\
\hline Benzy1 ch]oride & 0.5 & $\mu g / L$ \\
\hline Bis(chloroethyl)ether & 0.07 & $\mu g / L$ \\
\hline Bis(chloromethyl)ether & 0.0004 & $\mu g / L$ \\
\hline Bis(2-ethylhexyl) phtha] ate & 6.0 & $\mu \mathrm{g} / \mathrm{L}$ \\
\hline Bromodich loromethane & 0.3 & $\mu \mathrm{g} / \mathrm{L}$ \\
\hline Bromoform & 5 & $\mu g / L$ \\
\hline
\end{tabular}


Table 3-2. Groundwater Quality Criterla. (5 sheets)

\begin{tabular}{|c|c|c|}
\hline Contaminant & \multicolumn{2}{|c|}{ Criterion } \\
\hline \multicolumn{3}{|c|}{ II. Carcinogens (Cont'd) } \\
\hline Carbazo]e & 5 & $\mu \mathrm{g} / \mathrm{L}$ \\
\hline Carbon tetrachloride & 0.3 & $\mu g / L$ \\
\hline Chlordane & 0.06 & $\mu g / L$ \\
\hline Chlorodibromomethane & 0.5 & $\mu g / L$ \\
\hline Chloroform & 7.0 & $\mu \mathrm{g} / \mathrm{t}$ \\
\hline 4 Chloro-2-methyl antline & 0.1 & $\mu g / t$ \\
\hline 4 Chioro-2-methyl analine hydrochToride & 0.2 & $\mu g / L$ \\
\hline 0-Chloronitrobenzene & 3 & $\mu \mathrm{g} / \mathrm{L}$ \\
\hline p-Chloronttrobenzene & 5 & $\mu \mathrm{g} / \mathrm{L}$ \\
\hline Chlorthalonil & 30 & $\mu g / L$ \\
\hline Diallate & 1 & $\mu \mathrm{g} / \mathrm{t}$ \\
\hline DOT (includes DOE and COD) & 0.3 & $\mu \mathrm{gg} / \mathrm{L}$ \\
\hline 1,2 Dibromoethane & 0.001 & $\mu \mathrm{g} / \mathrm{L}$ \\
\hline 1,4 Dichlorobenzene & 4 & $\mu \mathrm{g} / \mathrm{L}$ \\
\hline 3,3' Dichlorobenz 1dine & 0.2 & $\mu \mathrm{g} / \mathrm{L}$ \\
\hline 1,1 Dichloroethane & 1.0 & $\mu \mathrm{g} / \mathrm{L}$ \\
\hline 1,2 Dichloroethane (ethylene chloride) & 0.5 & $\mu g / L$ \\
\hline 1,2 Dichloropropane & 0.6 & $\mu \mathrm{g} / \mathrm{L}$ \\
\hline 1,3 Dichloropropene & 0.2 & $\mu g / \mathrm{L}$ \\
\hline Dichlorvos & 0.3 & $\mu \mathrm{g} / \mathrm{L}$ \\
\hline Dieldrin & 0.005 & $\mu g / L$ \\
\hline 3,3' Dimethoxybenzidine & 6 & $\mu g / L$ \\
\hline 3,3 Dimethylbenzidine & 0.007 & $\mu g / L$ \\
\hline 1,2 Dimethylhydrazine & 60 & $\mu g / L$ \\
\hline 2,4 Dinitrotoluene & 0.1 & $\mu \mathrm{g} / \mathrm{L}$ \\
\hline 2,6 Dinitrotoluene & 0.1 & $\mu g / L$ \\
\hline 1,4 Dioxane & 7.0 & $\mu \mathrm{g} / \mathrm{L}$ \\
\hline 1,2 Diphenylhydrazine & 0.09 & $\mu \mathrm{g} / \mathrm{L}$ \\
\hline Direct Black 38 & 0.009 & $\mu \mathrm{g} / \mathrm{L}$ \\
\hline
\end{tabular}


Table 3-2. Groundwater Quality Criteria.. (5 sheets)

\begin{tabular}{|c|c|c|}
\hline Contamfnant & \multicolumn{2}{|c|}{ Criterion } \\
\hline \multicolumn{3}{|c|}{ II. Carcinogens (Cont'd) } \\
\hline Direct Blue 6 & 0.009 & $\mu g / L$ \\
\hline Direct Brown 95 & 0.009 & $\mu g / L$ \\
\hline Epichlorohydrin & 8 & $\mu \mathrm{g} / \mathrm{L}$ \\
\hline Ethyl acrylate & 2 & $\mu \mathrm{gg} / \mathrm{L}$ \\
\hline Ethylene dibraside & 0.001 & $\mu g / L$ \\
\hline Ethylene thiourea & 2 & $\mu g / L$ \\
\hline Folpet & 20 & $\mu \mathrm{g} / \mathrm{L}$ \\
\hline Furazoitidone & 0.02 & $\mu \mathrm{g} / \mathrm{L}$ \\
\hline Furium & 0.002 & $\mu \mathrm{g} / \mathrm{L}$ \\
\hline Furmecyclox & 3 & $\mu \mathrm{g} / \mathrm{L}$ \\
\hline Heptachlor & 0.02 & $\mu g / L$ \\
\hline Heptachlor Epoxide & 0.009 & $\mu g / L$ \\
\hline Hexachlorobenzene & 0.05 & $\mu \mathrm{g} / \mathrm{L}$ \\
\hline Hexachlorocyclohexane (alpha) & 0.001 & $\mu g / L$ \\
\hline Hexachlorocyclohexane (technical) & 0.05 & $\mu \mathrm{g} / \mathrm{L}$ \\
\hline Hexachlorodibenzo-p-dioxin, mix & 0.00001 & $\mu \mathrm{g} / \mathrm{L}$ \\
\hline Hydrazine/Hydrazine sulfate & 0.03 & $\mu g / L$ \\
\hline Lindane & 0.06 & $\mu g / L$ \\
\hline 2 Methoxy-5-nitroaniline & 2 & $\mu \mathrm{g} / \mathrm{L}$ \\
\hline 2 Wethylaniline & 0.2 & $\mu g / L$ \\
\hline 2 Methylanil ine hydrochloride & 0.5 & $\mu \mathrm{g} / \mathrm{L}$ \\
\hline 4,4' Nethylene bis(N,N'- dimethyl) aniline & 2 & $\mu g / L$ \\
\hline Wethylene chloride (dichloromethane) & 5 & $\mu g / L$ \\
\hline Mirex & 0.05 & $\mu g / L$ \\
\hline Nitrofurazone & 0.06 & $\mu g / L$ \\
\hline N-Nitrosodiethanolamine & 0.03 & $\mu g / L$ \\
\hline N-Nitrosodiethyl amine & 0.0005 & $\mu g / L$ \\
\hline N-Nitrosodimethi anine & 0.002 & $\mu \mathrm{g} / \mathrm{L}$ \\
\hline
\end{tabular}


Table 3-2. Groundwater quality Criterta. (5 sheets)

\begin{tabular}{|c|c|c|}
\hline Contapinant & \multicolumn{2}{|c|}{ Criterion } \\
\hline N-Nitrosodipheny? amine & 17 & $\mu \mathrm{g} / \mathrm{L}$ \\
\hline N-Nitroso-di-n-propylamine & 0.01 & $\mu \mathrm{g} / \mathrm{L}$ \\
\hline N-Nitrosopyrrolidfne & $0 . \overline{04}$ & $\mu \mathrm{g} / \mathrm{L}$ \\
\hline N-Nitroso-di-n-butyl amine & 0.02 & $\mu \mathrm{g} / \mathrm{L}$ \\
\hline N-Nitroso-N-methylethylamine & 0.004 & $\mu g / L$ \\
\hline Polyaromatic Hydrocarbons (PAH) & $0 . \overline{01}$ & $\mu g / L$ \\
\hline Polybrominated Biphenyls (PBBs) & 0.01 & $\mu g / L$ \\
\hline Polychlorinated Biphenyls (PCBs) & $\overline{0.01}$ & $\mu \mathrm{g} / \mathrm{L}$ \\
\hline o-Phenylened I anine & 0.005 & $\mu \mathrm{g} / \mathrm{L}$ \\
\hline Propylene oxide & 0.01 & $\mu g / L$ \\
\hline $2,3,7,8$-Tetrachlorodibenzo-p-dioxin & 0.0000006 & $\mu g / 1$ \\
\hline Tetrachloroethylene (perchloroethylene) & 0.8 & $\mu g / L$ \\
\hline$p, \alpha, \alpha, \alpha$-Tetrachlorotoluene & 0.004 & $\mu \mathrm{g} / \mathrm{L}$ \\
\hline 2,4 Toluenediamine & 0.002 & $\mu \mathrm{gg} / \mathrm{L}$ \\
\hline 0-Toluldine & 0.2 & $\mu g / L$ \\
\hline Toxaphene & 0.08 & $\mu g / L$ \\
\hline Trichloroethylene & 3 & $\mu \mathrm{\mu g} / \mathrm{L}$ \\
\hline 2,4,6-Trich Torophenol & 4 & $\mu \mathrm{gg} / \mathrm{L}$ \\
\hline Trimethyl phosphate & 2 & $\mu g / L$ \\
\hline Vinyl chloride & 0.02 & $\mu g / \mathrm{L}$ \\
\hline
\end{tabular}

Metals are measured as total metals. $\mathrm{mg} / \mathrm{L}$ - milligrams/liter.

oll - millititer

$\mathrm{pCi} / 1$ - pico Curie/liter.

$\mu g / L=$ micrograms/liter. 


\subsection{IDENTIFICATIOH/CHARACTERIZATION OF EFFLUEMT STREANS}

This section addresses the chemical and radiological composition of PUREX effluents. A description of the gaseous effluents is followed by a brief discussion of their routine and upset operating condjtions. Water effiuents are $s$ imilarly described.

\subsection{IDENTIFICATIOH/CHARACTERIZATIOH OF SOURCE TERHS CONTRIBUTION TO EACH AIR EFFLUENT STREAS}

The PUREX Plant has 10 sources of major a1r effluent streams with a potential for contamination. Characterization of the effluents is based on 1993 concentration and flow data. These are representative of standby or transition to shutdown conditions. The characterizations that follow are taken frow the Effluent Monitoring Plan PUREX Gaseous Effluents (UHC 1988a).

\section{1-A-1 - Main Buflding Exhaust Stack}

The point of discharge is a 61 mit (200 ft) tall stack, located south of the PUREX building. In 1993 , the typical flow rate was between 40 and $64 \mathrm{~m}^{3} / \mathrm{s}$ $\left(83,900\right.$ and $\left.137,000 \mathrm{ft}^{3} / \mathrm{min}\right)$; the average flow rate was $49 \mathrm{~m}^{3} / \mathrm{s}$ (104,000 $\mathrm{ft}^{3} / \mathrm{min}$ ). In 1993, the exhaust contained on the average $1.1 \times 10^{-12} \mu \mathrm{Ci} / \mathrm{mL}$ radioactivity. During the current transition to shutdown, flow rates are typically $100,000 \mathrm{ft}^{3} / \mathrm{min}$.

During 1985 and 1986 the annual releases of Ho, from the main stack were 168 and 147 metric tons (185 and 162 tons), respect 1 vely. This was well below the 395 metric tons (424 tons) permitted by the Prevention of Significant Deterioration (PSD) permit.

\section{6-A-1 - Product Removal Room Exhaust}

The point of discharge for the exhaust from PR roof and hoods, Q-cell rooms and hoods, Np loadout hoods, and $\mathrm{H}-\mathrm{C}$ e.7 hoods, is Stack 296-A-1. It is located on the north side of the northwest corner of the PUREX building. Its height is $23 \mathrm{~m}(74 \mathrm{ft})$ above grade.

The 296-A-1 Stack had an guerage flow of $2.4 \mathrm{~m}^{3} / \mathrm{s}\left(5,030 \mathrm{ft}^{3} / \mathrm{min}\right)$. The range of flow was 1,7 to $3.3 \mathrm{~m}^{3} / \mathrm{s}\left(3,600\right.$ to $\left.7,050 \mathrm{ft}^{3} / \mathrm{min}\right)$. The exhaust. contafned $3.9 \times 10^{-14} \mu \mathrm{Ci} / \mathrm{mL}$ of radioactivity during 1993 .

\section{6-A-2 - Nest Sanple Gallery Hood Exhaust}

The 296-A-2 Stack exhausts the hoods in the west half of the PUREX sample gallery. It is located at the southwest corner of the PUREX building. Its height is $24 \mathrm{~m}(78 \mathrm{ft})$ above grade. 
The 296-A-2 Stack had an average flow of $2.2 \mathrm{~m}^{3} / \mathrm{s}\left(4,700 \mathrm{ft}^{3} / \mathrm{min}\right)$. The range of flow is 1.9 to $2.8 \mathrm{~m}^{3} / \mathrm{s}\left(3,900\right.$ to $\left.5,900 \mathrm{ft}^{3} / \mathrm{min}\right)$. The exhaust contained no radioactivity detectable above background based on data from 1993.

\section{6-A-3 - East Sample Hood Exhaust}

The 296-A-3 Stack exhausts the hoods in the east half of the PUREX sample gallery. It is located at the northeast corner of the 202-A Building and its height above grade is 23 on $(74 \mathrm{ft})$.

Average flow for this stack was $1.3 \mathrm{~m}^{3} / \mathrm{s}\left(2,840 \mathrm{ft}^{3} / \mathrm{min}\right)$, while the range was 0.08 to $2.0 \mathrm{~m}^{3} / \mathrm{s}\left(166\right.$ to $\left.4,210 \mathrm{ft}^{3} / \mathrm{min}\right)$. The exhaust contained no radioactivity detectable above background based on 1993 data.

296-A-5A and 296-A-58 - Uest and East Anatytical Laboratory Exhausts

Stacks 296-A-5A and 296-A-5B alternate weekly in exhausting the PUREX analytical laboratory. The stacks are located on the north side of the 202-A Building above the analytical laboratory. Their heights are $27 \mathrm{~m}$ (89 ft) above grade.

The flow through Stacks 296-A-5A and 296-A-5B normally ranges from 4.2 to $8.8 \mathrm{~m}^{3} / \mathrm{s}\left(9,000\right.$ to $\left.18,600 \mathrm{ft}^{3} / \mathrm{min}\right)$. Their average flow rate was $8.6 \mathrm{f}^{3} / \mathrm{sec}$ $\left(18,360 \mathrm{ft}^{3} /\right.$ min). The exhaust from Stack $296-\mathrm{A}-5 \mathrm{~A}$ had an activity of $6.5 \mathrm{E}-16 \mathrm{\mu Ci} / \mathrm{mL}$, and stack 296-A-5B had an activity of $1.7 \mathrm{E}-16 \mathrm{NC} / \mathrm{aL}$ based on 1993 data. The combined average was $4.1 \mathrm{E}-16 \mu \mathrm{t} / \mathrm{mL}$.

\section{6-A-6 - East Sample Gallery and U-Cell Stack}

The 296-A-6 Stack is located on the north side of the 202-A Building near the east corner. The stack extends $3.0 \mathrm{~m}$ (10 ft) above the top of the building. Its hejght is $22.6 \mathrm{~m}$ (74 ft) above grade level. The 296-A-6 Stack exhausts the east half of the sample gallery and $U$ Cell (nitric acid recovery ce11).

The 296-A-6 Stack had an average flow of $6.0 \mathrm{~m}^{3} / \mathrm{s}\left(12,800 \mathrm{ft}^{3} /\right.$ min). The range of fior was 5.3 to $7.3 \mathrm{~m}^{3} / \mathrm{s}\left(11,200\right.$ to $\left.15,500 \mathrm{ft}^{3} / \mathrm{min}\right)$. The exhaust. contained no radioactivity detectable above background according to data from 1993.

\section{6-A-7 - Nest Sample Gallery and R-Cel1 Exhatust}

The 296-A-7 Stack is 1ocated on the west wall of the 202-A Building near the southwest corner. The height of the stack is $23 \mathrm{~m}(74 \mathrm{ft}$ ) above grade [3 m (10 ft) above the top of the building]. It exhausts the west half of the sample gajlery and $R-C e l l$ (second cycle solvent treatient). 
The 296-A-7 Stack had an average flow of $8.5 \mathrm{~m}^{3} / \mathrm{s}\left(18,000 \mathrm{ft}^{3} / \mathrm{min}\right)$, with a range of 8.0 to $9.2 \mathrm{~m}^{3} / \mathrm{s}\left(16,900\right.$ to $\left.19,400 \mathrm{ft}^{3} / \mathrm{min}^{3}\right)$. The exhaust contatned no radioactivity detectable above background based on data from 1993.

\section{6-A-B - Whtte Room Exhaust.}

The 296-A-8 Stack is located at the northwest corner of the 202-A Bujlding. It extends to $10.4 \mathrm{~m}$ (34 ft) above grade leve1. This stack exhausts the west end of the P\&O Gallery.

The 296-A-8 stack had an average flow of $4.3 \mathrm{~m}^{3} / \mathrm{s}\left(9,060 \mathrm{ft}^{3} / \mathrm{min}\right)$. The range of flow was 3.4 to $5.0 \mathrm{~m}^{3} / \mathrm{s}\left(7,290\right.$ to $\left.10,500 \mathrm{ft}^{3} / \mathrm{min}\right)$. The exhaust contained no radioactivity detectable above background based on data fron 1993.

\section{6-A-10 - Storage Tunnel Mo. 2 Exhaust}

The 296-A-10 stack is located about $640 \mathrm{~m}(2,100 \mathrm{ft})$ south of the 202-A Building. It is $6 \mathrm{w}(20 \mathrm{ft}) \mathrm{high}$. This stack exhausts the used equipment storage tunnel.

The 296-A-10 Stack had an average flow of $2.6 \mathrm{~m}^{3} / \mathrm{s}\left(5,550 \mathrm{ft}^{3} / \mathrm{min}\right)$. The exhaust contained no radioactivity detectable above background based on 1993 data.

\section{6-A-14 - Back-up Facility Exhaust (Building 299-A)}

The 293-A Building exhaust fan is located on the mezzanine roof. The stack rises $3 \mathrm{~m}$ (10 ft) above the top of the 293-A Bui]ding for a stack height of $7.47 \mathrm{~m} \mathrm{(24} \mathrm{ft} 6 \mathrm{fn}$ ). The 296-A-14 Stack exhausts the 293-A Building, which contains two absorption columns that recovered nitric acid from the dissolver off-gases. The dissolvers are not in operation.

Flow through the 296-A-14 stack averaged $2.3 \mathrm{~m}^{3} / \mathrm{s}\left(4,920 \mathrm{ft}^{3} / \mathrm{min}\right)$. The exhaust contained no radioactivity detectable above background based on 1993 data.

\subsubsection{Rourtine Operations}

The ventilation systems will continue to exhaust the sane areas of the PUREX Plant as described in Chapter 2.0. However, since the PUREX P] ant has been shutdom (i.e., no processing), the source radionuclides that might be vented have been reduced, and the effluent concentrations are expected to continue to decrease.

\subsubsection{Upsot Oporating Conditions}

The Effluent Monftoring Plan for PUREX Gaspous Effluents, (WHC 1988a) describes upset conditions for each stack. However, these conditions are based upon the PUREX process being active in the plant and are therefore no longer applicable. In the shutdown wode, upset operating conditions could 
WHC-EP-0468-3

involve fatlure of a single engineered barrier, which is taken to be a faiture of the HEPA filtration. Filtration is provided for all of the gas streams. A HEPA filter faiture is modeled in Section 4.1.3.2.

\subsubsection{Dispersion Modeling}

Only radiological emissions are present in the PUREX air effluent during the transition to shutdown mode of operation. The CAP-88 computer code calculates dose commitnents that result from the air transport of radionuclides released from the effluent discharge points above the PUREX Plant.

CAP-8g is approved by the EPA for denonstrating compliance with the NESHAPs (EPA 199la) standard for radiological releases. CAP-Be computes the radiation exposure to the maximally exposed individual (MEI) via the ingestion, inhalation, air-jumersion (exposure resulting from being inside plune of radiation), and groundshine (exposure resulting from deposited radioactive particles) pathways. CAP-88 incorporates dose conversion factors from the International Commission on Radiologica] Protection (ICRP) 26/30 methodology. Resulting doses are a 50-year cominitted effective dose equivalent. The magnitude of exposure via any of the aforementioned pathways is strongly rejated to the distance between the source and receptor.

CAP-8B utilizes a Gaussian plume methodology for dispersing air contaninants to downwind locations. Because of the low temperatures of the PUREX stacks, CAP-8B calculates pluie rise solely from stack exhaust momentum. During transport, the plume undergoes a reduction in air concentration, not only through dispersion, but also from plume depletion processes.

These processes include radioactive decay, precipitation, scavenging, and dry deposition. Because of the long hajf-jives of the radionuclides released and the relatively dry clinate in eastern Washington State, only the dry deposition renoval process has an appreciable effect on the resulting downind air concentration.

A total of 11 air effluent stacks contribute nearly all of the airborne radionuclide releases from the PUREX Plant (WHC 1988a). Each stack possesses its own unique stack characteristics, including stack height above the ground, stack diameter, and exhaust velocity or flow rate. Stack characteristics are used to assess the plume rise and deternine the final height of release of the plume. Air effluents are released at room temperature; as such, plume rises are not thermally driven. Table 4-1 summarizes the characteristics of the 11 PUREX exhaust stacks.

The emission points used for modeling purposes are centered on each of the major Hanford site operating areas that released radionuclides to the atmosphere. For the PUREX Facility, located in the 200 East Area, the reference point was the meteorology tower located approximately midway between the 200 East and 200 West Areas. This location was chosen to represent emissions from the 200 Areas because it lies between two major groups of 
facllities that account for the bulk of stack releases. A farm at Ringold, Washington, was determined to be the best location to use in the compliance analysis. Table 4-2 (WHC-EP-0498, 1991) shows the 200 East Area unit dose conversion factors for the Offsite Hypothetical HEI used to calculate the EDE.

4.1.3.1 Routine Release Dose Assessment. During normal operations in shutdown mode at.PUREX, only sma11 quantities of radionucl ides are released from the exhaust stacks (Tables 4-3 and 4-4). The maximally exposed individual used for the Hanford Site dose calculations is located approximately $16 \mathrm{ka}$ (10 ii) East of the PUREX Facility, based on a hypothetical release point at the Hanford Meterology Station.

An effective dose equivalent of 0.001 mrem was assessed for the MEI location as a result of releases from all ten operating PUREX stacks. This total dose is well below the EPA annual dose criterion (EPA 1991a) of 10 mrem to the MEI via the air pathway. This total dose is intended to be used for total-facility, emission-compliance purposes but not for monltoring requirements.

Table 4-5 summarizes the individual stack contributions to the MEI dose from each PUREX stack. As noted in Table 4-5, any stack with an individual dose greater than the EPA standard of $0.1 \mathrm{mrem} / \mathrm{yr}$ (1 percent of $10 \mathrm{mrem} / \mathrm{yr}$ ) is required to have "continuous radiation monitoring." This continuous radiation monitoring is an EPA designation but is futly met by continuous saapling with periodic analysis. The greatest dose from any PUREX stack effluent is from the main stack (291-A-1), which independently contributes a dose of $0.001 \mathrm{mrem}$ to the MEI. This dose is well below the 0.1 mrem annual dose standard.

The MEI dose resulted primarily from the ingestion and inhalation of ${ }^{129} \mathrm{I}$ that originated from the canyon exhaust stack (29l-A-1) at PUREX. Because all stack doses are below the 0.1 men annual dose standard, specific radionuclide analysis is not required.

4.1.3.2 Upset Release Dose Assessment. Applicable EPA regulations (EPA 1991a) require that a dose to the MEI be calculated from an unmitigated release. An unwitigated release occurs in the case of an upset in which all air pollution control equipment fails (or is considered to have been removed). At PUREX, this means a dose that results from the unfi]tered flaw from each of the stack effluents described in Table 4-6. Monitoring of the effluent stream is not ade upstream of the HEPA filters. Consequently, the increase in effluent radionuclides due to filter removal is based on an evaluation of fitter efficiencies and the particulate removal processes.

Stack 291-A-1 (the min stack) and Stack 296-A-1 exhaust through several stages of HEPA filters. The remaining stacks utilize a single stage of HEPA filtration. A conservative increase in particulate effluent due to filter removal is $3.0 \times 10^{3}$ for those stacks. With concurrence from EPA, this single factor was used for particulate removat efficiency for all stacks.

The lodine enission control equipment, the silver reactors of the dissolver offgas systew, are neither needed nor in service during the transition to shutdown. Since there is no increase in radioactive iodine emissions due to bypass of pollution control equipment, the unmitigated 
release factor is 1.0. There is no effective pol]ution controt equipment for the other volatile emissions (tritium and ${ }^{14} \mathrm{C}$ ), so their unmitigated release factors are also 1.0 .

The dose calculated for the MEI is directly proportional to the amount of radioactive material released. Because all particulate releases are increased by the same amount in a given stack, the resulting unmitigated dose is the MEI dose increased by a unitigated release factor of $3.0 \times 10^{3}$ for particulates and 1.0 for volatiles.

Table 4-6 sunmarizes the contributions to the unmitigated MEI dose from each PUREX stack during transition to shuttown. As noted in Table 4-6, any stack with an individual annual dose greater than the EPA standard of $0.1 \mathrm{mrem} / \mathrm{yr}$ is required to have a minimum of continuous sampling and subsequent analysis. The main stack and product removal (PR) stack (296-A-1) both have potential unmitigated dose consequences that are in excess of this standard.

The unmitigated MEI dose would result priwarily from the ingestion and inhalation of "'Am originating from the main stack at PUREX. The unmitigated MEI dose from the PR stack woutd result primarily from the ingestion and tnhalation of "'Am and ${ }^{m, 20} \mathrm{Pu}$. Table 4-7 sumarizes the most significant radionuclides and their dose contributions to the MEI. Any radionuclide that contributes 10 percent of the dose from a release point which could exceed the EPA annual dose standard of .1 mrem must be measured. One radionuclide from the main stack ("'Am) and two radionuclides from the $P R$ stack ("'Am and "mosto exceed this standard and will require measurement. Air monjtoring requirements are dtscussed in more detail in Section 7.1 .

\subsection{IDENTIFICATION/CHARACTERIZATION OF SOURCE TERHS CONTRIBUTING TO ERCH LIQUID EFFLUENT STREAN}

PUREX water effluents are described id detail in a series of streamspecific reports (WHC 1990a), which describe PUREX Tiquid effluents during operating mode. The points of discharge and coatositions for the CSL are given in Table 4-8. The composition data given in Table 4-8 are for the upper fimits of the 90 percent confidence interval as given in the stream-specific reports. These compositions are higher than anticipated for transition to shutdown conditions. Table 4-8 also indicates the average flow rate, point of discharge and stream-specific report number for each stream.

The following sections describe the only remaining liquid effluent from the PUREX Plant, the CSL.

\subsubsection{Routine operating Conditions}

The CSL collects waste water from the nonradiologically controlled service areas of the PUREX Plant (the 202-A Building and supporting facilities). Most of these streams are essentially clean, consisting of steam condensate from ventilation air heaters, water cooler drains, shower drains, 
and assorted floor drains. The floor drains, especially in the Pto gallery, AlU, and 211-A Building, have a potential for chemical contamination

(Figure 4-1).

The water in the streams which contribute to the CSL originates in three utilities provided to the PUREX Plant. by the powerhouse: raw water, sanitary water, and steam: During operation, the PUREX Plant generates a fourth ut 11 ity, demineralized water, which contributes slightly to the CSL. The schenatic flow diagran of the CSL is shown in Figure 4-1.

Untreated Colunbla River water is referred to as raw water. It is used in cooling process vessels and as a source for other water utility streams. Raw water way contain sone corrosion products from the piping used in its transport.

Sanitary water (potabie water) is obtained from raw water via a two stage process. First, particulates are settled and removed, with the help of aluminum sulfate (alum). Second, bacteria and organic debris are oxidized by the addition of chlorine. Consequently, sanitary water contains elevated levets of aluainum, sulfate, chloride, hypochlorite, carbonate, and organic chlorides, such as trichloronethane (chloroform).

The powerhouse produces stean by bolling stean make-up water, derived from sanitary water. The stean make-up water is first softened to replace caicium and magnesium ions with sodium ions. Additionally, hypochlorite is reduced to chloride and corrosion jnhibjtors are added. Of these corrosion inhibitors, Filmeen* contains volatile substances that can be carried over into the steam. According to the manufacturer, Filmeen contains both fatty amines and organic acids. The material safety data sheet (MSDS) for this product does not list chenical ingredients. It does, however, state that the product does not contain EPA hazardous constituents.

The following contribute to the PUREX Plant CSL waste stream (Figure 4-2).

- Floor drains in the 202-A P\&O gallery conly if diverted to PUREX Plant CSL from their normal routing to storage tanks in U-cell and to the $F$-cell sump). The routing of the P\&O Gallery floor drains to the CSL is a dinor modification to the normal configuration used for housekeeping. This modification adds 200 East Area raw water and dirt that has been tracked into the building from outside.

- The 618-1 and 618-2 flash tanks contain spray water and steam condensate from stean traps located in the P\&O gallery and the AMU. The 618-1 flash tank is outside the 202-A Building near the east end of the facility. The 618-2 flash tank is in the AMU.

* Filmeen 1s a trademark of Dearborn, a dfvision of W. R. Grace Co. 
- Cooling water from the three fractionator condensers and steam condensate from the fractionator reboiter in the 206-A Building. When the PUREX Plant is processing, this contributor accounts for most of the CSL flow. During transition to shutdown there is no effluent from this contributor.

- The sink drain from the battery roon, and the floor. and sink drains from the instrument shop and maintenance shop in the 202-A building. Westinghouse Hanford has an aggresstve prograta to prevent the improper disposal of dangerous wastes generated in these areas.

- Drains frow nonradioactive clothing changeroons in the PUREX Plant Taboratory (202-A Building).

- Shower drains from the two shower rooms. In addition to sanitary water, these drains contribute dirt washed from personnel and surfactants.

- Alr scrubber eff]uent from the ventilation air supply systems in the 202-A Building.

- Laboratory and process water stills condensate and still bottoms in the 202-A Bullding.

- Floor arains from the air compressor, process blower, and service blower rooms in the 202-A Bujiding.

- Cooling water and condensate from the air compressors. Fhis cooling water is normalily provided by the santtary water system. Raw water can also be used.

- Steam condensates from the blower rooms in the 202-A Buiting.

- Overflows from various demineralized water storage tanks (Tk-223 in the 202-A Building and Tk-30 in the 211-A Area).

- Floor drains from the 211-A Pumphouse.

- Sumps from the 203-A Area, via Tk-P1, are used to collect sunp waste (mostly rainwater). This is sampled to verify that it meets release iimits before discharge to the PUREX Plant CSL. Standard plant operating procedures ensure that chemical spills and radioactive liquids are not routed to the CSL, but are ultimately discharged to underground storage.

- Office area heater condensate from the 202-A Building and the 271-AB Butlding.

- Raw water [about 113.5 itter/min (30 gal/min)] used to continuous?y flush the CSL header line from its origin at the northwest corner of the PUREX Plant complex. 
- Overflow fron the emergency water supply tank (TK-2901A). The sanitary water feed [approximately 951 iter/min (25 gal/min)] to this tank is left runing to maintain residual chlorine leveis, ensure that the tank is full, and (in winter) provide protection against freezing.

- Nonhazardous wastewater condensate from the Fll Concentrator.

- N-Cell transfer vacuum pump seal water.

There is also a remote possibility for any of the chemicals handled within the ANU in the 202-A Bullding to escape from established spill barriers and enter the PUREX PIant CSL. See Table 4-9 for a partial list of chemicals previously used in the PUREX Plant. Host excess chemicals have been removed from the facility.

Project CKOOB1 installed an extensive chemical collection and reuse system in the ANU in 1987. The collection pipes merge into a common discharge line on the north side of the Plant. Only the sink drains, the electric water cooler drain, and the overflows and drains from the sugar tank and demineralized water tank feed directly into the CSL header. The floor drains can be routed through valves into the PUREX Plant CSL header, but normaliy flow into a catch tank. The remainfing overflows and drains flow into a system of catch tanks to collect the chemicals for reuse. (The overflow lines from the catch tanks do, however, feed into the CSL header. To date, there has not been an overfiow of chemicaís into the catch tanks, mich less an overflow from the catch tanks into the CSL.)

Data compiled in the CSL Strean-Specific Report were obtained during ion exchanger regeneration (5 samples) and during routine operation (6 samples). The evaluation contained in the stream specific report indicated that the CSL waste water stream did not contain any dangerous wastes, as defined in NAC 173-303-070 (WAC 1991a). A full discussion of the chenicals detected in the samples, the reported concentrations of these chemicals, analytical detection ijaits, and the pertinent regulatory limits are contained in the stream-specific report (WHC 1990a, Addendum 2).

The ventilation scrub water contributor is produced by the wet scrubbing process for ventilation air. Air from outside the 202-A Bujlding is brought. in contact with sanitary water to remove dust from the air and to coot the afr. Severa] microbiocides are added to the water in the air scrubbers:

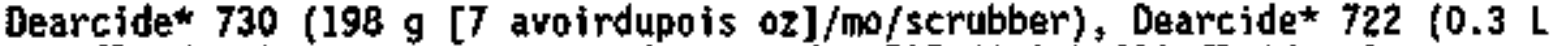
[10 fluid oz]/mo/scrubber), and Dearcide* $717(0.3 \mathrm{~L}$ [10 fluid 0z]/mo/ scrubber).

These microbiocides are added to the air scrubber to prevent the grouth of harnful microorganisms in the scrub water. These additives increase the chloride concentration and also add tin to the system. The flow of ventilation scrub water is estimated to range from 0.2 to $3.0 \mathrm{~L}<0.05$ to $0.8 \mathrm{ga}]$ ) $/ \mathrm{min}$, with an average of $0.8 \mathrm{~L}(0.2 \mathrm{gal}) / \mathrm{min}$.

*0earcide is a registered trademark of $\boldsymbol{H}$. R. Grace and Company. 
There are three water demineralizers in the 211-A Building that contributed water to the CSL intermittently during regeneration. The demineralizers converted sanitary water to the pure demineralized water required by the PUREX process. Each consists of two ion-exchange column: one for cations and one for anions. The regeneration process used sulfuric acid and sodium hydroxide which released contaminants rewoved from the sanitary water feed by the defineralizer. Use of the demineralizers is not. anticipated during transition to shutdown.

Project B-669 (recently insta]led) provided a three-chamber pH control system for the effluent from the 211-A Building. This effluent was composed of leakage from pipes and pumps in the building, seal water drainage from certatn punps, and demineralizer regeneration waste. In addition to the cations and anions renoved from the santtary water (the demineralizer feed), the regenerant contained sodium hydroxide $(\mathrm{NaOH})$, sulfuric acid $\left(\mathrm{H}_{2} \mathrm{SO}_{4}\right)$, sodiun hydrogen sulfate ( $\mathrm{HaHSO}_{4}$ ), and sodium suifate ( $\mathrm{Ha}_{2} \mathrm{SO}_{4}$ ) at different. times. The anionic and cationic deninera]izers were regenerated together to maximize the anount of neutrai $\mathrm{Na}_{2} \mathrm{SO}_{4}$ produced, while minimizing the amounts of the acidic $\left(\mathrm{H}_{2} \mathrm{SO}_{4}, \mathrm{MaHSO}_{4}\right.$ ) and basic ( $\mathrm{NaOH}$ ) species released. Use of this system is not anticipated during transition to shutdown.

The CSL was a highly variable strean. The vacuum fractionator effluent, which accounted for approximately 80 percent of the stream, normally flowed only during the PUREX Plant operation and contributed 11ttie, if any, contanination. The CSL is now a much more consistent stream durfing transition to shutdown.

The CSL flow rate is dependent upon process activities; the flow rates reported in the stream-speciftc report ranged from $4.7 \times 10^{7}$ to $1.23 \times 10^{8}$ L/mo (WHC 1990a). The Hanford Federal Faclitity Agreement and Consent Order (Tri-Party Agreement) requires that the CSL fiowrate be maintained at less than $600 \mathrm{gpm}\left(1 \times 10^{\circ} \mathrm{L} / \mathrm{mo}\right)$ on a month7y average after June 1992 . The CSL will continue to be discharged to the 216-B-3C Expansion Pond, unti1 June 1995 when connection to the TEDF is complete.

\subsubsection{Upset Operating Conditions}

The CSL could become contaminated during upset conditions. After most contributors to the CSL have combined, the CSL flows through Manhole 4 . A flowneter in Manhole 4 measures the flow rate of the CSL. A continuously operating sample pump located in Manhole 4 transfers a small stream from the CSL into the 295-AC Sample Shack, where the stream is monitored for $\mathrm{pH}$ and radiation. This stream also supplies a grab sampler (used for taking the characterization samples) and a flow proportional sampler used for providing a record. The radiation monitor is sensitive to gamna radiation and automatically diverts the CSL to the 216-A-42 Retention Basin when the count rate exceeds the alarm limit. Standard plant operating procedures require mantual diversion of the CSL if the pH drops below 3 or exceeds 11 . The current $\mathrm{pH}$ alarm settings are 5 and 10 . 


\subsubsection{Waste Water Discharge Criteria}

Current1y, the CSL is discharged to the 216-B-3C Expansion Pond. Enviromsenta] Compliance, MHC-CH-7-5 (WHC 1993a) contains the acceptance criteria for the Expansion Pond. All water effluent currently flowing to ponds or cribs $\$ 111$ cease by 1995 when water must be discharged to a State Approved Land Disposal Structure (SALOS).

The CSL will be discharged to a SALDS in June 1995. The discharge criteria for PUREX waste water effiuents then become the acceptance criteria for a SALDS. These criteria are currently being negotiated and wil] be included in the \$tate Waste Discharge Permit.

Based on WAC guidance, WAC 173-303 (WAC 1991a), an effluent wijl be considered acceptabie for soil colum discharge if it is below the following criteria (HHC 1990a-g, 199la, 19936):

- Primary Maximu Contaminant Leve]s (MCL),

- Secondary MCL,

- proposed NCL, and

- WAC groundwater quality enforcement timits.

Acceptance criteria for a SALDs are the same as acceptance criteria for the TEDF. The TEOF will not be designed or permitted to accept any effluent that is considered to be a dangerous waste under HAC 173-303 (WAC 1991a).

To be acceptable for discharge to the SALDS, the radionuclide content of each waste strean will be required to meet the intent of the State's groundwater standards and 7 init annua? pubic exposure to an effective dose equfvalent not to exceed 4 miren/yr. The effective dose equivalent of $4 \mathrm{mrem} /$ year is equal to $4 \%$ of the derived concentration guide (DCG) (DOE 1990a). 
WHC-EP-046B-3

Figure 4-1. Simplified Schematic Flow Diagram of the CSL.

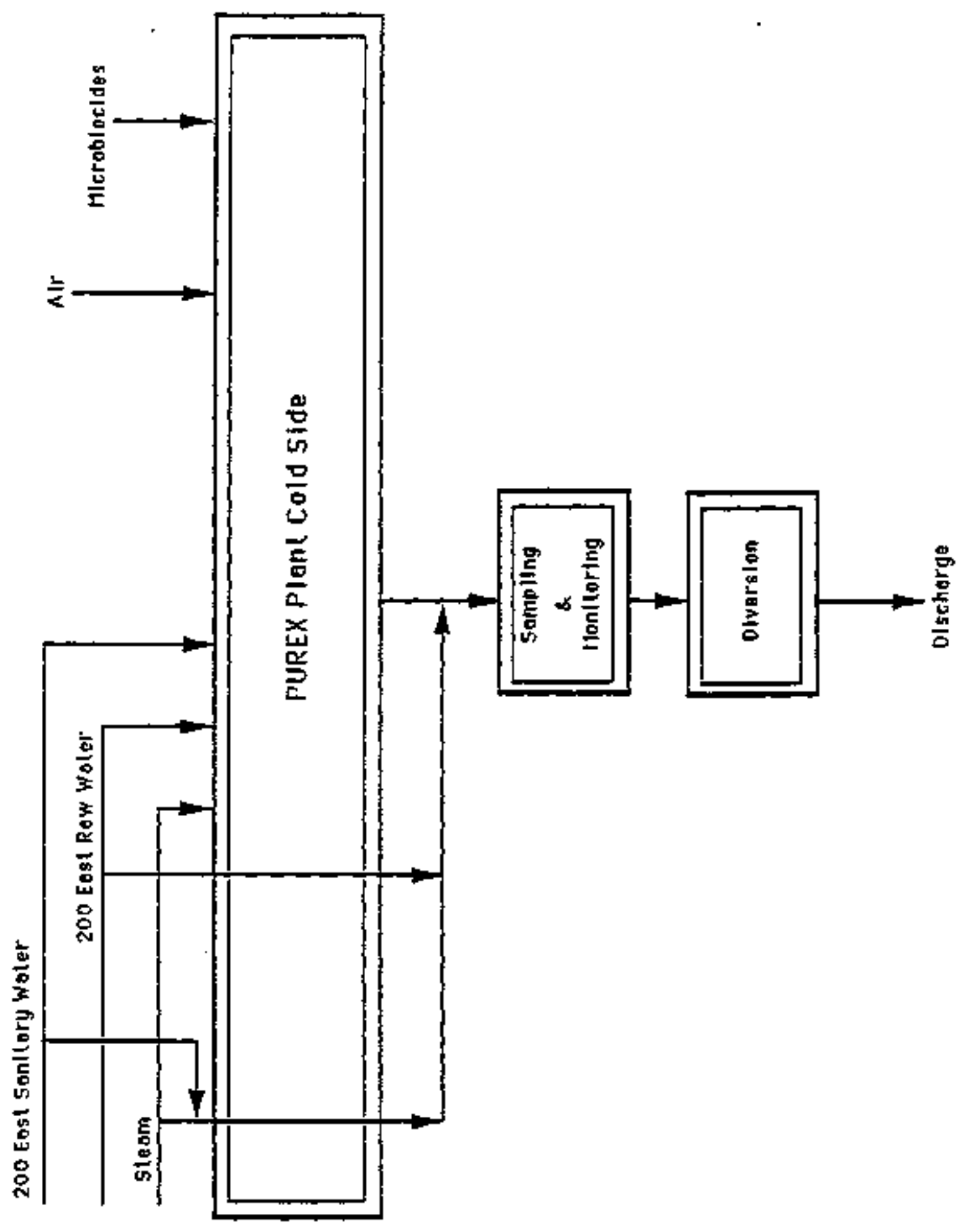


Flgure 4-2. CSL Flow Diagran.

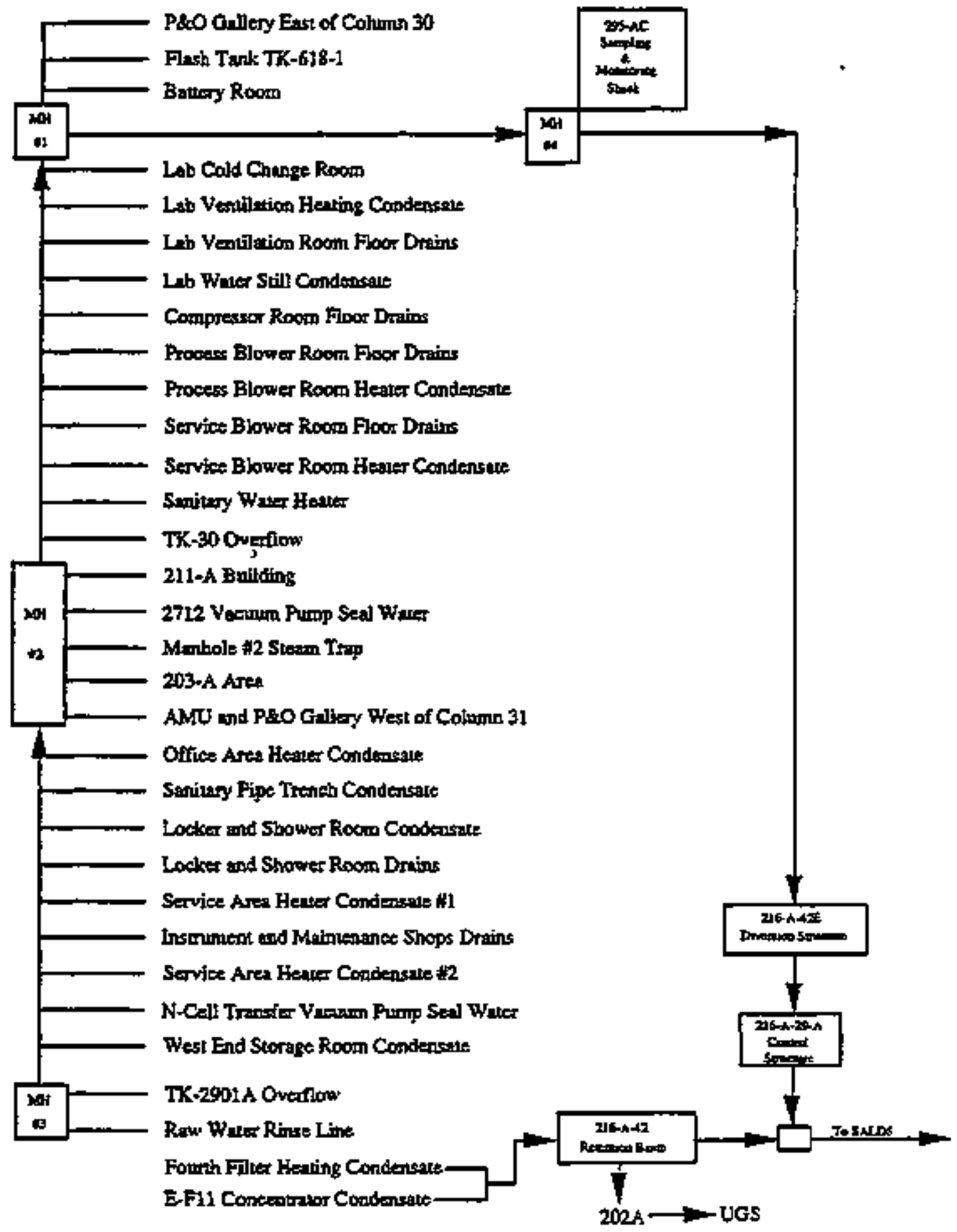


Table 4-1. Plutonium-Uranium Extraction Plants Stack Exhaust Data

\begin{tabular}{|l|c|c|c|c|c|c|c|c|c|c|}
\hline \multirow{2}{*}{$\begin{array}{c}\text { Stack } \\
\text { reference }\end{array}$} & \multicolumn{2}{|c|}{ Height } & \multicolumn{2}{c|}{$\begin{array}{c}\text { Stack } \\
\text { diameter }\end{array}$} & \multicolumn{2}{c|}{$\begin{array}{c}\text { 0utlet } \\
\text { dfameter }\end{array}$} & \multicolumn{2}{c|}{ Average flow } & \multicolumn{2}{c|}{ Temperature } \\
\cline { 2 - 12 } & $(\mathrm{ft})$ & $(\mathrm{m})$ & $(\mathrm{ft})$ & $(\mathrm{m})$ & $(\mathrm{ft})$ & $(\mathrm{m})$ & $(\mathrm{cfm})$ & $\left(\mathrm{m}^{3} / \mathrm{s}\right)$ & $\left({ }^{\circ} \mathrm{C}\right)$ & $\left({ }^{\circ} \mathrm{k}\right)$ \\
\hline $291-\mathrm{A}-1$ & 200 & 61.0 & 7.0 & 2.13 & 7.0 & 2.13 & $1.2 \mathrm{E}+05$ & 56.14 & 30 & 303 \\
\hline $296-\mathrm{A}-1$ & 74 & 22.6 & 2.0 & 0.61 & 1.8 & 0.53 & 4100 & 2.21 & 25 & 298 \\
\hline $296-\mathrm{A}-2$ & 78 & 23.8 & 1.7 & 0.51 & 1.3 & 0.41 & 4100 & 2.21 & 25 & 298 \\
\hline $296-\mathrm{A}-3$ & 74 & 22.6 & 1.7 & 0.51 & 1.3 & 0.41 & 2900 & 1.37 & 25 & 298 \\
\hline $296-\mathrm{A}-5 \mathrm{~A}$ & 89 & 27.1 & 3.5 & 1.07 & 3.0 & 0.91 & 18000 & 8.50 & 25 & 298 \\
\hline $296-\mathrm{A}-5 \mathrm{~B}$ & 89 & 27.1 & 3.5 & 1.07 & 3.5 & 1.07 & 18000 & 8.50 & 25 & 298 \\
\hline $296-\mathrm{A}-6$ & 74 & 22.6 & 3.3 & 1.02 & 2.8 & 0.84 & 15000 & 6.47 & 25 & 298 \\
\hline $296-\mathrm{A}-7$ & 78 & 23.8 & 3.7 & 1.12 & 3.3 & 1.02 & 19000 & 8.82 & 25 & 298 \\
\hline $296-\mathrm{A}-8$ & 34 & 10.4 & 3.3 & 1.02 & 3.3 & 1.02 & 10000 & 4.91 & 25 & 298 \\
\hline $296-\mathrm{A}-10$ & 20 & 6.1 & 2.3 & 0.71 & 2.3 & 0.71 & 5400 & 2.56 & 25 & 298 \\
\hline $296-\mathrm{A}-14$ & 42 & 12.8 & 2.0 & 0.61 & 2.0 & 0.61 & 5300 & 2.48 & 25 & 287 \\
\hline
\end{tabular}

'Stack $5 A$ and $5 B$ do not operate concurrently; only one is operational at any given time.

ZAverage flow from 1988 to 1993. 
Table 4-2. CAP-88 Unit Dose Factors for the Offsite Hypothetical Maximally Exposed Individual Affected by Radionuclide Air Emissions from the Hanford S1te (WHC-EP-0498, 1991).

\begin{tabular}{|c|c|}
\hline Release Locat ton & 200 East Area \\
\hline ReTease Height: & 89 m \\
\hline MEI" Locat Ion' & $10 \mathrm{mt}(16 \mathrm{~km}) \mathrm{E}$ \\
\hline Radionuel 1der & Effective Dose Equivalent (nren/C1-yr) \\
\hline$\overline{3}$ & $5.42 \mathrm{E}-06$ \\
\hline${ }^{60} \mathrm{Co}$ & $7.94 \mathrm{E}-03$ \\
\hline${ }^{90} \mathrm{Sr}$ & $1.20 E-02$ \\
\hline${ }^{106} R_{R u}$ & $5.71 \mathrm{E}-03$ \\
\hline${ }^{725} \mathrm{Sb}$ & 1.14 E-03 \\
\hline${ }^{129} I$ & $1.84 \mathrm{E}-01$ \\
\hline${ }^{157} \mathrm{Cs}$ & $6.54 E-03$ \\
\hline${ }^{267} \mathrm{Pm}$ & $3.11 \mathrm{E}-04$ \\
\hline${ }^{212} \mathrm{~Pb}$ & $9.42 \mathrm{E}-04^{\mathrm{b}}$ \\
\hline $23 \pi$ & $8.72[-0]$ \\
\hline 235 & $8.10 \mathrm{E}-01$ \\
\hline 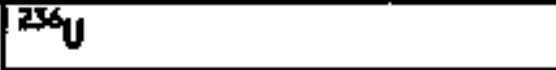 & $8.26 \mathrm{E}-01$ \\
\hline 230 & $7.77 E-01$ \\
\hline${ }^{233} \mathrm{Pu}$ & $2.19 E+00$ \\
\hline $23,{ }^{240} \mathrm{Pu}$ & $2.37 E+00$ \\
\hline${ }^{245} \mathrm{Pu}$ & $3.76 \mathrm{E}-02$ \\
\hline $2 h \mathrm{Amm}^{2}$ & $3.59 \mathrm{E}+00$ \\
\hline
\end{tabular}

YEI = Maxina1ly exposed individual.

bose for this radionuclide is the result of ingrowth from the parent. 
Table 4-3. Individual Radionuclide Doses to Maximally Exposed Individual for 1993 from 291-A-1.

\begin{tabular}{|c|c|c|}
\hline Radionucl ide & Release (Cj) & EDE $m r e m / y r$ \\
\hline${ }^{50} \mathrm{sr}$ & 4.9 E-05 & 5.9 E-07 \\
\hline${ }^{2} \mathrm{Zr}$ & $<1.8 \mathrm{E}-05$ & $<1.3$ E-0B \\
\hline${ }^{95} \mathrm{Nb}^{*}$ & $<1.1 \mathrm{E}-05$ & $<5.3 E-09$ \\
\hline${ }^{10 \hat{3}} \mathrm{Ru}^{*}$ & $<6.2$ E-05 & $<2.4 \mathrm{E}-08$ \\
\hline${ }^{106} \mathrm{Ru}$ & $3.6 \mathrm{E}-04$ & $2.1 \mathrm{E}-06$ \\
\hline${ }^{153} \mathrm{Sn}^{*}$ & $<7.5 \mathrm{E}-05$ & $<2.4$ E-08 \\
\hline${ }^{125} \mathrm{Sb}^{*}$ & $<4,4 E-04$ & $\langle 5.0 \mathrm{E}-0\rangle$ \\
\hline$\overline{16} I$ & $4.8 \mathrm{E}-03$ & $8.8 E-04$ \\
\hline${ }^{151} I^{*}$ & $<5.3 E-06$ & $<5.6 \mathrm{E}-08$ \\
\hline${ }^{134} \mathrm{Cs}^{*}$ & $<9.5 \mathrm{E}-06$ & $<8.1 \quad E-08$ \\
\hline${ }^{137} \mathrm{Cs}_{5}$ & $1.4 \mathrm{E}-04$ & $9.2 E-07$ \\
\hline${ }^{147} \mathrm{Pm}$ & $1.1 \mathrm{E}-04$ & $3.4 \mathrm{E}-08$ \\
\hline${ }^{212} \mathrm{pb}$ & 9.7 E-04 & 9.1 E-07 \\
\hline${ }^{250} \mathrm{Rn}$ & $1.2 \mathrm{E}+01$ & -- \\
\hline${ }^{238} 8_{P u}$ & $3.2 \mathrm{E}-06$ & $7.0 \mathrm{E}-06$ \\
\hline $250,240 \mathrm{Pu}$ & 4.9 E-06 & $1.2 \mathrm{E}-0.5$ \\
\hline${ }^{241} \mathrm{Pu}$ & 3.3 E-05 & $1.2 E-06$ \\
\hline${ }^{244_{A m}}$ & 2.7 E-05 & $9.7 E-05$ \\
\hline Total & & $1.0 \mathrm{E}-03$ \\
\hline
\end{tabular}

* - Releases calculated using minimum detection limits (MDL) based on annual average concentrations. 
Table 4-4. Individual Radionuc] fde Doses to Maximally Exposed Individual for 1993 from 296-A-1.

\begin{tabular}{|c|c|c|c|c|}
\hline Radionucl ide & Retease (Ci) & $\begin{array}{l}\text { Average } \\
\text { Concentration } \\
\text { (aci/ml) }\end{array}$ & $\underset{\text { Peak }}{A C j / m i l}$ & EDE mrem/yr \\
\hline $259.240 \mathrm{Pu}$ & $2.0 \mathrm{E}-06$ & $2.8 \mathrm{E}-14$ & 5.6 E-14 & 5.0 E-06 \\
\hline $241_{\text {AnI }}$ & 8.4 E-07 & 1.1 E-14 & $1.9 \mathrm{E}-14$ & $3.0 \mathrm{E}-06$ \\
\hline \multicolumn{4}{|l|}{ Total EDE } & $8.0[-06$ \\
\hline
\end{tabular}

Table 4-5. Doses to the Maximally Exposed Individual From Routine Releases During Transition to Shutdown.

\begin{tabular}{|l|c|c|}
\hline \multicolumn{1}{|c|}{$\begin{array}{c}\text { Stack } \\
\text { reference }\end{array}$} & $\begin{array}{c}\text { Effective dose } \\
\text { equivalent (nrem) }\end{array}$ & $\begin{array}{c}\text { Stack contribution to } \\
\text { MEI dose }(\boldsymbol{X})\end{array}$ \\
\hline $291-\mathrm{A}-1$ & $1.0 \mathrm{E}-03$ & 99.0 \\
\hline $296-\mathrm{A}-1$ & $8.0 \mathrm{E}-06$ & 0.8 \\
\hline $296-\mathrm{A}^{*}$ & $<2.3 \mathrm{E}-07$ & 0.0 \\
\hline $296-\mathrm{A}-3$ & $1.1 \mathrm{E}-07$ & 0.0 \\
\hline $296-\mathrm{A}-5 \mathrm{~A} / 5 \mathrm{~B}^{*}$ & $<2.3 \mathrm{E}-06$ & 0.2 \\
\hline $296-\mathrm{A}-6^{*}$ & $<4.6 \mathrm{E}-08$ & 0.0 \\
\hline $296-\mathrm{A}-7$ & $4.3 \mathrm{E}-07$ & 0.0 \\
\hline $296-\mathrm{A}-8$ & $3.4 \mathrm{E}-08$ & 0.0 \\
\hline $296-\mathrm{A}-10^{*}$ & $<3.0 \mathrm{E}-07$ & 0.0 \\
\hline $291-\mathrm{A}-14^{*}$ & $<2.9 \mathrm{E}-07$ & 0.0 \\
\hline Total & $<1.0 \mathrm{E}-03$ & 100.0 \\
\hline
\end{tabular}

* - Calculated using minjutin detection 17mits (MDC) for total alpha and beța based on annual average concentrations. Assuming ${ }^{29} \mathrm{Pu}$ and ${ }^{9} \mathrm{Sr}$ for alpha and beta respectively. 
Table 4-6. Potential Doses to the Maximally Exposed Individual From An Unustigated ReToase.

\begin{tabular}{|c|c|c|c|c|c|}
\hline \multicolumn{2}{|c|}{ Stack Reference } & \multirow{2}{*}{$\begin{array}{c}\begin{array}{c}\text { Effective } \\
\text { Dose } \\
\text { Equivalent } \\
\text { (mren) }\end{array} \\
\text { B.8 E-04 }\end{array}$} & \multirow{2}{*}{ 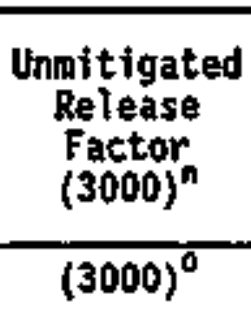 } & \multirow{2}{*}{$\begin{array}{c}\begin{array}{c}\text { Unmitigated } \\
\text { Effective } \\
\text { Dose } \\
\text { Equivalent } \\
\text { (mrem) }\end{array} \\
\text { 8.8 E-04 }\end{array}$} & \multirow[t]{2}{*}{$\begin{array}{c}\text { Dose } \\
\text { Standard" } \\
\text { for Required } \\
\text { Monitoring } \\
\text { (nrem) }\end{array}$} \\
\hline \multirow{3}{*}{ 291-A-1 } & Volatiles & & & & \\
\hline & Particulates & $1.2 \mathrm{E}-04$ & $(3000)^{3}$ & $3.2 E+06$ & \\
\hline & Total & $1.0 E-03$ & - & $3.2 E+06$ & $1.0 \mathrm{E}-01$ \\
\hline \multicolumn{2}{|l|}{ 296-A-1 } & 8.0 E-06 & $(3000)^{3}$ & $2.2 E+05$ & $1.0 \mathrm{E}-01$ \\
\hline \multicolumn{2}{|l|}{$296-A-2$} & $<2.3 \mathrm{E}-07$ & $(3000)^{7}$ & $<6.9$ E-04 & $1.0 \mathrm{E}-01$ \\
\hline \multicolumn{2}{|l|}{$296-A-3$} & $1.1 \mathrm{E}-07$ & $(3000)^{1}$ & $3.3 \mathrm{E}-04$ & $1.0 \mathrm{E}-01$ \\
\hline \multicolumn{2}{|c|}{$296-A-5 A / 5 B$} & $<2.3 \mathrm{E}-06$ & $(3000)^{4}$ & $<6.9$ E-03 & $1.0 \mathrm{E}-01$ \\
\hline \multicolumn{2}{|l|}{$296-A-6$} & $<4.6$ E-08 & $(3000)^{1}$ & $<1.4 \mathrm{E}-04$ & $1.0 \mathrm{E}-01$ \\
\hline \multicolumn{2}{|l|}{$296-A-7$} & $4.3 \mathrm{E}-07$ & $(3000)^{1}$ & $1.4 \mathrm{E}-03$ & $1.0 \mathrm{E}-01$ \\
\hline \multicolumn{2}{|l|}{$296-A-8$} & $3.4 \mathrm{E}-0 \mathrm{~B}$ & $(3000)^{7}$ & $1.0 \mathrm{E}-04$ & $1.0[-01$ \\
\hline \multicolumn{2}{|l|}{$296-A-10$} & $<3.0 \mathrm{E}-07$ & $(3000)^{1}$ & $<9.0 \mathrm{E}-04$ & 1.0 E-01 \\
\hline \multicolumn{2}{|c|}{$296-A-14$} & $<2.9$ E-07 & $(3000)^{1}$ & $<8.7$ E-04 & $1.0 \mathrm{E}-0 \mathrm{I}$ \\
\hline
\end{tabular}

Dose standard for total radioactivity effluent monttoring from 40 CFR 61, Subpart H.

$n=$ Number of HEPA filtration stages

Table 4-7. Potential Individual Radionuclide Doses to the Maximally Exposed Individual from An Unmit igated Release.

\begin{tabular}{|c|c|c|c|}
\hline PUREX Stack & Radionuclide & $\begin{array}{c}\text { EDE Contribution } \\
\text { mrem/yr }\end{array}$ & $\begin{array}{c}\text { Contribution to } \\
\text { Stack Total } \%\end{array}$ \\
\hline $291-\mathrm{A}-1$ & ${ }^{261} \mathrm{Am}$ & $2.6 \mathrm{E}+06$ & 78 \\
\hline $296-\mathrm{A}-1$ & ${ }^{239.240} \mathrm{PUH}$ & $8.3 \mathrm{E}+04$ & 63 \\
& $241_{\mathrm{Am}}$ & $1.4 \mathrm{E}+05$ & 37 \\
\hline
\end{tabular}


Table 4-8. Summary of PUREX Plant Liquid Effluent qualities'. (3 sheets)

\begin{tabular}{|c|c|c|}
\hline & Analyte & $\mathrm{CSL}^{2}$ Routine \\
\hline \multicolumn{3}{|c|}{ Inorganic Compounds - Metals ${ }^{3}$} \\
\hline Aluminum & - & 341 \\
\hline \multicolumn{3}{|l|}{ Antimony } \\
\hline \multicolumn{3}{|l|}{ Arsenfic } \\
\hline Barium & & 34 \\
\hline \multicolumn{3}{|l|}{ Beryllium } \\
\hline Boron & & 22 \\
\hline \multicolumn{3}{|l|}{ Cadmium } \\
\hline Calcium & & $1.9 \mathrm{E}+04$ \\
\hline \multicolumn{3}{|l|}{ Chromium } \\
\hline Copper & & 40 \\
\hline Iron & & 443 \\
\hline Lead & & 6 \\
\hline Nagnes I um & & 4,350 \\
\hline Manganese & & 30 \\
\hline Hercury & & 0.1 \\
\hline \multicolumn{3}{|l|}{ Nickel } \\
\hline Potassium & & 740 \\
\hline \multicolumn{3}{|l|}{ Selenium } \\
\hline Silicon & & 2,910 \\
\hline \multicolumn{3}{|l|}{ Silver } \\
\hline Soditum & & 2,160 \\
\hline Strontín & & 95 \\
\hline \multicolumn{3}{|l|}{ Thalliur } \\
\hline Uranitum & & 0.6 \\
\hline Zine & & 25 \\
\hline \multicolumn{3}{|c|}{ Inorganic Compounds - Ionic Species ${ }^{3}$} \\
\hline Ammoniun & & 63 \\
\hline Chloride & & $1.8 E+03$ \\
\hline Cyanide & & \\
\hline
\end{tabular}


Table 4-8. Sumary of PUREX Plant Liquid Effluent Qualities'. (3 sheets)

\begin{tabular}{|c|c|}
\hline Analyte & CSL $^{2}$ Routine \\
\hline \multicolumn{2}{|c|}{ Inorganic Compounds - Ionic Species ${ }^{3}$ (Cont'd) } \\
\hline Fluoride & 154 \\
\hline \multicolumn{2}{|l|}{ Fluoride (IC) ${ }^{2}$} \\
\hline \multicolumn{2}{|l|}{ Fluoride (ISE) ${ }^{2}$} \\
\hline Nitrate & 588 \\
\hline \multicolumn{2}{|l|}{ Nitrate } \\
\hline Sulfate & $1 . \overline{3 E+04}$ \\
\hline \multicolumn{2}{|c|}{ Organte Compounds ${ }^{3}$} \\
\hline \multicolumn{2}{|l|}{ Acetone } \\
\hline \multicolumn{2}{|l|}{ 1-Butano1 } \\
\hline \multicolumn{2}{|l|}{ 2-Butanone } \\
\hline \multicolumn{2}{|l|}{ Butylated } \\
\hline Hydroxytolyene & 10 \\
\hline \multicolumn{2}{|l|}{ Chloroform } \\
\hline \multicolumn{2}{|l|}{ Dibutyl phosphate } \\
\hline \multicolumn{2}{|l|}{ Dichloromethane } \\
\hline \multicolumn{2}{|l|}{ Tributy]phosphate } \\
\hline \multicolumn{2}{|c|}{ Other Parameters ${ }^{e}$} \\
\hline Alkalinity & $6.6 \mathrm{E}+04$ \\
\hline Conductivity (US) & 158 \\
\hline $\mathrm{pH}$ (standard unjts) & 7.8 \\
\hline $\operatorname{TDS}^{2}$ & $6.5 \mathrm{E}+04$ \\
\hline Temperature ("C) & 28 \\
\hline \multicolumn{2}{|l|}{$T O C^{2}$} \\
\hline Total Carbon & $1.5 E+04$ \\
\hline$T 0 x^{2}$ (as Cl) & 99 \\
\hline \multicolumn{2}{|c|}{ Radionuclides } \\
\hline Total A]pha & 1 \\
\hline Total Beta & 2 \\
\hline Radiun $(226+228)$ & $<1.9 E-01$ \\
\hline
\end{tabular}


Table 4-8. Sumnary of PUREX Plant Liquid Effluent Qualities'. (3 sheets)

\begin{tabular}{|c|c|}
\hline Analyte & CSL $^{2}$ Routine \\
\hline \multicolumn{2}{|c|}{ Radionuc]ides ${ }^{d}$ (Cont'd) } \\
\hline Gross uranjun-nạtural & $4.9 \mathrm{E}+02$ \\
\hline $3 \mathrm{H}$ & $4.9 \mathrm{E}+02$ \\
\hline${ }^{16} \mathrm{C}$ & $4.28 E+00$ \\
\hline \multicolumn{2}{|l|}{ si } \\
\hline \multicolumn{2}{|l|}{1201} \\
\hline${ }^{137} \mathrm{Cs}$ & $4.6 \mathrm{E}-01$ \\
\hline \multicolumn{2}{|l|}{${ }^{144} \mathrm{Ce} / \mathrm{Pr}$} \\
\hline \multicolumn{2}{|l|}{${ }^{147} \mathrm{Pm}$} \\
\hline${ }^{234} \mathrm{U}$ & $1.9 \mathrm{E}-01$ \\
\hline${ }^{238} \mathrm{Pu}$ & $1.6 \mathrm{E}-02$ \\
\hline $23 \mathbf{E}_{\mathrm{y}}$ & $1.6 \mathrm{E}-01$ \\
\hline $239,240 \mathrm{Pu}$ & $5.3 E-01$ \\
\hline \multicolumn{2}{|l|}{$23,240 \mathrm{U}$} \\
\hline $24 \mathrm{Am}$ & $2.0 \mathrm{E}-01$ \\
\hline $\begin{array}{l}\text { Stream Specific Report WHC-EP-0342 } \\
\text { Addendun Nunber }\end{array}$ & Addendum 2 \\
\hline Approxinate Average Flow Rate (Liters/month) & $7.7 \mathrm{E}+07$ \\
\hline Estimated Flow Rate for PUREX Shutdown L/month & $5.0 \mathrm{E}+07$ \\
\hline
\end{tabular}

${ }^{1}$ Analyte concentrations represented by the 90 percent confidence interval 1 imit (the upper 1 inft of the one-tailed 90 percent confidence interval for all data sets) as reported in the approprlate strean speciffic report. When a 90 percent confidence interval 1 init was not calculated, the maximum observed result is 1 isted.

'Abbreviations used:

CSL - chemical sever

TOS = total dissolved solids

TOC * total organic carbon

TOX - total organic hal ides

IC - fluoride analysis using lon chronatography technique

ISE - fluoride analysis using ion-spectfic electron technique.

${ }^{3}$ Effluent concentrations expressed as micrograms per liter unless fndicated otherwise. 
Tab]e 4-9. List of Plutoniun-Uranfum Extraction Plant Chemicals.

\begin{tabular}{|l|l|}
\hline Aluminum nitrate & Potassium fluoride \\
\hline Antifoam (00W 110) & Potassium permanganate \\
\hline Cadmium nitrate & Silver nitrate \\
\hline *Cleaning surfactants & Sodium carbonate \\
\hline Ferric nitrate & *5odium hydroxide \\
\hline Ferrous sulfamate & *Sodium nitrite \\
\hline Hydrazine & Sodium nitrate \\
\hline Hydrogen peroxide & Sodium thiosulfate \\
\hline Hydroxylamine nitrate & Sugar (sucrose) \\
\hline Ion exchange resins & Sulfamic acid \\
\hline Nitric acid & Sulfuric acid \\
\hline Normal paraffin hydrocarbon & Tartaric acid \\
\hline Oxalic acid & Tributyl phosphate \\
\hline Potassium hydroxide & \\
\hline
\end{tabular}

*way still be used at PUREX. 


\subsection{EFFLUENT PQIKT OF DISCHARGE DESCRIPTION}

This section deseribes the point of discharge for both the air and liquid effluents. Additional information on atr and water effluents, and sampling systems and operations, are contained in Sections 4.0 and 7.0

\subsection{AIR EFFLUERTS}

The 10 major air effluent streans, the associated stack dimensions, and the flow velocitles and temperatures have been summarized in Table 4-1. The location of each stack is shown in Figure 5-1. Additional information on each air effiuent discharge is given in Section 4.1.

\subsection{WATER EFFLUEMTS}

The only remaining water effluent from the PUREX Plant, the CSL, discharges into the 216-8-3C Expansion Pond (until June 1995 when connection into TEDF is complete). Under the Tri-Party Agreement, this discharge is 1 iuited to no more than $38 \mathrm{~L} / \mathrm{s}(600 \mathrm{gal} / \mathrm{min})$ average on a monthly basis.

Prior to March 1994, the B Pond system was comprised of four interconnected uni ined earthen ponds, designated as 216-B-3, 216-B-3A, 216-8-3B, and 216-B-3C. These ponds were placed into service in 1945, 1983, 1984, and 1985, respectively. In March 1994, the 216-B-3 Hain Pond was taken out of service and interin stabtlized. The 216-B-3A Pond was also removed from service during early 1994 . The 216-8-3B Pond remains out of service. Figure 5-2 shows the location of the $B$ Ponds in relation to adjacent facifties and groundwater monitoring wells.

The 216-B-3C Expansion Pond is the only rematning B pond in service. The 216-B-3C Pond has a surface area of $170,000 \mathrm{~m}^{2}$ and has a maximum capacity depth of about $1.2 \mathrm{~m}$ (4 ft). The 216-B-3C Expansion Pond has a series of nine trenches that are approximately $1.2 \mathrm{n}(4 \mathrm{ft})$ in depth and provide additional infiltration capacity. 


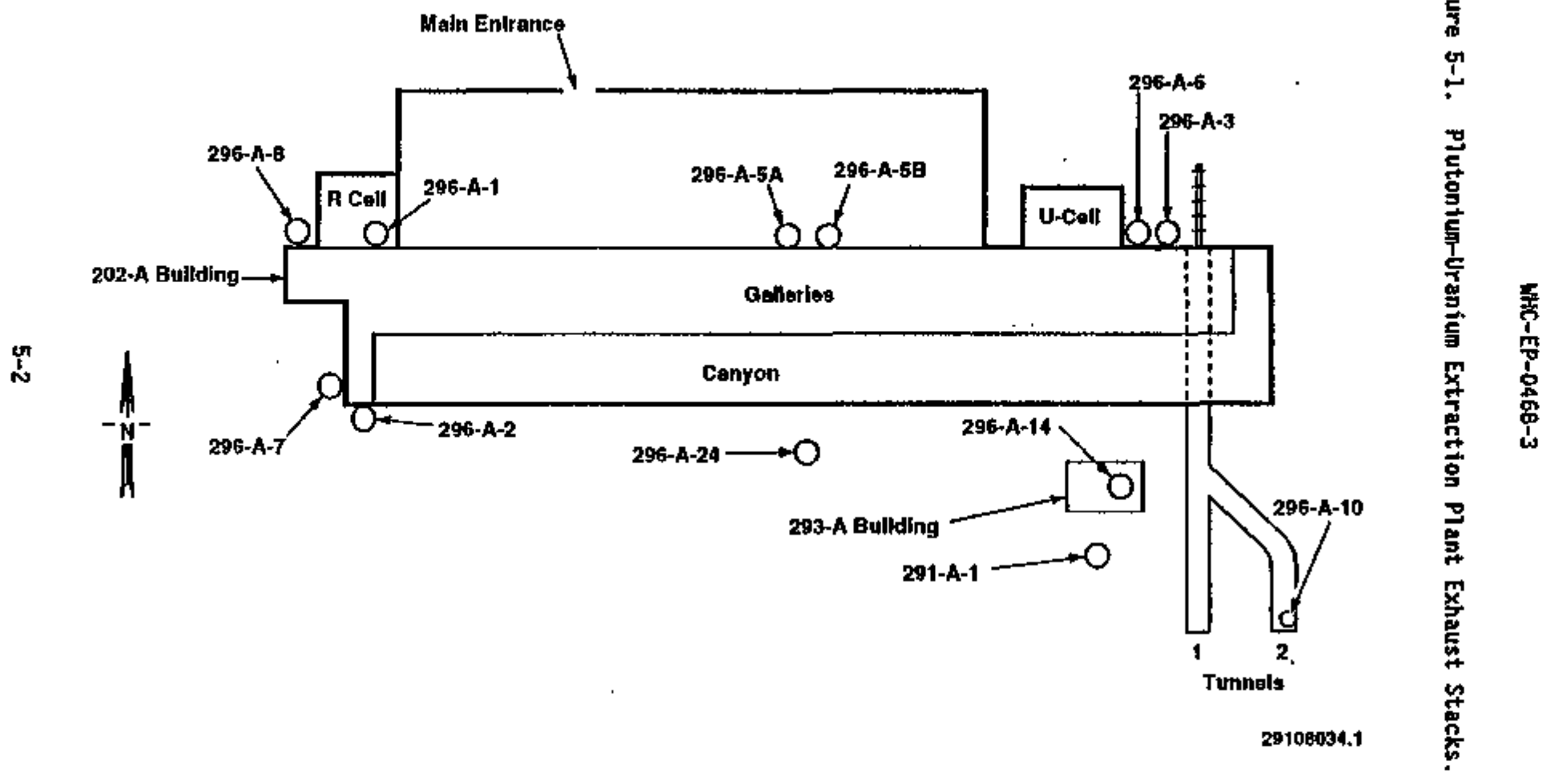




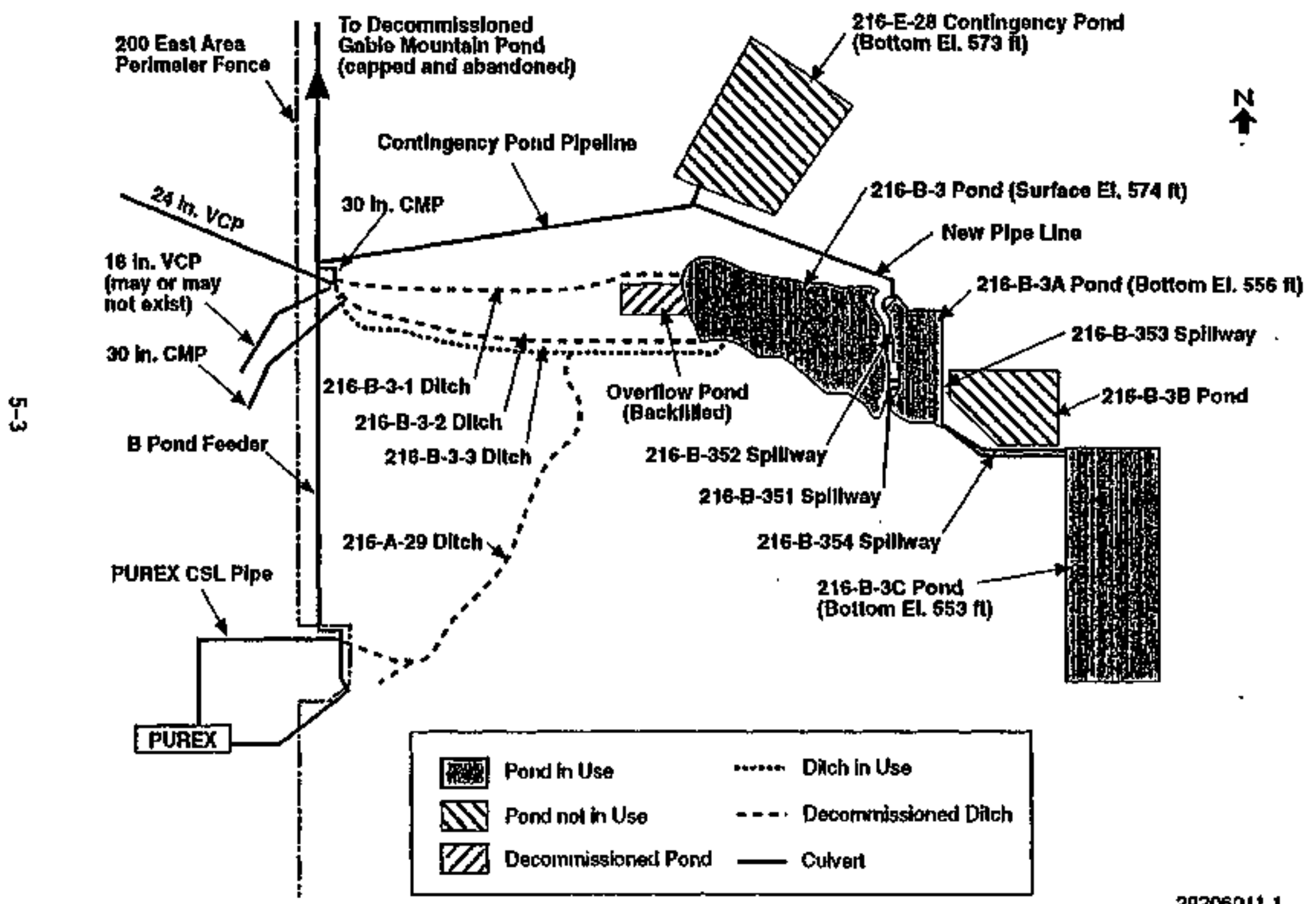


WHC-EP-0469-3

This page intentionally left blank. 
WHC-EP-046B-3

\subsection{EFFLUEET MOHITORIHG/SAMPLIHG SYSTEM DESIGN CRITERIA}

Adrborne and 1 lquid radionuclide concentration nonitoring requirements at PUREX are met by sampling and analysis. Atrborne chenical monitoring requirements are met through the use of real-time monitors. The design criteria for a system of equipwent states the functional requirements that must be met.

\subsection{HEN FACILITIES}

Project W-O49H (TEDF) will install a local control unit (LCU) near the PUJREX 295-AC Sample Shack to monitor the chentical sewer discharges. The LCU will contain instrumentation which will transifi $\mathrm{pH}$, beta/gamma, and flow data from the LCU to Project $W-049 H$ central control roon.

\subsection{EXISTING FACILITIES}

The equipment used to create both the air and liquid monitor/sample systems for the PUREX Plant is to meet the following comon design criteria: the equipment must be accurate, rugged, and low maintenance.

\subsubsection{Airborne Effluent Sampling and Monitoring System Design Critoria}

Airborne effluent sampling is required of all gaseous release points with the potential to emit artifictal radionuc]ides. Nonitoring al so is required of all gaseous release points with the potential to emit ammonta or oxides of nitrogen ( $\mathrm{NO}_{\mathrm{x}}$ ). Because the PUREX Plant only produces ammonta and $\mathrm{MO}_{\mathrm{x}}$ when it is processing, there is currently no requirement for ammonta or $\mathrm{MO}_{\mathrm{x}}$ monitoring.

Additional specific criteria that apply to the air effluents are the requirements to accouplish the following:

- Sense pressure drop across the HEPA falters

- Take continuous air samples with isokinetic sampling probes, filter holders, and vacuum pumps

- Detect and alarn upon a loss of ventilation flow in any individual effluent.

Design eriteria were developed for generic stack sampler/monitor systens to provide system design and operating capabilities as required in current DOE orders and directives, ANSI guidel ines, and Rockwell Hanford Operations Environmental Protection \$tandards. Design criteria were published in RHO-CD-1092, 200 Area Stack Sampler-Monitor Systems Upgrade: Generic Systems Applications. These criterla were further developed in 1984 as part of an upgrade of 200 Area stack systems and were published in SO-WM-CR-016, FY 1985 200 Area Stack Sampler/Nonitor Systens Upgrade. 
The design criteria specify that whenever the stack flow rate varies routinely by more than \pm 20 percent, a stack effluent flow-rate monitor with flow-totalizing capability shall be provided. The following are also specified in the design criteria:

- The stack flow-rate nonitoring systen sha]l have a flor-rate sensing elenent located within the stack in a location that will not interfere with the effluent sample extraction probes. The flow-rate transmitter shall provide an electrical signa] that is proportional to the stack flow rate, thus controlling a flow-rate indicator and totalizer.

- Flow-probe sensing lines shall be protected from condensation of motsture.

- Should the stack flow rate not vary routinely by \pm 20 percent, periodje flow-rate measurements shall be conducted to verify this condition.

- For continuous releases, the flow measurenents are required to be within 10 percent of span of the flow rate recording instrument. Instrunent span should be adjusted to best fit maximum potential flow.

- The sample extraction probes within the stacks shajl follow, in general, design guide] ines as presented in ANSI N13.1, 1969, Guide to Saspling Airborne Radioactive Naterials in a Nuclear Facflity (AN\$1 1969). Sample probes shall be designed to provide a nearf sokinetic representative sample extraction based on the average stack velocity.

- The average stack velocity shall be determined froa velocity profile measurements taken at or near the point of sample extraction.

- Sample probes shail be located a mintmum of five duct diameters downstream and two duct diameters upstrean of major flow disturbance points in the exhaust stack, unless the sultabllity of an alternate location can be demonstrated through repeatable flow profile measurements.

- Sample extraction probes sha]l be flange mounted to the stack to facilitate periodic renova], inspection, and cleaning activitles.

- Sample transport lines shall extend from the probe connection flange to the instrument cabinet located near the stack. Sample transport Iines shall be selected and installed in a manner designed to minimize particle loss attributed to gravity settling, turbulent impaction, and eiectrostatic effects. Sample transport i ine runs, bends, and tube transitions sha]l be nininized to the extent practjcal. Sample transport ije bend radij shall be at least ten times the inside diameter of the transport 1ine. Provisions shall be nade to inhibit condensation of moisture within sample transport lines. Sample transport lines shall be supported to minimize windinduced vibration effects. 
- Generic system assemblies shall be selected to provide fixed-fi7terhead record sampling and airborne radiation monitoring capabilities. The type of airborne radiation monitoring required is site specific and shall be appropriate for the radionuclides normally expected in exhaust stack effluents.

- The record sample afrstream shall be routed through a $47-n m$ fflter to obtain a buildup sample for laboratory analysis. The record sampling syster shall have sample flow-rate indicating and totalizing capabiltties. A flow-rate regulator shall be provided to maintajn a constant flow rate through the collection filter assembly to compensate for filter-loading effects. Audible and visible alari signals indicating low sample flow shall be provided locally and to an area subject to frequent or continuous occupancy. The record sample flow rates shall be of sufficient size to provide opt milum samples for laboratory analyses.

- The contintious air monitor (CAN) system shall have flow rate indicating and regulating capabilities. A flow-rate regulator shail be provided to maintain a constant flow rate through the collection filter assembly to compensate for filter loading effects. The CAM system shall have local readout count-rate meters with strip chart recerding capability to a remote area where alarms are to be located. Audible and visible alarms including, but not 1 imited to, high airborne radiation, instrument ma] function, and low sample flow jndications, shall be provided 7ocally and in an area subject to frequent or cont inuous occupancy.

- Monitoring systens shail have the capability to a]arm at the time-integrated equivalent concentration equal to 4-hour release at 5,000 times the BCG-Pub]tic as noted in Appendix A of $N H C-C H-7-5$, Environesental Complfance Manual (WHC 1993a). Monitoring systems shall alarn at release concentrations as low as possibje without resulting in an excessive number of alarus caused by nomal fluctuations in background or nornal fluctuations in releases.

- The stack sampler/monitor system shall operate continuously using the same entergency power backup capabjlities as the stack blower fan(s). An elapsed tiae meter shall be ganged with stack blower-fan operation to provide a measure of exhaust stack operation times. The record sanple vacuum purp shall be ganged to exhaust fan operation via a switched receptacle in the systen cabinet. The CAM vacuum pump will operate continuousiy via the unswitched receptacle in the cabinet.

- Particular attention shall be given to the maintainabjlity, testability, and, therefore, reijability of CAN systems. Fallure annunclation shail be provided, and the CAl systen shall be checked periodically to verify total systen response.

- Independent vacuum pumps shall be provided for each loop of the system. Redundant vacuum systems need not be furnished, but fallure annunciation (low flow rates) shall be provided and checked periodicaliy to demonstrate operability. 
- All gaseous effluent sampling and monitoring system equipment shall be protected from, or resistant to, environiental conditions that may cause damage to the squipnent or operation thereof. Routine maintenance shall be performed. Performance evaluations of CAM instrunentation agajnst a known standard shall be done periodically.

\subsubsection{Liquid Effluant Sarpling and Monitoring 5ysten Design Criteria}

Liquid radionuctide sampling is required for alt released liquid effTuents which have the potential to exceed a sum of the fractions of the derived concentration gutde (DCG) of $0.04 \mu \mathrm{Ct} / \mathrm{ml}$. Sampling is also required for I iquid effluents discharged to surface waters with settleable solids exceeding $5 \mathrm{pCi} / \mathrm{g}$ a]pha or $50 \mathrm{pCj} / \mathrm{g}$ beta/gamma emitting radionuclides. The samples are required to be representative: etther grab samples of well-nixed batch releases or proportional samples of continuous releases.

6.2.2.1 LIquid Effluent Monitoring/Sanpling General Design Criterfa. The general design criteria for liquid effluent sampling and monitoring systems are presented in MHC-CK-4-9, Radiological Design, Section 10.0, Rev. 3, "Sampting and lonitoring," (UHC 1991a). For sampling systems, the following criterja apply:

- Sampling systems shall be provided for all liquid effluents that have a potential for exceeding concentrations equivalent to the Drinking Water Standards contajned in 40 CFR 141 (EPA 1991d).

- Sampling systems shall be designed to take a representative sample of the effiuent strean. The sample location shall be as close to the environmental discharge point as practical and downstream of the effluent control systens. The sampler should sample only what is discharged to the environment. Samples of a stream diverted from environitental discharge should not be conbined with the samples of the discharged effluent.

- For continuous releases, the flow masurements are required to be within 10 percent of span of the flow rate recording instrunent. Instrument span should be adjusted to best fit maximum potentiai flow.

- Automatic samplers should operate on a flow-proportional basjs as controlled by a flow measurement system. The flow-metering device should be equipped with a flow totalizer for recording total effluent volune released from a given source.

- Sampling probes should be suspended in the water so as not to pick up particulate matter from the botton or top of the stream, pond, or basin.

- The sampler should have a sufficiently high transport velocity to ensure accurate collection and transport of suspended solids to the sample collector. Lengths of sample tubing should be ninimized. 
- The sampling systen should ensure that no unsanpled releases occur as a result of power failure.

- The sampler should be equjpped to mintmize cross contamination by sample 7 ine flushing or other methods.

- For a batch discharge system, mechanical mixing or other design should ensure reasonable homogeneity of a batch before sampling. The systen should have the means for accurate determinations of batch volumes to permit volume-weighed compositing of grab (taken at random) as opposed to continuous, samples.

For monitoring and diverston system, the following criteria apply:

- Monitoring systens shall be provided for all discharged liquid effluents that have the potential for exceeding four tines the appitcable adninistrative control lifuits in WHC-CH-7-5, Environgenta7 Compliance Manual (Whic 1993a).

- Monitoring shall be provided for each radionuclide with the potential for exceeding the values above specified values, unless an increase in one radienuct ide concentration is accompanied by proportionat. increases in another type.

- Honftoring systems should be placed upstream from diversion systens and downstream from effiuent treatment systems.

- Monitors should have distinguishable, audible, and visible highradiation alartis capable of alaring in an area subject to frequent or cont inuous occupancy.

- Monitors should have distinguishable, audible, and visible detectorfailure alarns capable of alarming in an area subject to frequent or continuous occupancy. The monitoring systen electronics should include a low-count alarm. This modute monitors the count rate provided by the electronics and alarms if the count rate drops be]ow a selected level. This acts as a failure alarm for the system components.

- Monitors should have distinguishable, audible, and visible loss-ofsample alarms capable of alarning in an area subject to frequent or continuous occupancy.

- Monitors should have distinguishable capability to transmit a realtime measurement to a remote location.

- Accessibility and maintainabtlfty should be considered with respect to the system and configuration to accommodate periodic in-place calibration and maintenance.

- A diversion and retention system shall be coupled with the monitoring system if the potential oxists for exceeding the limits contained in MHC-CH-7-5, Westinghouse Hanford Company Environmenta] Compliance Hanual (bilc 1993a). 
- Retention capacity shall be sufficient to retajn the volune of ifquid that exceeds the applicable 7 imits based on a safety analysis postulated upset. The retention bastn should be covered.

- It should be possible to flush or decontaminate the monitor if a buildup of contamination raises the background radiation ieveis.

Delivery of a representative portion of the effluent stream to the sampler or monitor depends on the design of the transport iline. The following are guidelines for the design of sampter or monitor system transport ifnes.

- The sampler and monitor should be located as far upstream as practical.

- Traps should be avoided and uphiti runs kept as short as practica] upstream of the sampler or monitor.

- Grab sample valves, throttling valves, and flov alams should be downstream of the sampler and monitor.

- To reduce the number of fittings needed, tubing should be used instead of piping. Sample tubing should be as short as practical, have as few valves and bends as possible, and contain no traps.

- Transport velocity in systems with horizontal or uphi1] runs should be $61 \mathrm{~cm} / \mathrm{s}(2 \mathrm{ft} / \mathrm{s})$ or greater to ensure transport or suspended solids.

- If a heat exchanger is used, it should be sized to baintatn the desired transport velocity and, if practical, the sample should flow downhill.

- The sampler should be upstrean of the monitor if both units are on the same transport line.

- The sampler should be separate or separable from the nonitor. The two capabilities may be on the same system if elther can be isolated by majntenance bypass loops. 


\subsection{CHARACTERIZATIOH OF CURREMT EFFLUEMT MONITORIHB SYSTEN}

Monitoring and Sampling systems must be capable of verifying compliance with the discharge criteria for the specific effluent strean. Air $\mathrm{W} / \mathrm{S}$ requirements are well defined in HESHAPs (40 CFR 61, Subpart H) (EPA 1991a). Currently, liquid effluent $\mathrm{M} / \mathrm{S}$ requirements are used to vertfy compliance with discharge criteria for effluents discharged to 216-B-3C Expansion Pond. After 1995, I fquid effluents must meet the more restrictive SALDS criterfa. Monitoring and Sampling of the air and Jiquid effluents will be conducted in accordance with WHC-CH-7-5 (WHC 1993a).

\subsection{AIR EFFLUENT MOHITORIMS SYSTEN DESCRIPTION AND SPECIFICATIONS}

\subsubsection{Monitoring/Sampling Requireaents and Criteria}

As a result of the dose analysis presented in Section 4.0 specific air $M / S$ requirements have been identified for each of the 11 PUREX stacks. Monitoring requirements fall into two types, "continuous radiation monitoring" [as defined by EPA (EPA 1991a); this is fully aet by continuous sampling and periodic analysis] and selective radionuclide monitoring. Continuous air monitoring requires filter analyses for total alpha and/or total bota radjoactivity. Selective radionuclide monitoring analyzes the filters for specific radionucitide air concentrations.

Continuous monitoring does not imply a real-time monitoring plan, but rather a systew that samples continuously so that variations in effluent concentrations are accurately represented by analysis. A continuous air sanpler which draws air through and deposits particulates on a filter is an exampie. Both alpha and beta emitters are present in all PUREX stack effluents.

Stack monitoring requirements are discussed below. Table 7-1 summarizes the results of the dose analysis.

- Stacks 291-A-1 and 296-A-1 will require radiation monitoring (EPA definition).

- Stacks 291-A-1 and 296-A-1 will require continuous total alpha/beta monitoring (EPA 1989a).

- The main stack 291-A-1, will require radionuclide selective analysis for 20 Am. The product removal (PR) stack, 296-A-1, will require radionuclide selective analysis for ${ }^{33,240} \mathrm{Pu}$ and ${ }^{241} \mathrm{Am}$.

- The other nine stacks in Table 7-1 require only periodic monitoring to verify compliance during transition to shutdown operations at PUREX.

- No stack at PUREX requires monitoring for nonradiological hazardous or EPA criteria pollutants during the transition to shutdown. Monitoring for 10. will be required if activities producing it are started during the transition to shutdown. 
WHC-EP-0468-3

\subsubsection{Existing Air Effluent Honftoring/Sampling System}

The descriptions of the air effluent $M / S$ program and associated equipment used at the PUREX PIant are compited from information included in existing effluent monitoring documents (WHC 198Ba) and engineering drawings (WHC 1988b, $1988 \mathrm{c}, 1990 \mathrm{c}, 1990 \mathrm{~d}, 1990 \mathrm{e}$ ).

7.1.2.1 291-h-1 Stack Honitoring/Sanpling Description. Multipoint sample probes are located at three elevations on the main stack; $18 \mathrm{~m}, 22.5 \mathrm{~m}$, and 27 m $(60,74$, and $88 \mathrm{ft}$ ). There are two saiple probes at each location. Two of the six probes, one each at 18 and $22.5 \mathrm{~m}$ (60 and $74 \mathrm{ft})$, are used for effluent sampling record purposes. The renaining probes lead to monttors or samplers used for process control or to sanplers which are not required during transition to shutdown conditions. Each of the record samplers consists of a fitter through which a near-isokinetic ( $\$ 20$ percent) sample is pulied. Automatic flow controjiers matntain the near-isokinetic samping conditions.

The particulate filters from the record sampling unit are renoved biweekiy and transferred to the 222-S Laboratory for radiochemical analyses. The samples are analyzed biweekly for gross alpha and beta and composited quarterly for specific radionuclide analyses. As of June 1994, sample times were increased frow one week to two weeks to obtain more sample for more sensitive laboratory anajysis.

7.1.2.2 296-A-1 Stack Monitoring/Sampling Description. Wultipoint sappling probes for the record sampler and alpha CAN are located at two elevations on the PR stack; $14 \mathrm{~m}$ and $16.5 \mathrm{~m}$ (46 and $54 \mathrm{ft}$ ) above grade. Samples are resoved from the gas stream by stack sampling probe SSP-V28A-1 and routed to the record sampler. As with Stack 291-A-1, particles are collected on a filter within the sampler. An Annubar probe (mulitpoint probe) is located 15m (50 $f t$ ) above grade on the PR stack and cont inuousty measures the flow through the stack. Fiow through the system is manually adjusted, when needed, to maintain a near-jsokinetic sampling condition.

The particulate filters fron the record sampler are reoved biweekly and transferred to the 222-5 Laboratory for radiochemical analyses. The samples are analyzed biweekly for gross alpha and beta and composited quarterly for specific radtonuclide analyses. As of June 1994, sample times were increased from one week to two weeks to obtain more sample for more sensitive laboratory anlaysis.

7.1.2.3 Wonitoring/Sampling Specifications and Deficiencies. Currently, the 291-A-1 and 296-A-1 stacks are continuously sampled for particulate radioactivity and monitored for flow rate.

A sanpling probe provides the capability for analys is of all required radionuclides. The current design, location, and nunber of sample probes on the main stack and PR stack are in conpliance with ANSI N13.1-1969 (AHSI 1969). The current stack sampling system uses the best avaitable technology and provides adequate assessnent of stack emissions based on historical sample analysis data. The sampling systen is well documented. 
Additional QA documentation is not available to address all the requirements of 40 CFR 61 (EPA 1991). However, many of the QA elements are addressed in the Quality Assurance Prograr Plan for Radionuclide Airborne Eutssions Nonitoring, WHC-EP-0536-1 (WHC 1993).

\subsubsection{Rewaining Stacks}

Based on EPA criteria (EPA 1991a), continuous monitoring for the remaining PUREX stacks is not required. However, periodic effluent sampling should be maintained to verify the low radionuclide air releases.

\subsubsection{Air Effluent Sampling Prograw}

The gaseous effluent in the main stack (291-A-1) and PR stack (296-A-1) shall be continuousiy sampled and periodically analyzed for total aipha and beta radiation and specific radionuclides as the means to provide the required sensftivity. Air samples from 291-A-1 will be analyzed for 261 an and samples from 296-A-1 will be analyzed for 24 An and $25,240 \mathrm{Pu}$. The $M / \mathrm{s}$ program for air effluents is included in Table 7-2. Air sampling shall comply with the criteria provided in applicable uHC manuals and procedures. Stack flow measurements shall comply with the criteria provided by the EPA (EPA 1991a).

Stack 291-A-1

Air sampling equipment is Tocated at the $18 \mathrm{~m}$ and $22.5 \mathrm{~m}$ (60 $\mathrm{ft}$ and $74 \mathrm{ft}$ ) levels of the main stack. Samples are removed from the airstream by stack sanpling probes SSP-V19-1 and SSP-YI8-2 and routed to record samplers. Particles are collected on filters within the samplers. Flow through the system is monitorad and controlled by flow controllers to ensure near-isokinetic saupling.

The particulate filters from the record sampling unit will be renoved biweekly and transferred to a laboratory for radiochemical analyses. These analyses will include Am determinations. Samples are analyzed biweekly for gross alpha and beta and composjted quarterly for specjfic radionuctide analyses. As of June 1994, sample times were increased fron one week to two weeks to obtain more sample for more sensitive laboratory analysis.

\section{Stack 296-h-1}

Samples are removed from the airstream by stack sampling probe SSP-V2BA-1 and routed to a record sampler. Particles are collected on a filter within the sampler. This system is capable of near isokinetic sampling, but requires manual adjustment wen stack flow conditions change. The stack flow conditions are usually constant.

The particulate filter from the record sampling unit will be removed biweakly and transferred to a laporatory for radiochemical analysis. The analyses will include $39 \mathrm{Pu}$ and ${ }^{241} \mathrm{Am}$ determinations. Samples are analyzed biweekly for gross alpha and beta and composited quarterly for specific radionucl tde analyses. As of June 1994, sample times were increased from one week to two weeks to obtain more sample for more sensitive laboratory analysts. 
WHC-EP-0468-3

\subsection{LIQUID EFFLUEKT MOAITORING SYSTEM DESCRIPTIOH AHD SPECIFICATIONS}

The descriptions of the liquid effluent $\mathrm{H} / \mathrm{S}$ program and associated equipment used at the PUREX Plant are compiled from information included in existing monjtoring docunents (WHC 1990a, 1990g) and engineering drawings (WHEC $1990 \mathrm{~b}, 1990 \mathrm{e}$, and 1990f).

\subsubsection{Monitoring/Sampl ing Requiresuents}

The concentration of contaminants in the CSL must meet current regutatory requirements. After June 1995, more restrictive SALDS criterja must be mot. The discharge criteria for PUREX waste water effluents will be the acceptance criteria for the SALBS. These criteria are currentiy being negotiated and will be included in the State Waste Discharge Pernit. The discharge criteria however, will meet all applicable federal and state standards for water quality.

7.2.1.1 Monitoring/0iversion Interface. How, the only mitigating control on effluent discharge from the PUREX Plant is in-1ine monitoring with the capabilfty for automatic diversion to the concrete-lined retention basin. However, the existing monitoring systen does not appear to be adequate for detecting releases that exceed the discharge criteria.

Because of the difference between detection and release 1 inits, it is possible to exceed the annual release 11 mits without detection. The detection 1 imits of the continuous effluent monitors that are used to activate the diversion controls are 3 to 5 orders of magnitude greater than the most restrictive limits establ ished in Section 4.2.3. Neekly process control samples will identify releases greater than annual 7 imits, and provide for timely response to releases greater than annua] ]imits but less than al arm sensitivity. Past upset conditions have typically produced releases an order of magnitude greater than alarn limits.

In addition, the CSL is not monitored continuously for pure beta emitters, such as strontiun, which have extremely low release limits and are difficult to quantify in aqueous solutions. Transit time from the point of monitoring to the point of diversion exceeds the response time of the manitors, so all upset flow is diverted.

7.2.1.2 Nonitoring/Sampling Criteria. During routine operations of the PUREX P7ant, the contaminant concentrations in the CSI were below the most restrictive of the applicable federal and state standards for water quality. The contaminant concentrations are also expected to meet the intent of the state's groundwater protection standards while the plant is in a shutdown mode. The $\mathrm{H} / \mathrm{S}$ activities will be performed to show continuing compliance with applicable WAC/EPA regulations and appropriate discharge criteria.

The existing monitoring instrumentation lacks the sensitivity to detect radionuclides in liquid effiuents at the concentrations of current discharge limits and therefore for SALDS acceptance criteria. Furthermore, instrumentation that can attain these sensitivities is not cosmercialiy available, nor is it likely that this type of instrumentation will be developed in the near future. As a result, instrument monitoring will be 
usefui only for detecting and quantifying upset releases. Oata for establishing environmental baseline conditions and determining compliance status will be collected by samping and analysis.

The sampling strategy must include provisions for correcting the deficiencies noted in this section. Unifornity and consistency must be incorporated in the sampling and analys is plan to ensure that .the database acceptability of PUREX liquid effluent for disposal at the SALDS. A new sampling and analysis plan will be written to reflect the new sampling requtrements for discharge to SALOS. The sampling criteria are summarized below and are presented in more detafl in Sections 10.2 and 10.3.

\subsubsection{CSL Effiuent Monitoring/Sampling System}

7.2.2.1 CSL Nonitoring/Sampling Description. The CSL monjtoring equipment is located in the 295-AC Buflding and includes continuous pH, ganma radiation, and flow monftoring. Excursions above or below $\mathrm{pH}$ limits and beta/gamma radiation alarm 1 inits and flow rates below set limits trigger alarms in the central control room. The radiation alarm triggers automatic diversion of the CSL to 216-A-42 Retention Basin and collection of verification samples. sanples are collected from the sample tank weekly for analysis. On a monthiy basis, the weekly samples are conbined in a flow proportional composite for envirommental retease records.

\subsubsection{CSL Monitoring/Sanpling 5pacifications. Table 7-3 describes the} normal operating paraneters for the CSL strean.

7.2.2.3 CSL Monitoring/Sampling Deficlencies. The minimundetection limits for "Am, "PU, and "Pu, which should be equal to 4 percent of the DCG are not currentify met. The current detection 1imits at the 222-\$ Laboratory are 5.0 $\times 10^{-4} \mu \mathrm{Ci} / \mathrm{m}^{1}$ for Plutonium and $1.2 \times 10^{-4} \mu \mathrm{Ci} / \mathrm{ml}$ for Americium (HHC $1990 \mathrm{~g}$ ). However, after connection to TEDF, PUREX CSL samples wl11 be analyzed at the Waste Sampling and Characterization Facility (WSCF). Improved detection limits are expected for conpliance with discharge criteria to SALDS, Revised detection limits, based on 4 percent of the DCG of $1.2 \times 10^{-*} \mathrm{aCi} / \mathrm{ml}$ for both, are required. Although reconmended, the monitoring systems for both radioactive and nonradioactive liquid discharges have no source of backup power in a power failure (WHC 1990g). Current procedures increase sampling and analysis in a power failure to ensure that unsampled releases do not occur.

\subsubsection{Liquid Effluents Monitoring Program}

The currently available alpha and betd/gamma monitoring equipment is inadequate for determining conpliance with discharge criteria. As a result, real-tine liquid effluent nonitoring will not be required for the PUREX Plant. Until more sensitive equipjant is developed and procured, compliance with discharge criteria shail be determined by sampling methodology as provided by DOE. 


\subsubsection{Lfquid Effluent Sampling Progran}

The sampling program for liquid effluents shall include composite and grab sampling methods. Samples shail be analyzed for major cations, major anions, pH, metals, volatile organic chemicals, and extractable organic chemfcals. The sampling and analytical plan is sumarized in Table 7-4.

7.2.4.1 CSL Effluent Stream. The CSL composite sampling equipment is located in the 295-AC Buflding. During stream operation, a 7-day compostte sample shall be collected week7y and recomposited monthiy for radjochemical and metal analyses in accordance with HHC-CM-7-5 (WHC 1993a). In addition, the pH of the CSL stream shall be determined fron each weekly composite sample.

7.2.4.2 Diverted Effluent. Upon receipt of a high radiation a 7 arm from the CSL gama monitor, an additional saiple shall be collected using the equipment provided for verification sampling of the CSL.

Samples collected during and immediately after the high radiation alarm event shall be analyzed for radionuclides. After a diverston, the 216-A-42 Basin will be recirculated and sampled according to procedure. Assuming the initial sample results meet acceptable criterta, the bastn will be pumped to the 216-B-3C Expansion Pond, or SALDS after June 1995. Before the basin is emptied, additional samples will be taken for environanental release recordkeeping. 
Table 7-1. Radioactive Sampling Requirements for Plutonium-Uranium Extraction Plant During Transition to Shutdown.

\begin{tabular}{|c|c|c|}
\hline \multirow[b]{2}{*}{ Stack } & \multicolumn{2}{|c|}{ Sampling/Analysis Requirements* } \\
\hline & Total alpha/beta & $\begin{array}{l}\text { Selective } \\
\text { radionuclide(s) }\end{array}$ \\
\hline $291-A-1$ & Yes & ${ }^{261} \overline{A m}$ \\
\hline $296-A-1$ & Yes & $\overline{250,260} \mathrm{Pu},{ }^{364} \overline{\mathrm{Aml}}$ \\
\hline 296-A-2 & Ho & Hone \\
\hline $296-A-3$ & Ho & None \\
\hline $296-A-5 A / 5 B$ & Ho & Hone \\
\hline $296-A-6$ & No & Mone \\
\hline $296-A-7$ & Mo & Mone \\
\hline $296-A-8$ & No & Hone \\
\hline $296-A-10$ & Ho & None \\
\hline 296-A-14 & No & None \\
\hline
\end{tabular}

*Based on 40 CFR 61 
Table 7-2. Monitoring/Sampling and Analysis Progran for Air Effiuents.

\begin{tabular}{|c|c|c|c|c|}
\hline $\begin{array}{l}\text { Monitor/Sample } \\
\text { location }\end{array}$ & Analytes & $\begin{array}{c}\text { Sample } \\
\text { frequency }\end{array}$ & $\begin{array}{c}\text { Type of } \\
\text { event }\end{array}$ & Equipment type \\
\hline \multicolumn{5}{|c|}{ Stack 291-A-1 } \\
\hline RM-V19-3 (60-ft) & Alpha, beta & Continuous & H & CPRMA \\
\hline SPL-V18-1 (74-ft) & $23 / 4 n$ & Biweekly & 5 & Record Sampler \\
\hline SPL-V19-1 (60-ft) & ${ }^{261} \mathrm{Am}$ & Biweekly & $\$$ & Record Sampler \\
\hline \multicolumn{5}{|c|}{ Stack 296-A-1 } \\
\hline RAN-V29A-1-1 (54-ft) & Alpha & Continuous & $M$ & CAM \\
\hline SPL-V28A-1 (46-ft) & $235,246 \mathrm{Pu},{ }^{241} \mathrm{Am}$ & Biweekly & 5 & Record Sampler \\
\hline
\end{tabular}

CPRY = Continuous particulate radiation monitor

CAM = Continuous air monitor 
Table 7-3. Chemical Sewer Normal Operating Parameters.

\begin{tabular}{|c|c|c|c|c|}
\hline \multirow{2}{*}{ Parameter } & \multirow{2}{*}{$\begin{array}{l}\text { Measurement } \\
\text { unit }\end{array}$} & \multicolumn{2}{|c|}{ Parameter range } & \multirow{2}{*}{$\begin{array}{c}\text { Monitor } \\
\text { identiffeation }\end{array}$} \\
\hline & & Low value & High value & \\
\hline Gamma & сpm & 0 & 6,500 & $R R-W 20-2-1$ \\
\hline $\mathrm{pH}$ & Standard units & 5.0 & 11.0 & HE-W20-19-1 \\
\hline Total alpha & $\mu \mathrm{C} 1 / \mathrm{m}]$ & 0 & $2.0 \mathrm{E}-5$ & Laboratory analyses \\
\hline Total beta & HC1/ml & 0 & $1.2 E-6$ & Laboratory analyses \\
\hline $\bar{H}$ & $\mu C i / n 1$ & $\overline{0}$ & $1.2 \mathrm{E}-2$ & Laboratory analyses \\
\hline${ }^{6} \mathrm{Sr}$ & $\mu \mathrm{Ci} / \mathrm{mi}$ & 0 & $1.2 \mathrm{E}-2$ & Laboratory analyses \\
\hline${ }^{137}$ Cs & $\mu \mathrm{Ci} / \mathrm{ml}$ & 0 & $8.0 \mathrm{E}-5$ & Laboratory ana]yses \\
\hline Flaw & L/ain & 1 & 2,300 & $F R-W 20-1-1$ \\
\hline
\end{tabular}




\begin{tabular}{|c|c|c|c|c|c|}
\hline $\begin{array}{l}\text { Sample } \\
\text { locatton }\end{array}$ & $\begin{array}{l}\text { Waste } \\
\text { strean }\end{array}$ & Analytes & Sample frequency & $\begin{array}{c}\text { Sample } \\
\text { type }\end{array}$ & Analytical technique \\
\hline 295-AC & CSt & $\begin{array}{l}\text { pH, Metals, } \\
\text { Radionuclides }\end{array}$ & Monthly & C & Llquid Scintillation, ICP \\
\hline 295-AC & $\begin{array}{l}\text { Diverted } \\
\text { Effluent }\end{array}$ & Radionuclides & $\begin{array}{l}\text { During and Imwediately } \\
\text { after high radiation } \\
\text { alarm. More sainples } \\
\text { will be taken if deesined } \\
\text { necessary. }\end{array}$ & G,C & Liquid Scintfllation \\
\hline
\end{tabular}

C a Compostte

G = Grab

ICP = Inductively-coupled plasma atomic entssion spectroscopy 
WHC-EP-0468-3

\subsection{HISTORICAL MOHIJORIAG/SA,PLING DATA FOR EFFLUENT STREAMS}

\section{B.I AIR EFFLUETSS}

\subsubsection{Normal Condtitions}

Historical air effluent $\mathcal{M} S$ data have been assambled in annual reports. These reports typically record the routine releases, thusual occurrences ( $1 . e .$, upset conditions), sanple points, analytical data sheets, instrument calibration records and other information. The last ten annual reports are listed below, but only the recent reports present data collected during transition to shutdown conditions.

\section{Annual Reports}

RHD. 1985, Rockwell Hanford Operations Annual and Environaental Survejllance Report for 1985, RHO-HS-SR-85-13P, Rockwell Hanford Operations, Richland, Hashington.

AHO, 1986, Rockwell Hamford Operations Annual and Environsental Survelllance Report for 1986, RHO-HS-SR-86-13P, Rockwell Hanford Operations, Richiand, Washington.

WHC, 1987, Nestinghouse Hamford Cowpany Environasntal Survell7ance Report for 1987, WHC-EP-0145, Westinghouse Hanford Company, Richland, Washington.

WHC, 1987, Westinghouse Hamford Company Effluent Discharge and Solfd Weste Managewent Report for Calendar Year 1987: 200/600 Areas, WHC-EP-0141, Westinghouse Hanford Company, Richland, Washington.

WHC, 1989, Hestinghouse Hanford Cowpany Effluent Discharge and Solid Waste Hanagement Report for Calendar Year 1988: 200/600 Areas, WHC-EP-0141-1, Hestinghouse Hanford Company, Richland, Washington.

WHC, 1989, Westinghouse Hanford Company Effluent Discharge and Soltd Haste Hanagewent Report for Calendar Year 1989: 200/600 Areas, WHC-EP-0141-2, Westinghouse Hanford Company, Richiand, Washington.

WHC, 1992, Environmental Releases for Calendar Year 1990, WHC-EP-0527, West inghouse Hanford Company, Richiand, Washington.

WHC, 1992, Environmental Releases for Calendar Yoar 1991, WHC-EP-0527-1, Westinghouse Hanford Company, Richiand, Washington.

HHC, 1993, Emvironmental Releases for Calendar Year 1992, WHC-EP-0527-2, Westinghouse Hanford Company, Richland, Washington.

WHC, 1994, Environmental Releases for Calendar Year 1993, WHC-EP-0527-3, Westinghouse Hanford Company, Richland, Washington. 
Pertinent information on the historical gaseous effluent nonitoring may also be found in the following:

WHC, 1990, Effluent Monitoring PJan PUREX Gaseous EffTuents, SD-CP-EMP-004, Westinghouse Hanford Corapany, Richland, Washington.

Tables 8-1a through h show Radioactive Airborne Effluent Releases for calendar years 1990, 1991, 1992, and 1993 for the PUREX 291-A-1 Ma in 5tack and 296-A-1 Product Removal Stack.

\subsubsection{Upset Conditions}

Section 4.1.3 describes the upset operating conditions of each stack.

\section{B.2 LIQUID EFFLUERTS}

\section{B.2.1 Normal Conditions}

Historical liquid $M / S$ data have been assembled in various reports. The four Effluent Releases and Solid Waste Management Reports for 1987, 1988, 1989, and 1990 given in Section 8.1.1 7ist much of this information. Routine operations and releases, upsets, sample potnts, analytical data sheets and other information are typically recorded. The following reports contain additional historical data and transition to shutdown data.

WHC, 1990, PUREX Liquid Effluent Monitoring PTan, WHC-SD-CP-EMP-006, Westinghouse Hanford Company, Richland, Washington.

WHC, 1990, Streak Specific Reports, WHC-EP-0342, Addendum 1-33, Westinghouse Hanford Company, Richland, Washington.

WHC, 1990, Addendum 2, PUREX Plant Chemical Sever Strean-Specific Report, WHC-EP-0342, Westinghouse Hanford Company, Richland, Washington.

WHC, 1990, Addendum 5, PUREX Plant Stean Condensate Strear-Specific Report, WHC-EP-0342, Westinghouse Hanford Company, Richland, Washington.

WHC, 1990, Addendum 12, PUREX Plant Process Condensate Streap-Specific Report, WHC-EP-0342, Westinghouse Hanford Company, Richland, Washington.

WHC, 1990, Addendum 14, PUREX P7ant Ammonia Scrubber Condensate StreamSpecific Report, WHC-EP-0342, Westinghouse Hanford Company, R1ch] and, Washington.

WHC, 1990, Addendum 20, PUREX Plant Cooling Hater Strear-Specific Report, WHC-EP-0342, Kestinghouse Hanford Company, Rich] and, Washington.

Monitoring data for the PUREX CSL for release to 216-B-3 Pond is presented in Tables 8-2a through d for calendar years 1990, 1991, 1992, 1993 respectively.

\subsubsection{Upset Conditions}

Section 4.2 .3 describes upset operating conditions of each 1 iquid discharge. 
Table 8-1a. Final 1990 Radionuclide Airborne Releases from 291-A-1 (A552), 200 East Area.

\begin{tabular}{|c|c|c|}
\hline Radionucl ide & Release (C1) & $\begin{array}{c}\text { Average Concentration } \\
(\mu \mathrm{Cl} / \mathrm{ml})\end{array}$ \\
\hline$\vec{H}$ & $1.7 E+01$ & $1.0 \mathrm{E}-08$ \\
\hline${ }^{14} \mathrm{C}$ & 5.7 E-01 & $3.5 E-10$ \\
\hline${ }^{85} \mathrm{Kr} n$ & $5.7 E+03$ & $3.6 \mathrm{E}-06$ \\
\hline${ }^{90} \mathrm{Sr}$ & $1.2[-03$ & $7.3 \mathrm{E}-13$ \\
\hline${ }^{95} \mathrm{Zr}$ & HD & $<1.9$ E-14 \\
\hline $\bar{F}_{\mathrm{Bb}}$ & no & $<9.8 \mathrm{E}-15$ \\
\hline${ }^{103} \mathrm{Ru}$ & $4.2 \mathrm{E}-05$ & $2.6 \mathrm{E}-14$ \\
\hline${ }^{806} \mathrm{Ru}$ & $1.4 \mathrm{E}-03$ & 8.6 E-13 \\
\hline${ }^{113} \mathrm{Sn}$ & $2.4 E-04$ & $1.5 \mathrm{E}-13$ \\
\hline${ }^{125} s b$ & $1.5 \mathrm{E}-03$ & 9.0 E-13 \\
\hline$\sqrt{129} I$ & $1.1 \mathrm{E}-01$ & $6.6 \mathrm{E}-11$ \\
\hline${ }^{737} 1$ & $1.4 E-03$ & $8.6 E-13$ \\
\hline${ }^{134} \mathrm{CS}_{5}$ & ND & $<1.0 \mathrm{E}-14$ \\
\hline${ }^{137} \mathrm{Cs}$ & $2.1 \mathrm{E}-05$ & $1.3 \mathrm{E}-14$ \\
\hline${ }^{144} \mathrm{Ce}$ & ND & $<9.7$ E-14 \\
\hline${ }^{147} \mathrm{Pm}$ & $1.9 \mathrm{E}-04$ & $1.2 \mathrm{E}-13$ \\
\hline${ }^{212} \mathrm{~Pb}$ & $2.9 \mathrm{E}-02$ & $1.8 \mathrm{E}-11$ \\
\hline${ }^{220} \mathrm{Rn}$ & $3.6 \mathrm{E}+02$ & 2.2 E-07 \\
\hline${ }^{238} \mathrm{Pu}$ & $2.1 \mathrm{E}-06$ & $1.3 \mathrm{E}-15$ \\
\hline $239,{ }^{240} \mathrm{Pu}$ & 3.2 E-05 & $1.9 \mathrm{E}-14$ \\
\hline${ }^{241} \mathrm{Pu}$ & $1.6 \mathrm{E}-04$ & $1.0 \mathrm{E}-13$ \\
\hline$\overline{241} \mathrm{Am}$ & $3.8 \mathrm{E}-06$ & $2.4 \mathrm{E}-15$ \\
\hline
\end{tabular}

The release of value and concentration for ${ }^{65} \mathrm{Kr}$ are calculated from the plant inventory and stack flow, respectively; it is not measured effluent.

NO $=$ Hone detected 
Table 8-1b. Radionucl jde Ajr Enisstons in 1991 from 291-A-1 (A552), 200 East Area.

\begin{tabular}{|c|c|c|}
\hline Radtonuclide & Release (C1) & $\begin{array}{l}\text { Average concentration } \\
\qquad(\mu \mathrm{C} \mathrm{i} / \mathrm{m} \mathrm{T})\end{array}$ \\
\hline$\sqrt{3} \mathrm{H}$ & $1.0 \mathrm{E}-00$ & $7.6 \mathrm{E}-10$ \\
\hline${ }^{14} \mathrm{C}$ & $8.1 \mathrm{E}-02$ & $6.1 \mathrm{E}-11$ \\
\hline${ }^{60} \mathrm{Sr}$ & $7.9 \mathrm{E}-04$ & $6.0 \mathrm{E}-13$ \\
\hline${ }^{95} \mathrm{Zr}$ & ND & $<1.8 \mathrm{E}-14$ \\
\hline $\mathrm{S}_{\mathrm{Hb}}$ & ND & $<1.1$ E-14 \\
\hline${ }^{105} \overline{R u}$ & ND & $<2.0 \mathrm{E}-13$ \\
\hline${ }^{106} \overline{\mathrm{Ru}}$ & $2.8 \mathrm{E}-03$ & $2.1 \mathrm{E}-12$ \\
\hline $113 \sqrt[5 n]{5 n}$ & ND & $<2.3 \mathrm{E}-13$ \\
\hline${ }^{125} \mathrm{Sb}$ & $\overline{N D}$ & $<1.5 \mathrm{E}-12$ \\
\hline${ }^{139} I$ & $4.8 \mathrm{E}-02$ & $3.6 \mathrm{E}-11$ \\
\hline${ }^{131} I$ & ND & $<1.8 \mathrm{E}-13$ \\
\hline${ }^{134} \mathrm{Cs}$ & ND & $<9.6$ E-15 \\
\hline${ }^{137} \mathrm{Cs}$ & $3.0 \mathrm{E}-03$ & 2.2 E-12 \\
\hline${ }^{144} \mathrm{Ce}$ & 2.3 E-04 & $1.8 \mathrm{E}-13$ \\
\hline${ }^{147} \mathrm{Pm}$ & $6.5 \mathrm{E}-04$ & $4.9 \mathrm{E}-13$ \\
\hline${ }^{212} \mathrm{pb}$ & $2.7 E-03$ & $2.0 \mathrm{E}-12$ \\
\hline${ }^{220} \mathrm{Rn}$ & $3.3 E+01$ & $2.5 \mathrm{E}-08$ \\
\hline${ }^{238} \mathrm{Pu}$ & $3.2 \mathrm{E}-06$ & 2.4 E-15 \\
\hline $239,240 \mathrm{Pu}$ & $3.8 \mathrm{E}-05$ & $2.8 \mathrm{E}-14$ \\
\hline${ }^{241} \mathrm{Pu}$ & $2.9 \varepsilon-04$ & $2.2 \mathrm{E}-13$ \\
\hline $261_{\text {An }}$ & $3.5 \mathrm{E}-04$ & $2.6 \mathrm{E}-13$ \\
\hline
\end{tabular}

ND $=$ Mone detected 
Tab7e 8-1c. Radiontuclide Air Emissions in 1992 fron 291-A-1 (A552), 200 East Area.

\begin{tabular}{|c|c|c|}
\hline Radionucl Ide & Release (Ci) & $\begin{array}{c}\text { Average concentration } \\
(\mu \mathrm{Ci} / \mu \mathrm{ll})\end{array}$ \\
\hline${ }^{90} \mathrm{Sr}$ & $3.3 E-04$ & $1.4 \mathrm{E}-13$ \\
\hline${ }^{5} \mathrm{Zr}$ & ND & $<3.8$ E-14 \\
\hline${ }^{55} \mathrm{Nb}$ & ND & $<2.3$ E-14 \\
\hline${ }^{103} \mathrm{Ru}$ & ND & $<1.1 \mathrm{E}-13$ \\
\hline${ }^{106} \mathrm{Rtu}$ & NO & $<1.3 \mathrm{E}-12$ \\
\hline${ }^{113} \mathrm{Sn}$ & $\overrightarrow{N D}$ & $<1.2$ E-13 \\
\hline${ }^{125} \mathrm{Sb}$ & $\overline{N D}$ & $<2.0$ E-12 \\
\hline 129 & $2.7 E-02$ & $1.5 \mathrm{E}-11$ \\
\hline${ }^{737} 1$ & ND & $<2.2$ E-13 \\
\hline${ }^{134} \mathrm{Cs}$ & ND & $<2.1 \mathrm{E}-14$ \\
\hline${ }^{135} \mathrm{Cs}$ & $1.6 \mathrm{E}-03$ & 7.1 E-13 \\
\hline${ }^{146} \mathrm{Ce}$ & ND & $<1.9$ E-13 \\
\hline${ }^{147} \mathrm{P}_{\mathrm{m}}$ & 1.7 E-04 & $7.5 \mathrm{E}-14$ \\
\hline${ }^{272} \mathrm{~Pb}$ & $2.7 \mathrm{E}-03$ & $1.2 \mathrm{E}-12$ \\
\hline${ }^{220} R n$ & $3.4 \mathrm{E}+0 \mathrm{I}$ & $1.5 \mathrm{E}-08$ \\
\hline${ }^{2 \times \bar{p}} \mathrm{Pu}$ & $1.3 \mathrm{E}-05$ & 5.7 E-15 \\
\hline $25.240 \mathrm{Pu}$ & $2.2 \mathrm{E}-05$ & 9.7 E-15 \\
\hline${ }^{24} \mathrm{Pu}$ & $4.7 \mathrm{E}-04$ & $2.0 \mathrm{E}-13$ \\
\hline${ }^{241} \mathrm{Am}$ & $1.3 \mathrm{E}-04$ & 5.7 E-14 \\
\hline Total $\alpha$ & $1.4 \mathrm{E}-04$ & $6.0 \mathrm{E}-14$ \\
\hline Total B & $1.6 \mathrm{E}-03$ & $7.2 \mathrm{E}-13$ \\
\hline
\end{tabular}

HD - Hone detected 
Table 8-Id. Radionucl ide Air Emissions in 1993 from 291-A-1 (A552), 200 East Area.

\begin{tabular}{|c|c|c|}
\hline Radionuclide & Release (Ci) & $\begin{array}{l}\text { Average concentration } \\
\qquad\left(\Delta C^{1} 1 / n 1\right)\end{array}$ \\
\hline${ }^{90} \mathrm{sr}$ & $4.9 \mathrm{E}-05$ & 3.2 E-14 \\
\hline 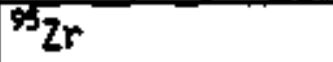 & ND & $<1.2 \mathrm{E}-14$ \\
\hline${ }^{95} \mathrm{Nb}$ & ND & $<7.1$ E-15 \\
\hline${ }^{10 \sqrt[3]{3}} \mathrm{Ru}$ & NO & $<4.1 E-14$ \\
\hline${ }^{105} \mathrm{Ru}$ & $3.6 \mathrm{E}-04$ & $2.4 E-13$ \\
\hline${ }^{113} \mathrm{Sn}$ & 10 & $<5.0 \mathrm{E}-14$ \\
\hline${ }^{125} \mathrm{Sb}$ & 10 & $<2.9 \mathrm{E}-13$ \\
\hline 126 & $4.8 \mathrm{E}-03$ & $3.2 \mathrm{E}-12$ \\
\hline${ }^{1351} I$ & ND & $<3.5$ E-14 \\
\hline${ }^{134} \mathrm{Cs}$ & ND & $<6.3$ E-15 \\
\hline${ }^{137} \mathrm{Cs}$ & $1.4 E-04$ & 9.2 E-14 \\
\hline${ }^{147} \mathrm{PT}$ & $1.1 \mathrm{E}-04$ & 7.2 E-14 \\
\hline${ }^{212} \mathrm{pb}$ & 9.7 E-04 & $6.4 \mathrm{E}-13$ \\
\hline${ }^{220} \mathrm{Rn}$ & $1.2 E+01$ & $7.9 \mathrm{E}-09$ \\
\hline${ }^{238} \mathrm{Pu}$ & $\overline{3.2 E-06}$ & $2.1 \mathrm{E}-15$ \\
\hline $239,{ }^{240} \mathrm{Pu}$ & $4.9 \mathrm{E}-05$ & $3 . \overline{2} \mathrm{E}-15$ \\
\hline${ }^{261} \mathrm{pu}$ & $3.3 \mathrm{E}-05$ & 2.2 E-14 \\
\hline $\mathrm{ZW1}_{\mathrm{A} / \mathrm{B}}$ & 2.7 E-05 & $1.7 \mathrm{E}-14$ \\
\hline Totaj $\alpha$ & $2.9 \mathrm{E}-05$ & $1.9 \mathrm{E}-14$ \\
\hline Total B & $3.7 E-04$ & $2.4 E-13$ \\
\hline
\end{tabular}

ND = None detected 
Table 8-le. Radionuclide Air Enfssions in 1990 from 296-A-1 (A540), 200 East Area.

\begin{tabular}{|l|c|c|}
\hline \multicolumn{1}{|c|}{ Radionuclide } & Release (Ci) & $\begin{array}{c}\text { Average concentration } \\
(\text { (AC } 1 / \mathrm{ml})\end{array}$ \\
\hline $239.260 \mathrm{Pu}$ & $1.9 \mathrm{E}-06$ & $2.2 \mathrm{E}-14$ \\
\hline $241 \mathrm{Asl}$ & $9.5 \mathrm{E}-07$ & $1.1 \mathrm{E}-14$ \\
\hline Gross $\alpha$ & $2.8 \mathrm{E}-06$ & $3.1 \mathrm{E}-14$ \\
\hline Gross B & HD & $<2.3 \mathrm{E}-15$ \\
\hline
\end{tabular}

ND = None detected

Table B-1f. Radionuclide Air Entissions in 1991 from 296-A-1 (A540), 200 East Area.

\begin{tabular}{|l|c|c|}
\hline \multicolumn{1}{|c|}{ Radionucijide } & ReTease (Ci) & $\begin{array}{c}\text { Average concentration } \\
(\mu \mathrm{Ci} / \mathrm{al})\end{array}$ \\
\hline${ }^{26,}{ }^{240} \mathrm{Pu}$ & $1.7 \mathrm{E}-06$ & $2.4 \mathrm{E}-14$ \\
\hline Total a & $7.4 \mathrm{E}-07$ & $1.1 \mathrm{E}-14$ \\
\hline Total B & $1.5 \mathrm{E}-06$ & $2.2 \mathrm{E}-14$ \\
\hline
\end{tabular}

ND = None detected 
Table 8-19. Radionuclide Air Enissions in 1992 from 296-A-1 (A540), 200 East Area.

\begin{tabular}{|c|c|c|}
\hline Radionucl ide & Release (Ci) & $\begin{array}{l}\text { Average concentration } \\
(\Delta \mathrm{CC} \mathrm{i} / \mathrm{m}])\end{array}$ \\
\hline $239,{ }^{240} \mathrm{Pu}$ & $1.0 \mathrm{E}-06$ & $1.2 \mathrm{E}-14$ \\
\hline${ }^{241} \mathrm{Pu}$ & $7.1 \mathrm{E}-06$ & $8.2 \mathrm{E}-14$ \\
\hline $\mathrm{za}_{\mathrm{Axl}}$ & $3.5 \mathrm{E}-07$ & $4.0 \mathrm{E}-15$ \\
\hline Total a & 9.7 E-07 & $1.1 \mathrm{E}-14$ \\
\hline Total B & ND & $<3.1$ E-15 \\
\hline
\end{tabular}

ND = None detected

Table 8-1h, Radionucl ide Air Emissions in 1993 from 296-A-1 (A540), 200 East Area.

\begin{tabular}{|l|c|c|}
\hline \multicolumn{1}{|c|}{ Radionuclide } & Release (C1) & $\begin{array}{c}\text { Average concentration } \\
(\mu \mathrm{C}(\mathrm{l} / \mathrm{m}])\end{array}$ \\
\hline${ }^{24,}{ }^{240} \mathrm{Pu}$ & $2.1 \mathrm{E}-06$ & $2.8 \mathrm{E}-14$ \\
\hline${ }^{261} \mathrm{AP}$ & $8.4 \mathrm{E}-07$ & $1.1 \mathrm{E}-14$ \\
\hline Total $\alpha$ & $2.3 \mathrm{E}-06$ & $3.1 \mathrm{E}-14$ \\
\hline Total B & $3.4 \mathrm{E}-07$ & $4.5 \mathrm{E}-15$ \\
\hline
\end{tabular}

ND - None detected 
Table 8-2a. Plutonfuw-Uranium Extraction Chemical Sewer (CSL) to 216-8-3 Pond, 200 East Area (H118) in 1990.

\begin{tabular}{|l|c|c|}
\hline \multicolumn{1}{|c|}{ Radionuci ide } & Release (Ci) & $\begin{array}{c}\text { Average concentration } \\
(\mu \mathrm{Cl} / \mathrm{ml})\end{array}$ \\
\hline${ }^{3 \mathrm{H}}$ & $5.6 \mathrm{E}-01$ & $7.6 \mathrm{E}-07$ \\
\hline${ }^{50} \mathrm{Sr}$ & $1.3 \mathrm{E}-02$ & $1.7 \mathrm{E}-08$ \\
\hline${ }^{103} \mathrm{Ru}$ & $2.2 \mathrm{E}-02$ & $3.0 \mathrm{E}-08$ \\
\hline${ }^{106} \mathrm{Ru}$ & $3.8 \mathrm{E}-02$ & $5.2 \mathrm{E}-08$ \\
\hline${ }^{137} \mathrm{Cs}$ & $4.8 \mathrm{E}-02$ & $6.5 \mathrm{E}-08$ \\
\hline${ }^{147} \mathrm{Pu}$ & $\mathrm{ND}$ & $<9.0 \mathrm{E}-07$ \\
\hline${ }^{239,}{ }^{240} \mathrm{Pu}$ & $8.2 \mathrm{E}-03$ & $1.1 \mathrm{E}-08$ \\
\hline${ }^{247} \mathrm{Am}$ & $1.6 \mathrm{E}-02$ & $2.2 \mathrm{E}-08$ \\
\hline $6 \mathrm{ross}$ a & $2.3 \mathrm{E}-03$ & $3.2 \mathrm{E}-09$ \\
\hline Gross B & $6.5 \mathrm{E}-03$ & $8.8 \mathrm{E}-09$ \\
\hline Yoluate & \multicolumn{2}{|c|}{$7.4 \mathrm{E}+08 \mathrm{~L}$} \\
\hline
\end{tabular}

MD = None detected 
Table 8-2b. Plutonium-Uraniun Extraction Chemical Sewer (CSL) to 216-B-3 Pond, 200 East Area (H118) in 1991.

\begin{tabular}{|c|c|c|}
\hline Radionuclide & Release (Ci) & $\begin{array}{l}\text { Average concentration } \\
(\mu C i / \omega 1)\end{array}$ \\
\hline 3 & $4.1 E-01$ & 5.1 E-07 \\
\hline${ }^{90} \mathrm{Sr}$ & $1.5 \mathrm{E}-02$ & $2.4 E-08$ \\
\hline${ }^{103} \mathrm{Ru}$ & ND & $<3.7$ E-08 \\
\hline${ }^{137} \mathrm{Cs}$ & $5.0 \mathrm{E}-02$ & $6.2 \mathrm{E}-0 \mathrm{~B}$ \\
\hline${ }^{147} \mathrm{Pm}$ & ND & $<9.0 \mathrm{E}-07$ \\
\hline $24,240 \mathrm{pu}$ & $1.9 \mathrm{E}-02$ & $2.3 \mathrm{E}-08$ \\
\hline $261 \overline{A m}$ & $2.6 \mathrm{E}-02$ & $3.2 \mathrm{E}-08$ \\
\hline Gross $\alpha$ & $2.0 \mathrm{E}-03$ & $2.4 \mathrm{E}-09$ \\
\hline Gross B & $3.9 \mathrm{E}-03$ & 4.7 E-09 \\
\hline Vol unle & \multicolumn{2}{|c|}{$8.2 \mathrm{E}+08 \mathrm{~L}$} \\
\hline
\end{tabular}

ND - Hone detected 
Table 8-2c. Radionuclides in Plutonium-Uranium Extraction Plant Chemical Sewor Discharge (CSL) to 216-B-3 Pond, 200 East Area (H118) in 1992.

\begin{tabular}{|l|c|c|}
\hline \multicolumn{1}{|c|}{ Radionuclide } & Release (C) & $\begin{array}{c}\text { Average Concentration } \\
(\mu \mathrm{CI} / \mathrm{ml})\end{array}$ \\
\hline${ }^{3 \mathrm{H}}$ & $3.4 \mathrm{E}-01$ & $6.4 \mathrm{E}-07$ \\
\hline${ }^{90} \mathrm{Sr}$ & $7.2 \mathrm{E}-03$ & $1.3 \mathrm{E}-08$ \\
\hline${ }^{137} \mathrm{Cs}$ & $1.4 \mathrm{E}-01$ & $2.6 \mathrm{E}-07$ \\
\hline${ }^{147} \mathrm{Pm}$ & $\mathrm{MD}$ & $<9.0 \mathrm{E}-07$ \\
\hline${ }^{239},{ }^{240} \mathrm{Pu}$ & $\mathrm{ND}$ & $<3.3 \mathrm{E}-08$ \\
\hline${ }^{241} \mathrm{Am}$ & $\mathrm{ND}$ & $<2.8 \mathrm{E}-08$ \\
\hline Gross $\alpha$ & $5.3 \mathrm{E}-04$ & $1.0 \mathrm{E}-09$ \\
\hline Gross B & $4.2 \mathrm{E}-03$ & $7.9 \mathrm{E}-09$ \\
\hline Volume & \multicolumn{2}{|c|}{$5.3 \mathrm{E}+08 \mathrm{~L}(1.4 \mathrm{E}+08 \mathrm{gal})$} \\
\hline
\end{tabular}

ND - Mone detected 
Table 8-2d. Radionuclides in Plutonium-Uranfun Extraction Plant Chenical Sewer D1scharge (CSL) to 216-B-3 Pond, 200 East Area (HI18) in 1993.

\begin{tabular}{|c|c|c|}
\hline Radionuclide & Release (C1) & $\begin{array}{c}\text { Average Concentration } \\
\text { ( } \mu \mathrm{C} 1 / \mathrm{m} \mathrm{l})\end{array}$ \\
\hline${ }^{3} \mathrm{H}$ & $4.1 \mathrm{E}-01$ & $7.4 \mathrm{E}-07$ \\
\hline${ }^{90} \mathrm{sr}$ & $6.8 \mathrm{E}-03$ & $1.2 \mathrm{E}-08$ \\
\hline${ }^{137} \mathrm{Cs}$ & ND & $<4.1 E-08$ \\
\hline${ }^{447} \mathrm{Pan}$ & ND & $\langle 9.0 \mathrm{E}-0\rangle$ \\
\hline $25,240 \mathrm{Pu}$ & $1.2 \mathrm{E}-02$ & $2.2 \mathrm{E}-08$ \\
\hline $241_{\mathrm{Am}}$ & ND & $<2.8 \mathrm{E}-08$ \\
\hline Gross a & $9.7 \mathrm{E}-04$ & $1.8 \mathrm{E}-09$ \\
\hline Gross $B$ & $5.2 \mathrm{E}-03$ & 9.3 E-09 \\
\hline Volume & \multicolumn{2}{|c|}{$5.5 \mathrm{E}+08 \mathrm{~L}(1.5 \mathrm{E}+08 \mathrm{gal})$} \\
\hline
\end{tabular}

ND = None detected 


\subsection{SANPLE AMLLSIS}

\subsection{Alalytical LaboRatoRy and procenures}

Requirements for the development, tssuance, and control of instructions and procedures within the Analytical Laboratories are covered by $\mathrm{HC}-\mathrm{CH}-5-4$, Analyt lcal Chewistry Services Laboratories Operating Instructions (WHC 1993c). This procedure is an adpinistrative procedure which provides guidance on how to write, review, and control analytical procedures and other supporting procedures used within the analytical laboratories.

The analytical laboratories presently have over 1,000 procedures that define operations. These procedures, individually numbered and controlled, are divided into six categories as show below:

1. L Sertes - Anatytical Procedures. These procedures cover a specific analysis or analysis type for each sample.

2. Lo Sertes - Operating Procedures. These procedures provide guidance for all 1aboratory operations supporting analytical techniques. This would include such operations as packaging and shipping.

3. LE Sertes - Essential Haterials Procedures. These procedures cover the analysis of supplies, chemicals, and metais, using industry standard analyses such as American Society for Testing and Naterials (ASTM) procedures.

4. LR Series - Reagent Procedures. These procedures provide guidance for the preparation, dilution and storage of standards and reagents used in specific Analytical Procedures (LA Series).

5. LC Series - Computer Operation Procedures. These procedures cover the use of database systens and computer operations associated with specifjc analysis techniques.

6. LQ Series. These procedures cover the techniques used for QC guidance, calibration and verification of analysis techniques and analytical systens.

Each Analytical Procedure (LA Series) covers a specific analys is for a variety of sample types. The procedures are individuaily numbered, issued, and controlled by the Procedure Controt group. Each procedure is a controlled documant and contains the following information:

- Title

- Author

- Issued by

- Laboratory manager

- Release date

- Review date

- Document number

- Revision/Modification

- Page number. 
Each procedure contajns the following generic sections as applicable to the specific analysis technique:

- Summary

- Limitations

- Application

- Safety.

- Reagents

- Equipment

- Standards

- Procedure steps

- Calculations

- Discussion

- References.

Additional requirements are defined in PUREX/NO, Plant Administration, WHC-CK-5-9 (WHC 1993b). These procedures define operations not covered by existing codes and standards and contatn all necessary requirements for qualifying personnel, procedures, and/or equipment to conduct processes in a timely, competent manner. Analytical Laboratory operating instructions also cover the preparation, documentation, and control of individual procedures.

Quality Assurance requirements for the Analytical Laboratory procedures are deftned by the following documents:

- MHC-CM-4-2, Hestinghouse Quality Assurance Hanual (WHC 1988e)

- WHC-CM-5-9, PUREX/WO

The 222-S Laboratory on the Hanford Site has one program plan and two project plans to address applicable quality requirements related to sample analysis. These plans are as follows:

- WHC-SD-CP-QAPP-003, Quality Assurance Progran PIan for the Chemica] Analyses of Environmental Samples (UHC 199la)

- WHC-SD-QAPP-001, Analytical Chemistry Services Laboratories Quality Assurance Plan (WHC 1989a)

- WHC-SD-CP-QAPP-002, Qualfty Assurance Project PIan for the Chemical Analysis of Highly Radioactive Hixed Haste Samples in Support of Environmental Activities on the Hanford Site (WHC 1989b).

The Resources Conservation and Recovery Act of 1976 (RCRA) protocol for liquid effivent sanpling, associated with the liquid effluent study, is not part of the FEMPS. The QA requirements for the sampling anaiys is plans (SAP) associated with the liquid effluent study are identified in the latest version of the WHC-SD-MH-QAPP-011, Lfquid Effluent Sampling Quality Assurance Prograat Plan (whC 1992b).

Detal1s of the analytical laboratory and analytica] procedures are discussed in the 222-5 Laboratory FEMP. 
The analytical and laboratory procedure for the FENP activities aro identified in Quality Assurance Project Plan for Facility Effluent Honitoring Plan (WHC 1992C). General requirenents for laboratory procedures, data analyses, and statistical treatment are addressed in the Qua]ity Assurance Project P1an (QAPjP).

The following elements are contained in the 222-5 Laboratory Analytica] Procedures (identiffed in QAPJP, HAC-EP-0446 [WHC 1992C], Table 8-1).

- Procedures preventing cross contamination

- Documentation of methods

- Gana emitting radionuclides

- Calibration

- Handling of samples

- Analysis method and capabilities

- Gross alpha, beta, and gamma measurements

- Direct gamma-ray spectrometry

- Beta counters

- Alpha-energy analysis

- Radiochemical separation procedures

- Reporting of results

- Counter calibration

- Intercalibration of equipment and procedures

- Counter background

- Quality assurance

- Sumnary of data and statistical treatment requirements

- Variability of effluent and environmental data

- Summarization of data and testing for outliers

- Treatment of stgniffcant figures

- Parent-decay product relationships 
- Comparisons to regulatory or admintstrative control standards and control data

- Quality assurance

\subsection{SAMPLE AND OATA CHAIH OF CUSTODY}

Sample identification is initiated by the operations group taking the sample. Sampling personnel use the chain of custody fortu and $\log$ in system to provide sample identification. Sample custody is transferred when the properly marked sample is received by the analytical iaboratory.

Sample chain of custody within the Analytical Laboratory is covered by WHC-CH-5-4, Analytical Chemistry Services Laboratories Operating Instructions (HHC 1993c) and individual analytical laboratory procedures.

The PUREX Factlity has a chain-of-custody procedure for gaseous effiuents as described in WHC-IP-0718, Section 3.3.3, Rev, O (WHC 1993h). For liquid effluents, the chain-of-custody procedure is described in the plant operating procedure $\mathrm{PO}-080-315$.

Because the Hanford \$ite has 33 separate discharges, the Tr1-Party Agreement has estabilished milestones as part of the Ljquid Effluent Study program for compli ance plans of 1 iquid discharges to land that could infiltrate to groundwater (WAC 1990). Sampling and analysis plans (SAP) are required for each Hanford Site liquid effluent stream. A SAP for PUREX, PUREX CSL Saapling and Analysis PJ an was prepared in September 1991 (WHC 1991C). The SAP describes the sampling, analysis, and related activities required under the Tri-Party Agreenent for PUREX 1iquid effluent streants.

Sampling was performed according to the SAP. The SAPs have been prepared pursuant to the Trij-Party Agreement (WAC 1990) and are avaliable for review. 


\subsection{HOTIFICATIOH AMD REPORTIRE REQUIREMEMTS}

Notification and reporting requirements are imposed by federal and state law as well as by DOE orders. Because DOE and EPA documents are periodically updated, the current requirentents should be obtained from the latest CFR and DoE order. This'section is to serve as a guideline for general notification and reporting requirements and as a reference to the sources where specific information bay be found for federal, state, and oof requirements.

\subsection{OCCURREHCE CATEGORIZATIOH, MOTIFICATION, AND REPORTING}

Hotifications and reporting of specific events related to environmental releases and/or events involving effluents and/or hazardous materials shall be made in accordance with DOE Orders 5400.1 (DOE 1991a) and 5000.3B (1993). Implementing the orders is accompl ished via Nanagegent Reguirements and Procedures ifanual. Specific implementation, where required, is included in the appropriate facility's "Occurrence Categorization, Hotification, and Reporting" procedure. Implenenting environmental liaits and requirements is found in the Envfroniental Cowpliance Hanual, WHC-CH-7-5 (WHC 1993a).

\subsubsection{Occurrence Identification and Imediate Response}

Each employee shall identify events and conditions and shal] promptly notify management of such occurrences.

a. Call 911 if ibanediate help such as fire, ambulance, or patrol is required.

b. Call 373-3800 (the Patrol Operations Center) if assistance other than fire, ambulance, or patrol is required.

c. After requesting necessary outside assistance, the employee shall notify his or her supervisor, who sha]l notify the facility manager, the building energency director, and the Occurrence Hotification Center (376-2900).

Operations personnel shall take appropriate immediate action to stabilize or return the facility/operation to a safe condition. Actions taken in response to nonroutine releases, as evidenced by high salple results from

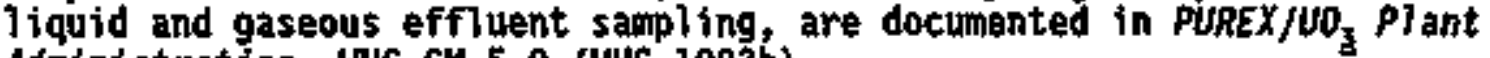
Adatintstration, WHC-CH-5-9 (WHC 1993b).

The oversight organtzations shall notify their BoE Field office, Richland, counterparts of the event after recelving notifications from, and discussing the event wth, the factlity manager.

\subsection{2 occurrence Categorization}

Occurrences (environmental) shall be categorized as soon as practjcal using the specific criteria listed in section 10.2 for radioactive and 
hazardous materials release. These categorizations should be made within 2 hours of identification. Occurrences shall be categorized by their seriousness; if categorization is not clear, the occurrence shall be categorized initially at the higher level being considered. The occurrence categorization sha11 then be either evaluated, maintained, or lowered as information becomes avallable.

\subsection{OCCURREFICE CATEGORIZATIOH}

The following eriteria for categorization of occurrences are establ ished in MHC-CM-1-3, Ident ifying and Resolving Unreviewed Safety Questions (wiC 1989d), which inplements the requirements contained in DOE Order 5000.3B (DOE 1993).

\subsubsection{Radioactive Releases}

\subsubsection{Energency.}

- Any release of radionuclide naterial to controlled or uncontrolled areas in concentration which, if averaged over 24-hour period, would exceed 5 times the respective reportabie quantities specified for such materials in 40 CFR 302 (EPA 1991b). Hote: This event must al so meet the criteria for classified emergency in accordance with Emergency PIan, WHC-CH-4-1 (WHC 1989e), and/or factlity specific exergency action levels.

\subsubsection{Unusua] Occurrence.}

- Release of a radionuclide material that exceeds a federally permitted release by the amount of a CERCLA reportable quantity or, where no federally permitted release exists, the release exceeds the reportable quantity.

- Release of radionuclide material that violates environmental requirements in federal permits, federal regulations, or DOE standards.

- Release below energency levels which requires immediate (less than 4 hours) reporting to Federal regulatory authorities or trtggers specific action levels for an outside agency.

\subsubsection{Off-Normal.}

- Any release of radionuclide material to controlled or uncontrolled areas that is not part of a normal monitored release and exceeds 50 percent of a CERCLA reportable quantity specified for such material in accordance with 40 CFR 302 (EPA 19g1b).

- Any controlled release of radionuclide material that occurs as a monitored part of norral 1 operations wich exceeds what historical data and/or analysis show is expected as a result of norma 1 operations. 
- Any monitored facility or site boundary where exposure of concentrations exceed what historical data and/or analysis show is expected as a result of normal operations.

- Any detection of a radionuclide in a santtary or storm sewer, waste or process stream, or any holding points where such a material is not expected.

- Any controlled, uncontrolled, or accidental release which is not classified as an unusual occurrence but which will be reported in writing to state/local agencies in a fornat other than routine monthly or quarterly reports. Note: This does not include rout ine offsite distribution of notification reports.

\subsubsection{Release of Hazardous substances/Regulated Pollutants/0il}

\subsubsection{Emergency.}

- Any actual or potential release of material to the environment that results in, or could result in, significant off-site consequences (e.g., need to relocate people, major wildlife kills, major wetl and degradation, major aquifer contamination, need to secure downstream water supply intakes, etc.). Hote: This event must also meet the criteria for classifjed emergency in accordance with $\mathrm{NHC}-\mathrm{CN}-4-1$ (WHC 1989e), and/or facility specific emergency action levels.

- Any release of hazardous substances or regulated pollutants in concentrations wich exceed 5 times the respective reportable quantities specified for such materials in 40 CFR 302 EPA (1991b). Note: This event must also meet the criteria for classifled emergency in accordance with WHC-CH-4-1 (WHC 1989e), and/or faci1ity specific emergency action levels.

\subsubsection{Unusual accurrence.}

- Release of a hazardous substance or regulated pollutant that exceeds a CERCLA reportable quantity in accordance with 40 CFR 302 (EPA 1991b) or exceeds a federally permitted release by a reportable quantity.

- Release of a hazardous substance, regulated pollutant, or oil that violates environmental requirements in federal permits, federal regulations, or DOE standards.

- Release below emergency levels that requires immediate (less than 4 hours) reporting to federal regulatory agencies or triggers specific levels for an outside federal agency.

- Any release of 100 gallons or more of ot]. 


\subsubsection{Off-Hormal.}

- Release of a hazardous substance or regulated pollutant to controlled or uncontrolled areas that is not part of a normal, monitored release and exceeds 50 percent of a CERCLA reportable quantity as specified for such material in accordance with 40 CFR.302 (EPA 19916).

- Any release of oil less than unusual occurrence levels but greater than 10 gallons.

- Any detection of a toxic or hazardous substance in a sanitary or storn sewer, waste or process stream, or any holding points where such a material is not expected.

- Any controlled, uncontrolled, or accidental release which is not classified as an unusual occurrence but which will be reported in writing to state/local agencies in a format other than rout ine monthly or quarterly reports. Hote: This does not include routine offsite distribution of notification reports.

- Any controlled release of hazardous/regulated naterial that occurs as a monitored part of normal operations which exceeds what historical data and/or analysis shows is expected as a result of normal operations.

- Any general environmental monitoring where concentration increases to a level which exceeds what historical data and/or analysis shows is expected as a result of normal operations.

\subsubsection{Discovery of Hazardous haterial Contanination} Due to DOE Operations

\subsubsection{Energency.}

- Discovery of contamination that results or could result in significant consequences (i.e. exceeding safe exposure limits to workers or pubi ic). Hote: This event must al so meet the criteria for $\mathrm{classified}$ emergenty in attordance with WHC-CH-4-1 (WHC 1989e) and/or facility specific emergency action levels.

- Discovery of onsite or offsite hazardous material contanination in concentrations that exceed 5 times the respective reportable quantities specified for such materials in 40 CFR 302 (EPA 1991b). Note: This event must al so meet the criteria for classified emergency in accordance with WHC-CK-4-1 (HHC 1989e) and/or facility specific energency action levels. 
10.2.3.2 Unusual Oceurrence.

- Discovery of on-site or off-site contamination due to DDE operations which does not represent an immediate threat to the public, that exceeds a reportable quantity for such materials in accordance with 40 CFR 302 (EPA 1991b).

- Any discovery of groundwater contamination that is not part of an existing plume previously identified either in an annual report or in any CERCLA/RCRA activity or report.

10.2.3.3 off-Hornal.

- Discovery of onsite contamination attributable to DOE operations that exceeds 50 percent of a reportable quantity for such material in accordance with 40 CFR 302 (EPA 1991b).

\subsubsection{Agreement/Compliance Act1vities}

10.2.4.1 Unusual 0ccurrence.

- Any agreement, compliance, remediation, or perm1t-mandated activity for which formal notification has been received from the relevant regulatory agency that a site plan is not satisfactory, or that a site is considered to be in noncompitance with schedules or requirements. Hote: Formal notification must be recelved by WHC in writing.

- Any occurrence under any agreement or compliance area that requires notification of an outside regulatory agency within 4 hours or less, or triggers an outside regulatory agency action leve1, or otherwise indicates spectfic interest/concern from such agencies. Note: This does not include notifications made for radionuclide/hazardous material releases that are less than 50 percent of the reportable quantity as specified in 40 CFR 302 (EPA 1991b).

\subsubsection{Off-Hormal.}

- Any occurrence under any agreement or compliance area that will be reported in writing to outside agencies in a format other than routine monthily or quarterly reports. Note: This does not include routine offsite distribution of notification reports.

\subsubsection{EcologicaJ Resources}

\subsubsection{Unusual Occurrence.}

- Any occurrence causing significant impact to any ecological resource for which the DOE 1 s a trustee (i.e. destruction of a critical habitat, damage to an historical/archeological site, or damage to wetlands). 


\subsection{FEDERAL REQUIREMENTS}

\subsubsection{Resource Conservation and Recovery Act of 1976}

The RCRA requires biennial reports to be submitted to the regiona] administrator of EPA. The 40 CFR 262, Subpart D (EPA 1988a), sets forth the reporting requirements for generators of hazardous waste that ship waste offsite, or store, treat, or dispose of hazardous waste onsite.

Owmers or operators of treatuent, storage, or disposal (TSO) facilfties must comply with the reporting requirenents contained in 40 CFR 264, Subpart E (EPA 1988b) and 40 CFR 265, Subpart E (EPA 1988c).

\subsubsection{Comprehensive Environmental Response, Compensation} and Lf ebility Act of 1980

The 40 CFR 302 (EPA 1991b) contajns reportable quantities and notification requirements for releases of hazardous substances as designated by CERCLA and the Safe Drinking water Act.

\subsubsection{Hational Emission Standards for Hazardous Air Pollutants}

Compliance and reporting requirements for DOE facilities emitting radtonuclides other than Radon are contained in 40 CFR 61, Subpart H (EPA 1991a). The NESHAP requires that an annual report be subaitted to EPA headquarters and the appropriate regional office.

\subsection{STATE REQUIREMENTS}

\subsubsection{Generator Reporting}

Generator reporting requirements are found in WAC 173-303-220 (WAC 1991e). The State requires that annual reports covering the preceding year be submitted by March 1 to Ecology.

\subsubsection{Facllity Reporting}

Owners or operators of TSD facilities are also required to prepare and submit annual reports. These must be subuitted by March 1 and cover facjity activities for the previous year. The specific content requirements are specified in WAC I73-303-390 (WAC 1991e).

Effluents produced by PUREX while in transition to shutdown do not contain hazardous or dangerous wastes; therefore, PUREX operations are not subject to RCRA or WAC 173 reporting requirements. WHC would only have to 
comply with the above federal and state reporting requirements in the event that the facility operations were to change, and discharges (either liquid or gaseous) from the PUREX facility contained a hazardous or dangerous components.

\subsection{B.S. DEPARTMENT OF ENERGY REQUIREMEMTS}

\subsubsection{U.S. Department of Energy Order 5400.1, Chapter II General Environmental Protection Program - Hotification and Roports}

Consistent with the notification requirements contained in DOE Orders 5484.1 (DDE 1983), 5000.38 (DOE 1993) and the DOE 5500 series, field organizations shall notify the Emergency Operations Center (EOC) of the significant nonroutine releases of any pollutant or hazardous substance.

All BOE facilities that conduct significant environmental protection prograus shall prepare an annual site environmental report. Annual summary reports on environmental occurrences shall be included in the annual site environwental report. Suggested content and format for the annual site environmental report are contained in DOE Order 5400.1 (DOE 1991a).

The DOE Order 5400.1 also requires that a radioactive eff]uent and onsite discharge data report, covering the previous calendar year be submitted to the Waste Inforation Systems Branch, EG\&G Idaho, in Idaho Falls, Idaho 83415, by Apri1 1. Unplanned releases of radioactive material in effluents, whether onsite or offsite, shall also be reported. The content and forms to be used for these reports are contained in DOE Order 5400.1, Chapter II.

10.5.2 U. S. Department of Energy Order 5484.1 Environmental Protection, Safety and Health Protection Information Reporting Requirements

Annual radiation exposure reports for the preceding calendar year are required to be submitted to the System Safety Development Center by March 31 . Content and form requirements are in Chapter IV of this order.

The DOE Order 5484.1 also requires radiation exposures of individuals that exceed the specified liatits in one calendar quarter to be reported in the form of a memorandum to the Operational and Environmental Safety Division. Radiation exposure limits are listed in Chapter II of this order.

Events that occur in the facility and adversely affect operations, personnel safety, or DOE requirements should recejve a thorough investigation and an investigation report should be prepared. The DOE Order 5484.1 (DOE 1983) sets forth occurrences requiring tnvestigation as well as the investigation requirements as determined by the severity of the occurrence, investigation report format, and content outilines. 
The RL Order 5484.1 contajns the following requirements for the

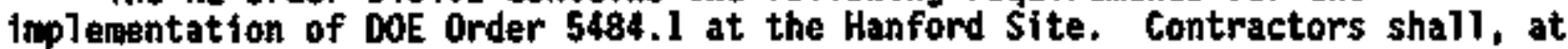
a minimum, make oral notffication to the appropriate RL program division or office, to the Public Affairs Office (PAO), and to Safety and Quality Assurance (SQA) or the SQA duty officer as soon as it is apparent that an incident may meet the crtteria of a Type A or Type B occurrence. A listing of occurrences requiring a Type A or Type B investigation is contained in Chapter I of DOE Order 5484.1.

Contractors are required to verbally notify responsible SQA environmental protection officials within 24 hours of becomfing aware of any of the following occurrences:

- Violation of applicable federal, state, or local pollution control standards and requirenents

- Any noncompliance with the terms and/or conditions of an existing Hational Pollutant Discharge Elimination System (NPOES) perwit, PSD permit, or any other environsenta] protection based permit or formal agreement with an applicable regulatory body

- Any gaseous or liquid radiological effluent releases which exceed DOE requirements and/or contractor speciftc radiological release concentration guides. 


\subsection{IMTERFACE MITH THE OPERATIOHAL ENIRONHEMTAL MONITORING PROGRA}

\subsection{DESCRIPTIOH}

The sitewide Envirenmental Honitoring Plan (EMP), as deseribed in the FEMP Managenent Plan (WHC 1991g), consists of two distinct but related components; environmental survelilance conducted by PNL and effluent monitoring conducted by WHC. The responsibilities for these two portions of the EMP are del Ineated in a Menorandum of Understanding (HOU 1989).

Environmental surveillance, conducted by PHL, consists of survetilance of al1 environmental parameters to denonstrate compliance with regulations. Effluent. monttoring inciudes both in-line and faciltty effluent monitoring as well as near-field (near-facility) operational environmental monitoring. Projected EDEs, reported in this FEIP, are the products of $1 n-1$ ine effluent monitoring. Mear-field monitoring is required by section 5.4, "Environmental Manitoring," Environtental Compliance Manual (WHC 1993), and procedures described in operational Environdental Nonitoring (WHC 1992d).

\subsection{PURPOSE}

The purpose of the Operational Environmental Monitoring Prograw (OEMP) is to provide facility-specific environmental monitoring to protect the environment adjacent to facilities under the responsibility of wht and assure compliance with WHC requirements and local, state, and federal environaental regulations.

The objectives of the OEMP are to evaluate the following:

- Compliance with DOE, EPA, Ecology, WDOH, and internal WHC environnental radiation protection requirements and gujdes

- Performance of radioactive waste confinement systens

- Trends of radioactive materials in the environment at and adjacent to nuclear facilities and waste disposal sites.

Specifically, the OEMP is developed to:

- Monitor all inactive, existing, and new low-level waste (LLW) disposal sites to assess both radiological and nonradiological hazards (DOE Order 5820.2A).

- Deternine the effectiveness of effluent treatment and controls in reducing effluents and entssions (DOE/EH-0173T, Page l-1, Par. l) (DOE/EV/1830-T5).

- Detect and quantify unplanned releases (0OE/EH-0173T, Page 1-1, Par. 2) (40 CFR 302) (WAC 173-303-145) (OOE 5000.3B) (DOE 5484.1). 
- Monitor fugitive emisstons and diffuse sources fron contaminated areas for compliance wt th HESHAP (40 CFR 61), (DOE/EH-0173T, Pg. 3-4, 3.3.2), Toxic Air Emissions Inventory (40 CFR 265, Subparts AA \& B13), State Operating Permit Program (40 CFR 70), and Source Registration (WAC 246-247).

- Monitor all surplus facilities before decontaminating or decomissioning (DOE Order 5820.2A).

- Monitar new and existing sites, processes, and facilities for potential impacts and releases (DOE Order 5484.1 and DOE/EH-0173T).

- Honitor and assess radioactive contamination and potential exposure to employees and the public (DOE Orders 5400.1 \& 5400.5).

The purpose and fustification for the OEMP is contained in WHC-CH-7-4, Operational Environmental Monitoring, WHC-CK-7-5, Environmental Compliance. The primary fustification for the OENP include the following:

- The OEMP provides a level of assurance to lihC that the efftuent and contamination controls for the various facilities and waste sites are effective.

- The OEYP monitors a diversity of operations, activities, and programs managed by several different HHC organizations. Accordingly, the program direction and integration function performed by Environmental Engineering Studies (EES) is needed to assure program consistency, technical quality, and cost effectiveness.

- A secondary aspect of the OEMP is additional assurance beyond that provided by the Occupational Health and Safety Program that it is "OK" to work onsite and for visitors to safely tour the site.

\subsection{BASIS}

Hear-field environmental surveillance is conducted to (1) monitor enployee protection; (2) monitor environmental protection; and (3) ensure compliance with local, State, and Federal regulations. Compliance with parts of the following DOE orders, 40 CFRs, and WACs are addressed through this activity.

- DOE Order 5000.38, Occurrence Reporting and Processing of Operational Information

- DOE Order 5400.1, General Environmental Protection Progran

- DOE Order 5400.5, Radiation Protection of the Public and the Environment

- Order 5484.1, Protection, Safety, and Health Protection Information Reporting Systew 
- Order 5820.2A, Radioactive Waste Management

- DOE/EH-0173T, Environmental Regulatory Guide for Radiological Effluent Nonitoring and Environwental Surveillance

- D0E/1830-T5, A guide to Reducing Radiation Exposure as Low as Reasonably Achievable (ALARA)

- 40 CFR 61, "Hational Emission Standards for Hazardous Air Pollutants"

- 40 CFR 70. "State Operating Permit Programs"

- 40 CFR 265, Subpart AA and B13, "Interim Status Standards for Owners and Operators of Hazardous Waste Treatment, Storage, and Disposal Facilities"

- 40 CFR 302, "Designation, Reportable Quantities, and Motification"

- WAC 173-303-145, "Dangerous Waste Regulations (Spills and Discharges)"

- WAC 246-247, "Radiation Protection--Air Emissions."

\subsection{MEDIA SAYPLED AND ANALYSES PERFORNED}

Procedure protocols for sampling, analys is, data handling, and reporting are specified in WHC-CH-7-4. Media include amblent air, surface water, groundwater, external radiation dose, soil, sedimant, vegetation, and animals at or near active and inactive facilities and/or waste sites. Parameters monitored include the following, as needed: $\mathrm{pH}$, water temperature, radionuclides, radiation exposure, and hazardous constituents. Animals that are not contaminated, as determined by a field instrument survey, are released to a nonhazardous environment.

\subsection{LOCATIOHS}

Samples are collected from known or suspected effluent pathways (e.g., downwind of potential releases, liquid streams, or proxisal to release points). To avoid duplication, WHC relies on existing sample locations where PANL has previously established sample sites (e.g., air samplers in the 300 Area). There are 3B air samplers (4 in the 100 Area and 34 in the $200 / 600$ Areas), 35 surface water sample sites (22 in the 100 Area and 13 in the 200/600 Areas), 110 groundwater monitoring wells (20 in the 100 Area, 89 in the 200/600 Areas, and 1 in the 300/400 Areas), 299 external radiation nonitor points (182 survey points and 41 thermo] uminescent dosimeter (TLD) sites in the 100 Area, 61 TLD sites in the 200/600 Areas, and 15 TLD s1tes in the 300/400 Areas), 157 s0il sample sites (32 in the 100 Area, 110 in the $200 / 600$ Areas, and 35 in the 300/400 Areas), and 95 vegetation sample sites (40 tn the 100 Area, 40 in the 200/600 Areas, and 15 in the $300 / 400$ Areas). Antmal samples are collected at or near facilities and/or waste sites. Specific locations of sample sites are found in $\mathrm{WHC}-\mathrm{CH}-7-4$. 
Surveys to detect surface radiological contamination, scheduled in WHC-\$P-0098-5, are conducted near and on liquid waste disposal sites (e.g., cribs, trenches, drains, retention bas in perimeters, pond perimeters, and ditch banks), solid waste disposal sites (e.g., burial grounds and trenches), unplanned release sites, tank farm perimeters, stabilized waste disposal sites, roads, and firebreaks in the Operations Areas. There are 391 sites in the Operations Areas (100. in the 100 Area, 273 in the $200 / 600$ Areas, and 18 in the $300 / 400$ Areas) where radiological surveys are conducted.

\subsection{PROGRAM REVIEN}

The near-field (operational environmenta]) monitoring program will be reviewed at least annually to determine that the appropriate effluents are being monitored and that the monitor locations are in position to best determine potential releases.

\subsection{SAMPLER DESIGN}

Sampler design (e.g., air monitors) will be reviewed at least biannually to determine equipment efficiency and compliance with current EPA and industry (e.g., ANSI and American Society for Testing and Katerials [ASTM]) standards.

\subsection{COHLANICATION}

The operations and engineering contractor and the research and development contractor will compare and communicate results of their respective monitoring programs at least quarterly and as soon as possible under upset conditions.

\subsection{REPORTS}

Results of the near-field operationa] environmenta] monitoring progran are published in Environmental Releases for Calendar Year 1992, WHC-EP-0527-2 (WHC 1993d), and WHC Operational Environmental Annual Report Calendar Year 1992, $\mathrm{KHC}-\mathrm{EP}-0573-1$ (WHC 1993). The radionuclide values in these reports are expressed in curies, or portions thereof, for each radionuclide per unit weight of sample (e.g., picocuries per gram) or in field instrument values (e.g., counts per minute). Values are reported in this manner, rather than EDE, which is calculated as the summation of the products of the dose equivalent received by specified tissues of the body and a tissue-specific weighting factor. 
WHC-EP-0468-3

\subsection{QUALITY ASSURANCE}

\subsection{PURPOSE}

The QAPJP (WHC 1992C) describes the QA requirenents associated with implementing FEMSs. The plan identifies the FEMP activities and assigns the appropriate QA requirements defined by the MHC Quality Assurance Hanud, WifC-CH-4-2 (WHC 1993e). The QAPJP sha71 be consistent with the requirements in DOE 5700.6C "Quality Assurance" (DOE 1991d). In addition, QA requirements in 40 CFR 61 (EPA 1990a), Appendix B, Method 114 shall be considered when performing monitoring calculations and establishing monitoring systems for airborne emissions.

\subsection{OBJECTINE}

The plan was to provide a documented QA plan describing QA requirements for facilities implementing the FEMPs.

\subsection{REQUIREMENTS}

A QAPjP (WHC 1992c) has been developed to impTement the overall QA program requirements defined by WHC-CM-4-2 (WHC 1993e) and 40 CFR 61, Hethod 114, Appendix B (EPA 1991a). The QAPJP appTies specifically to the field activities, laboratory analyses, and continuous monitoring performed for all FENPs by WHC. Plans and procedures referenced in the QAPJP are avallable for regulatory review upon request by the direction of the Mestinghouse Hanford Effluent and Eoission Monitoring manager. A QAPJP for Radioactive Airborne Emissions Monitoring (WHC 1993f), was prepared to address the QA elements of 40 CFR 61 and was subustted to the EPA. 
WHC-EP-0468-3

This page intentionally left blank.

$12-2$ 


\subsection{IMTERHAL AM EXTERUAL PLAN REYIEN}

The DOE Order 5400.1, General Environoental Protection Program (DOE 1991a), chapter IV.4 requires the facility effluent monitoring p]an be reviewed annually and updated every 3 years. The fEMP should be reviewed and updated as necessary after each major change or modification in the facility processes, facility structure, ventilation and liquid collection systems, monitoring equipment, or waste treatment, or for a significant change to the safety analysis reports. In addition, EPA regulations requtre that records on the results of radioactive airborne emissions monitoring be maintained onsite for 5 years. Operations managentent. shal1 maintain records of reports on measurements of stack particulates or other nonradioactive hazardous pollutant emissions for 3 years.

Facility operators w177 have to certify on a semiannual basis that no changes in operations that would require new testing have occurred. Al though the report is based on the calendar year, the emission limits apply to any period of 12 consecutive months. Hestinghouse Hanford Effluent and Emissions Wonitoring prepares an annual effluent discharge report for each area on the Hanford Site to cover both airborne and 11quid release pathways. In addition, a report on the air enissions and complyance to the HESHAP is prepared by Effluent and Emission Nonjtoring and submitted to EPA as well as to DOE Headquarters.

Facility management is required to obtain the Effluent and Enission Monitoring function's approval for all changes to the FEMPs, including those generated in the annual review and update. In addition, the FEMP shall be reviewed by QA and Regulatory Analysis.

Contractor management is responsible for assigning appropriate personne 1 to perform the reviews, assessments, and approvals as required, and for maintaining this documentation. The DOE nay require additional reviews, as necessary, to ensure program integrity. 
WHC-EP-0468-3

- This page intentionally left b]ank. 


\subsection{COMPLIAHCE ASSESSWENT}

A comparison of $M / S$ system capabilities with regulatory and other requirements was conducted to determine which areas were not in conpliance. This section summarizes that comparison. A detalled point-by-point evaluation of the NESHAP requirements (EPA 1991a) is included in Tables 14-1 and 14-2.

\subsection{COMPLIANCE ASSESSWENT}

\subsubsection{Comparison of Instrument Specifications with Required Standard}

The existing air effluent $M / S$ system of near-isokinetic continuous sampling with periodic analysis of the resultant samples coaplies with 40 CFR 61, Subpart $H$. Laboratory analysis and chatn-of-custody procedures are adequate to maintain sample accuracy and rel tabtility. QA elements are addressed in the Quality Assurance Progras Plan for Radionuclide Airborne Eolssions Nonitoring, WHC-EP-0536-1, (WHC 1993).

Current water effluents are periodically sampled and analyzed. This technique meets estabitished standards for discharge to the 216-B-3C Expansion Pond. Future discharge to SALOS will be under a negotiated permit. Comparison to as-yet-to-be-defined discharge criteria, which are the result of the negottation process, is not possfble.

\subsubsection{Comparison of Instrument Specifications with Vonitoring criteria}

The current afr monitoring systems with its capability of continuous, near-isokjnetic saxpling followed by periodic analyses achieve full compliance with monitoring criterfa. Hater effluent monitoring criteria of flow, pH and chemical composition are also fully met by the existing $M / S$ system.

\subsubsection{Coipartson of Instrument Specifications with Effluent Characteristics}

Existing monitoring equipment for both the atr and water offlutent streams have the capability to accurately characterize the stream's general paraneters such as flow rate, loss of flow, temperature, and $\mathrm{pH}$. These general parameters are also appropriate to indicate changes in the effiuents. Laboratory analysis can be selected to characterize any desired effluent parameter. 


\subsubsection{Comparison of Projected Effluent Characteristics with Historjcel Data}

Historical data used to project effluent characteristics throughout this FEMP reflect the current transition to shutdown conditions at PUREX.

Projected emissions characteristics should remain the same as the nost recent historical data, which reflect projected transition to shutdown conditions.

\subsubsection{Comparison of Effluent Honitoring Capabilities with Regulatory and Contractor Requirements}

Effluent monitoring capabilities for both the air and water discharges meet both regulatory and WHC requirements, with the exception noted in Section 14.1.1.

\subsection{EXEMPTIOHS}

Ho current or pending exemptions have been identified.

\subsection{SYSTEN UPGRADES REQUIRED FOR COWPLIANCE}

No system upgrades are currently required.

\subsection{CLEAN AIR ACT REQUIREMENTS}

The NESHAP requirements are discussed in Tab]e 14-1 for the ma in stack and Tabie 14-2 for the PR stack. (NOTE: Tables 14-1 and 14-2 blocks not filled in are either not applicable or covered in explanitory remarks.) 


\begin{tabular}{|c|c|c|c|}
\hline $\begin{array}{l}\text { APPLICABLE REGULATION, STANDARD, OR } \\
\text { REQUIREMENT }\end{array}$ & $\begin{array}{c}\text { PLANT } \\
\text { OOCUHEHTATIOH }\end{array}$ & $\begin{array}{l}\text { DOES SYSTEM } \\
\text { HEET } \\
\text { REQUIREPENTS? }\end{array}$ & EXPLAMATORY REMARKS \\
\hline 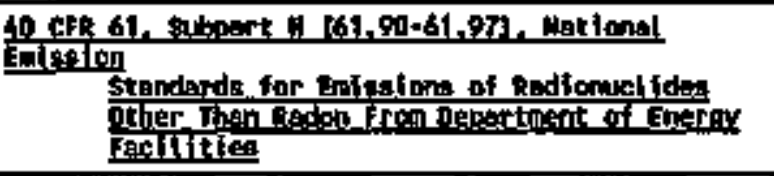 & & & • \\
\hline
\end{tabular}




\begin{tabular}{|c|c|c|c|}
\hline $\begin{array}{l}\text { APPLICABLE REGULATION, STAMDARO, OR } \\
\text { REQUIREMEMT }\end{array}$ & $\begin{array}{l}\text { PLANT } \\
\text { DOCUMEKTATIOH }\end{array}$ & $\begin{array}{l}\text { DOES SYSTEM } \\
\text { MEET } \\
\text { RE,QUIREMENTS? }\end{array}$ & EXPLAALTORY REMARKS \\
\hline 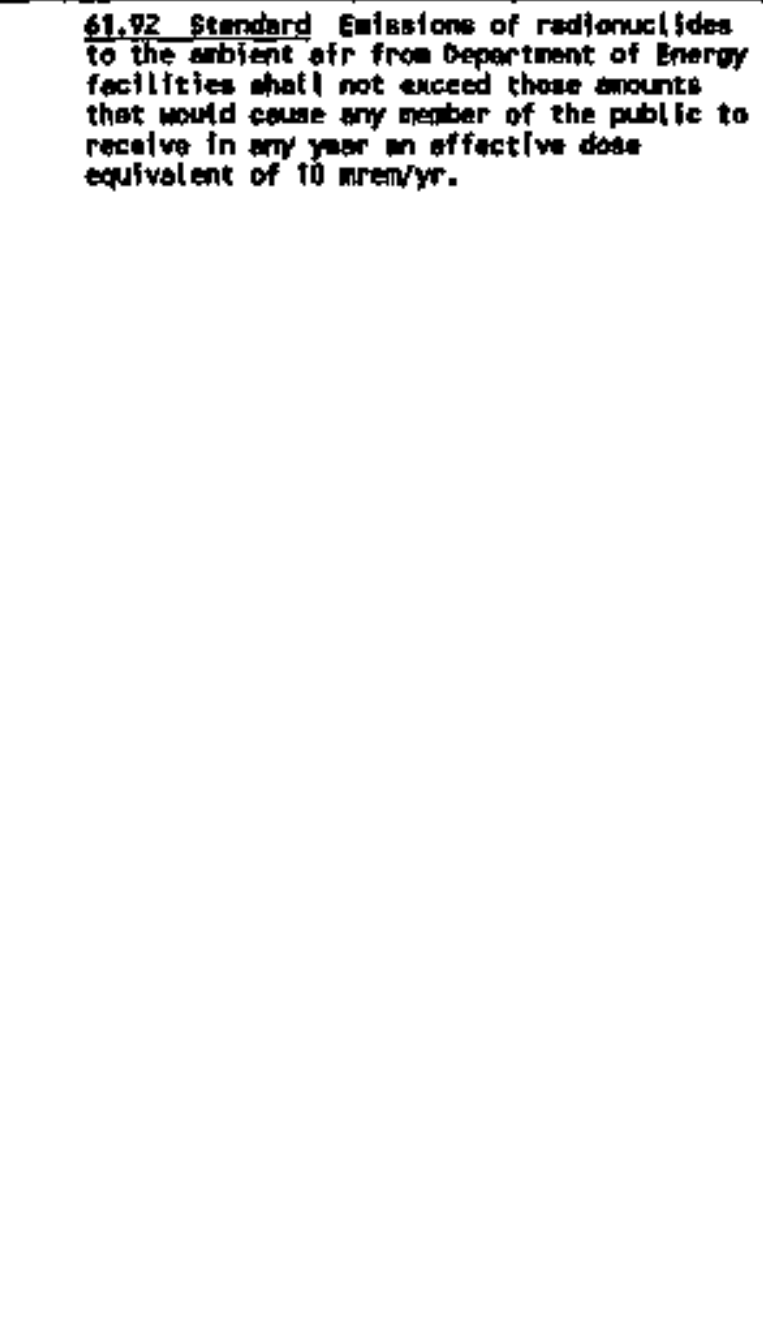 & & Yeu & 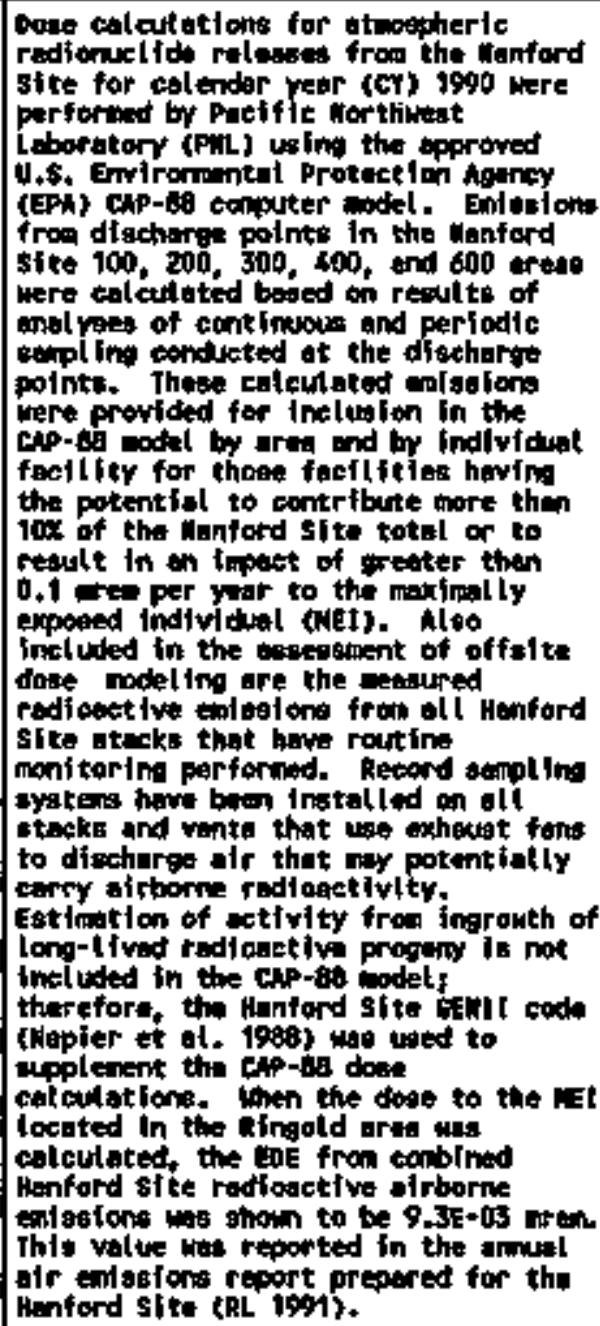 \\
\hline
\end{tabular}




\begin{tabular}{|c|c|c|c|}
\hline $\begin{array}{l}\text { APPLICABLE REGULATION, STANDARD, OR } \\
\text { REQUIREMENT }\end{array}$ & $\begin{array}{l}\text { PLANT } \\
\text { DOCLNENTATION }\end{array}$ & $\begin{array}{c}\text { DOES SYSTEH } \\
\text { MEET } \\
\text { REQUIREEHENTS? }\end{array}$ & EXPLAMATORY REMARKS \\
\hline 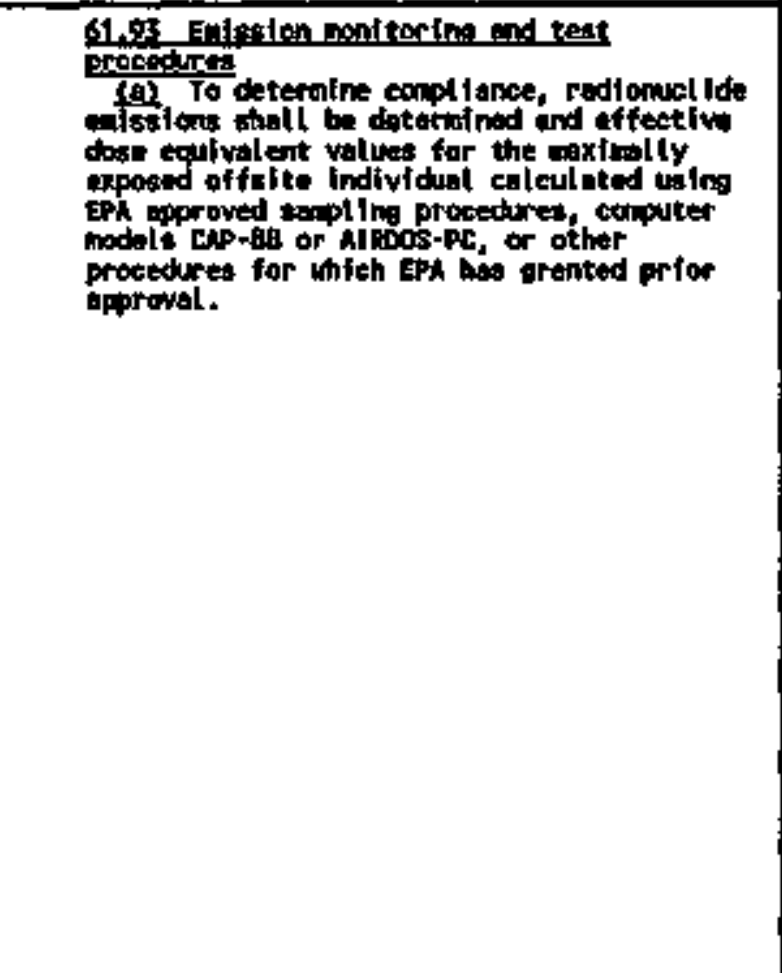 & & Tee & 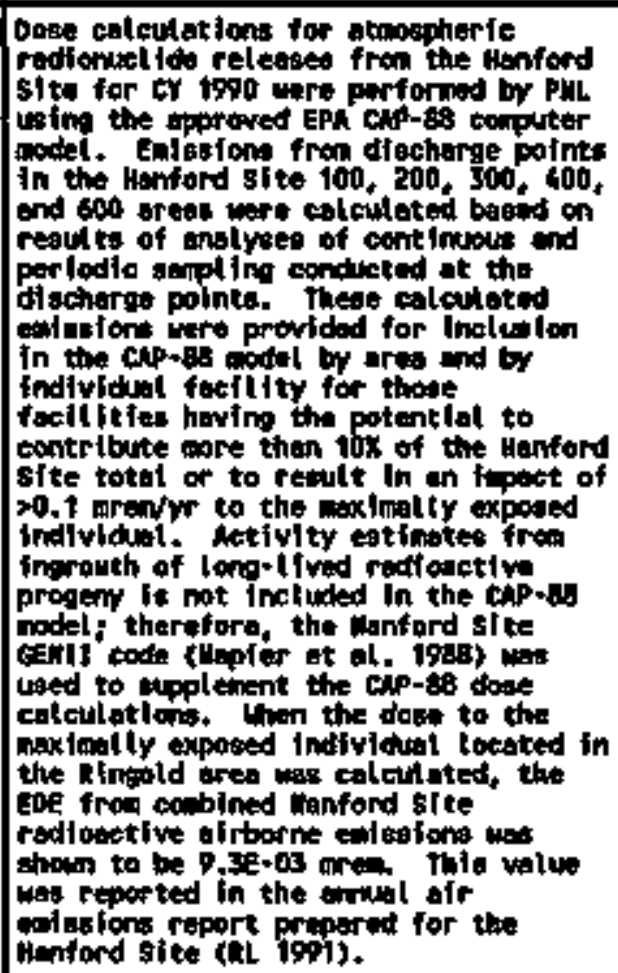 \\
\hline 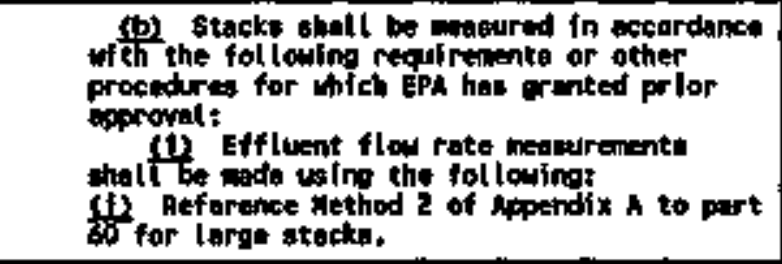 & 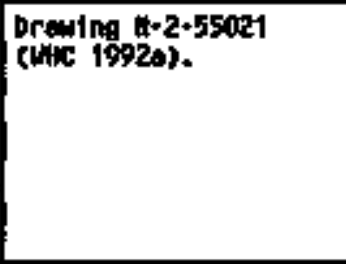 & $\mu_{0}$ & 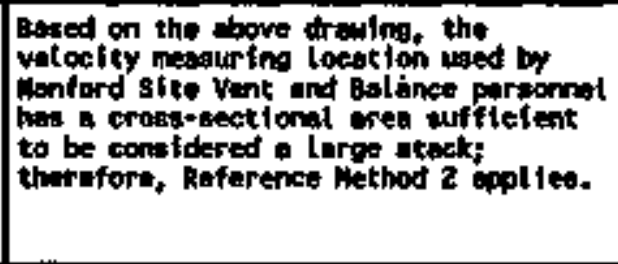 \\
\hline
\end{tabular}




\begin{tabular}{|c|c|c|c|}
\hline $\begin{array}{l}\text { APPLICABLE REGULATION, STANOARO, OR } \\
\text { REQUIREMERT }\end{array}$ & $\begin{array}{c}\text { PLANT } \\
\text { DOCLMENTATION }\end{array}$ & $\begin{array}{l}\text { DOES SYSTEM } \\
\text { HEET } \\
\text { REQUTREMENTS? }\end{array}$ & EXPLANATORY REMARKS \\
\hline 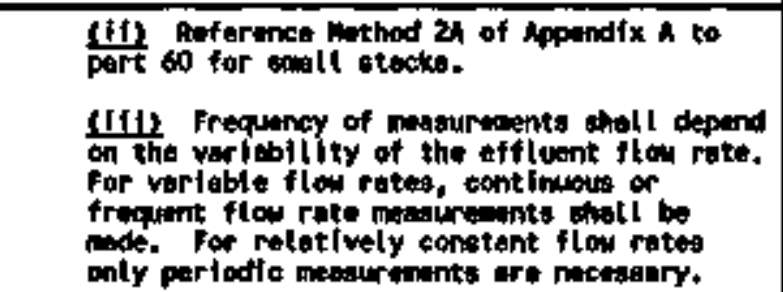 & & Equivalent & 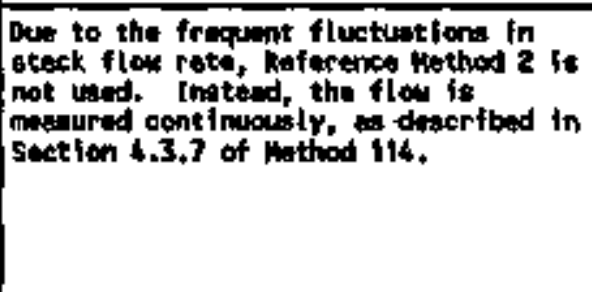 \\
\hline 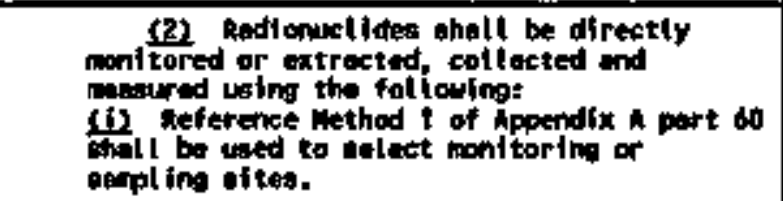 & 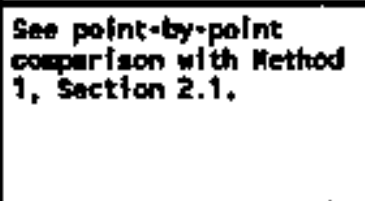 & Yeas & \\
\hline 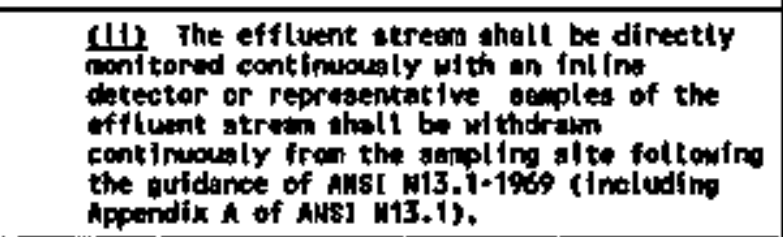 & $\begin{array}{l}\text { see point-by-point } \\
\text { comperison with } \\
\text { A1si w13.1. } \\
\text { r }\end{array}$ & rea & \\
\hline 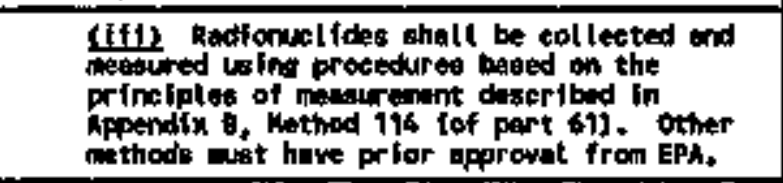 & 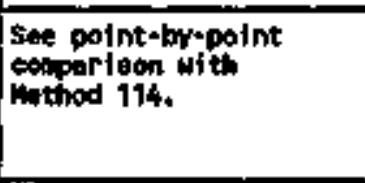 & 700 & \\
\hline 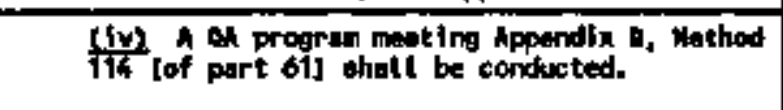 & 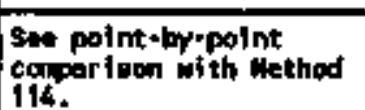 & Yoo & \\
\hline
\end{tabular}




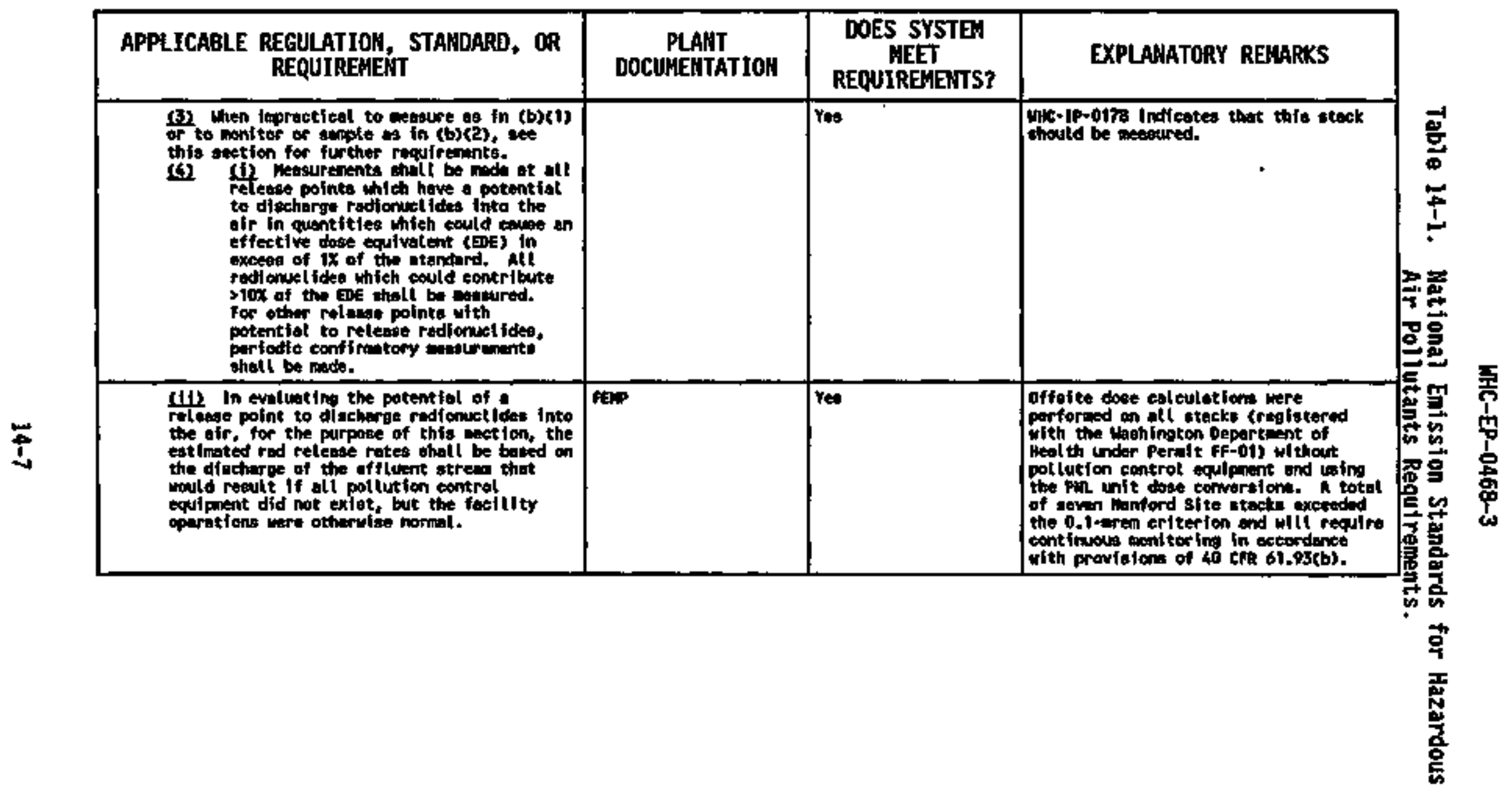




\begin{tabular}{|c|c|c|c|}
\hline $\begin{array}{l}\text { APPLICABLE REGULATION, STANDARD, OR } \\
\text { REQUIREMENT }\end{array}$ & $\begin{array}{l}\text { PLANT } \\
\text { DOCUMEMTATIOH }\end{array}$ & $\begin{array}{c}\text { DOES SYSTEM } \\
\text { HEET } \\
\text { REQUIRENENTS? }\end{array}$ & EXPLANATORY REMARKS \\
\hline 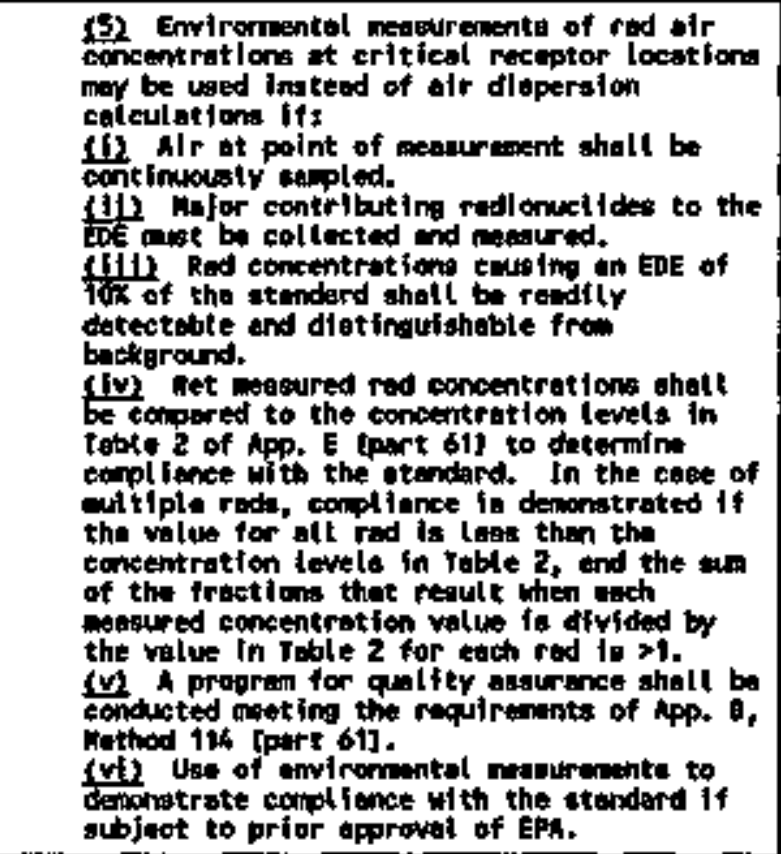 & & Kot expl factite. & $\begin{array}{l}\text { Air dippersion colculot lons tore } \\
\text { parforned. }\end{array}$ \\
\hline
\end{tabular}




\begin{tabular}{|c|c|c|c|}
\hline $\begin{array}{l}\text { APPLICABLE REGULATICN, STANIDARD, OR } \\
\text { REQUIREHENT }\end{array}$ & $\begin{array}{l}\text { PLANT } \\
\text { OOCUAENTATIOA }\end{array}$ & $\begin{array}{l}\text { DOES SYSTEM } \\
\text { NEET } \\
\text { REQUIREHEHTS }\end{array}$ & EXPLAMATORY REMARKS \\
\hline 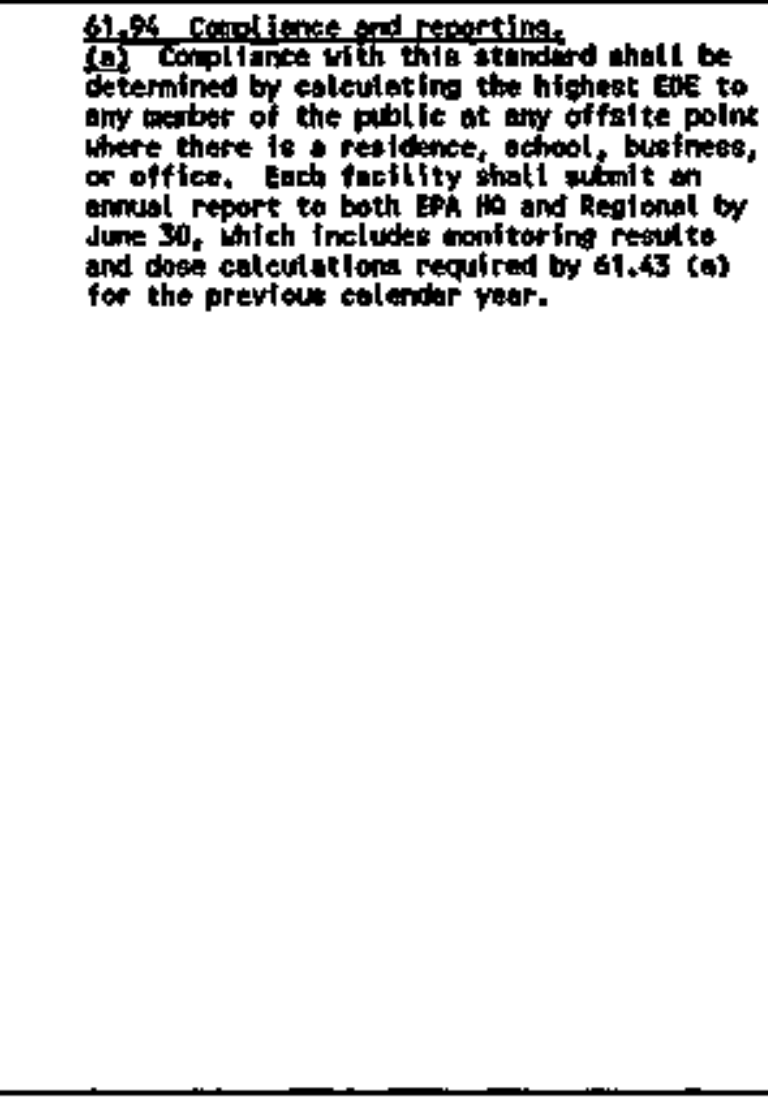 & & Yea & 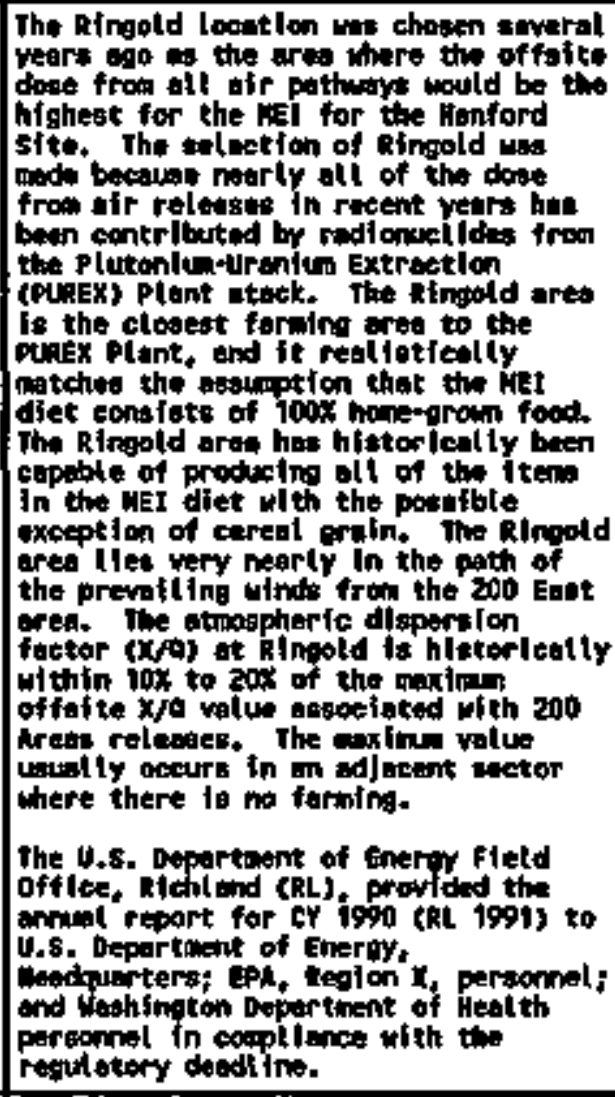 \\
\hline (b) The amusl report thell also include: & & Yes & 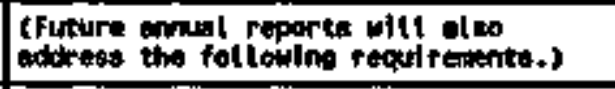 \\
\hline c11 Mene and location of facility. & 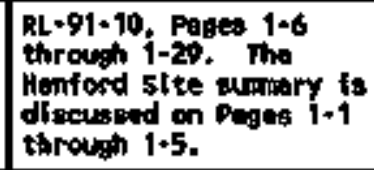 & rea & \\
\hline
\end{tabular}




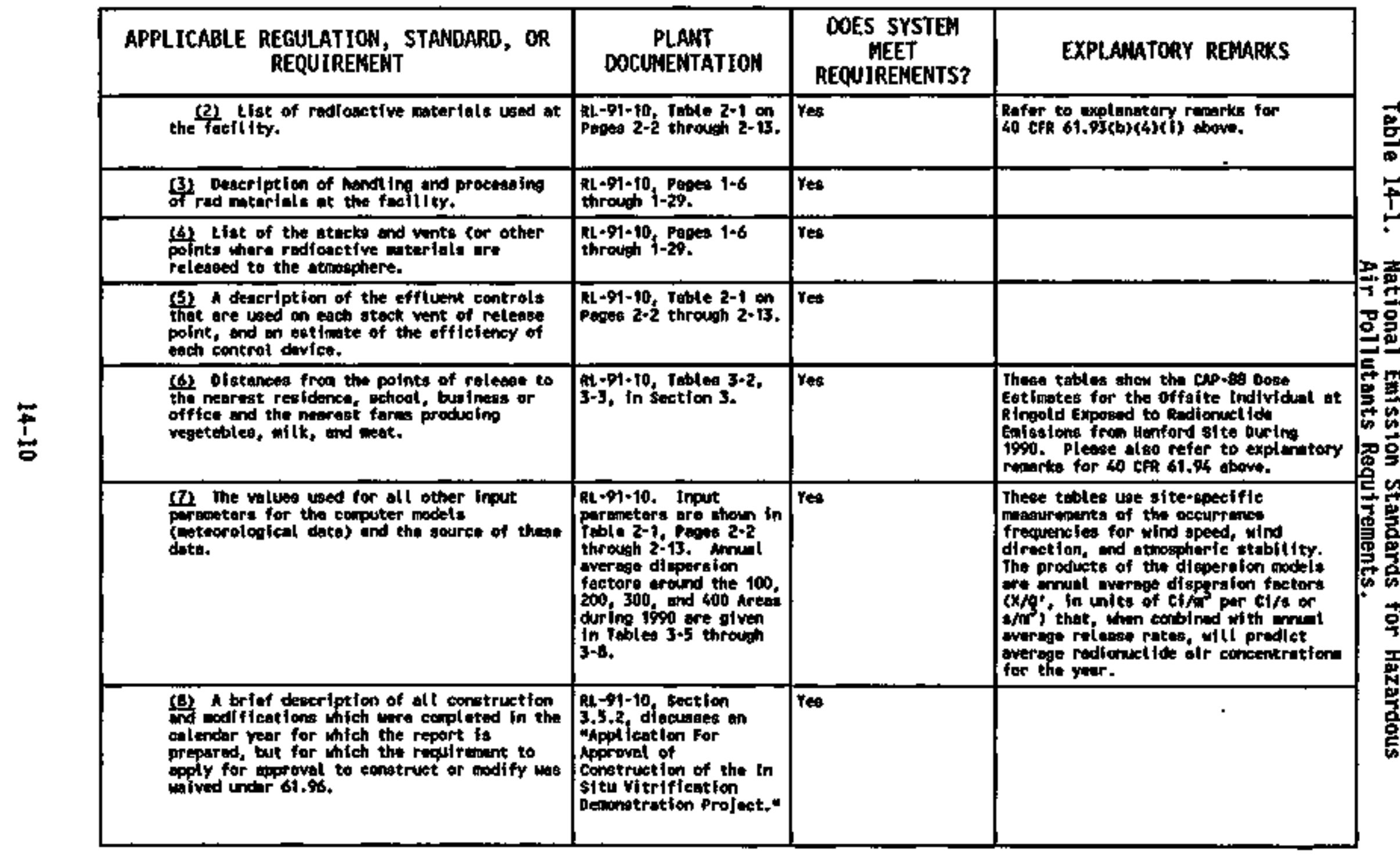




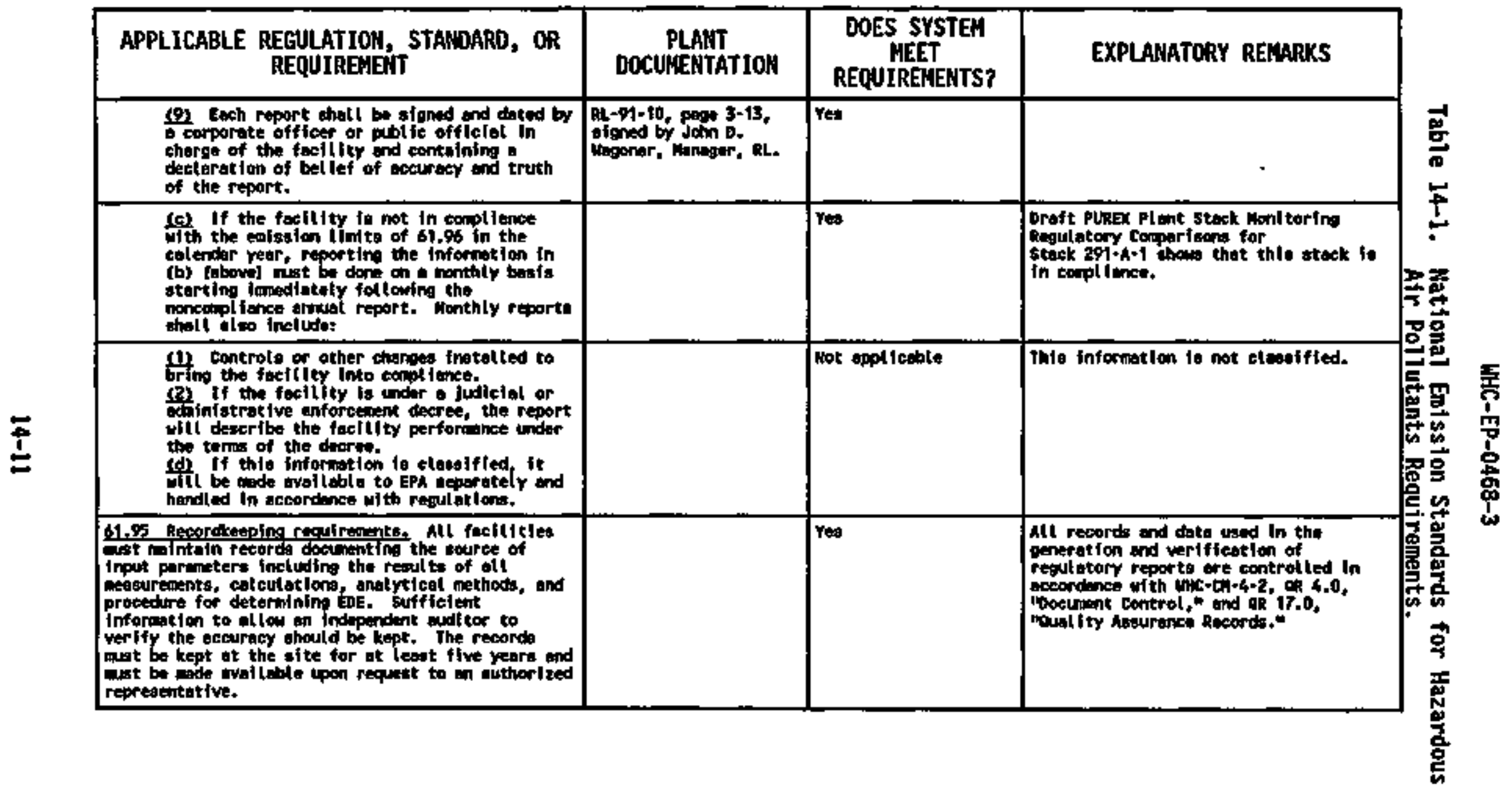




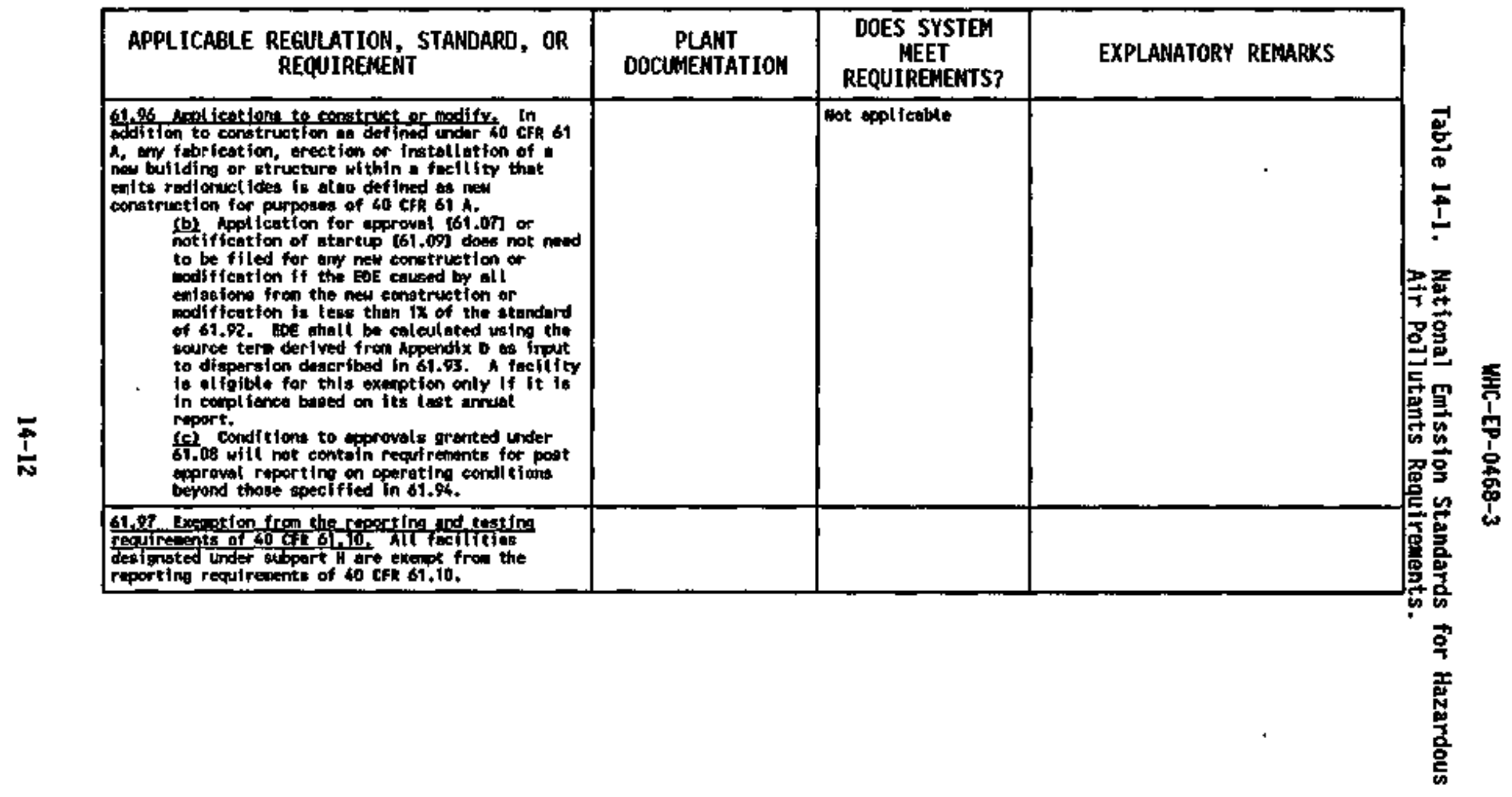




\begin{tabular}{|c|c|c|c|}
\hline $\begin{array}{l}\text { APPLICABLE REGULATION, STAMDARD, OR } \\
\text { REQUIREKENT }\end{array}$ & $\begin{array}{l}\text { PLANT } \\
\text { DOCONEATATION }\end{array}$ & $\begin{array}{l}\text { DOES SYSTEM } \\
\text { HEET } \\
\text { REQUIREMEATS? }\end{array}$ & EXPLAMATORY REHARKS \\
\hline 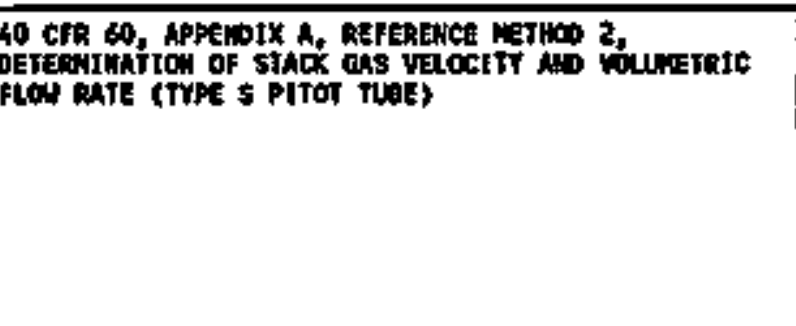 & & & 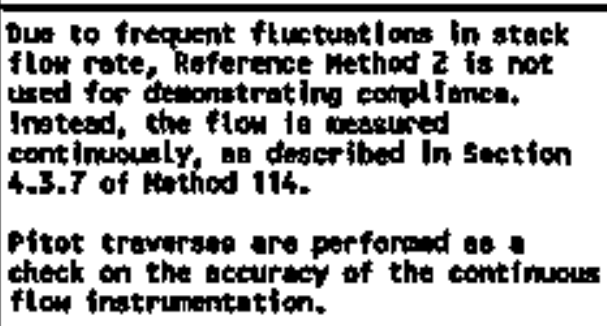 \\
\hline 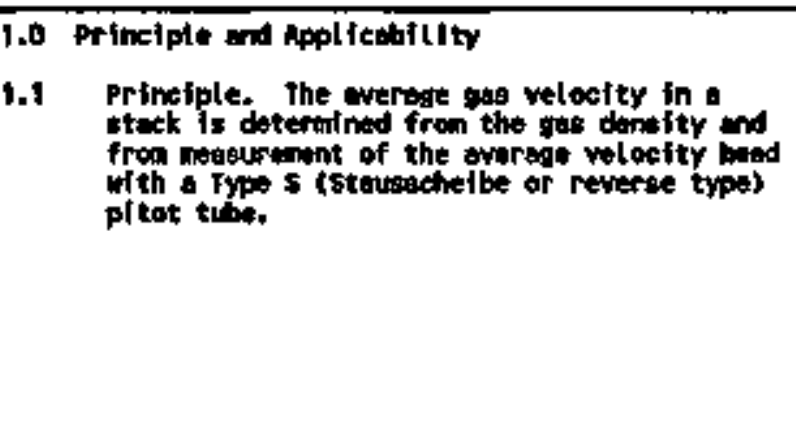 & 7-04-56 (Mix 1991e). & & 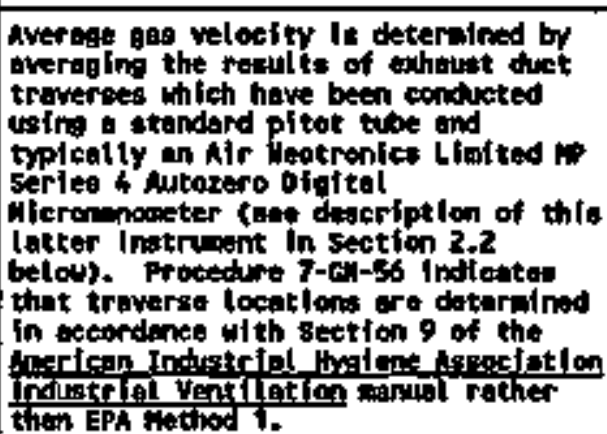 \\
\hline
\end{tabular}




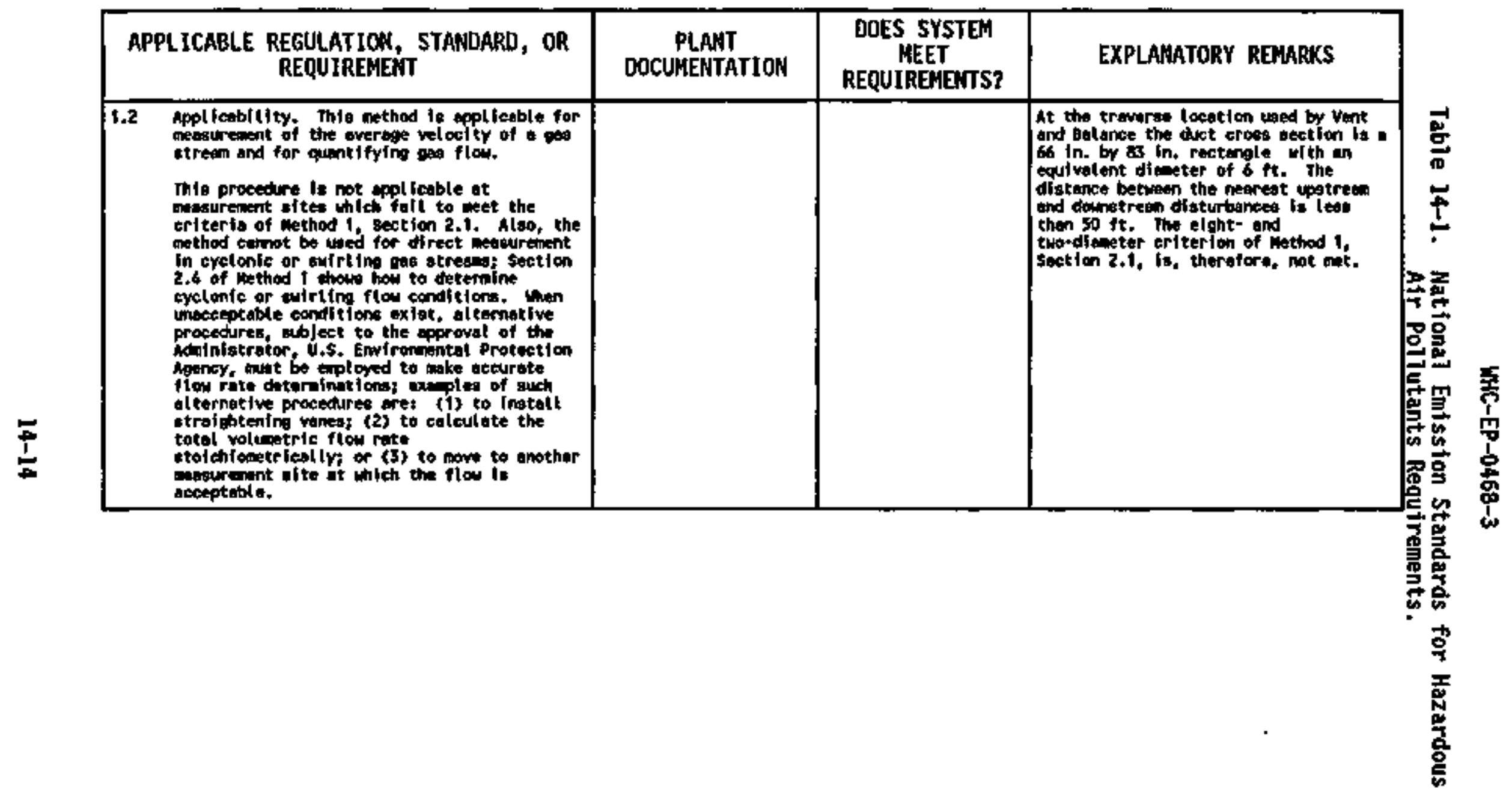




\begin{tabular}{|c|c|c|c|}
\hline $\begin{array}{l}\text { APPLICABLE REGULATION, STANDARD, OR } \\
\text { REQUIREMENT }\end{array}$ & $\begin{array}{l}\text { PLANT } \\
\text { DOCUHEHTATION }\end{array}$ & $\begin{array}{c}\text { DOES SYSTEH } \\
\text { MEET } \\
\text { REQUIREMENTS? }\end{array}$ & EXPLAHATORY REMARKS \\
\hline 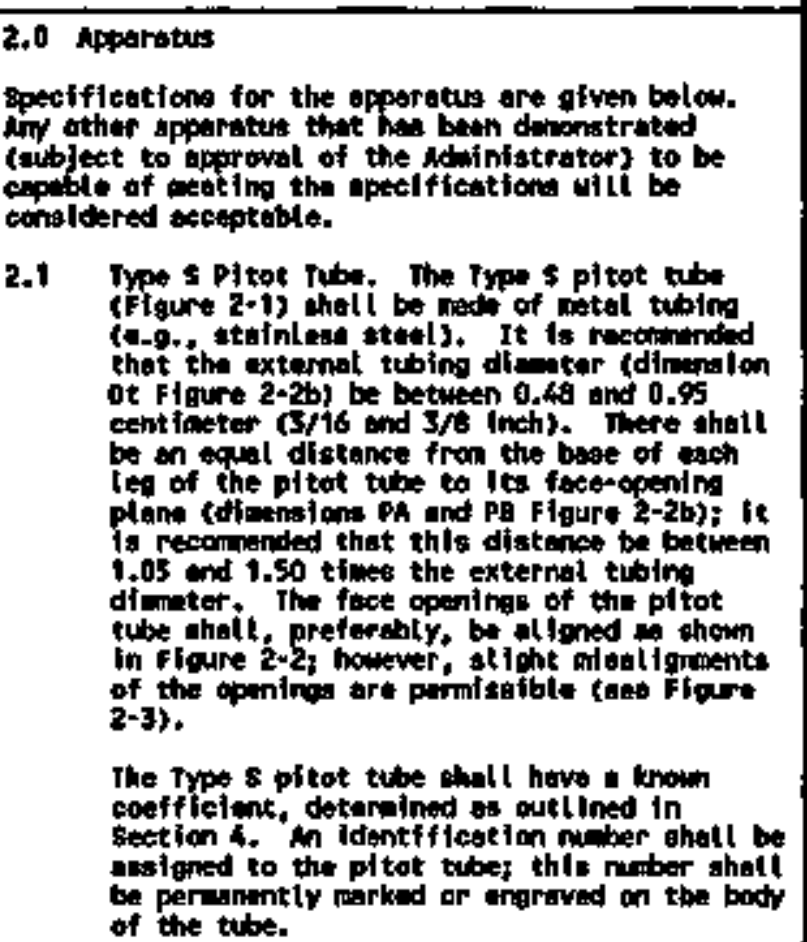 & & * & \\
\hline
\end{tabular}




\begin{tabular}{|c|c|c|c|}
\hline $\begin{array}{l}\text { APPLICABLE REGULATION, STAMDARD, OR } \\
\text { REQUIREMENT }\end{array}$ & $\begin{array}{l}\text { PLANT } \\
\text { OOCUHENTATION }\end{array}$ & $\begin{array}{c}\text { DOES SYSTEH } \\
\text { HEET } \\
\text { REQUIRENEHTS? }\end{array}$ & EXPLANATORY REMARKS \\
\hline 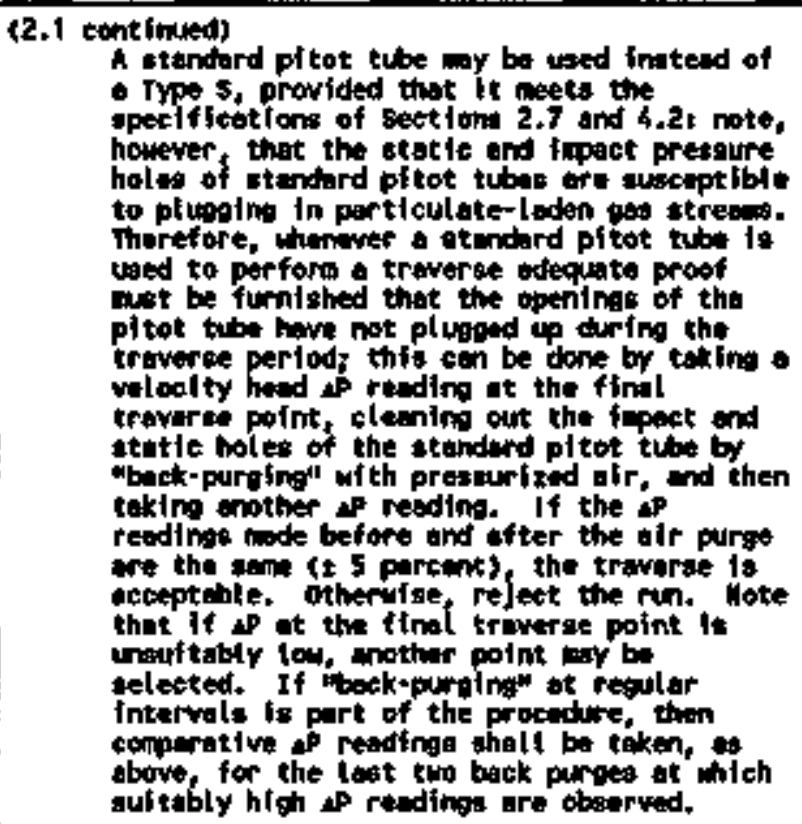 & $7-6 \mathrm{an}-56$ & & 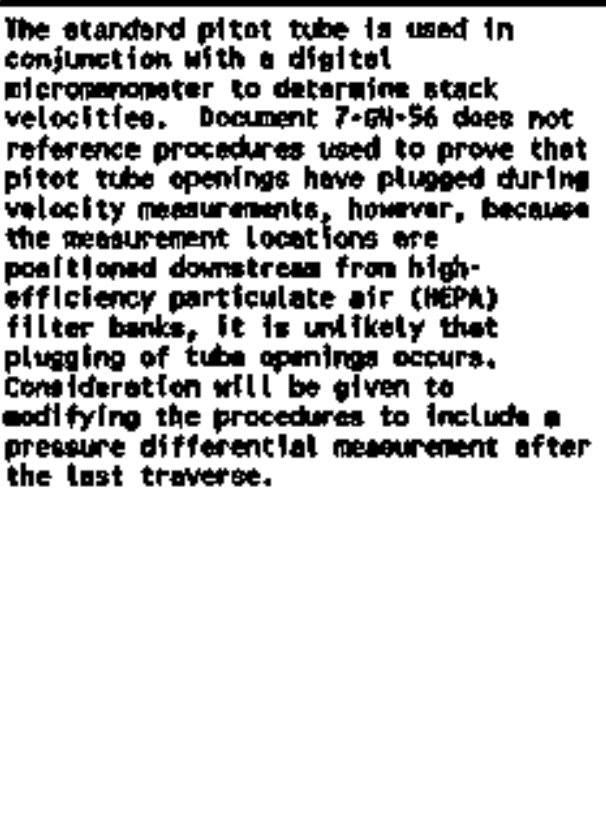 \\
\hline
\end{tabular}




\begin{tabular}{|c|c|c|c|}
\hline $\begin{array}{l}\text { APPLICABLE REGULATION, STAMOARD, OR } \\
\text { REQUIREMENT }\end{array}$ & $\begin{array}{l}\text { PLANT } \\
\text { DOCUNENTATIOA }\end{array}$ & $\begin{array}{l}\text { DOES SYSTEH } \\
\text { MEET } \\
\text { REQUIREMENTS? }\end{array}$ & EXPLANATORY REMARKS \\
\hline 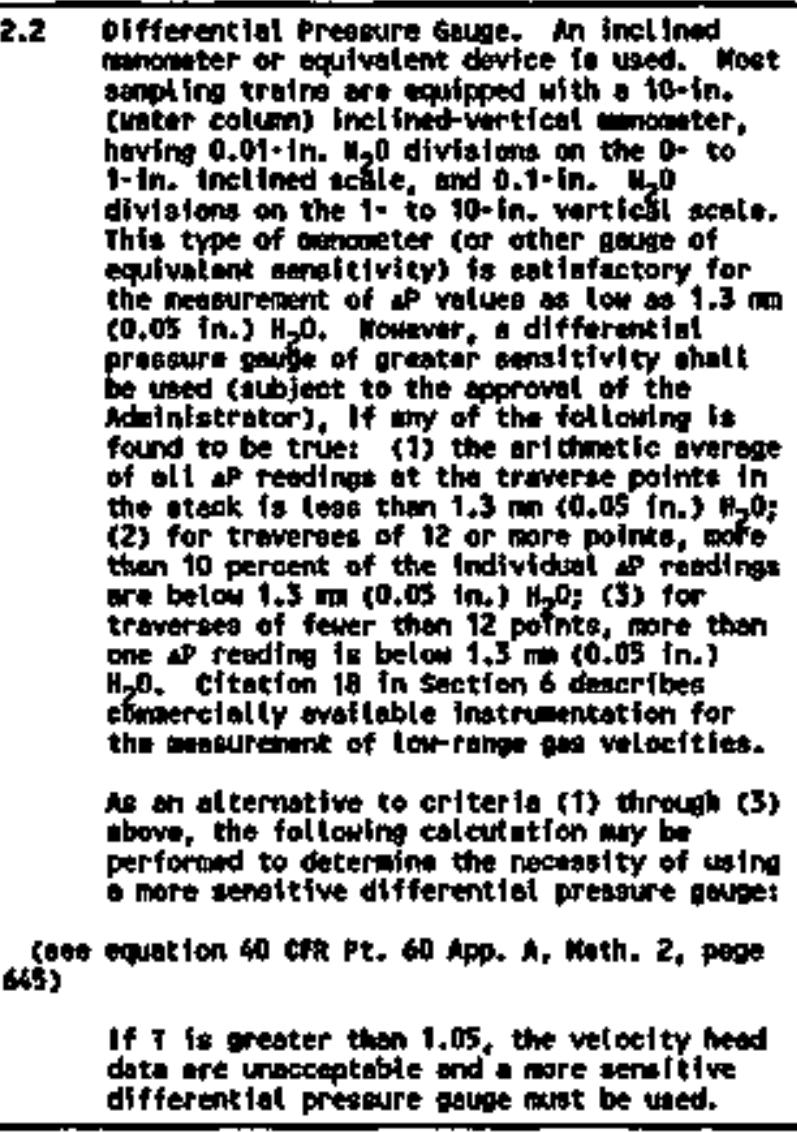 & & & v \\
\hline
\end{tabular}




\begin{tabular}{|c|c|c|c|}
\hline $\begin{array}{l}\text { APPLICABLE REGULATION, STAHDARD, OR } \\
\text { REQUIREFENT }\end{array}$ & $\begin{array}{l}\text { PLANT } \\
\text { DOCENEKTATION }\end{array}$ & $\begin{array}{c}\text { DOES SYSTEM } \\
\text { MEET } \\
\text { REQUIRENEKTS? }\end{array}$ & EXPLAHATORY REMARKS \\
\hline 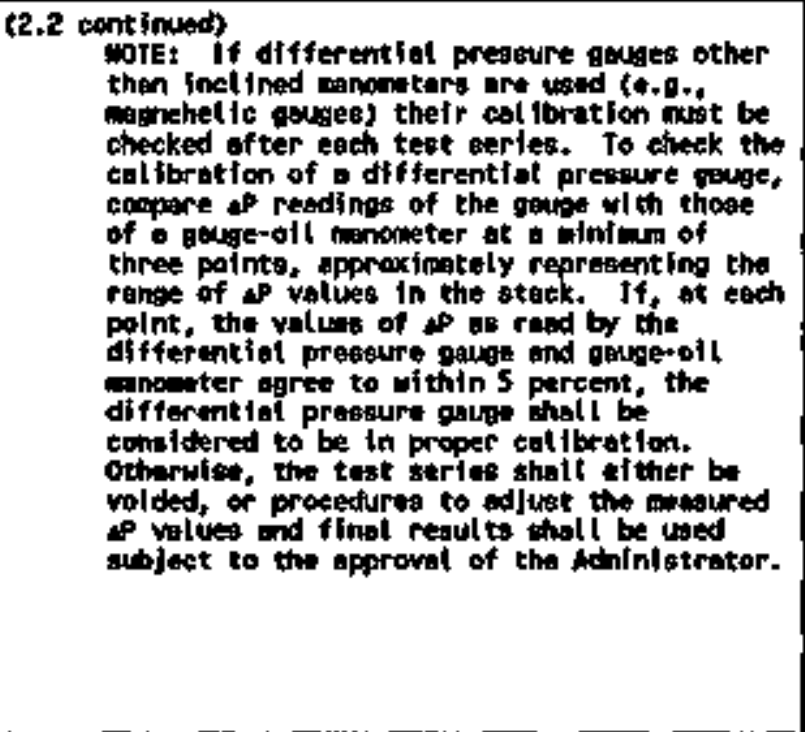 & 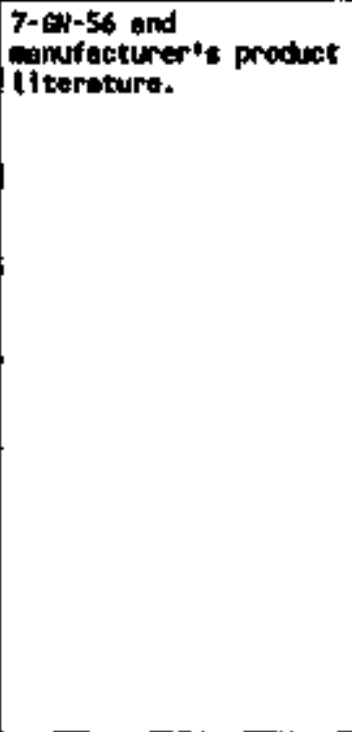 & & 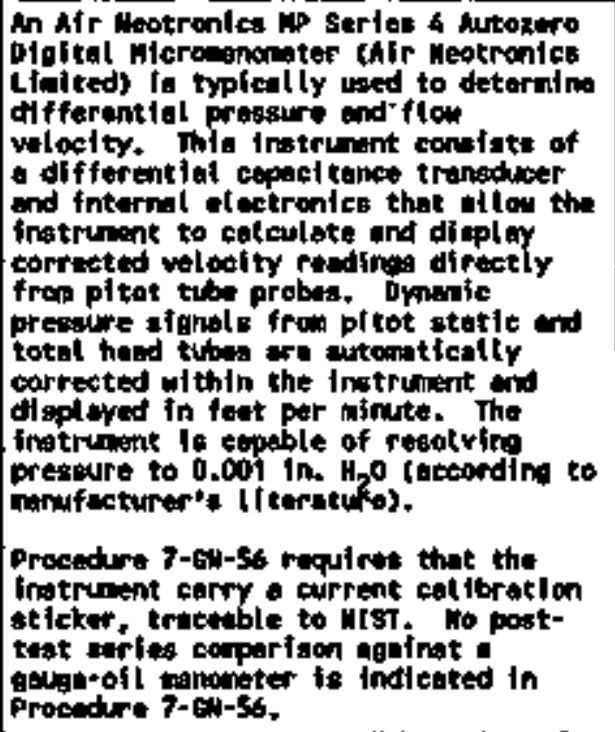 \\
\hline 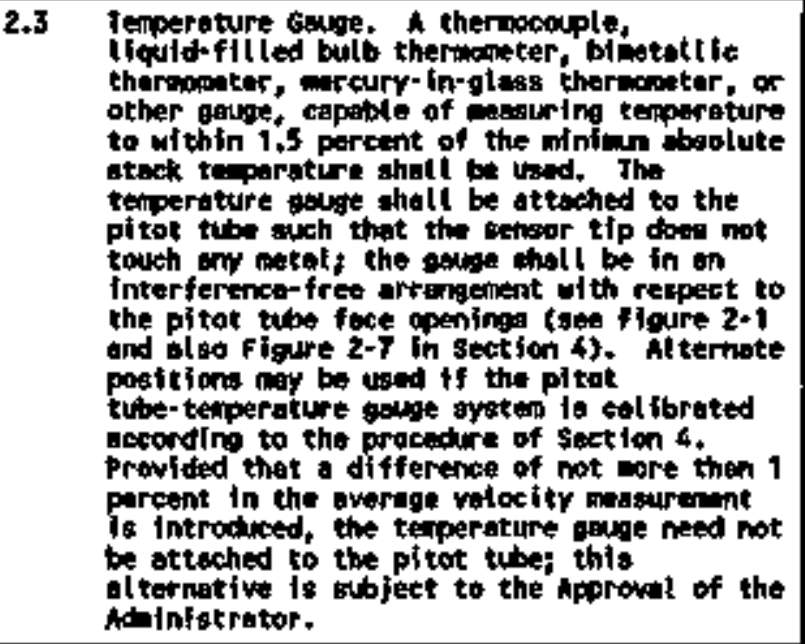 & $7-64+56$ & & 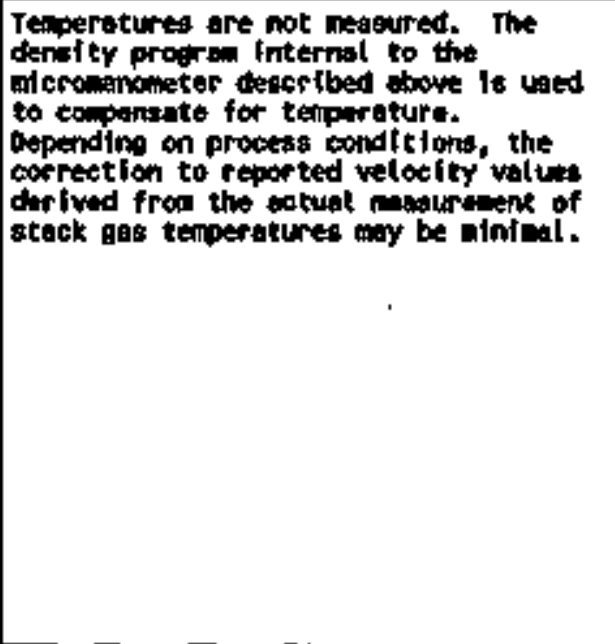 \\
\hline
\end{tabular}




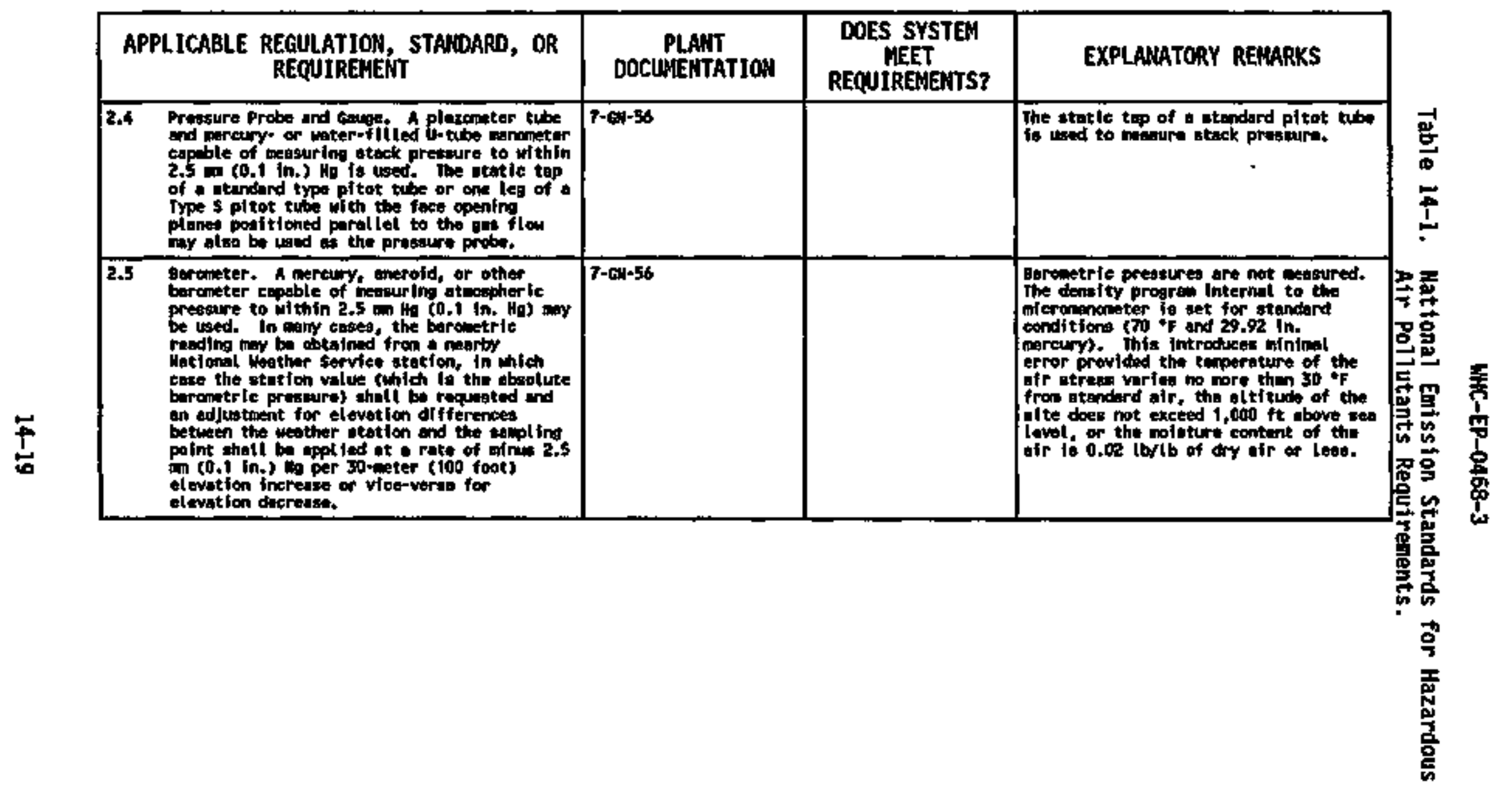




\begin{tabular}{|c|c|c|c|c|}
\hline \multicolumn{2}{|c|}{$\begin{array}{l}\text { APPLICABLE REGULATIOH, STANBARD, OR } \\
\text { REQUIRENENT }\end{array}$} & \multirow[t]{3}{*}{$\begin{array}{c}\text { PLANT } \\
\text { DOCUNENTATION }\end{array}$} & \multirow[t]{3}{*}{$\begin{array}{l}\text { DOES SYSTEH } \\
\text { HEET } \\
\text { REQUIREHENTS? }\end{array}$} & EXPLAHATORY REMARKS \\
\hline & 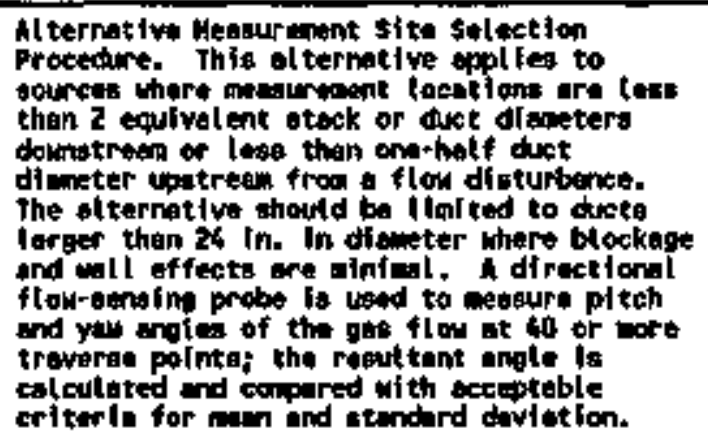 & & & 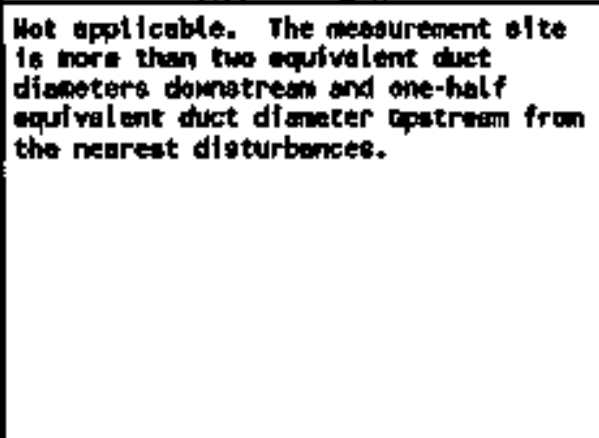 \\
\hline & 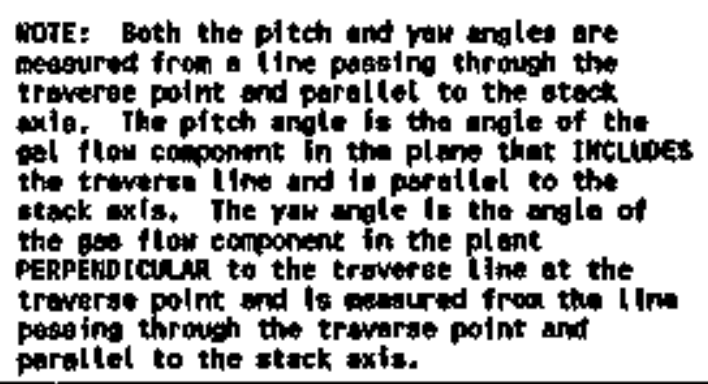 & & & \\
\hline 2.6 & 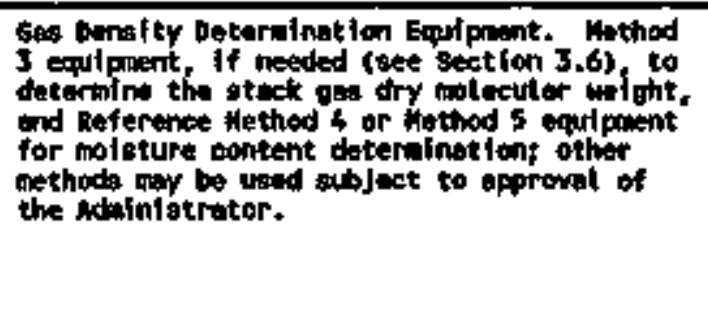 & 7 -6마-56 & & 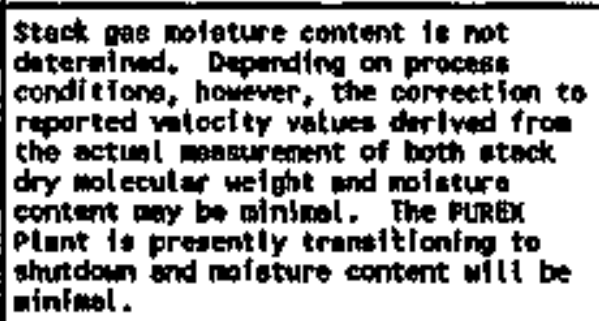 \\
\hline
\end{tabular}




\begin{tabular}{|c|c|c|c|c|}
\hline \multicolumn{2}{|r|}{$\begin{array}{l}\text { APPLICABLE REGULATIOH, STAHDARD, OR } \\
\text { REQUIRENENT }\end{array}$} & \multirow{2}{*}{$\begin{array}{l}\text { PLAAT } \\
\text { DOCLNENTATION } \\
\text { 7-CN-56 }\end{array}$} & \multirow[t]{2}{*}{$\begin{array}{l}\text { DOES SYSTER } \\
\text { MEET } \\
\text { PEQUIREMENTS? }\end{array}$} & \multirow{2}{*}{ 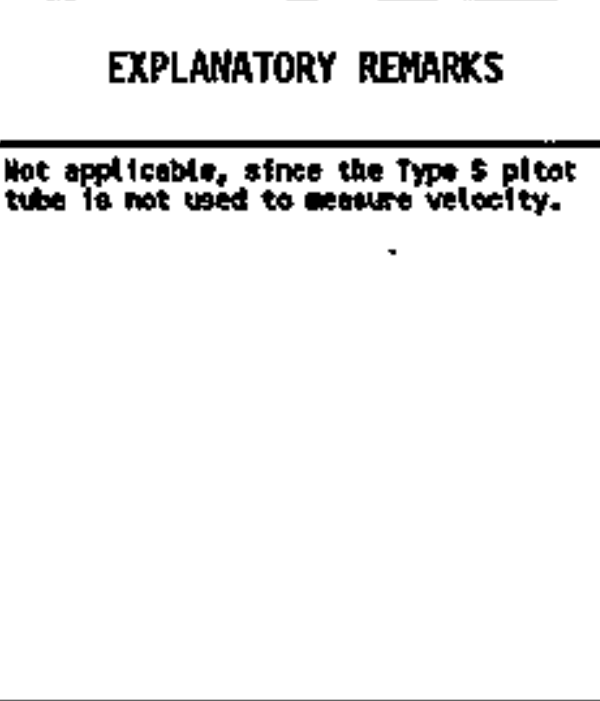 } \\
\hline 2.7 & 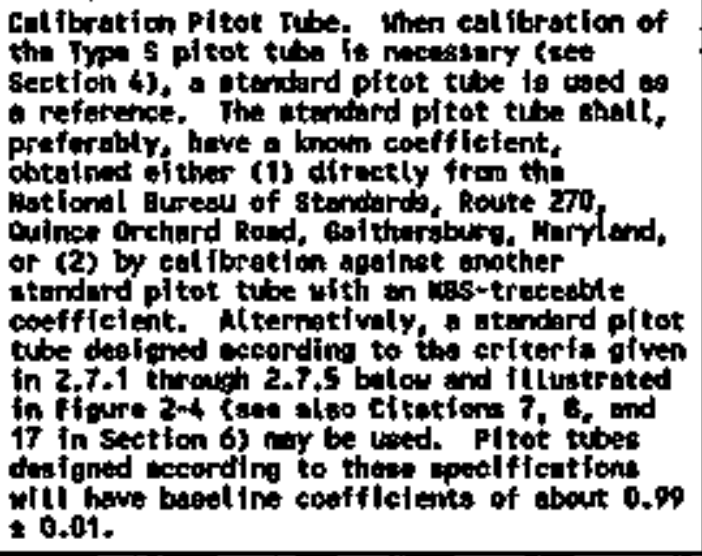 & & & \\
\hline 2.7 .1 & 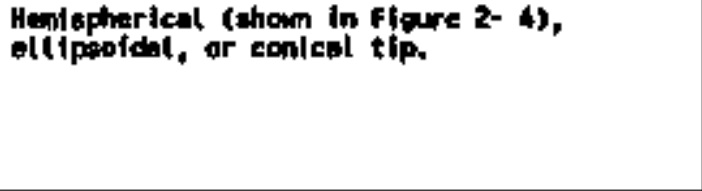 & 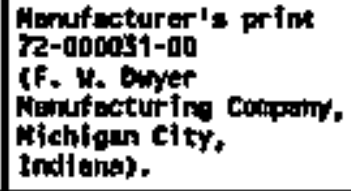 & & 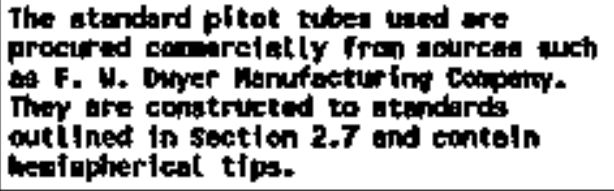 \\
\hline 2.7 .2 & 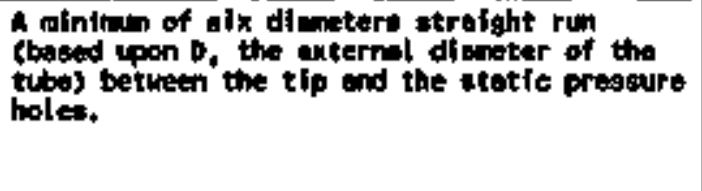 & 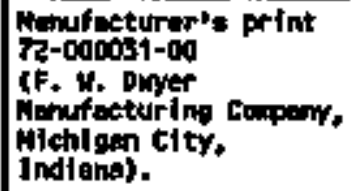 & & 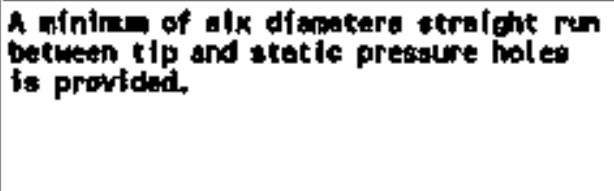 \\
\hline 2.7 .3 & 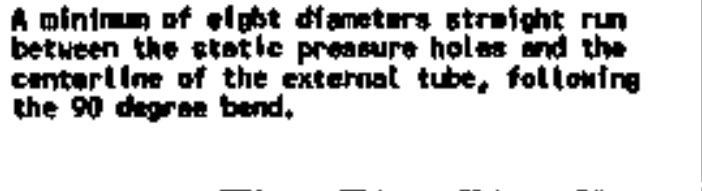 & 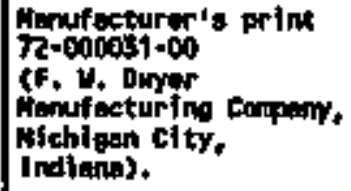 & & 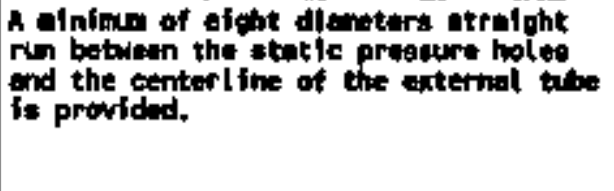 \\
\hline $2,7,4$ & 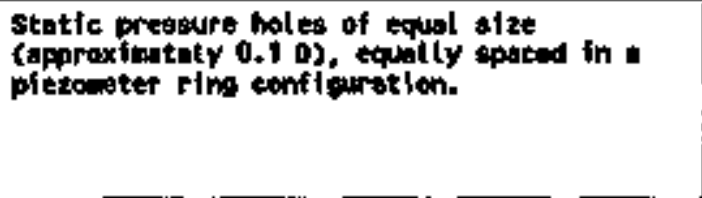 & 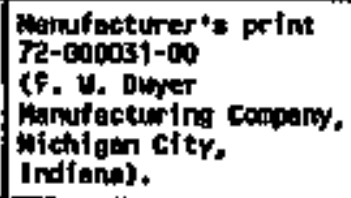 & & $\begin{array}{l}\text { The above triterlo are wet by the } \\
\text { nemufatturar. }\end{array}$ \\
\hline
\end{tabular}




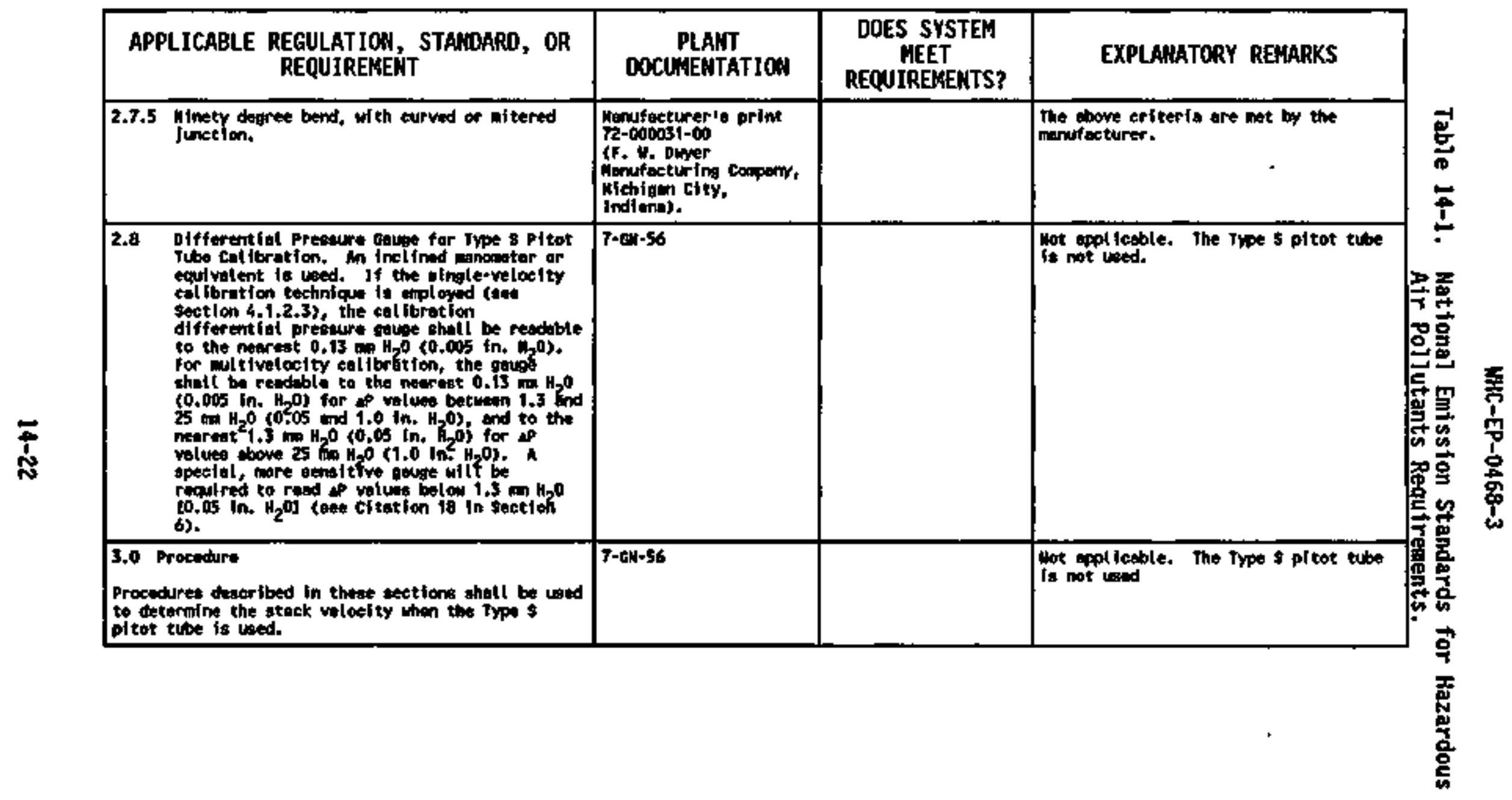




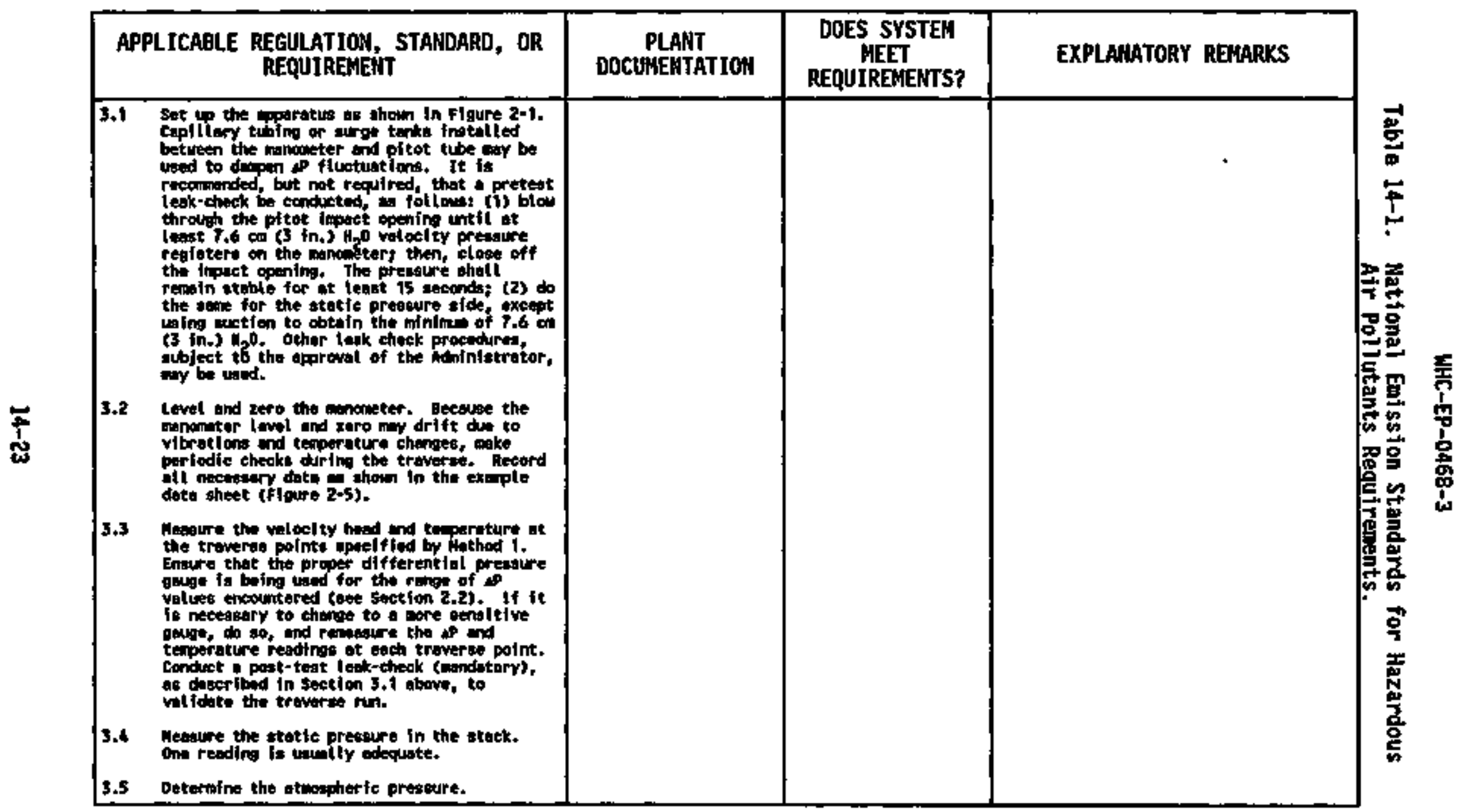




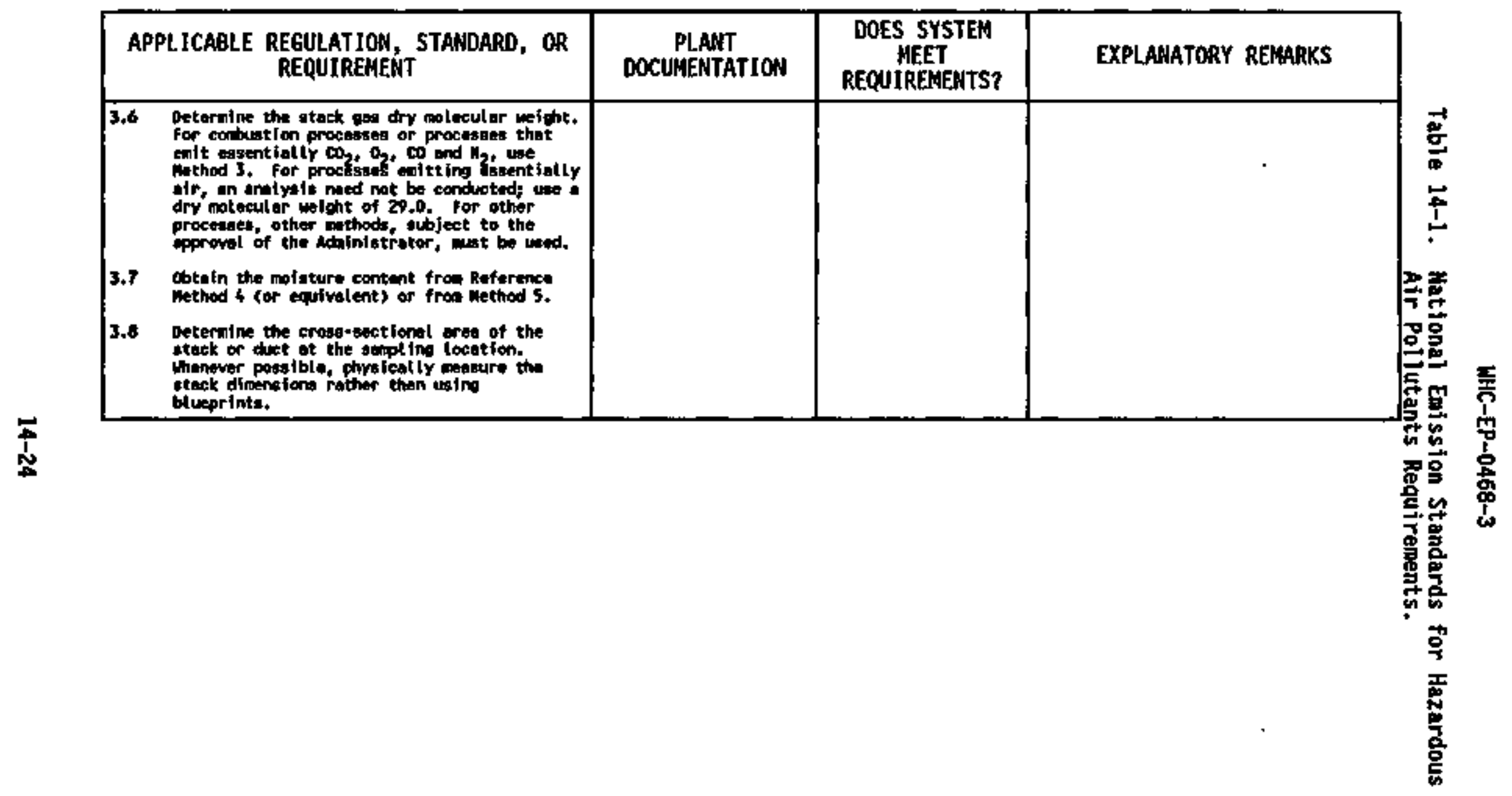




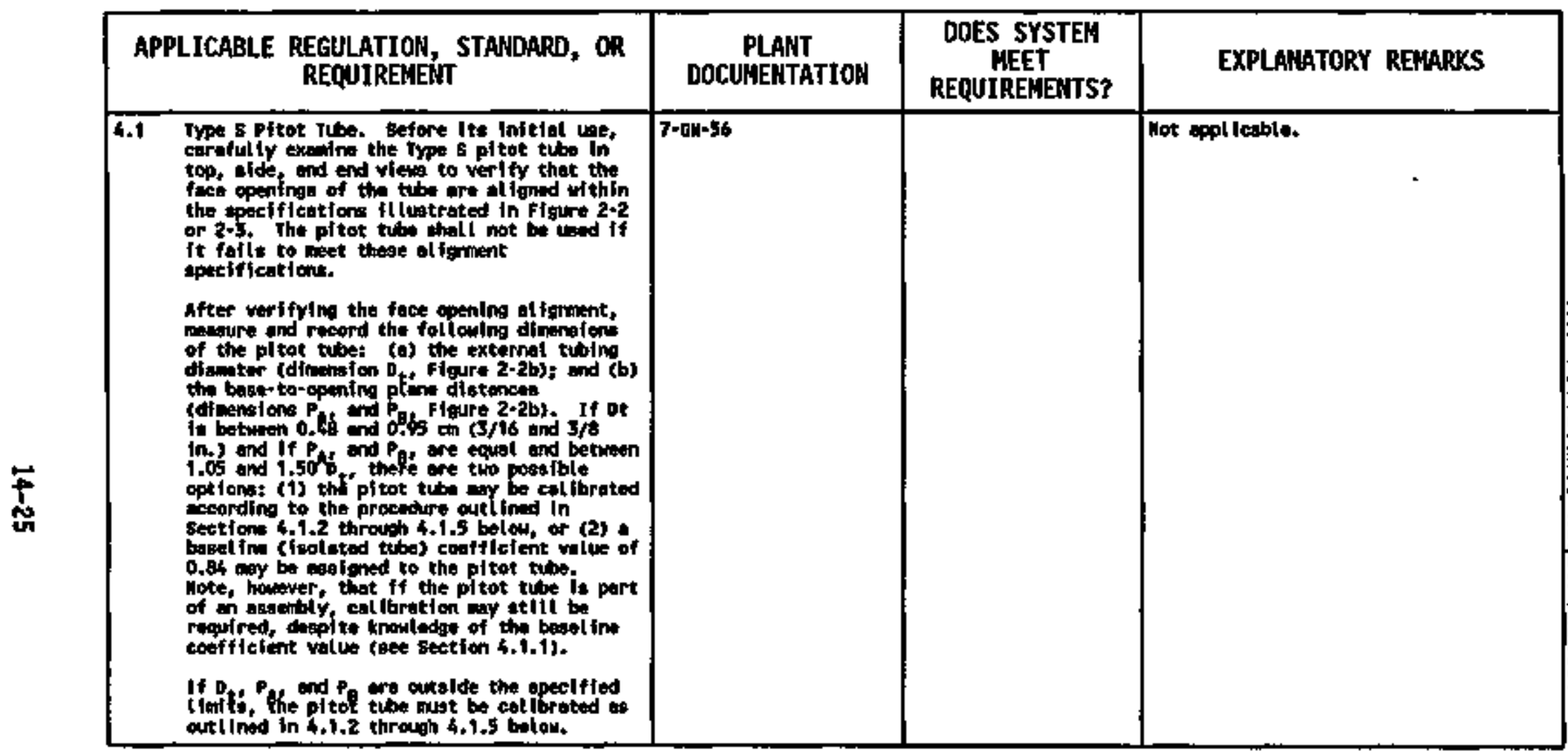




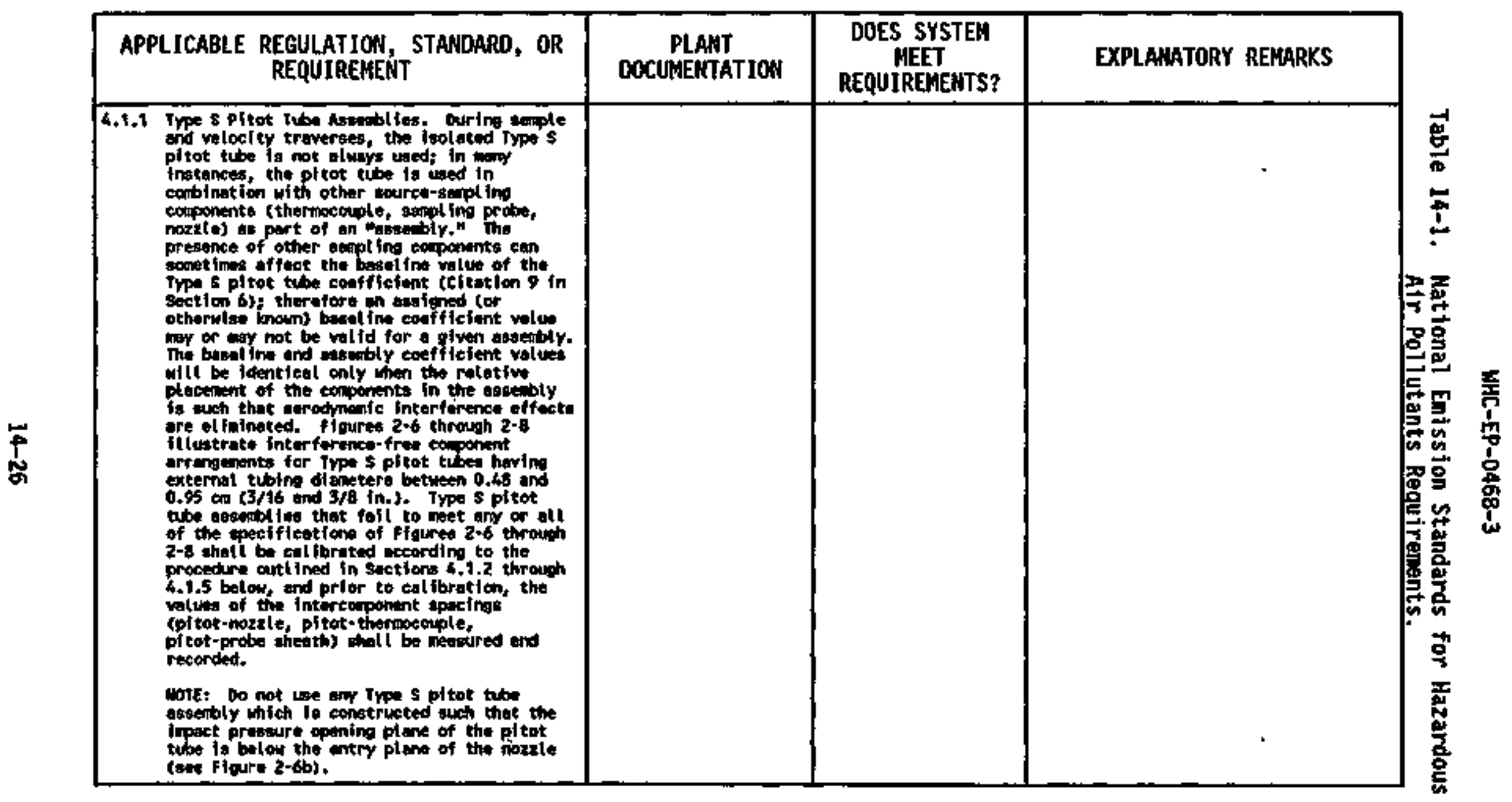




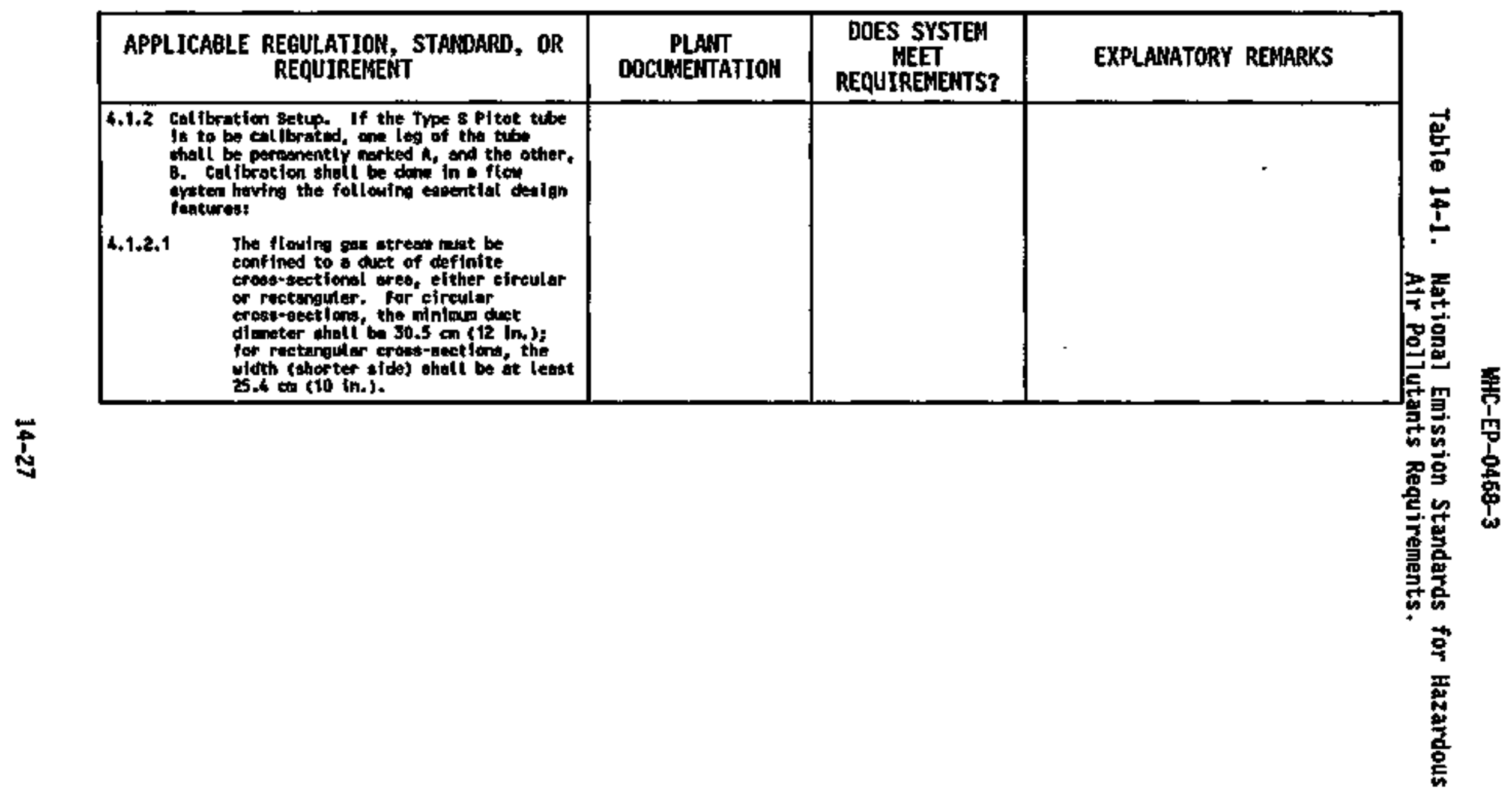




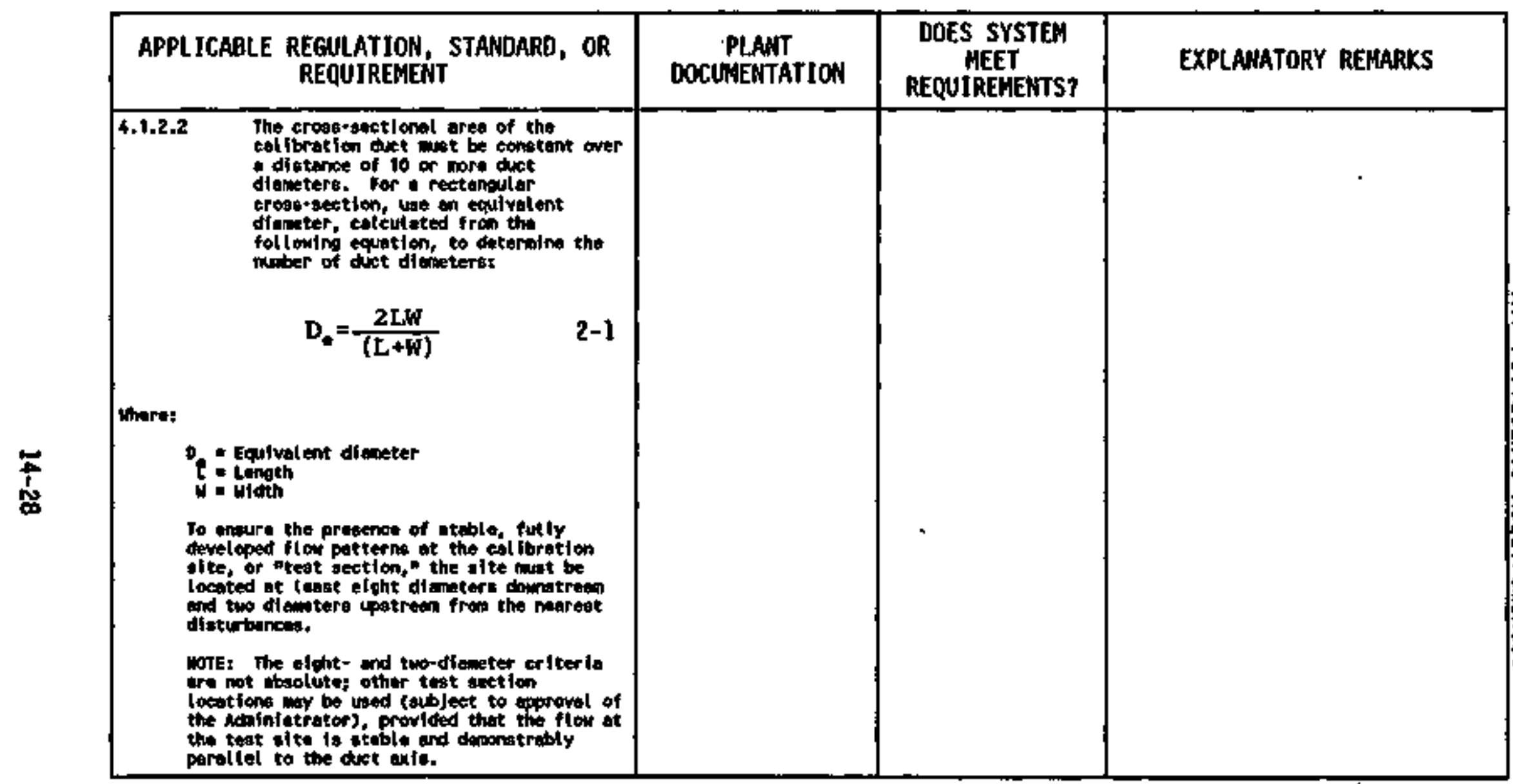




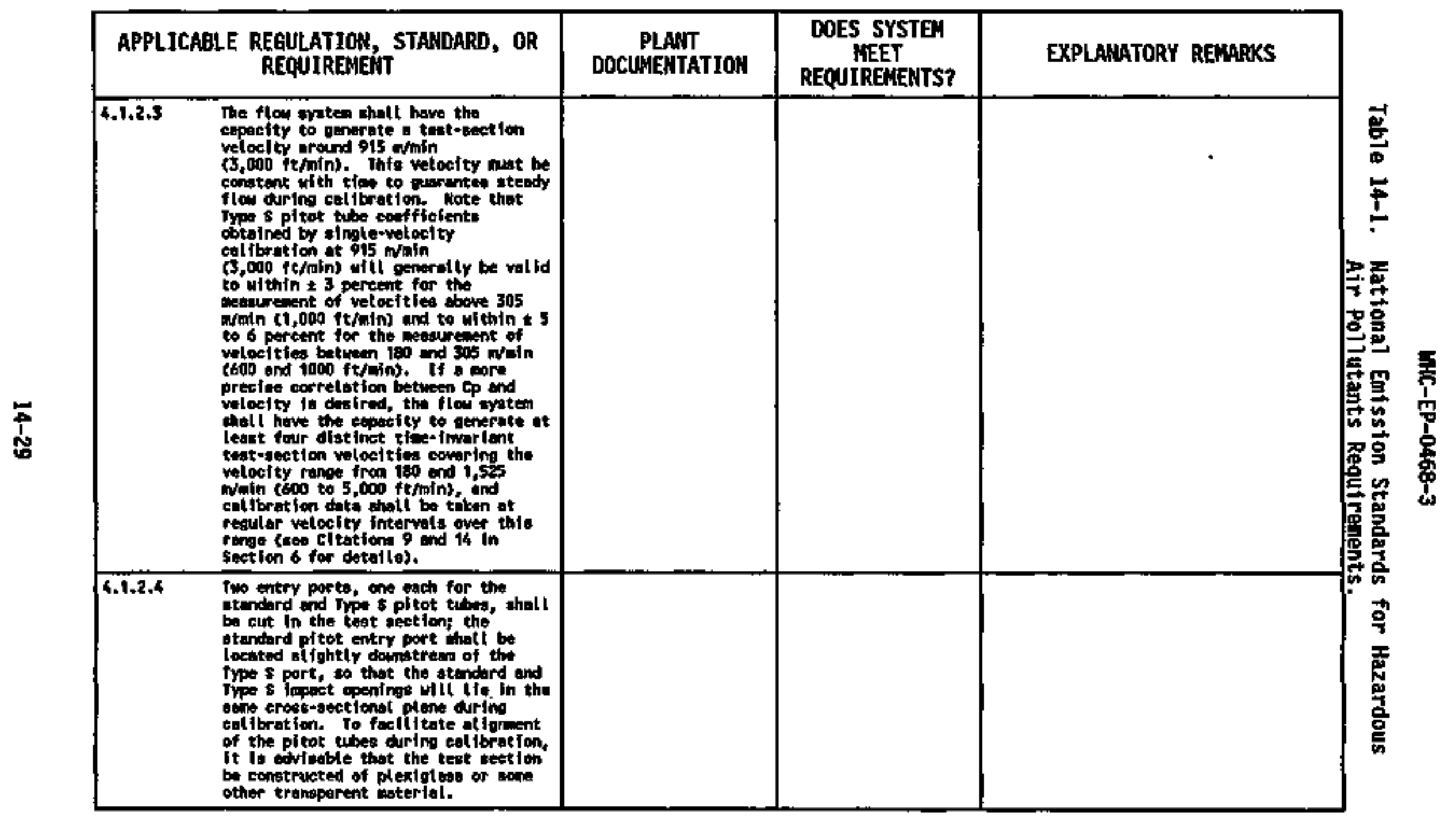




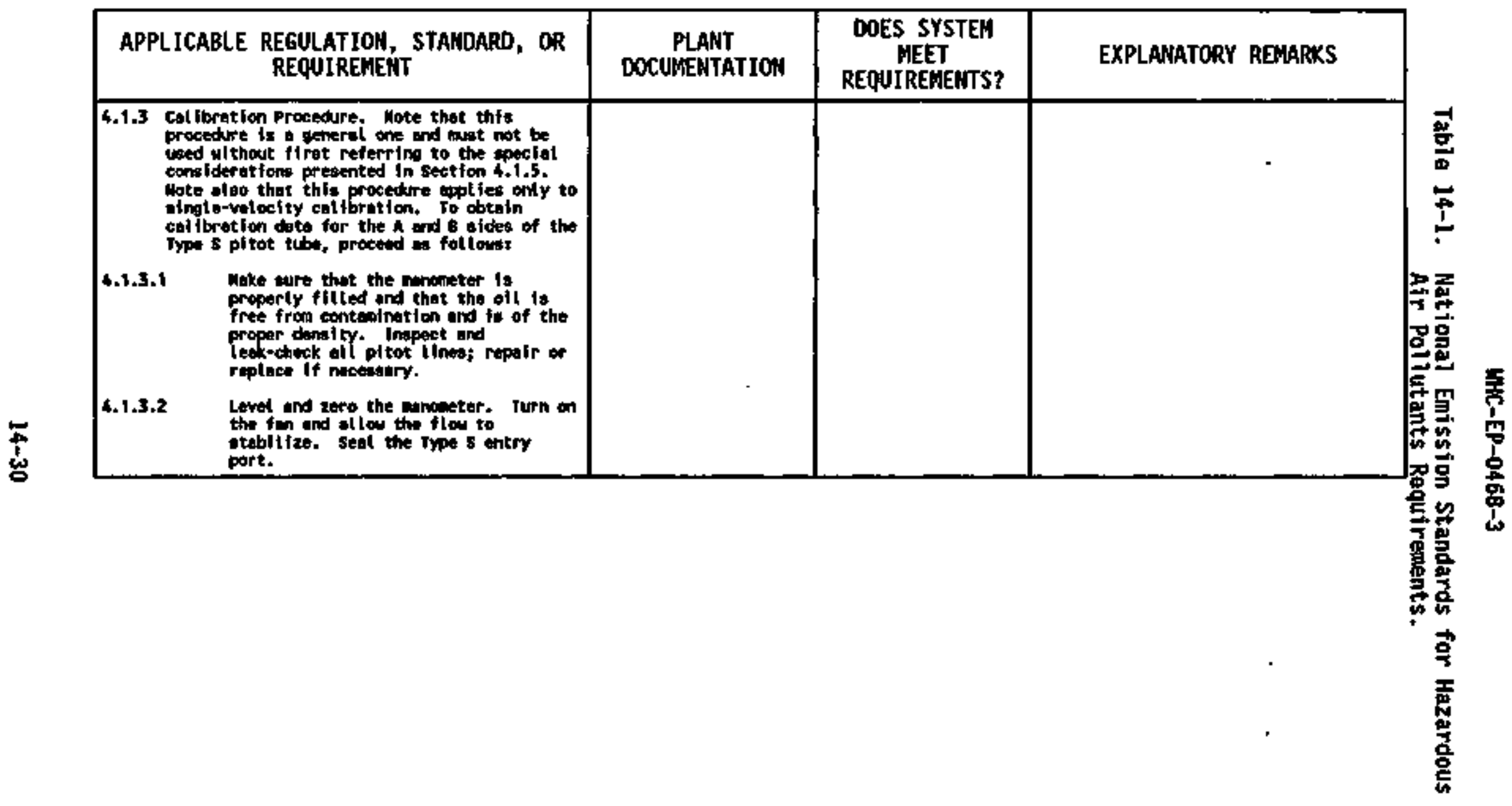




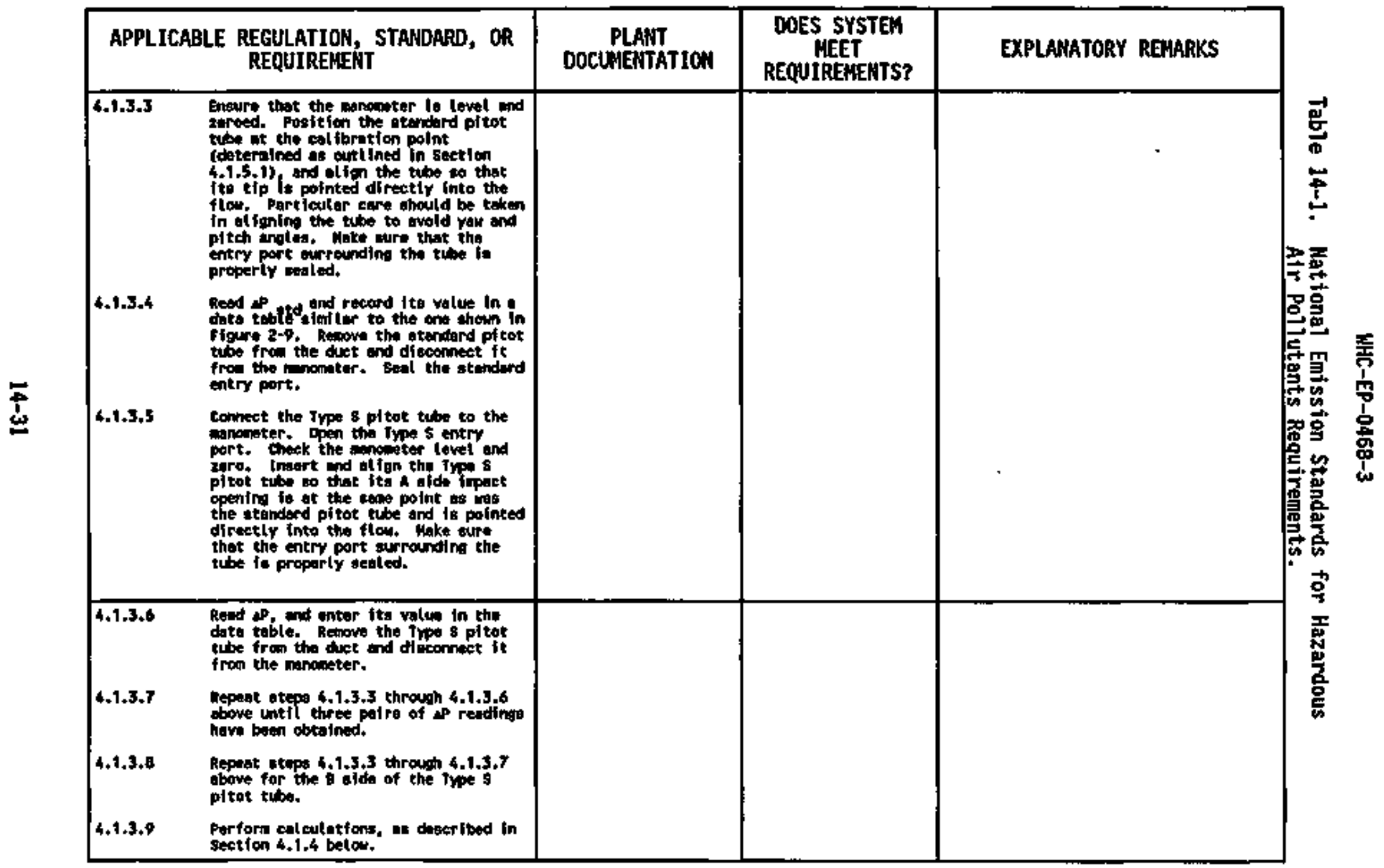




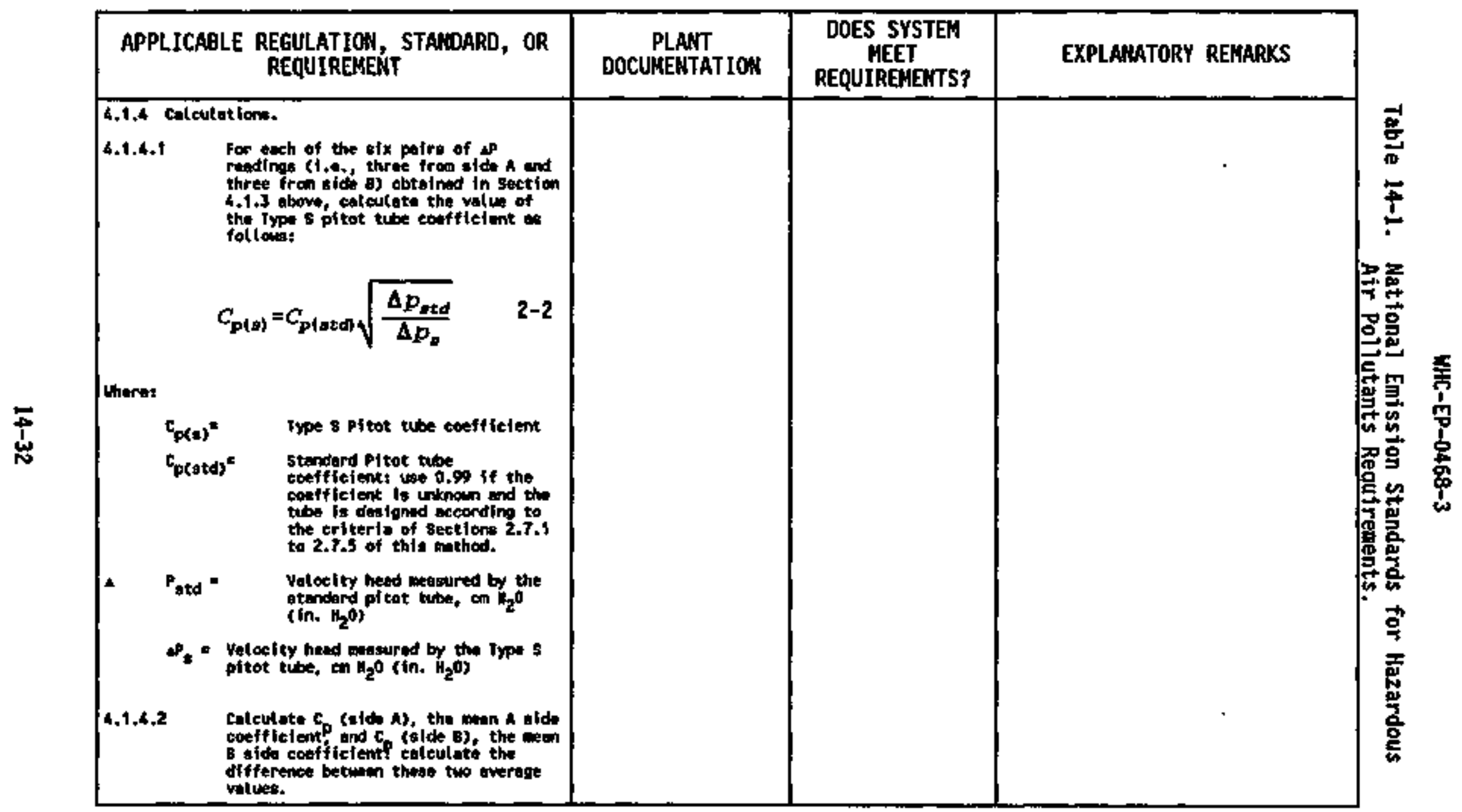




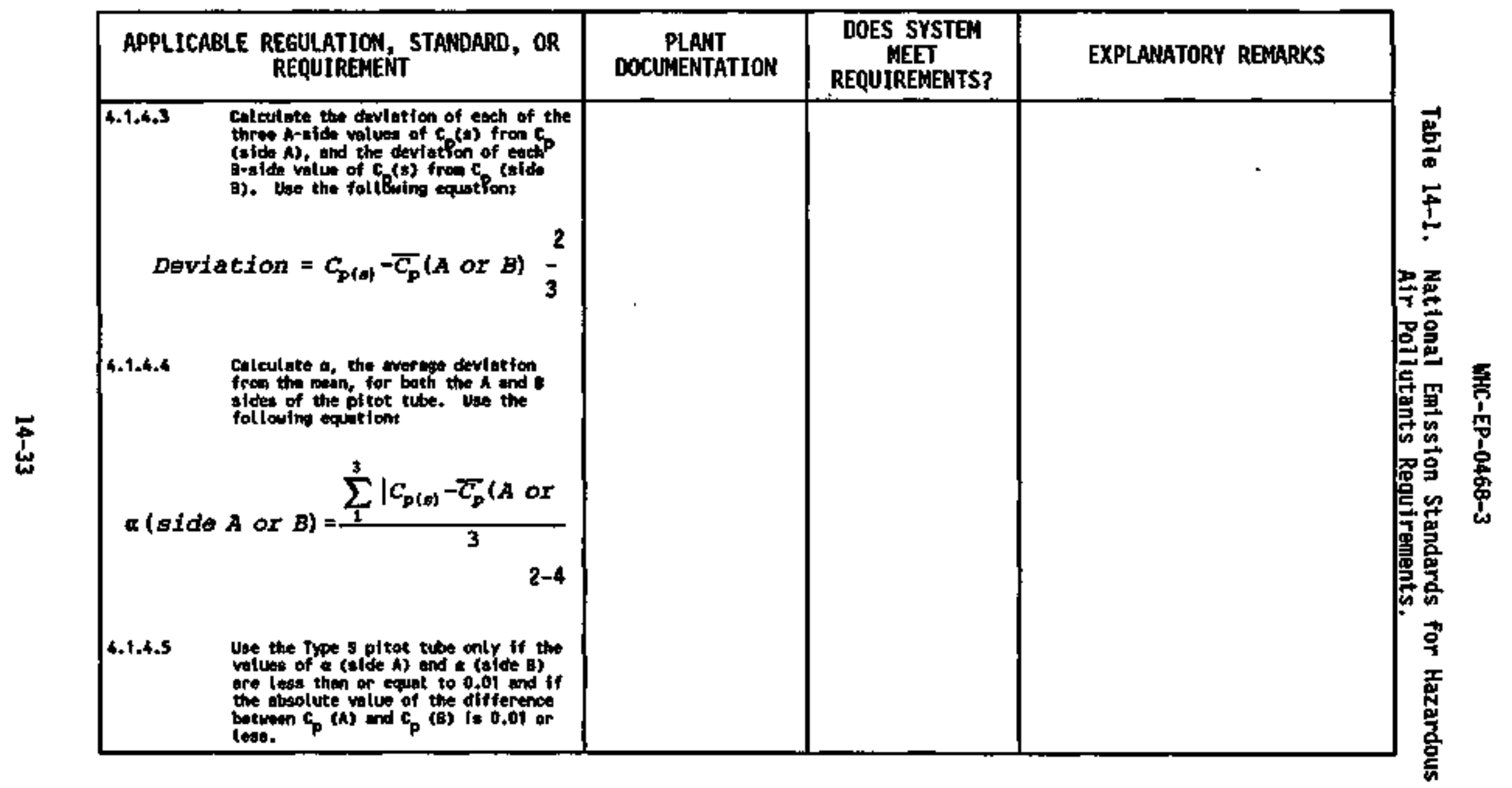




\begin{tabular}{|c|c|c|c|}
\hline $\begin{array}{l}\text { APPLICABLE REGULATION, STAMDARD, OR } \\
\text { REQUIREMENT }\end{array}$ & $\begin{array}{c}\text { PLANT } \\
\text { DOCUMENTATION }\end{array}$ & $\begin{array}{c}\text { DOES SYSTEN } \\
\text { MEET } \\
\text { REQUIREMENTS? }\end{array}$ & EXPLAMATORY REMARKS \\
\hline 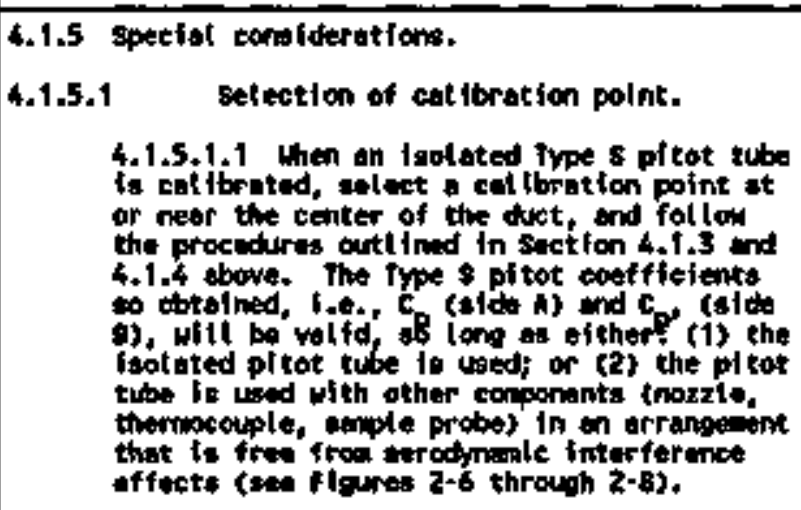 & & & \\
\hline 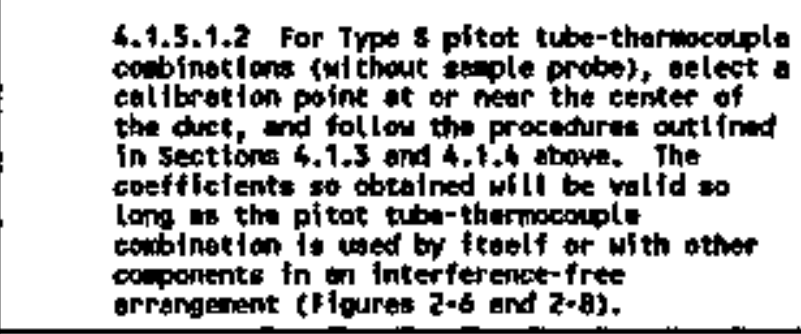 & & & \\
\hline 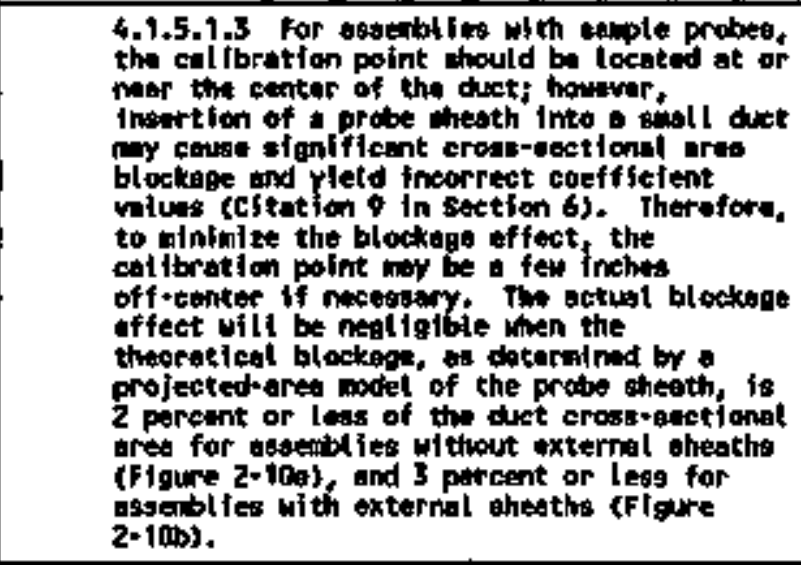 & & & . \\
\hline
\end{tabular}




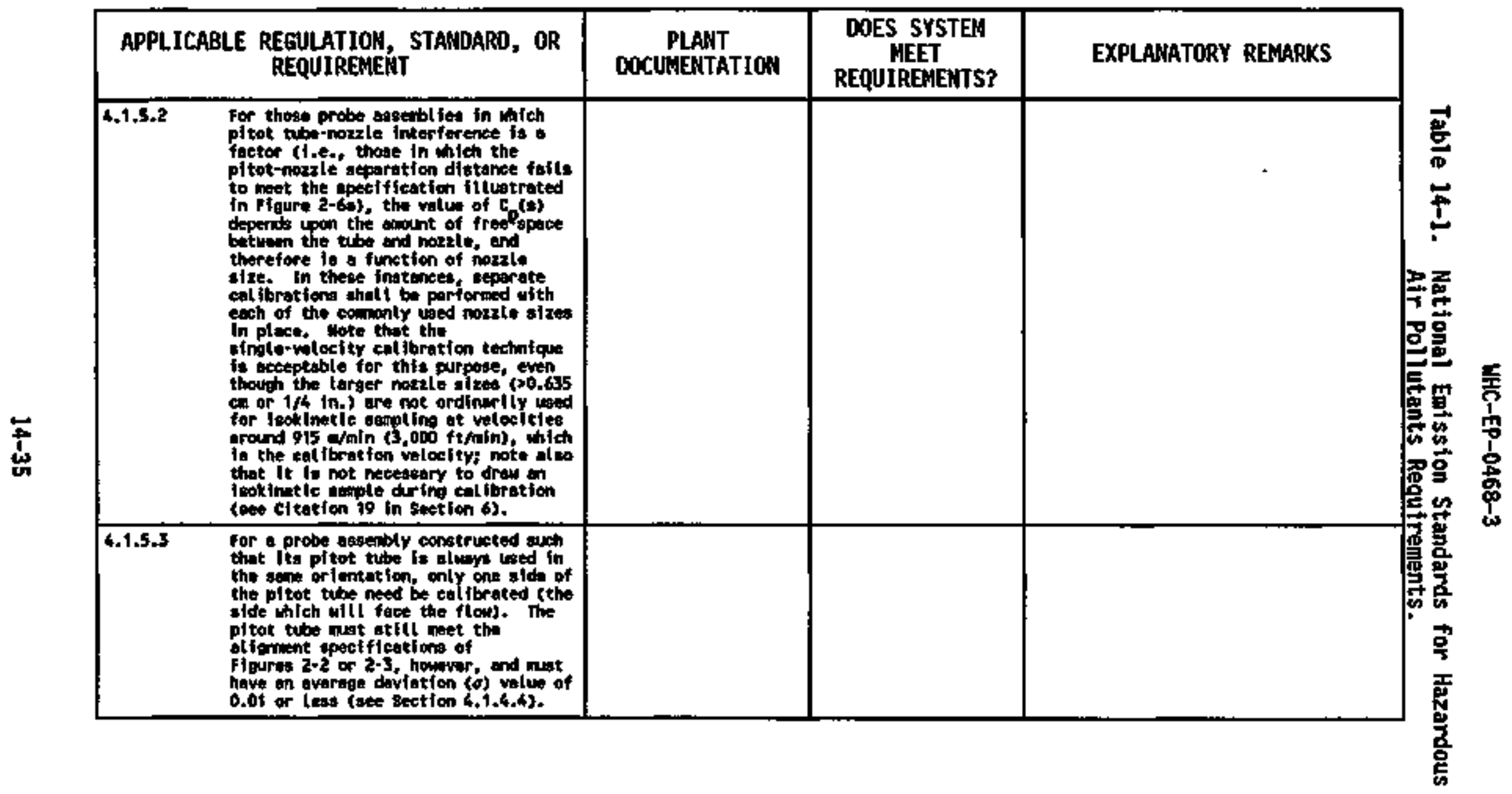




\begin{tabular}{|c|c|c|c|}
\hline $\begin{array}{l}\text { APPLICABLE REGULATION, STANDARO, OR } \\
\text { REQUIREMENT }\end{array}$ & $\begin{array}{c}\text { PLANT } \\
\text { OOCUMENTATION }\end{array}$ & $\begin{array}{l}\text { DOES SYSTEM } \\
\text { MEET } \\
\text { REQUIREMEKTS? }\end{array}$ & EXPLAMATORY REMARKS \\
\hline 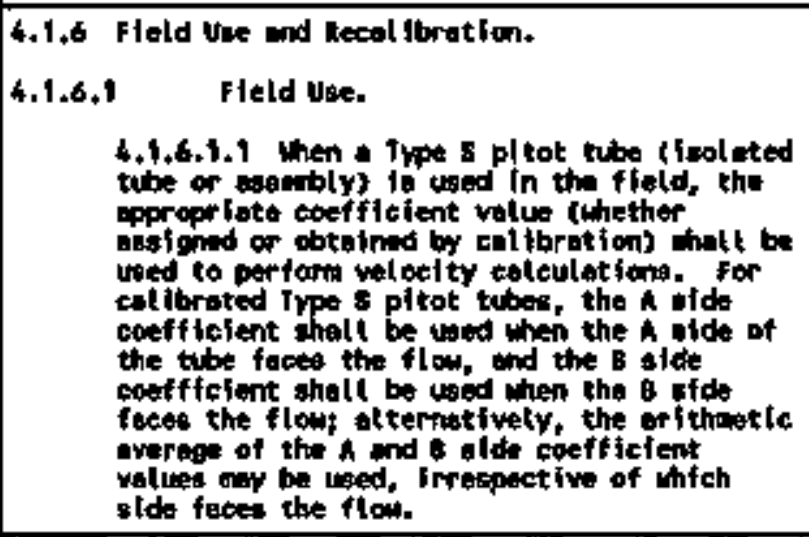 & & & \\
\hline 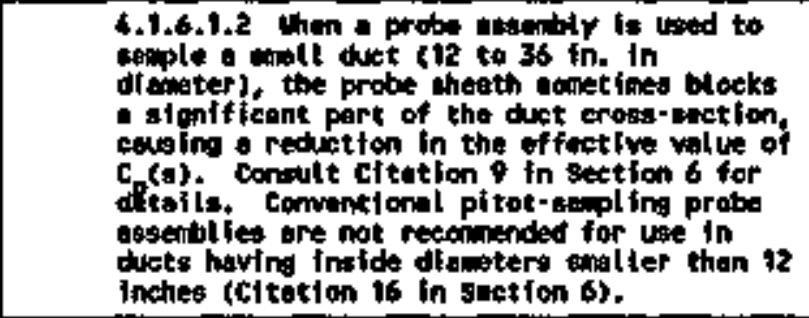 & & & \\
\hline 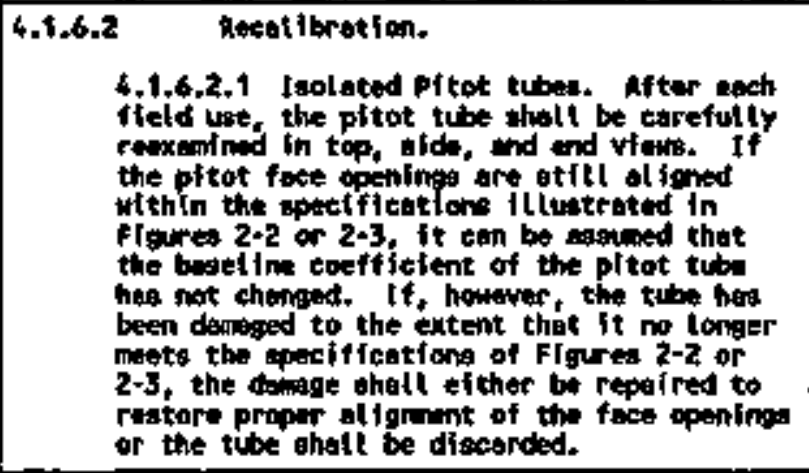 & & & - \\
\hline
\end{tabular}




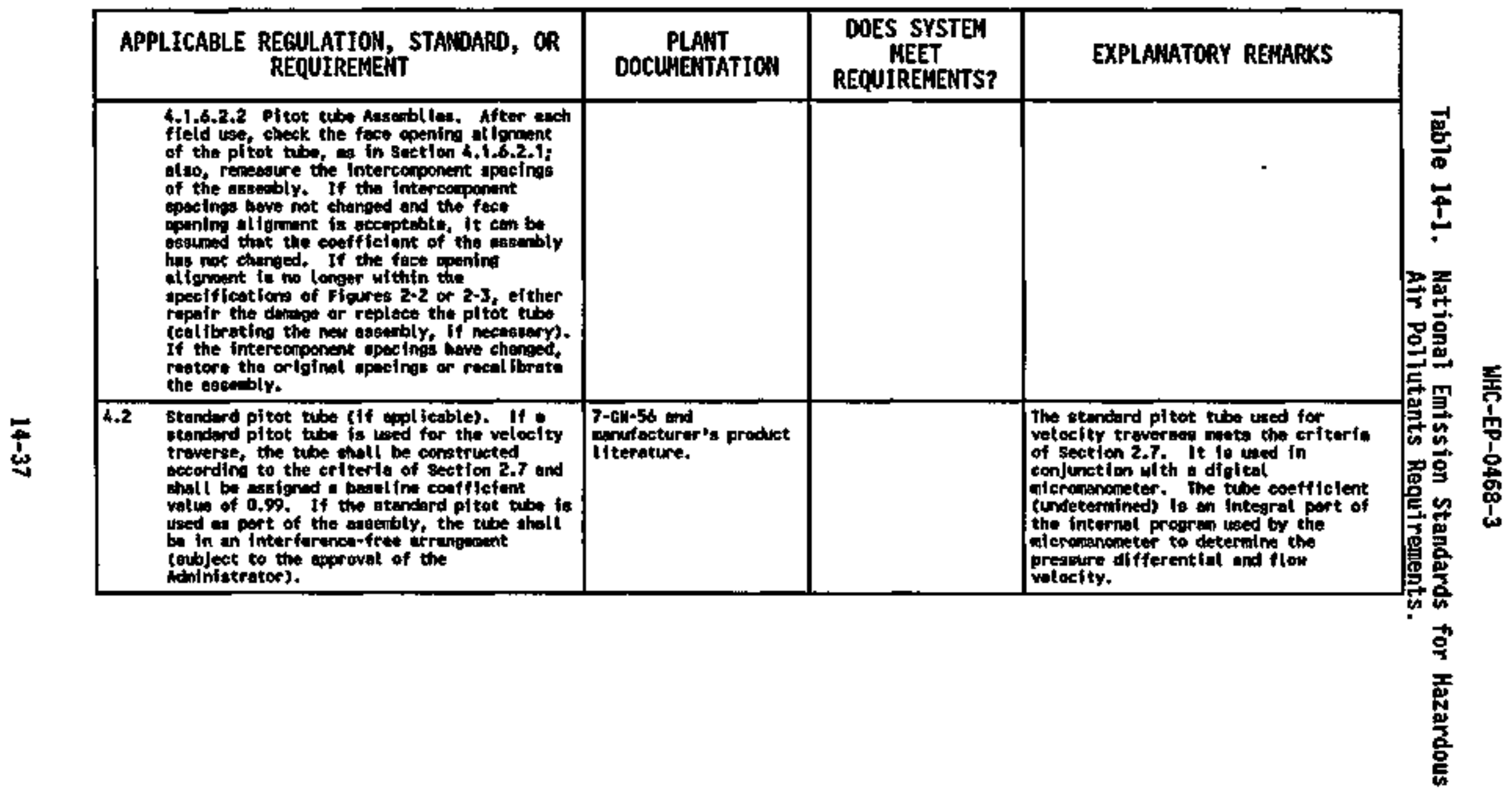




\begin{tabular}{|c|c|c|c|}
\hline $\begin{array}{l}\text { APPLICABLE REGULATION, STANOARD, OR } \\
\text { REQUIREMENT }\end{array}$ & $\begin{array}{l}\text { PLAHT } \\
\text { DOCLNEHTATIOH }\end{array}$ & $\begin{array}{l}\text { DOES SYSTEH } \\
\text { MEET } \\
\text { REQUIREMEHTS? }\end{array}$ & EXPLAHATORY REMARKS \\
\hline 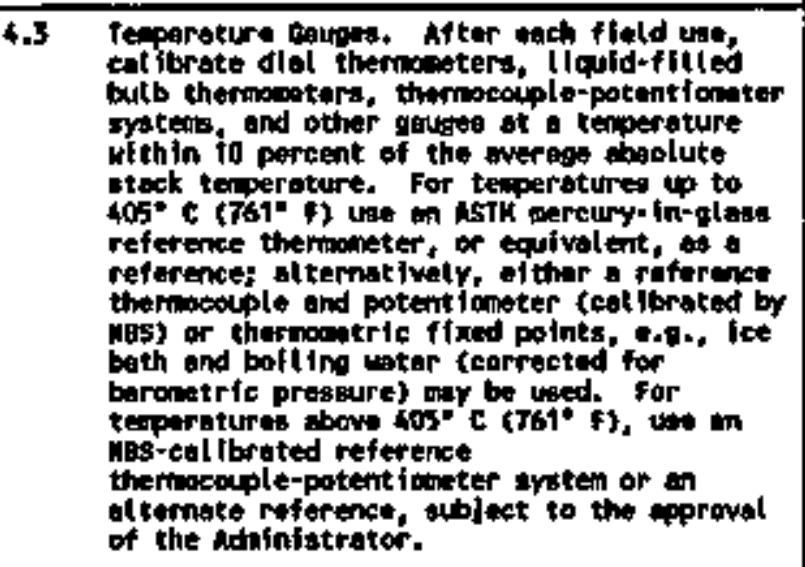 & 7-en-36 & & $\begin{array}{l}\text { Mo teipereture-medetring devites are } \\
\text { toesed. }\end{array}$ \\
\hline 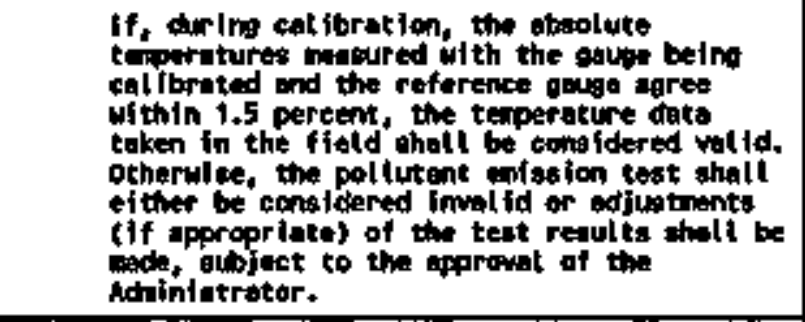 & & & \\
\hline 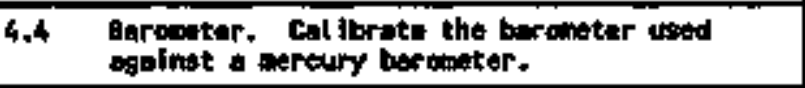 & 7-GH-5b & & $\begin{array}{l}\text { Mo barchetric-pressure-neasur ing } \\
\text { derrlcos are wesd. }\end{array}$ \\
\hline 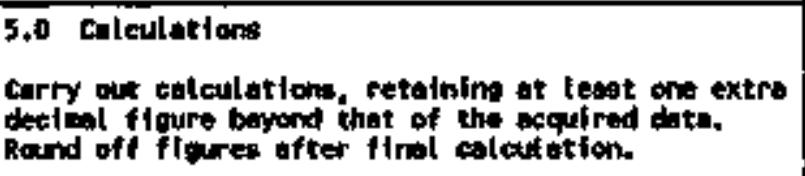 & $\begin{array}{l}\text { 7-GW-56 and } \\
\text { manuffactivenr'o product } \\
\text { lftersture. }\end{array}$ & & 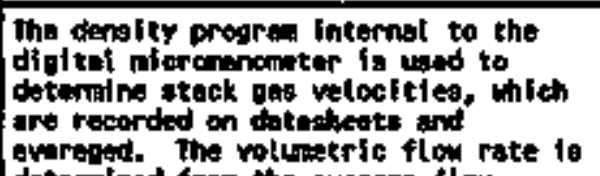 \\
\hline 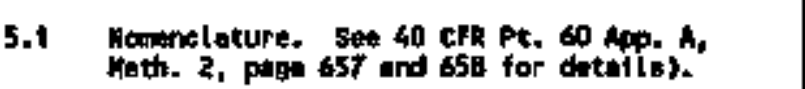 & & & 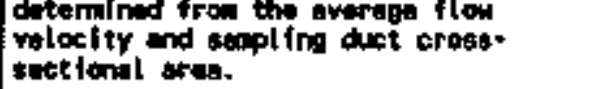 \\
\hline
\end{tabular}




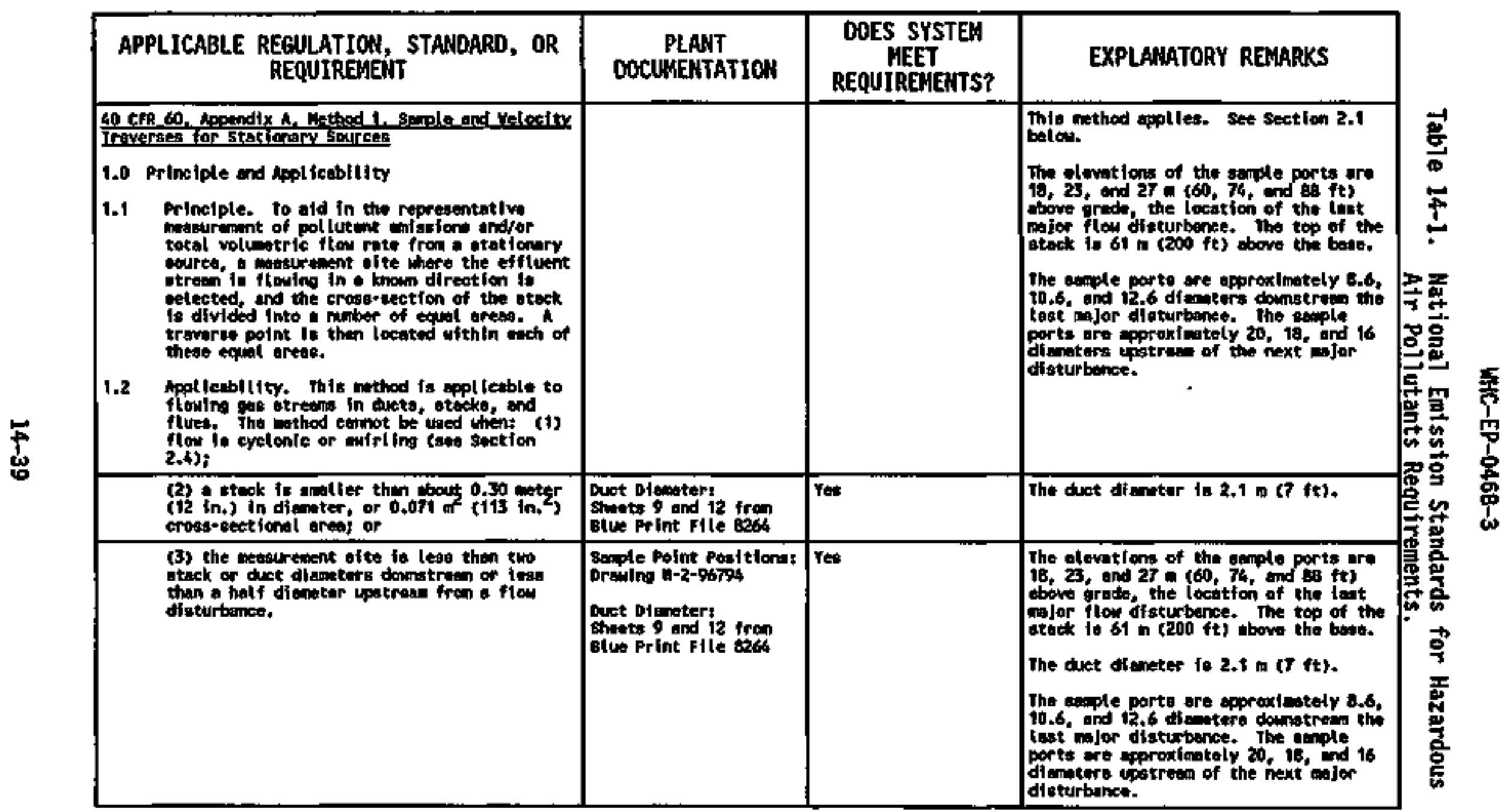




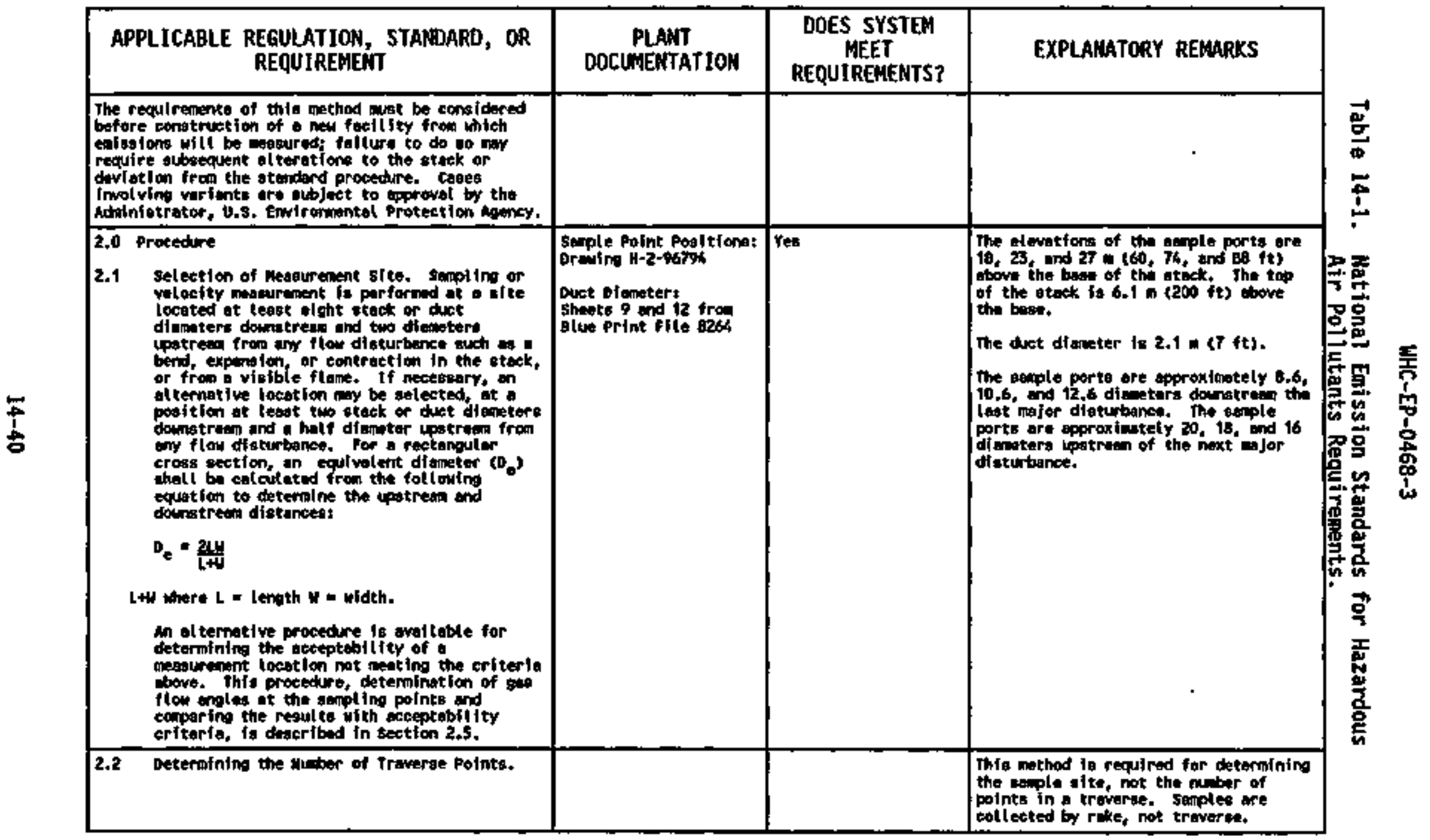




\begin{tabular}{|c|c|c|c|c|}
\hline \multicolumn{2}{|r|}{$\begin{array}{l}\text { APPLICABLE REGULATYON, STANBARD, OR } \\
\text { REQUIREMENT }\end{array}$} & \multirow[t]{2}{*}{$\begin{array}{c}\text { PLANT } \\
\text { DOCUMENTATION }\end{array}$} & \multirow[t]{2}{*}{$\begin{array}{l}\text { DOES SYSTEM } \\
\text { MEET } \\
\text { REQUIRENENTS? }\end{array}$} & \multirow{2}{*}{ 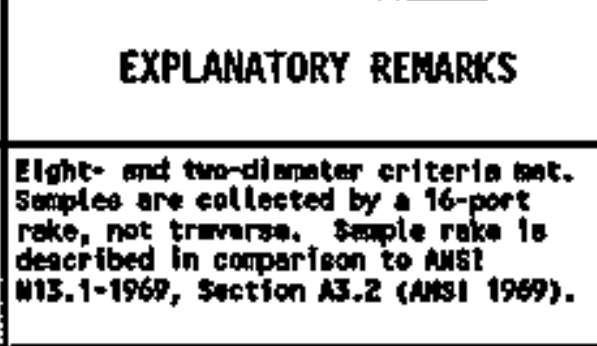 } \\
\hline 2.2 .1 & 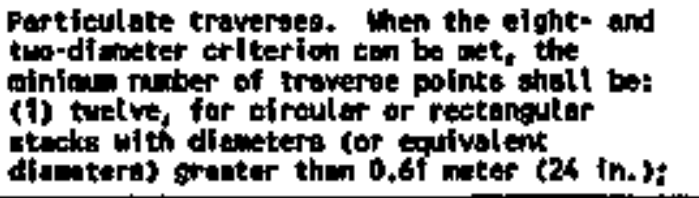 & & & \\
\hline & 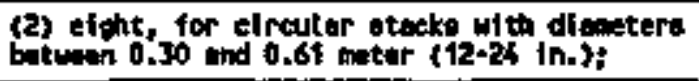 & & Mot applicable & 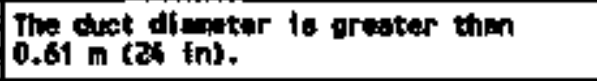 \\
\hline & 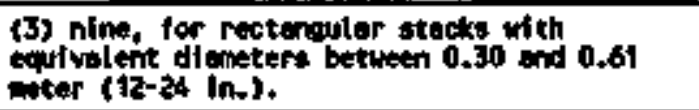 & & Hot appl Ieboble & $\begin{array}{l}\text { This atack is clrculur, not } \\
\text { reetenguler. }\end{array}$ \\
\hline \multicolumn{2}{|c|}{ 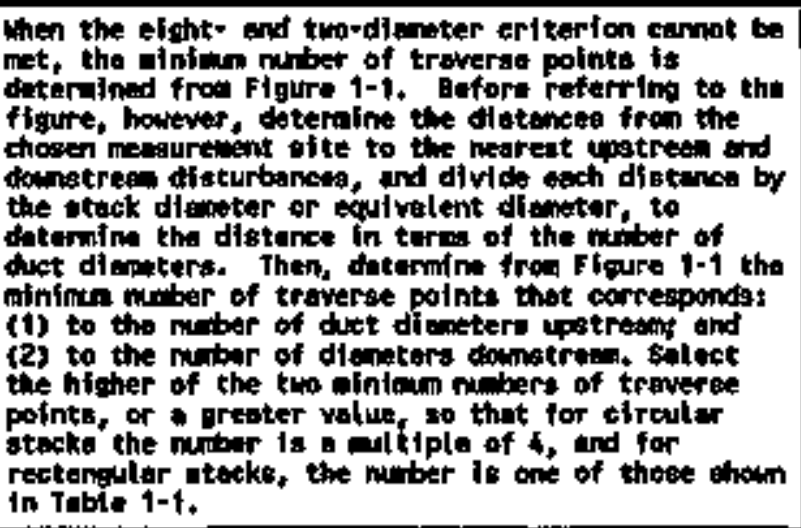 } & & Hot appllewte & Eight and two tetiterlon mt. \\
\hline 2.2 .2 & 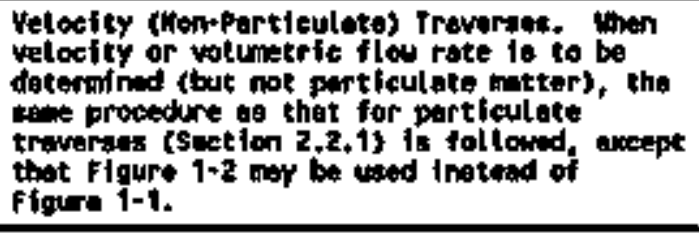 & & Hot appl teuble & 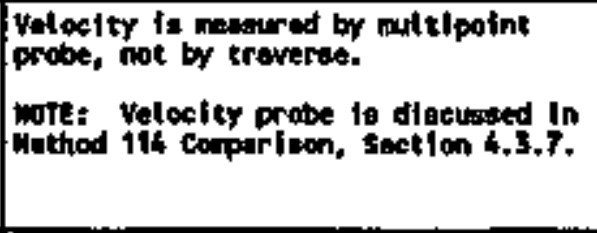 \\
\hline 2.3 & $\begin{array}{l}\text { troos+suctionat loyout and locetion of } \\
\text { irmarse Polnts. }\end{array}$ & & Wot appl teoble & 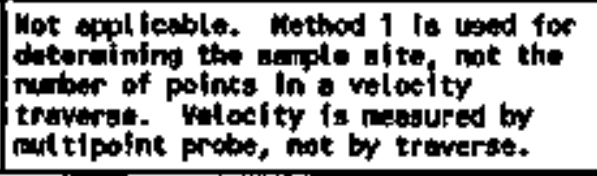 \\
\hline
\end{tabular}




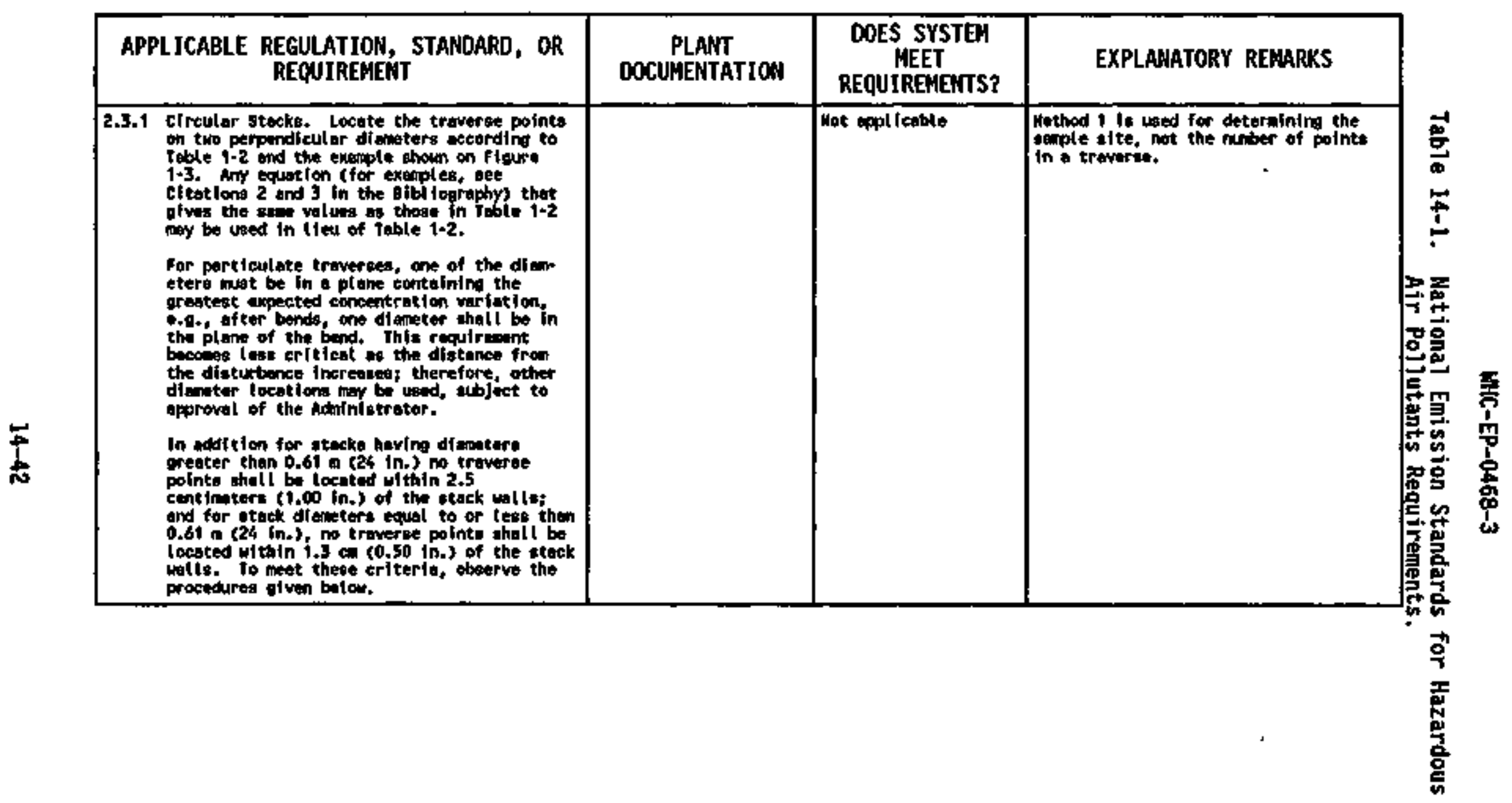




\begin{tabular}{|c|c|c|c|c|}
\hline \multicolumn{2}{|c|}{$\begin{array}{l}\text { APPLICABLE REGULATIOW, STANOARD, OR } \\
\text { REQUIREMENT }\end{array}$} & $\begin{array}{l}\text { PLANT } \\
\text { DOCUMENFATION }\end{array}$ & $\begin{array}{l}\text { DOES SYSTEN } \\
\text { MEET } \\
\text { REQUIREMENTS? }\end{array}$ & EXPLAMATORY REMARKS \\
\hline$\overline{2.3 .1 .1}$ & 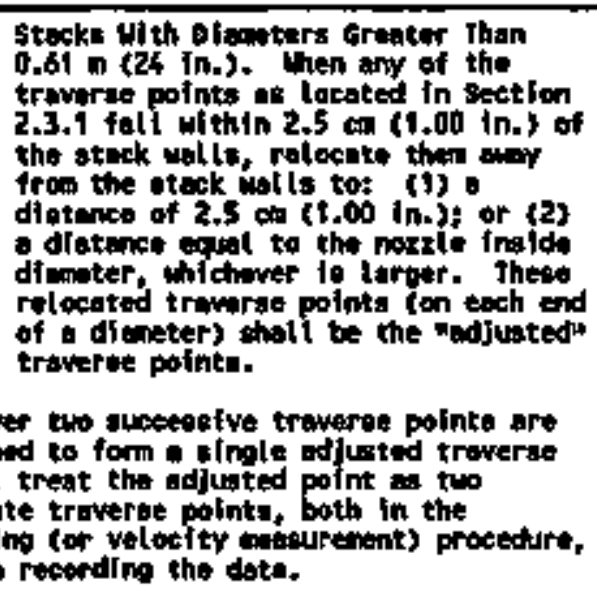 & & Wot applifesble & 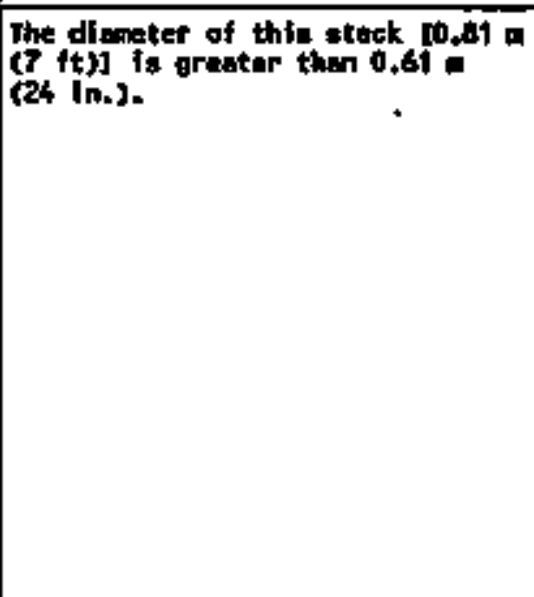 \\
\hline 2.3 .1 .2 & 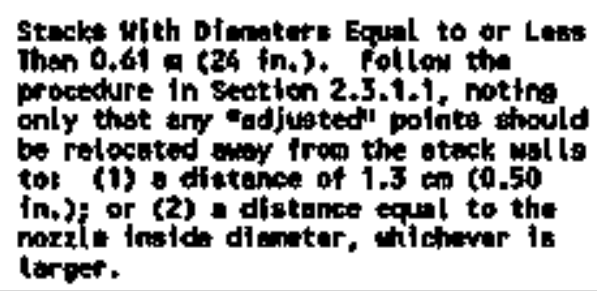 & & & \\
\hline
\end{tabular}




\begin{tabular}{|c|c|c|c|c|}
\hline \multicolumn{2}{|r|}{$\begin{array}{l}\text { APPLICABLE REGULATION, STAMDARD, OR } \\
\text { REQUIREMENT }\end{array}$} & $\begin{array}{l}\text { PLANT } \\
\text { DOCUMENTATION }\end{array}$ & $\begin{array}{c}\text { DOES SYSTEM } \\
\text { MEET } \\
\text { REQUIREMENTS? } \\
\end{array}$ & EXPLAMATORY REMARKS \\
\hline & 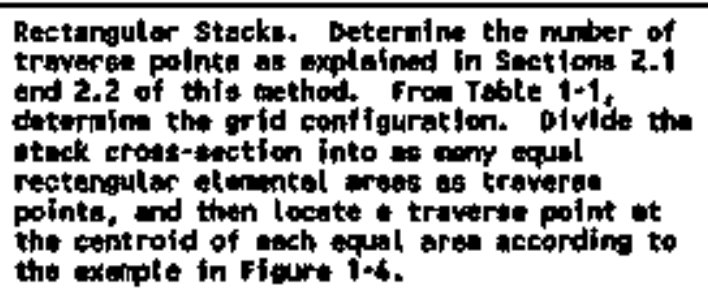 & & Hot wostite & 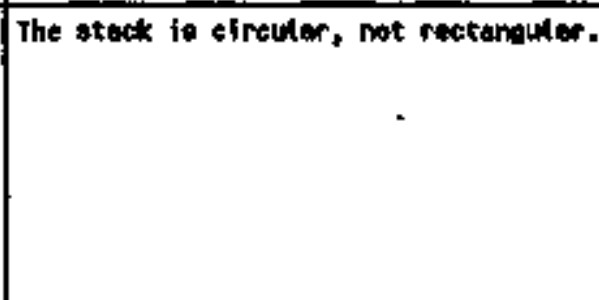 \\
\hline & 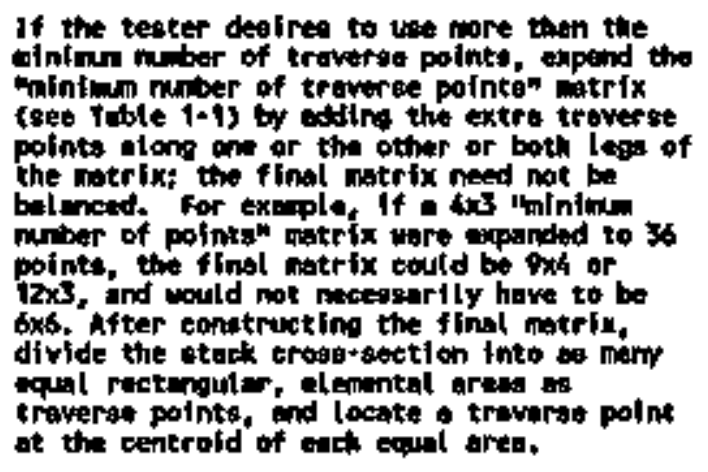 & & & \\
\hline & 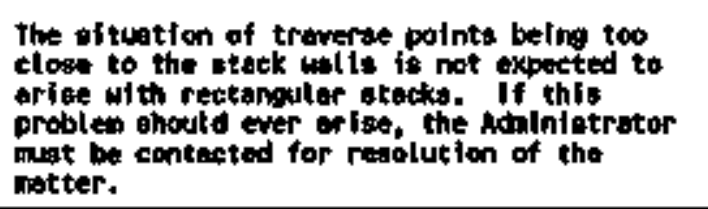 & & & \\
\hline 2,4 & 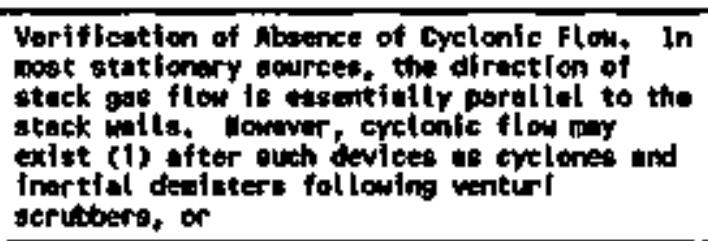 & & ves & 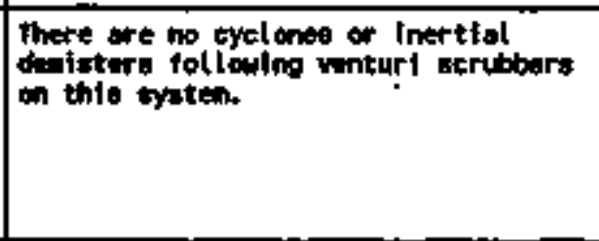 \\
\hline
\end{tabular}




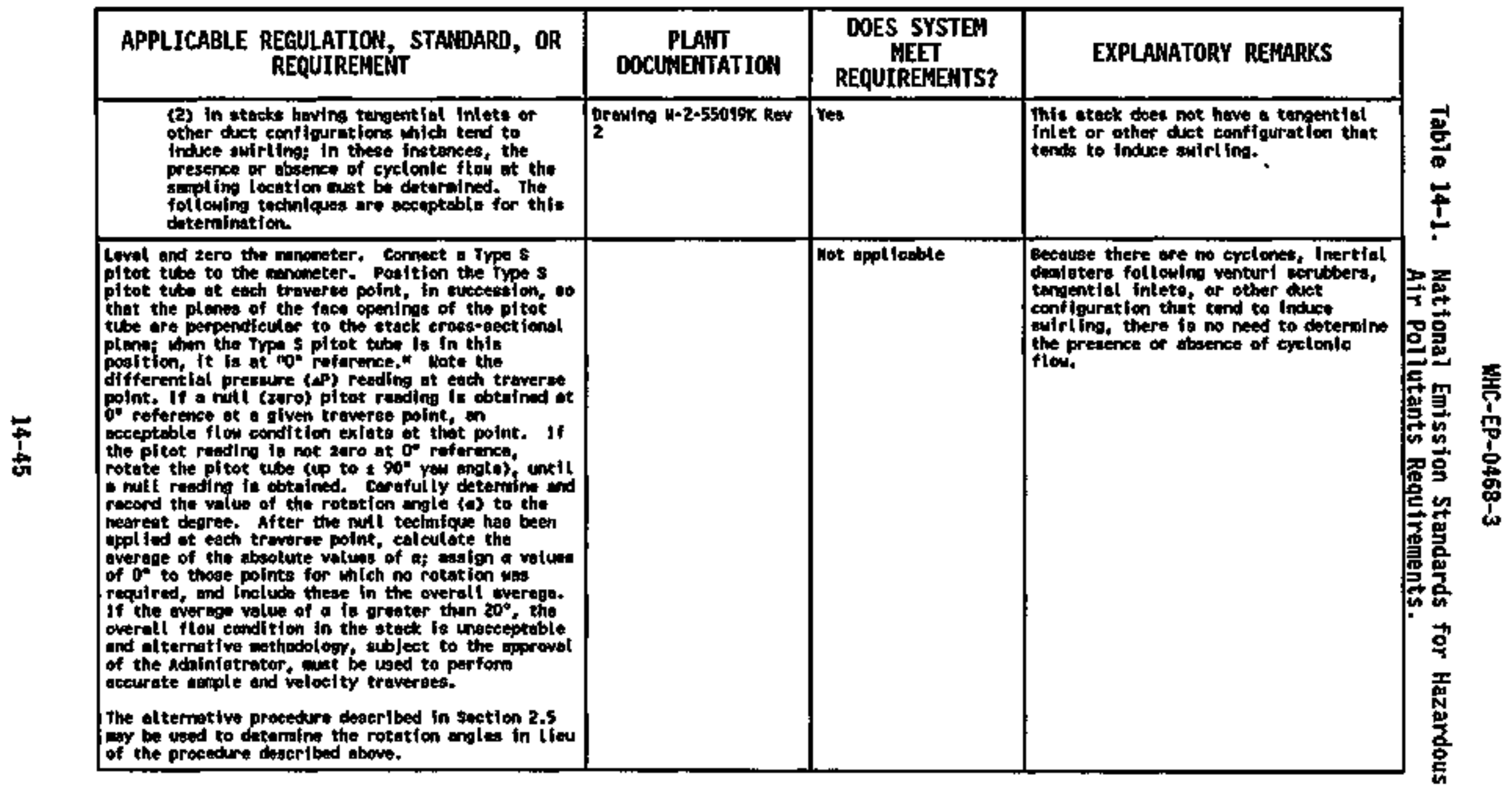




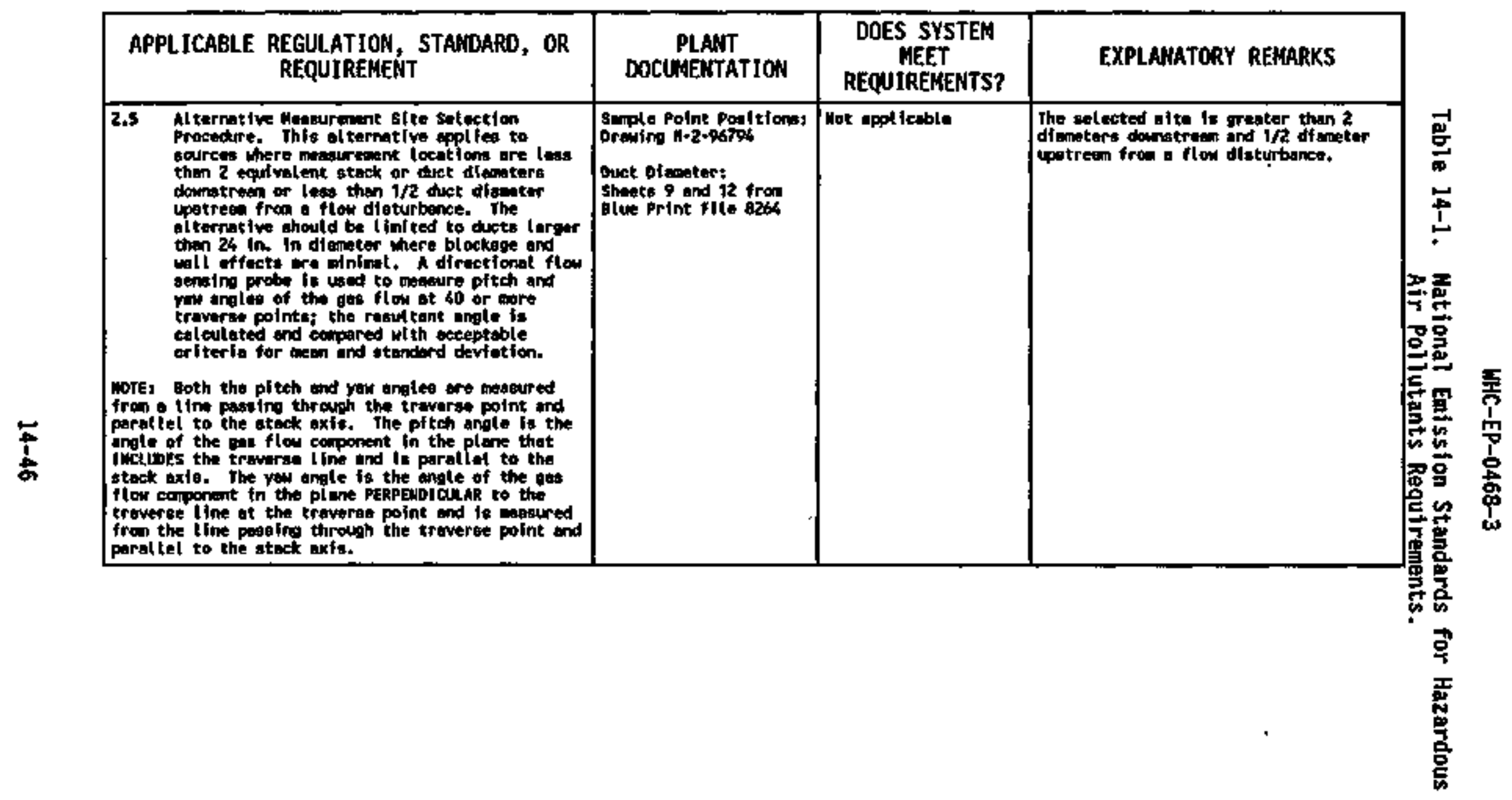




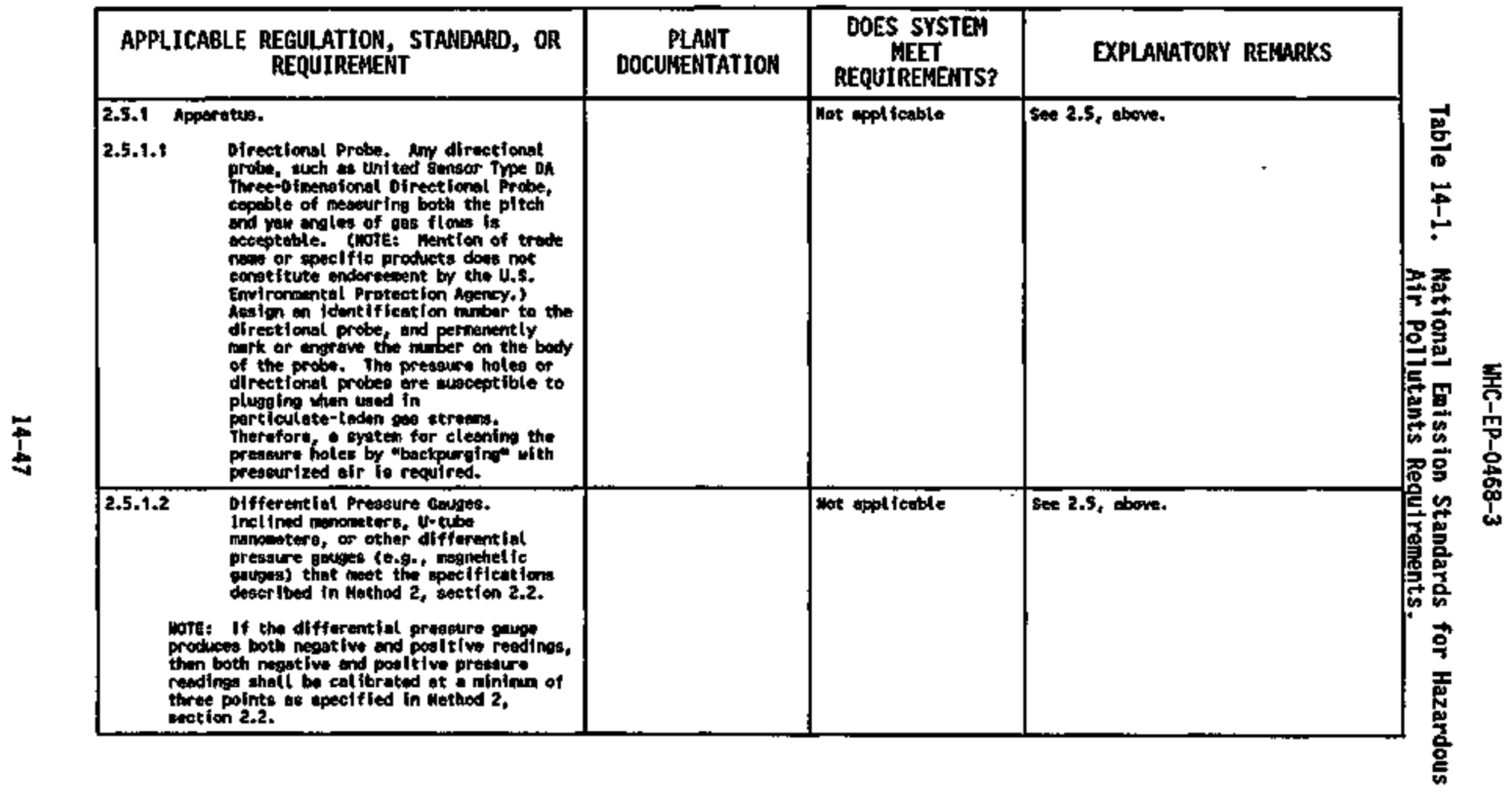




\begin{tabular}{|c|c|c|c|c|}
\hline \multicolumn{2}{|c|}{$\begin{array}{l}\text { APPLICABLE REGULATION, STAMDARD, OR } \\
\text { REQUIREMENT }\end{array}$} & \multirow[t]{2}{*}{$\begin{array}{c}\text { PLANT } \\
\text { DOCUMENTATIOH }\end{array}$} & \multirow{2}{*}{$\begin{array}{c}\text { DOES SYSTEM } \\
\text { MEET } \\
\text { RECUIREMENTS? } \\
\text { Mot oppl tcable }\end{array}$} & EXPLAMATORY REMARKS \\
\hline 2.5 .2 & 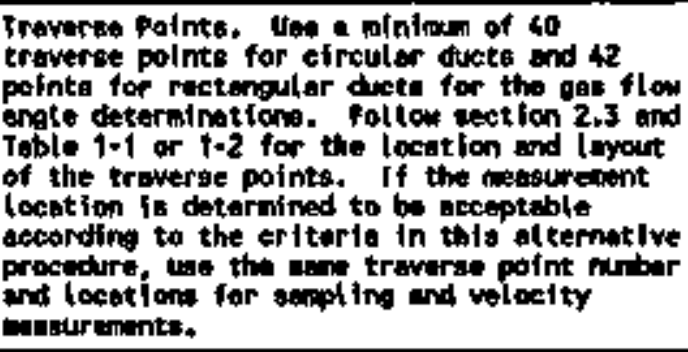 & & & See 2.5, bove. \\
\hline $2,5,3$ & Monsurereint Procedtere. & & Wot appltcable & see 2.5, ebove. \\
\hline 2.5 .3 .1 & 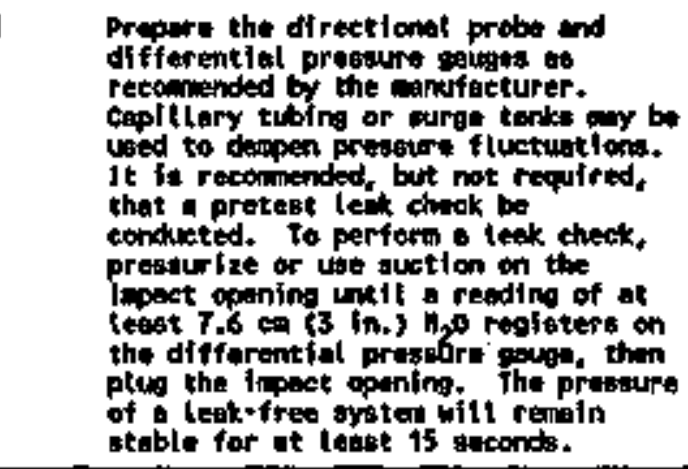 & & & \\
\hline 2.5 .3 .2 & 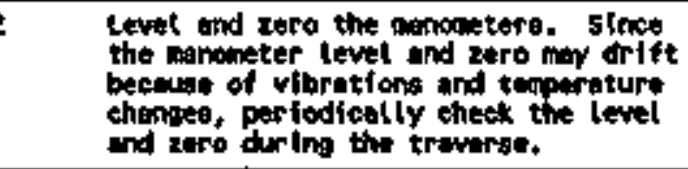 & & wot appl techke & the 2.5, bove. \\
\hline
\end{tabular}




\begin{tabular}{|c|c|c|c|c|}
\hline \multicolumn{2}{|r|}{$\begin{array}{l}\text { APPLICABLE REGULATIOH, STAHOARD, OR } \\
\text { REQUIRENEKT }\end{array}$} & \multirow[t]{2}{*}{$\begin{array}{l}\text { PLANT } \\
\text { DOCLNEENTATION }\end{array}$} & \multirow{2}{*}{$\begin{array}{c}\text { DOES SYSTEN } \\
\text { MEET } \\
\text { REQUIREMENTS? } \\
\text { pot Dpot lesble }\end{array}$} & EXPLAMATORY REHARKS \\
\hline 2.5 .3 .3 & 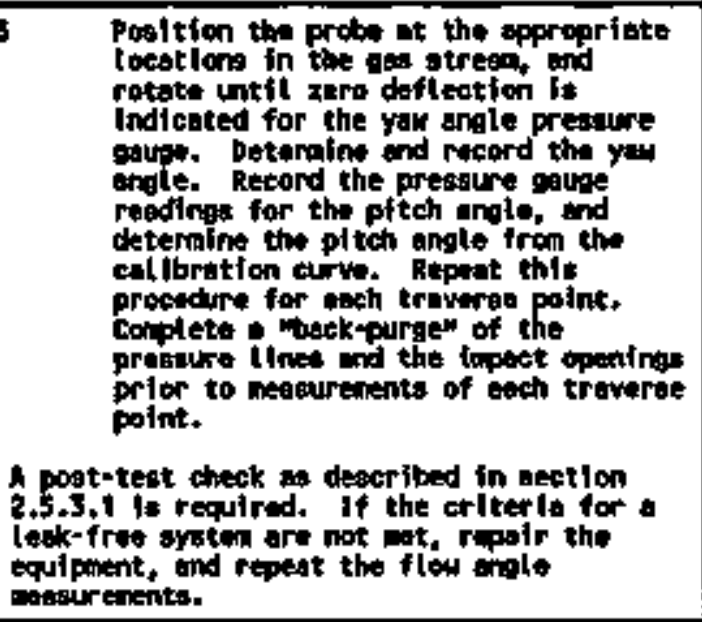 & & & See 2.5, thore. \\
\hline 2.5 .4 & 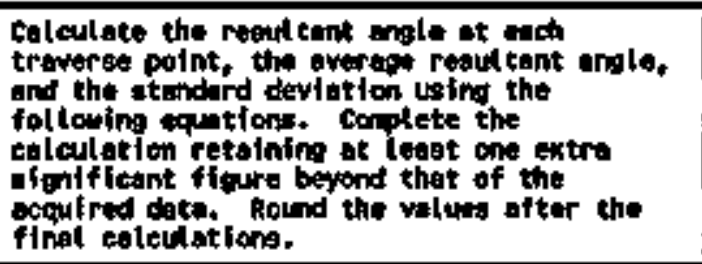 & & Wot eppl fcable & Seet 2.3, whowt. \\
\hline 2.5 .4 .1 & $\begin{array}{l}\text { Calculate the resultent angle of each } \\
\text { traverses point: }\end{array}$ & & Mot appl Icable & See 2.5, ebove. \\
\hline $2,5.5$ & 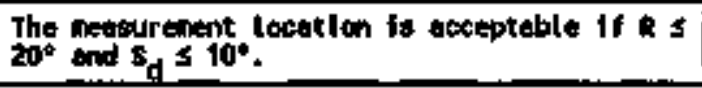 & & Mot appl fcabie & Soe 2.5, ebove. \\
\hline 2.5 .6 & 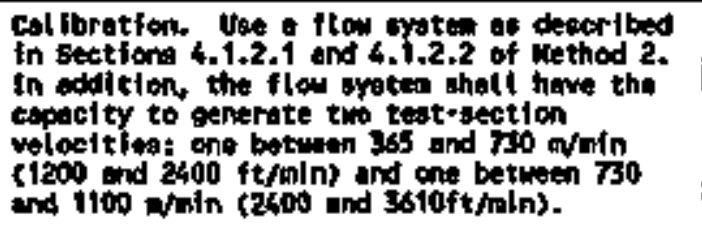 & & Wot appl lcabte & see 2.5, otene. \\
\hline
\end{tabular}




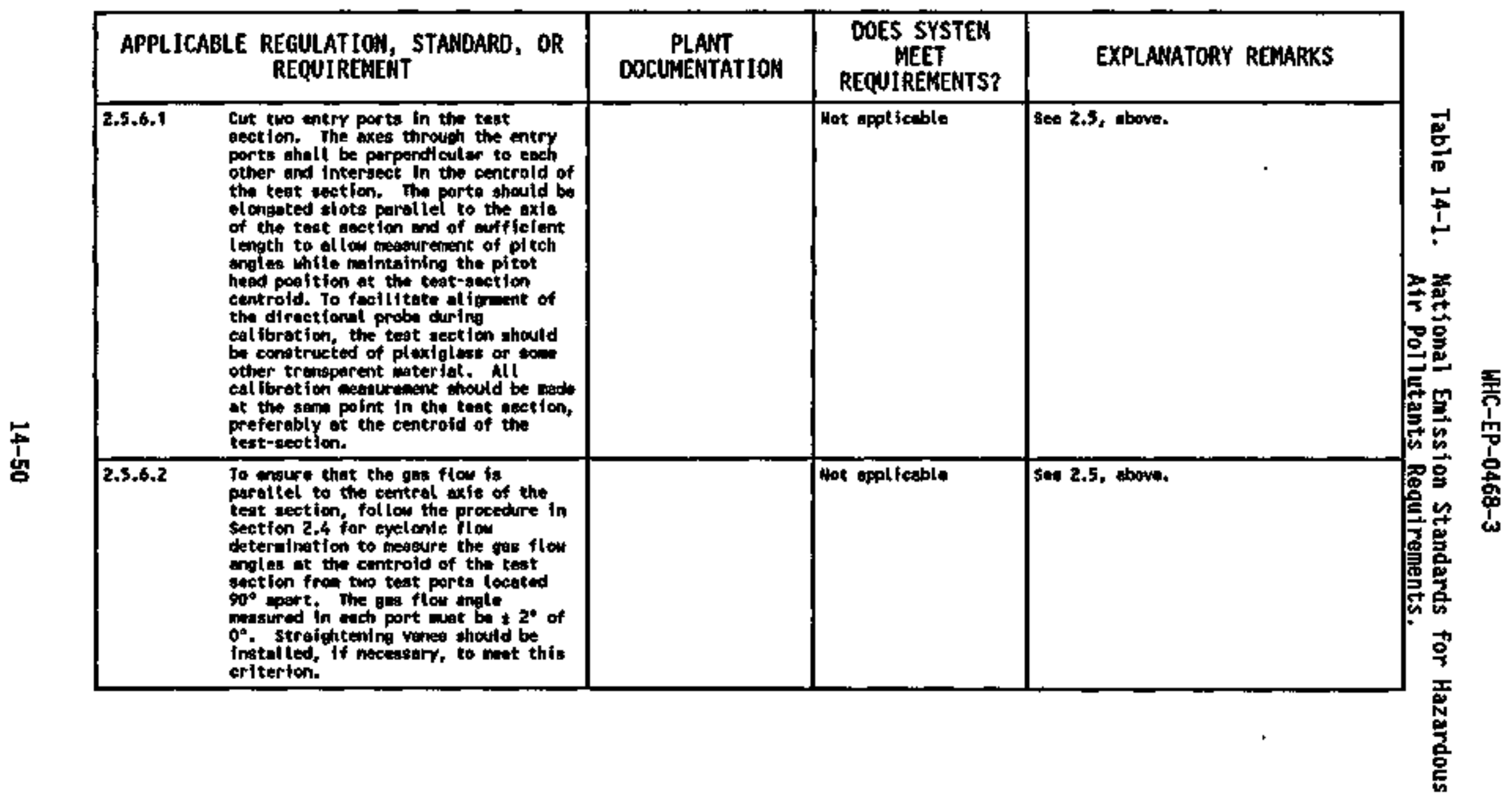




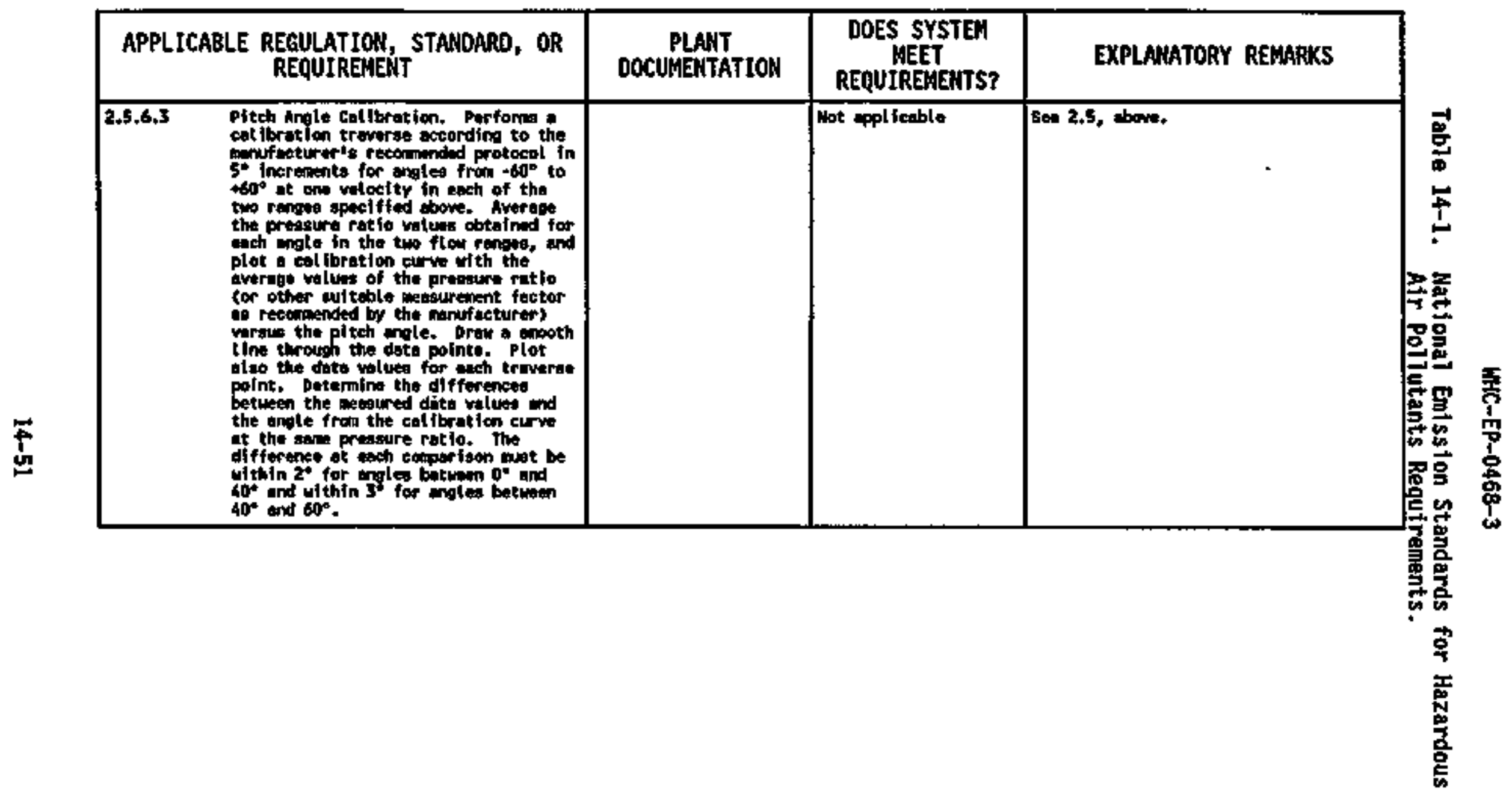




\begin{tabular}{|c|c|c|c|}
\hline $\begin{array}{l}\text { APPLICABLE REGULATION, STANDARD, OR } \\
\text { REQUUTREMENT }\end{array}$ & \multirow[t]{2}{*}{$\begin{array}{l}\text { PLAMT } \\
\text { DOCUMENTATION }\end{array}$} & \multirow{2}{*}{$\begin{array}{c}\text { DOES SYSTEM } \\
\text { HEET } \\
\text { REQUIREMENTS? } \\
\text { oot sppl t cobte }\end{array}$} & \multirow{2}{*}{\begin{tabular}{|l|} 
EXPLANATORY REMARKS \\
3et 2.5, above.
\end{tabular}} \\
\hline 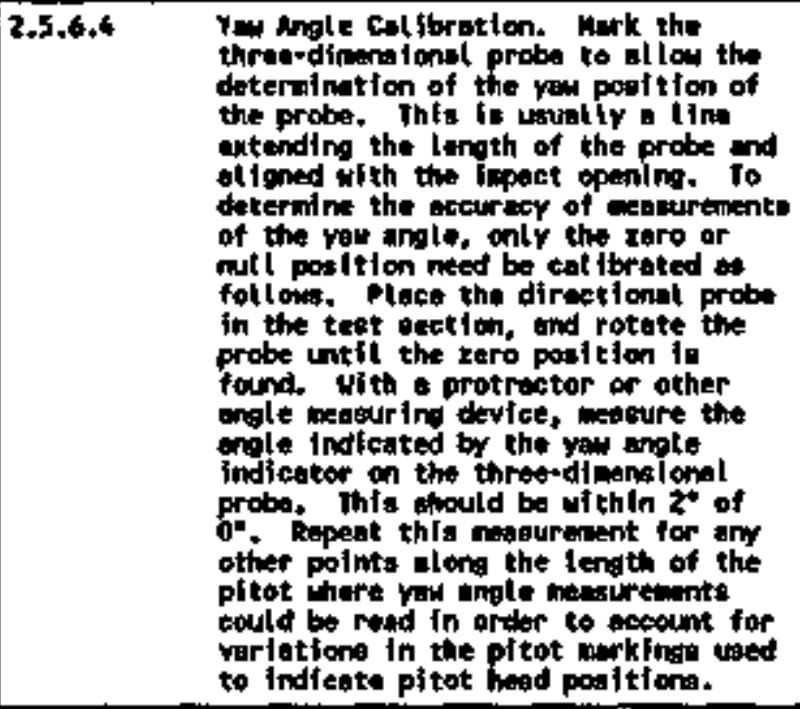 & & & \\
\hline 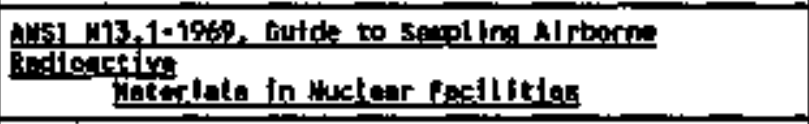 & & & \\
\hline 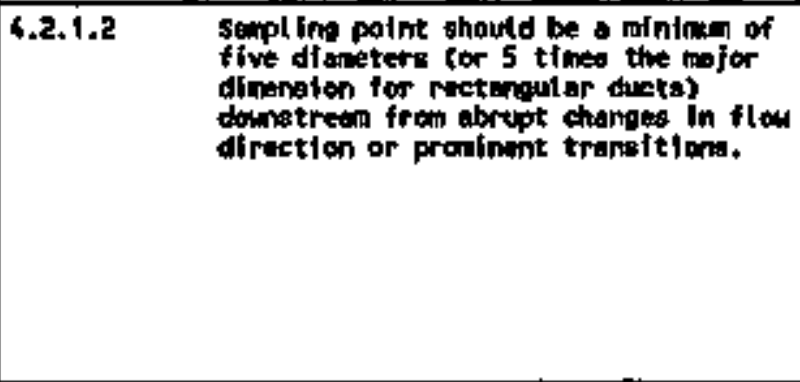 & 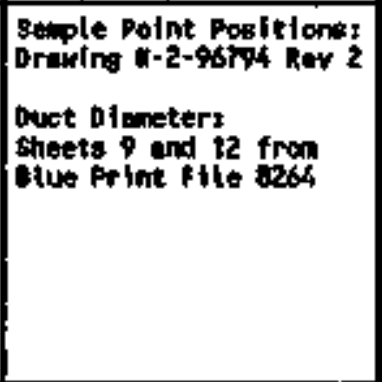 & Yes & 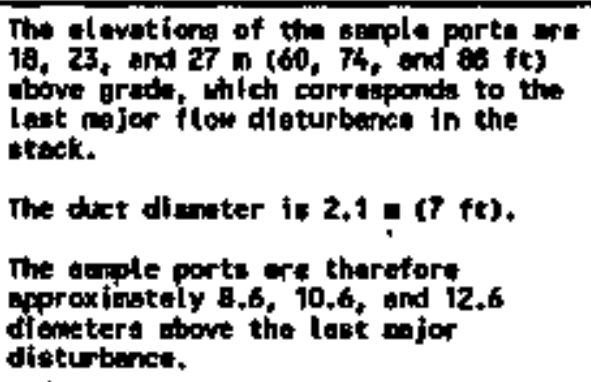 \\
\hline
\end{tabular}




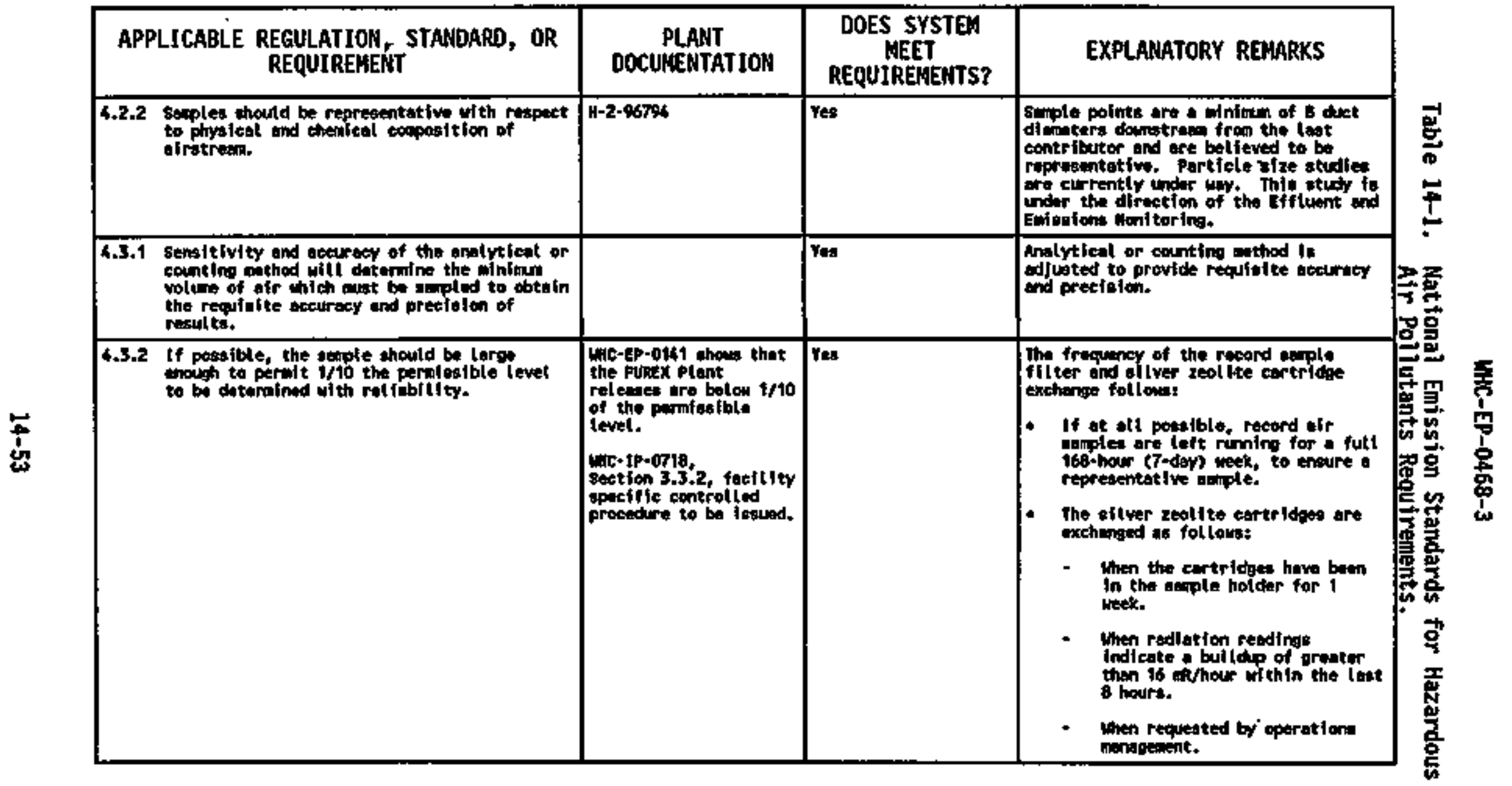




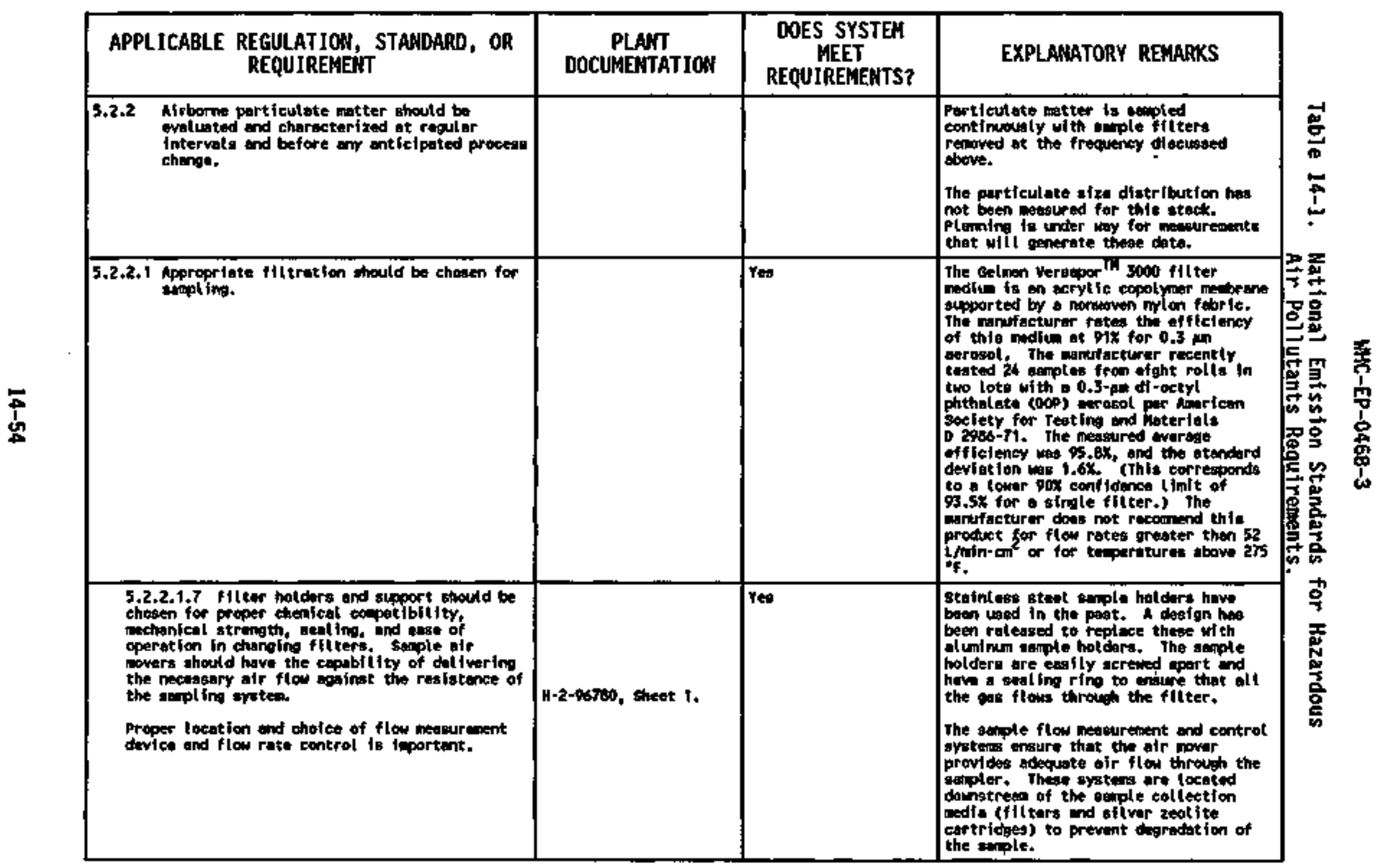




\begin{tabular}{|c|c|c|c|c|}
\hline \multicolumn{2}{|c|}{$\begin{array}{l}\text { APPLICABLE REGULATION, STAABARD, OR } \\
\text { REQUUIREHEMT }\end{array}$} & \multirow[t]{2}{*}{$\begin{array}{c}\text { PLANT } \\
\text { DOCUNENTATIOA }\end{array}$} & \multirow{2}{*}{$\begin{array}{l}\text { DOES SYSTEM } \\
\text { MEET } \\
\text { REQUIREMEHTS? } \\
\text { TES }\end{array}$} & \multirow[b]{2}{*}{ 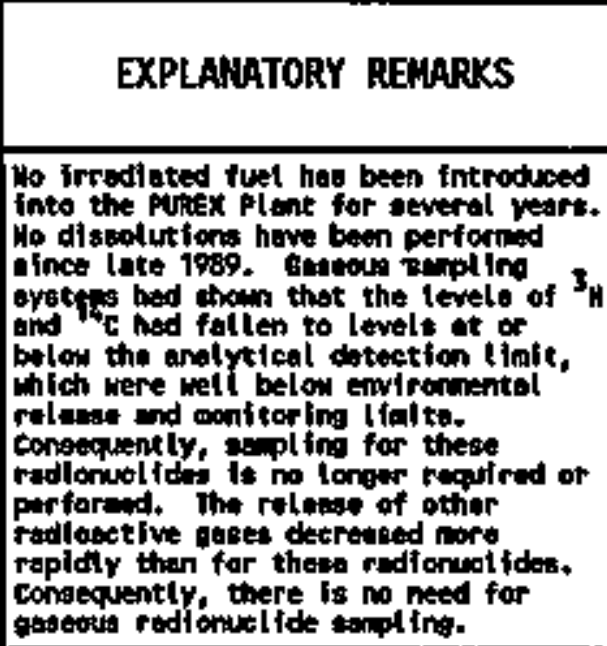 } \\
\hline 5,3 & 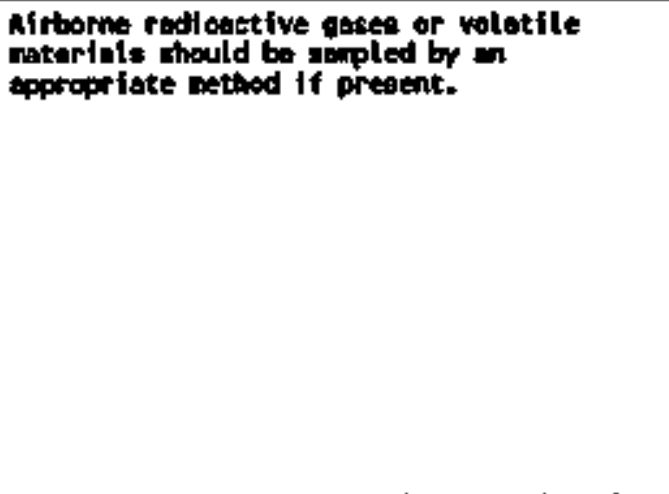 & & & \\
\hline A1. & 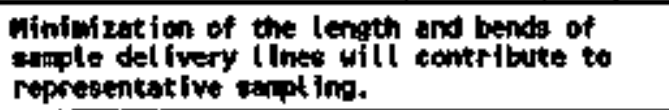 & & & (no response requested.) \\
\hline$A 3.1$ & 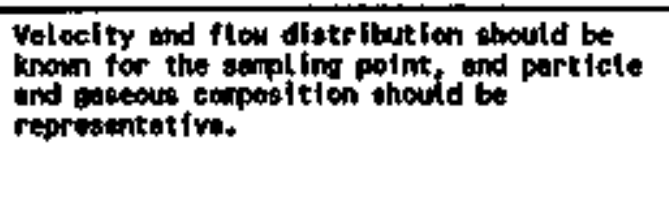 & 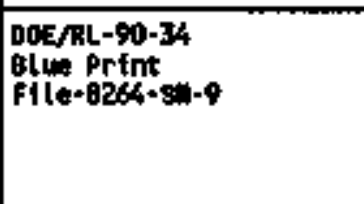 & res: & 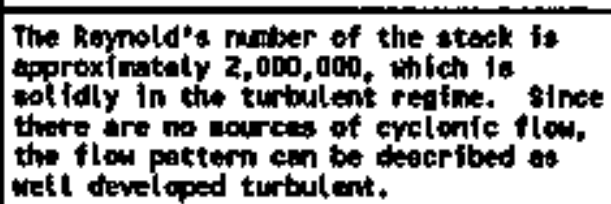 \\
\hline
\end{tabular}




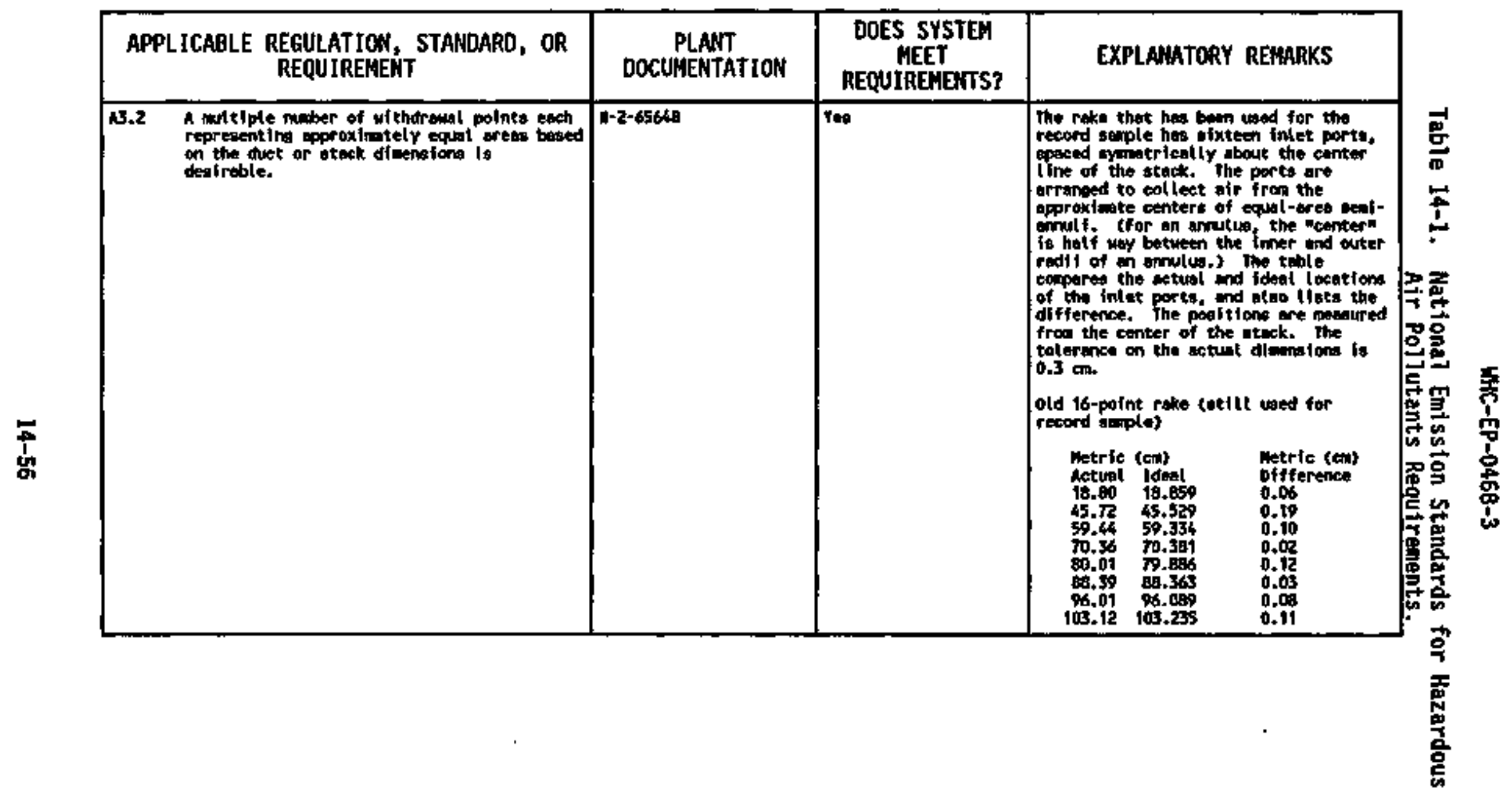




\begin{tabular}{|c|c|c|c|c|c|c|}
\hline APF & $\begin{array}{l}\text { LICABLE REGULATIOW, STAMDARD, OR } \\
\text { REQUIREMENT }\end{array}$ & $\begin{array}{l}\text { PLAAT } \\
\text { DOCLNEHTATIOA }\end{array}$ & $\begin{array}{l}\text { DOES SYSTEM } \\
\text { NEET } \\
\text { REQUIREMENTS? }\end{array}$ & \multirow{2}{*}{\multicolumn{3}{|c|}{ 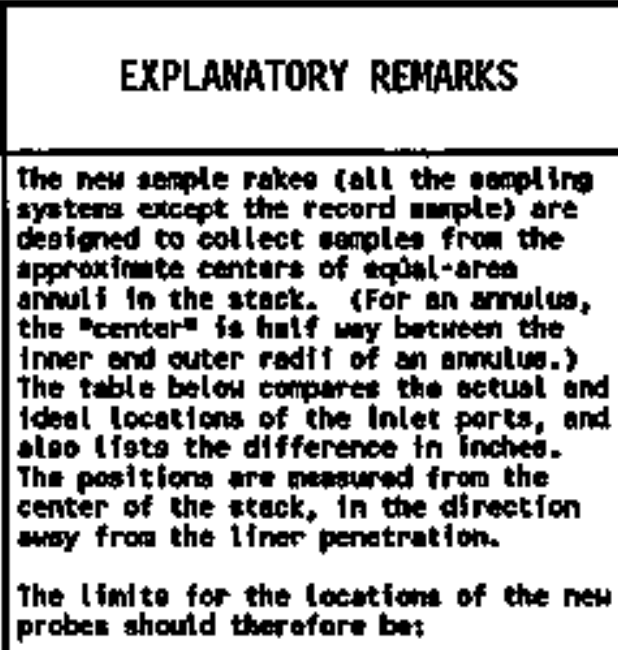 }} \\
\hline \multirow[t]{2}{*}{13.2} & \multirow[t]{2}{*}{ 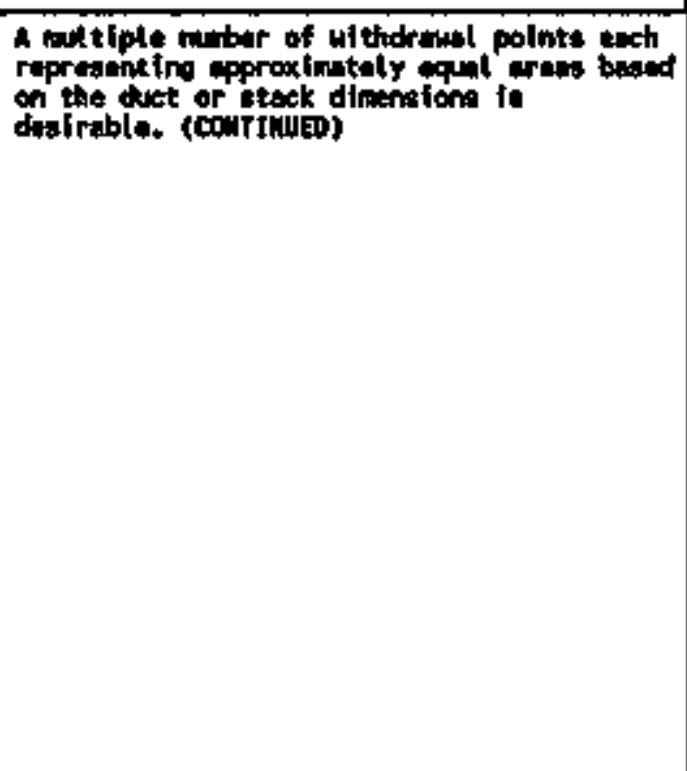 } & \multirow[t]{2}{*}{$\begin{array}{c}1-2-96792 \\
1-2-296793\end{array}$} & \multirow[t]{2}{*}{ res } & & & \\
\hline & & & & 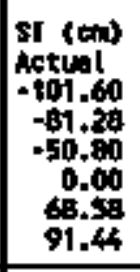 & 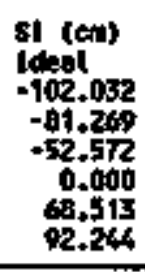 & 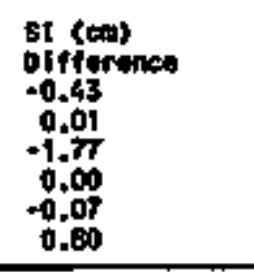 \\
\hline 13.3 & 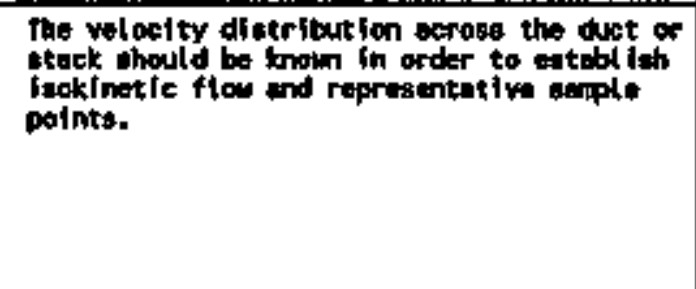 & 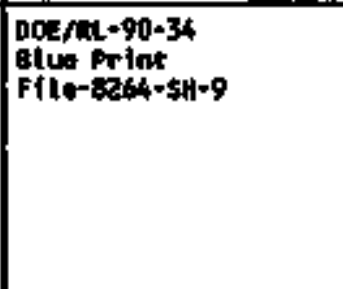 & Tes & \multicolumn{3}{|c|}{ 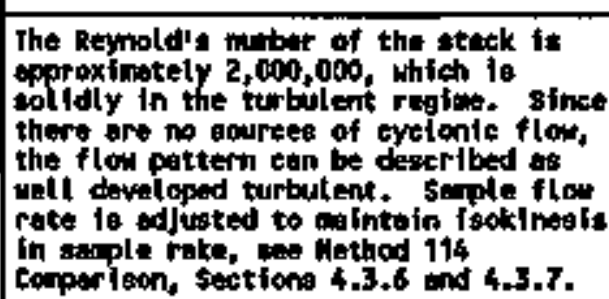 } \\
\hline
\end{tabular}




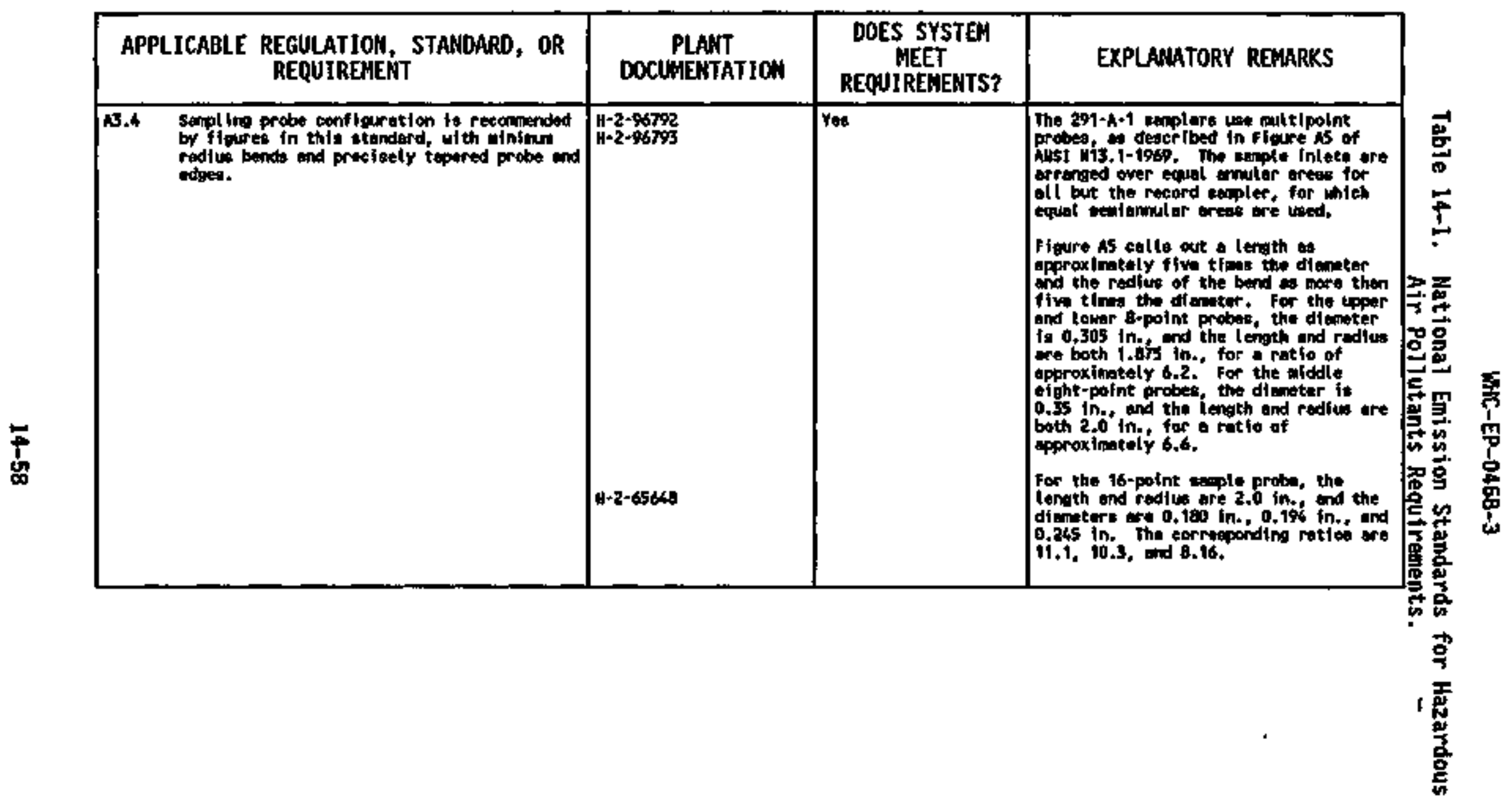




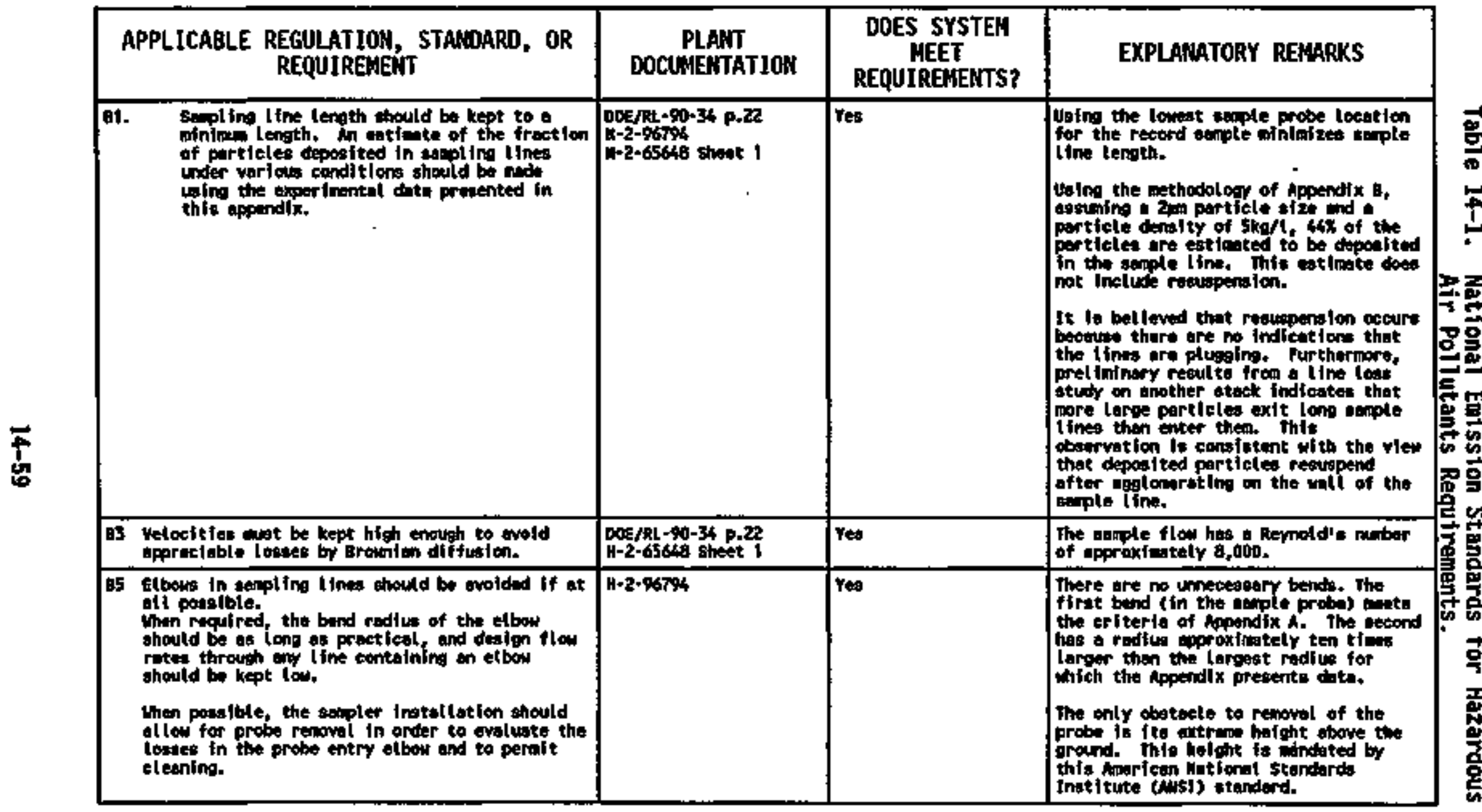




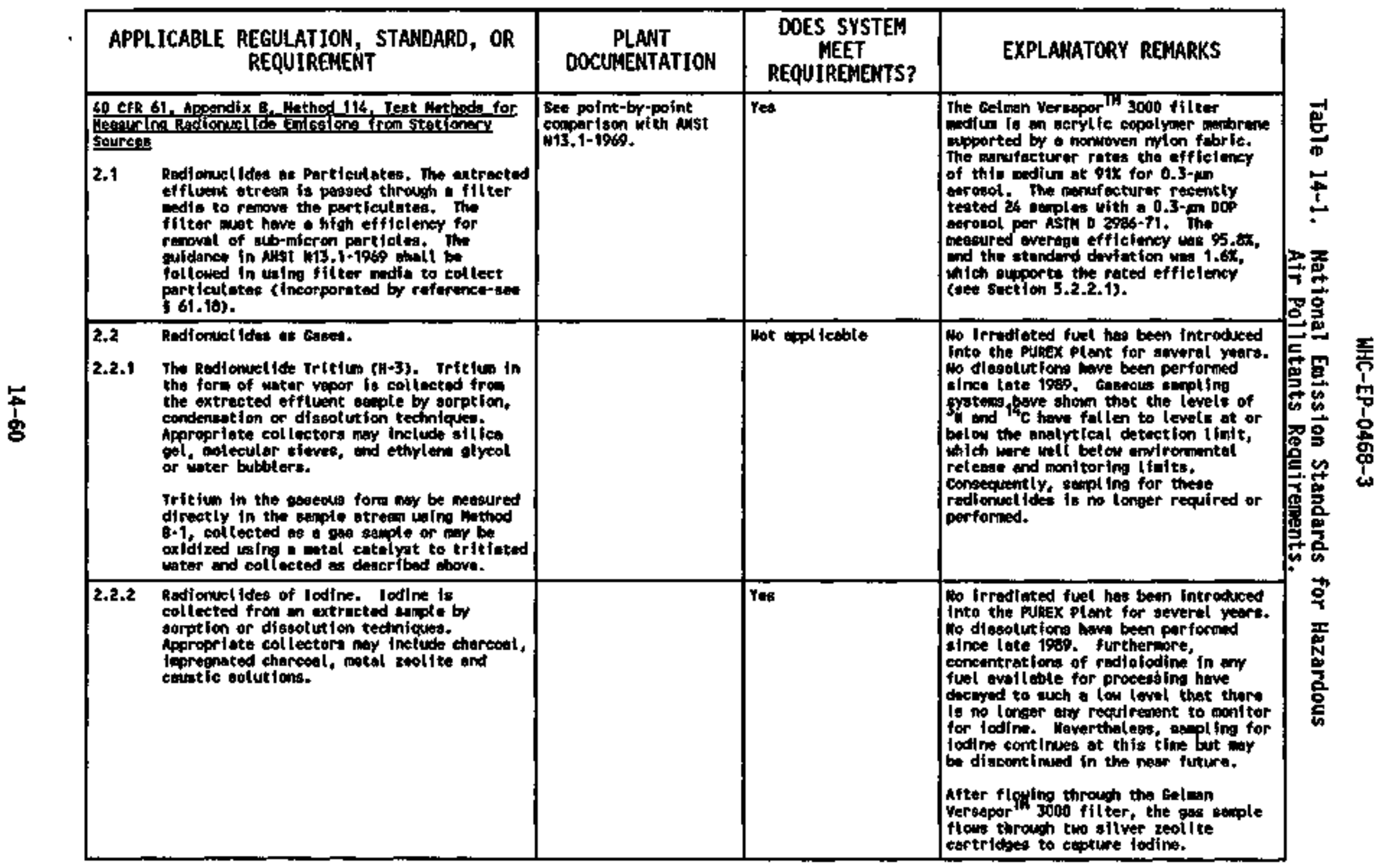




\begin{tabular}{|c|c|c|c|c|c|}
\hline \multicolumn{2}{|c|}{$\begin{array}{l}\text { APPLICABLE REGULATION, STAMDARD, OR } \\
\text { REQUIREMENT }\end{array}$} & $\begin{array}{c}\text { PLANT } \\
\text { DOCLWEATATION }\end{array}$ & $\begin{array}{l}\text { DOES SYSTEH } \\
\text { MEET } \\
\text { REQUIREMENTS? }\end{array}$ & EXPLANATORY REMARKS & \\
\hline 2.2 .3 & 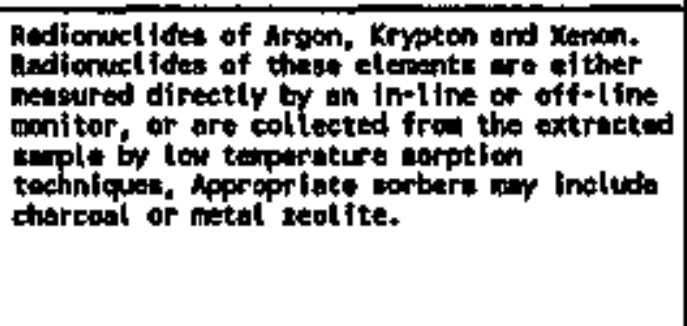 & & Hot applicesble & 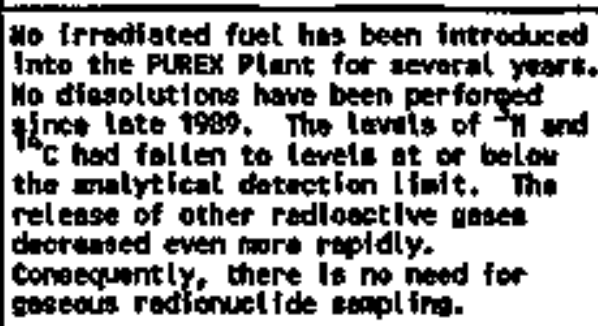 & \\
\hline 2.2 .4 & 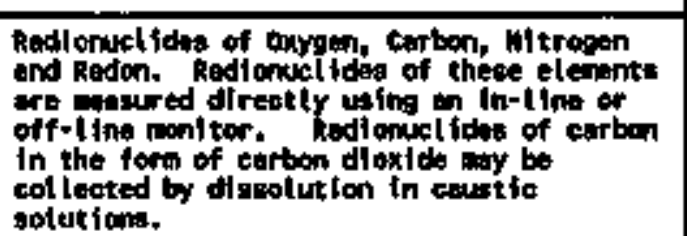 & & Hox appliceble & 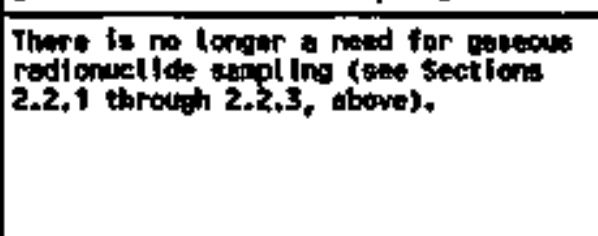 & $\Rightarrow=$ \\
\hline & - & & & . & 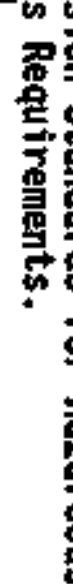 \\
\hline
\end{tabular}




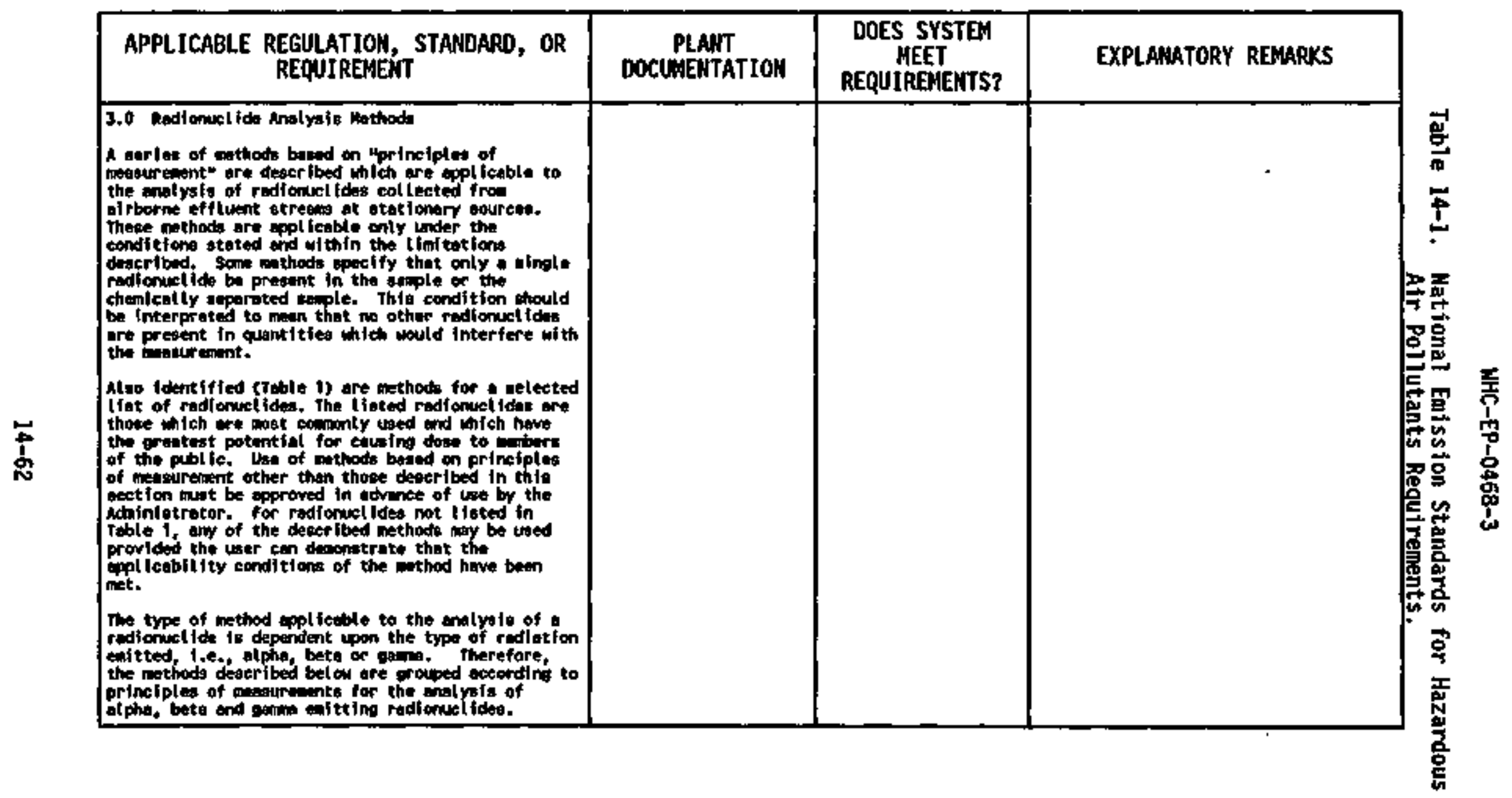




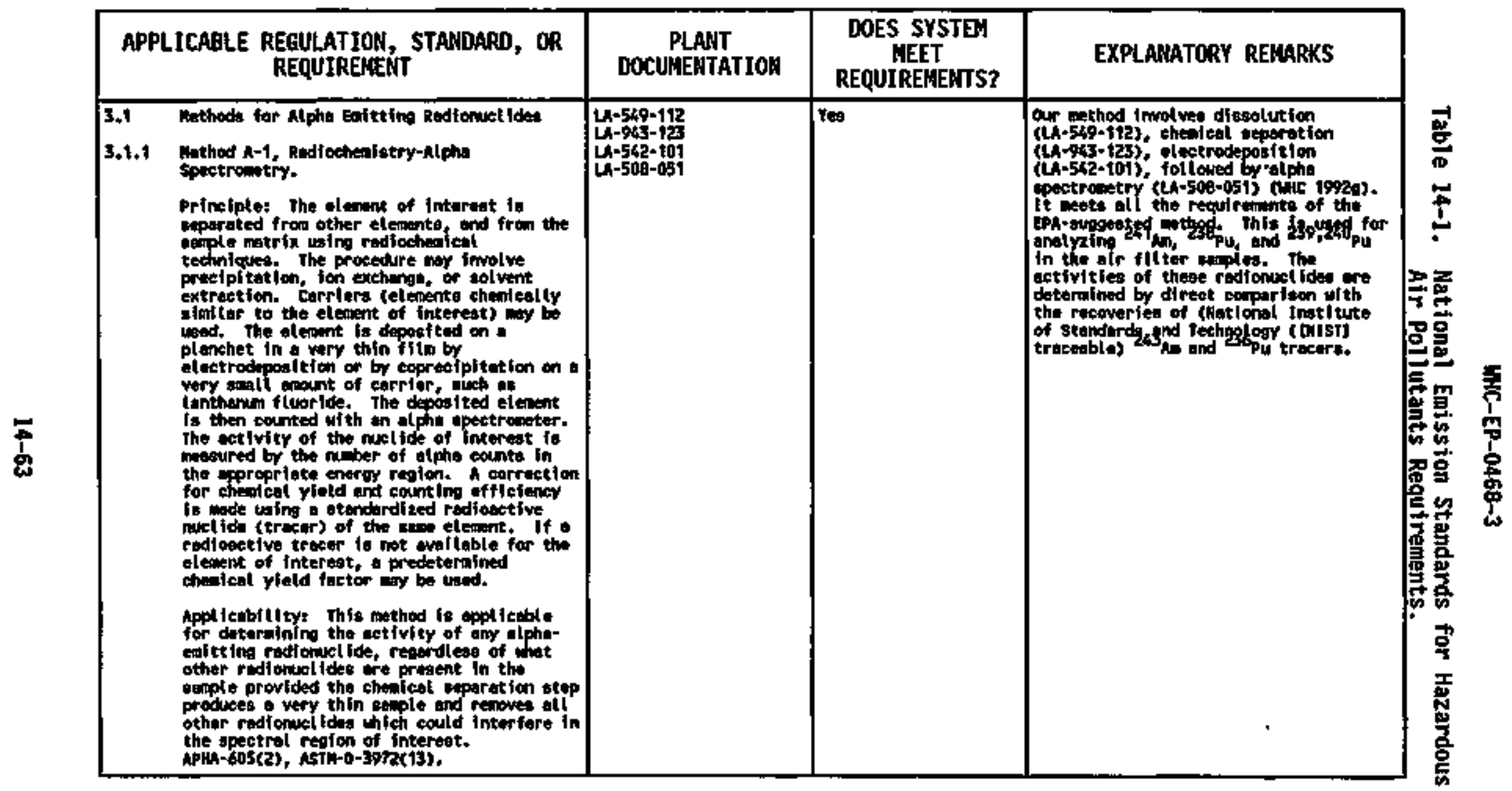




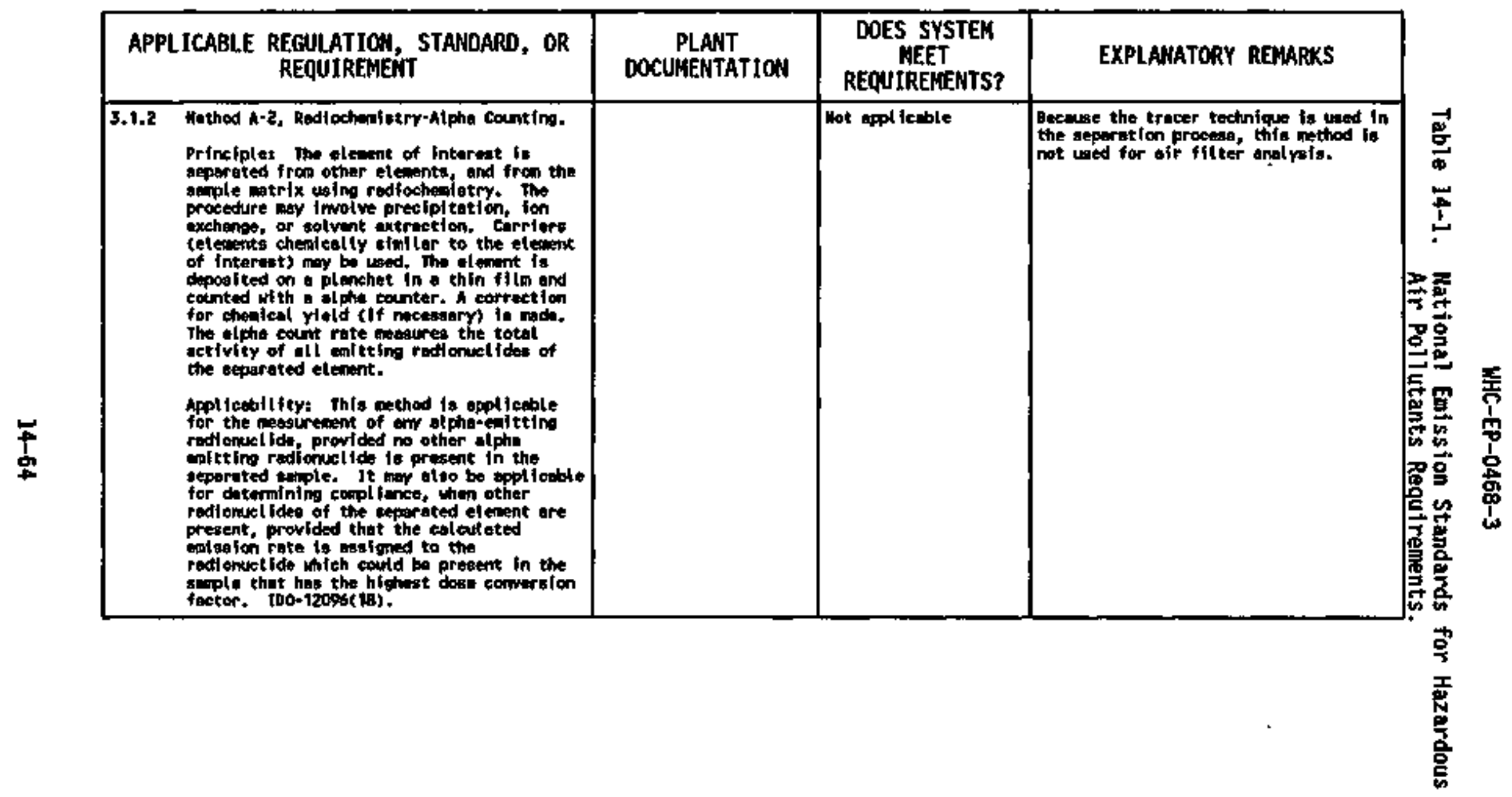




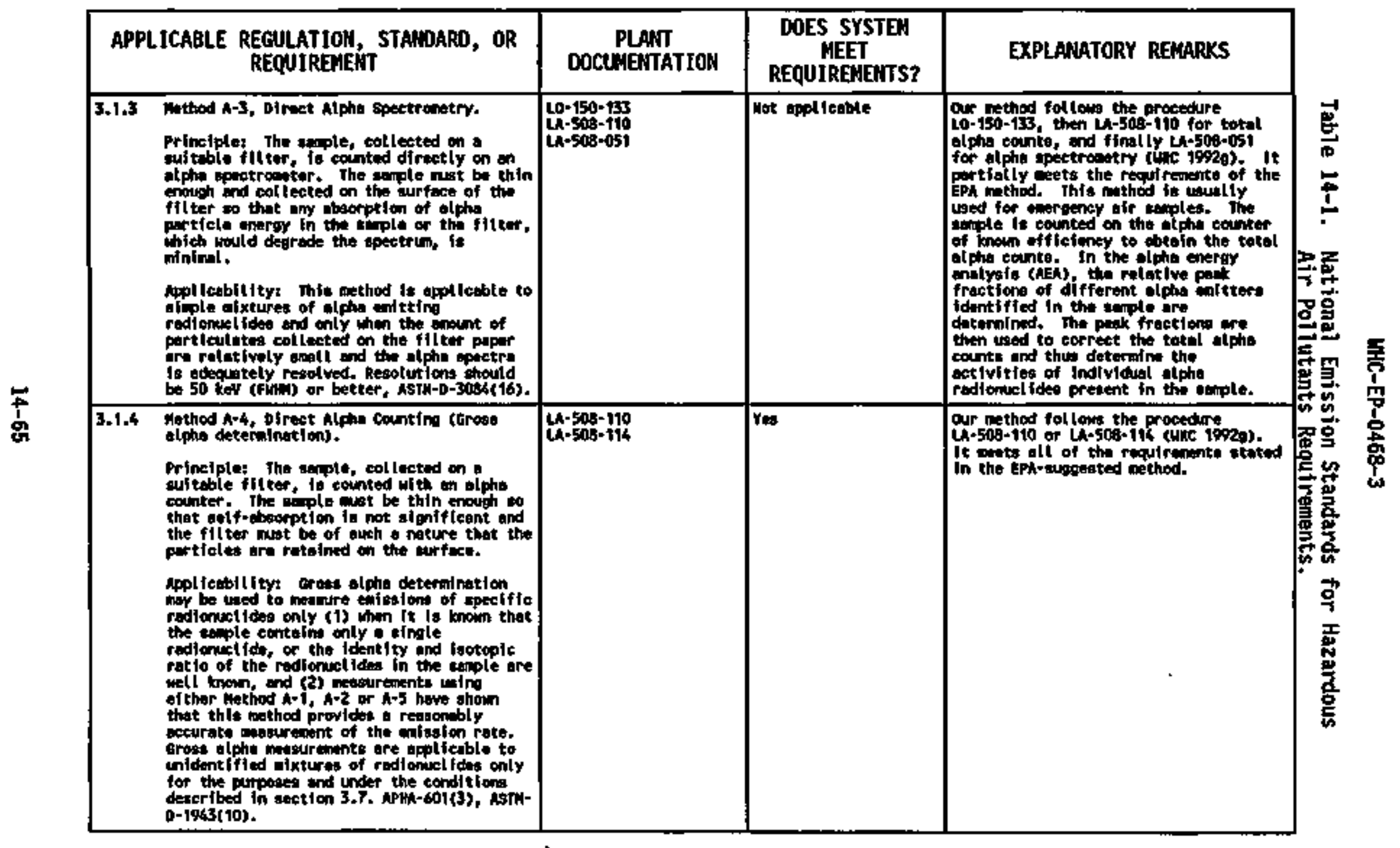




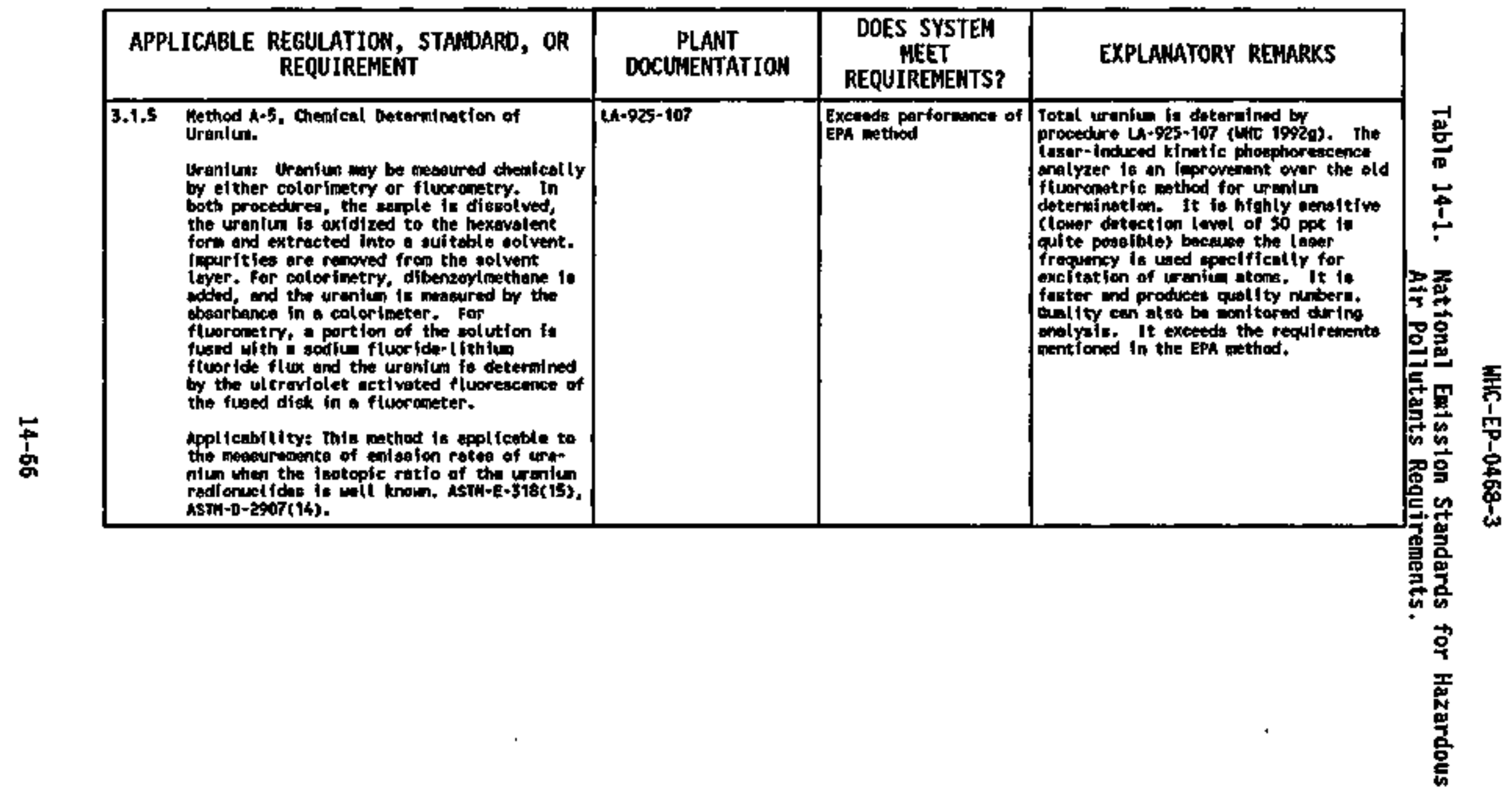




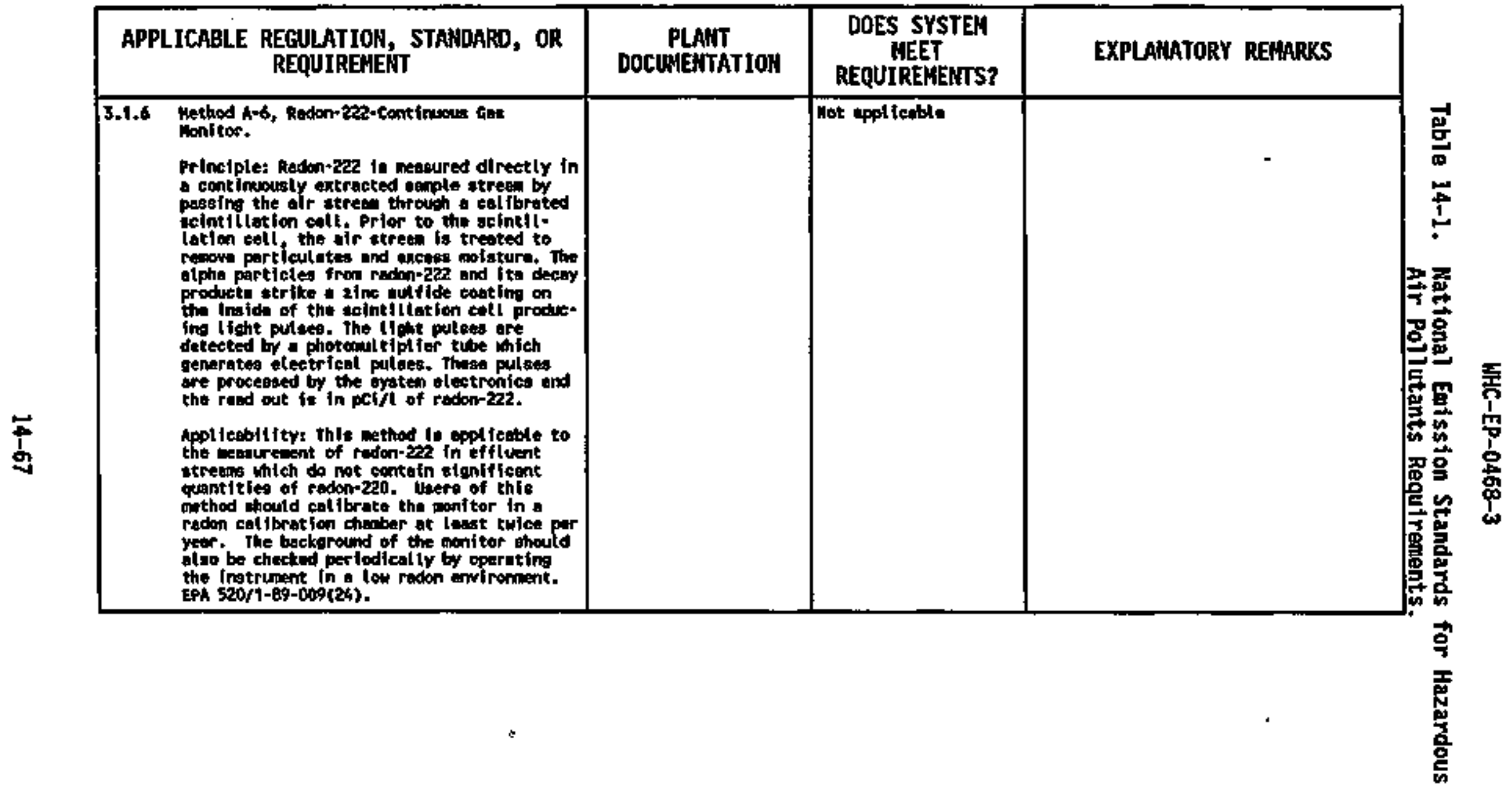




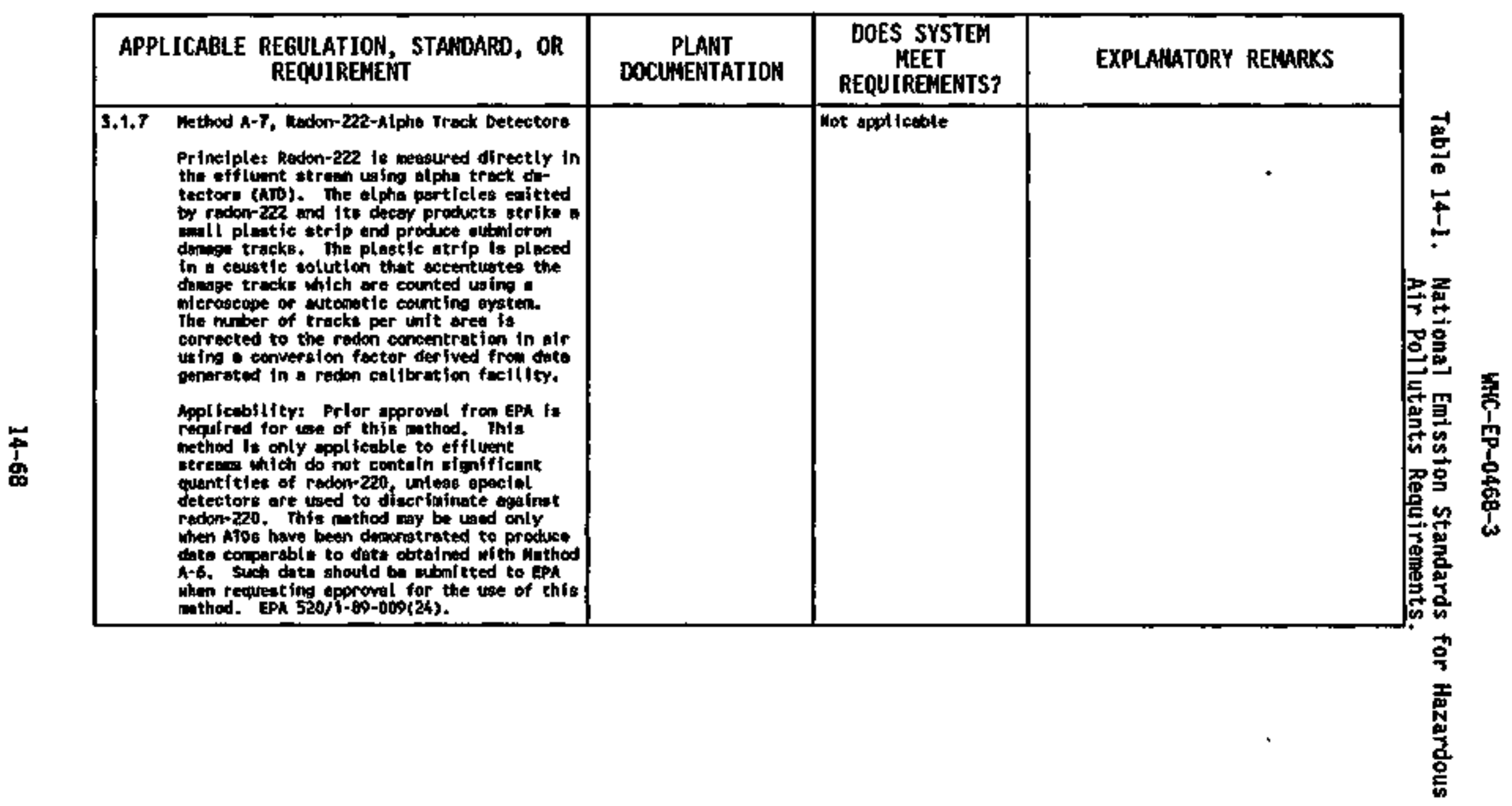




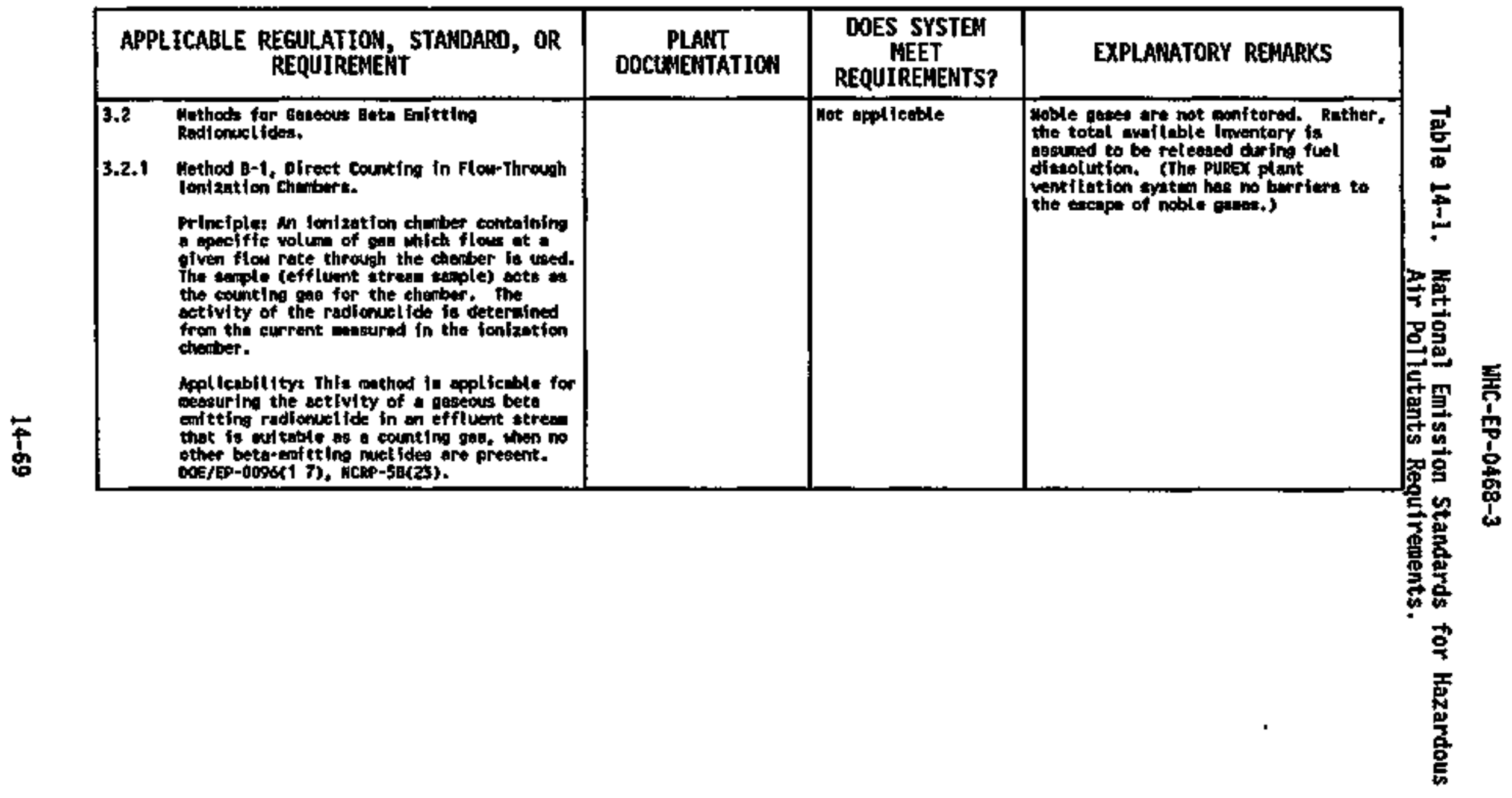




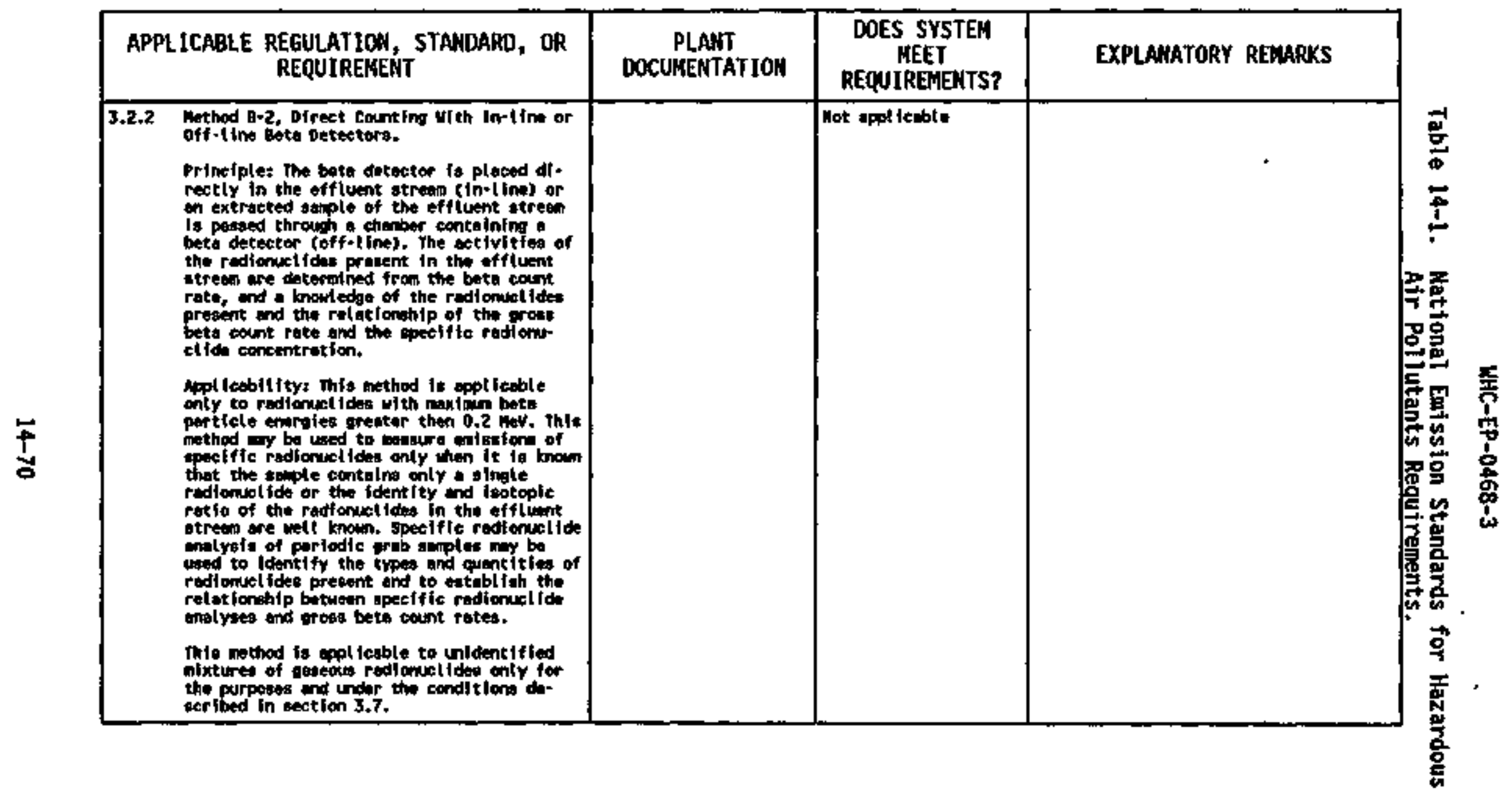




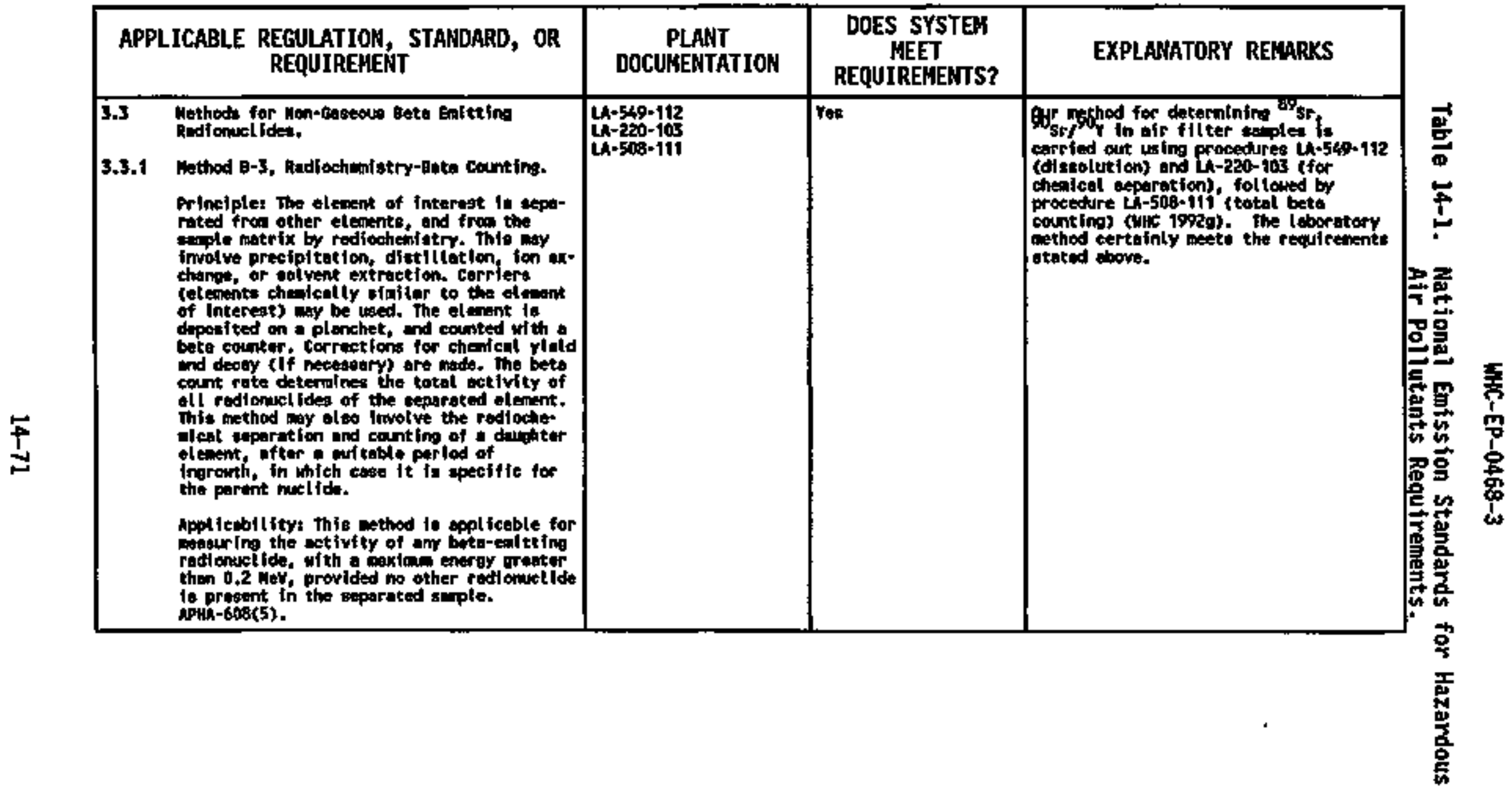




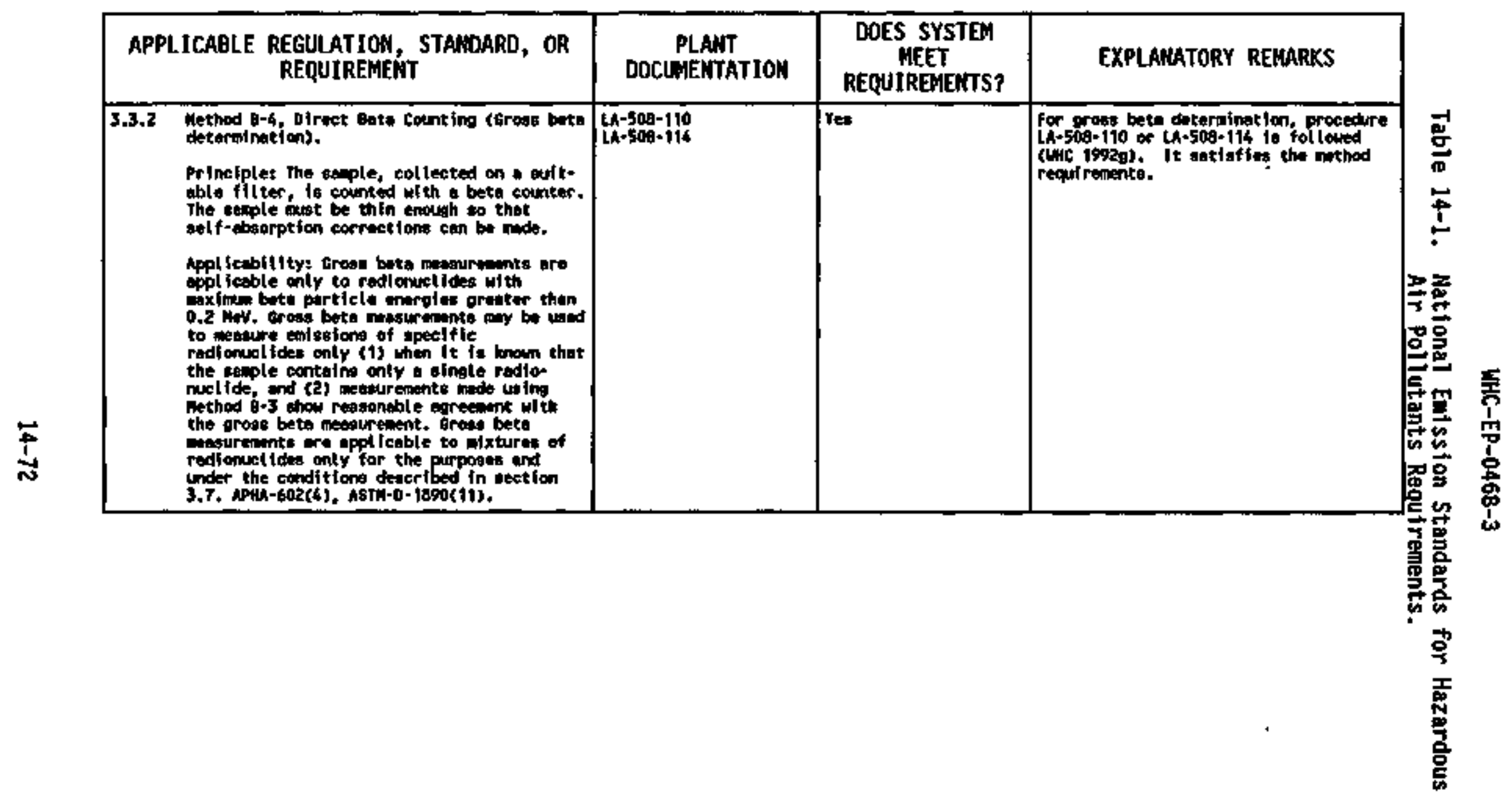




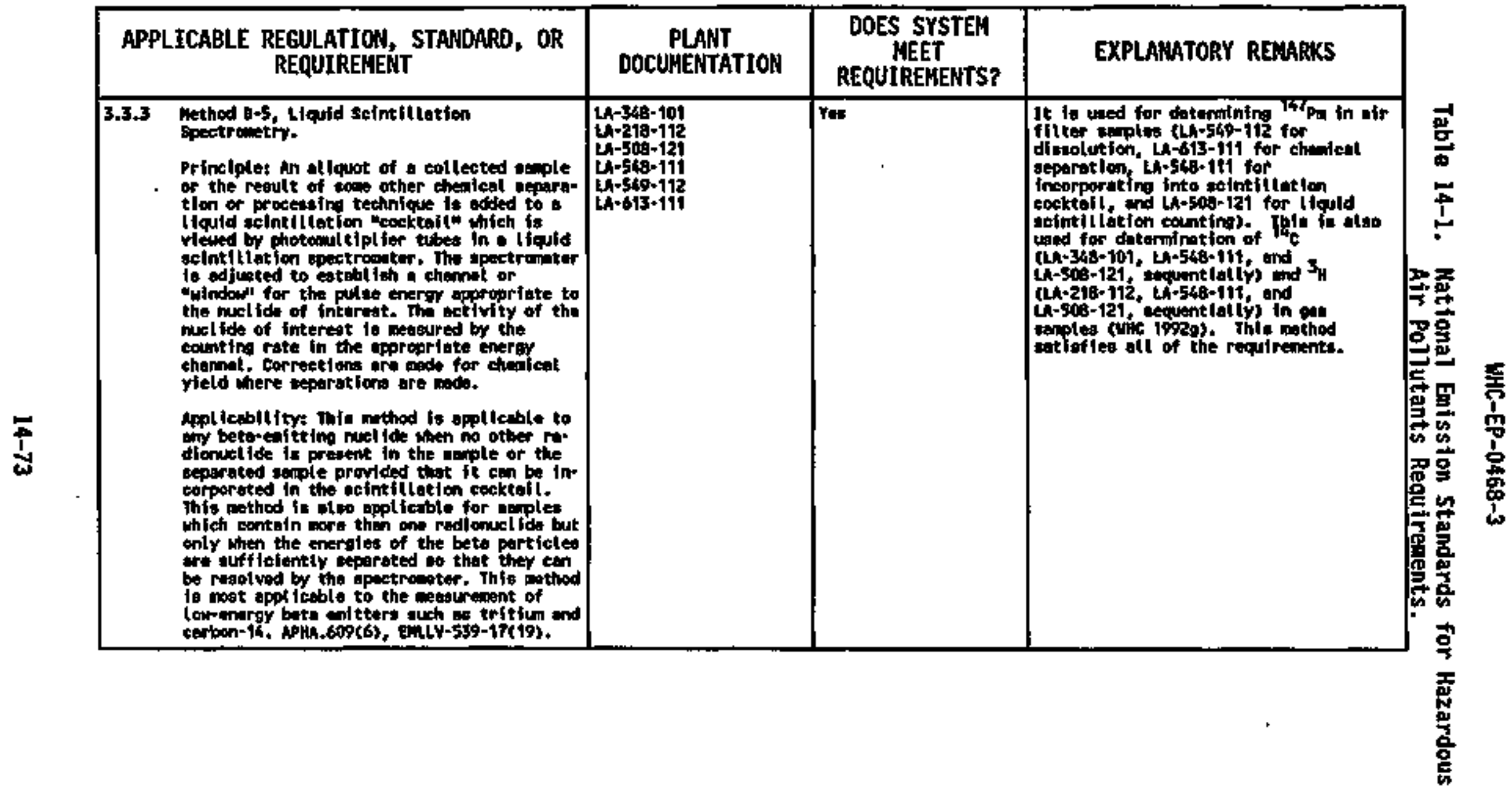




\begin{tabular}{|c|c|c|c|c|}
\hline \multicolumn{2}{|c|}{$\begin{array}{l}\text { APPLICABLE REGULATIOH, STAHOARO, OR } \\
\text { REQUIREMEKT }\end{array}$} & $\begin{array}{l}\text { PLANT } \\
\text { DOCUNAERTATIOH }\end{array}$ & $\begin{array}{l}\text { DOES SYSTEM } \\
\text { NEET } \\
\text { REQUIREMENTS? }\end{array}$ & EXPLAMATORY REMARKS \\
\hline $\begin{array}{l}3.4 \\
3.4 .4\end{array}$ & 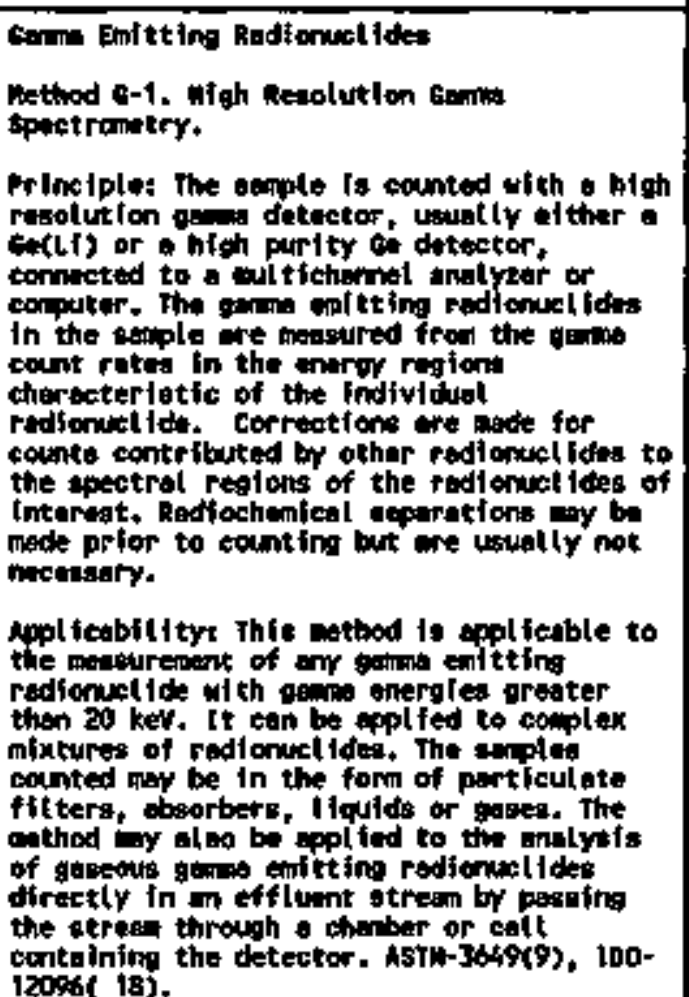 & LA-500-052 & Treg & 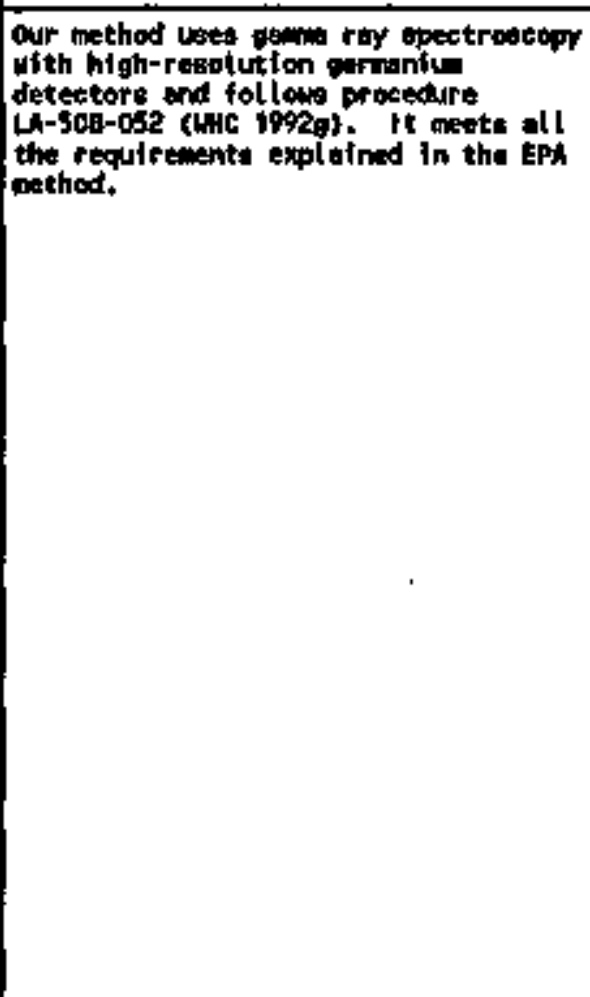 \\
\hline
\end{tabular}




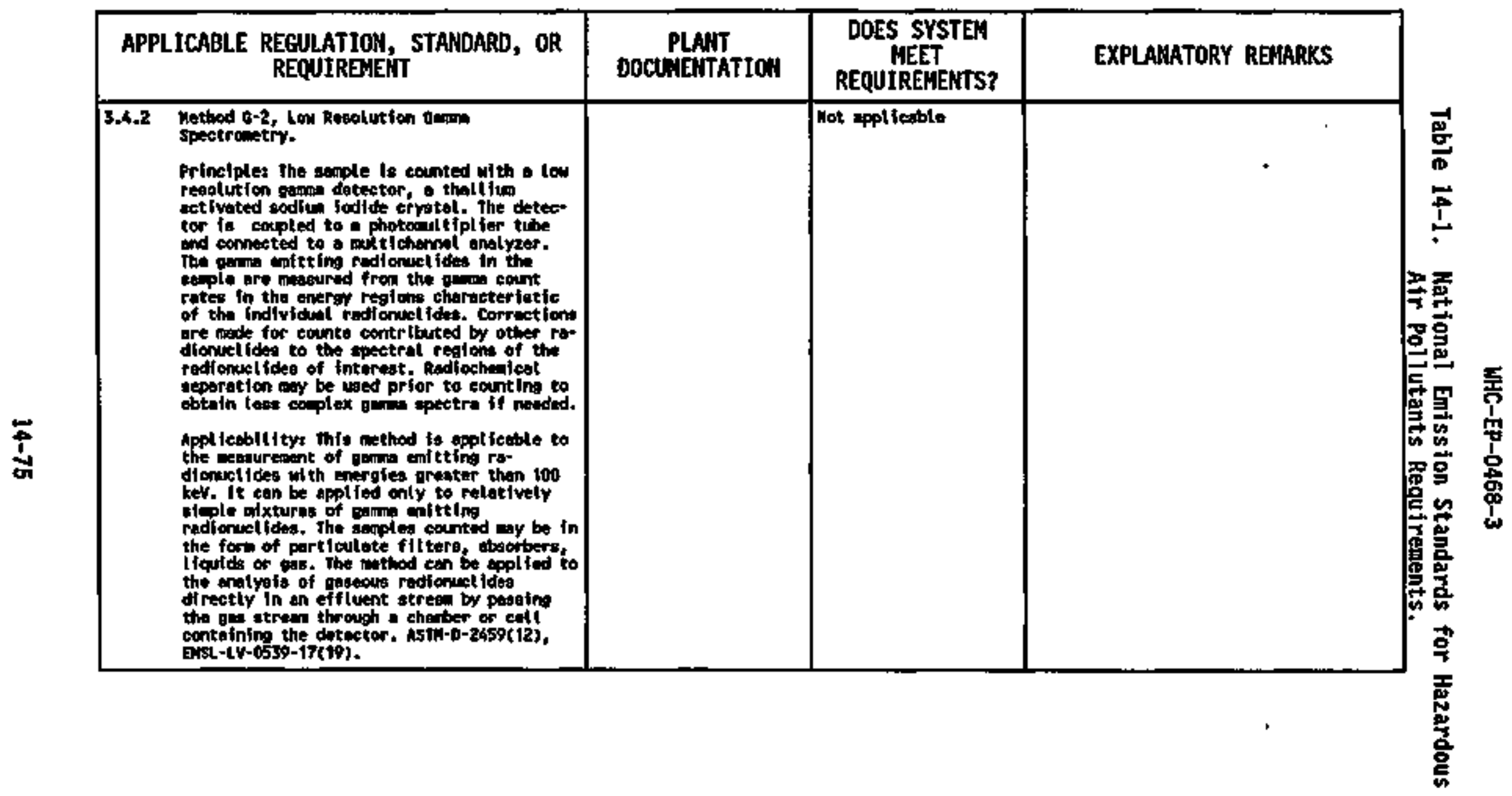




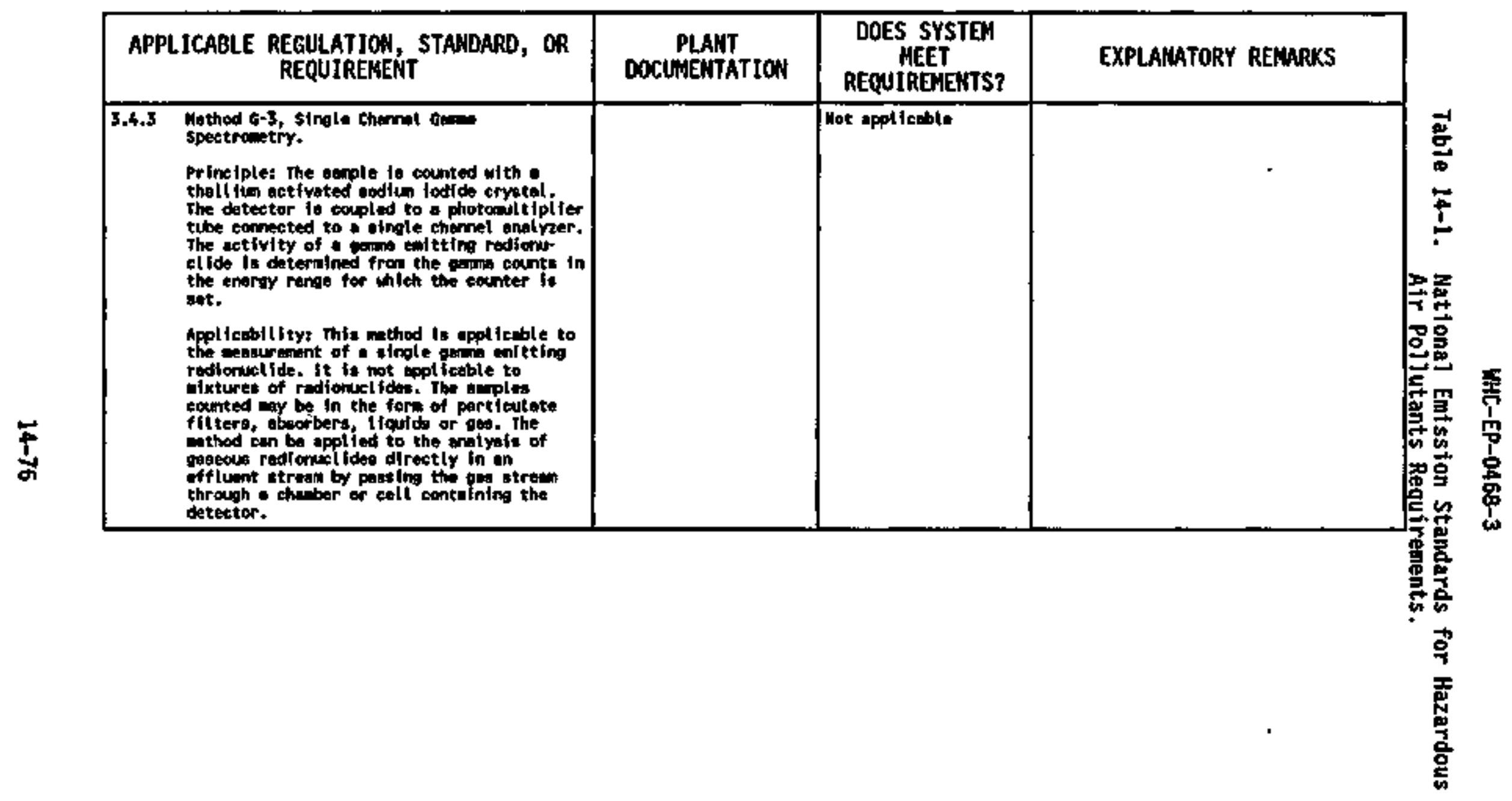




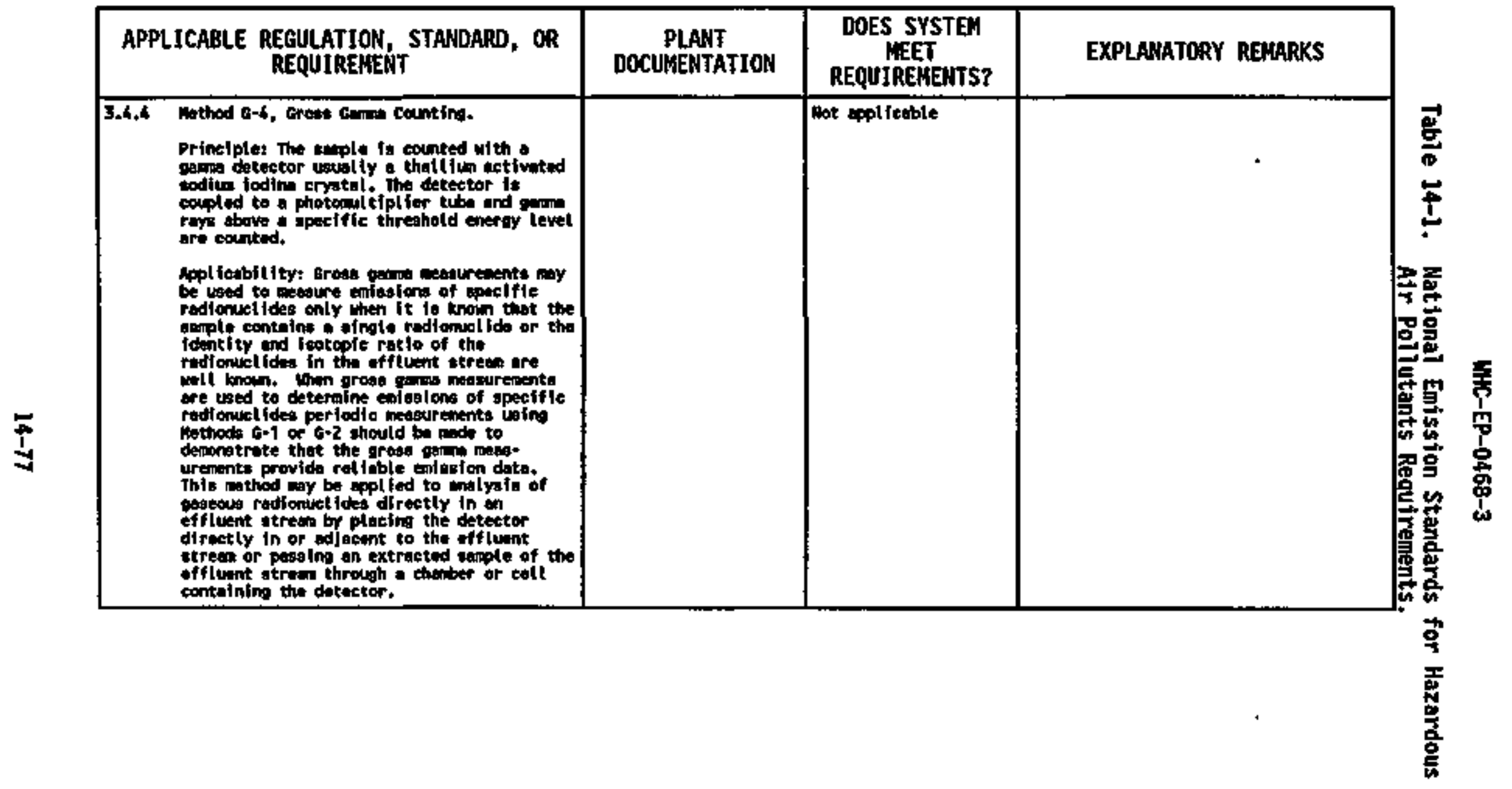




\begin{tabular}{|c|c|c|c|c|}
\hline \multicolumn{2}{|c|}{$\begin{array}{l}\text { APPLICABLE REGULATION, STANDARD, OR } \\
\text { REQUIRENENT }\end{array}$} & \multirow[t]{2}{*}{$\begin{array}{l}\text { PLANT } \\
\text { DOCUHENTATIOH }\end{array}$} & \multirow{2}{*}{$\begin{array}{c}\text { DOES SYSTEM } \\
\text { MEET } \\
\text { REQUIREHENTS? }\end{array}$} & \multirow{2}{*}{ 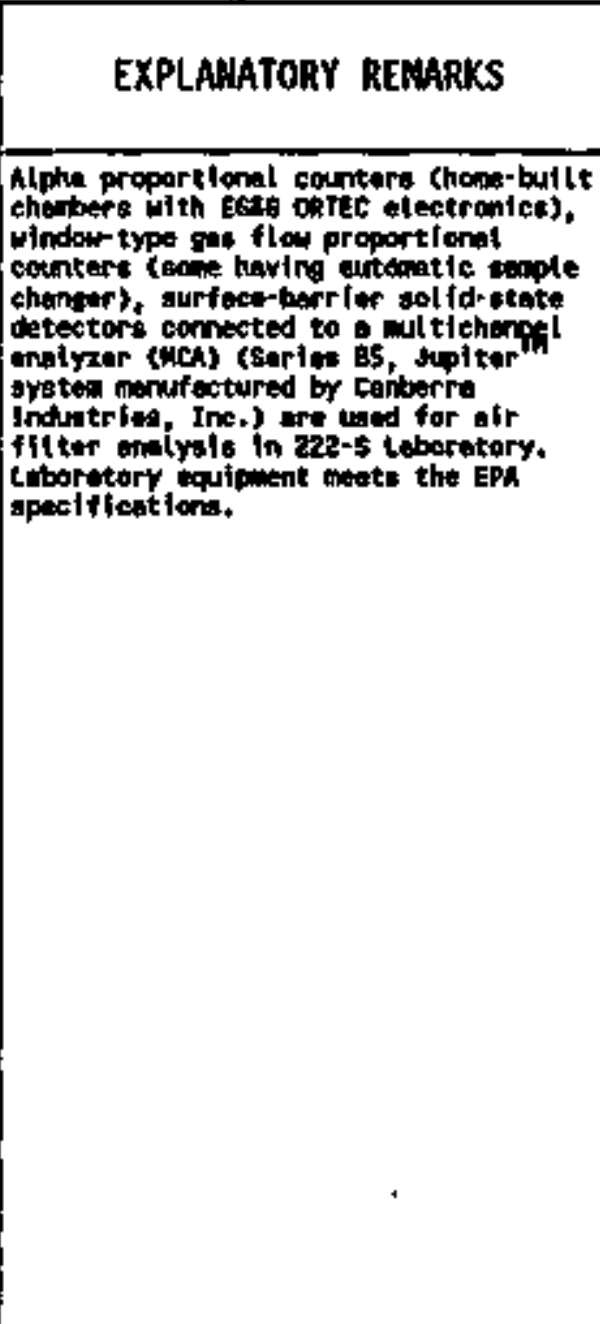 } \\
\hline 3.5 .1 & 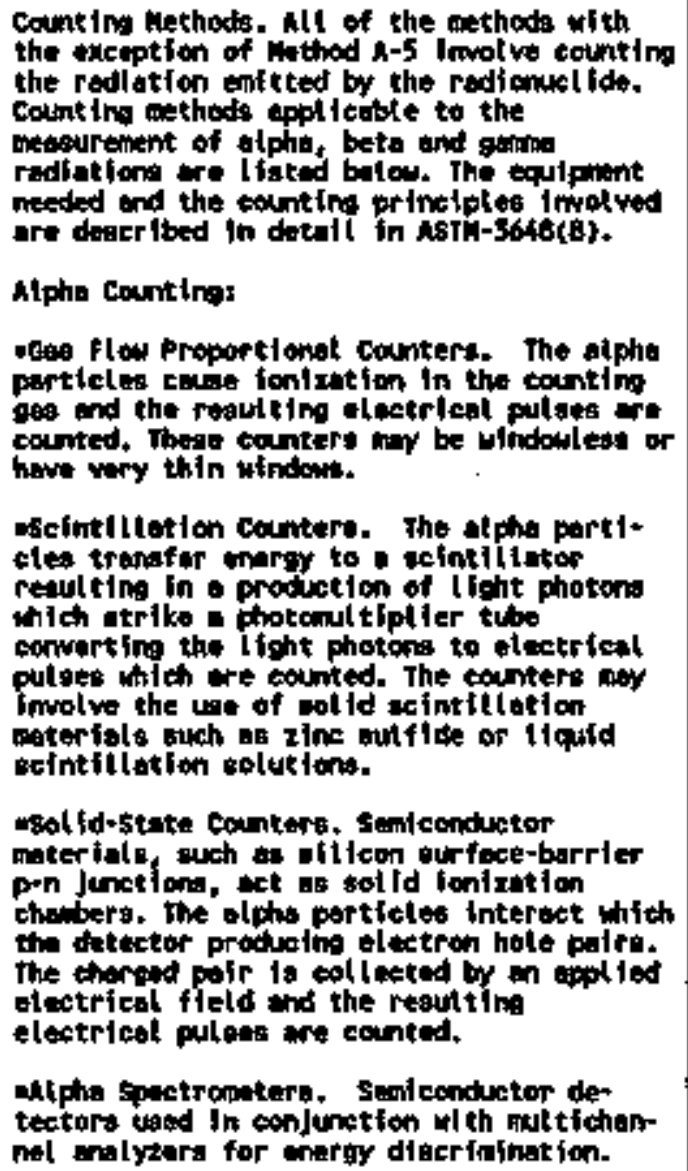 & & & \\
\hline
\end{tabular}




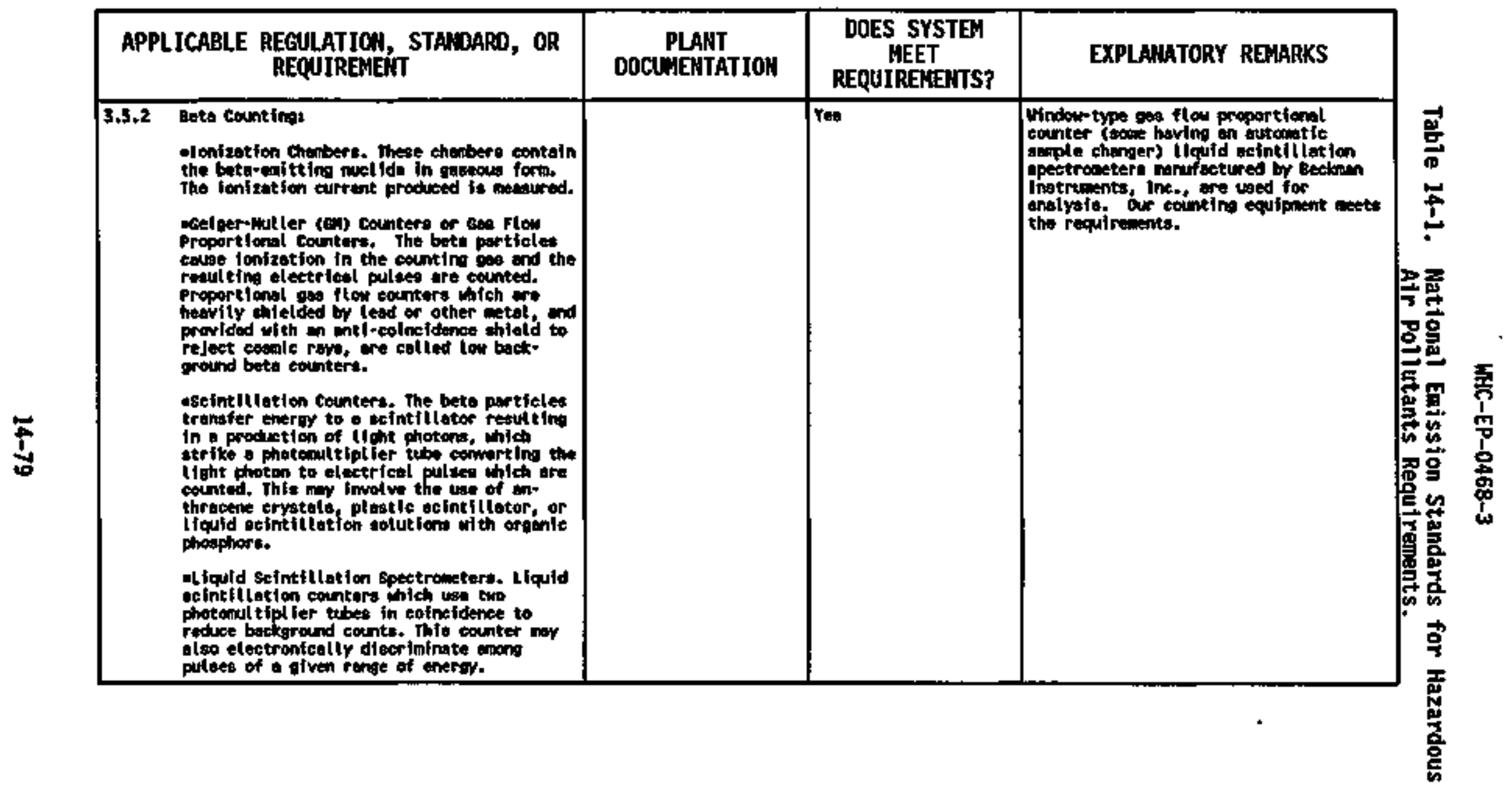




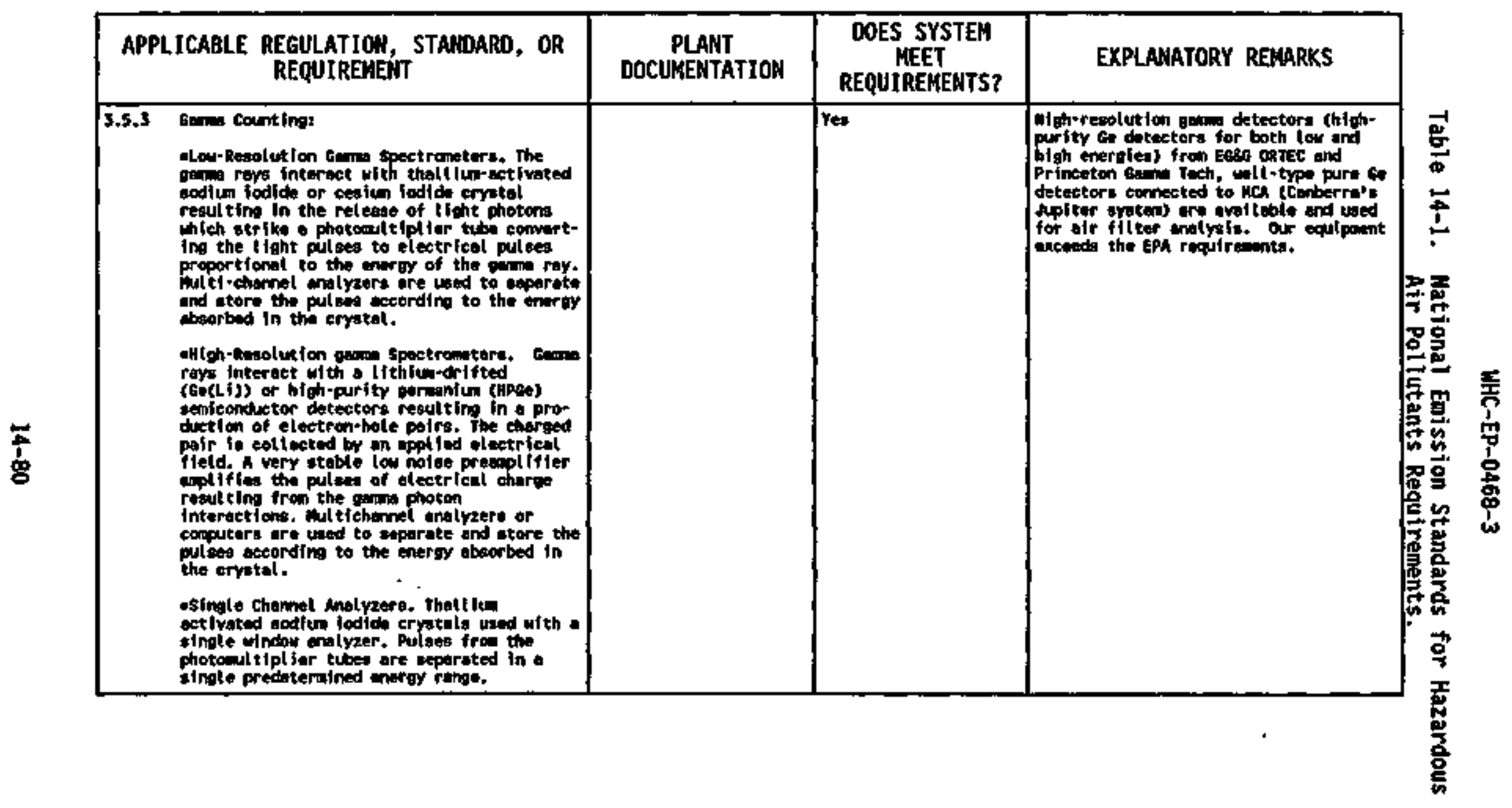




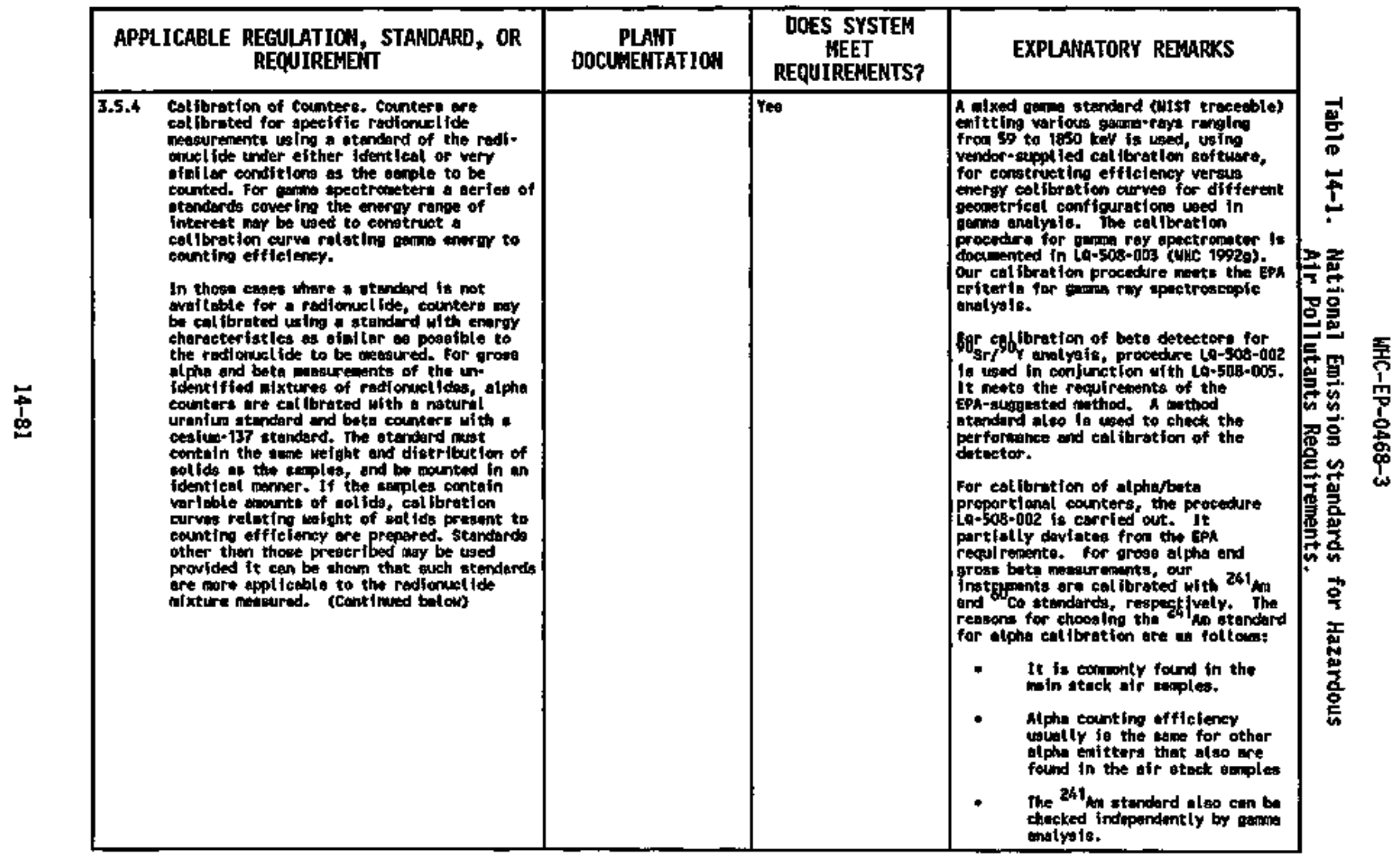




\begin{tabular}{|c|c|c|c|}
\hline $\begin{array}{l}\text { APPLICABLE REGULATJOW, STAHIOARD, OR } \\
\text { REQUIREKENT }\end{array}$ & $\begin{array}{c}\text { PLANT } \\
\text { DOCUMENTATION }\end{array}$ & $\begin{array}{l}\text { DOES SYSTEM } \\
\text { MEET } \\
\text { REQUIREMENTS? }\end{array}$ & EXPLAHATORY REMARKS \\
\hline 3.5.4. (Continued) & & res & 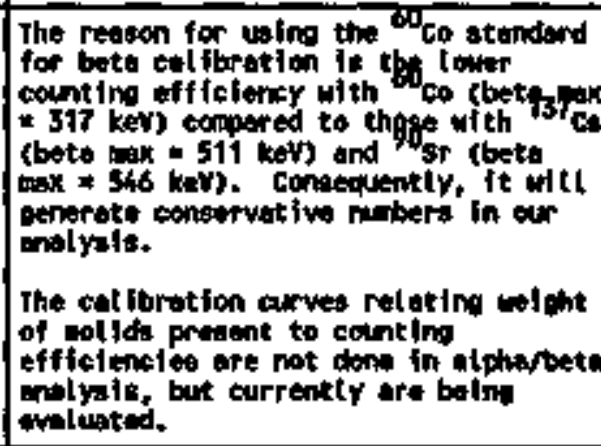 \\
\hline 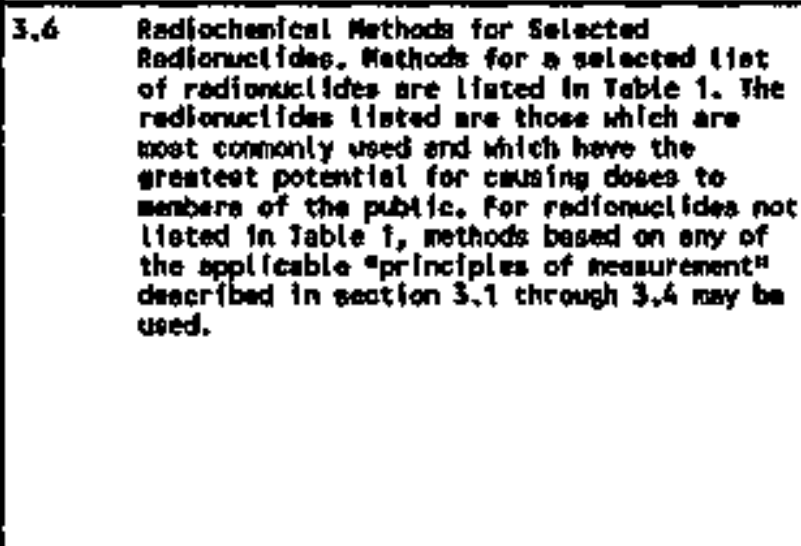 & & ress & 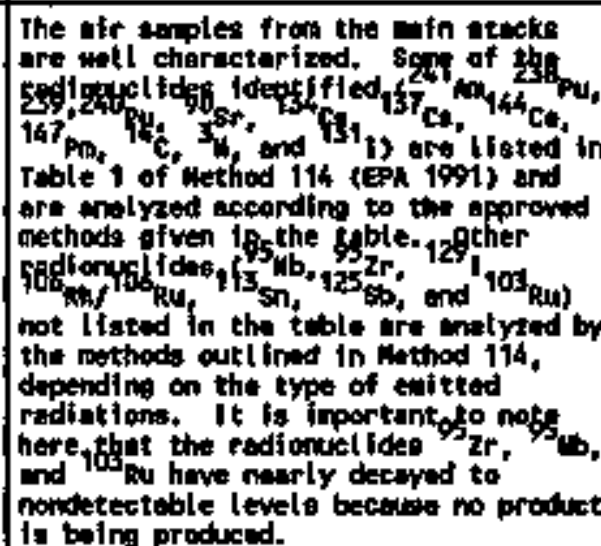 \\
\hline
\end{tabular}




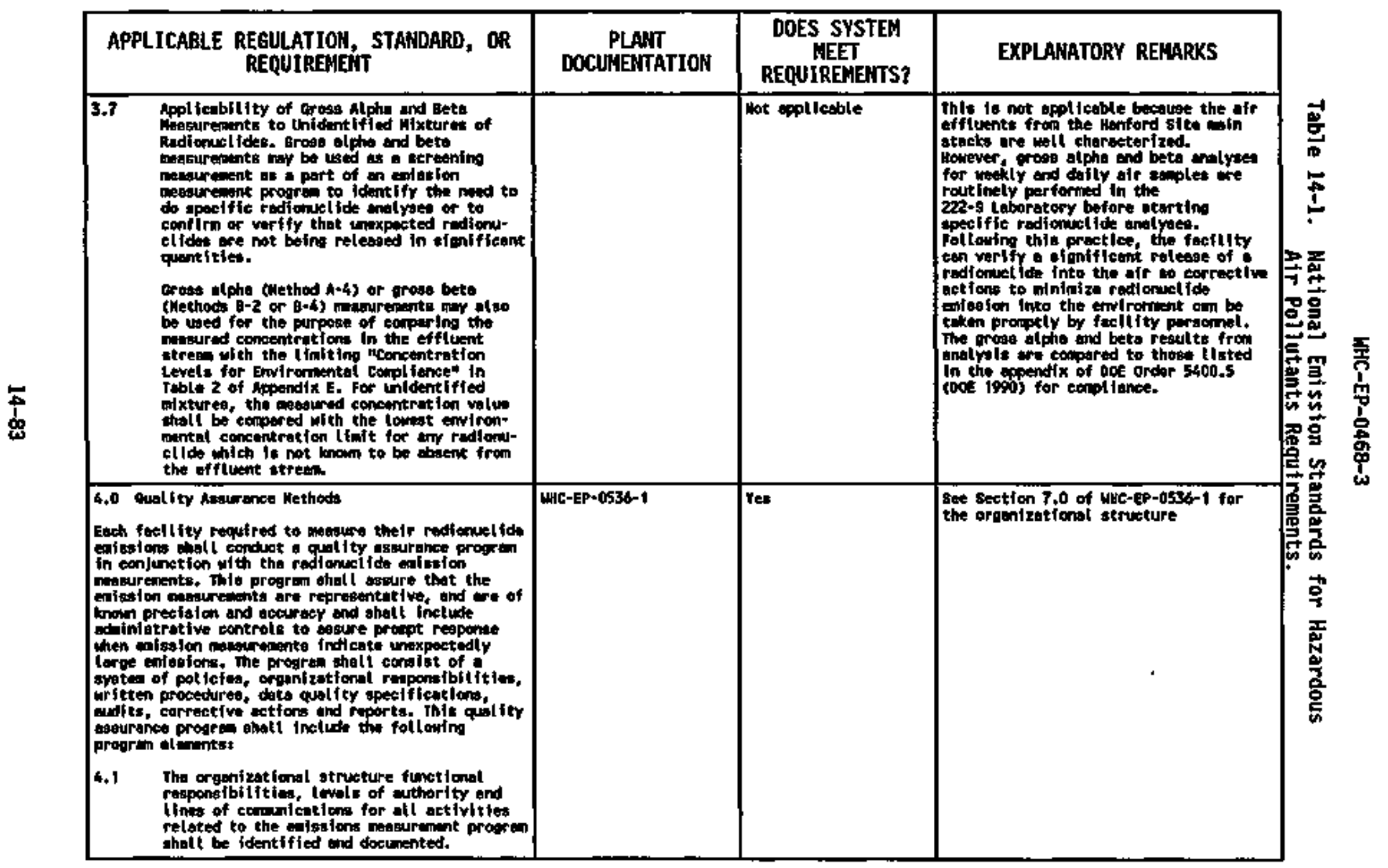




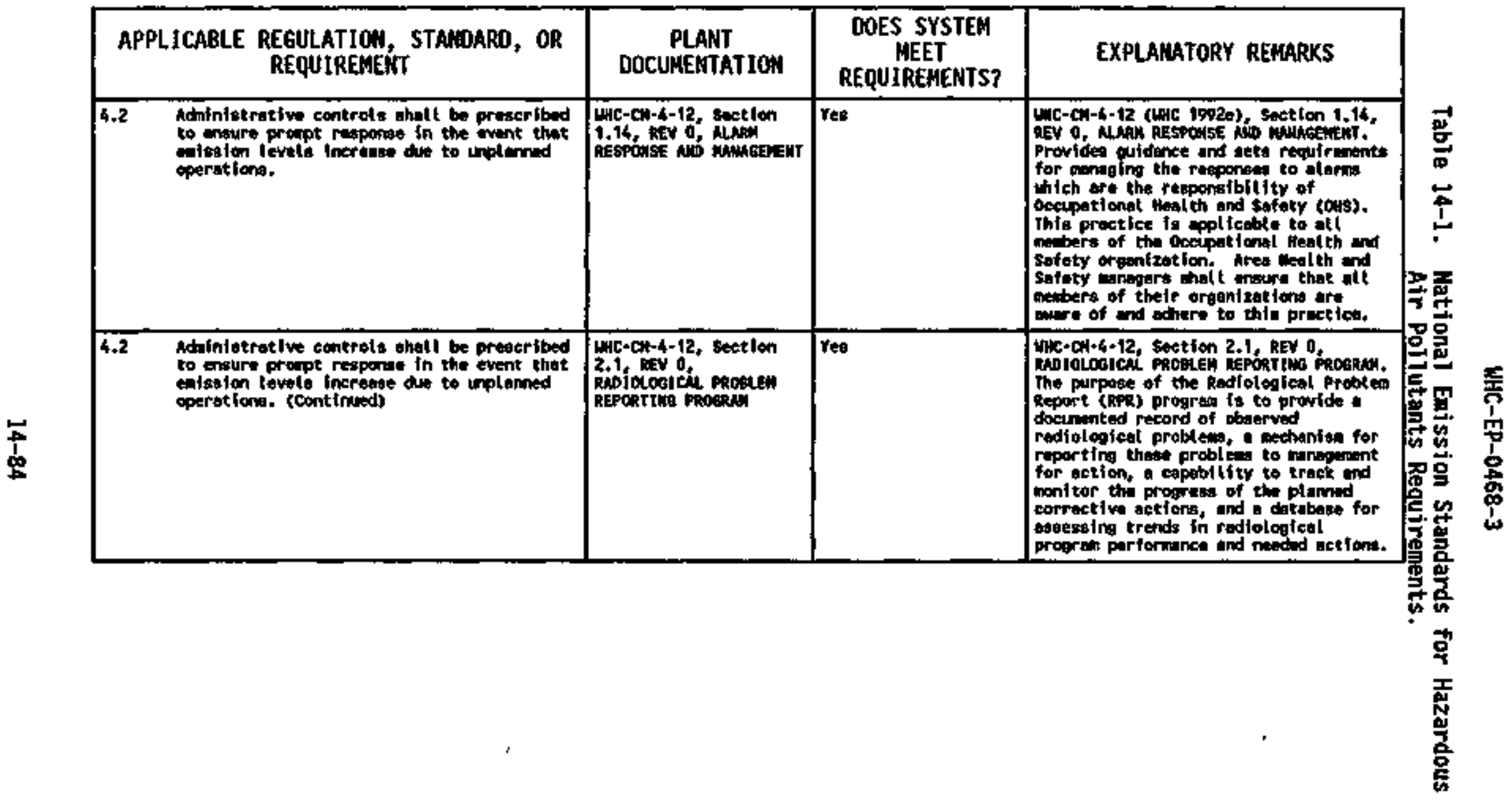




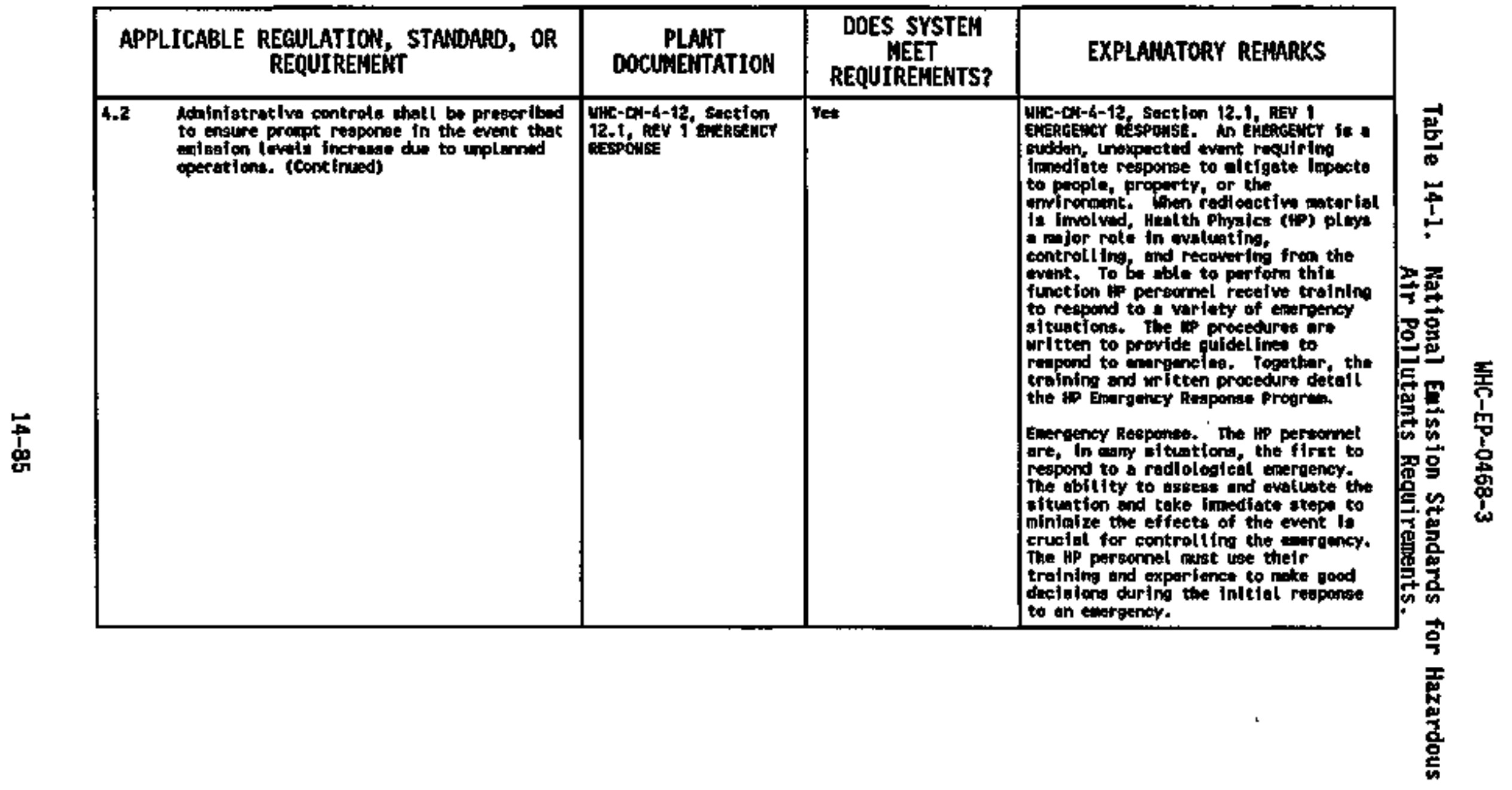




\begin{tabular}{|c|c|c|c|}
\hline $\begin{array}{l}\text { APPLICABLE REGULATION, STANDARD, OR } \\
\text { REQUIREMENT }\end{array}$ & $\begin{array}{l}\text { PLANT } \\
\text { DOCUMENTATION }\end{array}$ & $\begin{array}{c}\text { DOES SYSTEM } \\
\text { MEEY } \\
\text { REQUIRENENTS? }\end{array}$ & EXPLANATORY REMARKS \\
\hline 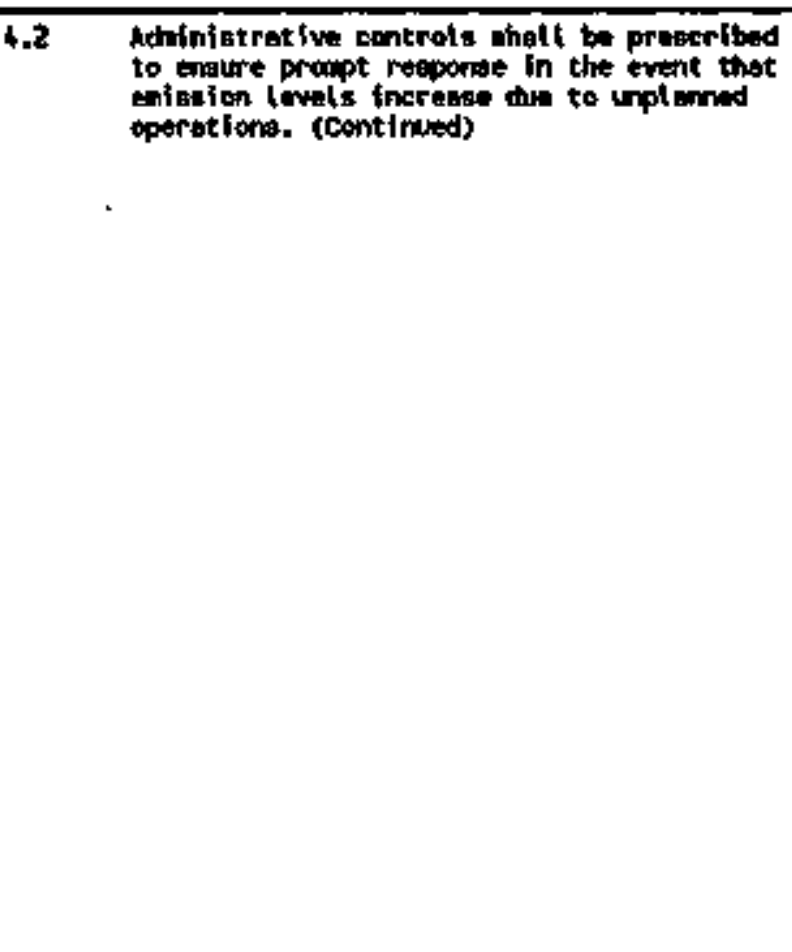 & 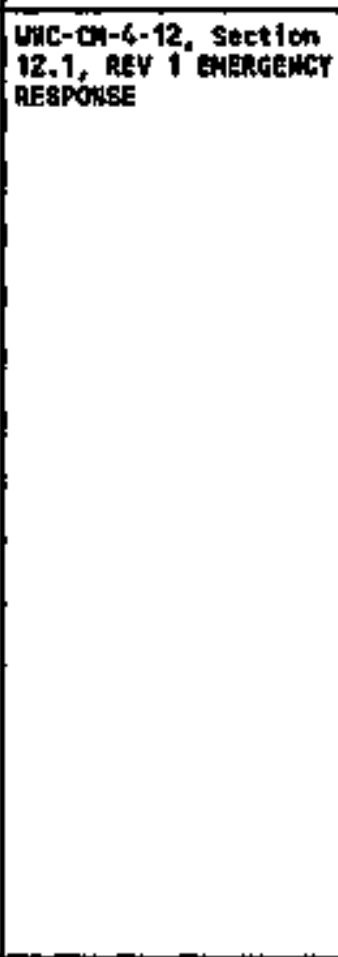 & rea & 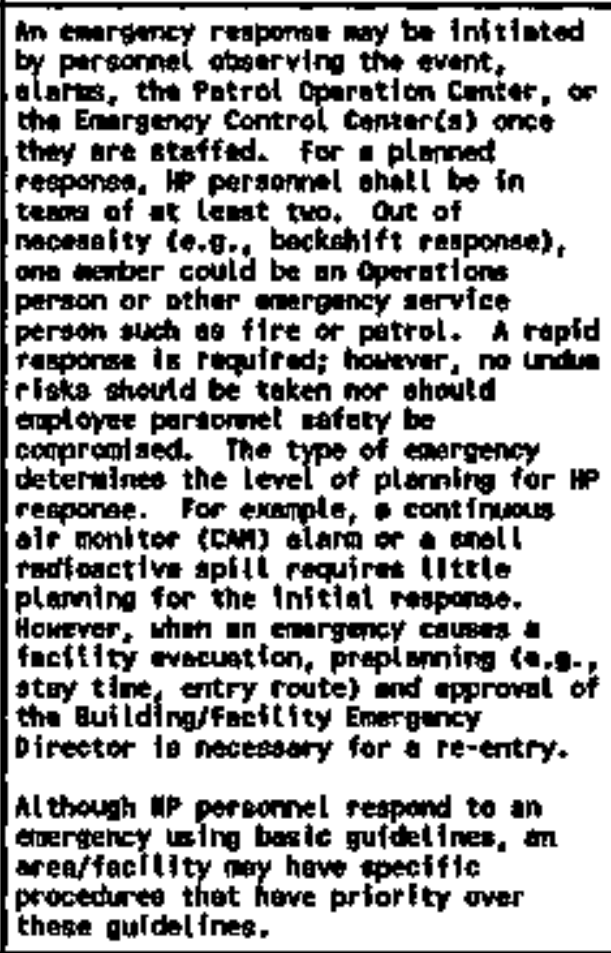 \\
\hline
\end{tabular}




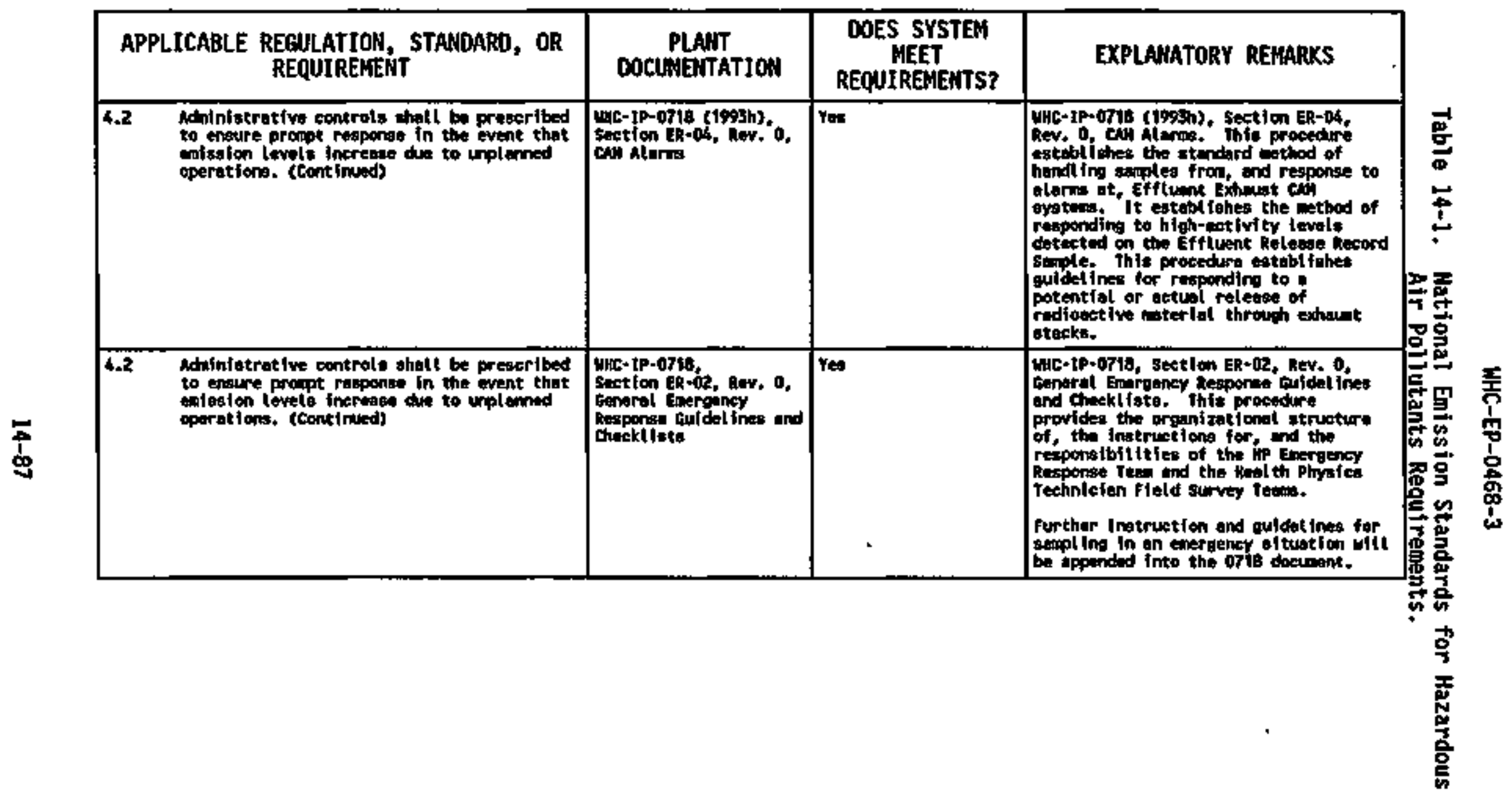




\begin{tabular}{|c|c|c|c|c|}
\hline \multicolumn{2}{|c|}{$\begin{array}{l}\text { APPLICABLE REGULATION, STAMDARD, OR } \\
\text { REQUIRENEHT }\end{array}$} & \multirow{2}{*}{ 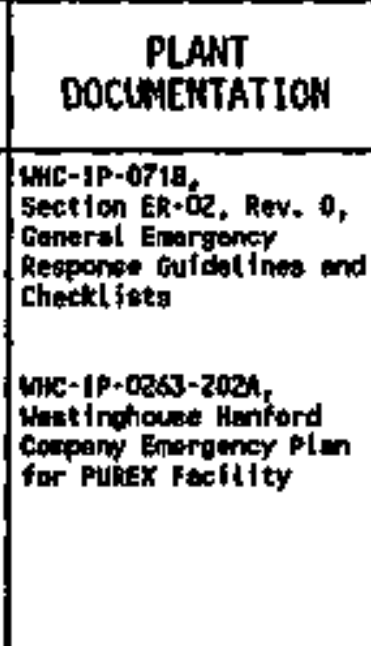 } & \multirow{2}{*}{$\begin{array}{c}\text { DOES SYSTEM } \\
\text { MEET } \\
\text { REQUIRENENTS? } \\
\text { YaE }\end{array}$} & \multirow[b]{2}{*}{ 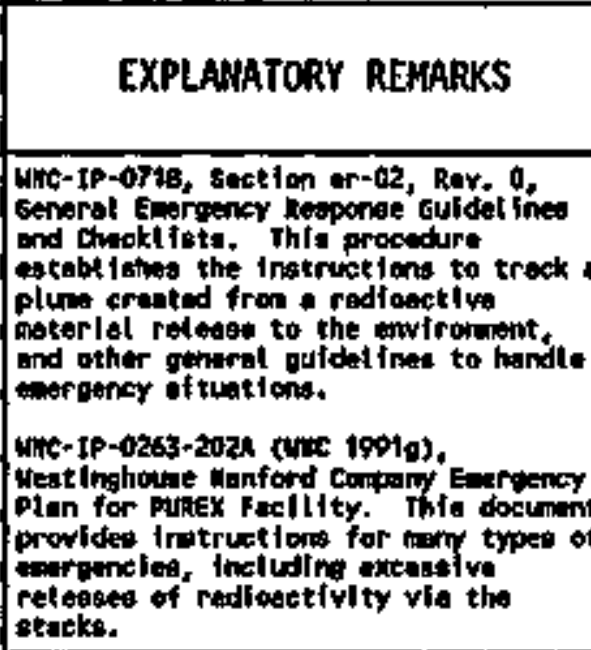 } \\
\hline 4.2 & 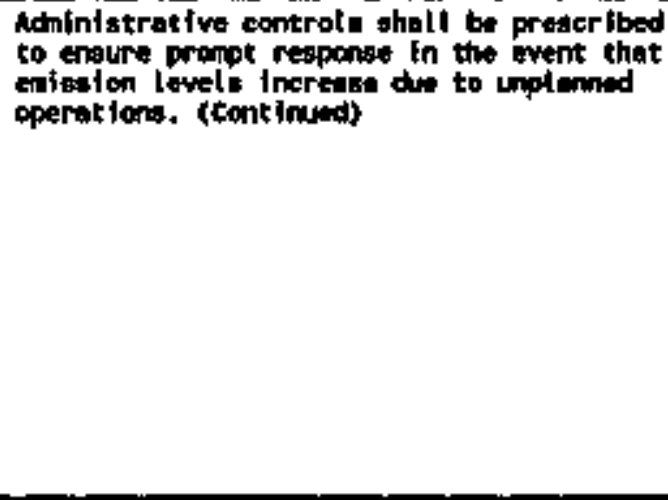 & & & \\
\hline 4.2 & 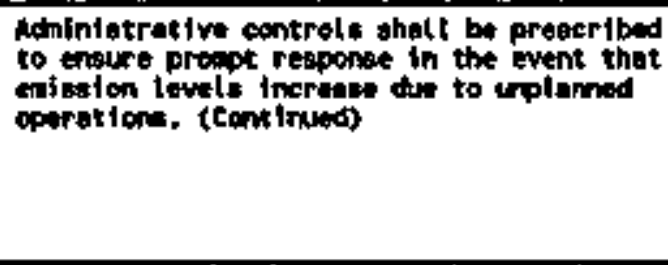 & 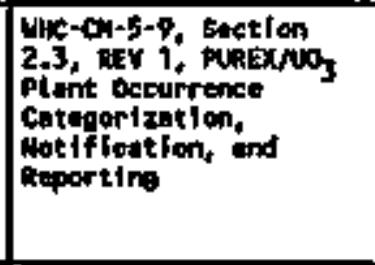 & Yes & 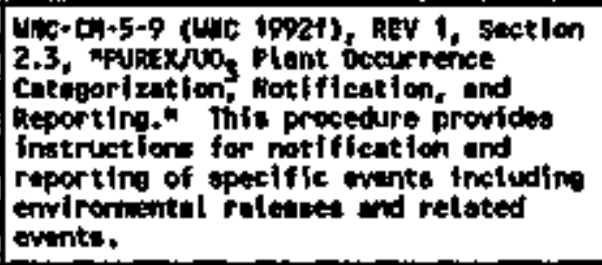 \\
\hline 4.3 & 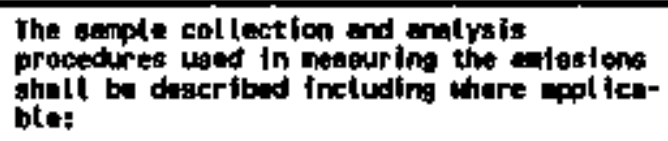 & & & \\
\hline
\end{tabular}




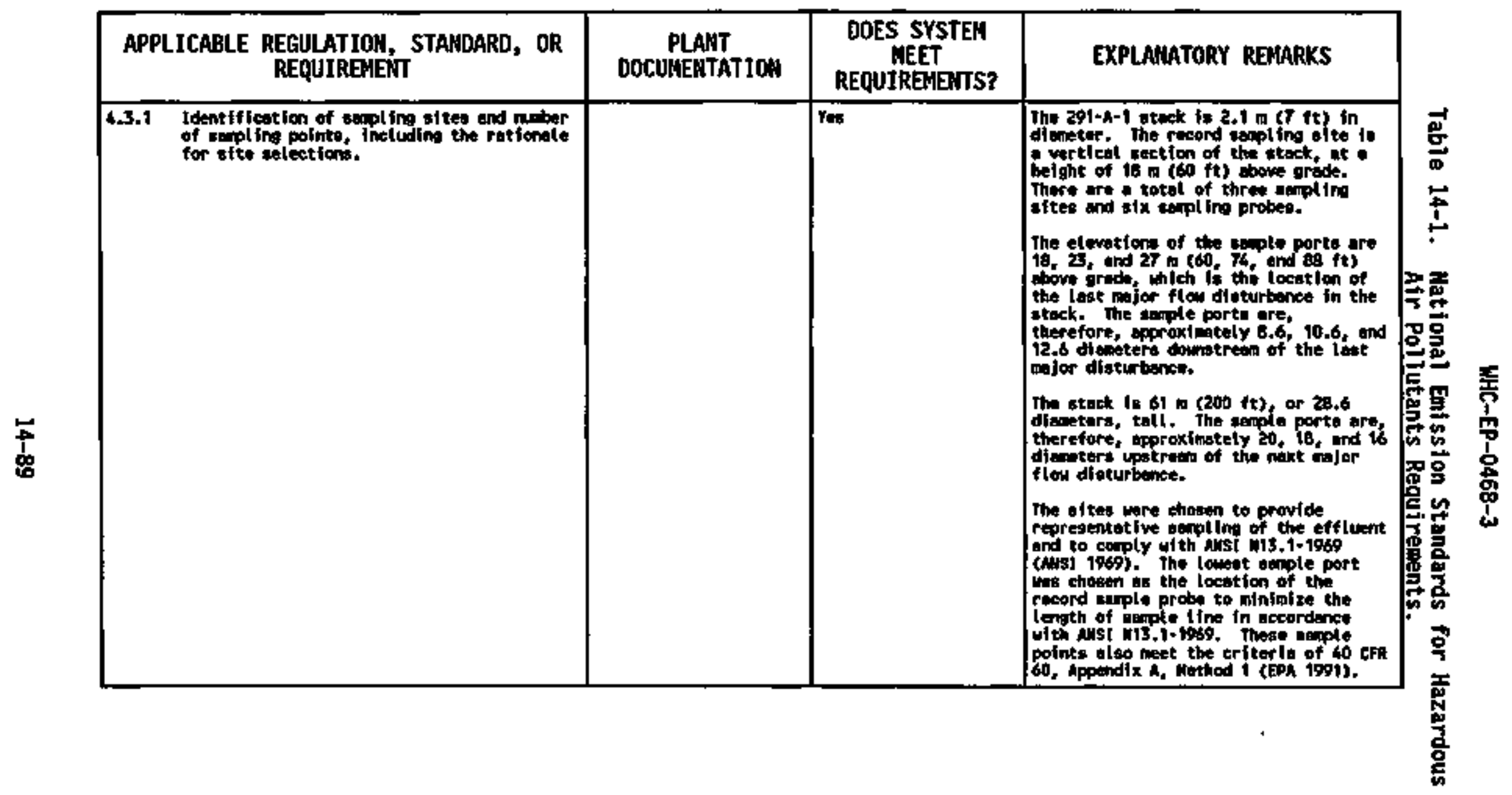




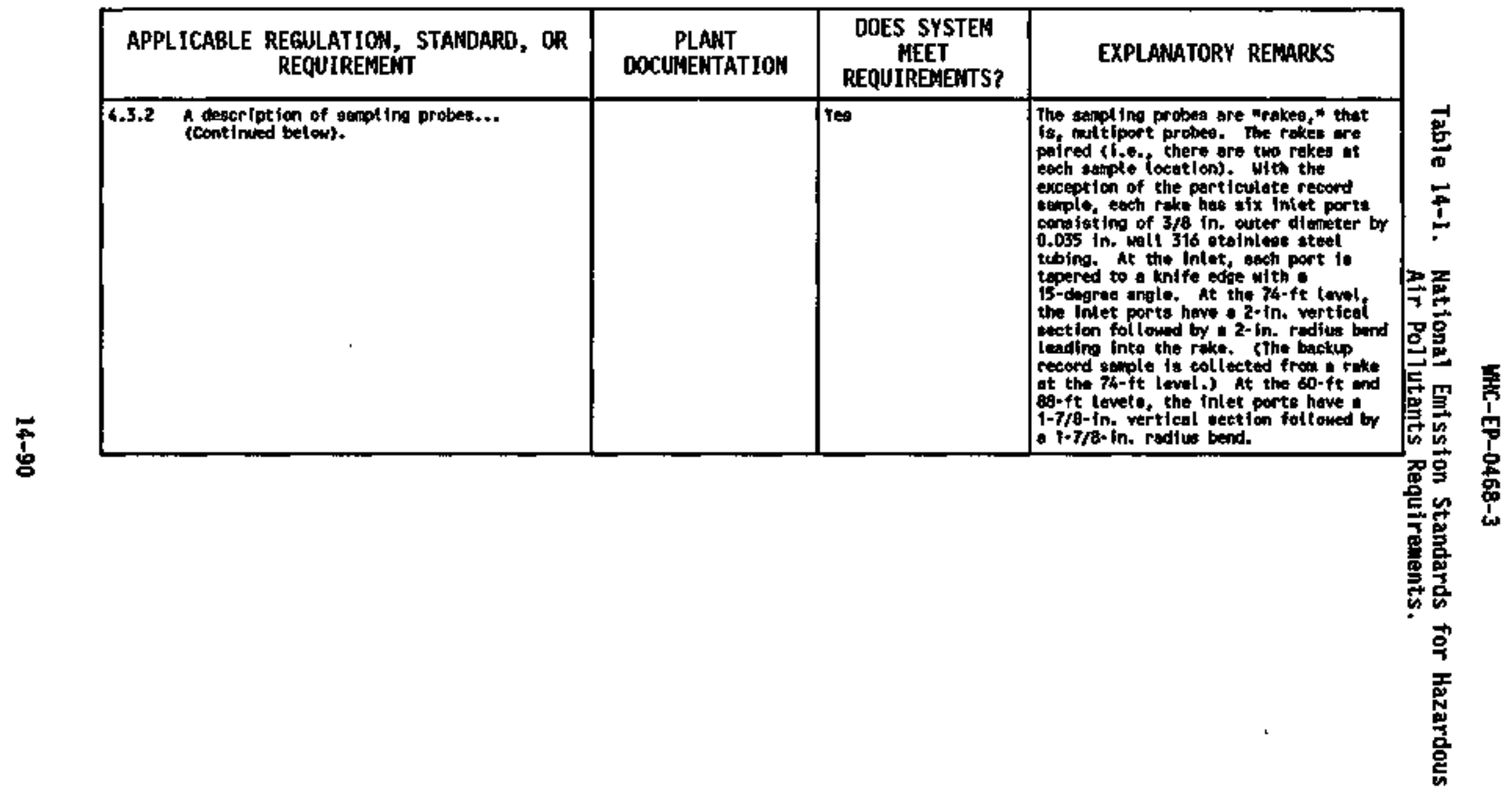




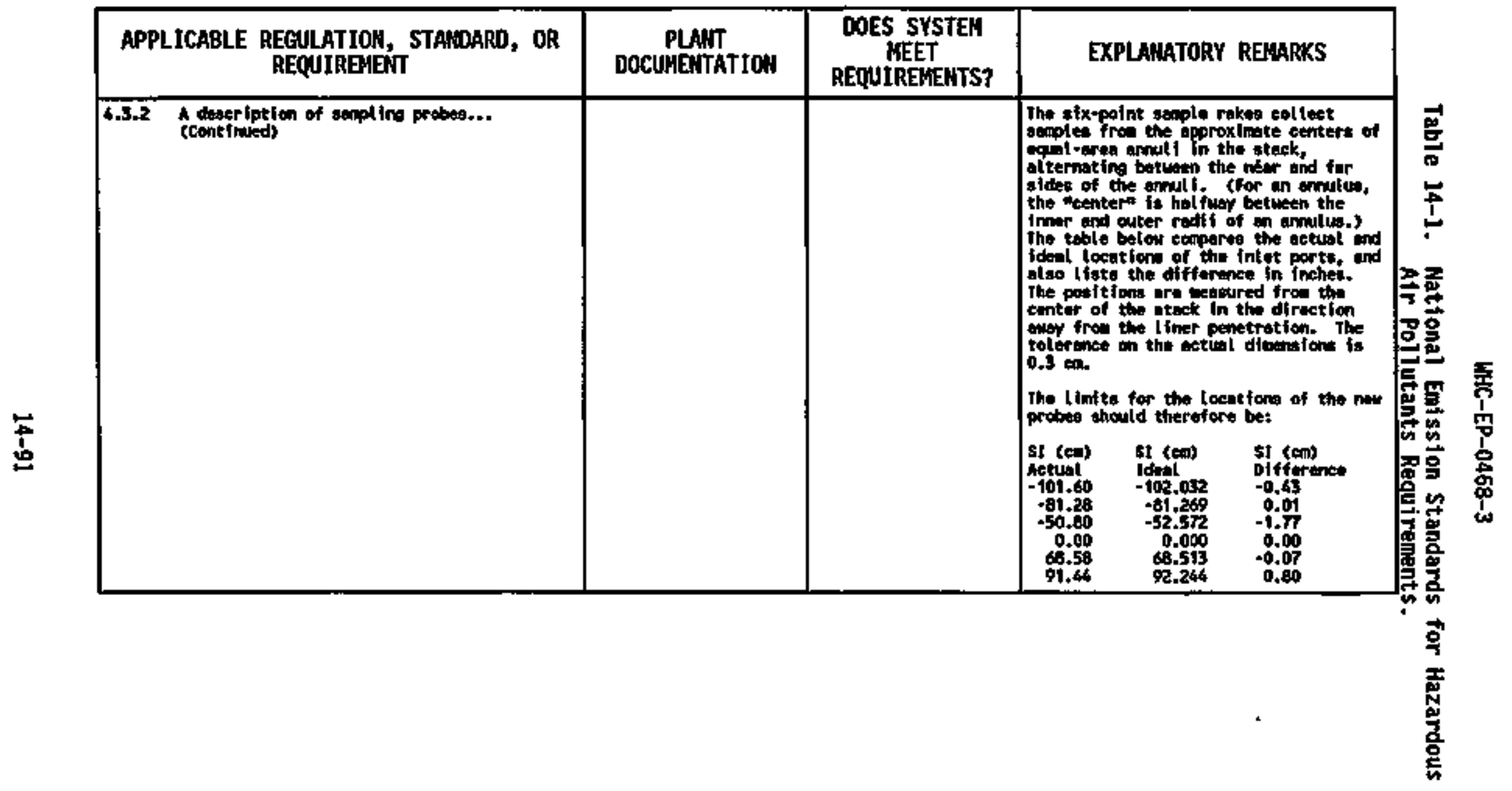




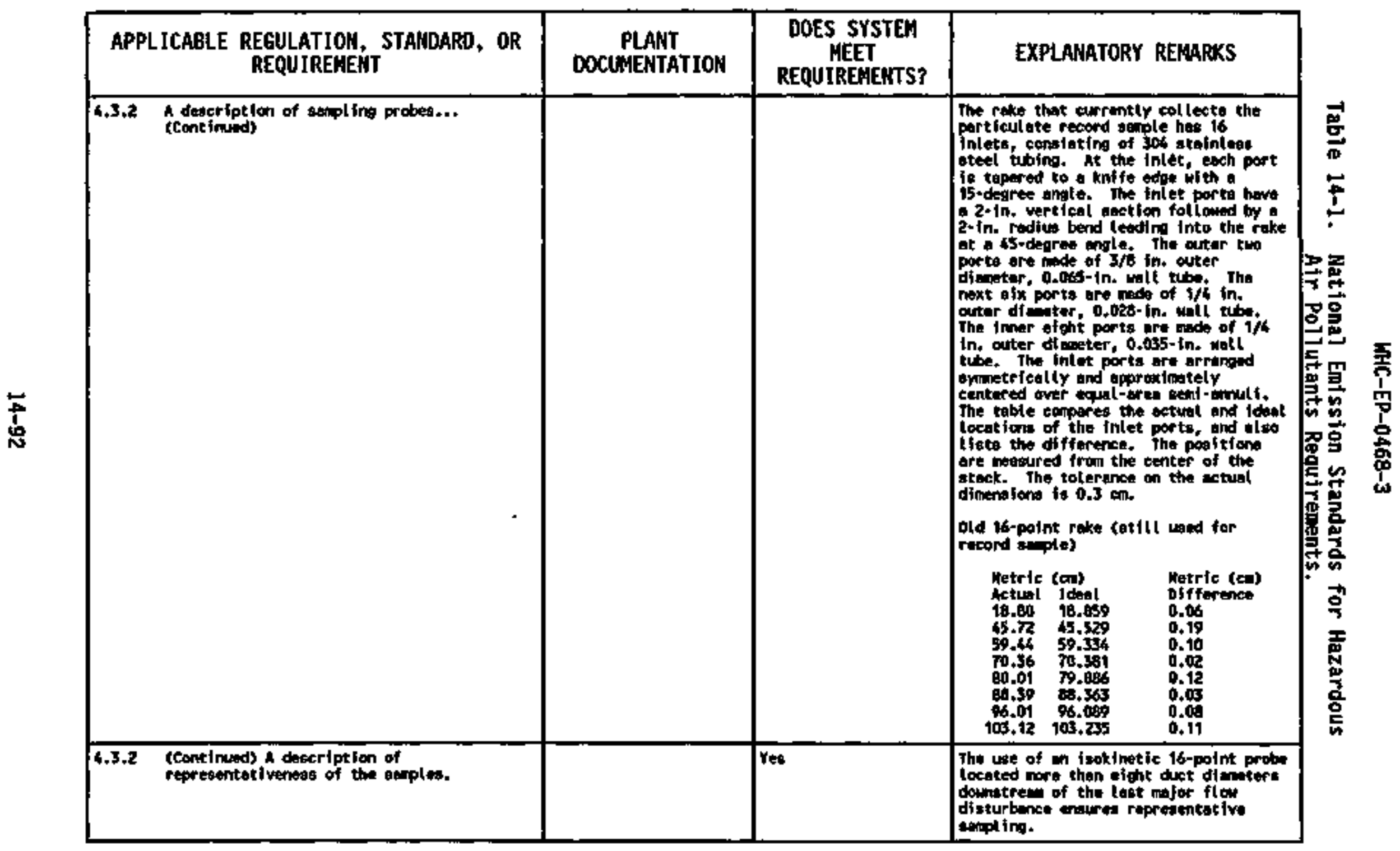




\begin{tabular}{|c|c|c|c|c|}
\hline \multicolumn{2}{|c|}{$\begin{array}{l}\text { APPLICABLE REGULATIOH, STAAWARD, OR } \\
\text { REQUIREMENT }\end{array}$} & \multirow[t]{2}{*}{$\begin{array}{l}\text { PLAHT } \\
\text { DOCUNEHTATIOH }\end{array}$} & $\begin{array}{l}\text { DOES SYSTEM } \\
\text { HEET } \\
\text { REQUIREHEMTS? }\end{array}$ & \multirow{2}{*}{ 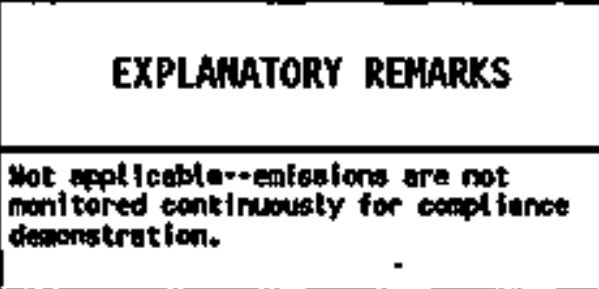 } \\
\hline 4.3 .3 & 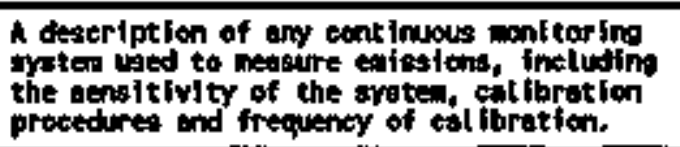 & & Ves: & \\
\hline 4.3 .4 & 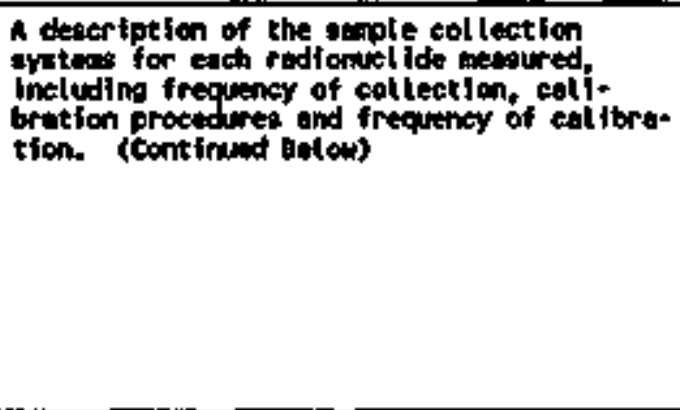 & & Tes & 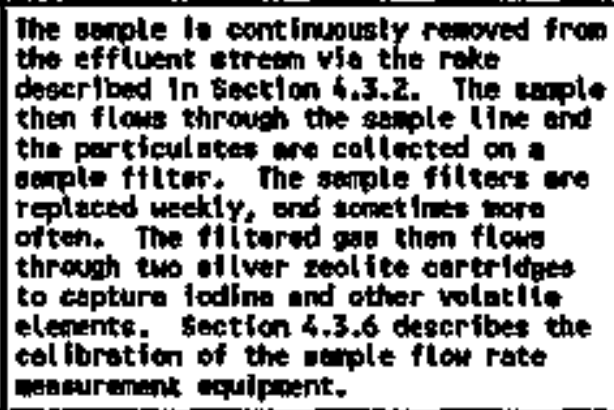 \\
\hline 4.3 .4 & 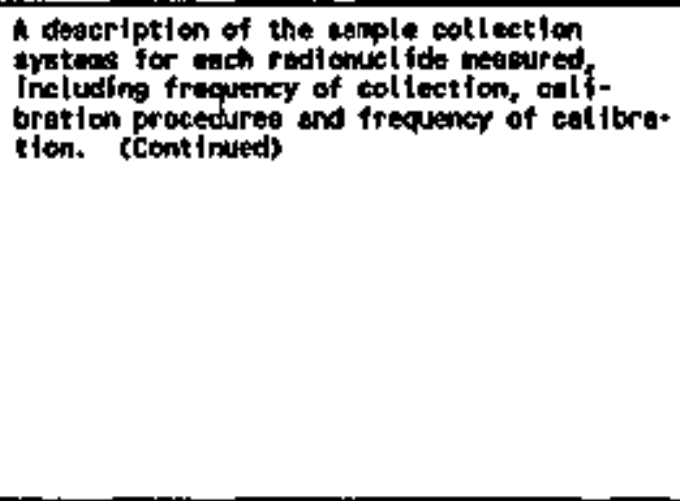 & & Tes & 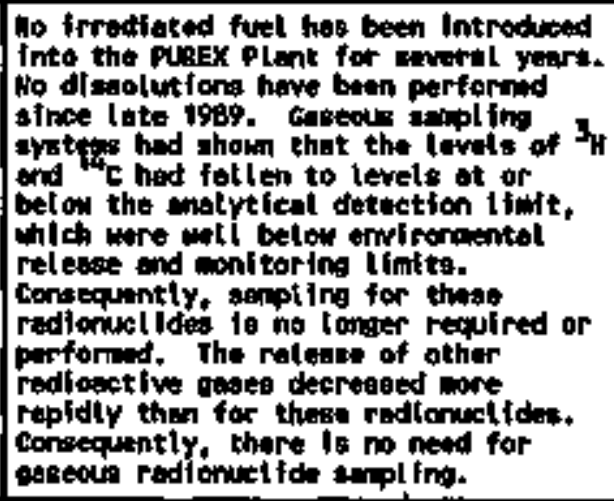 \\
\hline
\end{tabular}




\begin{tabular}{|c|c|c|c|c|}
\hline \multicolumn{2}{|c|}{$\begin{array}{l}\text { APPLICABLE RECULATION, STANDARD, OR } \\
\text { REQUIREMEHT }\end{array}$} & \multirow{2}{*}{$\begin{array}{c}\text { PLANT } \\
\text { DOCUAENTATIOH } \\
\begin{array}{c}\text { LA-508-110 } \\
\text { LA-508-116 } \\
10-150-115 \\
10-500-002\end{array}\end{array}$} & \multirow{2}{*}{\begin{tabular}{|c|}
$\begin{array}{c}\text { DOES SYSTEM } \\
\text { MEET } \\
\text { REQUIREMENTS? }\end{array}$ \\
YeE
\end{tabular}} & \multirow[b]{2}{*}{ 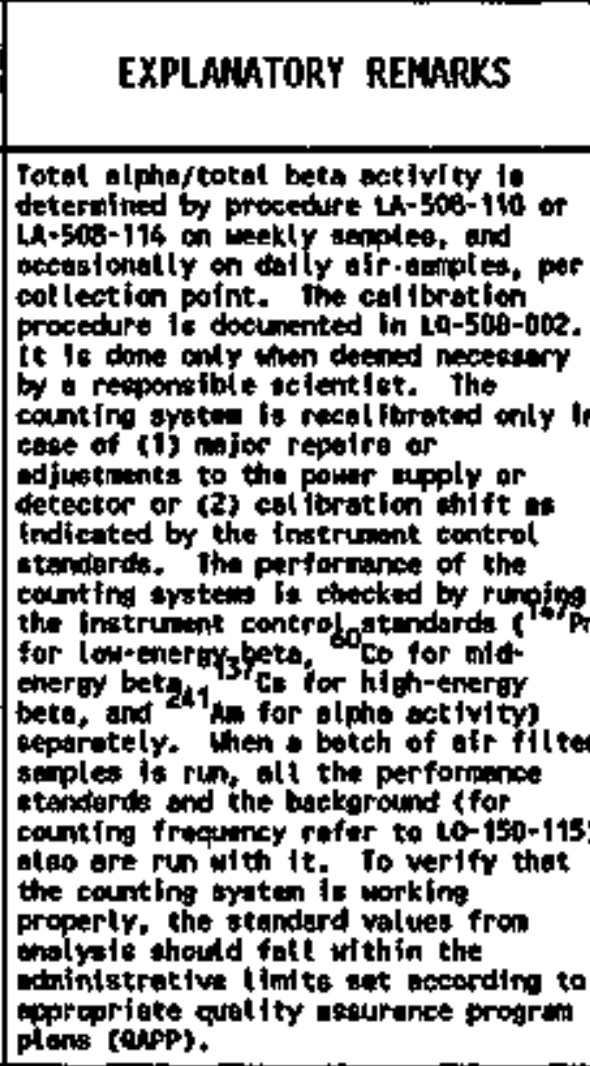 } \\
\hline 4.3 .5 & 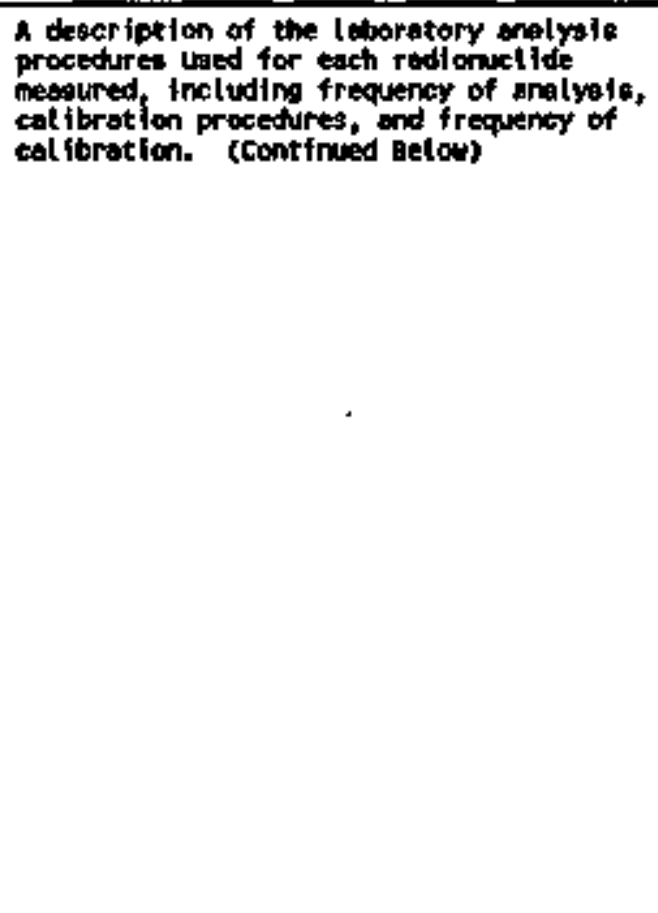 & & & \\
\hline
\end{tabular}




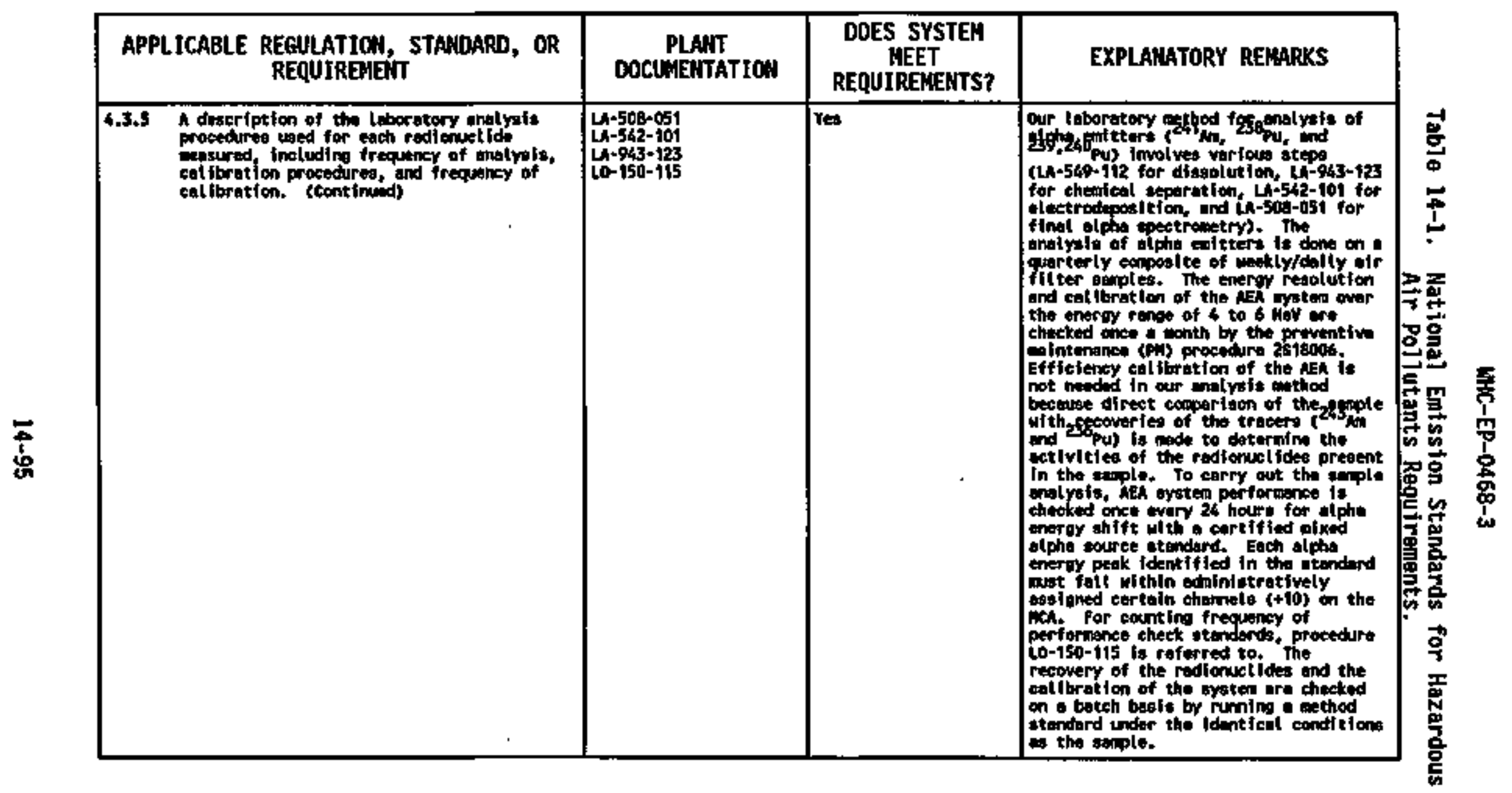




\begin{tabular}{|c|c|c|c|c|}
\hline \multicolumn{2}{|c|}{$\begin{array}{l}\text { APPLICABLE REGULATION, STANDARD, OR } \\
\text { REQUIREMENT }\end{array}$} & \multirow{2}{*}{$\begin{array}{c}\text { PLANT } \\
\text { DOCUNENTATION } \\
\begin{array}{l}4-220-103 \\
14+509+11 \\
4 A+569-112 \\
0+509+002 \\
60-500-005\end{array}\end{array}$} & \multirow{2}{*}{$\begin{array}{l}\text { OOES SYSTEM } \\
\text { MEET } \\
\text { REQUIRENENTS? }\end{array}$} & \multirow[b]{2}{*}{ 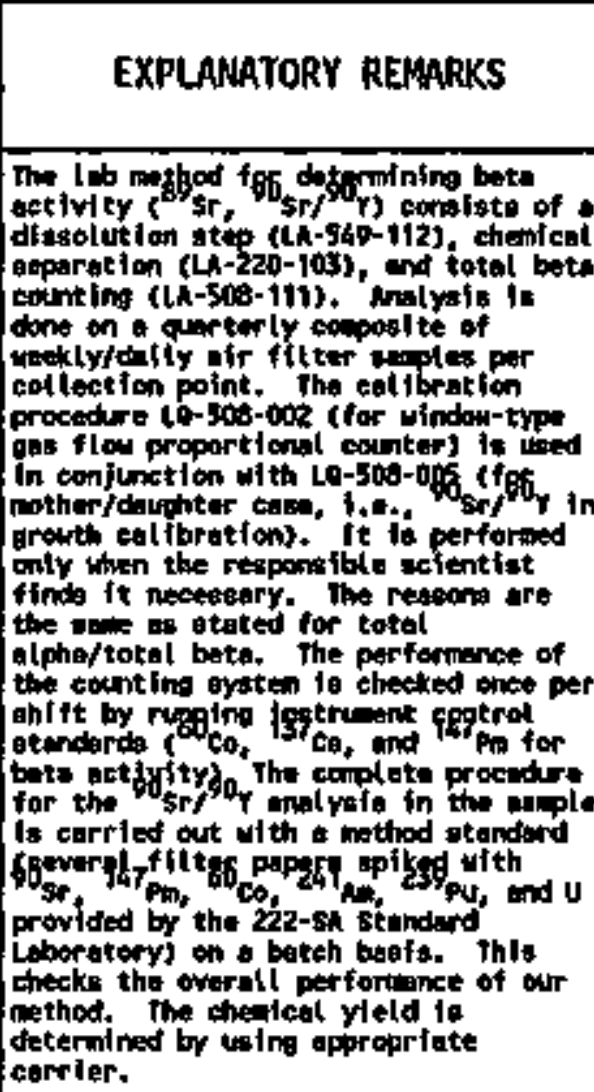 } \\
\hline 4.3 .5 & 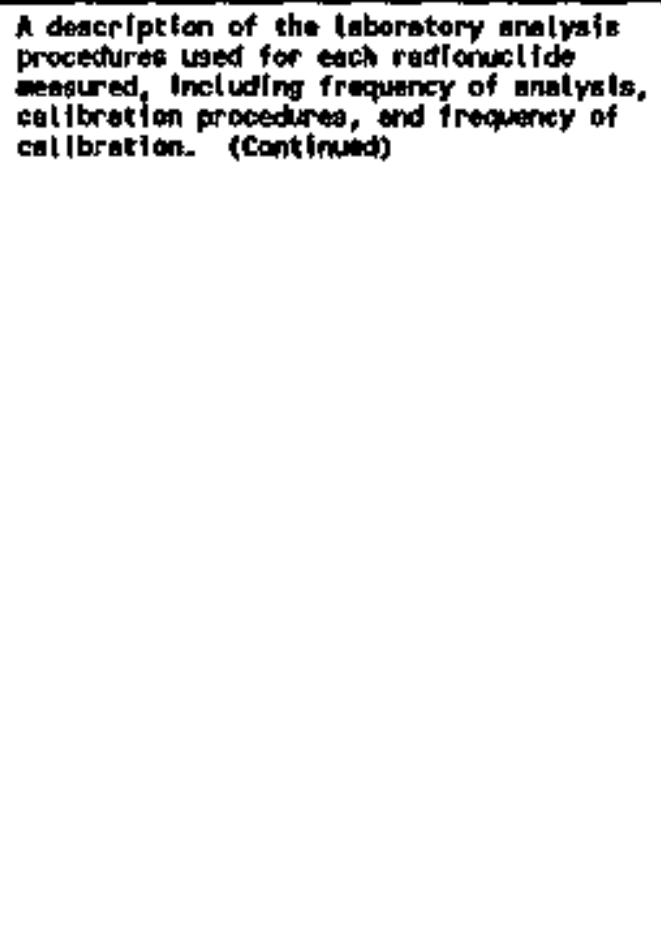 & & & \\
\hline
\end{tabular}




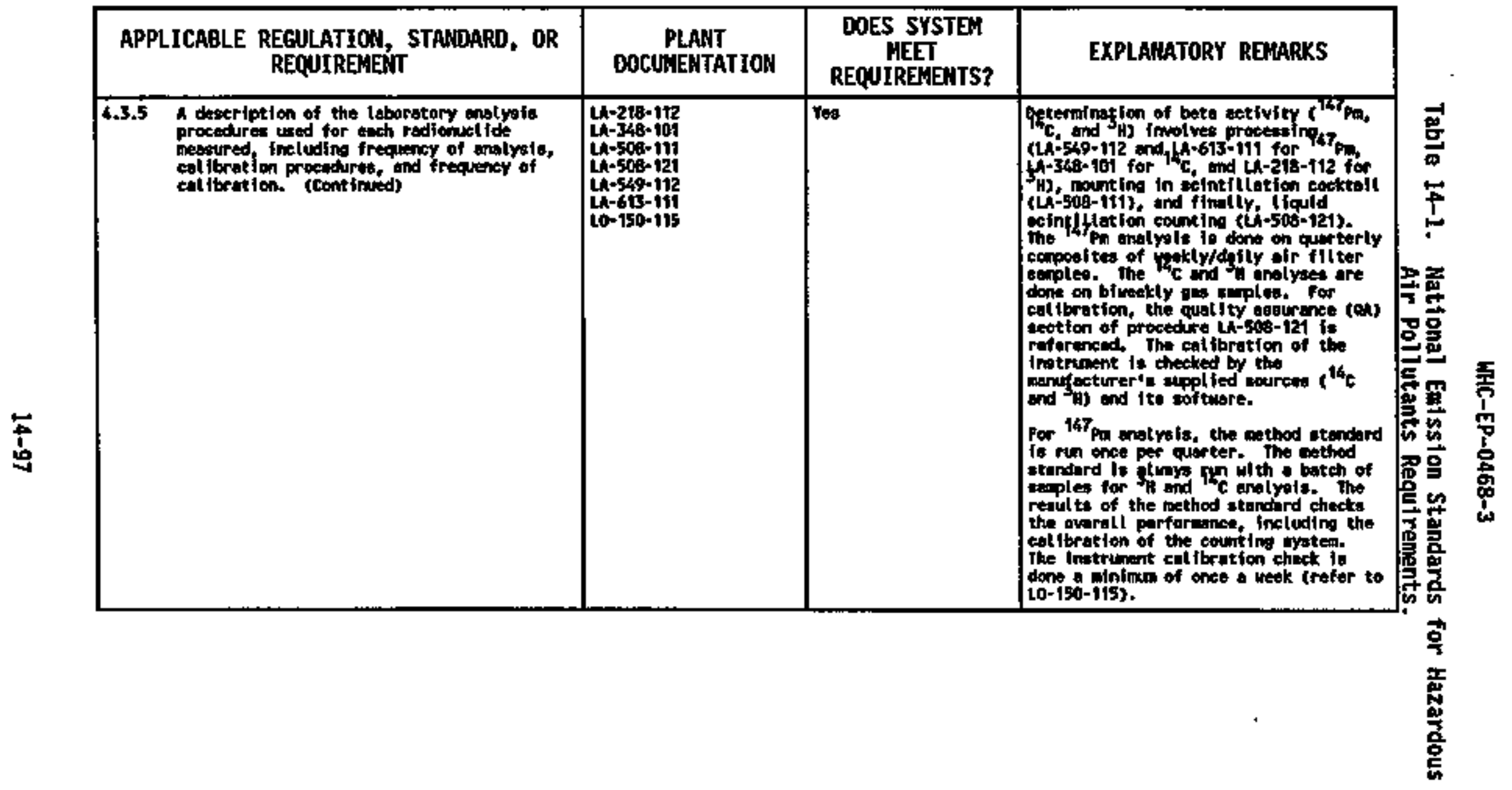




\begin{tabular}{|c|c|c|c|c|}
\hline \multicolumn{2}{|c|}{$\begin{array}{l}\text { APPLICABLE REGULATICN, STANDARD, OR } \\
\text { REQUIREMEAT }\end{array}$} & $\begin{array}{l}\text { PLANT } \\
\text { DOCUHENTATION }\end{array}$ & $\begin{array}{l}\text { DOES SYSTEM } \\
\text { MEET } \\
\text { REQUIREMENTS? }\end{array}$ & EXPLANATORY REMARKS \\
\hline 4.3 .5 & 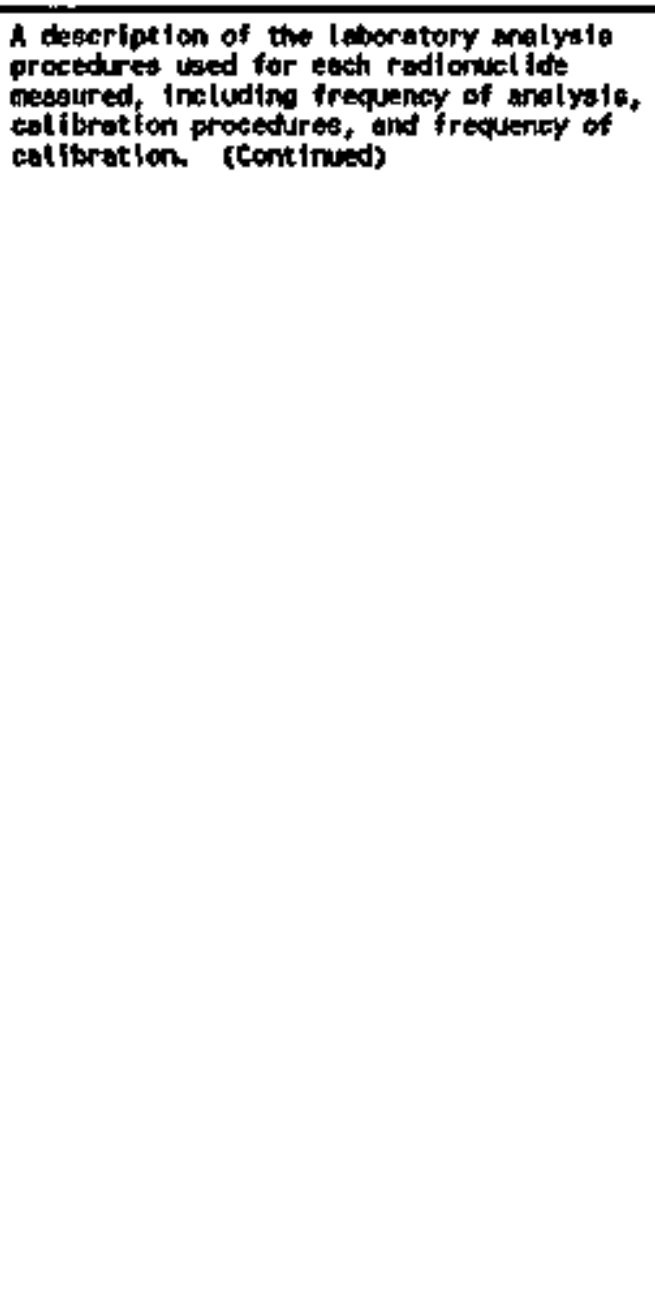 & 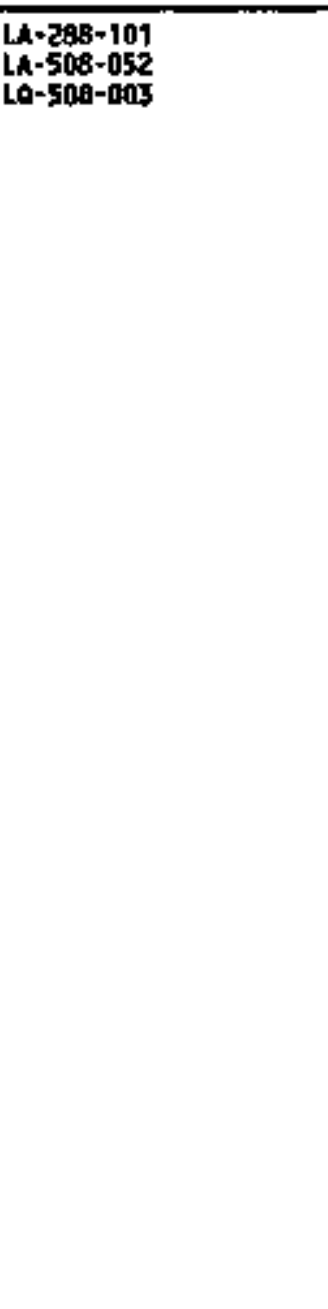 & trea & 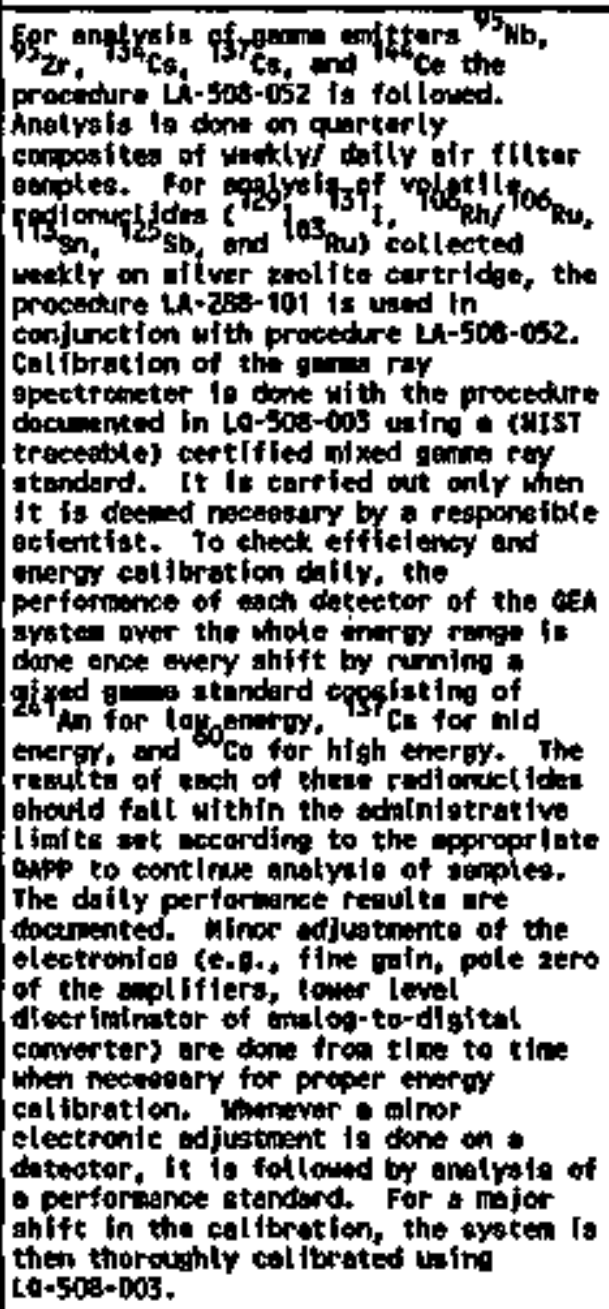 \\
\hline
\end{tabular}




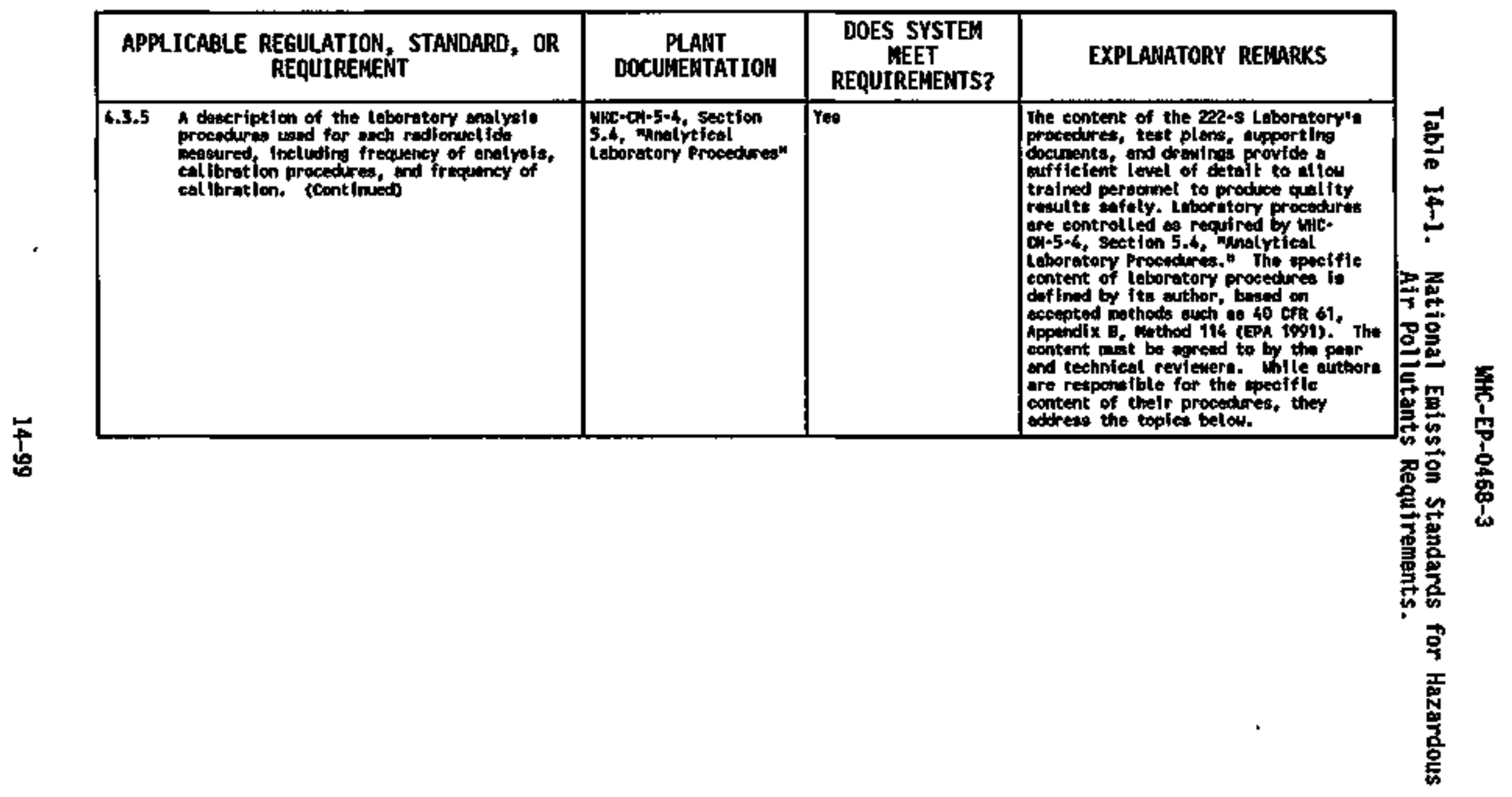




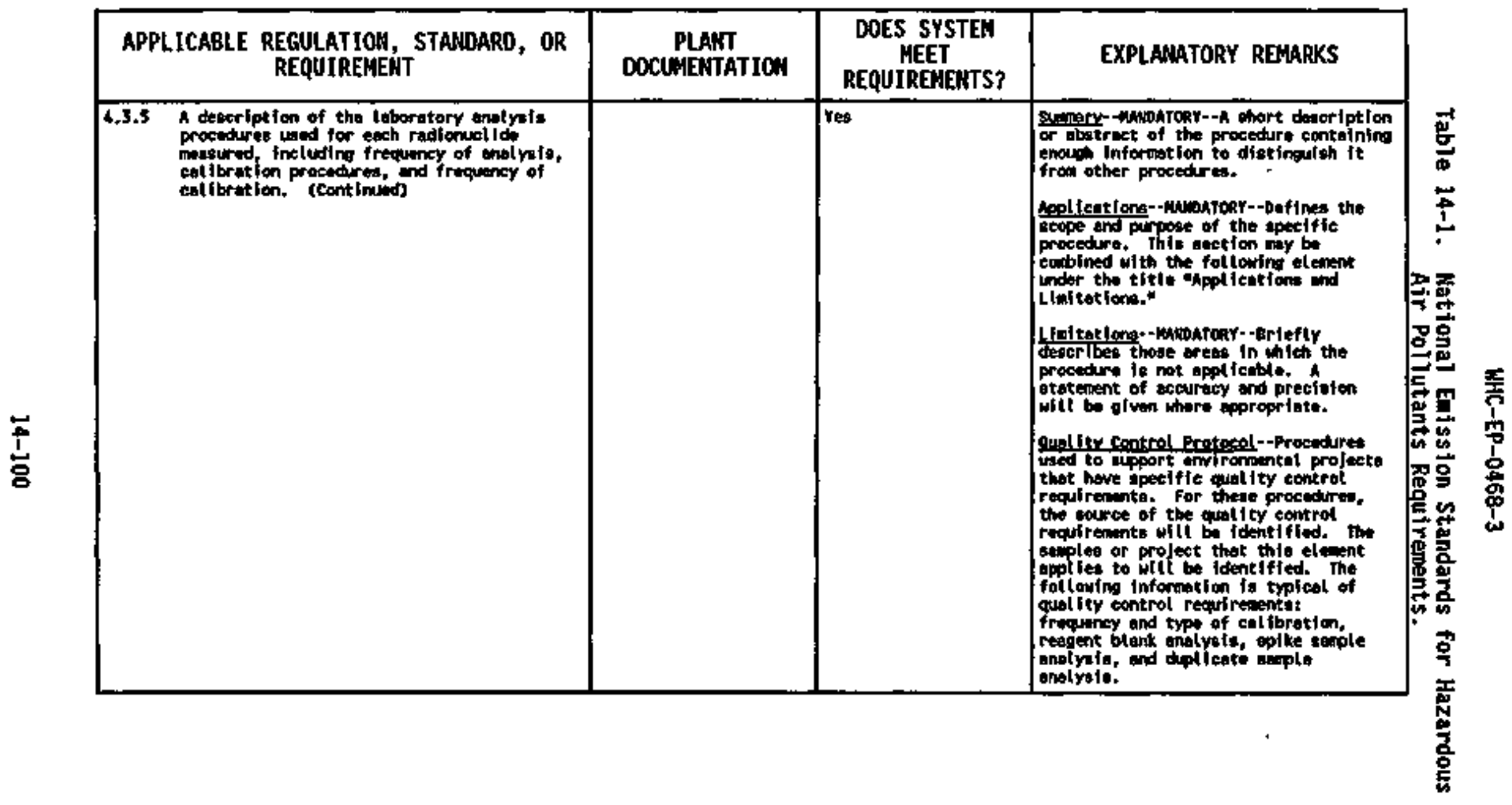




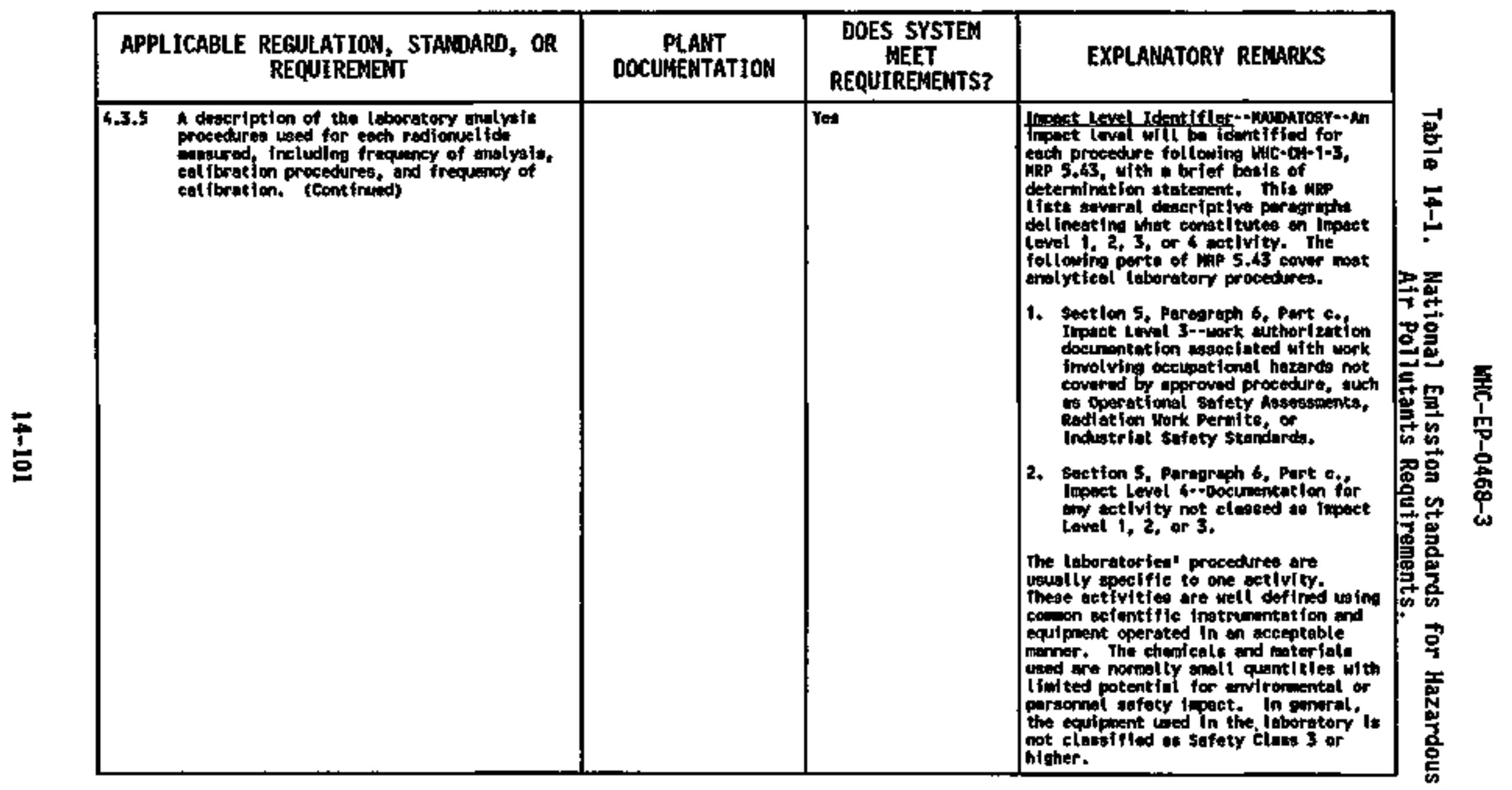




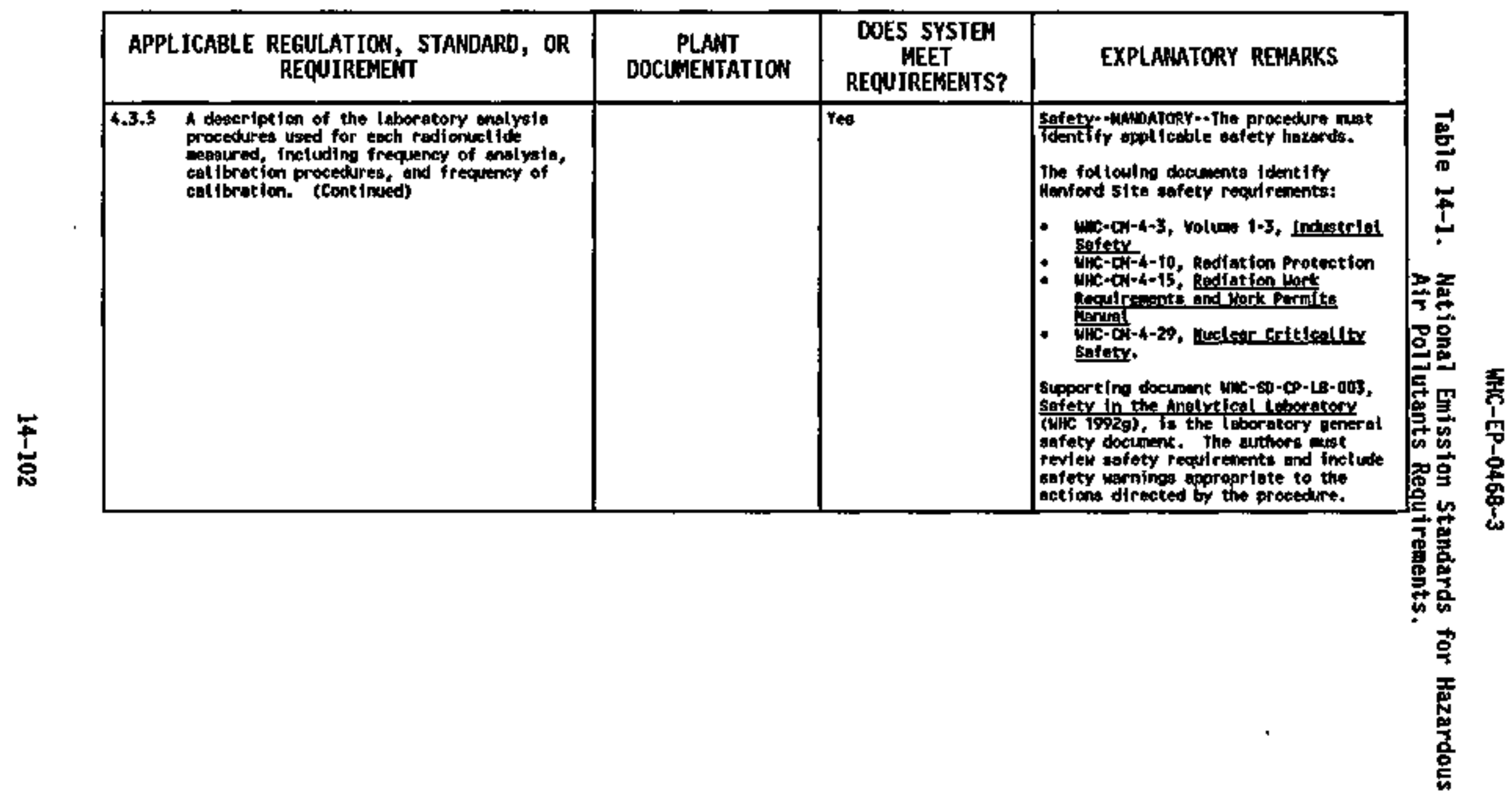




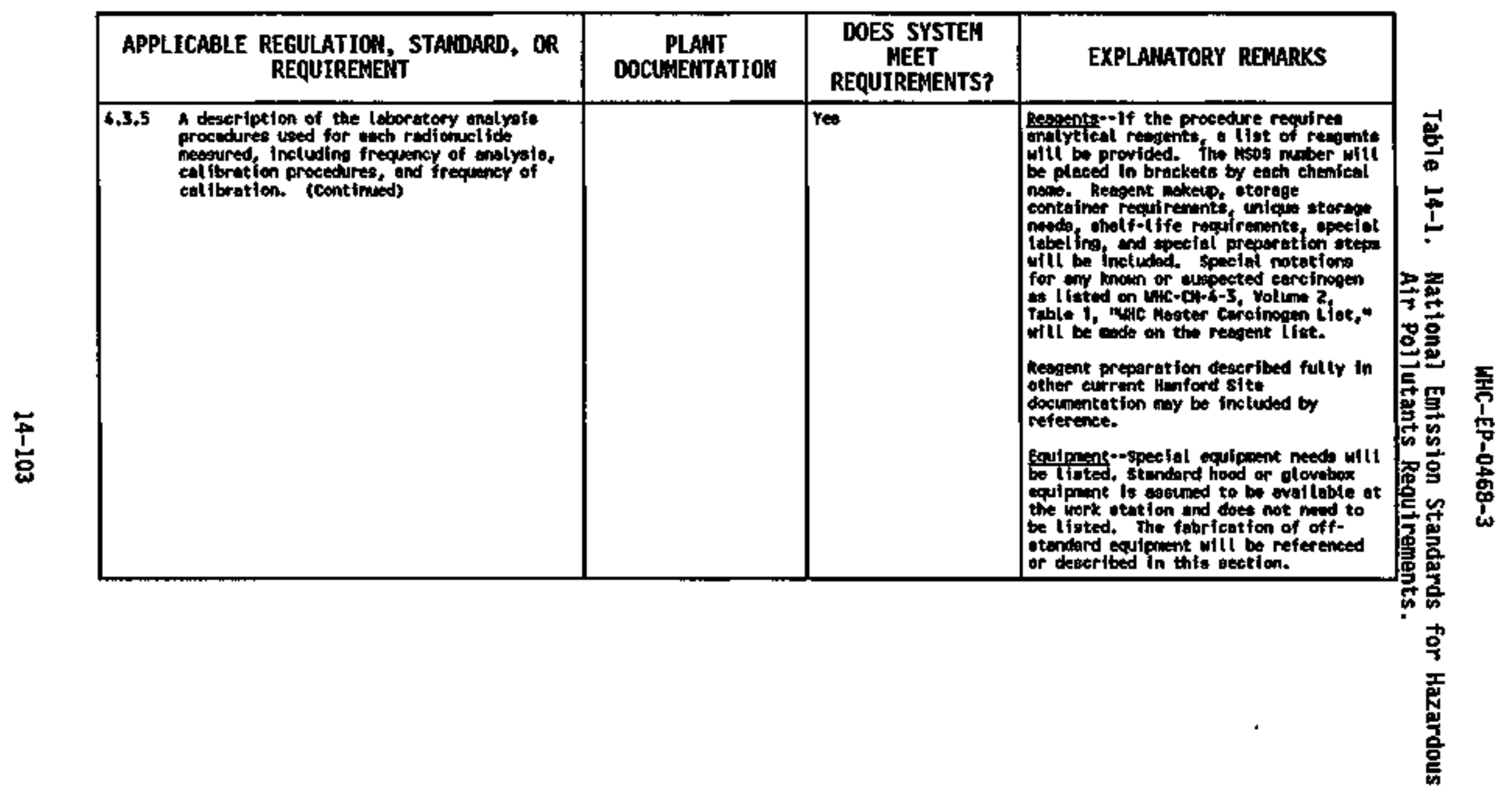




\begin{tabular}{|c|c|c|c|}
\hline $\begin{array}{l}\text { APPLICABLE REGULATIOH, STAMOARO, OR } \\
\text { REQUIREMEHT }\end{array}$ & $\begin{array}{l}\text { PLANT } \\
\text { DOCUMEATATION }\end{array}$ & $\begin{array}{c}\text { DOES SYSTEM } \\
\text { MEET } \\
\text { REQUIREKENTS? }\end{array}$ & EXPLANATORY REMARKS \\
\hline 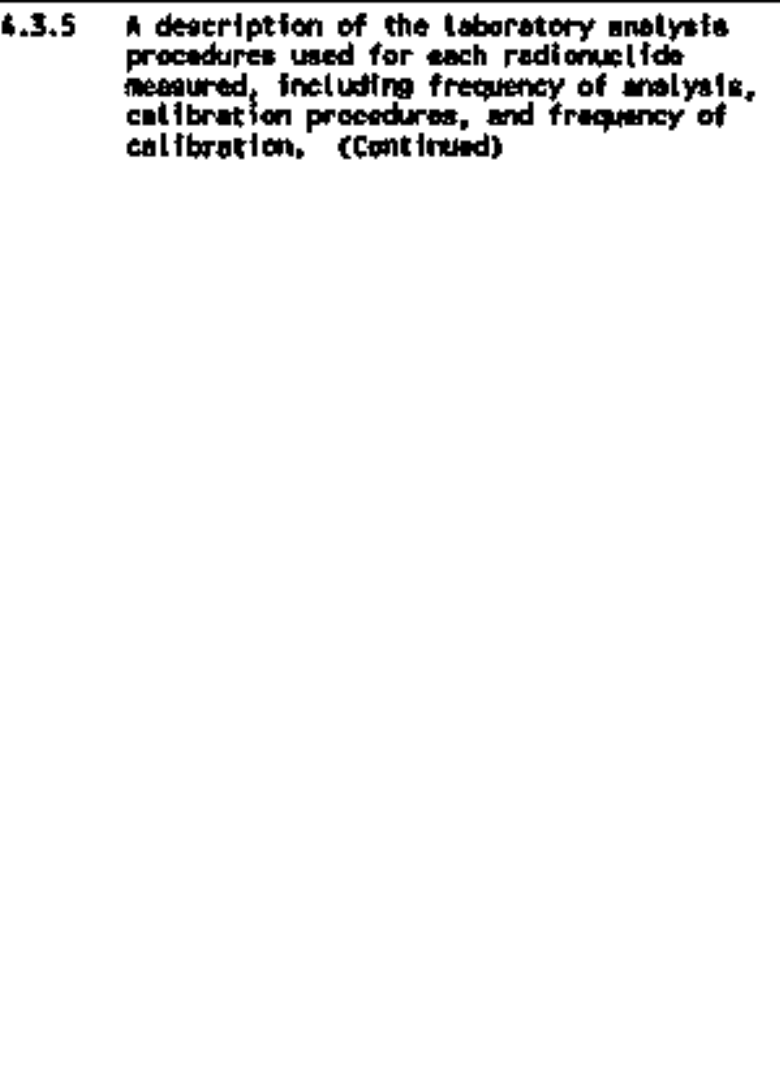 & & Tes & 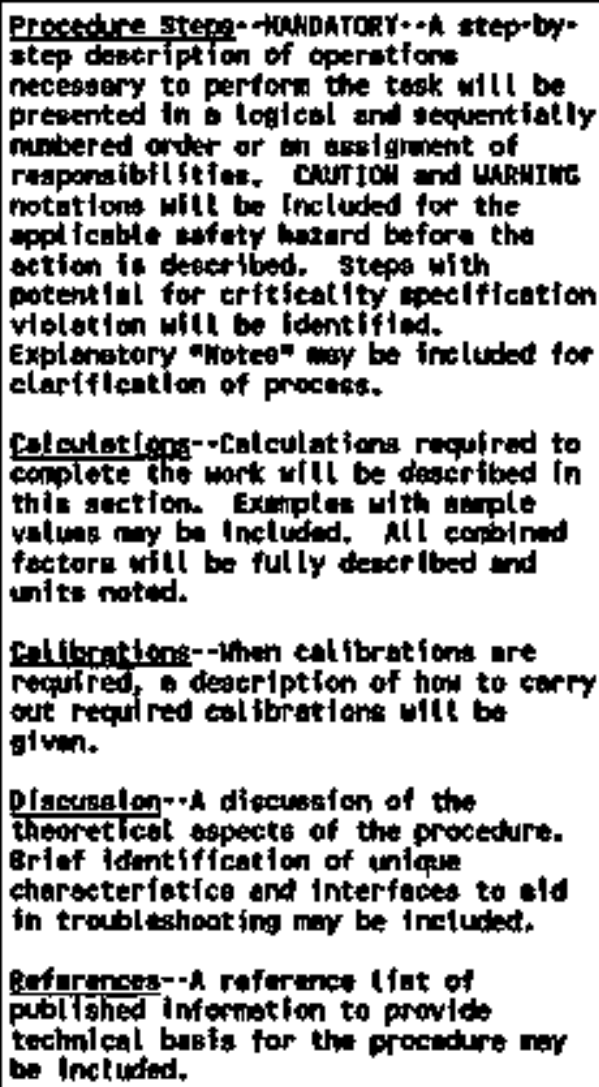 \\
\hline
\end{tabular}




\begin{tabular}{|c|c|c|c|c|}
\hline \multicolumn{2}{|c|}{$\begin{array}{l}\text { APPLICABLE REGULATIION, STANDARD, OR } \\
\text { REQUIREMENT }\end{array}$} & \multirow[t]{2}{*}{$\begin{array}{c}\text { PLANT } \\
\text { DOCUIEEKTATIOH }\end{array}$} & \multirow{2}{*}{\begin{tabular}{|c|} 
DOES SYSTEM \\
MEET \\
REQUIREMENTS? \\
YEs
\end{tabular}} & \multirow[b]{2}{*}{ 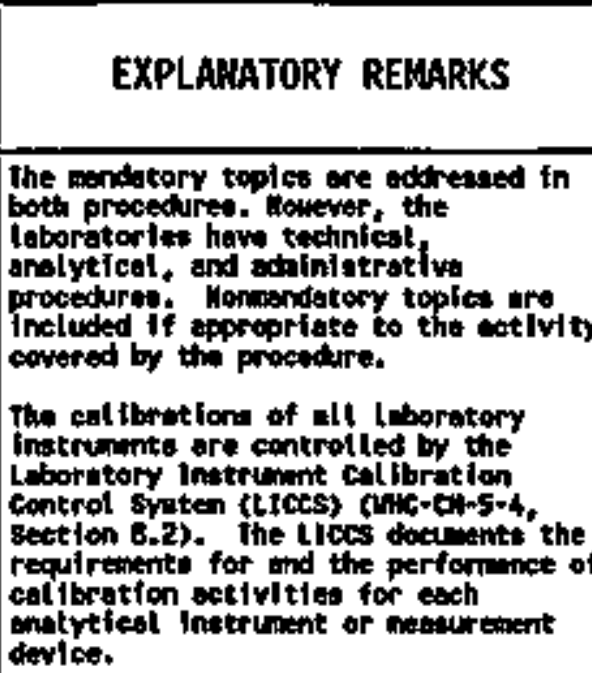 } \\
\hline 4.3 .5 & 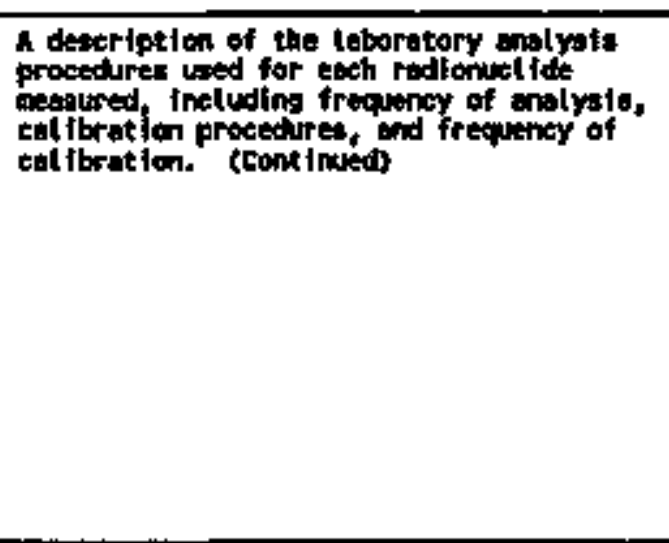 & & & \\
\hline 4.3 .5 & 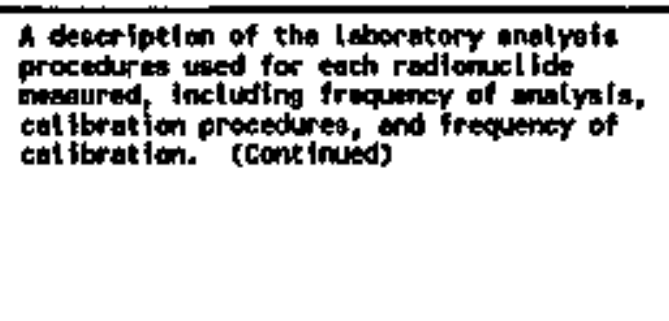 & & res & 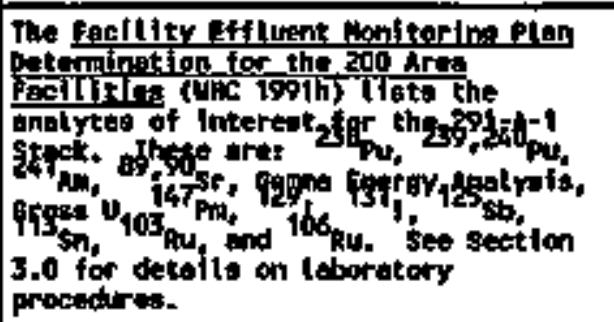 \\
\hline
\end{tabular}




\begin{tabular}{|c|c|c|c|c|}
\hline \multicolumn{2}{|c|}{$\begin{array}{l}\text { APPLICABLE REGULATIOH, STAMDARD, OR } \\
\text { REQUIRENEMT }\end{array}$} & \multirow{2}{*}{$\begin{array}{c}\text { PLANT } \\
\text { OOCUNENTATION } \\
\begin{array}{l}\text { PSCP-1-045 } \\
\text { PSPP-4-16 } \\
\text { PSCP-4-197 }\end{array}\end{array}$} & \multirow{2}{*}{\begin{tabular}{|c|} 
DOES SYSTEH \\
NEET \\
REQUIREMEHTS? \\
Ye:
\end{tabular}} & \multirow[b]{2}{*}{ 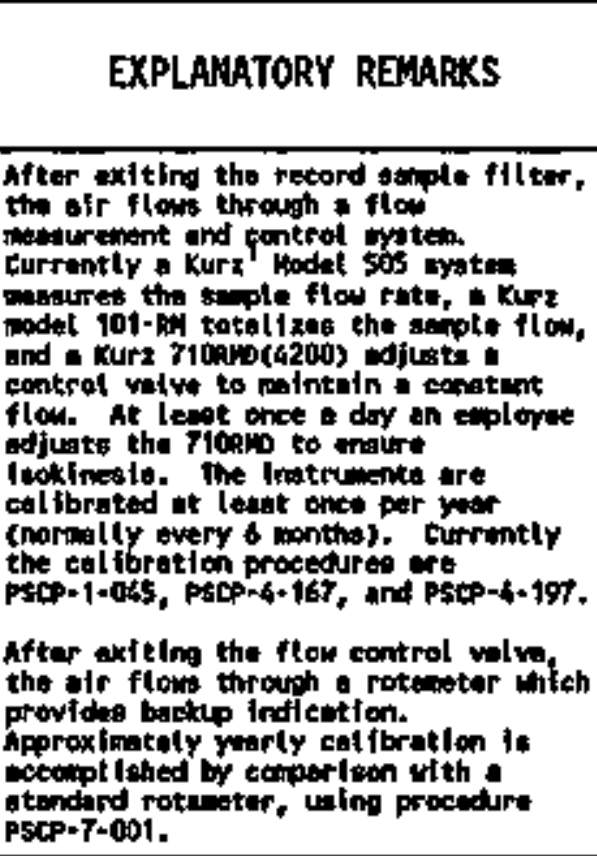 } \\
\hline 4.3 .6 & 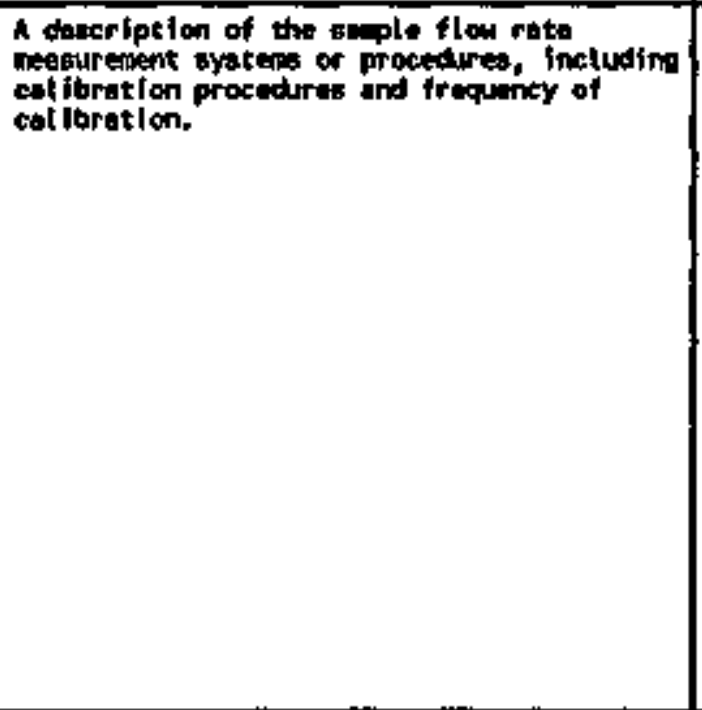 & & & \\
\hline
\end{tabular}

${ }^{1}$ Kurz is a trademark of Kurz Instruments, Inc. 


\begin{tabular}{|c|c|c|c|c|c|}
\hline \multicolumn{2}{|c|}{$\begin{array}{l}\text { APPLICABLE REGULATIOH, STAHDARD, OR } \\
\text { REQUIRENEHT }\end{array}$} & \multirow{2}{*}{ 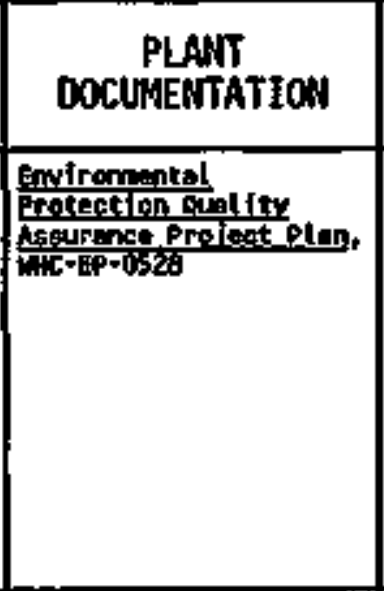 } & \multirow{2}{*}{$\begin{array}{c}\text { DOES SYSTEN } \\
\text { MEET } \\
\text { REQUIREPENTS? } \\
\text { Y }\end{array}$} & \multirow{2}{*}{ 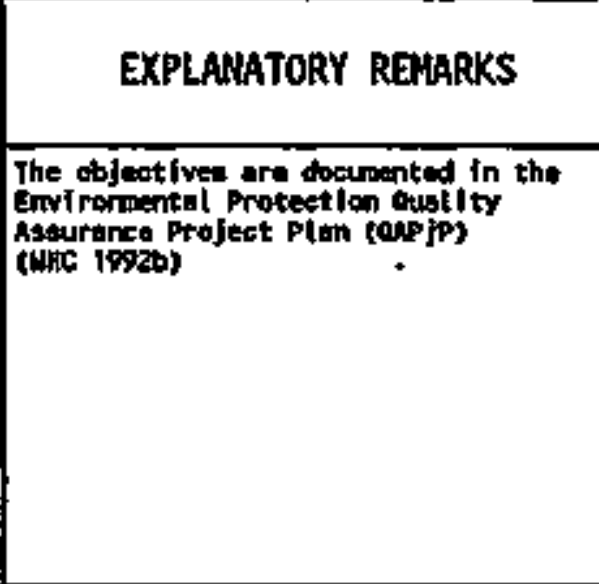 } & \multirow[b]{2}{*}{ 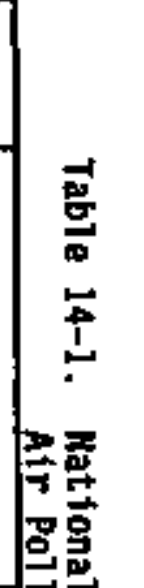 } \\
\hline 4.4 & 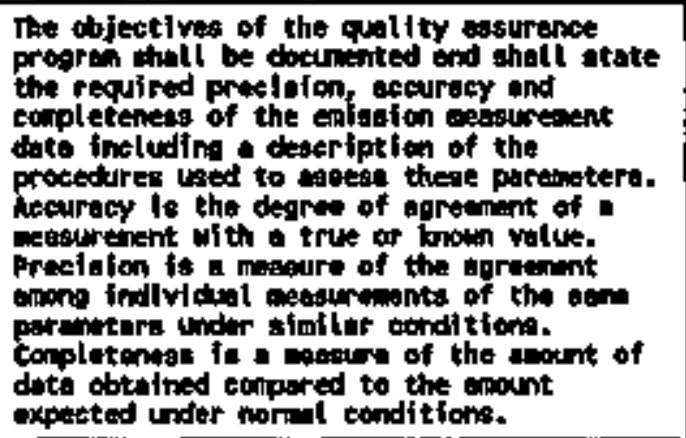 & & & & \\
\hline 4.5 & 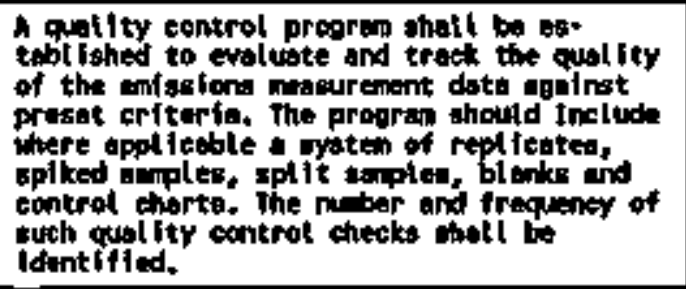 & 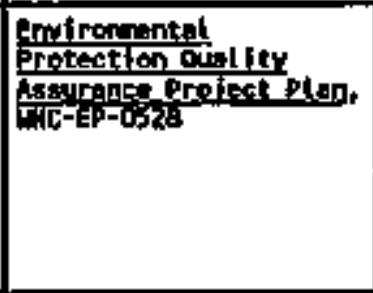 & & 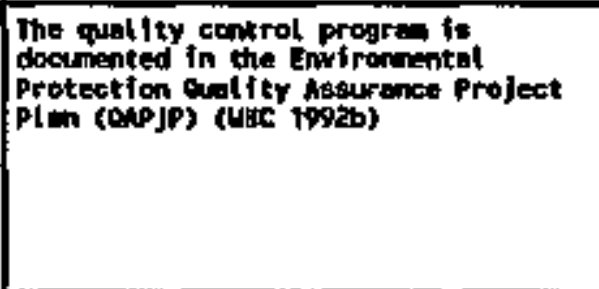 & \multirow{3}{*}{ 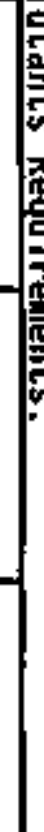 } \\
\hline 4.6 & 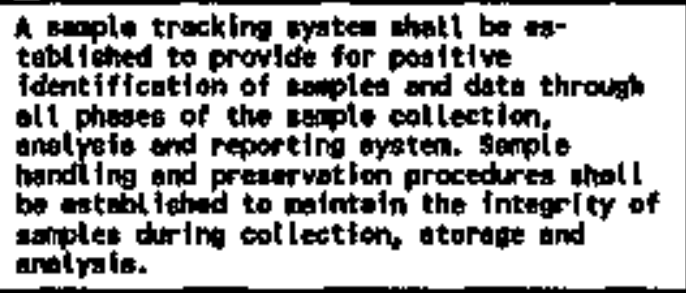 & 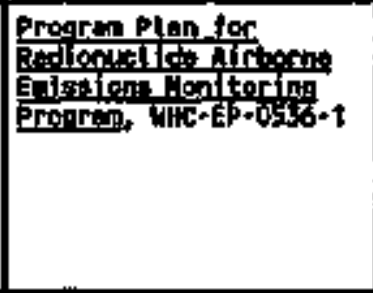 & $Y_{40}$ & $\begin{array}{l}\text { Refor to section } 6.2 .2 \text { of } \\
\text { WidC-EP-0536-1. }\end{array}$ & \\
\hline 4.7 & 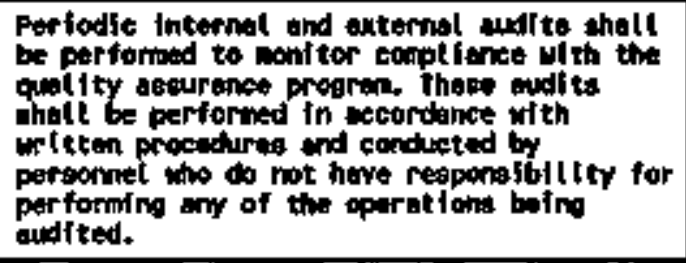 & 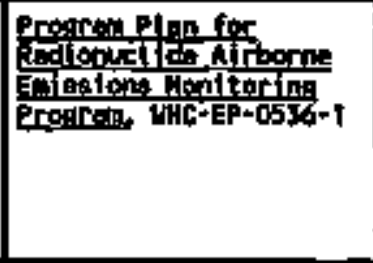 & Yet & Hefor to section 0.0 of WHC-EP-0536-1. & \\
\hline
\end{tabular}




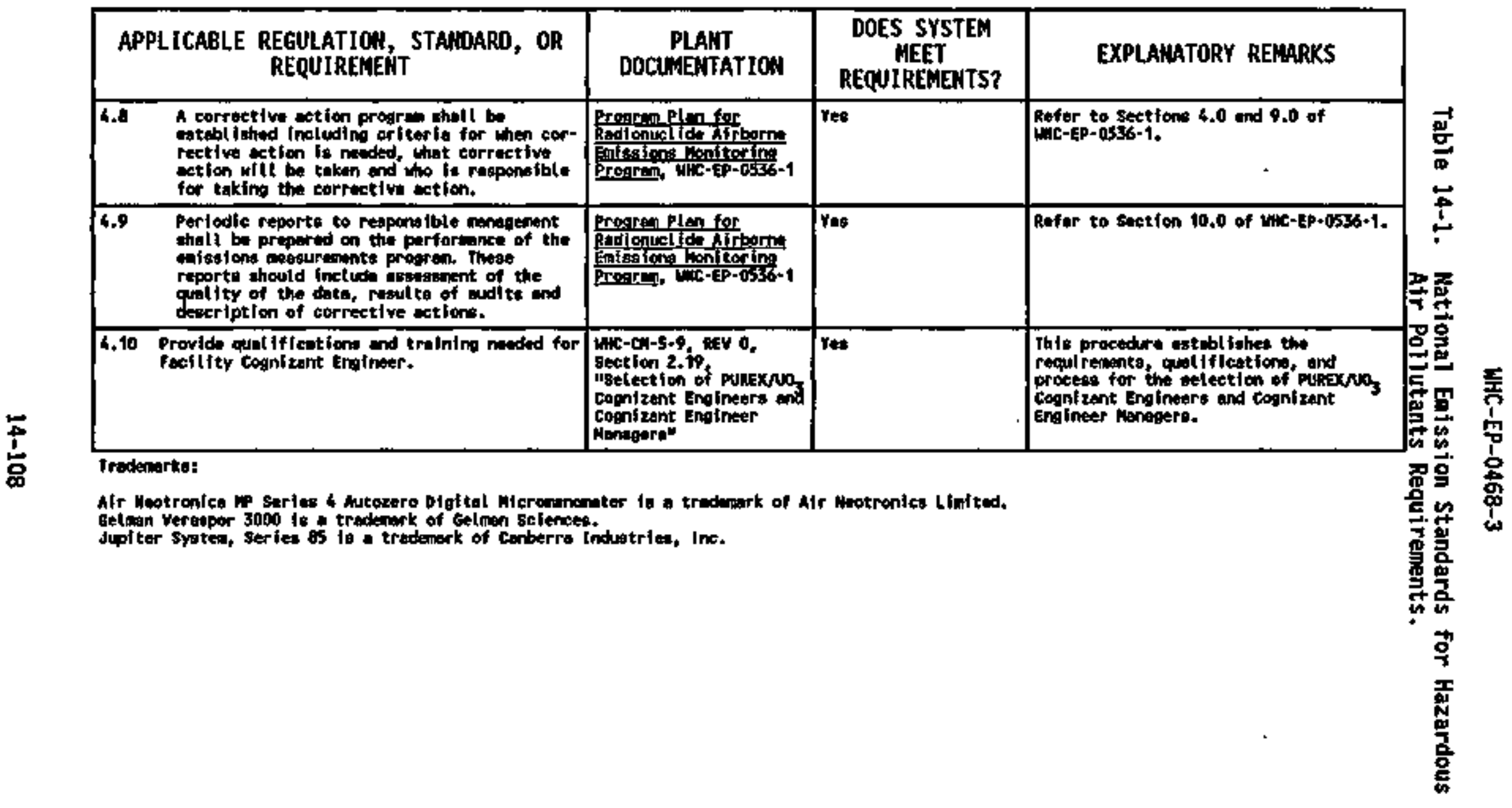




\begin{tabular}{|c|c|c|c|}
\hline $\begin{array}{l}\text { APPLICABLE REGULATION, STANDARD, OR } \\
\text { REQUIREMENT }\end{array}$ & $\begin{array}{c}\text { PLANT } \\
\text { DOCUMEATATIOH }\end{array}$ & $\begin{array}{l}\text { DOES SYSTEM } \\
\text { MEET } \\
\text { REQUIREHENTS? }\end{array}$ & EXPLAMATORY REMARKS \\
\hline 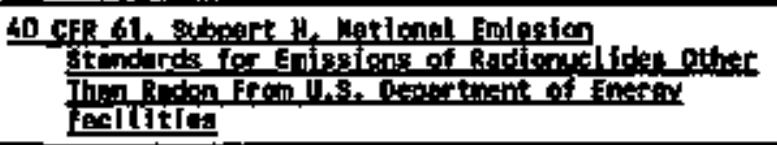 & & & - \\
\hline
\end{tabular}




\begin{tabular}{|c|c|c|c|}
\hline $\begin{array}{l}\text { APPLICABLE REGULATION, STAHDARO, OR } \\
\text { REQUIREHENT }\end{array}$ & $\begin{array}{c}\text { PLANT } \\
\text { OOCUHAEHTATIOH }\end{array}$ & $\begin{array}{l}\text { DOES SYSTEM } \\
\text { MEET } \\
\text { REQUIREMENTS? }\end{array}$ & EXPLANATORY REHARKS \\
\hline 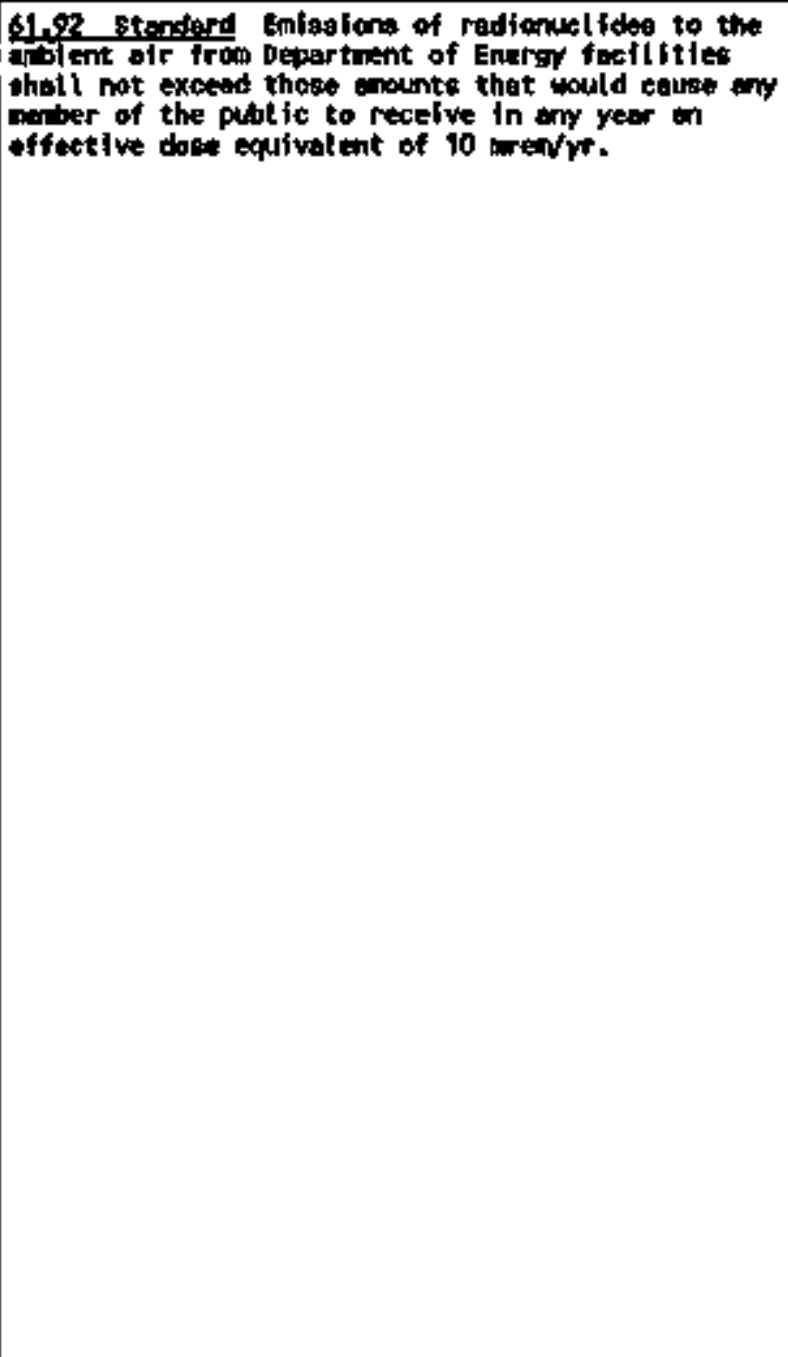 & & Yes & 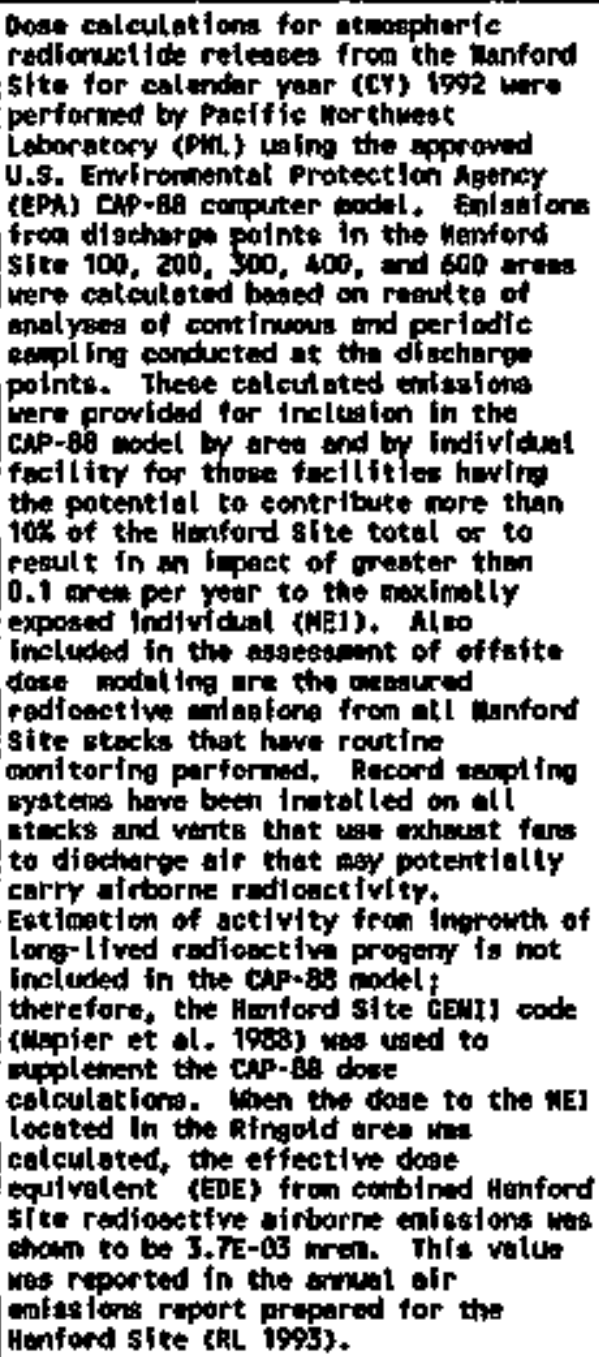 \\
\hline
\end{tabular}




\begin{tabular}{|c|c|c|c|}
\hline $\begin{array}{l}\text { APPLICABLE REGULATION, STANDARD, OR } \\
\text { REQUIREMENT }\end{array}$ & $\begin{array}{c}\text { PLANT } \\
\text { OOCLNEMTATION }\end{array}$ & $\begin{array}{c}\text { DOES SYSTEM } \\
\text { MEET } \\
\text { REQUIRENENTS? }\end{array}$ & EXPLAMATORY REMARKS \\
\hline 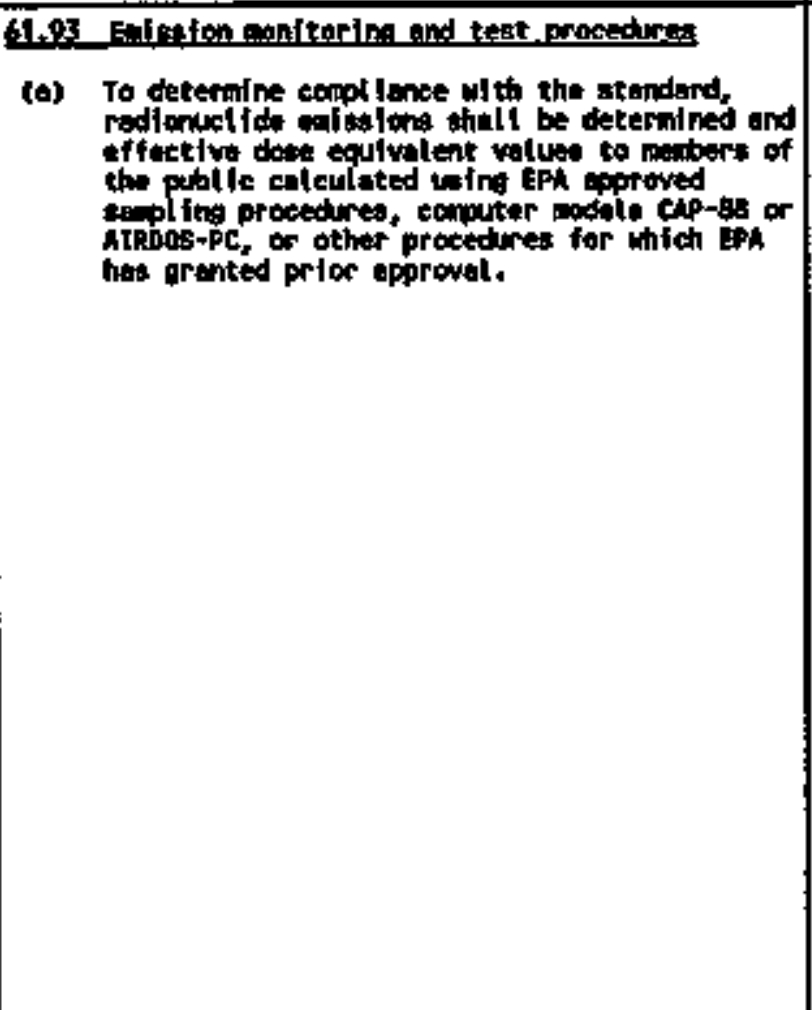 & & res & 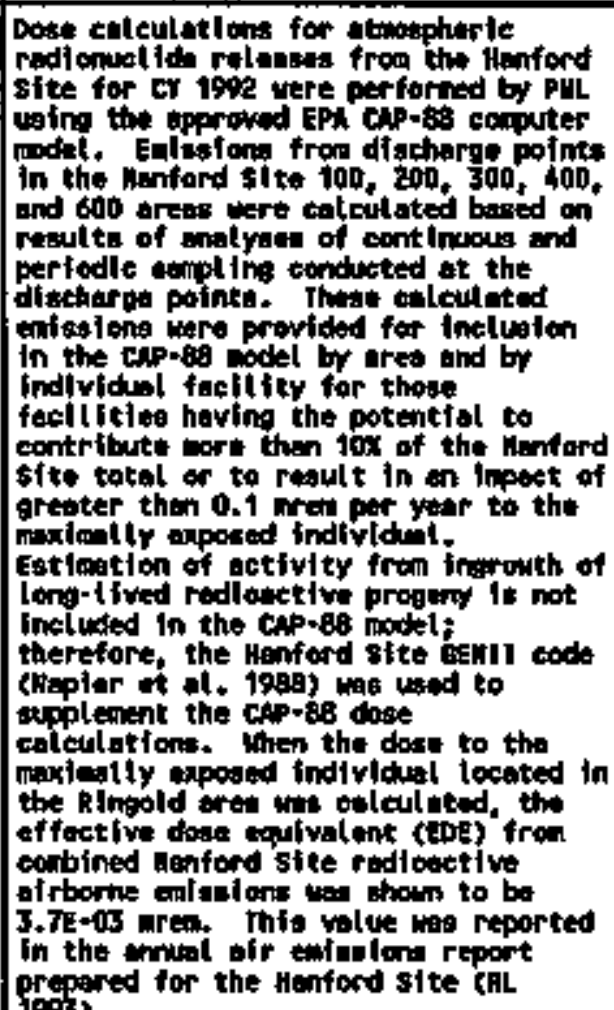 \\
\hline
\end{tabular}




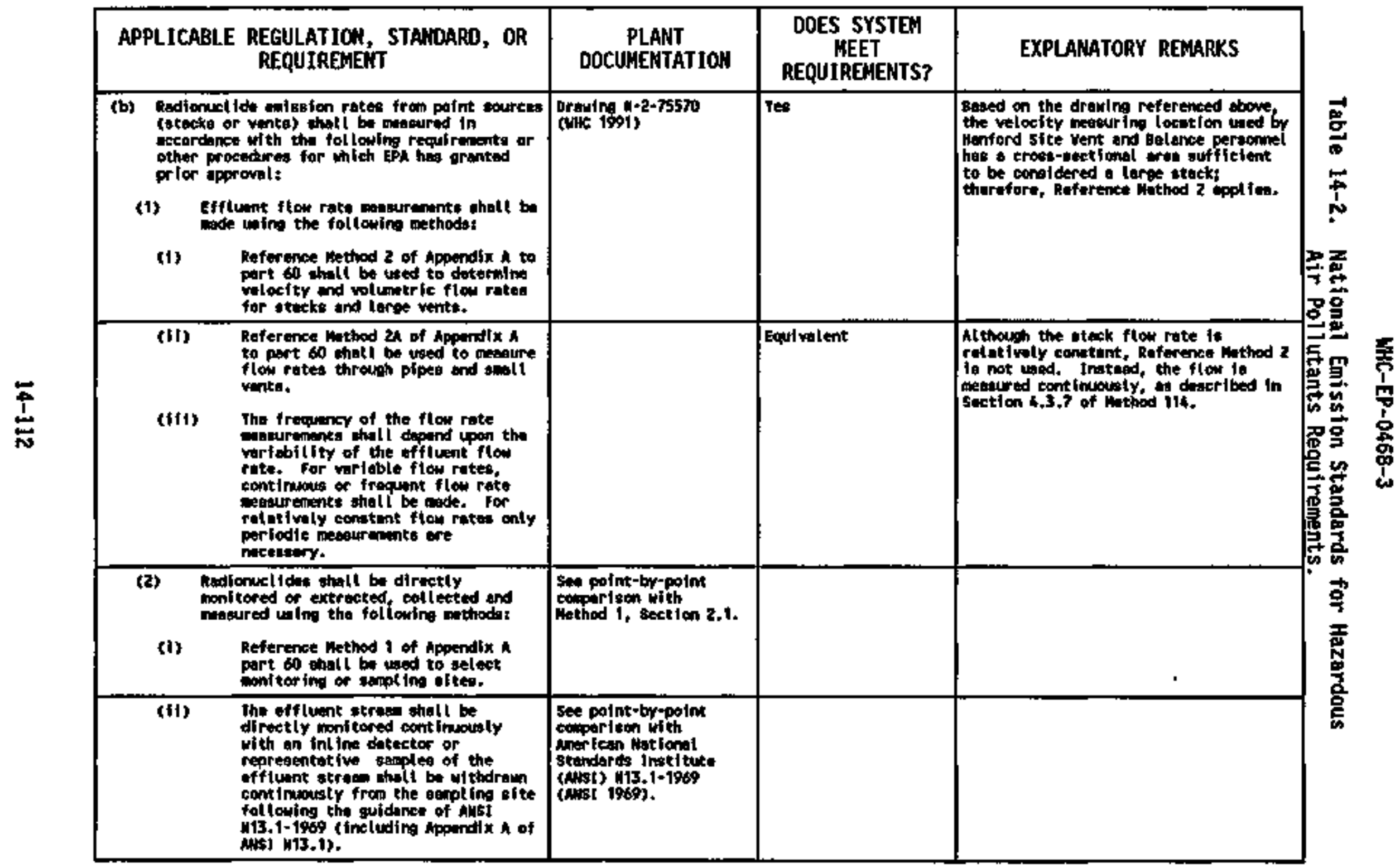




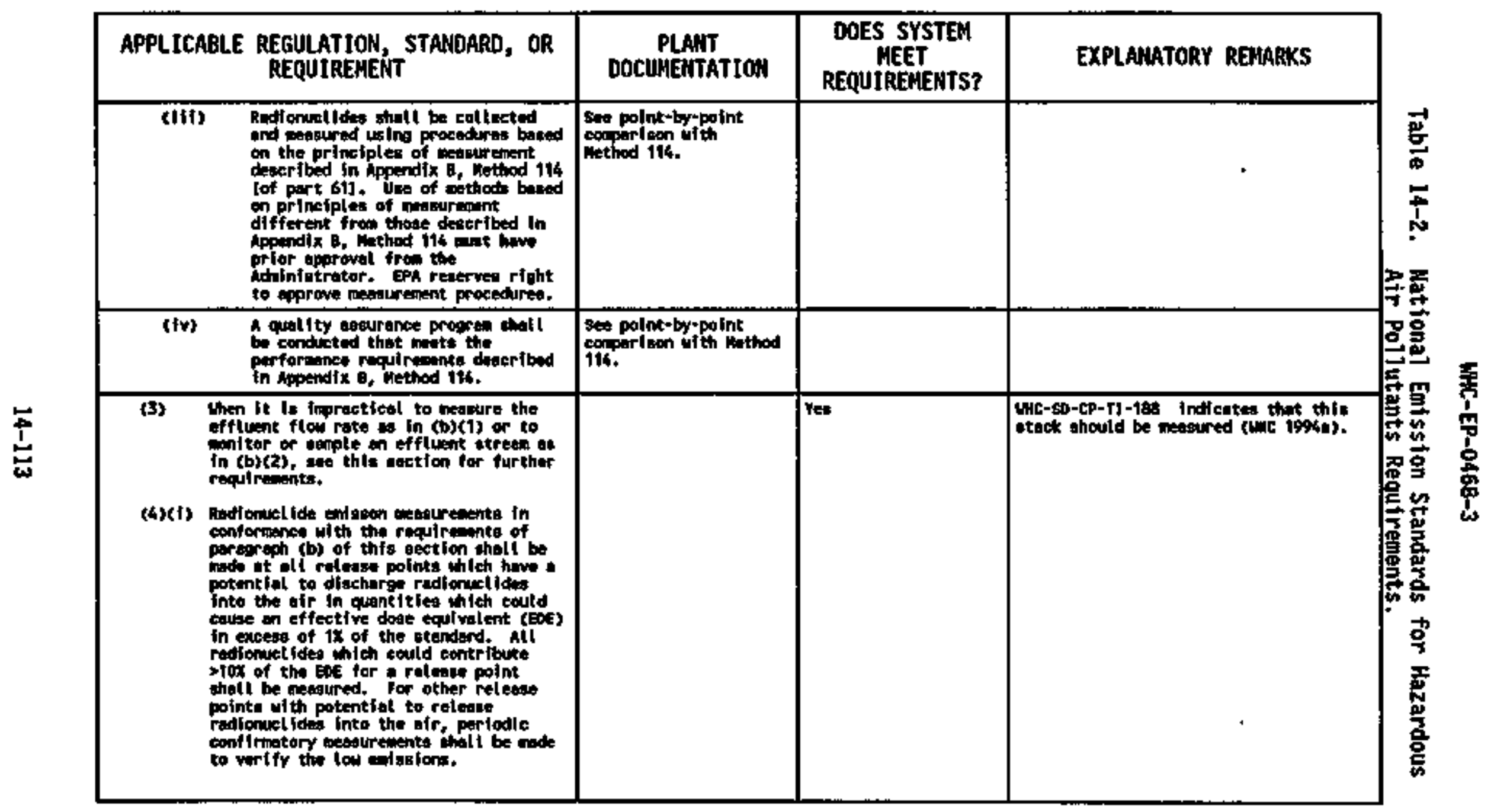




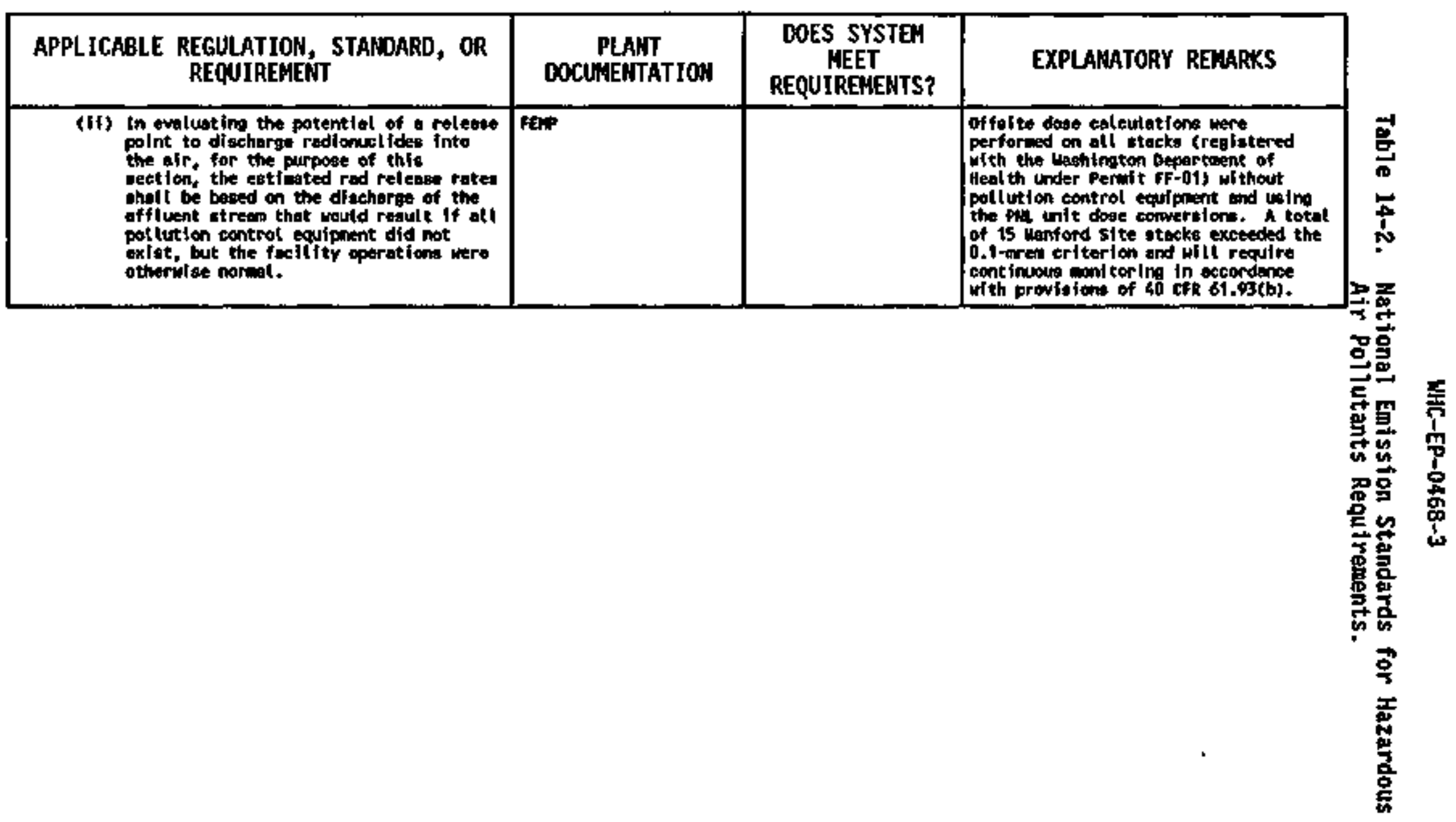




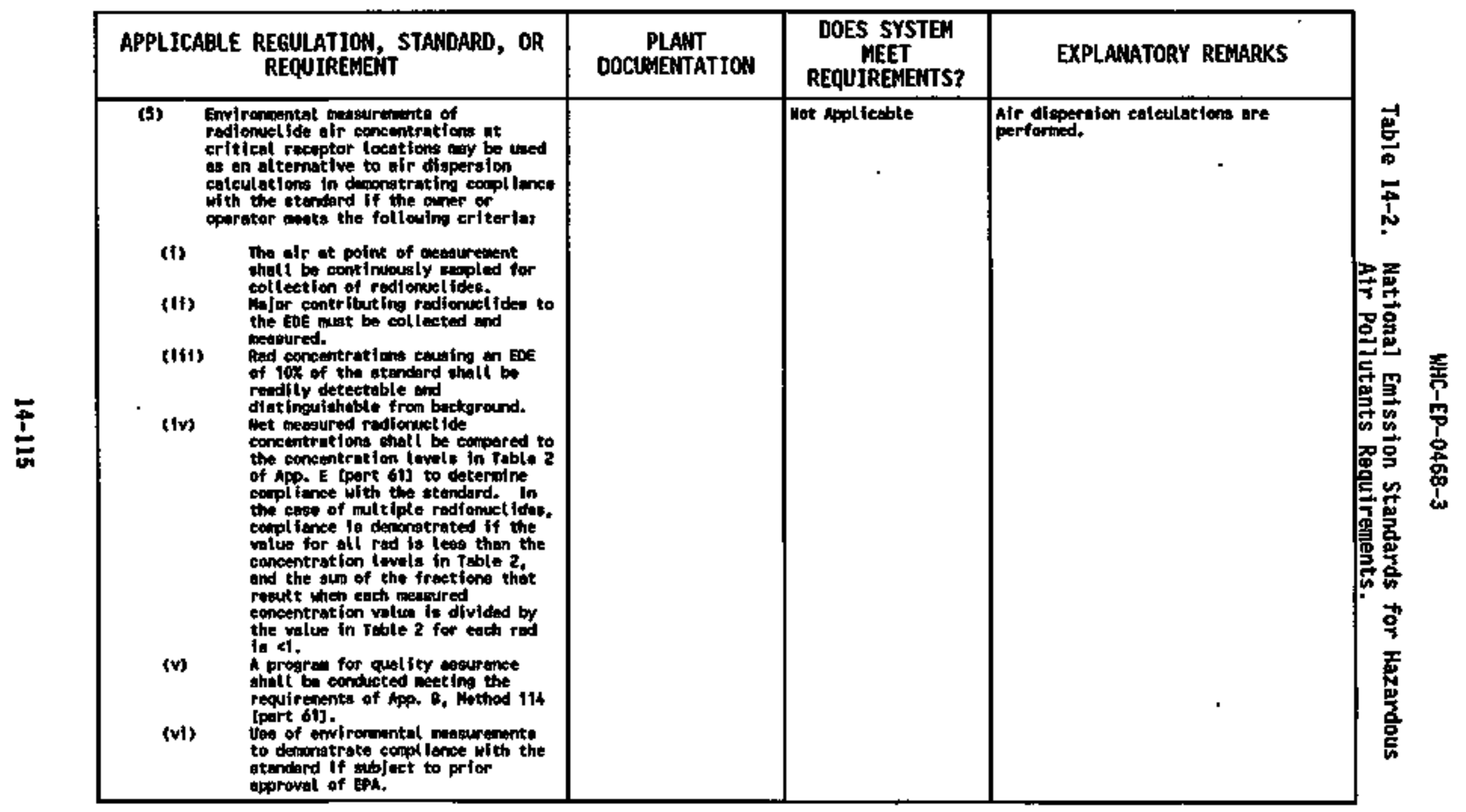




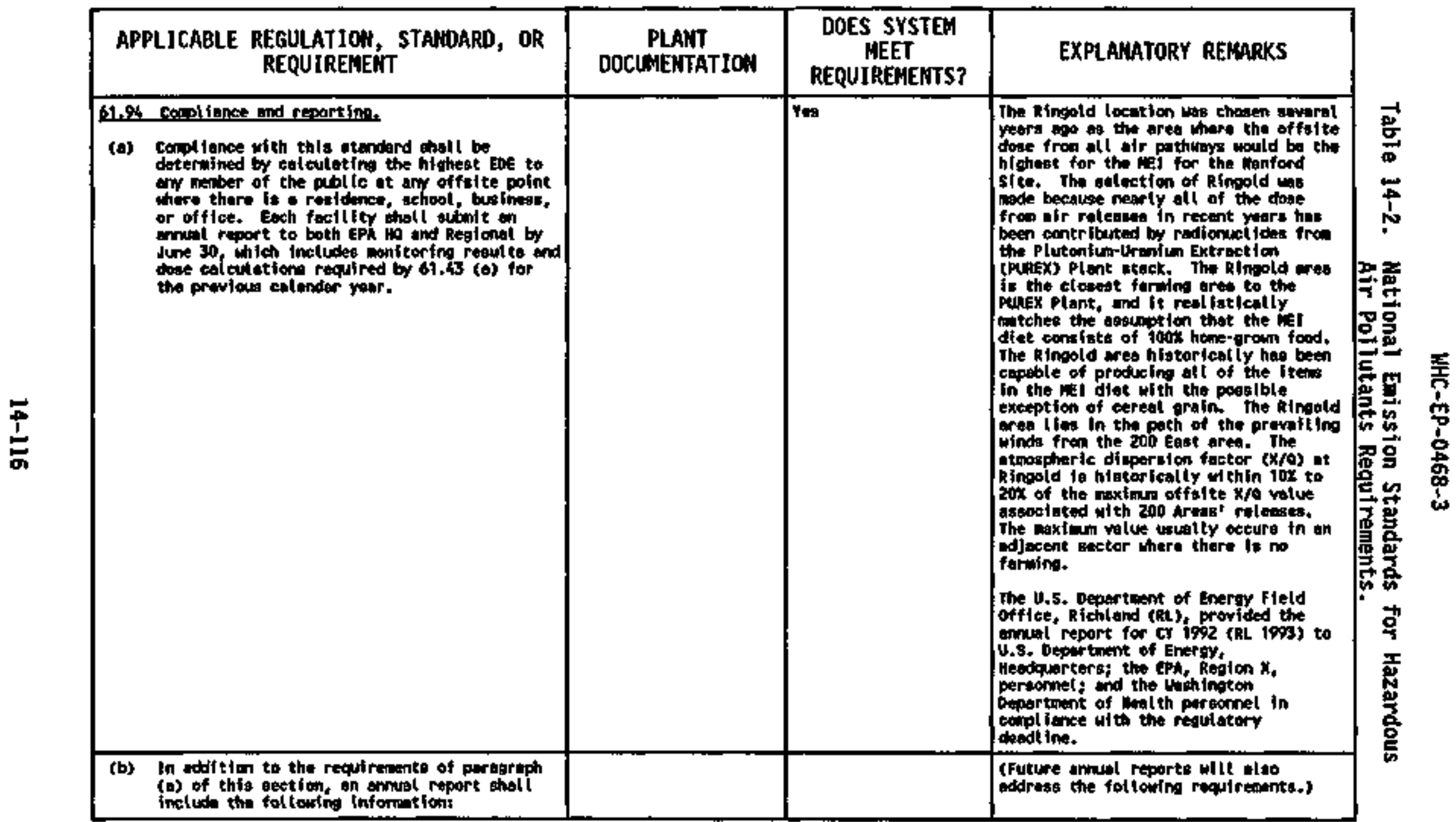




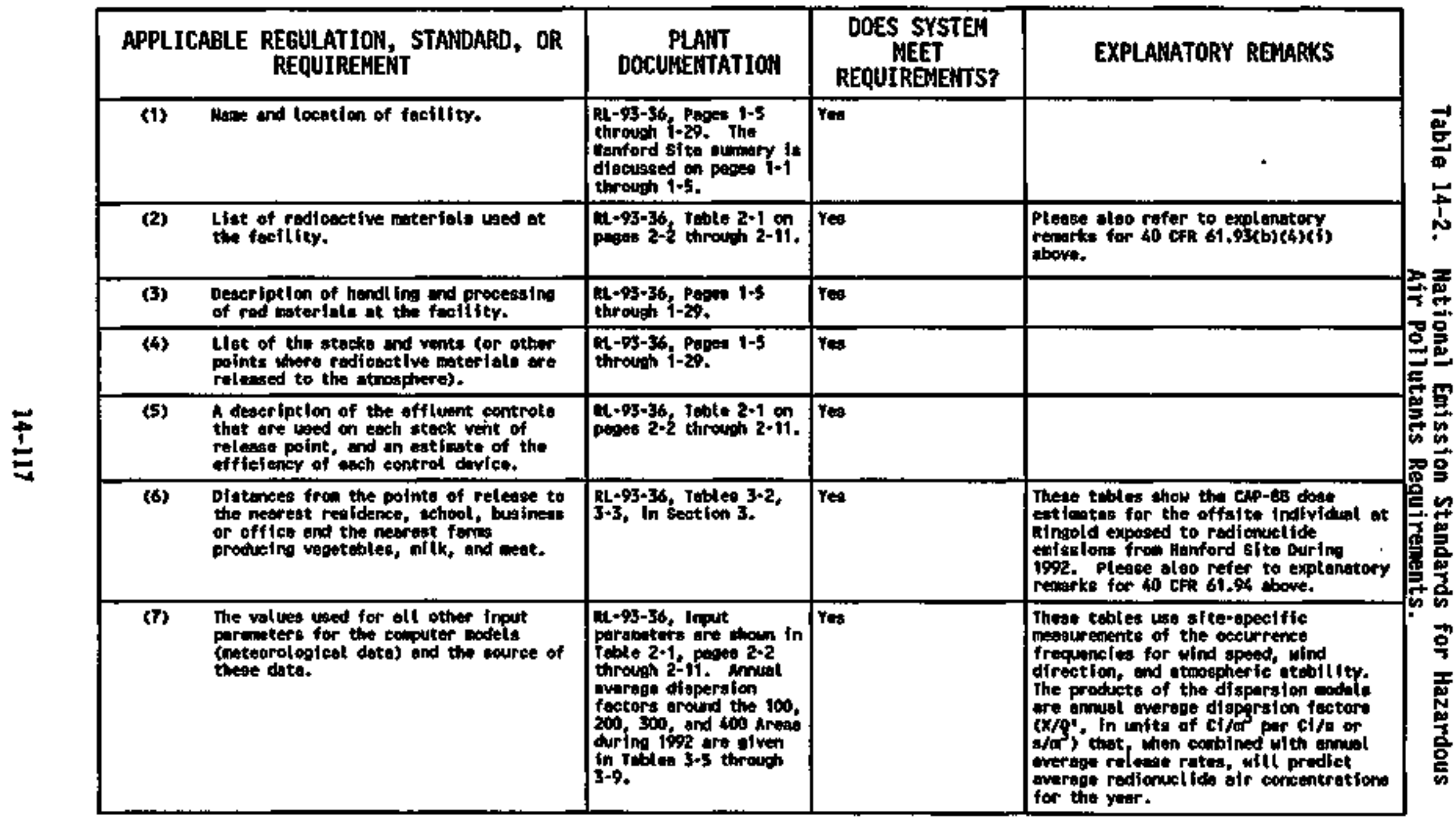




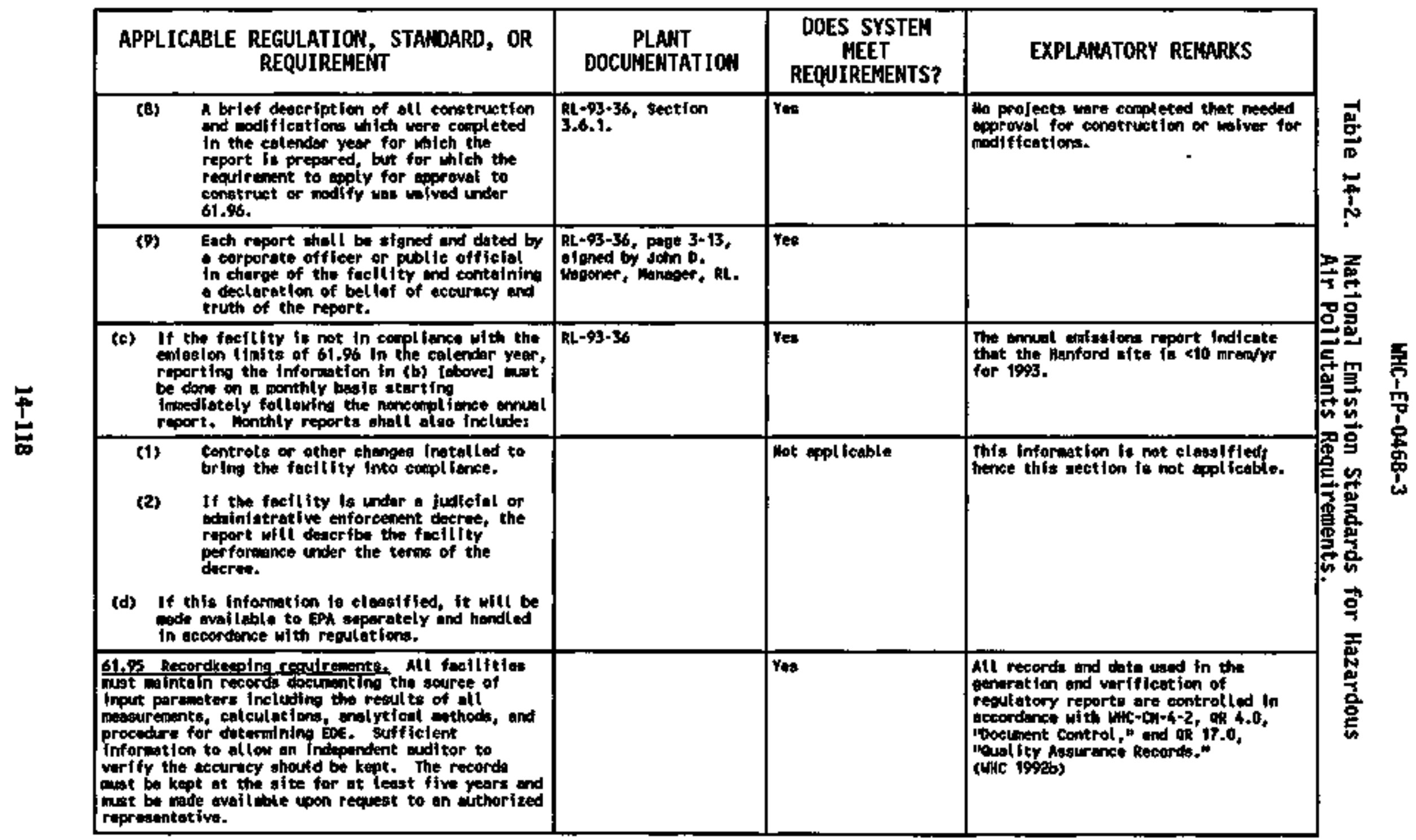




\begin{tabular}{|c|c|c|c|}
\hline $\begin{array}{l}\text { APPLICABLE REGELATION, STANDARD, OR } \\
\text { REQUIREMEAT }\end{array}$ & $\begin{array}{l}\text { PLANT } \\
\text { DOCUNEATATION }\end{array}$ & $\begin{array}{c}\text { DOES SYSTEH } \\
\text { MEET } \\
\text { REQUIREKENTS? }\end{array}$ & EXPLAMATORY REMARKS \\
\hline 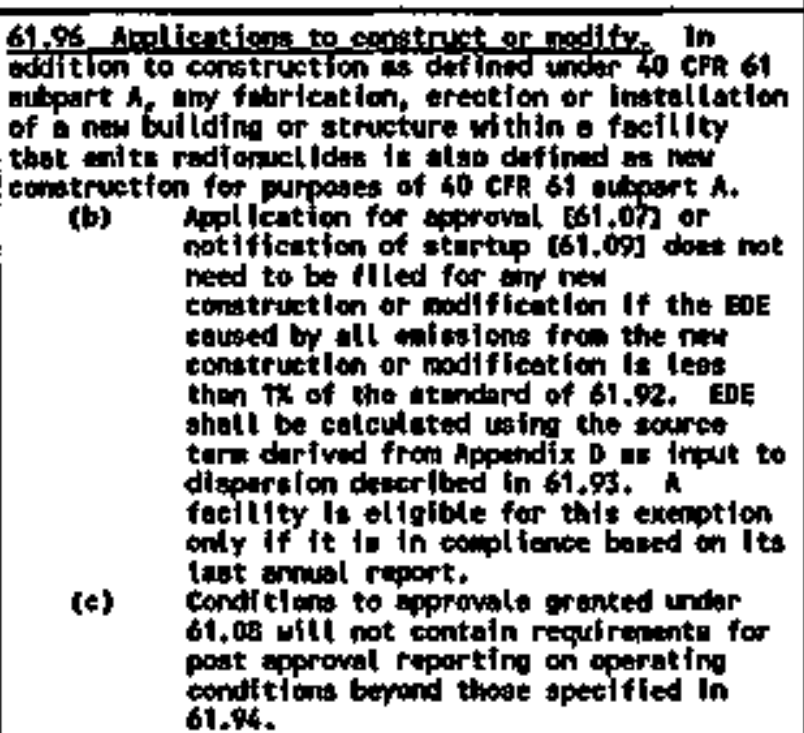 & & not eppl liesble & \\
\hline 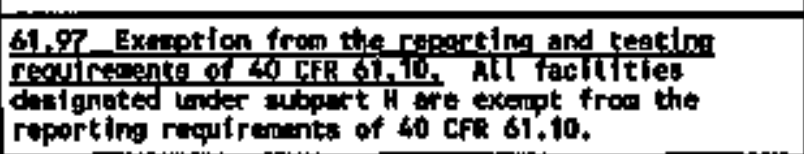 & & & \\
\hline
\end{tabular}




\begin{tabular}{|c|c|c|c|}
\hline $\begin{array}{l}\text { APPLICABLE REGULATIOH, STANDARD, OR } \\
\text { REQUIRENENT }\end{array}$ & $\begin{array}{c}\text { PLANT } \\
\text { DOCUNENTATIOAM }\end{array}$ & $\begin{array}{c}\text { DOES SYSTEH } \\
\text { HEET } \\
\text { REQUIREMENTS? }\end{array}$ & EXPLANATORY REMARKS \\
\hline 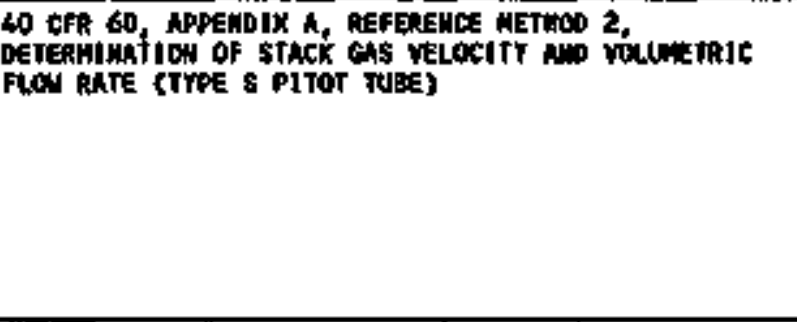 & & & 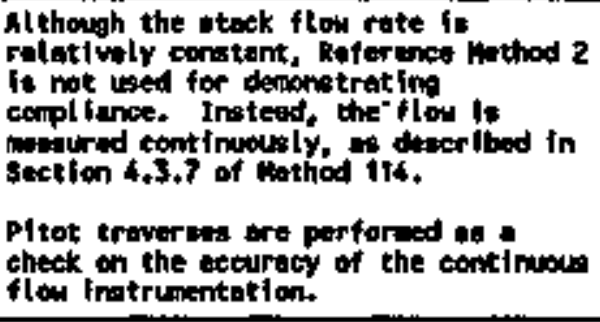 \\
\hline 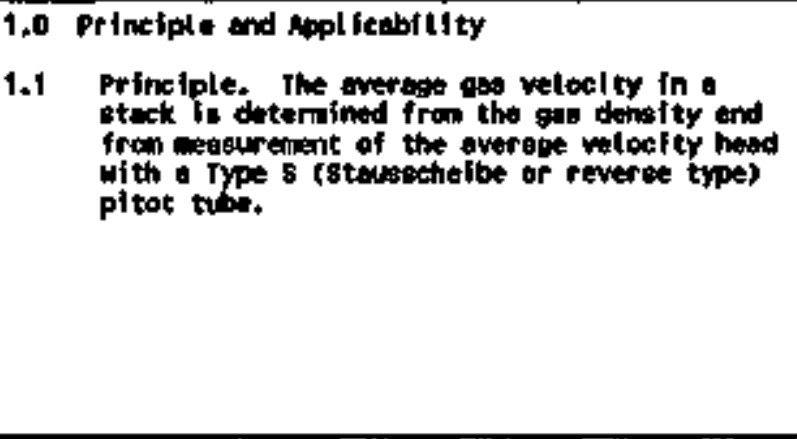 & 7-64-56 (w+1C t9930). & & 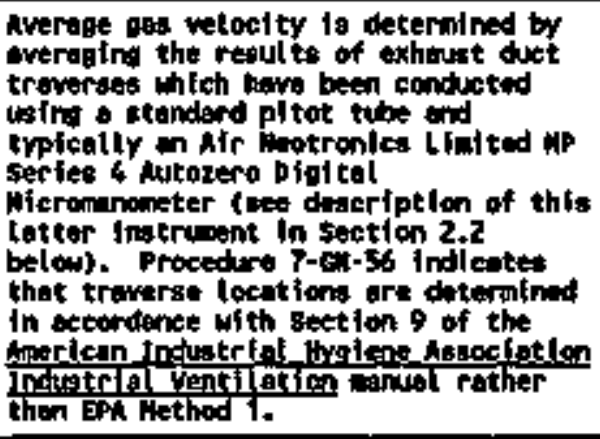 \\
\hline 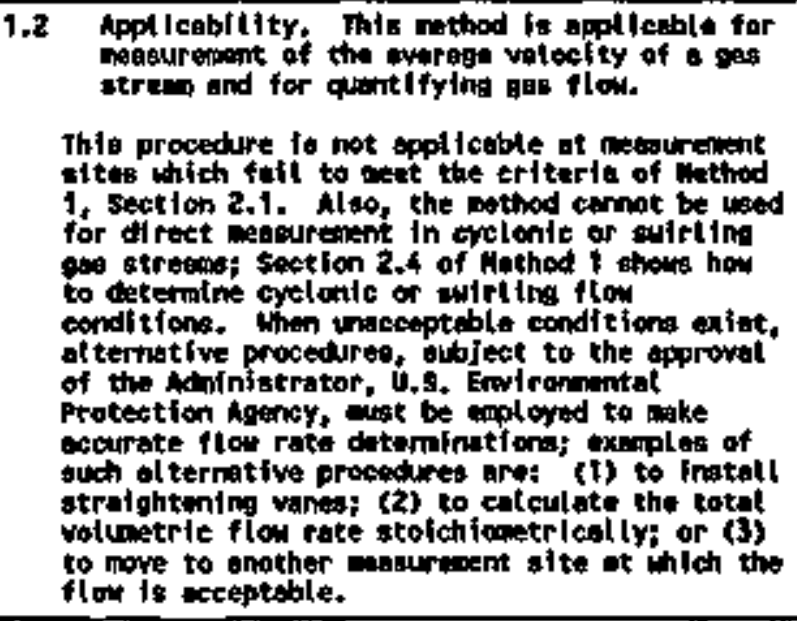 & & & 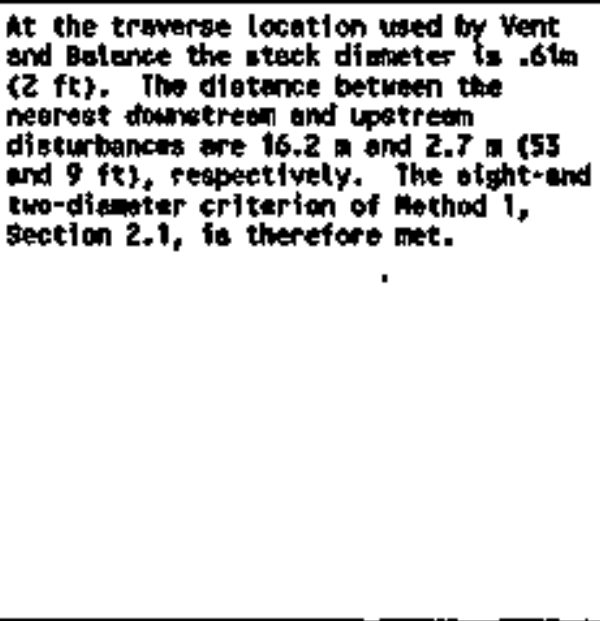 \\
\hline
\end{tabular}




\begin{tabular}{|c|c|c|c|}
\hline $\begin{array}{l}\text { APPLICABLE REGULATION, STANDARD, OR } \\
\text { REQUIREMENT }\end{array}$ & $\begin{array}{c}\text { PLART } \\
\text { DOCUNERTATION }\end{array}$ & $\begin{array}{c}\text { DOES SYSTEM } \\
\text { MEET } \\
\text { REQUIRENENTS? }\end{array}$ & EXPLAMATORY REMARKS \\
\hline 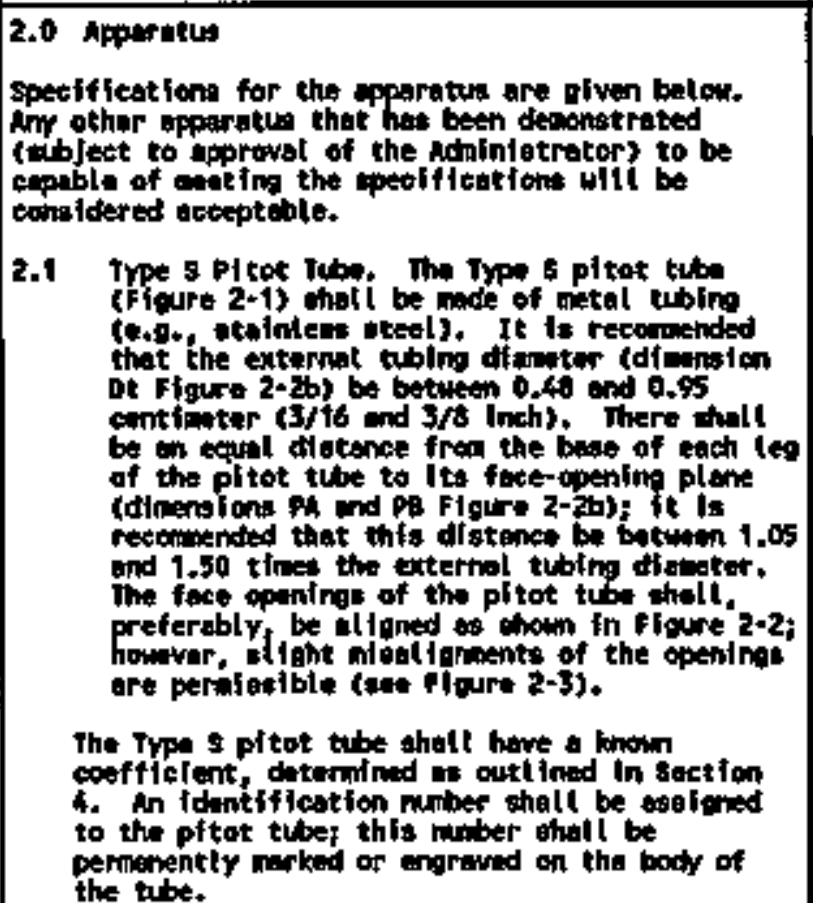 & & & - \\
\hline
\end{tabular}




\begin{tabular}{|c|c|c|c|}
\hline $\begin{array}{l}\text { APPLICABLE REGULLATICN, STAMDAPD, OR } \\
\text { REQUIREMENT }\end{array}$ & $\begin{array}{c}\text { PLART } \\
\text { DOCLNEKTATION }\end{array}$ & $\begin{array}{l}\text { DOES SYSTEM } \\
\text { MEET } \\
\text { REQUIREHENTS? }\end{array}$ & EXPLAMATORY REMARKS \\
\hline 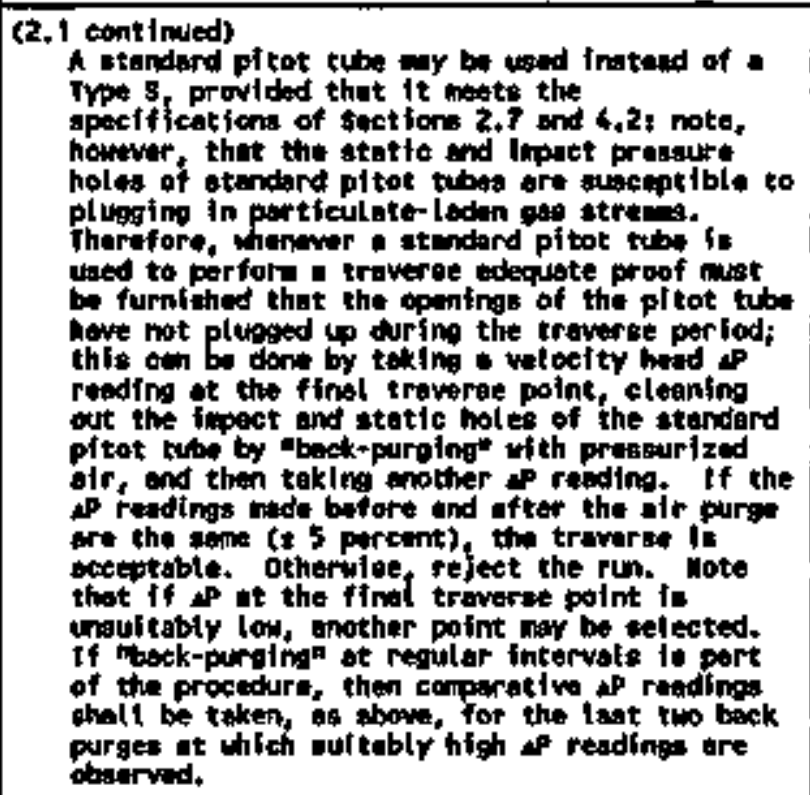 & $7-6 n-56$ & & 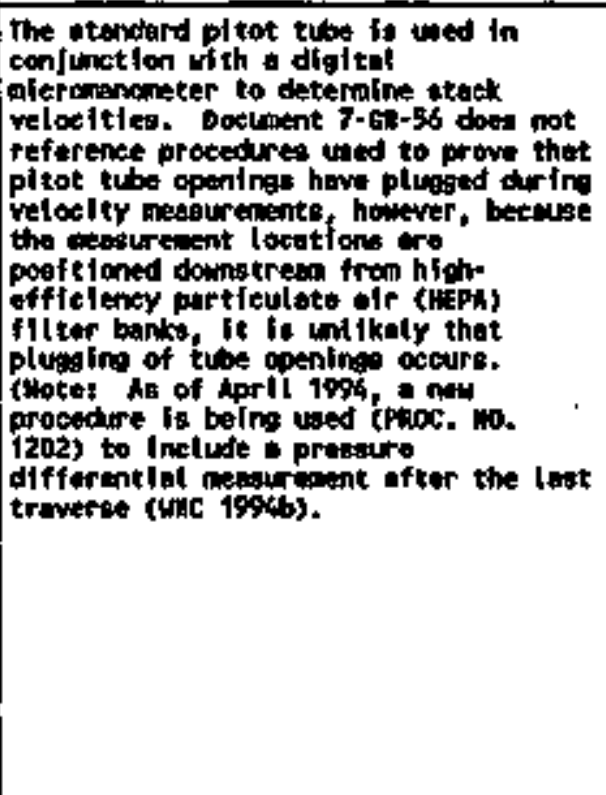 \\
\hline
\end{tabular}




\begin{tabular}{|c|c|c|c|}
\hline $\begin{array}{l}\text { APPLICABLE REGULATION, STANDARD, OR } \\
\text { REQUIREMENT }\end{array}$ & $\begin{array}{l}\text { PLANT } \\
\text { DOCUNERTATION }\end{array}$ & $\begin{array}{c}\text { DOES SYSTEN } \\
\text { MEET } \\
\text { REQNIREMENTS? }\end{array}$ & EXPLANATORY REPARKS \\
\hline 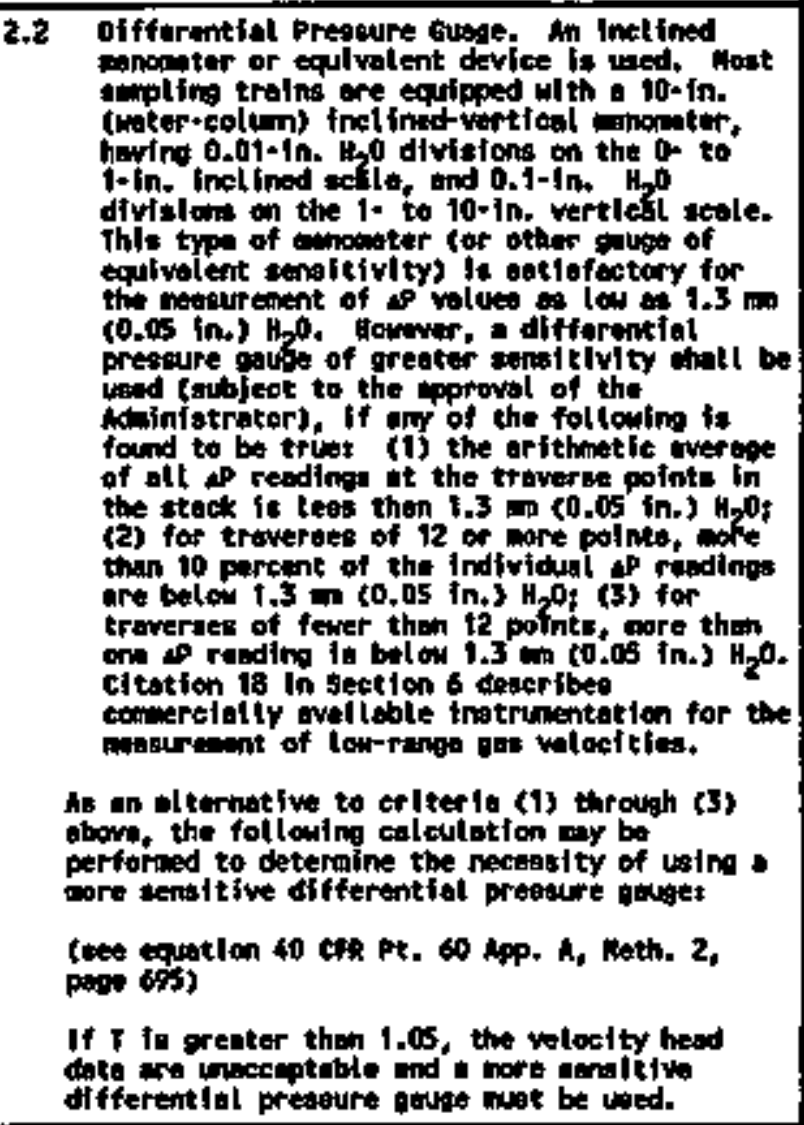 & & & . \\
\hline
\end{tabular}




\begin{tabular}{|c|c|c|c|}
\hline $\begin{array}{l}\text { APPLICABLE REGULATIOH, STAHDARO, OR } \\
\text { REOJIREAEWT }\end{array}$ & $\begin{array}{l}\text { PLAHT } \\
\text { DOCLNEHTATIOH }\end{array}$ & $\begin{array}{l}\text { DOES SYSTEK } \\
\text { MEET } \\
\text { REOUIREYETTS? }\end{array}$ & EXPLAKATORY RENARKS \\
\hline 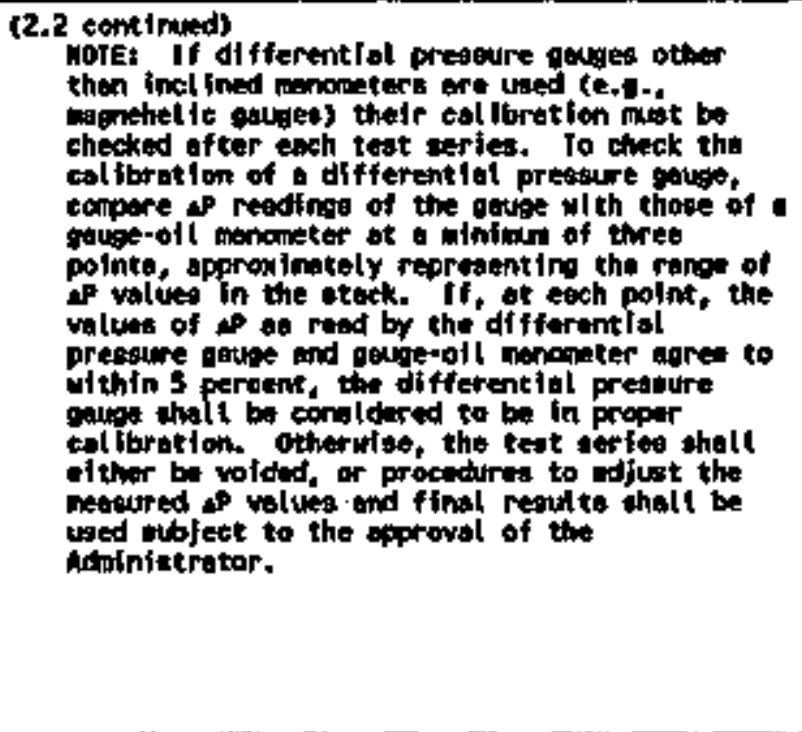 & 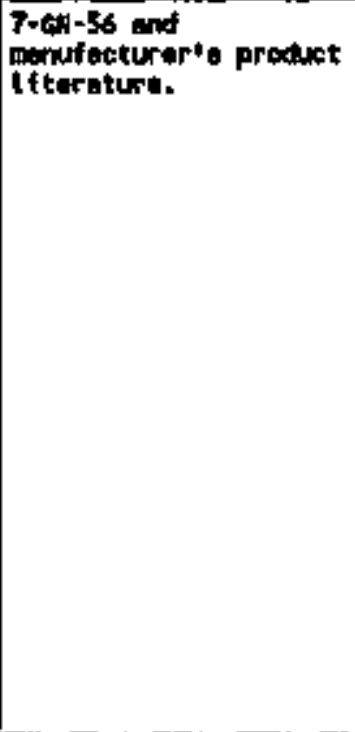 & & 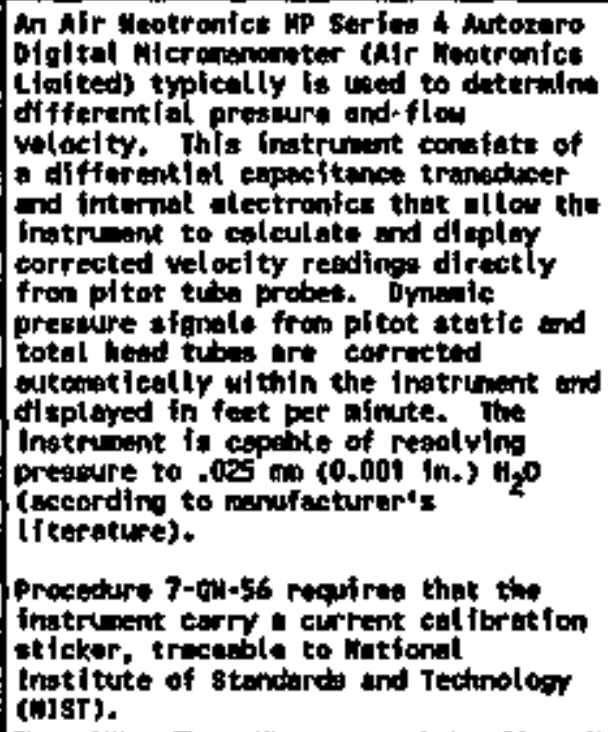 \\
\hline 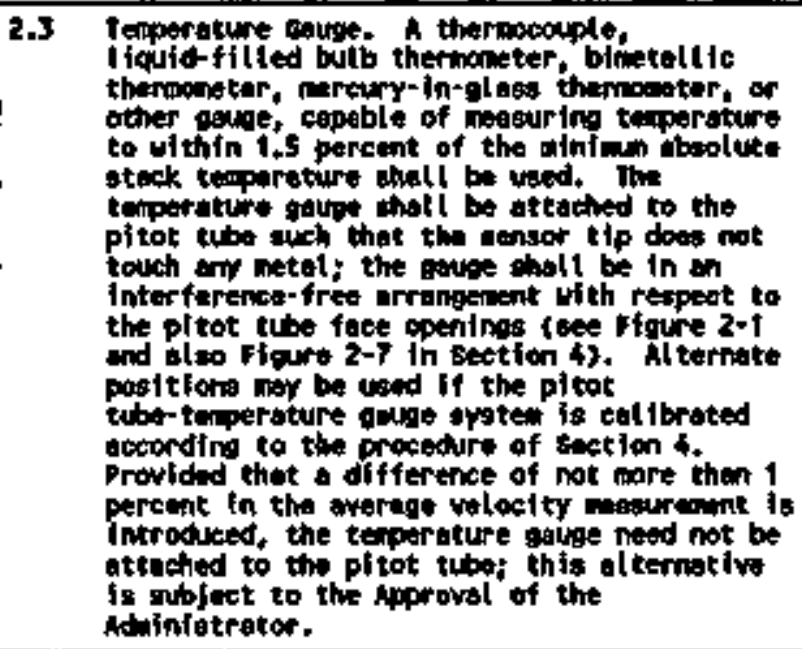 & $7 \cdot \mathrm{ch}-56$ & & 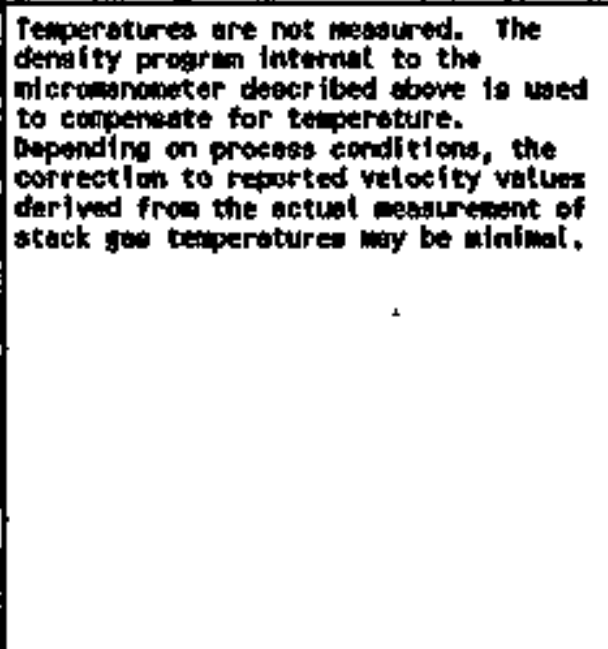 \\
\hline
\end{tabular}




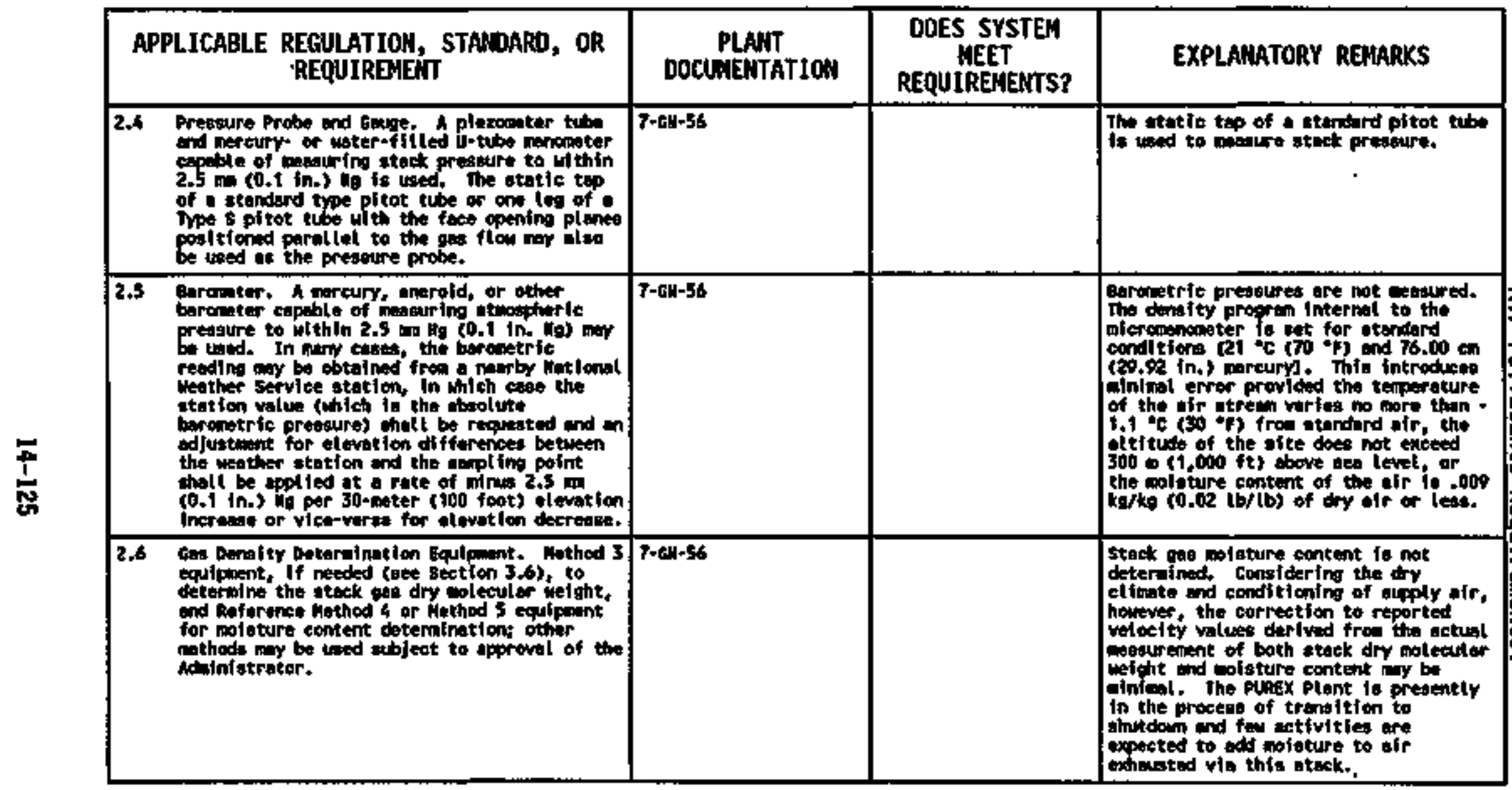




\begin{tabular}{|c|c|c|c|c|}
\hline \multicolumn{2}{|r|}{$\begin{array}{l}\text { APPLICABLE REGULATIGN, STANDAFD, OR } \\
\text { REQUIRENENT }\end{array}$} & \multirow[b]{2}{*}{\begin{tabular}{|c} 
PLANT \\
OOCUMENTATION \\
7 -es-56 \\
\end{tabular}} & \multirow{2}{*}{\begin{tabular}{|c|} 
DOES SYSTEN \\
MEET \\
REQUIREMENTS? \\
wot appl leable
\end{tabular}} & \multirow{2}{*}{ 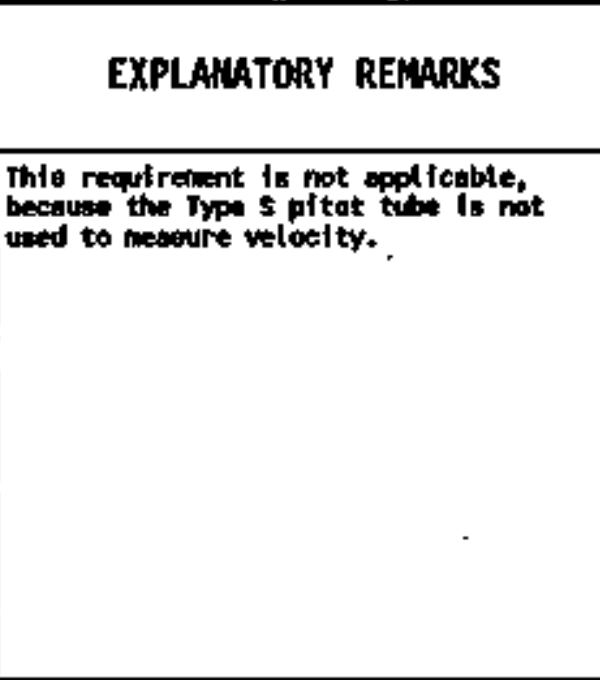 } \\
\hline & 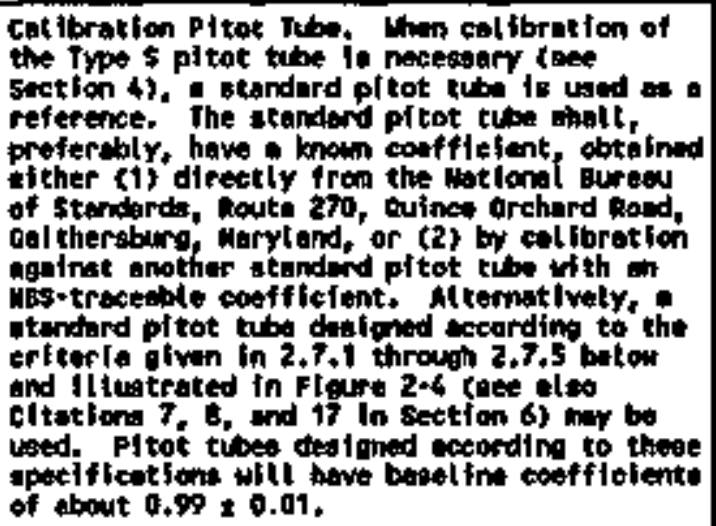 & & & \\
\hline 2.7 .1 & 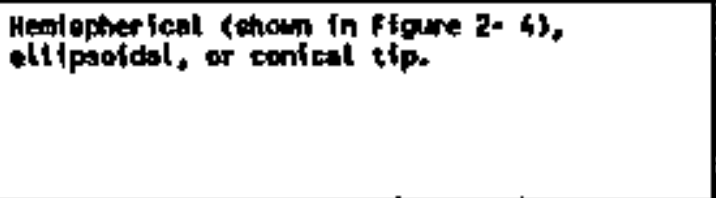 & 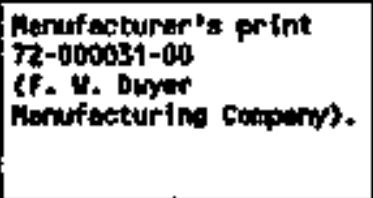 & & 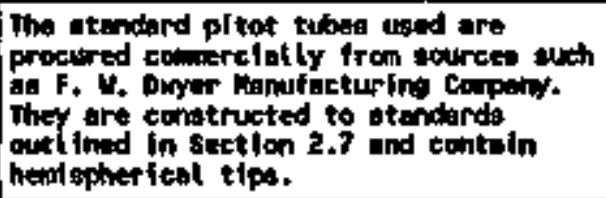 \\
\hline 2.7 .3 & 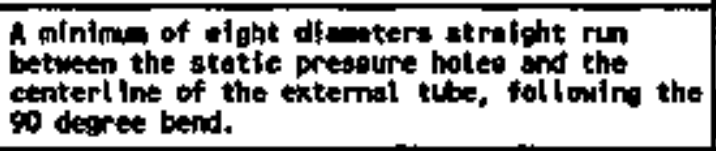 & $\begin{array}{l}\text { Manuf acturer's print } \\
72-000031-00 \\
\text { 6F. W. Dwyer } \\
\text { honufecturing compuns. }\end{array}$ & & 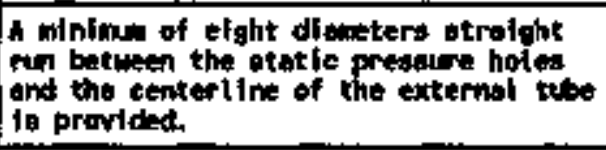 \\
\hline $2,7,4$ & 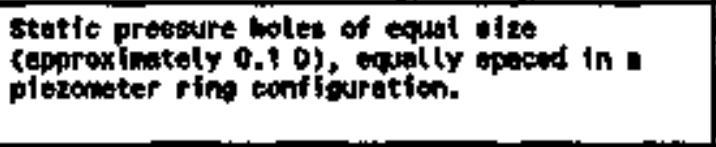 & 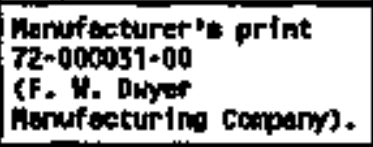 & & $\begin{array}{l}\text { The obove eriteria are net by the } \\
\text { ondifacturet. }\end{array}$ \\
\hline $2,7.5$ & $\begin{array}{l}\text { Winety degree bend, with eurved or mitered } \\
\text { Jinction. }\end{array}$ & 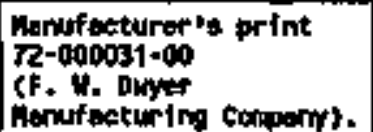 & & $\begin{array}{l}\text { The obowe triteris are ales by the } \\
\text { minufacturer. }\end{array}$ \\
\hline
\end{tabular}




\begin{tabular}{|c|c|c|c|c|c|}
\hline $\begin{array}{l}\text { APPLICABLE REGULATION, STANDARO, OR } \\
\text { REQUIREMENT }\end{array}$ & $\begin{array}{l}\text { PLAMT } \\
\text { DOCUMENTATIOH }\end{array}$ & $\begin{array}{c}\text { DOES SYSTEM } \\
\text { MEET } \\
\text { REQUIREMENTS? }\end{array}$ & EXPLAN & TTORY REMARKS & \\
\hline 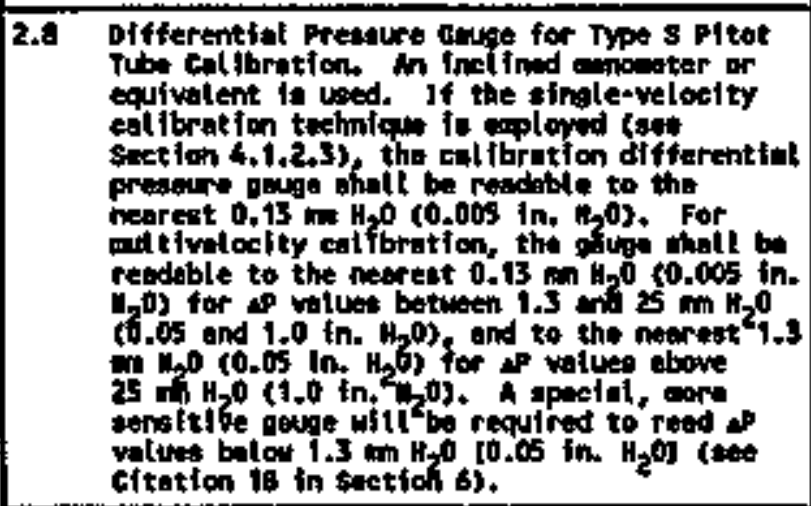 & 7-an-56 & & Hot appl ieable. & The type 8 pitot tube & 疍 \\
\hline 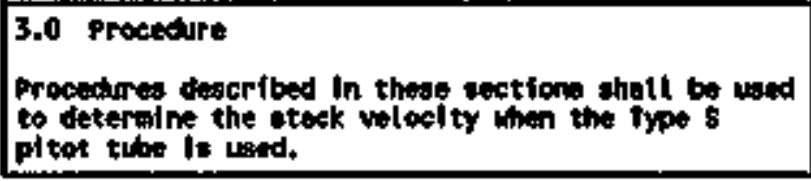 & $7 \cdot 6 n-56$ & & $\begin{array}{l}\text { yot eppliseste. } \\
\text { is not ixed }\end{array}$ & The Type s pltot tubo & n \\
\hline
\end{tabular}




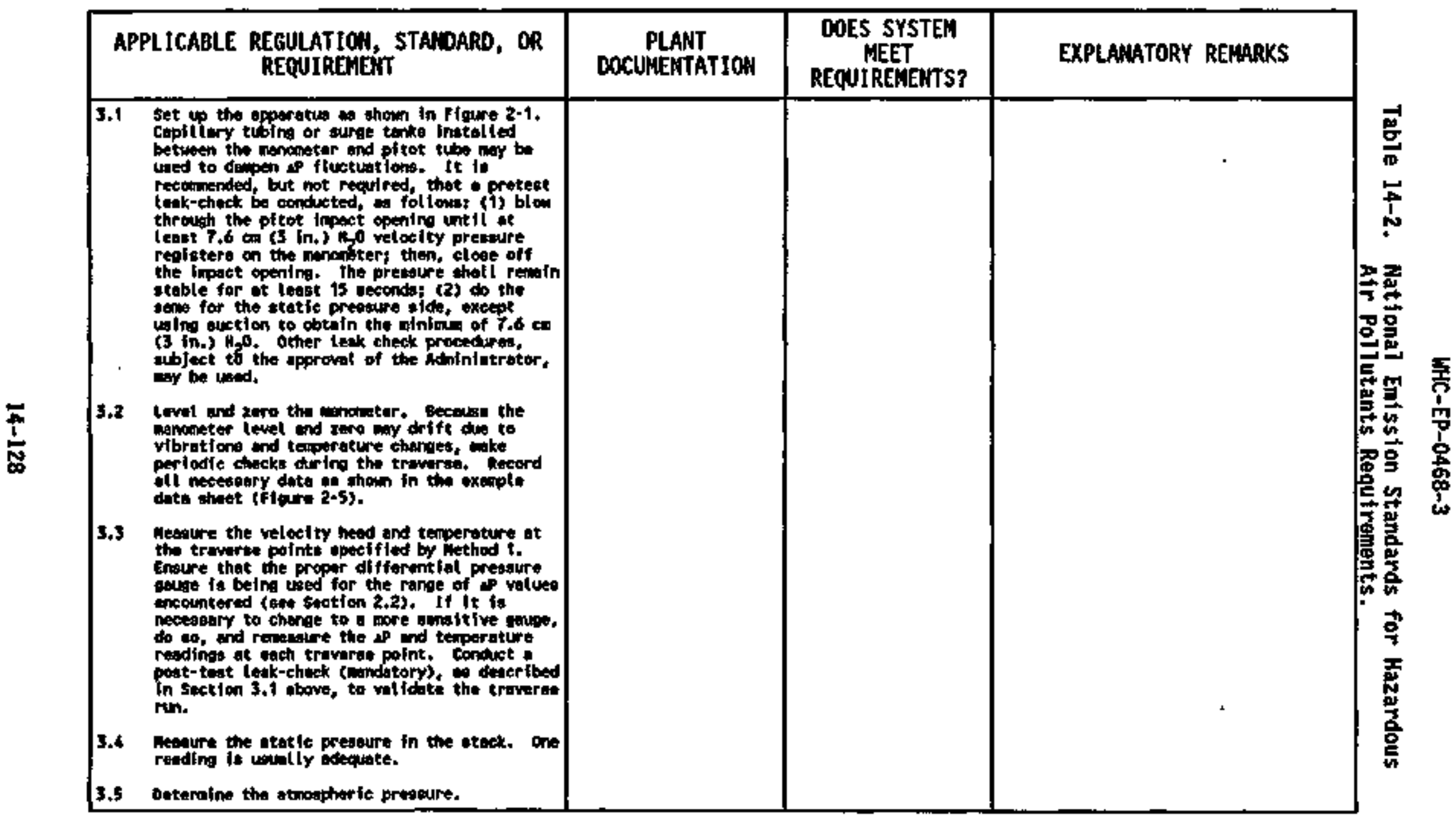




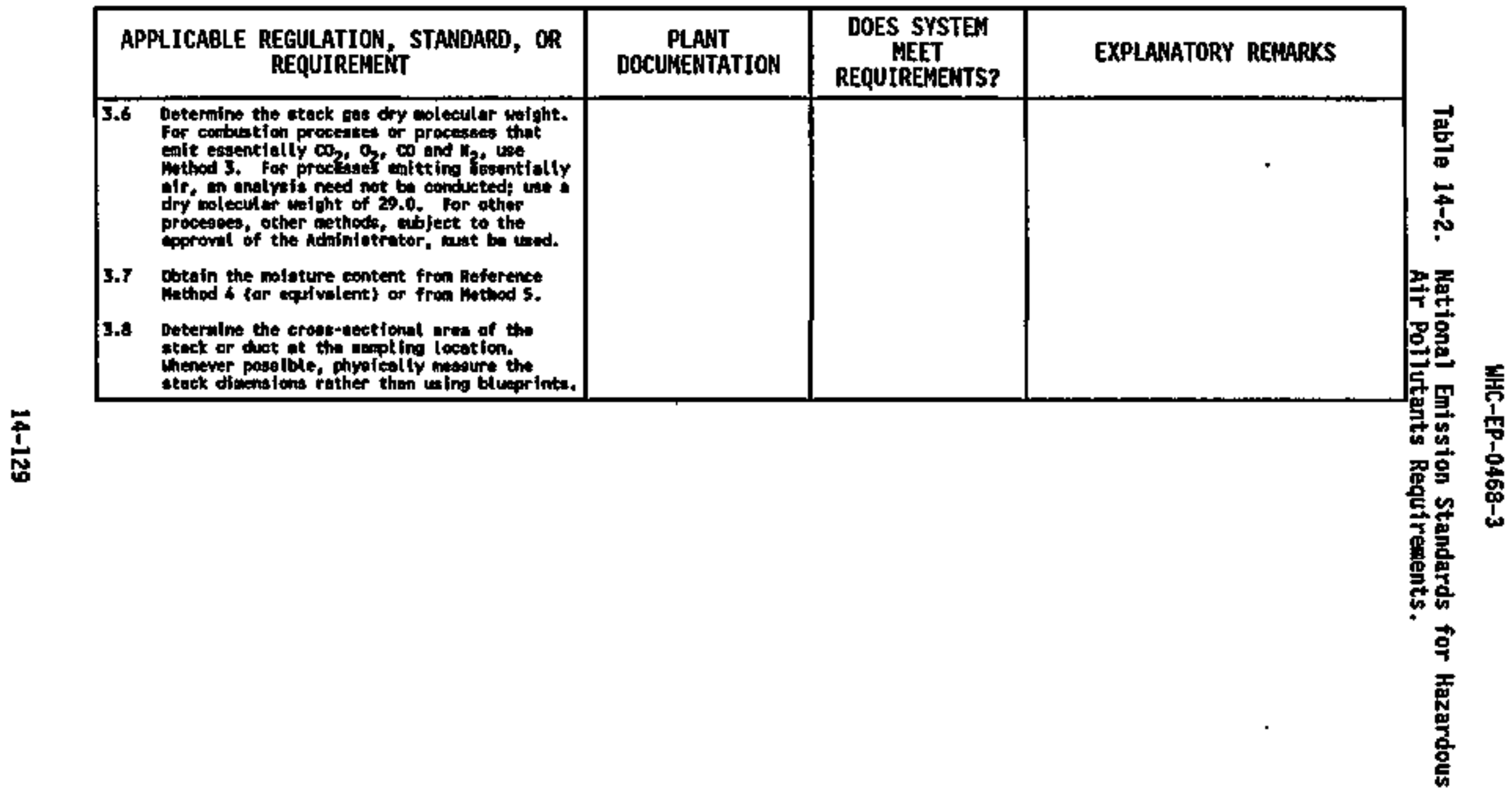




\begin{tabular}{|c|c|c|c|}
\hline $\begin{array}{l}\text { APPLICABLE REGULATION, STANOARD, OR } \\
\text { REQUIREMENT }\end{array}$ & $\begin{array}{c}\text { PLANT } \\
\text { DOCUMENTATION }\end{array}$ & $\begin{array}{l}\text { DOES SYSTEK } \\
\text { MEET } \\
\text { REQUIREMEHTS? }\end{array}$ & EXPLAMATORY REFARKS \\
\hline 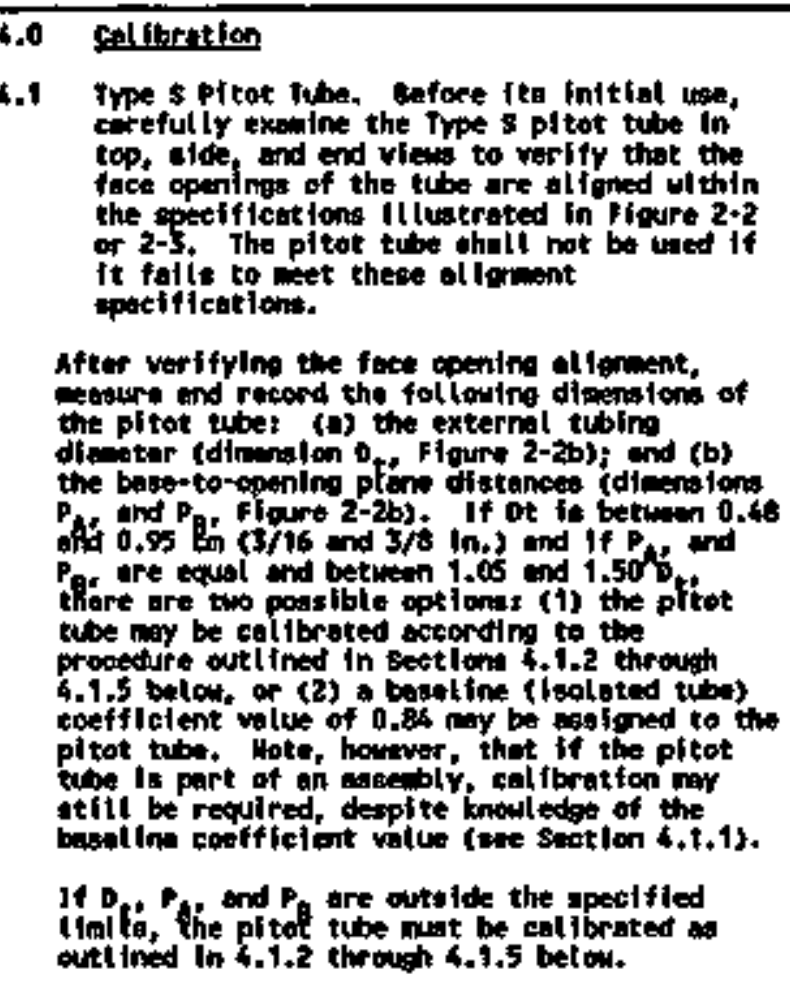 & $7 \cdot 6+10-56$ & & Hot sppt iesbles. \\
\hline
\end{tabular}




\begin{tabular}{|c|c|c|c|}
\hline $\begin{array}{l}\text { APPLICABLE REGULATION, STAMDARD, OR } \\
\text { REQUIREMENT }\end{array}$ & $\begin{array}{l}\text { PLANT } \\
\text { OOCLAHENTATIOH }\end{array}$ & $\begin{array}{l}\text { DOES SYSTEH } \\
\text { MEET } \\
\text { REQUIREYENTS? }\end{array}$ & EXPLANATORY REEARKS \\
\hline 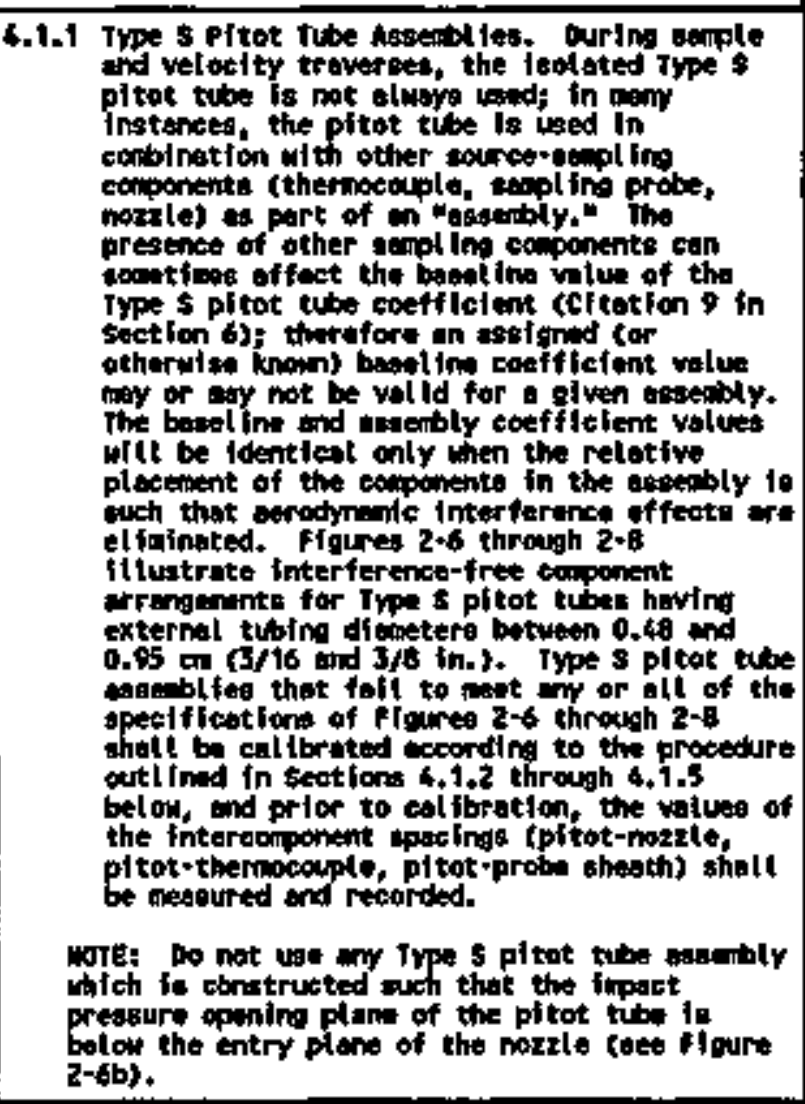 & & & \\
\hline
\end{tabular}




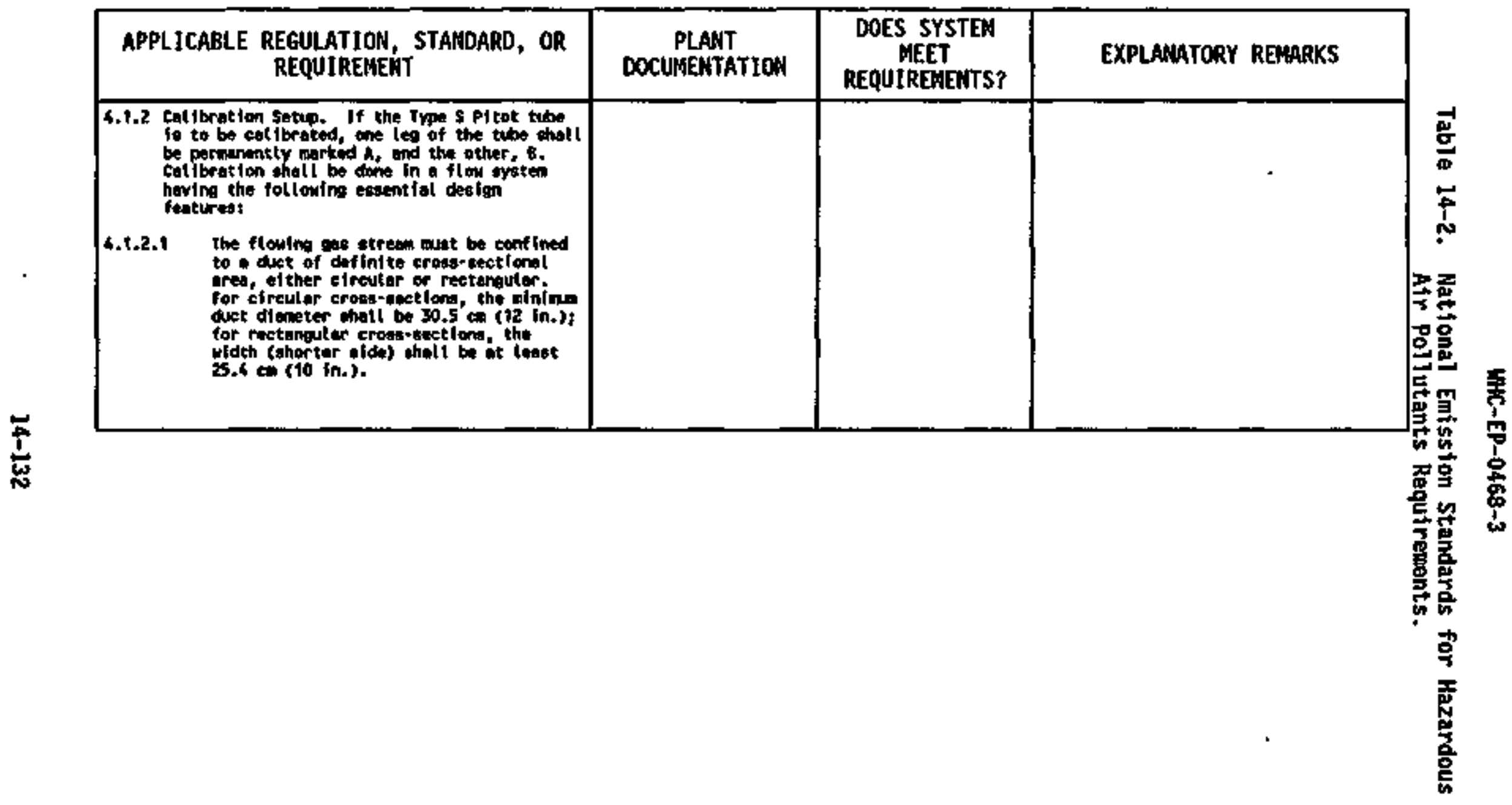




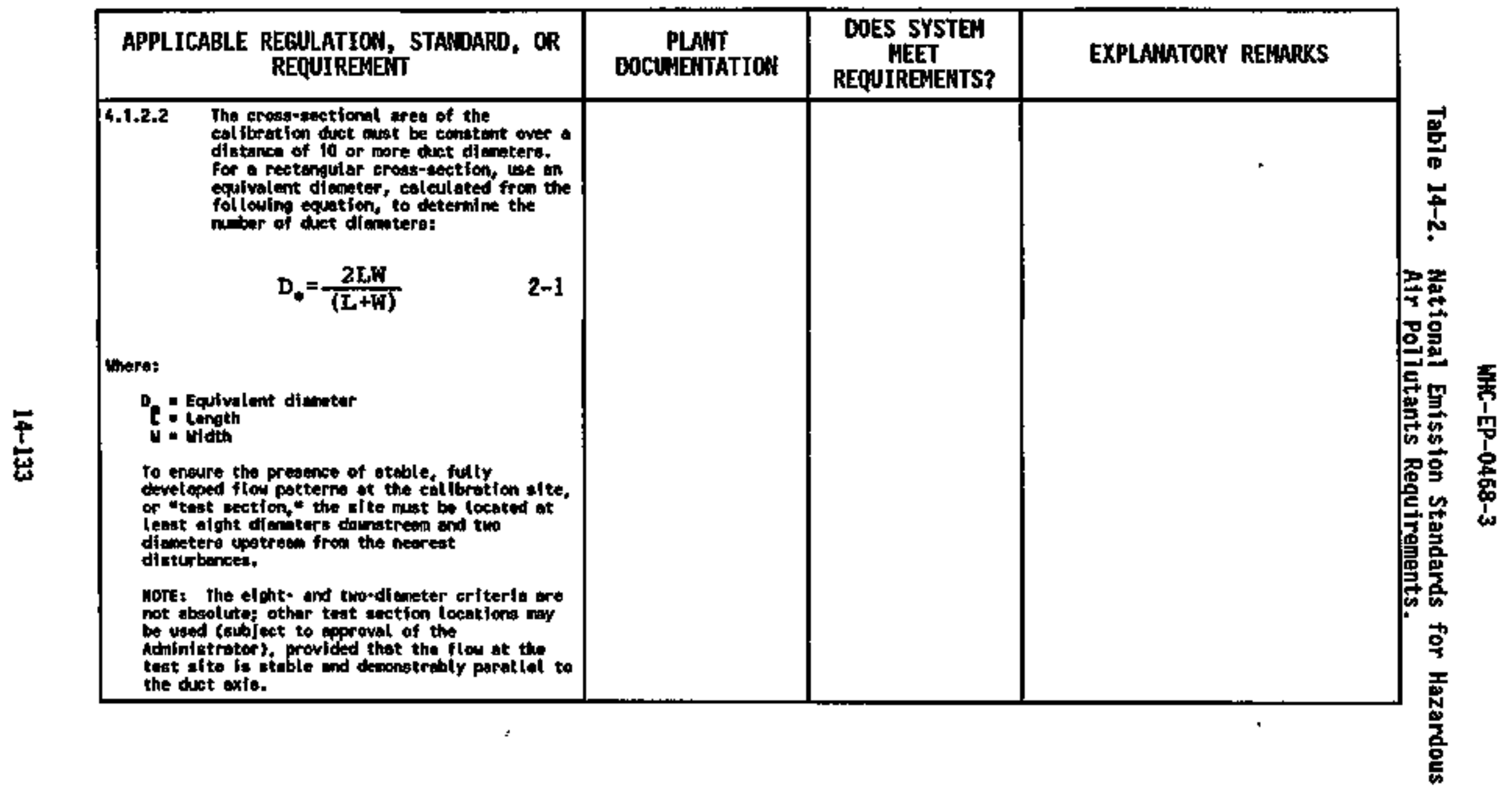




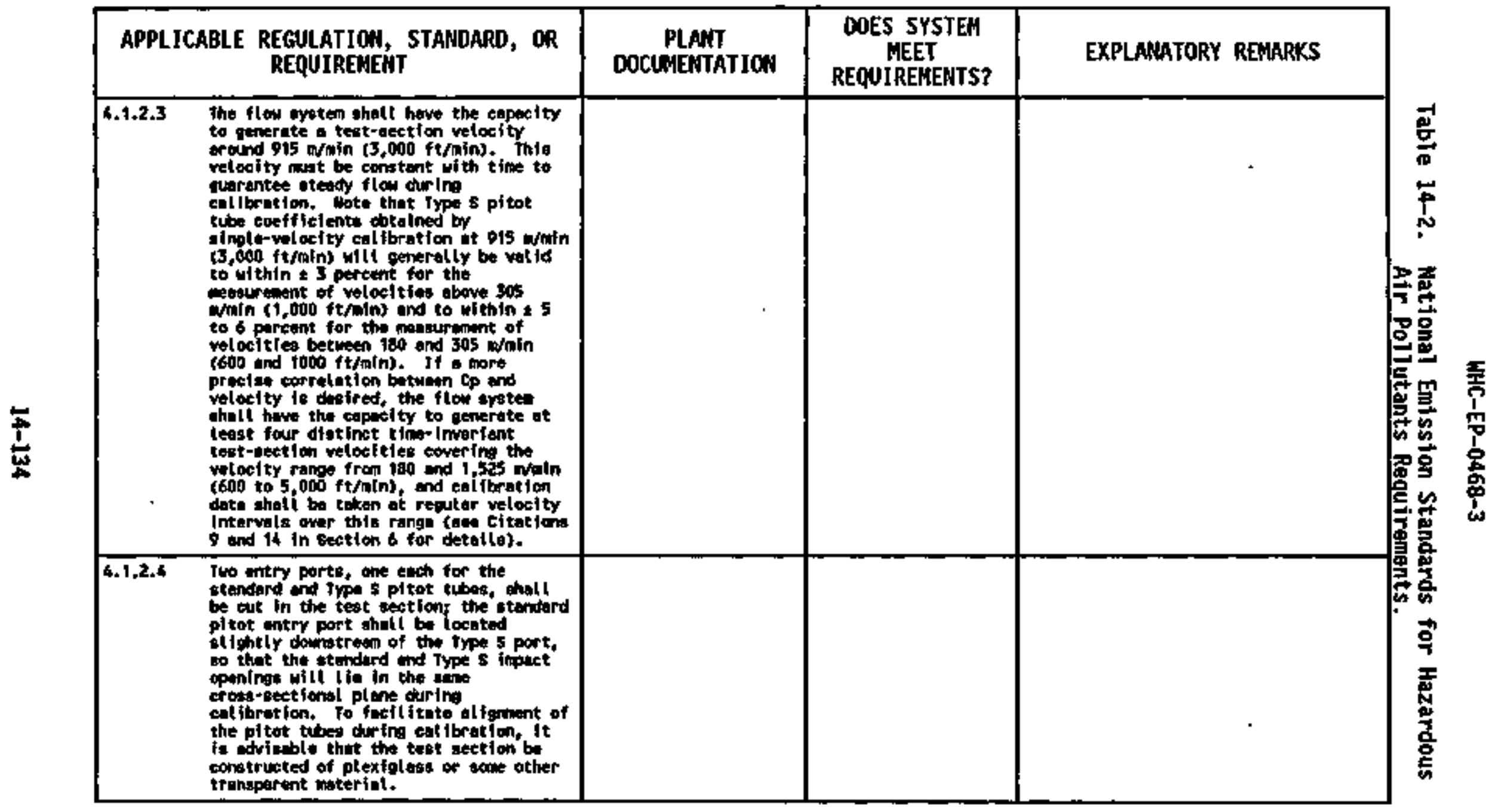




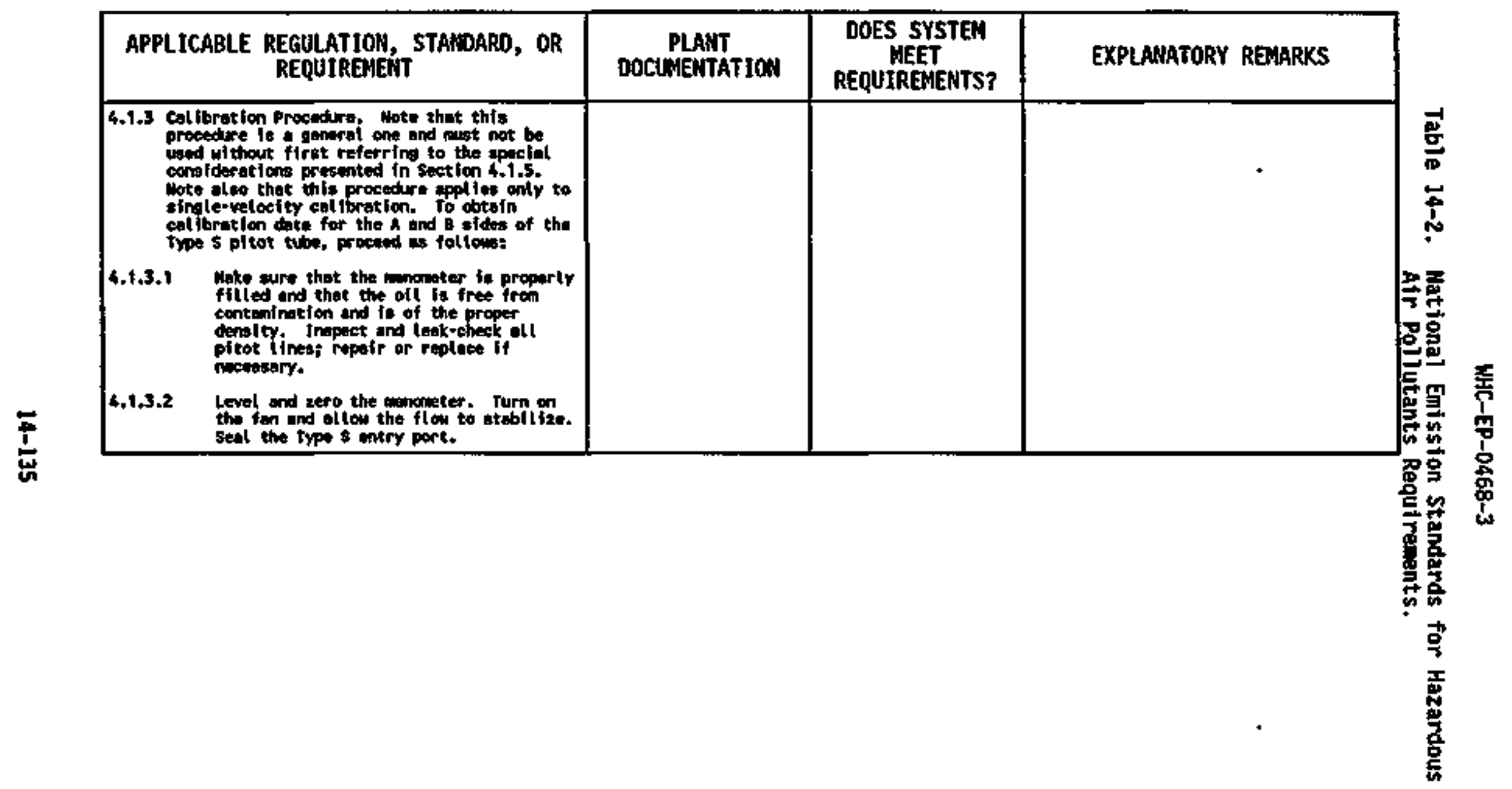




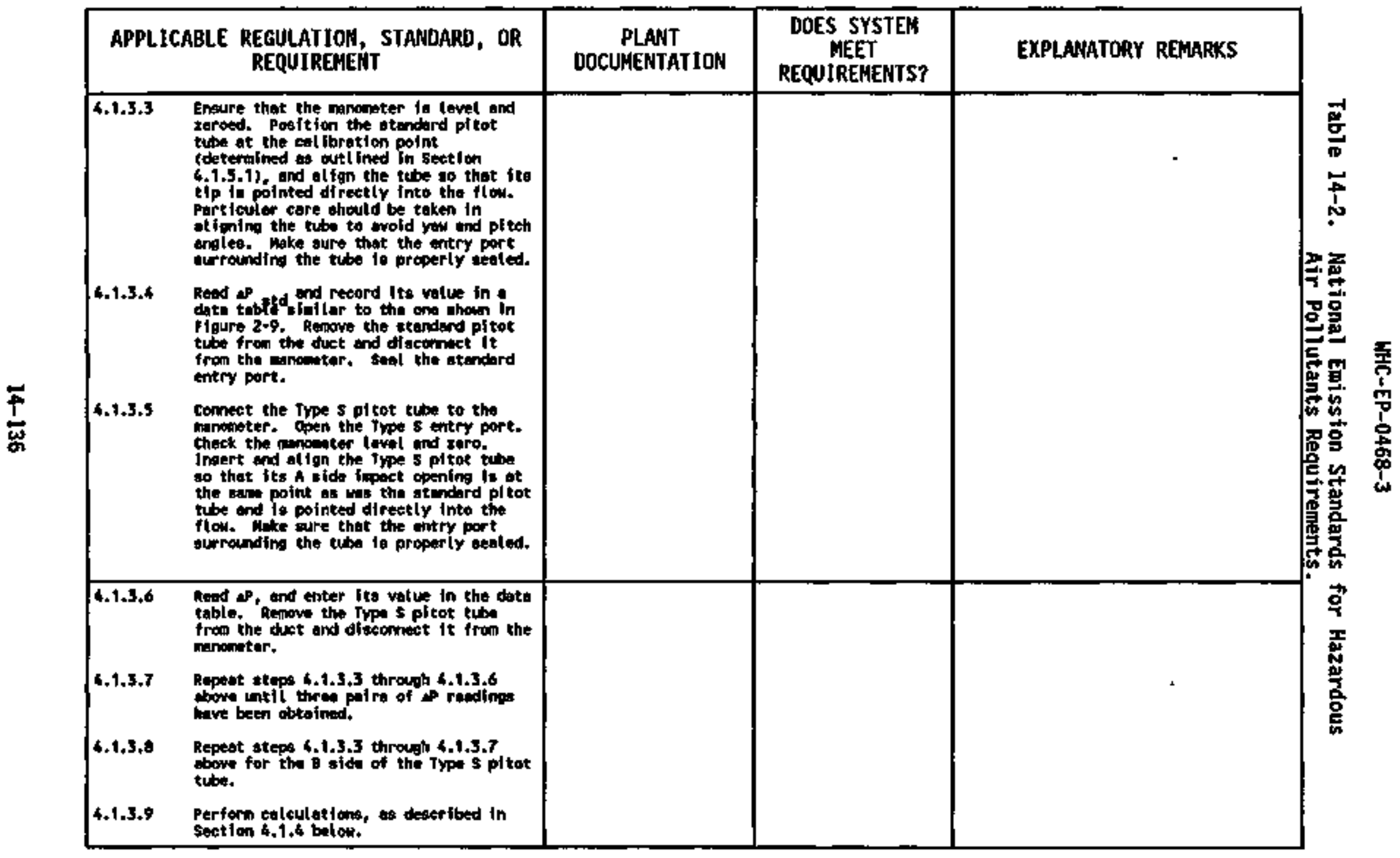




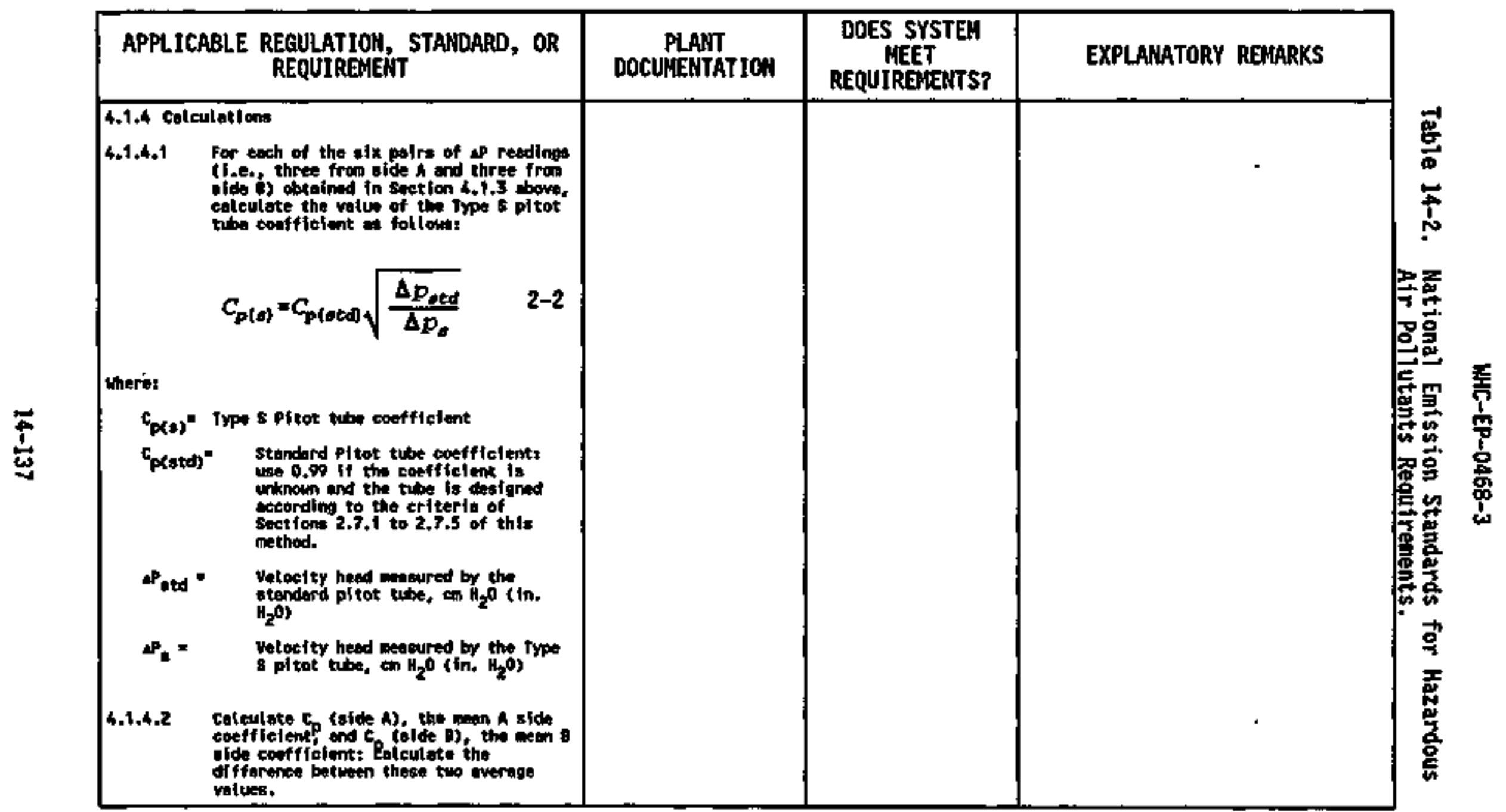




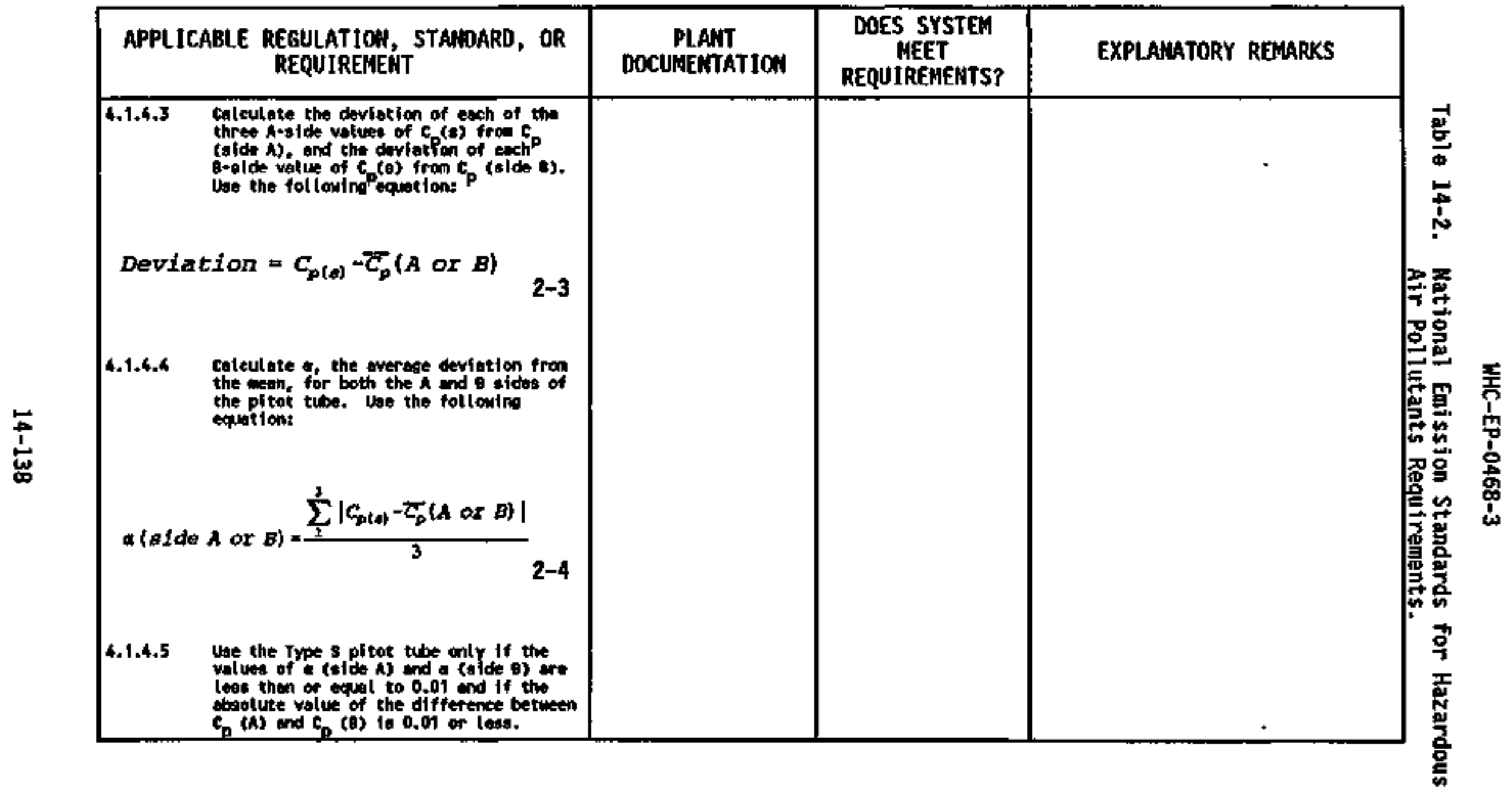




\begin{tabular}{|c|c|c|c|}
\hline $\begin{array}{l}\text { APPLICABLE REGULATIOH, STAMDARD, OR } \\
\text { REQUUIREMEGT }\end{array}$ & $\begin{array}{l}\text { PLANT } \\
\text { DOCUMENTATION }\end{array}$ & $\begin{array}{l}\text { DOES SYSTER } \\
\text { MEET } \\
\text { REQUIREMEHTS? }\end{array}$ & EXPLAMATORY REMARKS \\
\hline 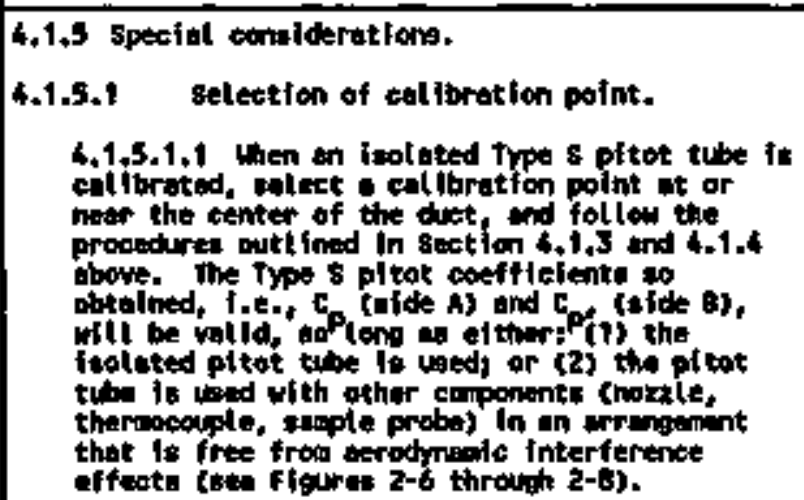 & & & . \\
\hline 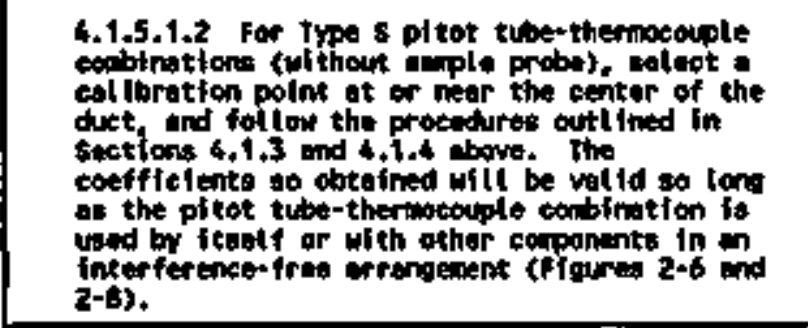 & & & \\
\hline 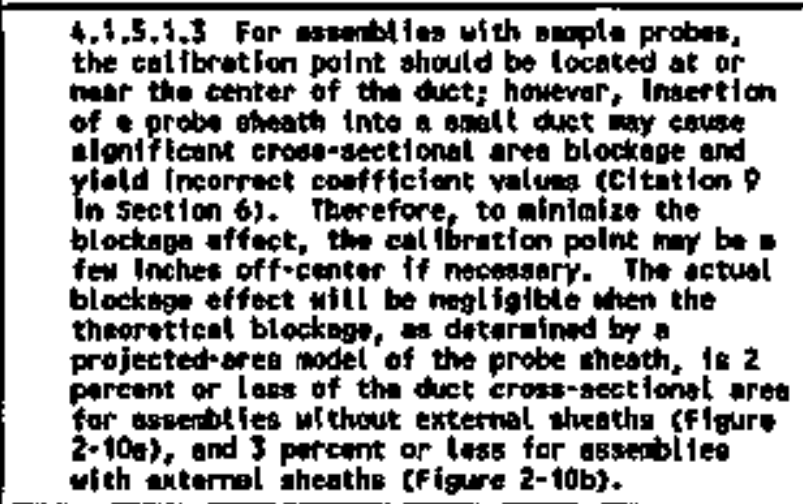 & & & . \\
\hline
\end{tabular}




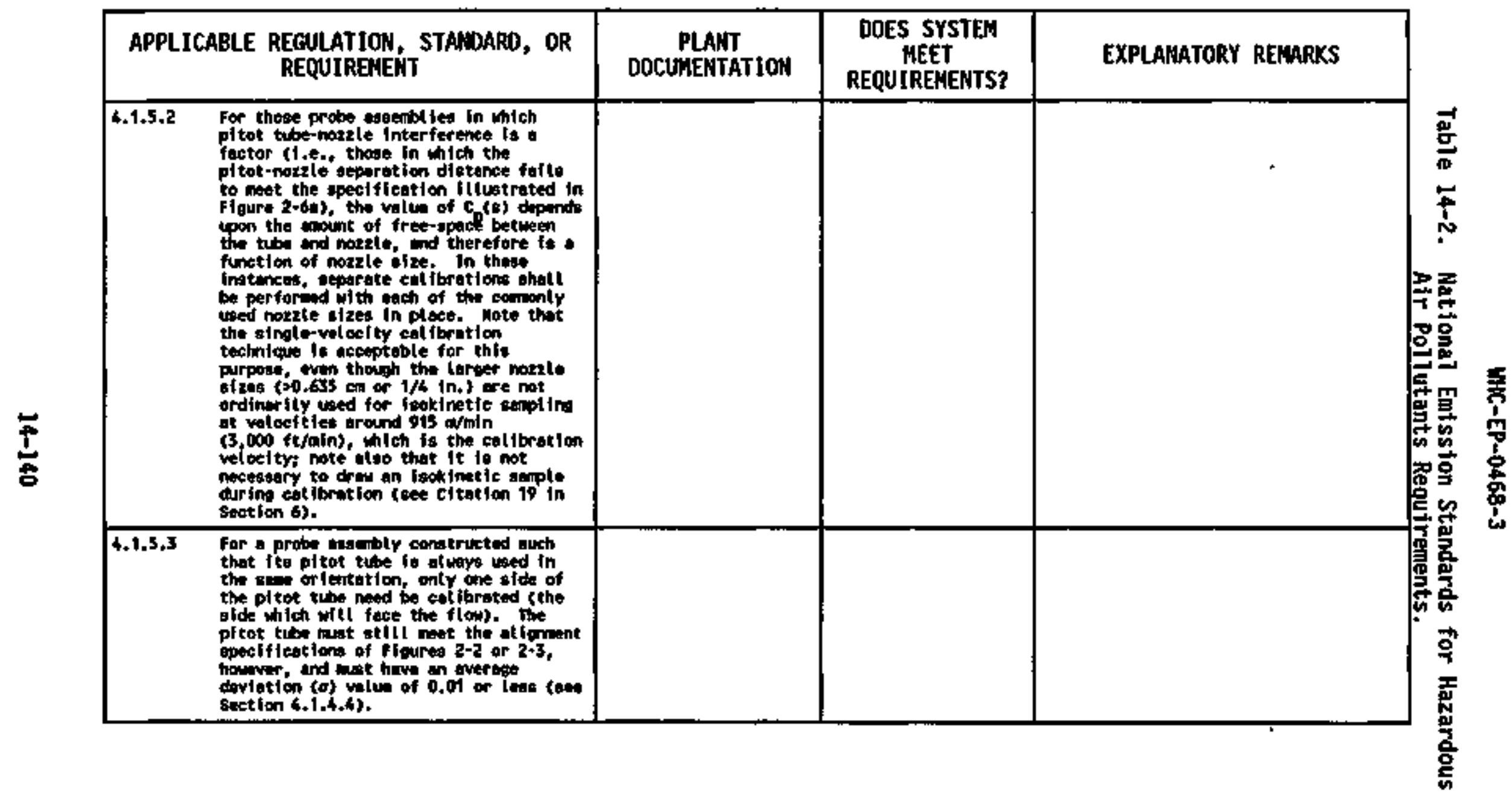




\begin{tabular}{|c|c|c|c|}
\hline $\begin{array}{l}\text { APPLICABLE REGULATIOA, STAHDARD, OR } \\
\text { REQUIREMENT }\end{array}$ & $\begin{array}{l}\text { PLANT } \\
\text { DOCLNENTATION }\end{array}$ & $\begin{array}{c}\text { DOES SYSTEY } \\
\text { HEET } \\
\text { REQUIREMENTS? }\end{array}$ & EXPLANATORY RENARKS \\
\hline 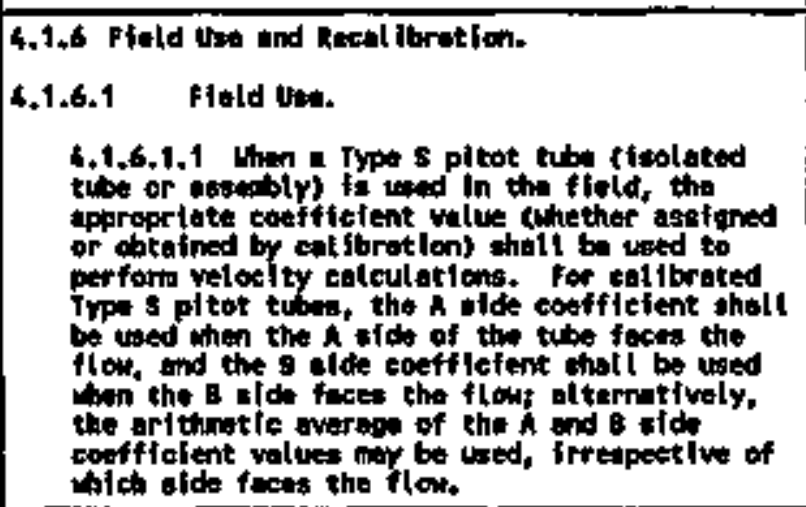 & & & * \\
\hline 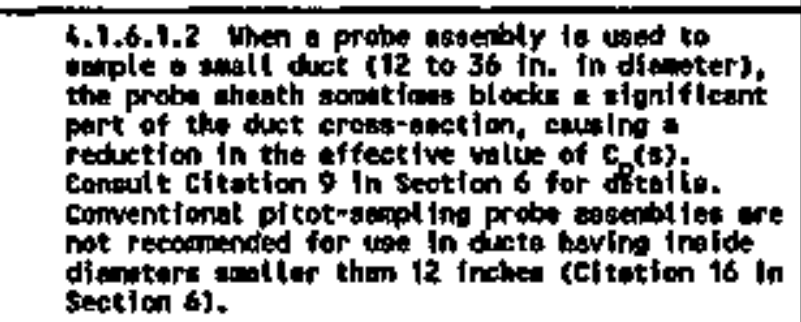 & & & - \\
\hline 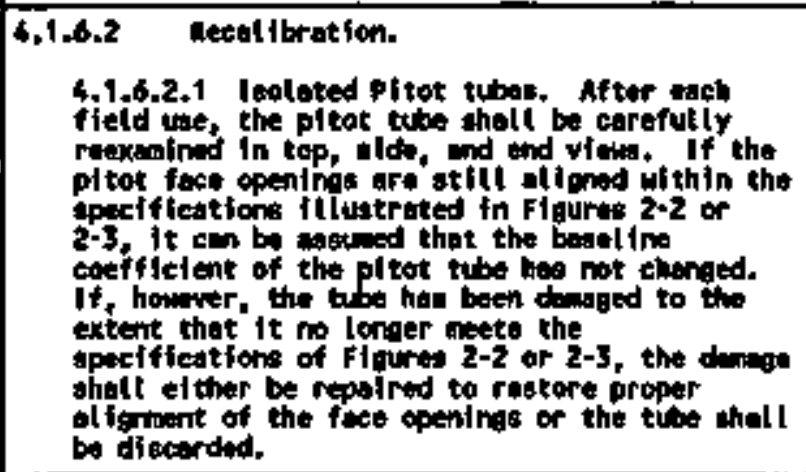 & & & . \\
\hline
\end{tabular}




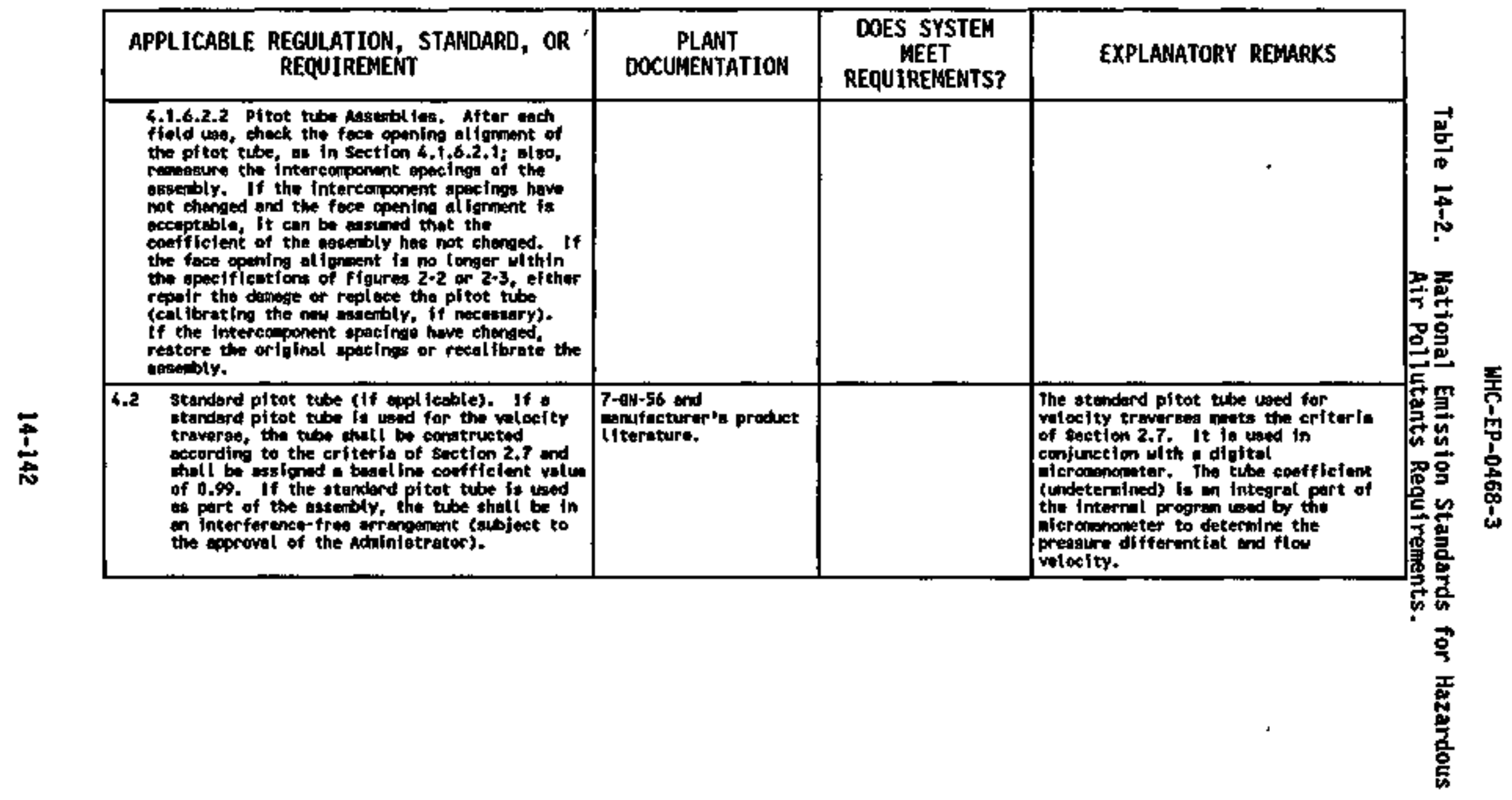




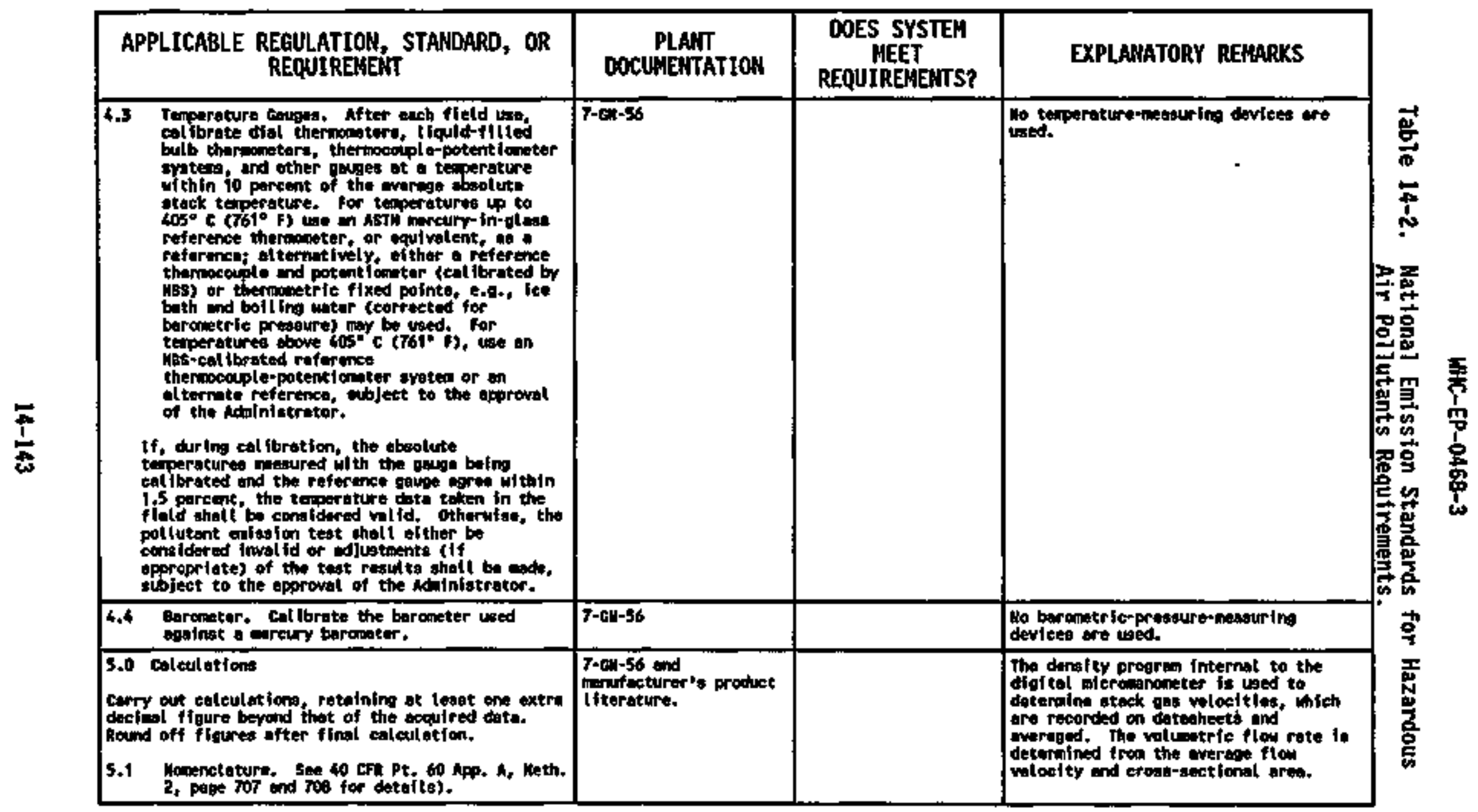




\begin{tabular}{|c|c|c|c|}
\hline $\begin{array}{l}\text { APPLICABLE REGULATIOH, STAMDARD, OR } \\
\text { REQUTREMENT }\end{array}$ & $\begin{array}{l}\text { PLANT } \\
\text { DOCUNEATATIOH }\end{array}$ & $\begin{array}{c}\text { DOES SYSTEM } \\
\text { MEET } \\
\text { REQUIREMENTS? }\end{array}$ & EXPLANATORY REMARKS \\
\hline 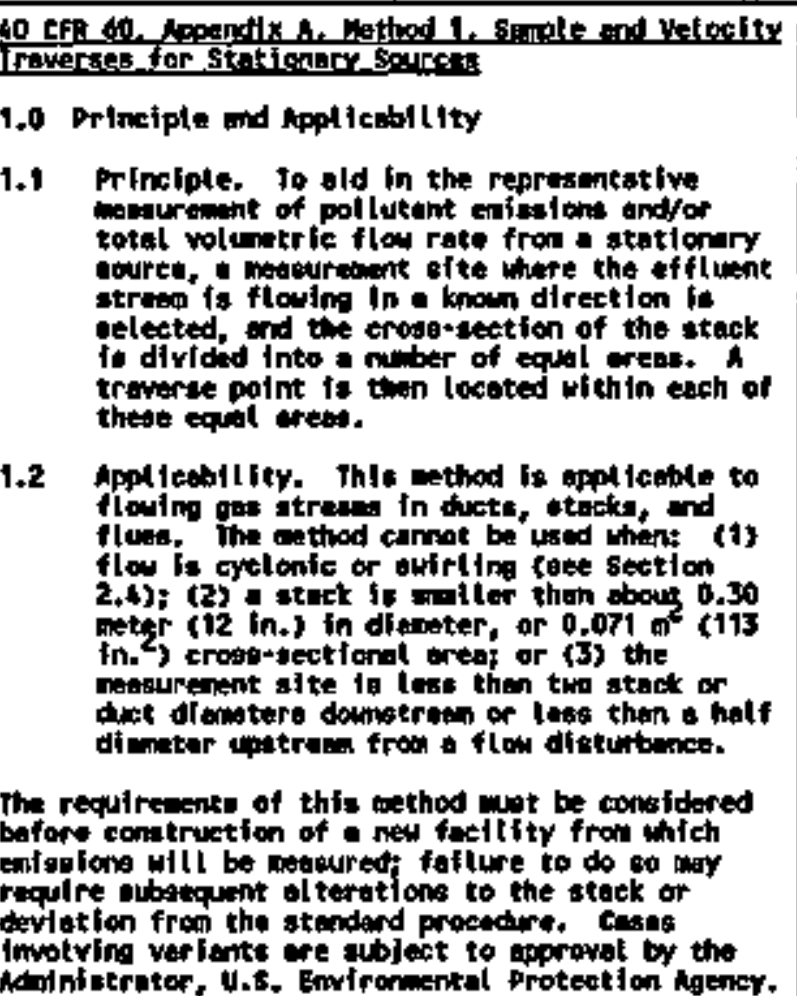 & & Tes. & 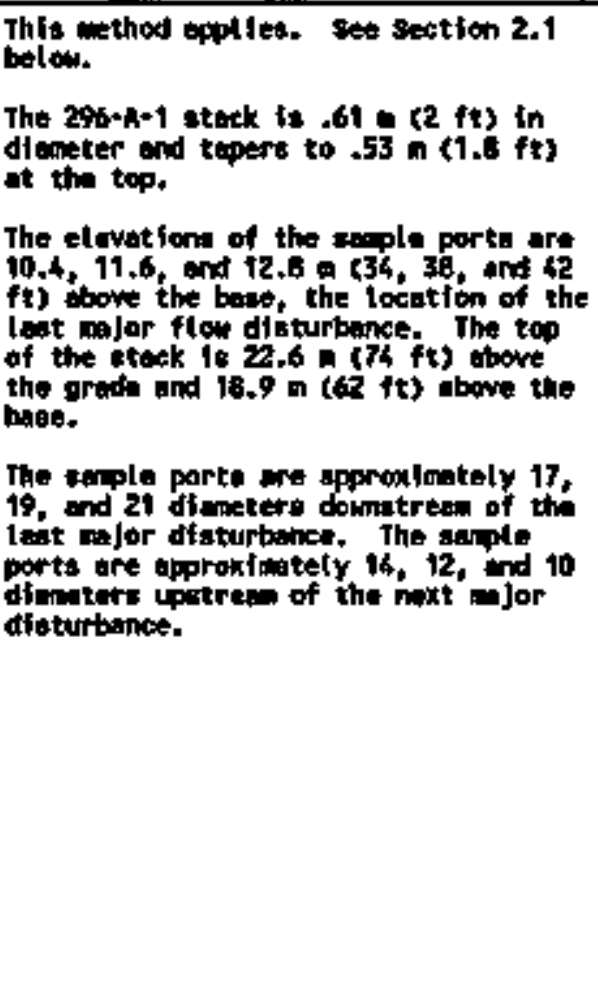 \\
\hline
\end{tabular}




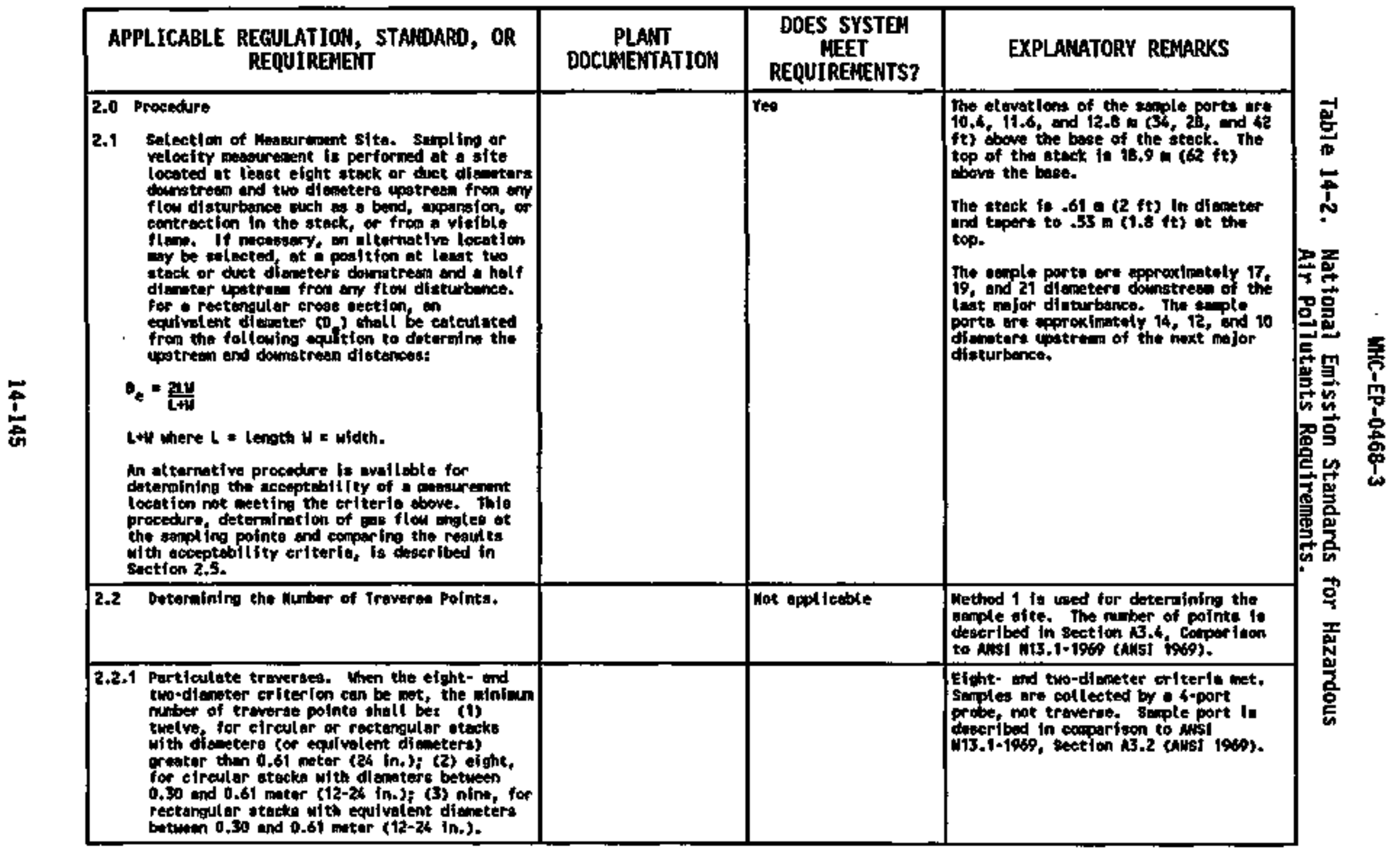




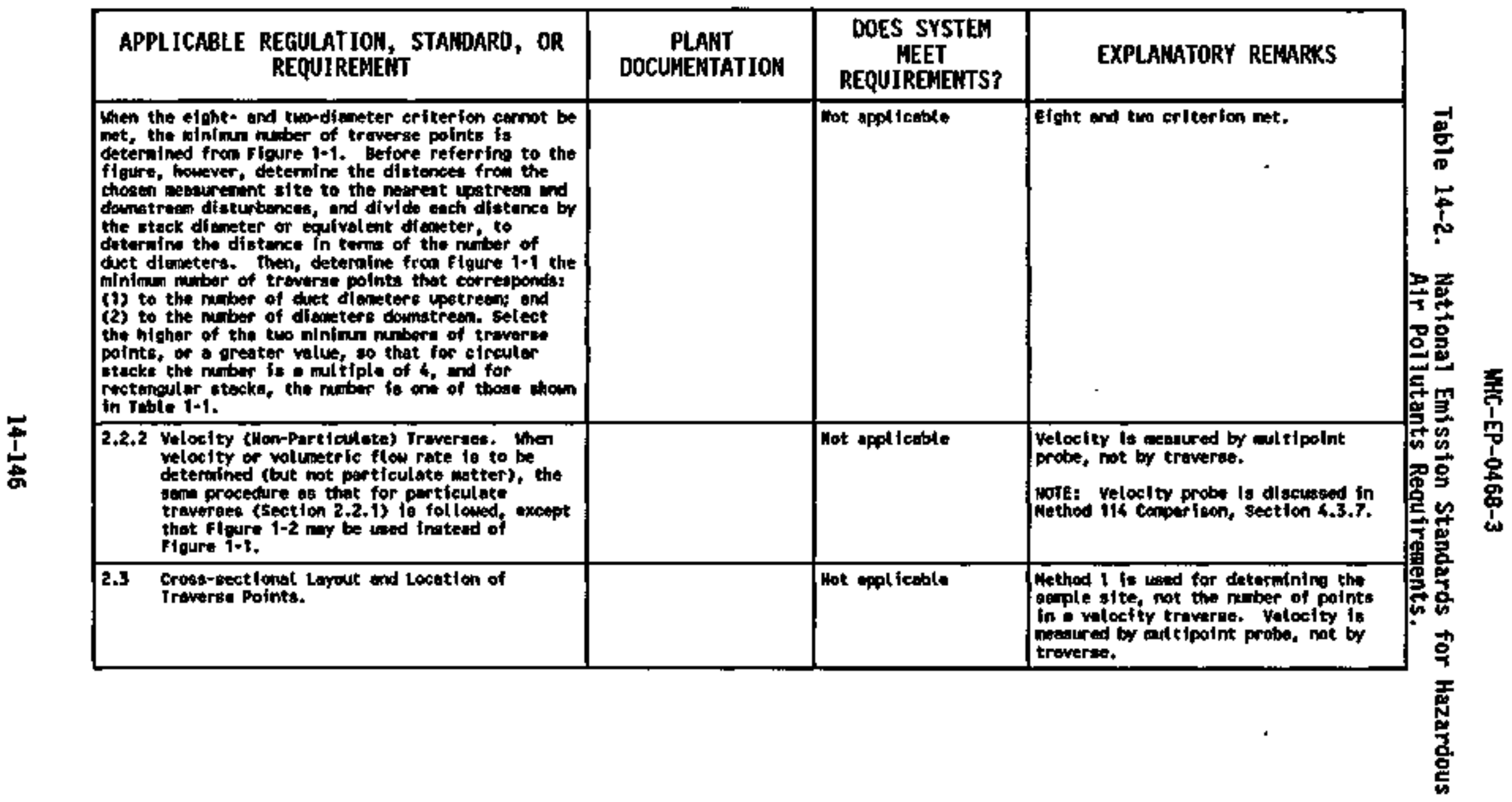




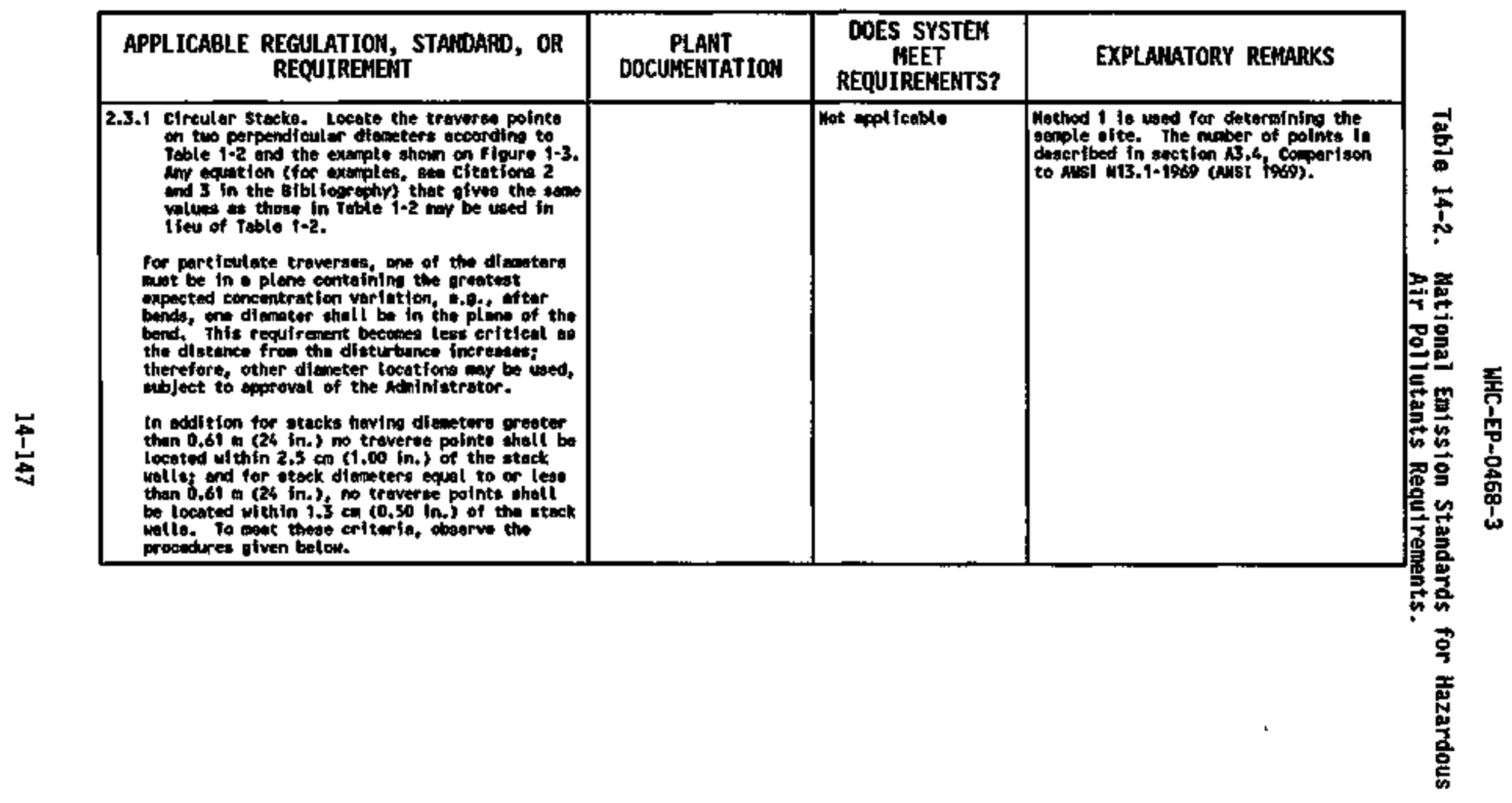




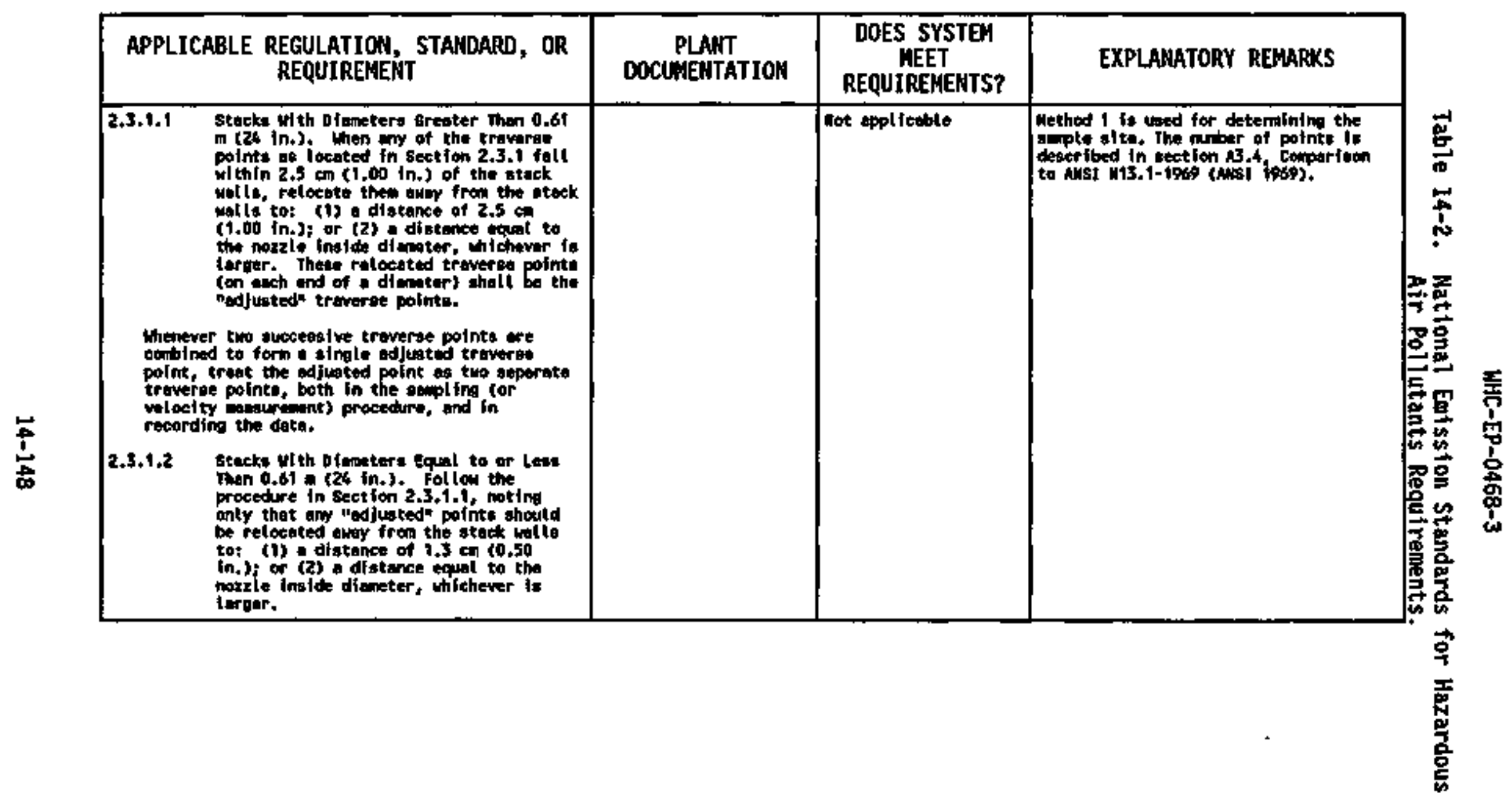




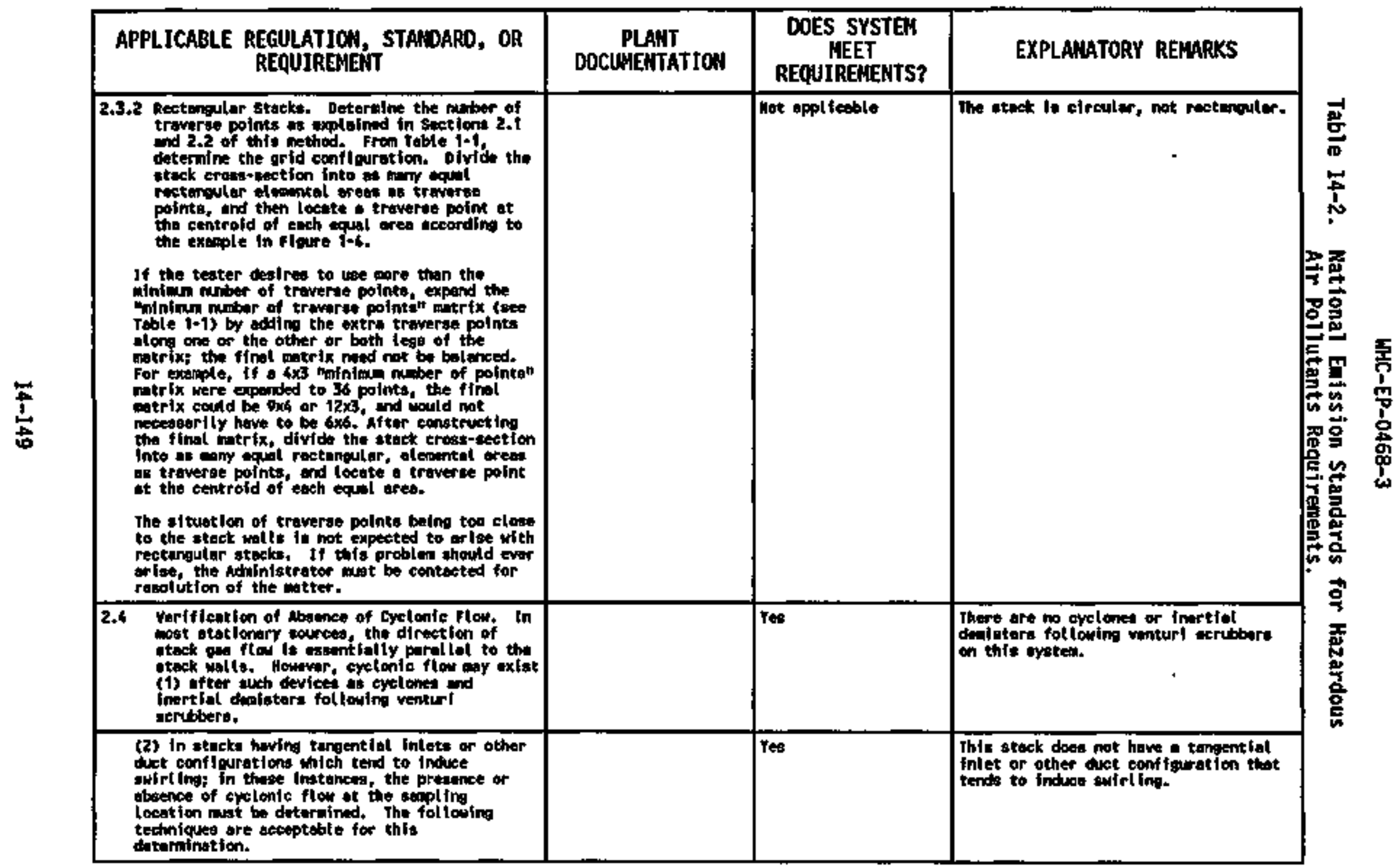




\begin{tabular}{|c|c|c|c|}
\hline $\begin{array}{l}\text { APPLICABLE REGULATION, STAMBARD, OR } \\
\text { REQUIRENEAT }\end{array}$ & $\begin{array}{l}\text { PLAMT } \\
\text { DOCUMENTATION }\end{array}$ & $\begin{array}{l}\text { DOES SYSTEH } \\
\text { MEET } \\
\text { REQUIREAERTS? }\end{array}$ & EXPLANATORY REMARKS \\
\hline 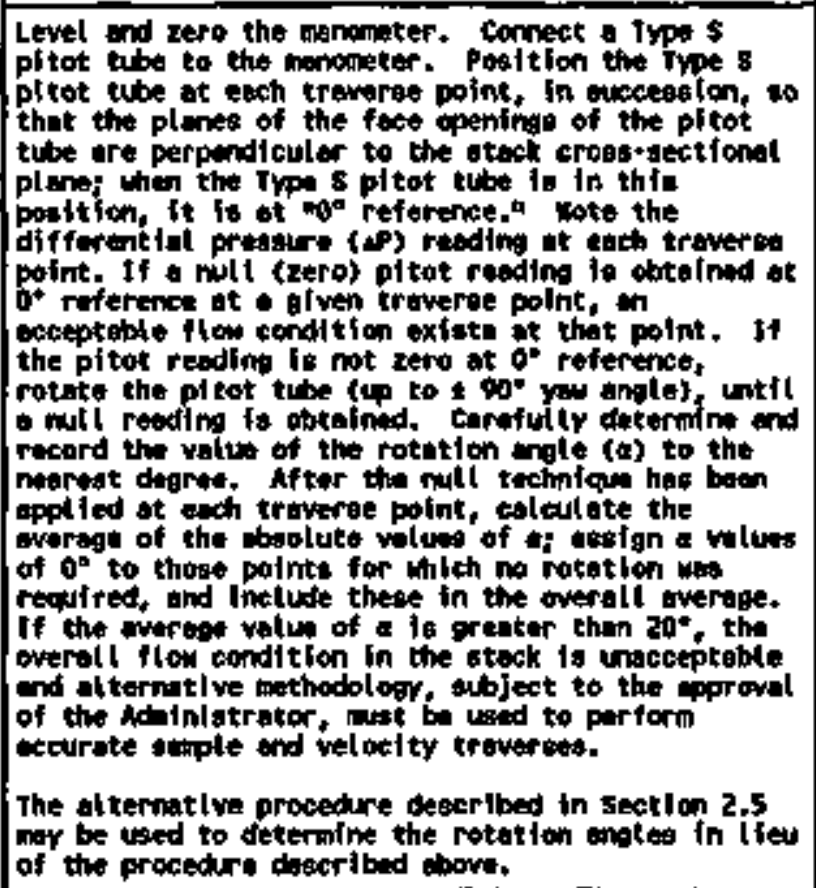 & & Wat applicento & 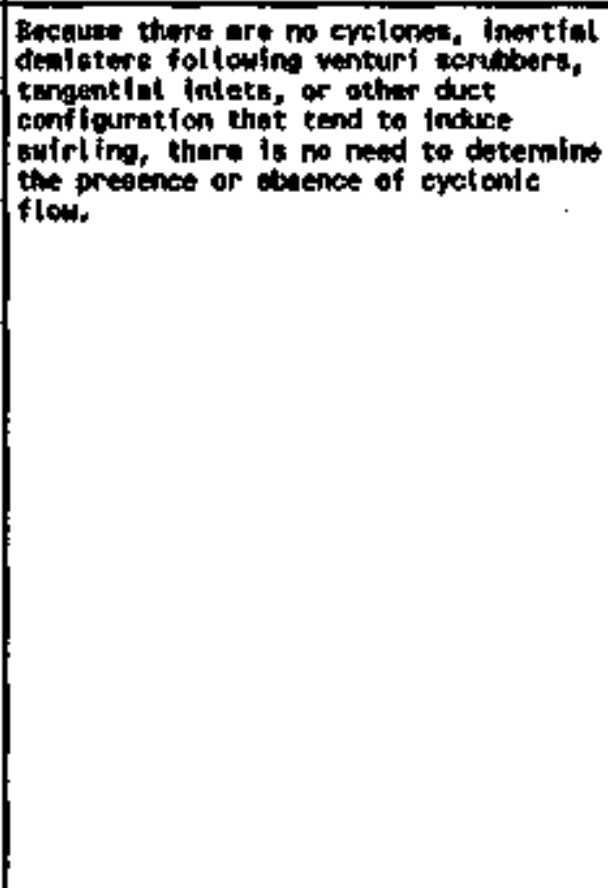 \\
\hline
\end{tabular}




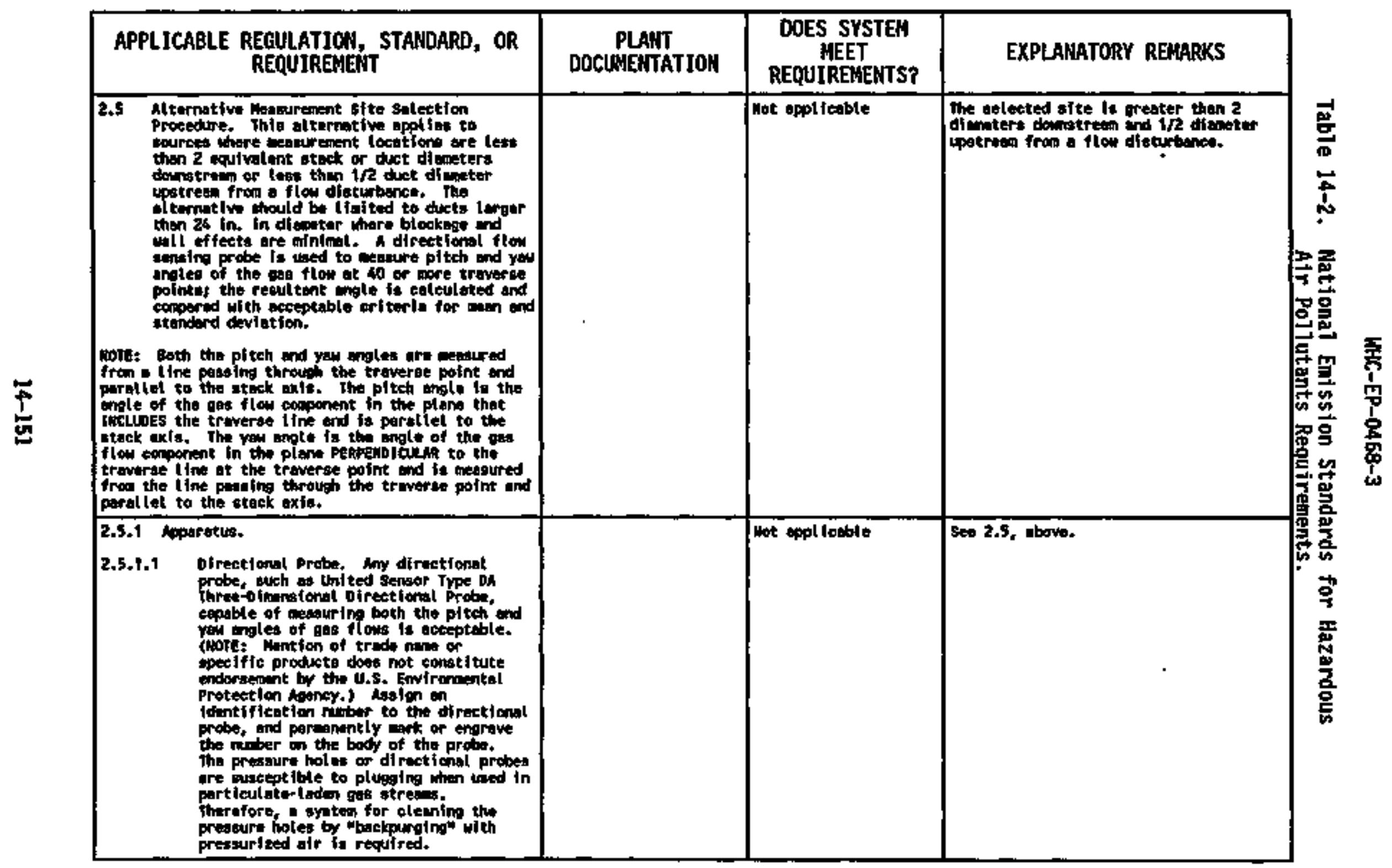




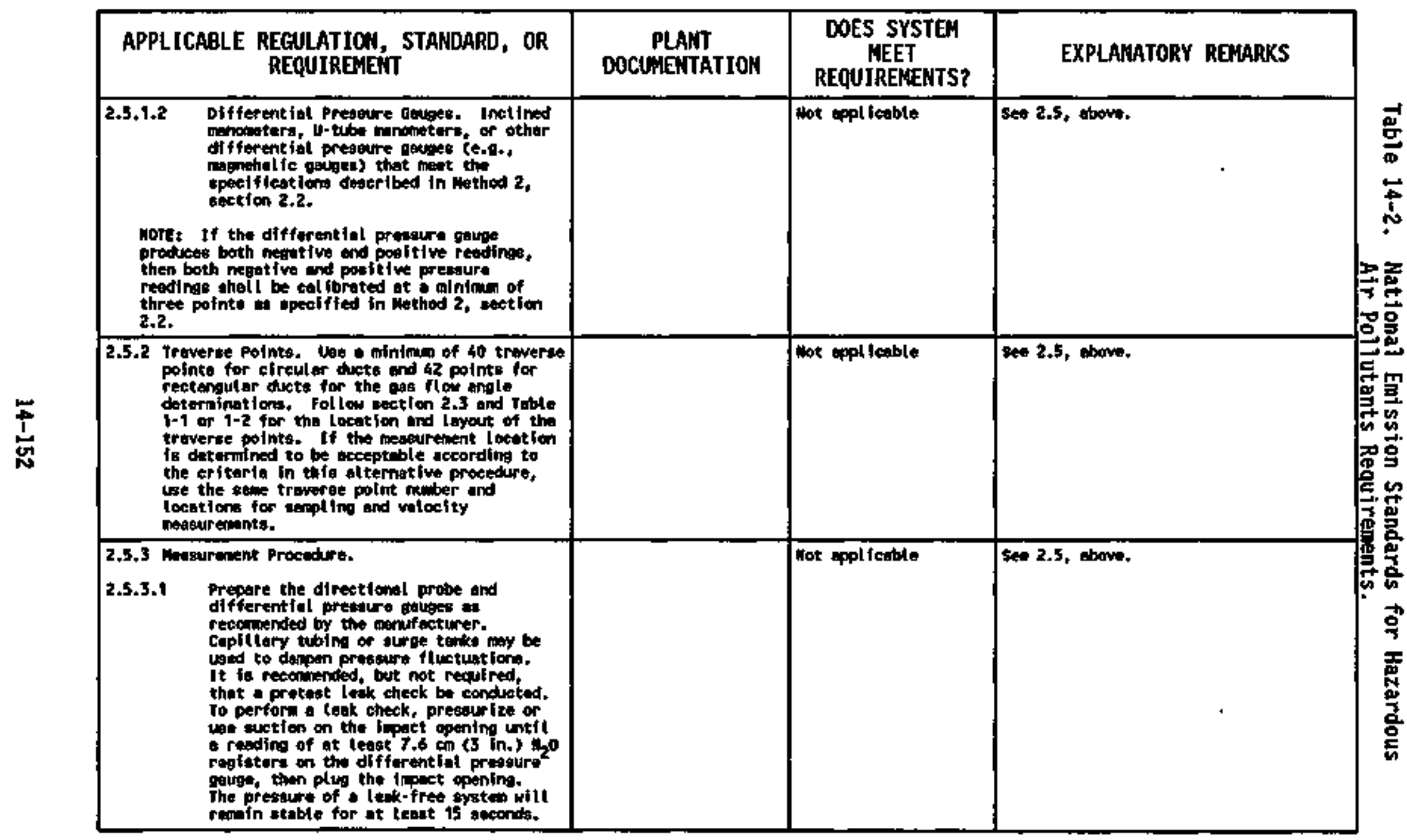




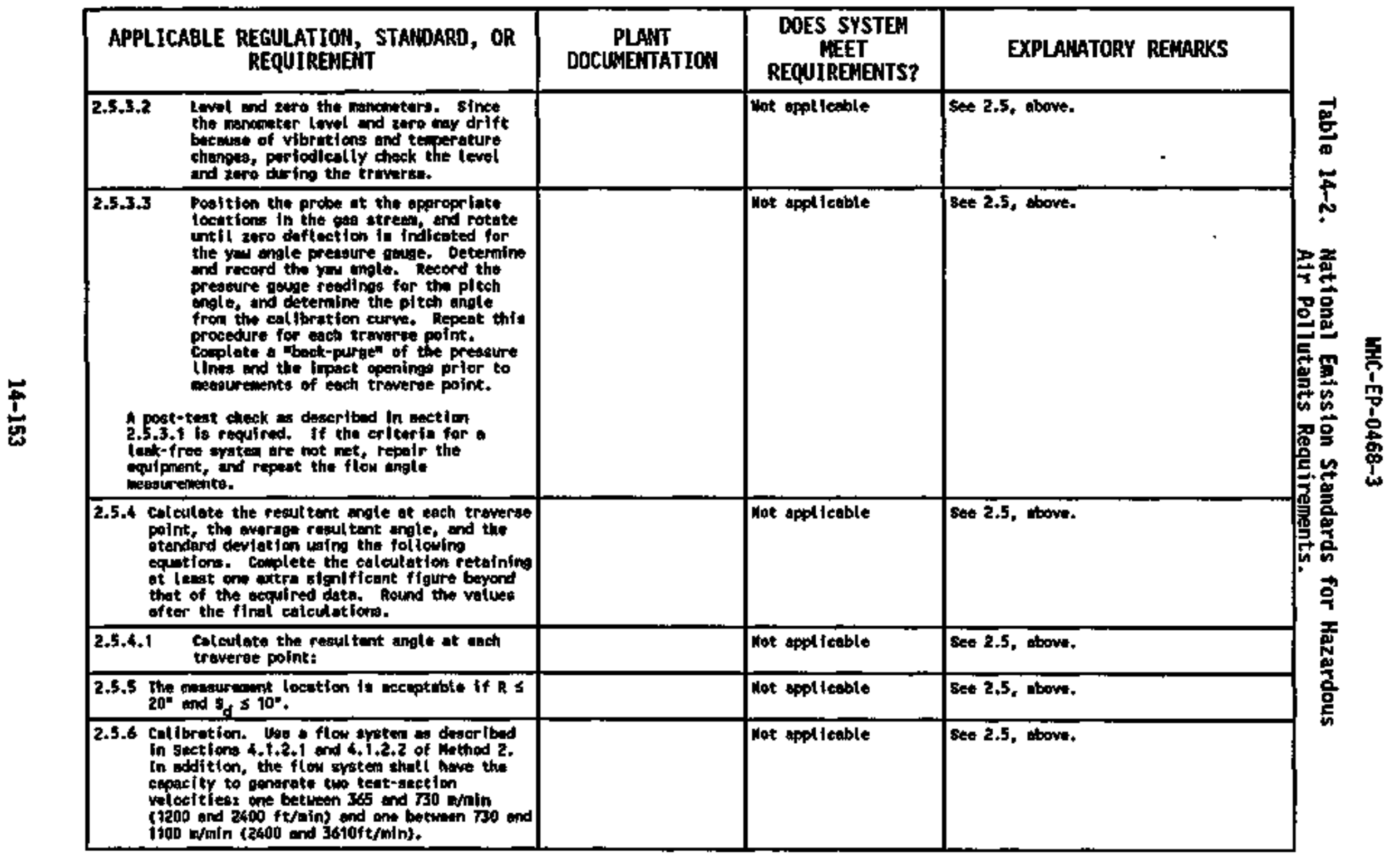




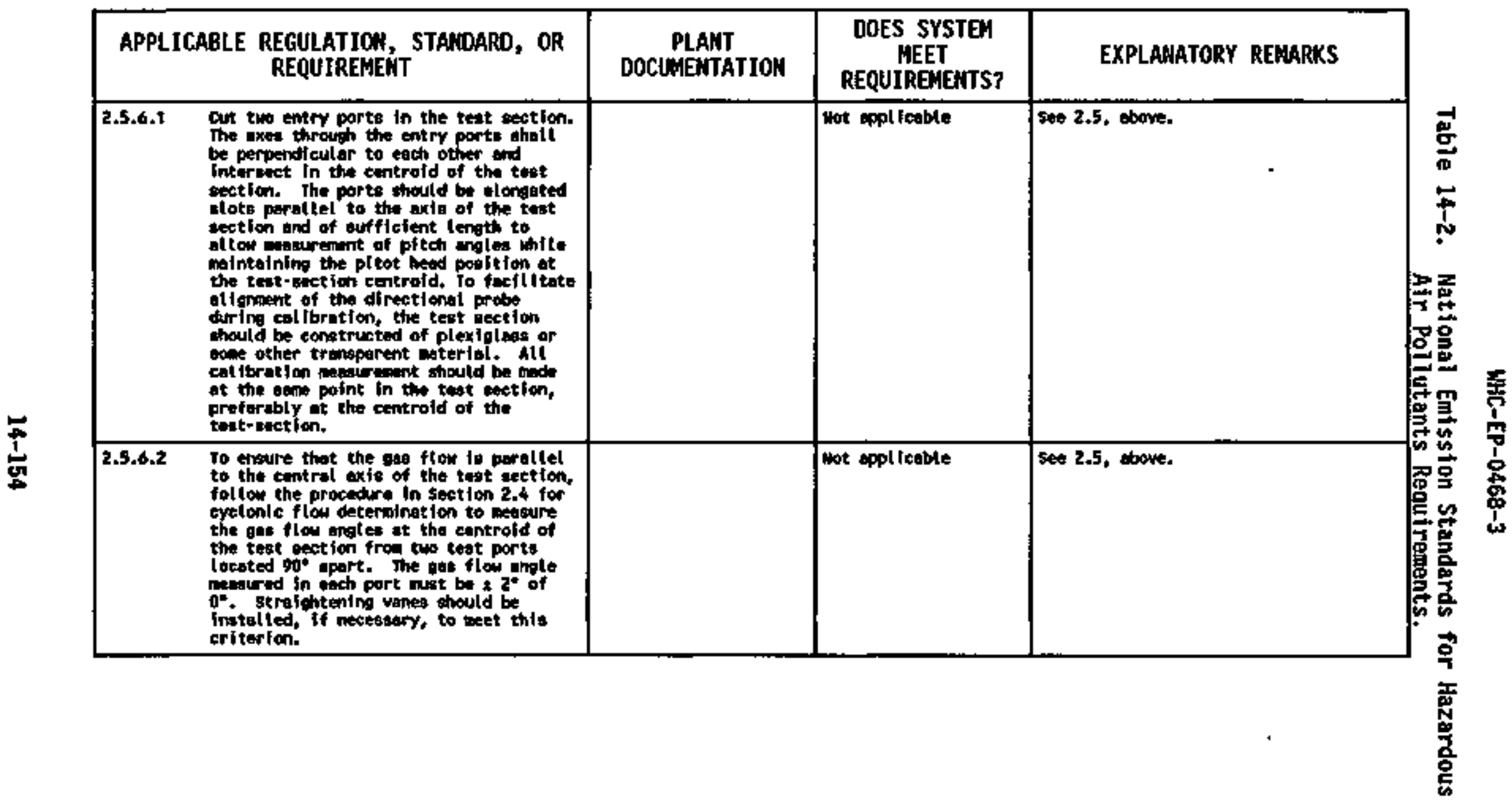




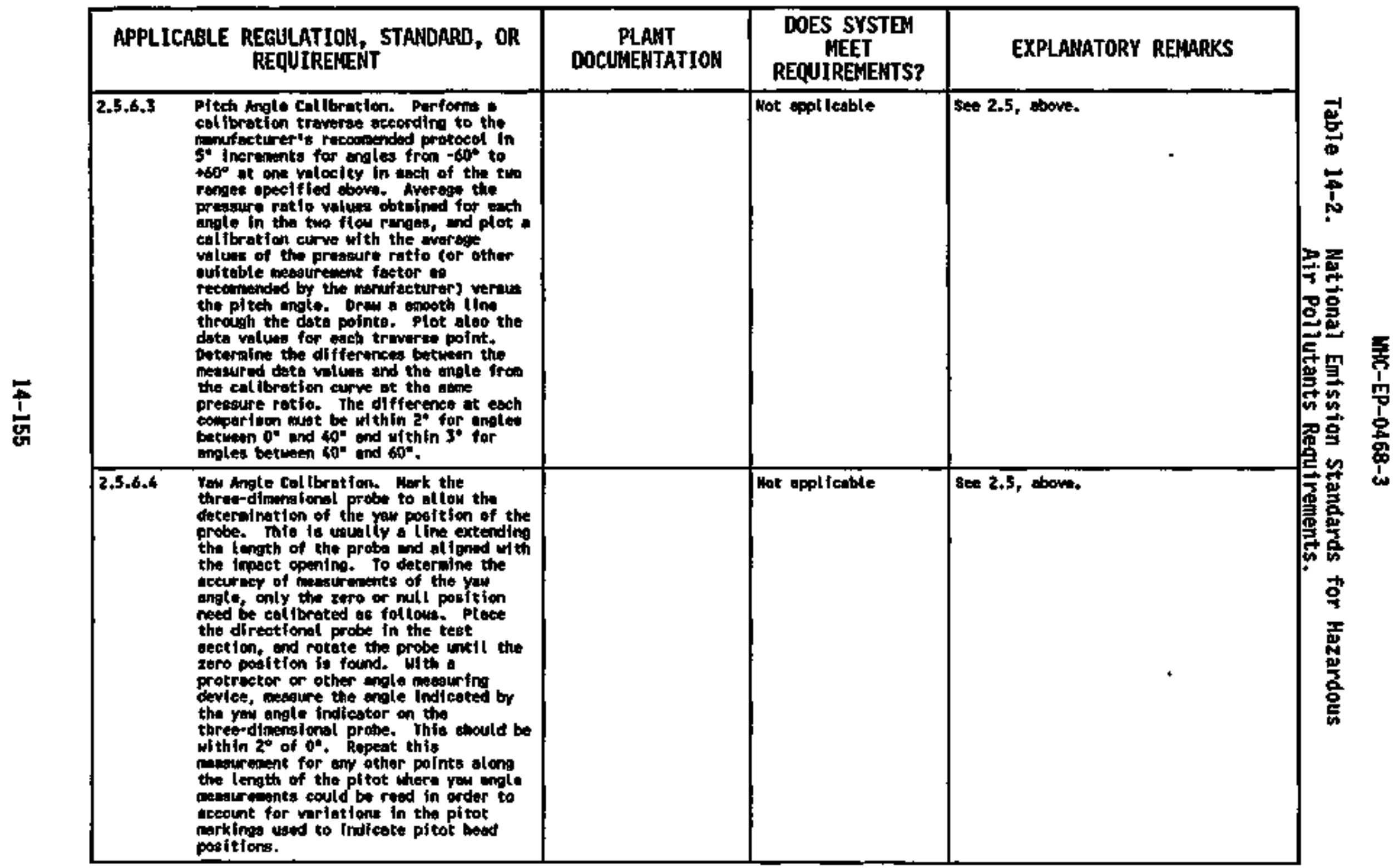




\begin{tabular}{|c|c|c|c|c|}
\hline \multicolumn{2}{|r|}{$\begin{array}{l}\text { APPLICABLE REGULATION, STANIOARD, OR } \\
\text { REQUIREKENT }\end{array}$} & $\begin{array}{l}\text { PLANT } \\
\text { DOCUMEKTATIOH }\end{array}$ & $\begin{array}{l}\text { DOES SYSTEM } \\
\text { HEET } \\
\text { REQUIREMERTS? }\end{array}$ & EXPLAMATORY REMARS \\
\hline \multicolumn{2}{|c|}{ 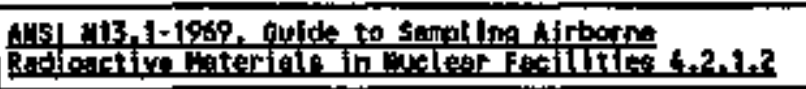 } & & & \\
\hline 4.2 .1 .2 & 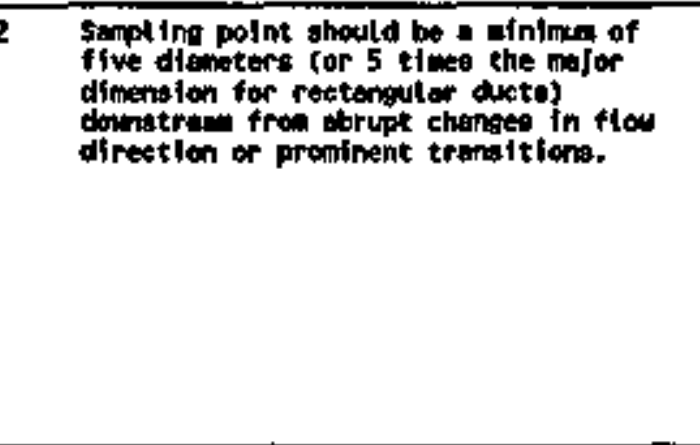 & & Yeat & 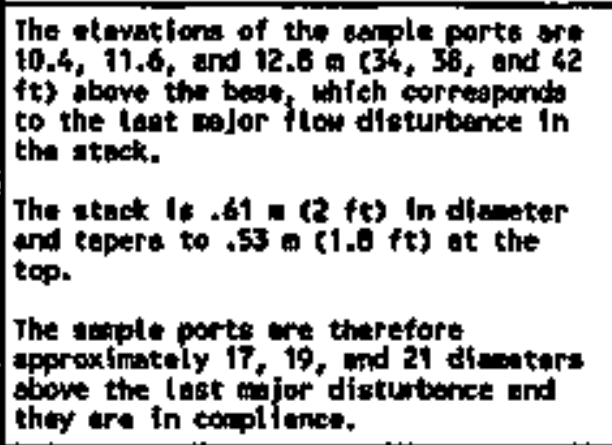 \\
\hline \multicolumn{2}{|c|}{ 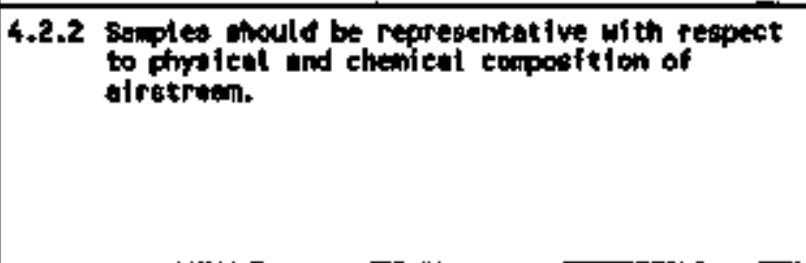 } & & res & 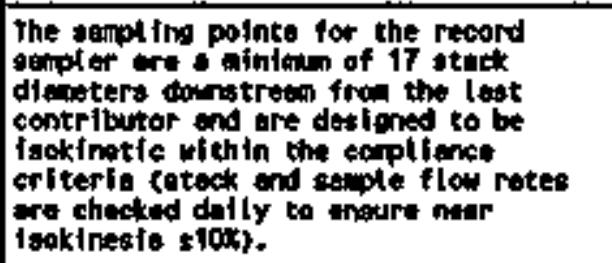 \\
\hline \multicolumn{2}{|c|}{ 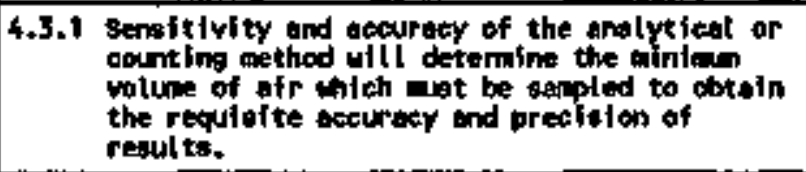 } & & $r=$ & 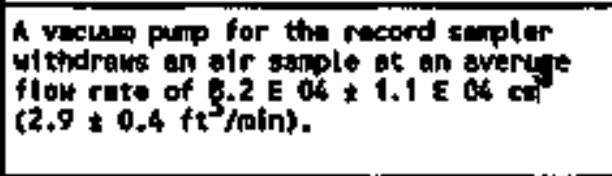 \\
\hline \multicolumn{2}{|c|}{ 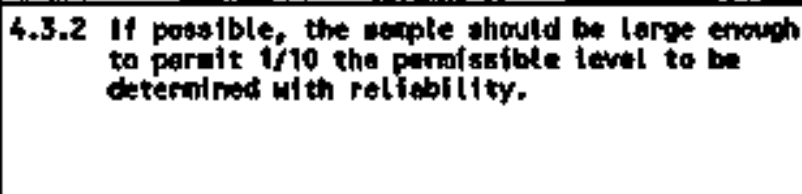 } & 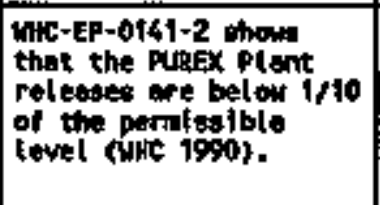 & Yes & 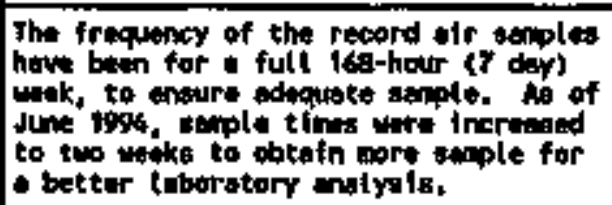 \\
\hline
\end{tabular}




\begin{tabular}{|c|c|c|c|}
\hline $\begin{array}{l}\text { APPLICABLE REGULATIOH, STAMDARD, OR } \\
\text { REQUIREYENT }\end{array}$ & $\begin{array}{l}\text { PLANT } \\
\text { DOCUNENTATIOH }\end{array}$ & $\begin{array}{l}\text { DOES SYSTEN } \\
\text { MEET } \\
\text { REQUIRENENTS? }\end{array}$ & EXPLANATORY REMARKS \\
\hline 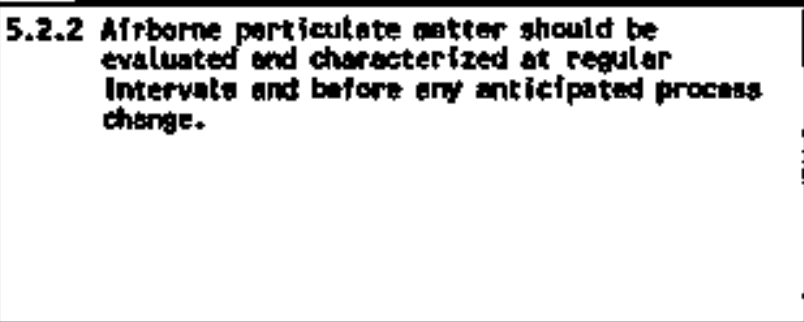 & & & 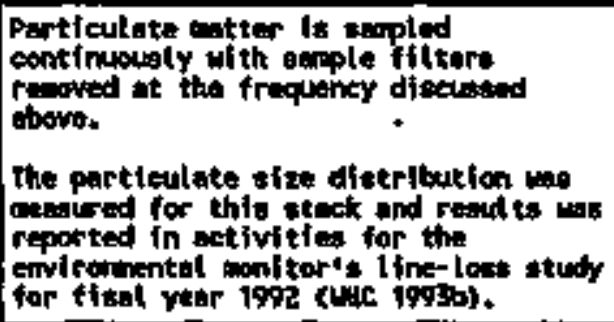 \\
\hline 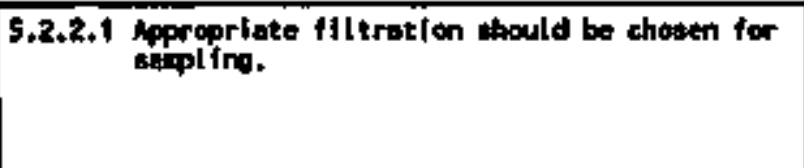 & & res & 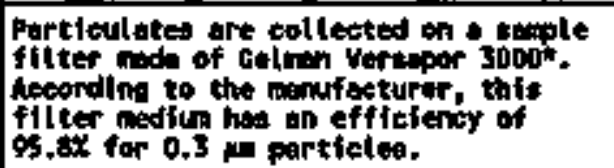 \\
\hline 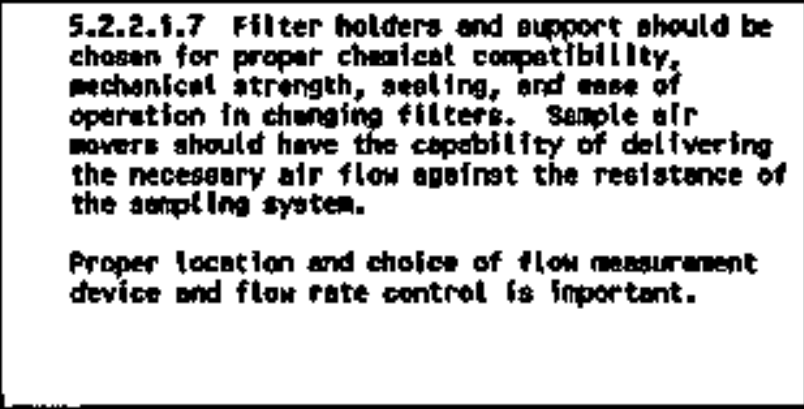 & & res & 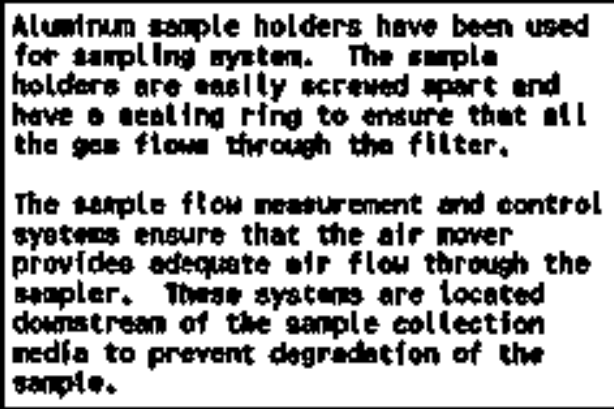 \\
\hline 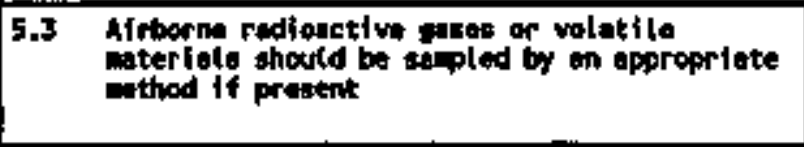 & & Hot appl feoble & 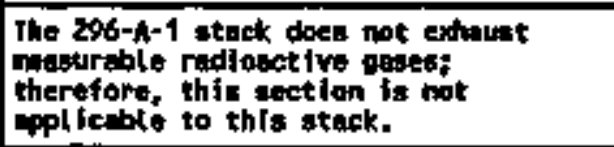 \\
\hline 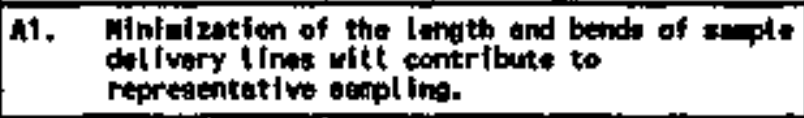 & & & $\begin{array}{l}\text { The atinple IInes are censtruoted to } \\
\text { ninimixo bends. }\end{array}$ \\
\hline
\end{tabular}




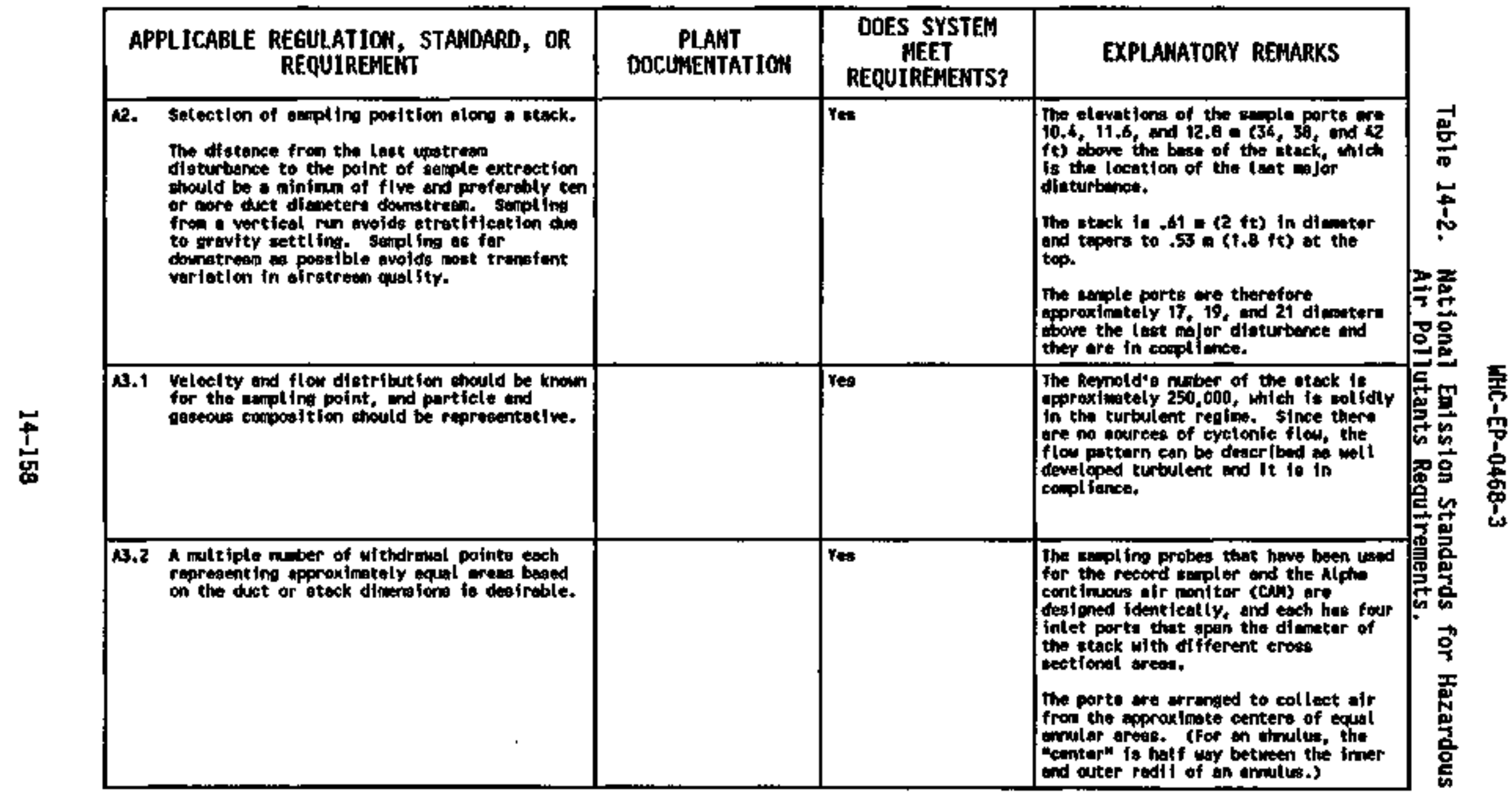




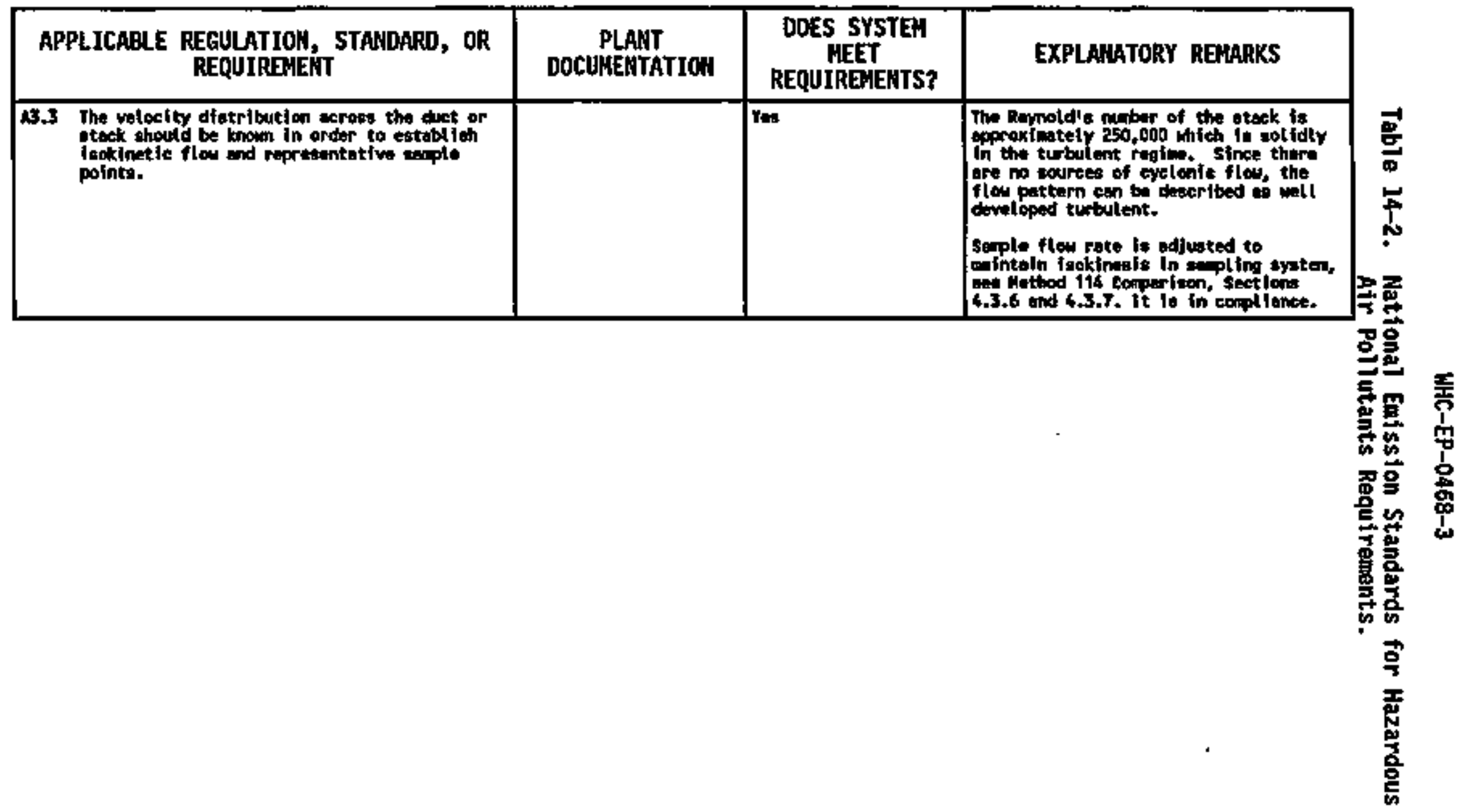




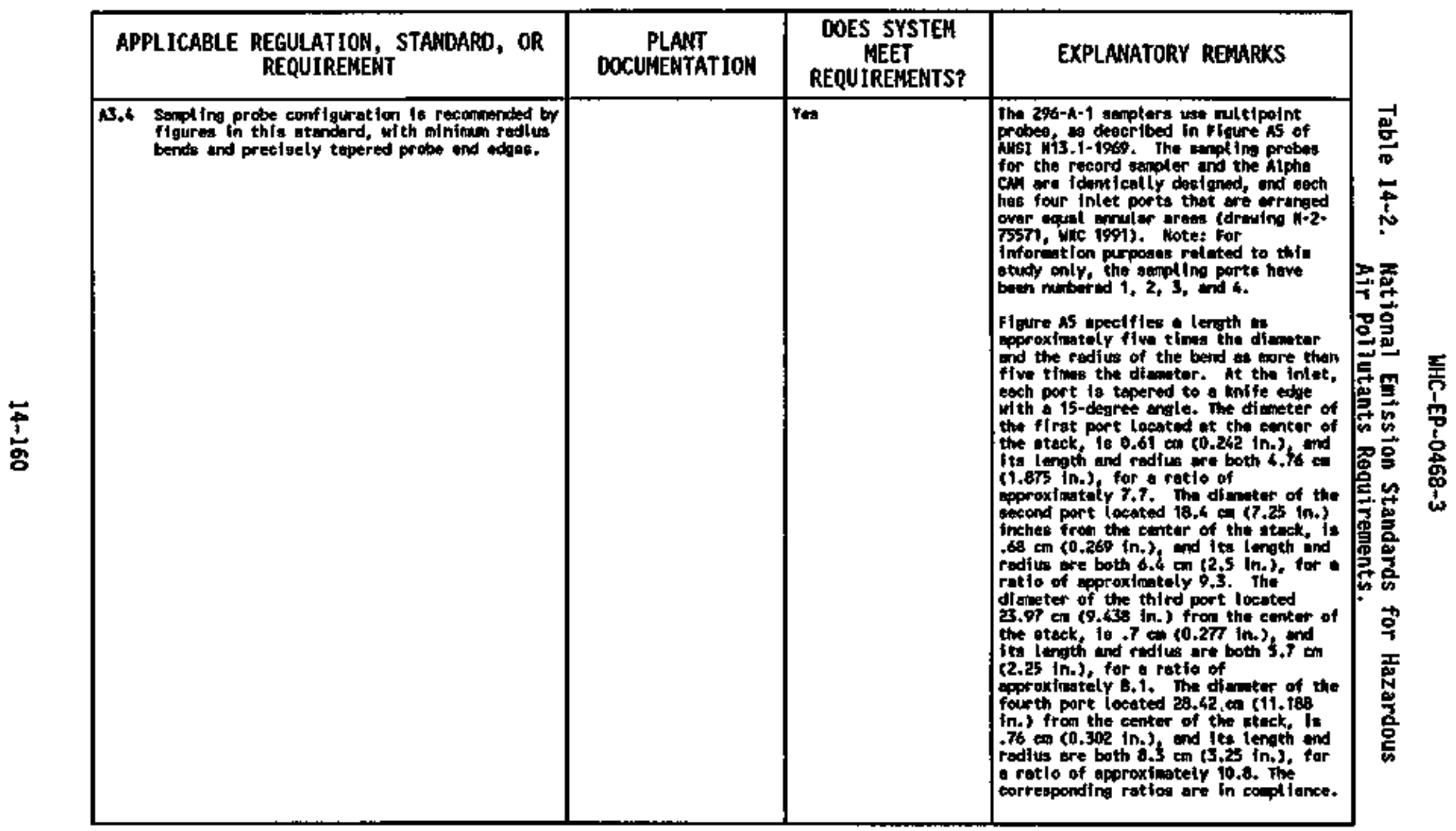




\begin{tabular}{|c|c|c|c|}
\hline $\begin{array}{l}\text { APPLICABLE REGULATION, STANDARD, OR } \\
\text { REQUIREMENT }\end{array}$ & $\begin{array}{l}\text { PLANT } \\
\text { DOCUAEENTATIOH }\end{array}$ & $\begin{array}{l}\text { DOES SYSTEH } \\
\text { MEET } \\
\text { REQUIRENENTS? }\end{array}$ & EXPLAMATORY REMARKS \\
\hline 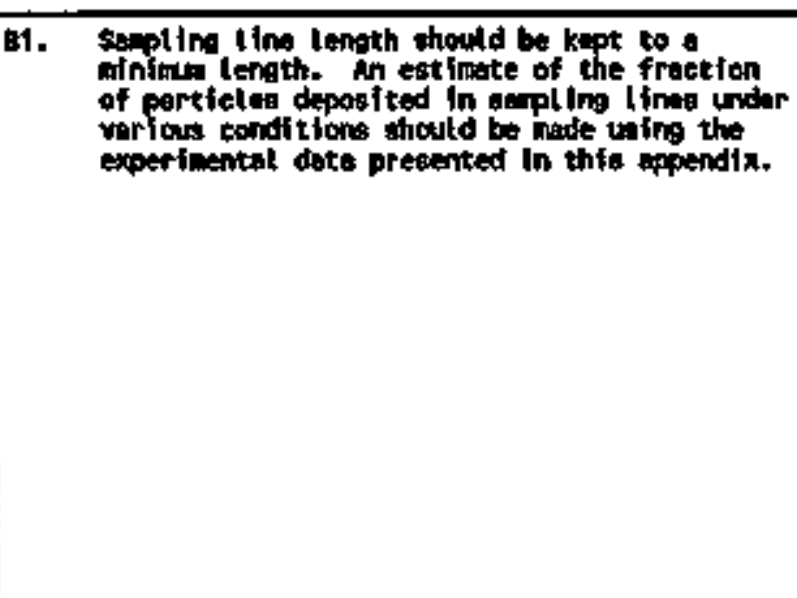 & & $r \Leftrightarrow$ & 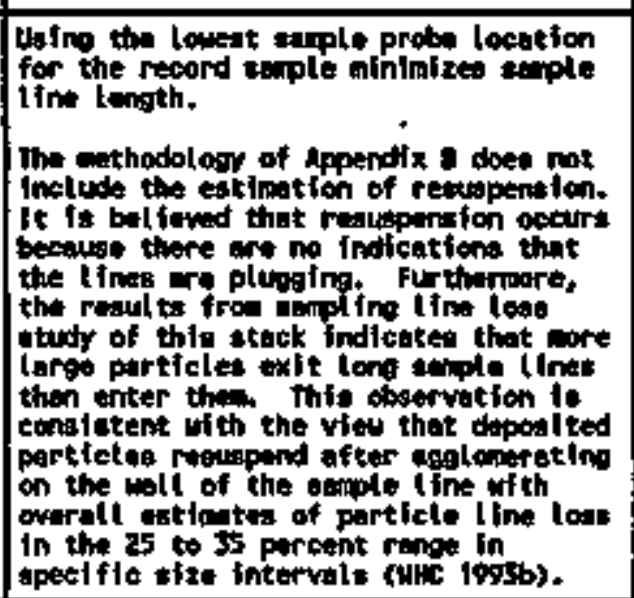 \\
\hline 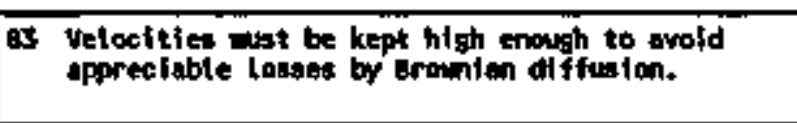 & & Yes & 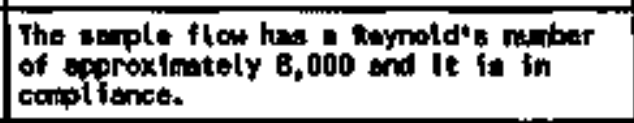 \\
\hline 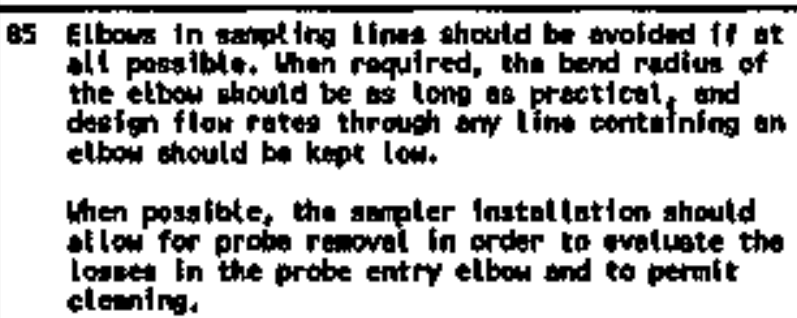 & & ress & 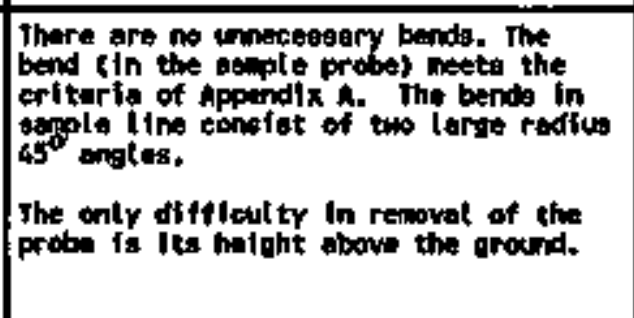 \\
\hline
\end{tabular}




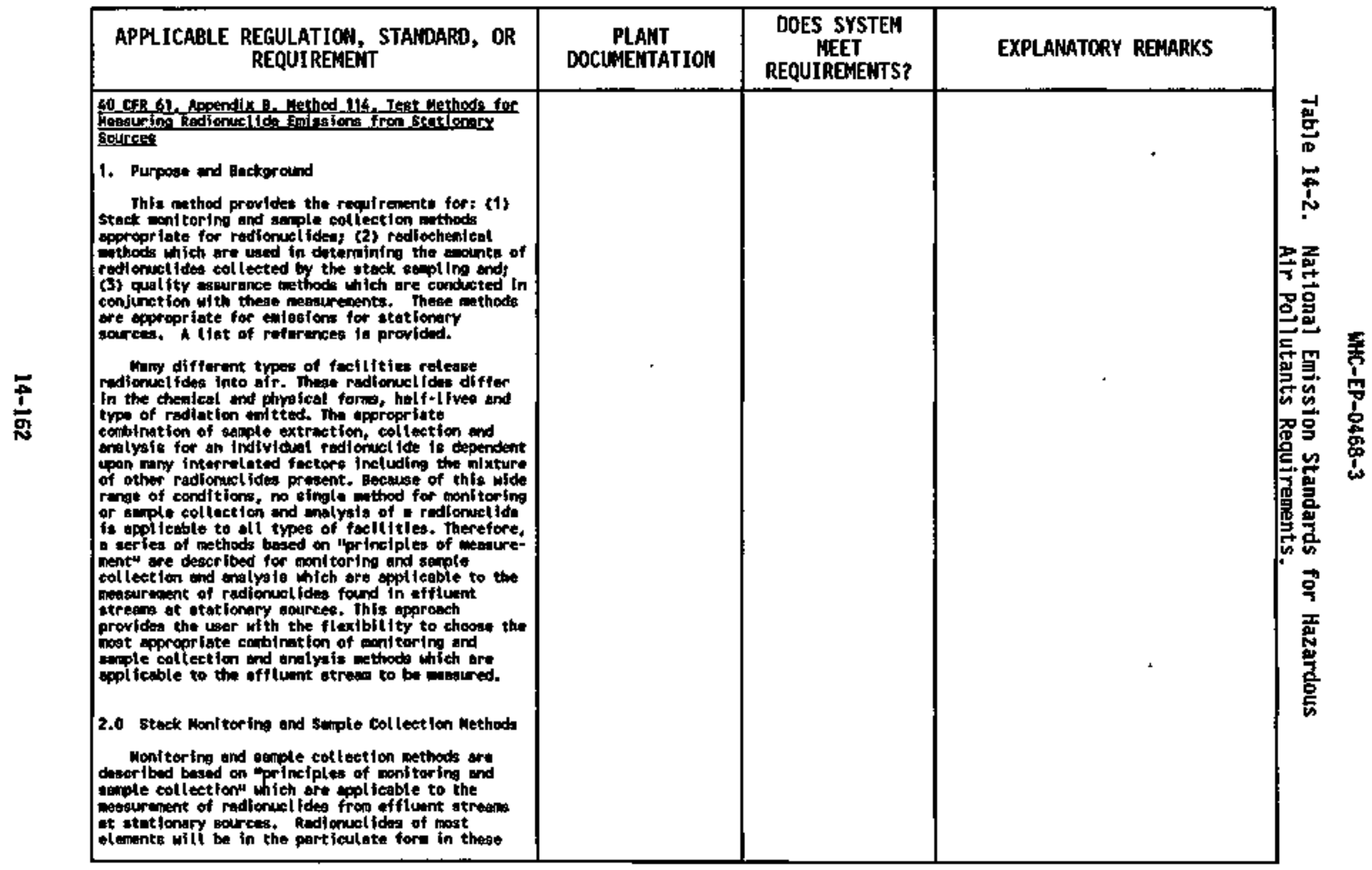




\begin{tabular}{|c|c|c|c|}
\hline $\begin{array}{l}\text { APPLICABLE REGULATION, STANDARD, OR } \\
\text { REQUIREMENT }\end{array}$ & $\begin{array}{c}\text { PLANT } \\
\text { DOCUMENTATIOA }\end{array}$ & $\begin{array}{l}\text { DOES SYSTEN } \\
\text { HEET } \\
\text { REQUIRENENTS? }\end{array}$ & EXPLANATORY RENARKS \\
\hline 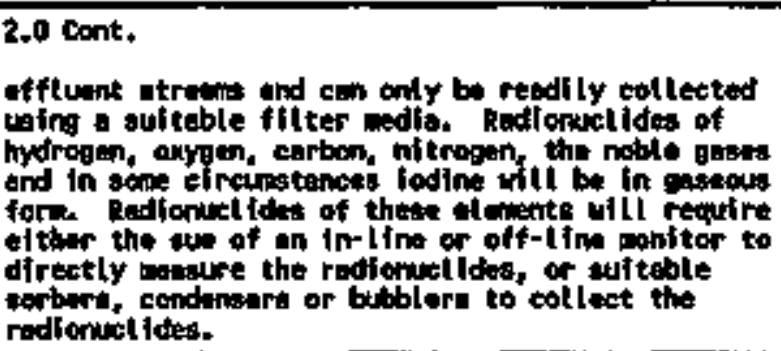 & & $\cdot$ & $v$ \\
\hline 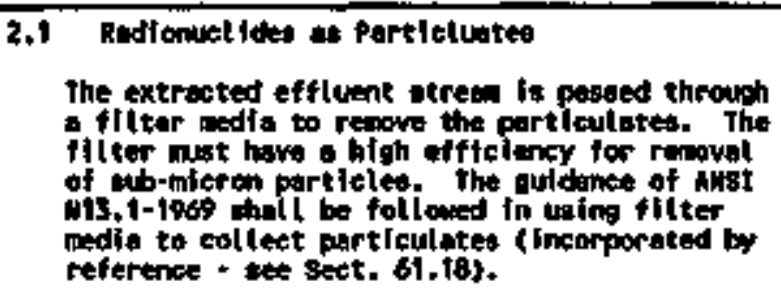 & & & 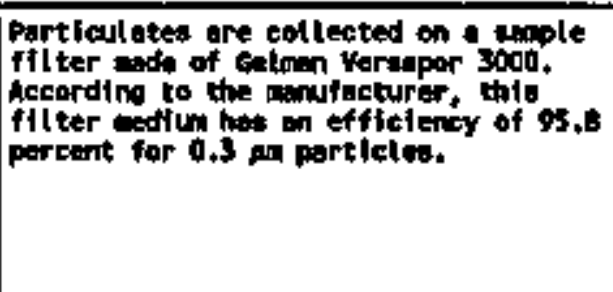 \\
\hline 2.3 befinition of terns. & & & Wo ensuser is requitract. \\
\hline
\end{tabular}




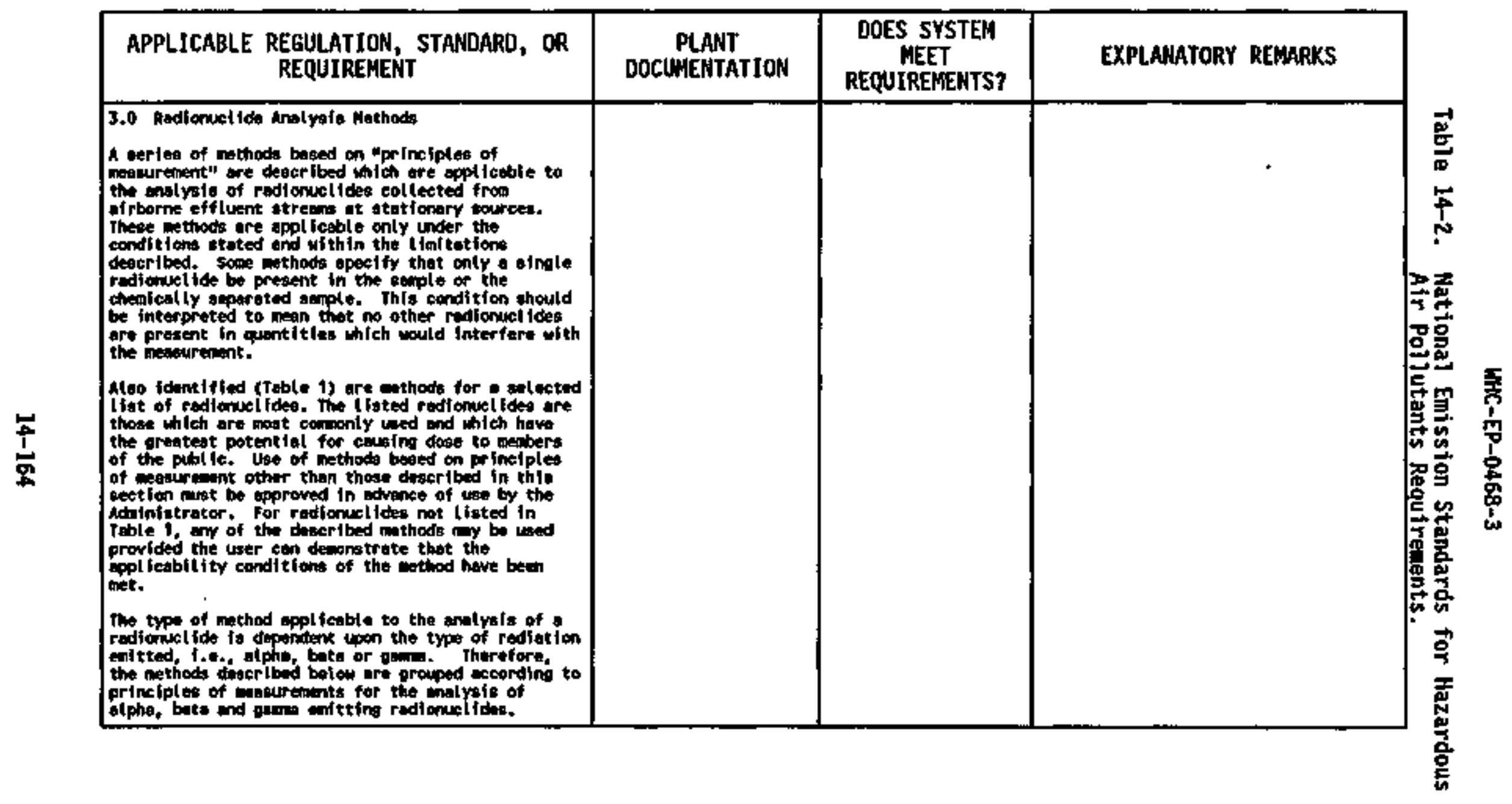




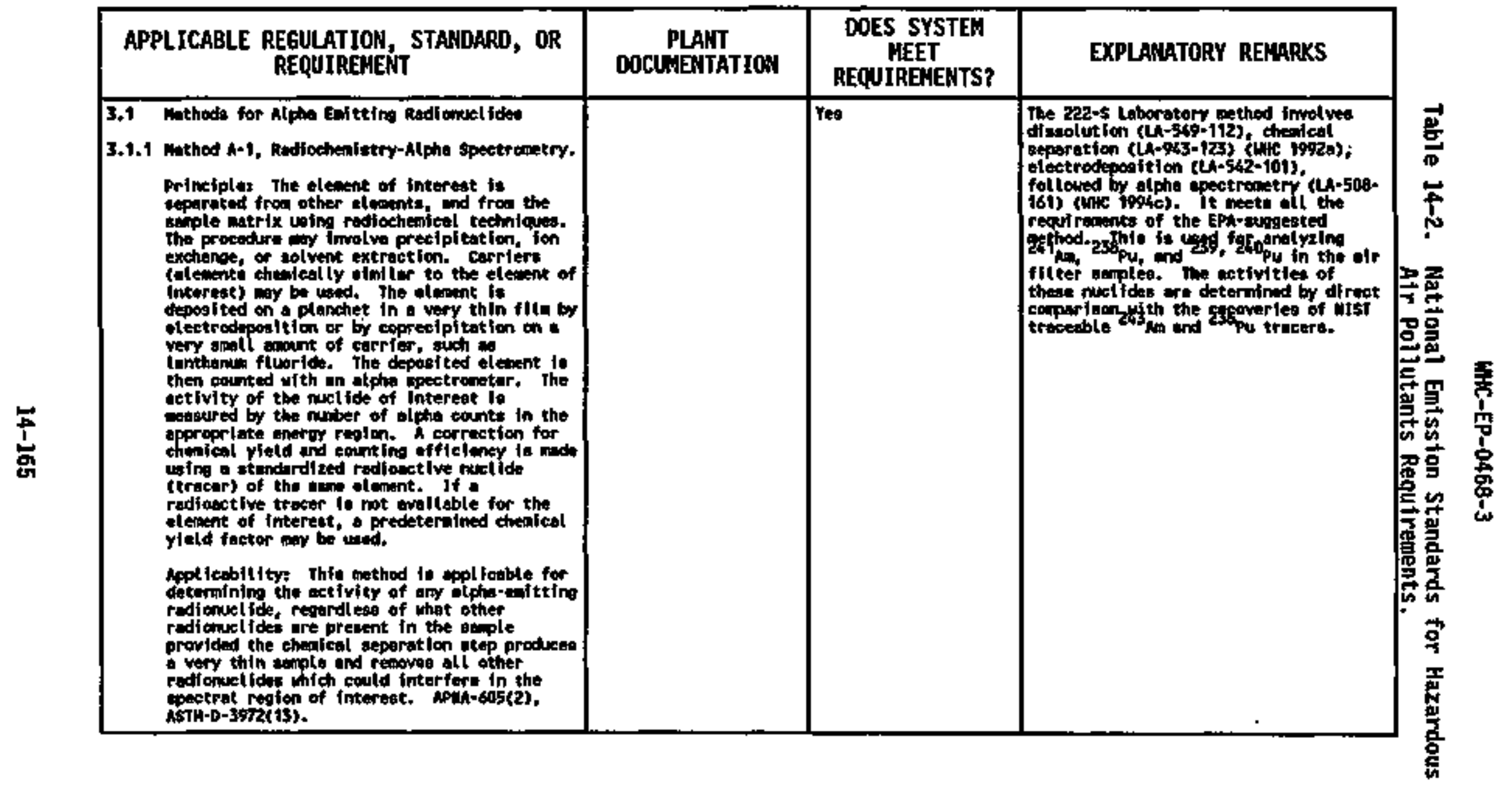




\begin{tabular}{|c|c|c|c|}
\hline $\begin{array}{l}\text { APPLICABLE REGULATION, STAMDARO, OR } \\
\text { REQUIREMENT }\end{array}$ & $\begin{array}{l}\text { PLANT } \\
\text { DOCUNERTATION }\end{array}$ & $\begin{array}{c}\text { DOES SYSTEM } \\
\text { MEET } \\
\text { REQUIRENENTS? }\end{array}$ & EXPLAMATORY REMARKS \\
\hline 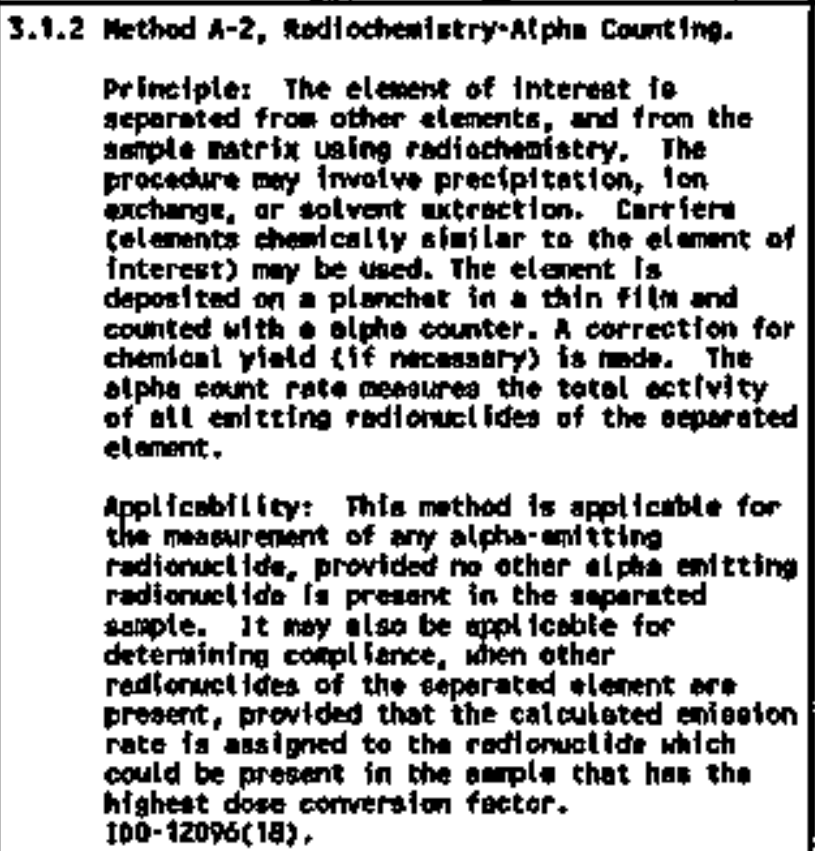 & & wot epplifable & 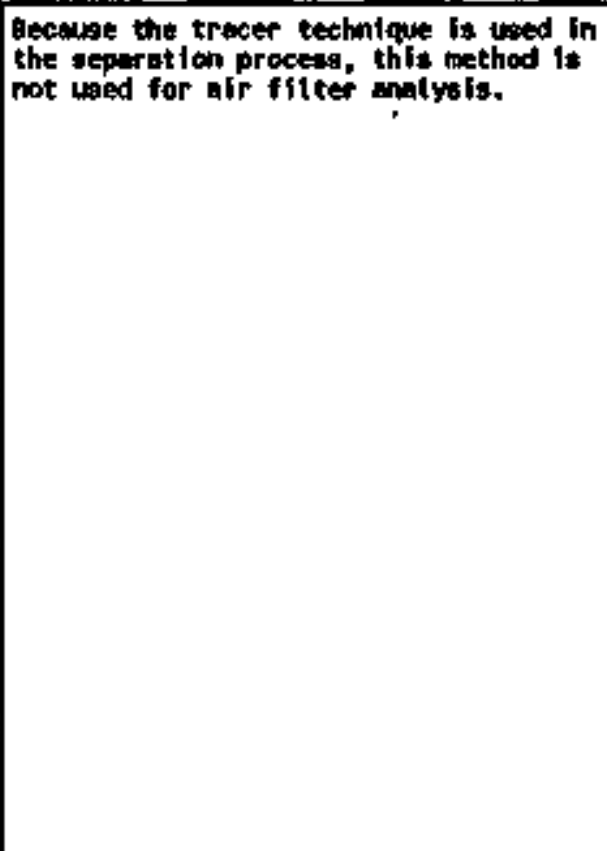 \\
\hline
\end{tabular}




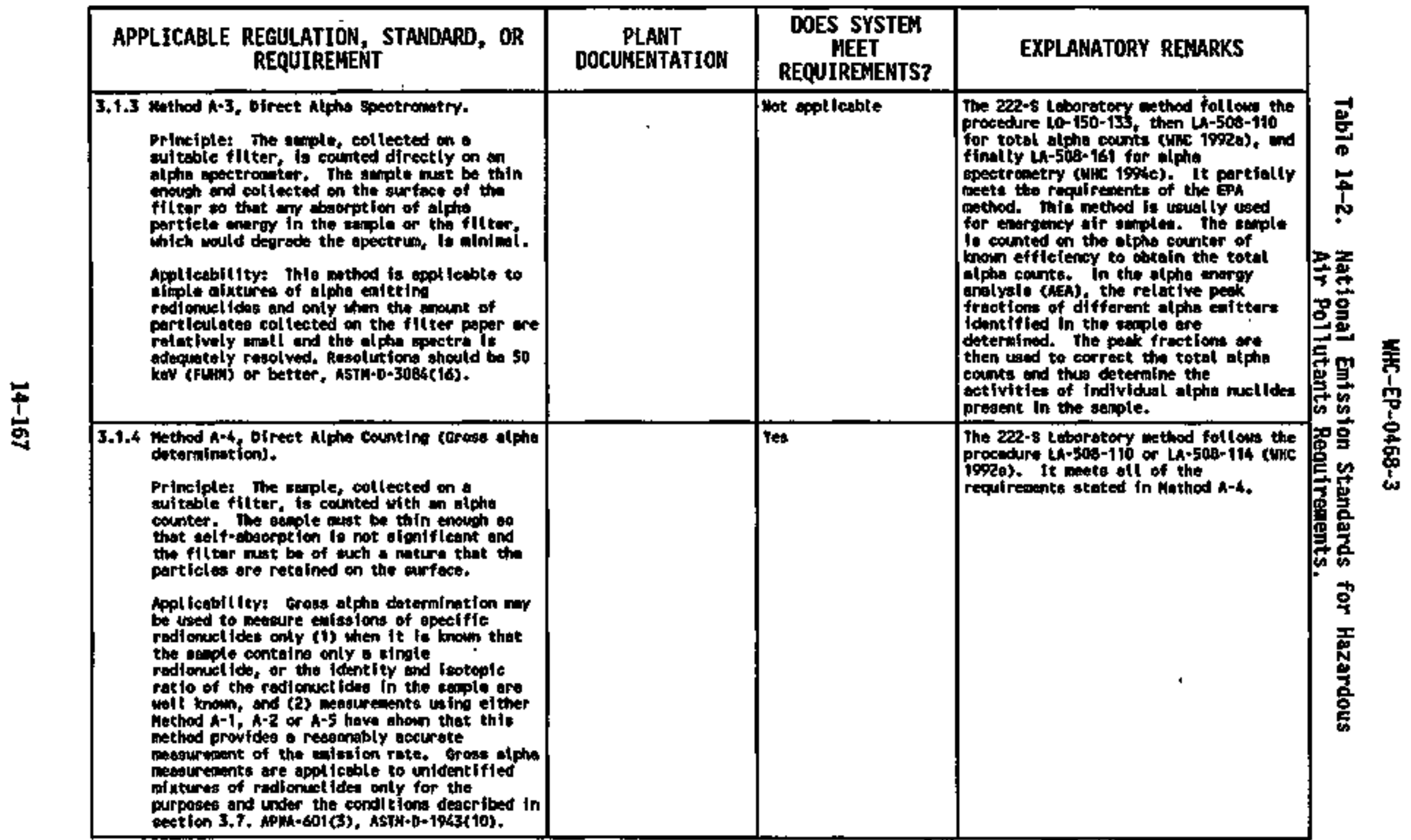




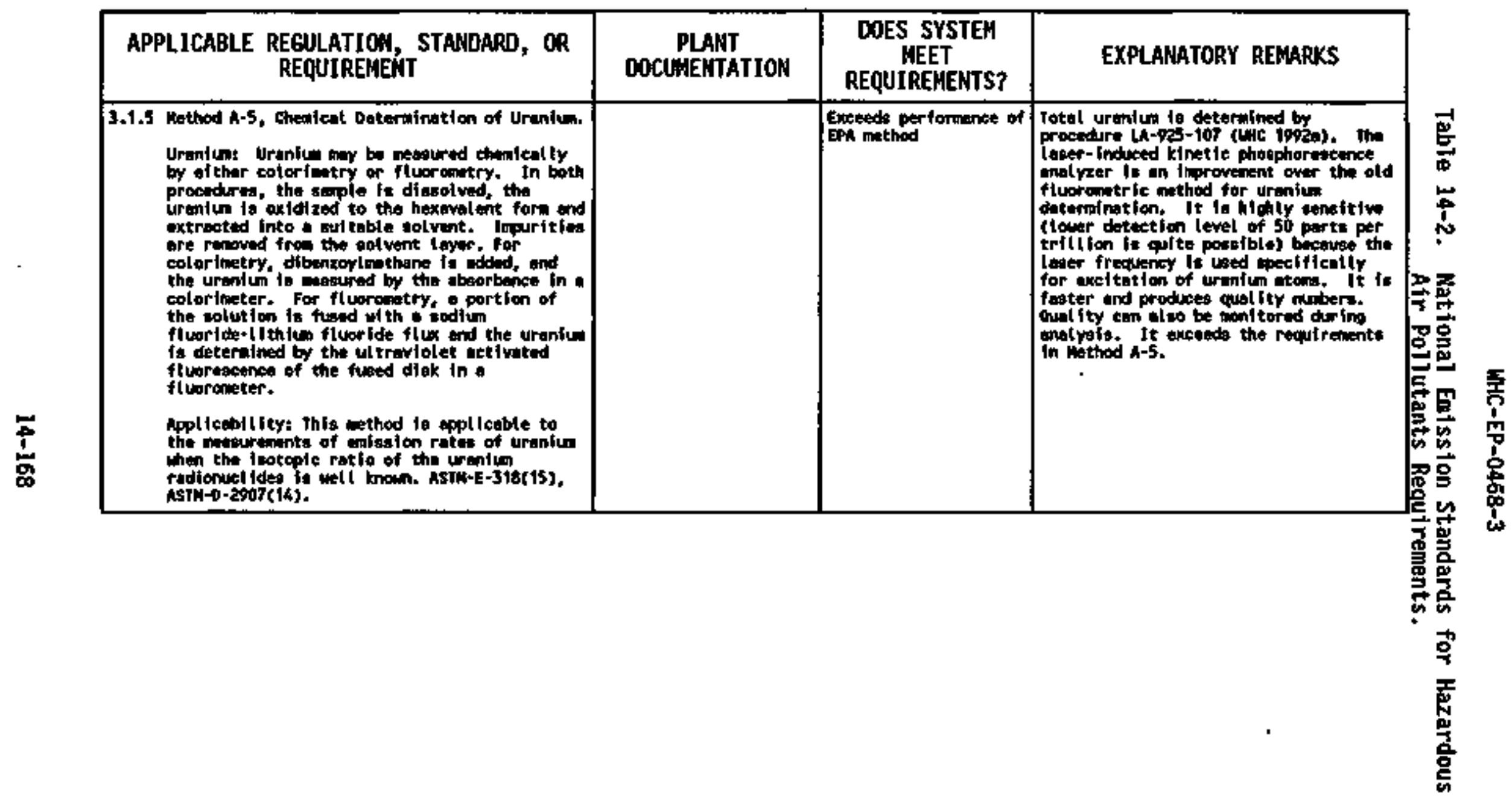




\begin{tabular}{|c|c|c|c|}
\hline $\begin{array}{l}\text { APPLICABLE REGULATIOH, STAMDARD, OR } \\
\text { REQUIREMEHT }\end{array}$ & $\begin{array}{c}\text { PLANT } \\
\text { DOCUMENTATION }\end{array}$ & $\begin{array}{l}\text { DOES SYSTEN } \\
\text { MEET } \\
\text { REQUIRENENTS? }\end{array}$ & EXPLAMATORY REMARKS \\
\hline 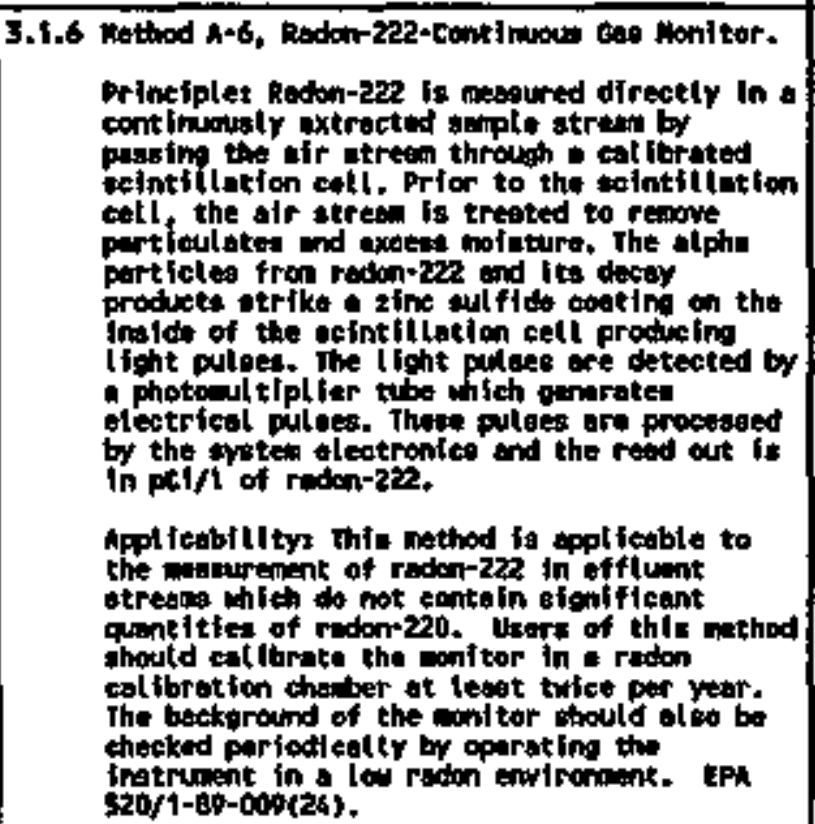 & & Hot appd feoble & 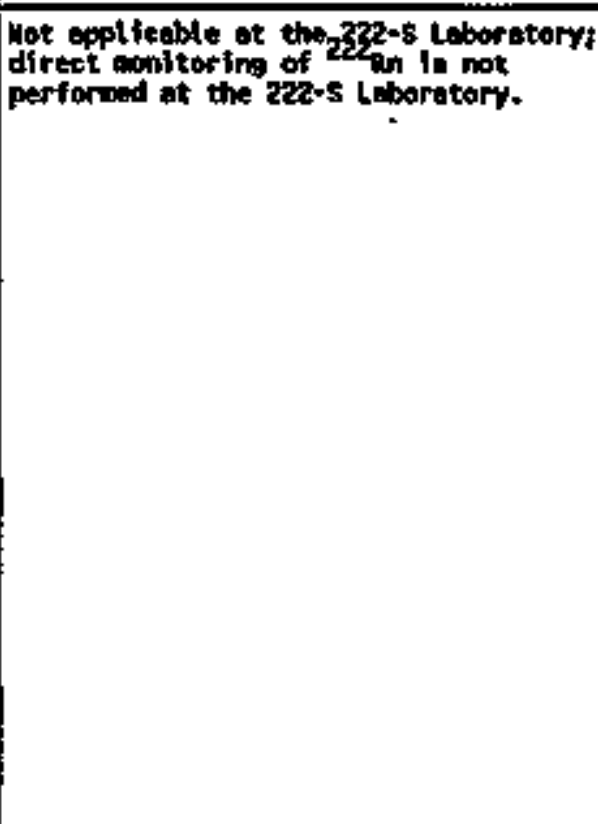 \\
\hline
\end{tabular}




\begin{tabular}{|c|c|c|c|}
\hline $\begin{array}{l}\text { APPLICABLE REGULATION, STANDARD, OR } \\
\text { REQUIREMEMT }\end{array}$ & $\begin{array}{c}\text { PLANT } \\
\text { DOCUNEETATION }\end{array}$ & $\begin{array}{c}\text { COES SYSTEN } \\
\text { MEET } \\
\text { REQUIREMEATS? }\end{array}$ & EXPLAAATORY REMARKS \\
\hline 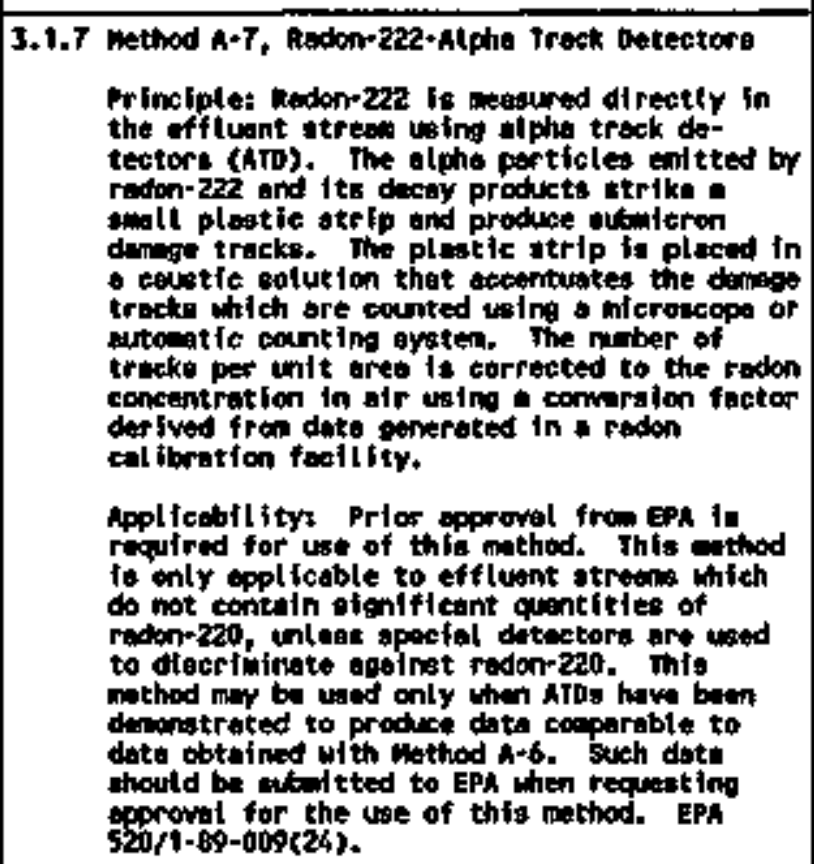 & & Wat appl leabla & 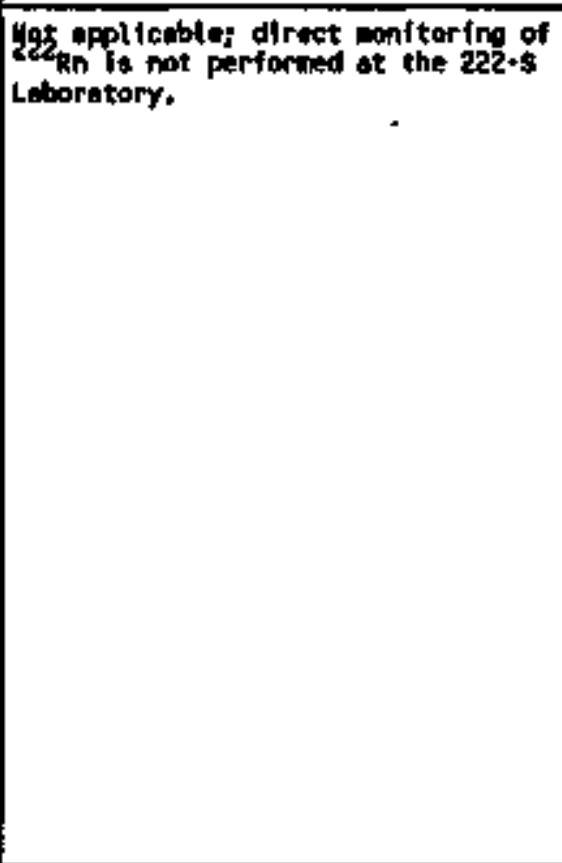 \\
\hline
\end{tabular}




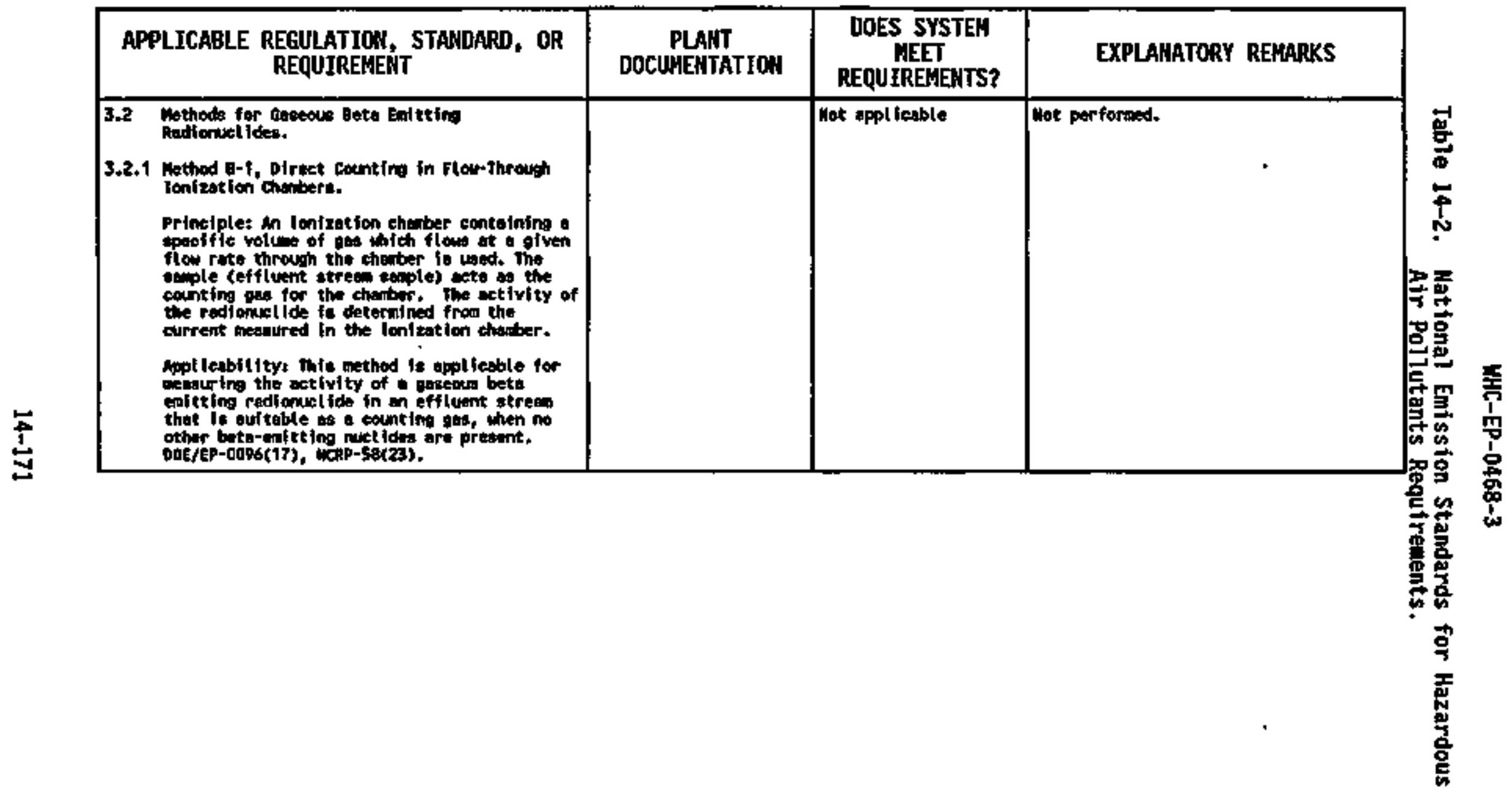




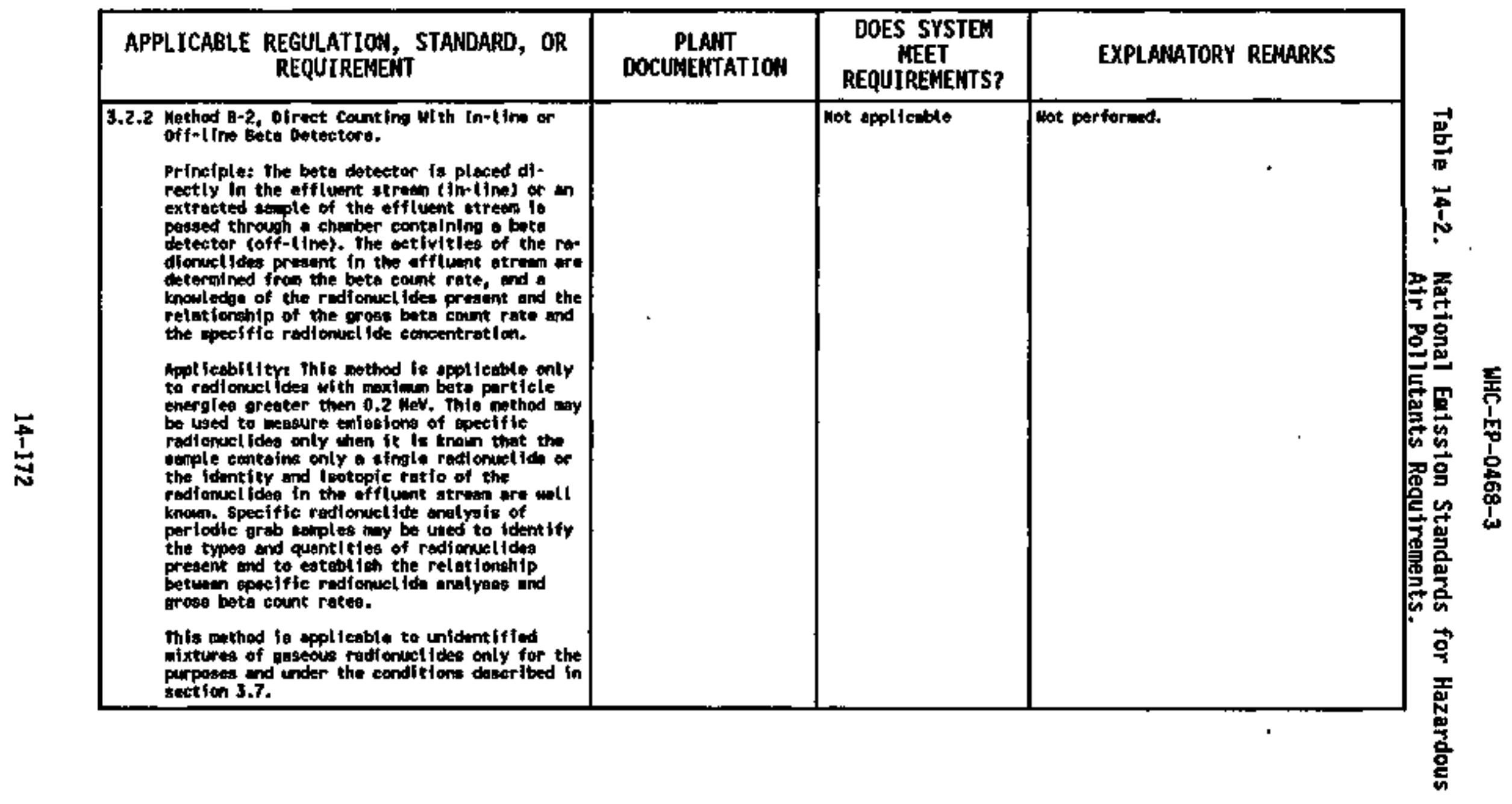




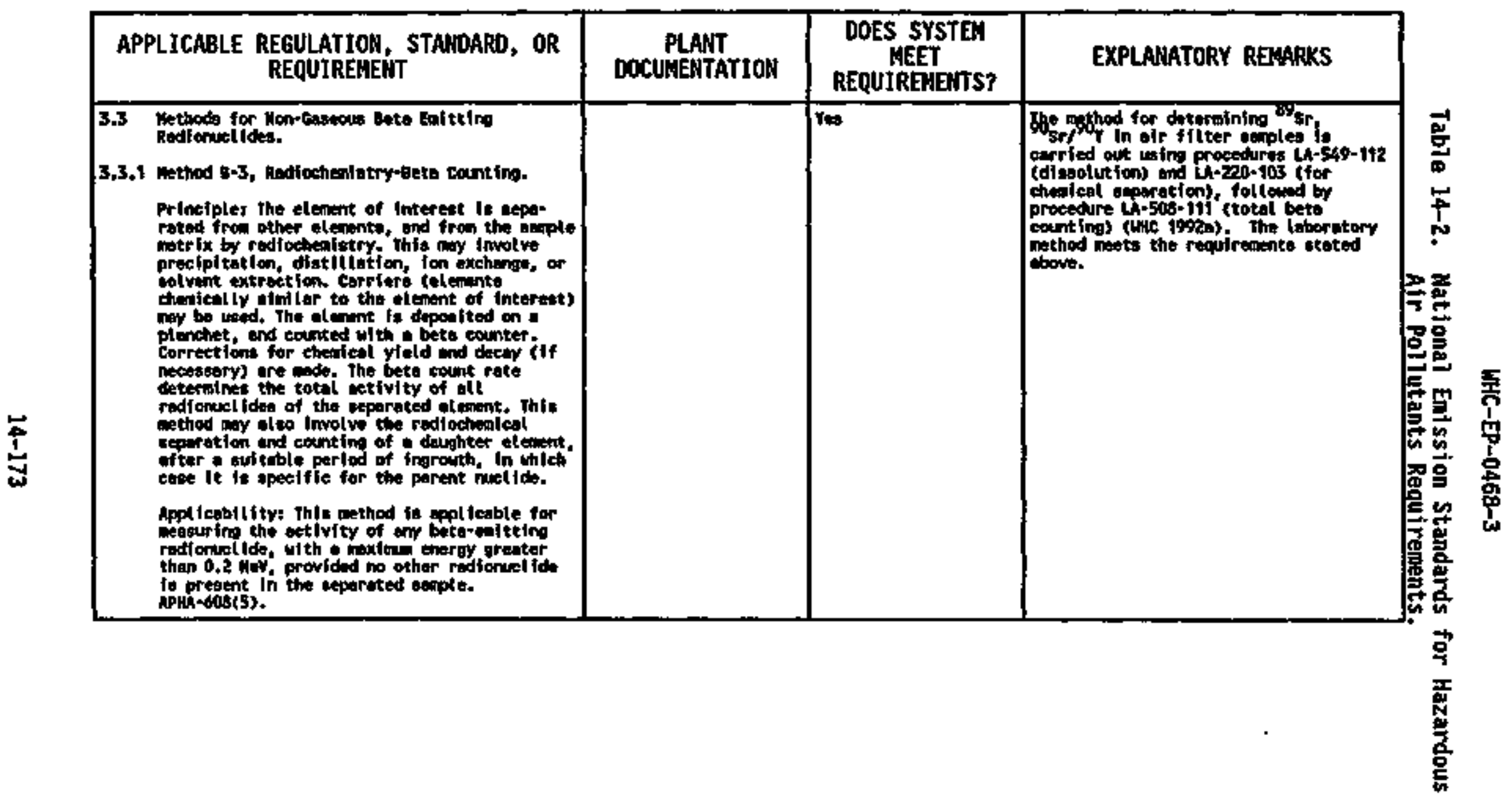




\begin{tabular}{|c|c|c|c|c|}
\hline $\begin{array}{l}\text { APPLICABLE REGULATION, STAMDARO, OR } \\
\text { REQUIREMENT }\end{array}$ & $\begin{array}{l}\text { PLANT } \\
\text { DOCUNEKTATION }\end{array}$ & $\begin{array}{l}\text { DOES SYSTEM } \\
\text { MEET } \\
\text { REQUIREHENTS? }\end{array}$ & EXPLANATORY REMARKS & \\
\hline 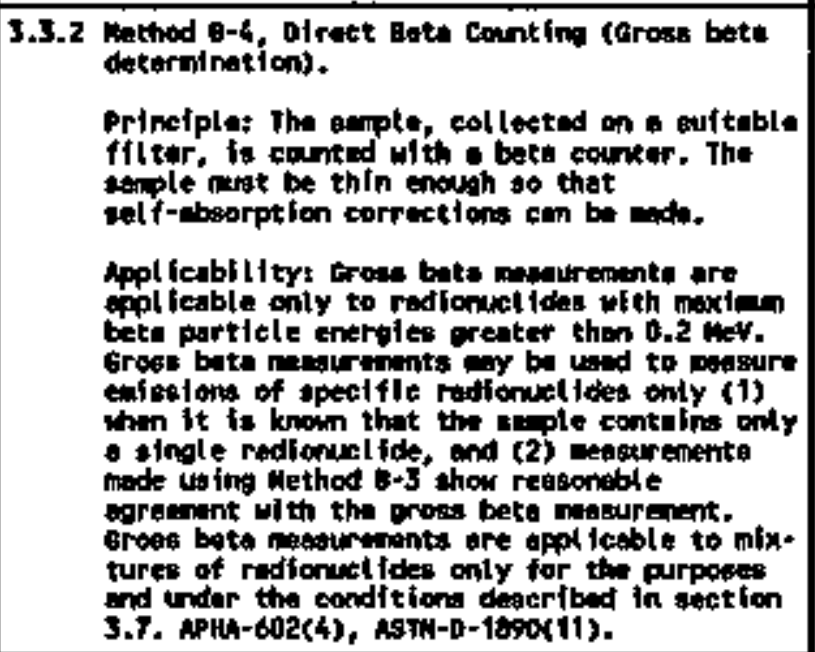 & & $y+a$ & 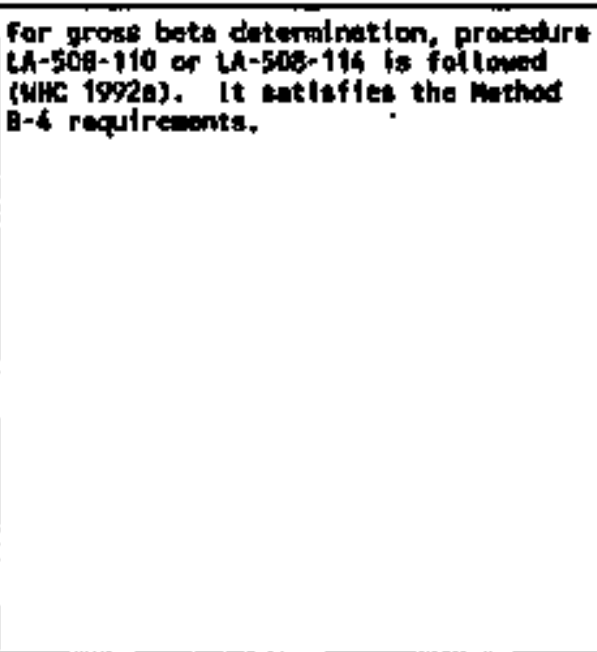 & 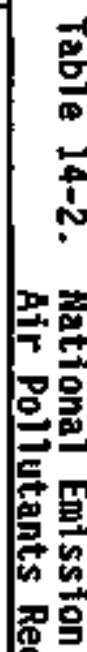 \\
\hline
\end{tabular}




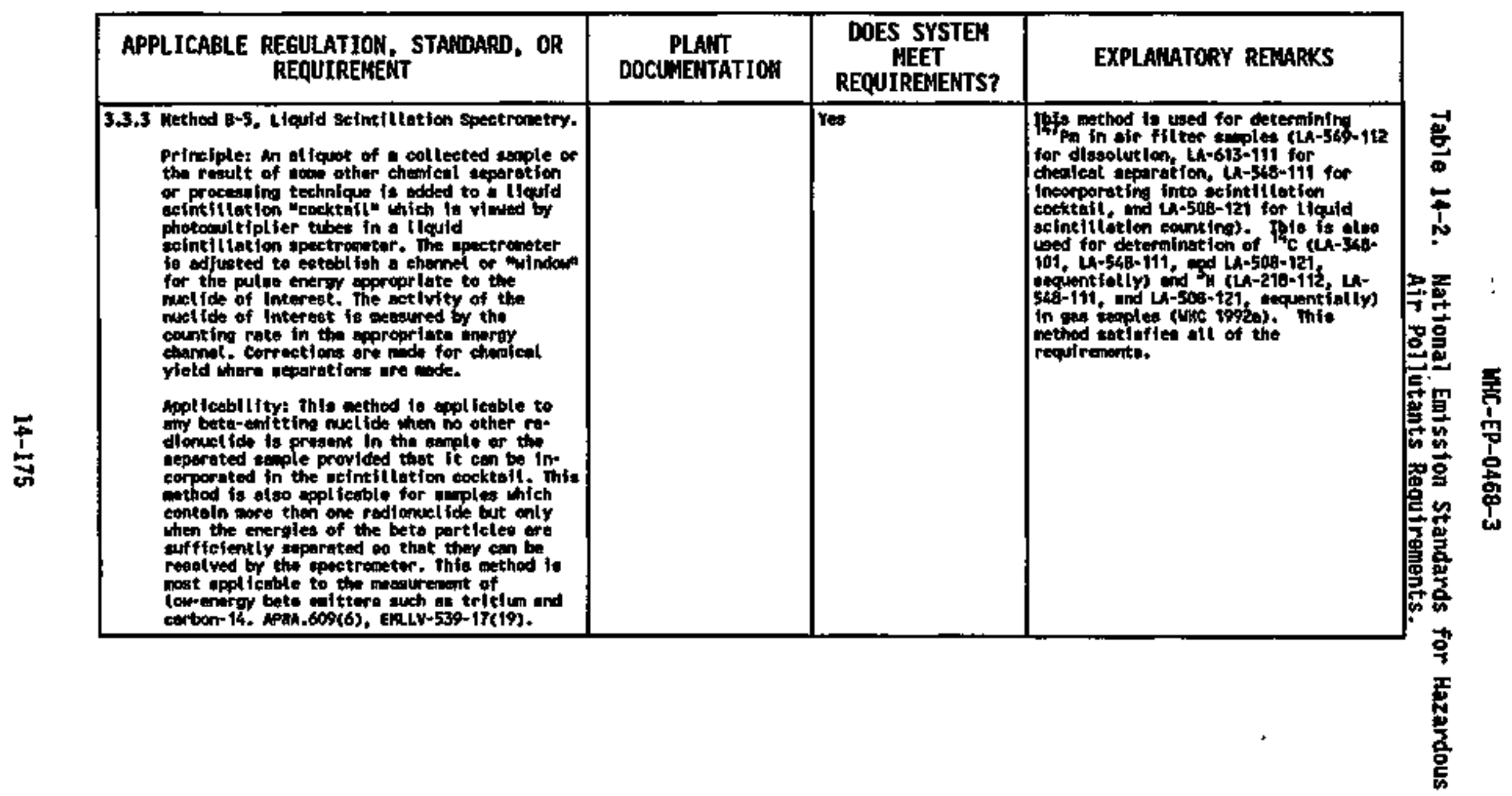




\begin{tabular}{|c|c|c|c|}
\hline $\begin{array}{l}\text { APPLICABLE REGULATION, STAHDARD, OR } \\
\text { REOUIREMENT }\end{array}$ & $\begin{array}{c}\text { PLAHT } \\
\text { OOCUMEKTATIOA }\end{array}$ & $\begin{array}{l}\text { DOES SYSTEN } \\
\text { MEET } \\
\text { REQUIREMEHTS? }\end{array}$ & EXPLAHATORY REMARKS \\
\hline 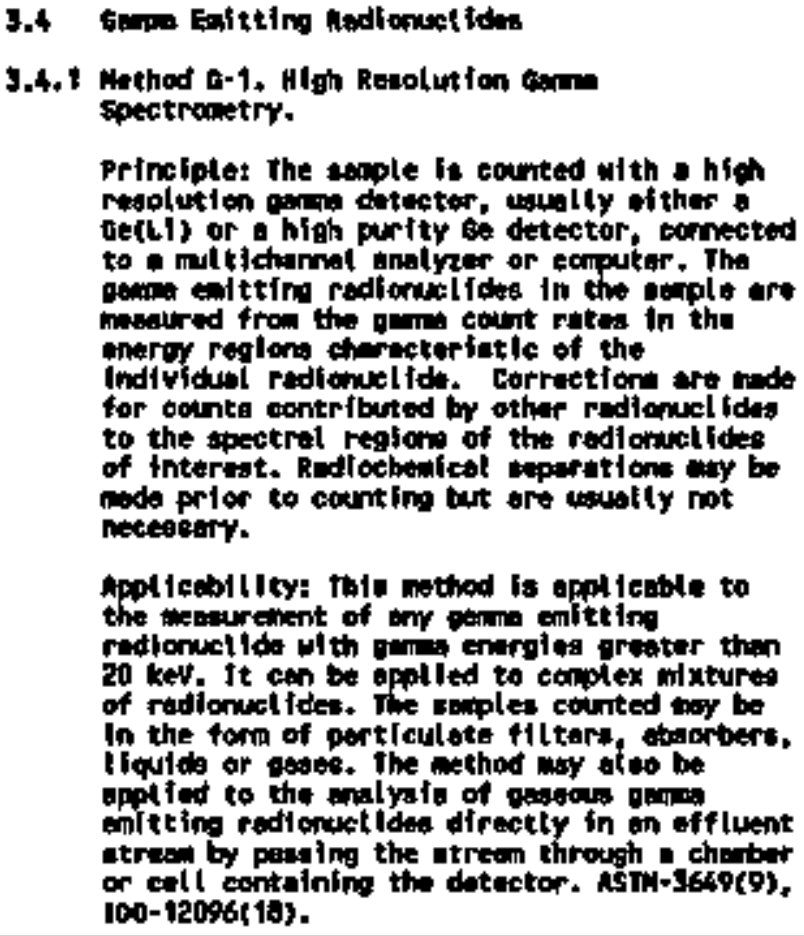 & & $\gamma \in{ }^{\prime}$ & 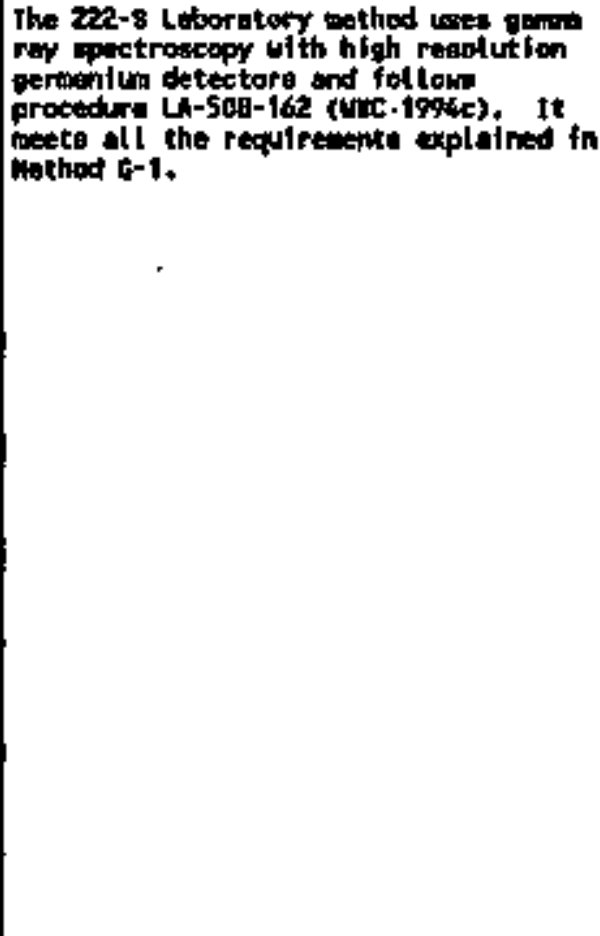 \\
\hline
\end{tabular}




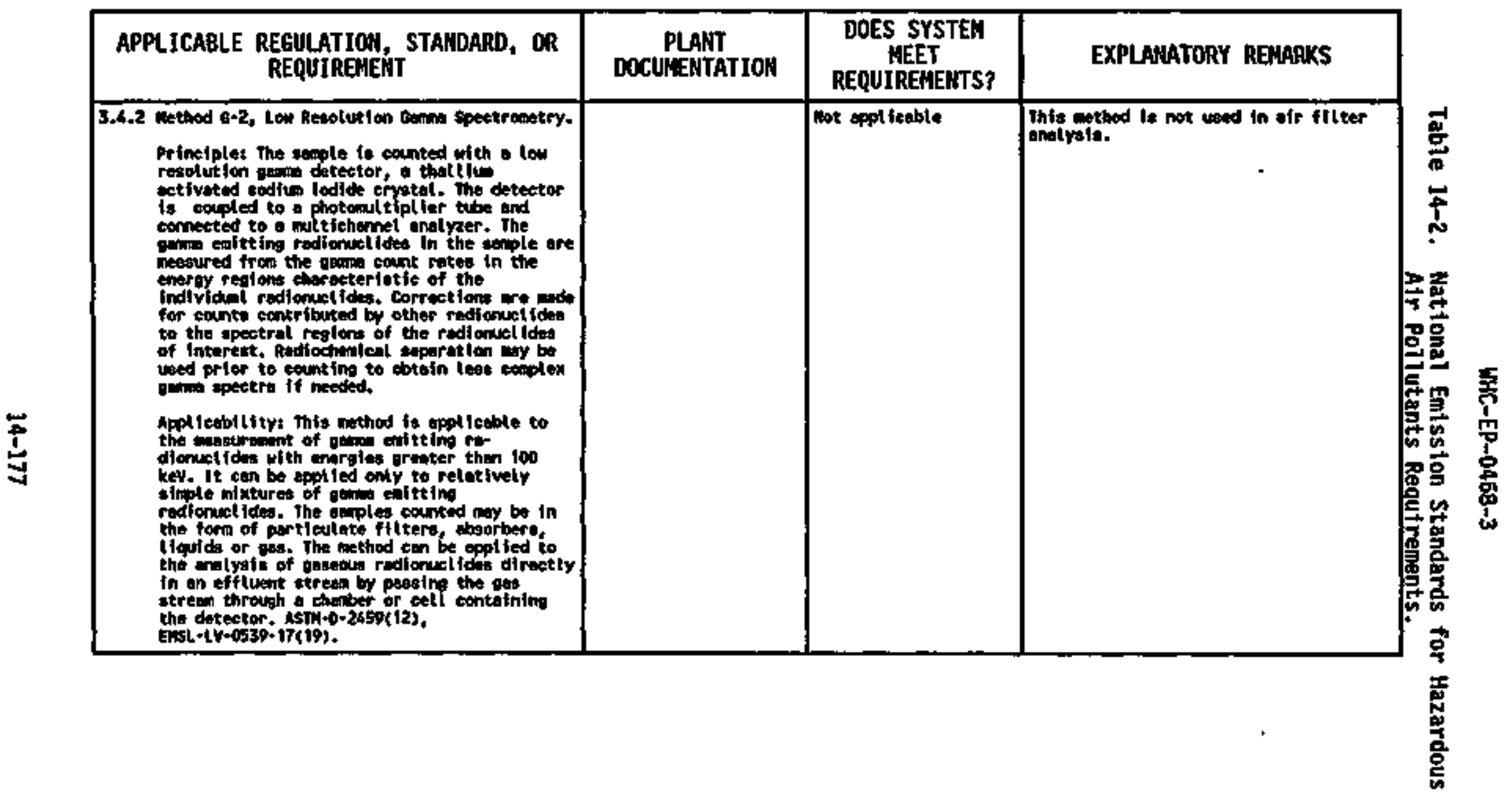




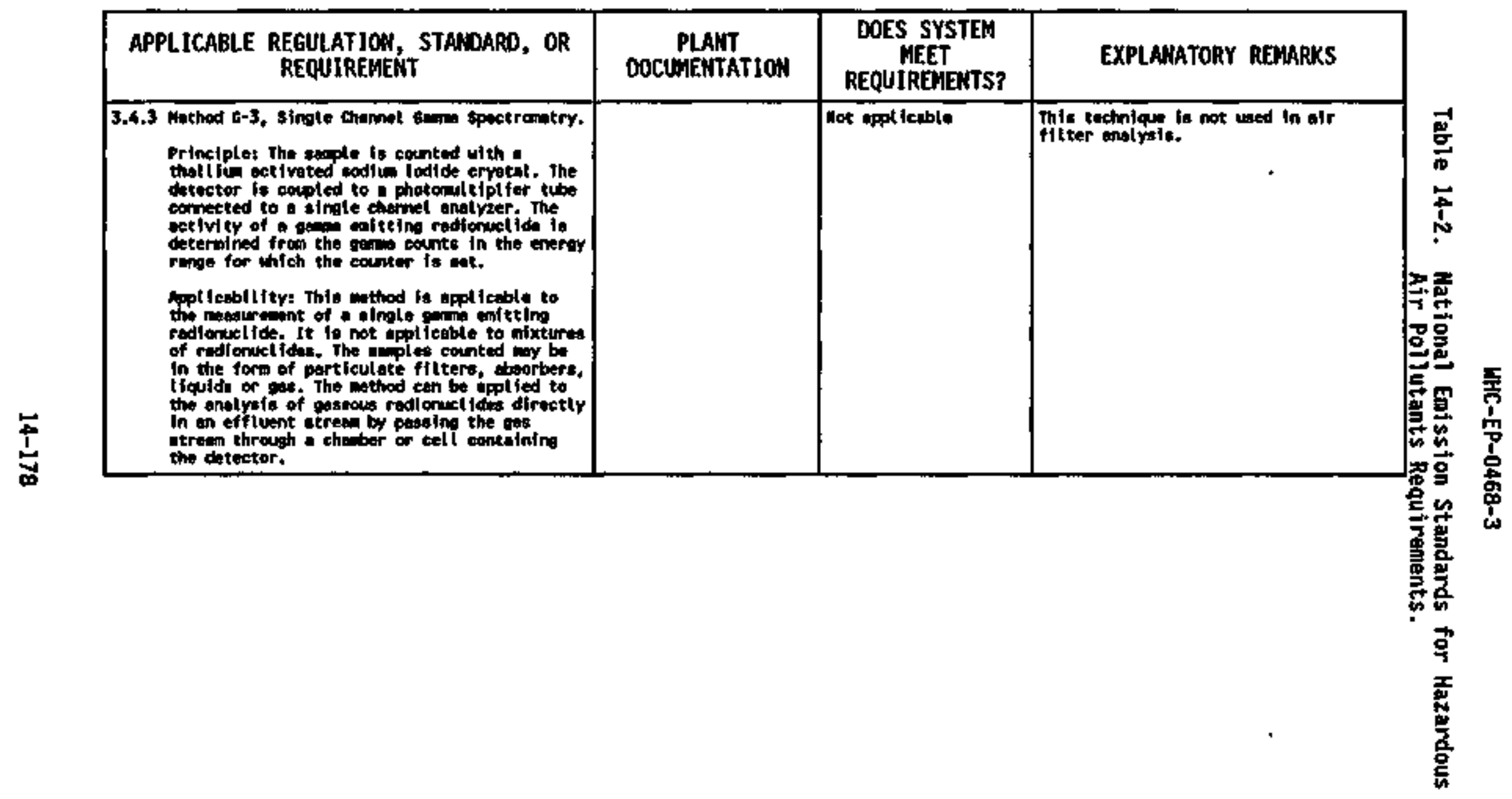




\begin{tabular}{|c|c|c|c|}
\hline $\begin{array}{l}\text { APPLICABLE REGULAJION, STANDARD, OR } \\
\text { REQUIREMENT }\end{array}$ & $\begin{array}{l}\text { PLANT } \\
\text { DOCUNENTATIOH }\end{array}$ & $\begin{array}{l}\text { DOES SYSTEN } \\
\text { HEET } \\
\text { REQUIREMETS? }\end{array}$ & EXPLAMATORY REMARKS \\
\hline 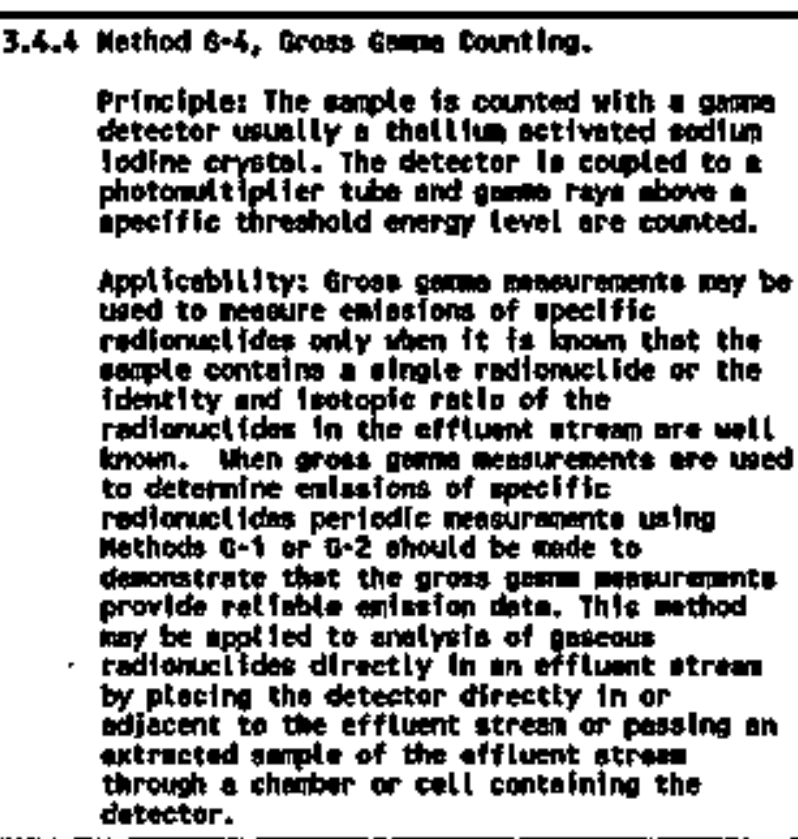 & & Wot spped lathle & $-e^{4}$ \\
\hline
\end{tabular}




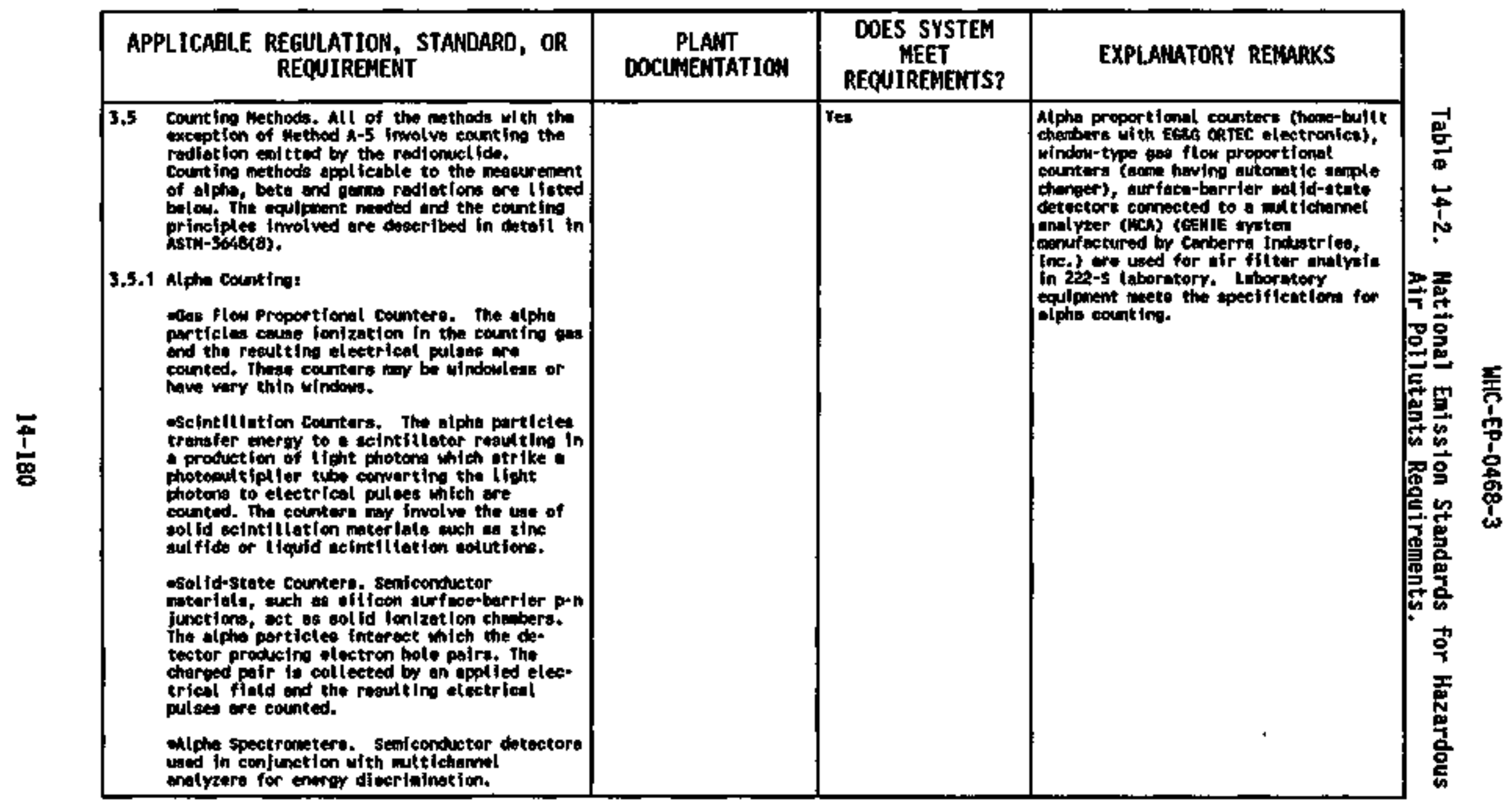




\begin{tabular}{|c|c|c|c|}
\hline $\begin{array}{l}\text { APPL ICABLE REGULATION, STAMDARD, OR } \\
\text { REQUIREMENT }\end{array}$ & $\begin{array}{c}\text { PLANT } \\
\text { DOCUMENTATION }\end{array}$ & $\begin{array}{l}\text { DOES SYSTEN } \\
\text { MEET } \\
\text { REQUIREMENTS? }\end{array}$ & EXPLAMATORY REMARKS \\
\hline 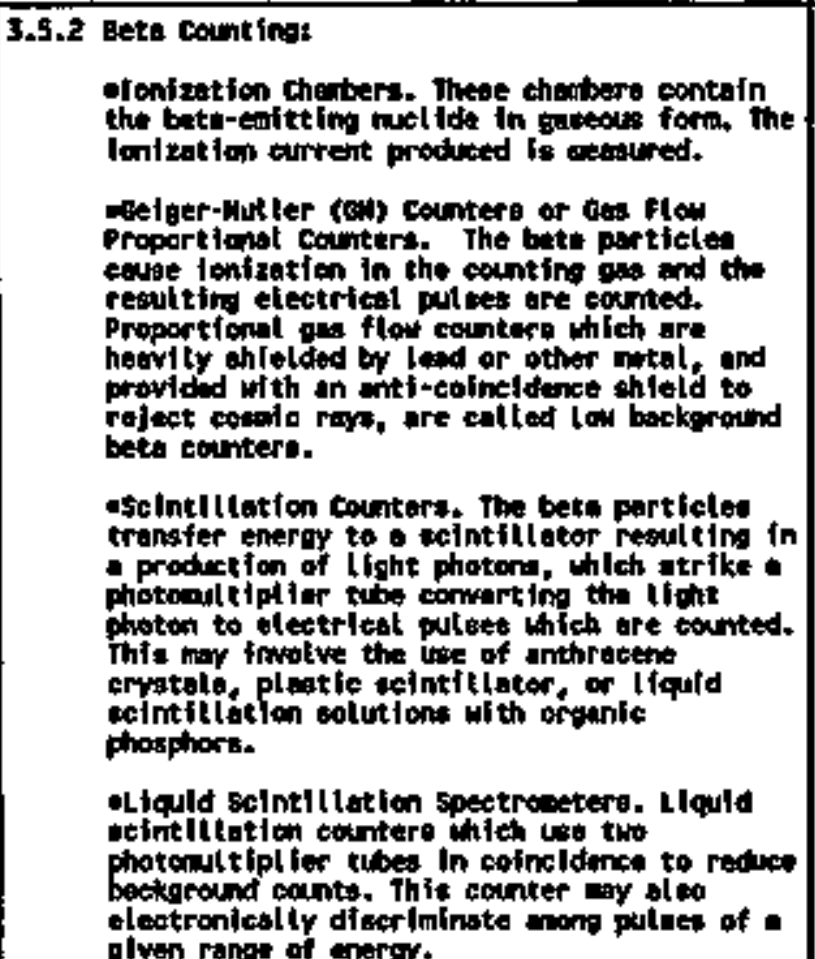 & & Yres & 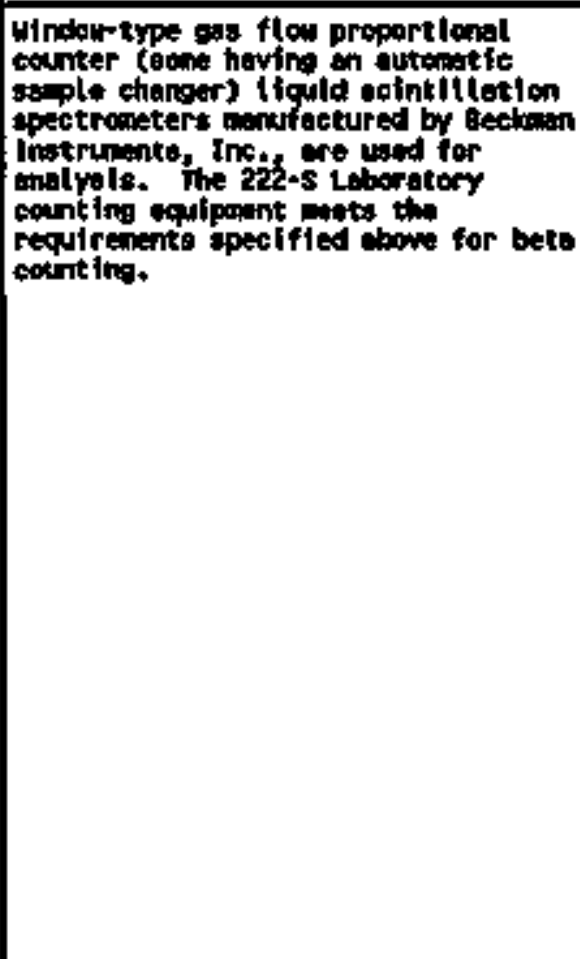 \\
\hline
\end{tabular}




\begin{tabular}{|c|c|c|c|}
\hline $\begin{array}{l}\text { APPLICABLE REGULATIOH, STAHDARD, OR } \\
\text { REQUIREHERT }\end{array}$ & $\begin{array}{l}\text { PLANT } \\
\text { DOCLNENTATION }\end{array}$ & $\begin{array}{c}\text { DOES SYSTEM } \\
\text { NEET } \\
\text { REQUIREMENTS? }\end{array}$ & EXPLANATORY REMARKS \\
\hline 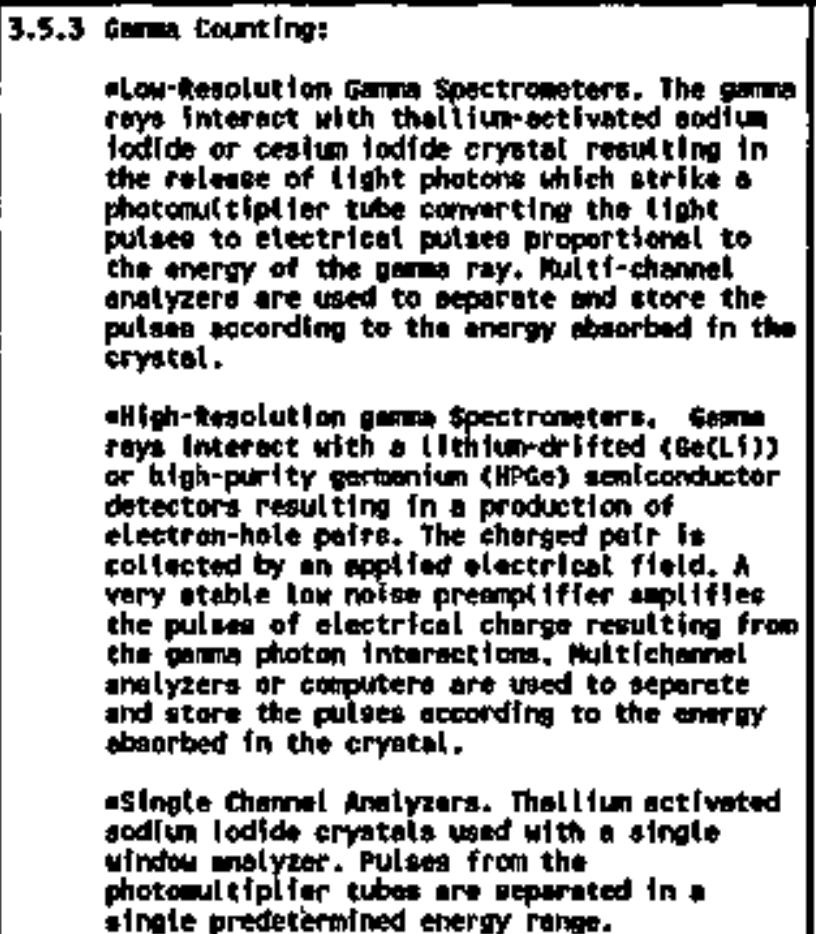 & & TaB & 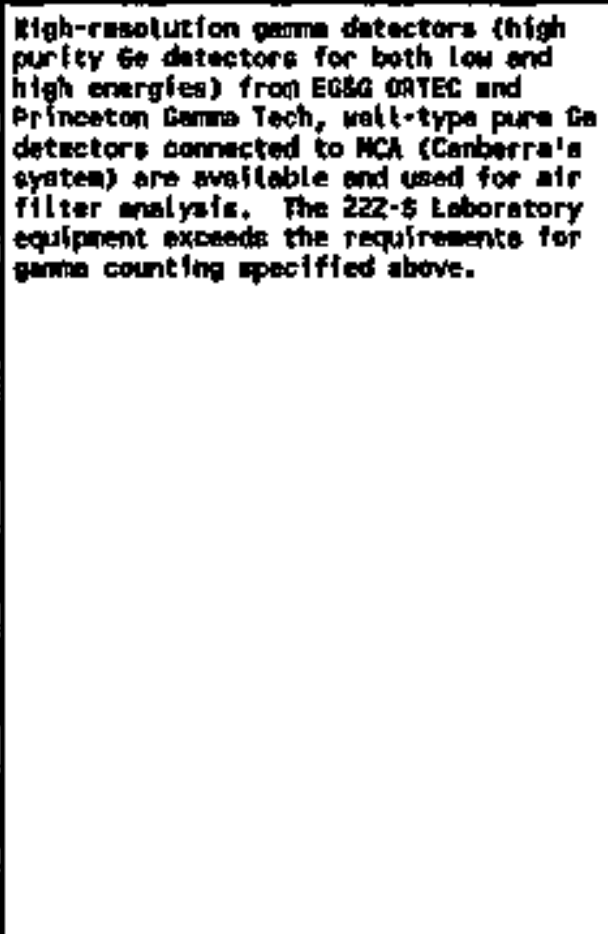 \\
\hline
\end{tabular}




\begin{tabular}{|c|c|c|c|}
\hline $\begin{array}{l}\text { APPLICABLE REGULATION, STANDARD, OR } \\
\text { REQUIREMEHT }\end{array}$ & $\begin{array}{c}\text { PLANT } \\
\text { DOCUHENTATION }\end{array}$ & $\begin{array}{l}\text { DOES SYSTEN } \\
\text { MEET } \\
\text { REQUIRENENTS? }\end{array}$ & EXPLANATORY RENARKS \\
\hline 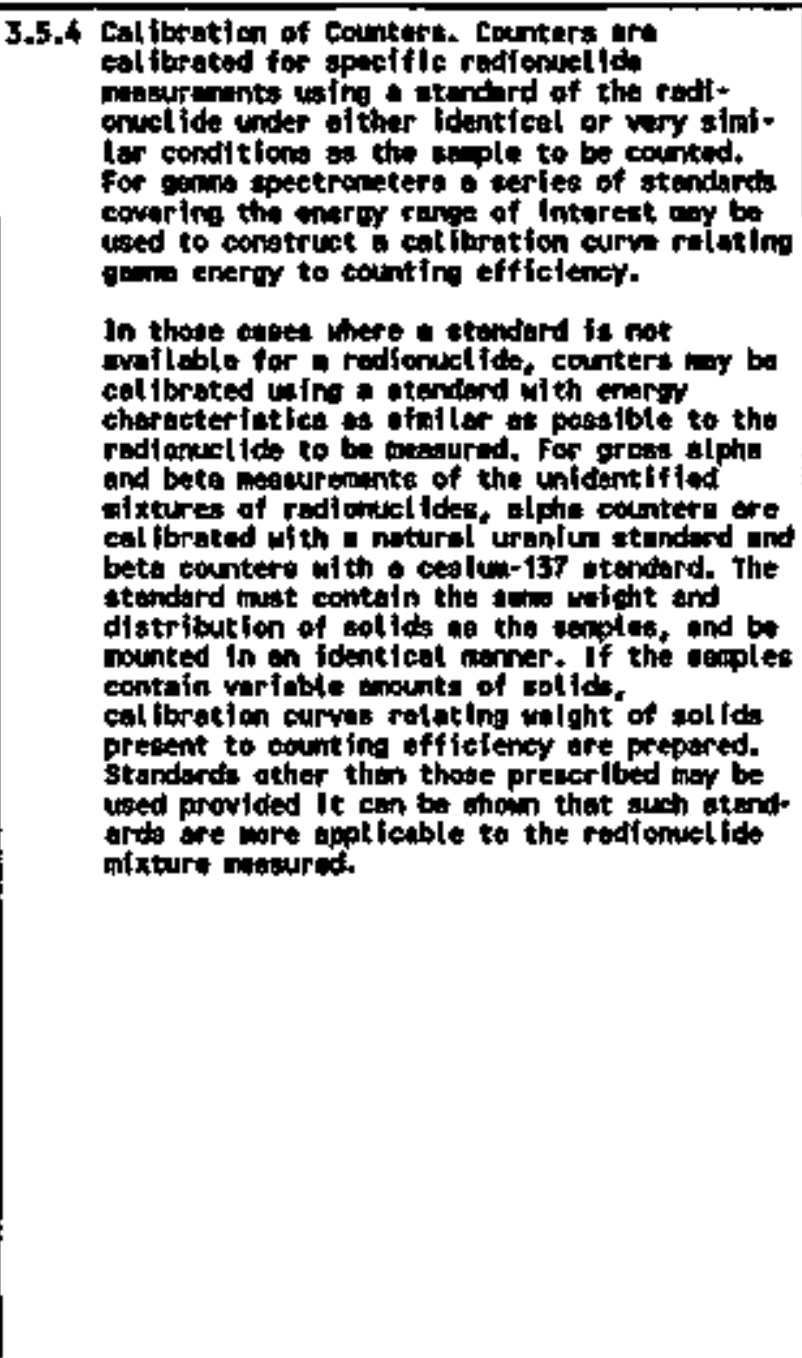 & & Yes & 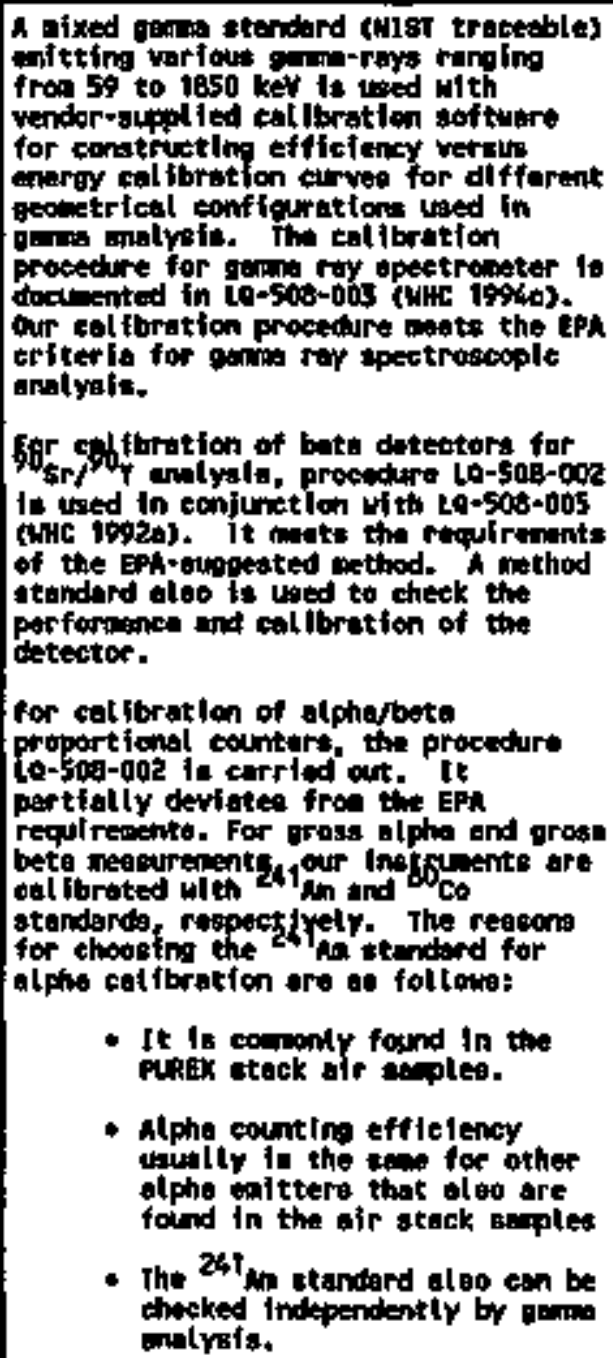 \\
\hline
\end{tabular}




\begin{tabular}{|c|c|c|c|}
\hline $\begin{array}{l}\text { APPLICABLE REGULATIOH, STANDARO, OR } \\
\text { REQUIREMENT }\end{array}$ & $\begin{array}{c}\text { PLANT } \\
\text { DOCUNEMTATIOH }\end{array}$ & $\begin{array}{c}\text { DOES SYSTEM } \\
\text { MEET } \\
\text { REQUIREMENTS? }\end{array}$ & EXPLAHATORY RENARKS \\
\hline 3.5 .4 continined & & & 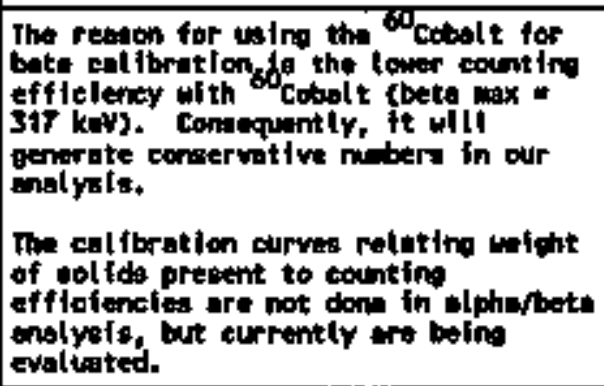 \\
\hline 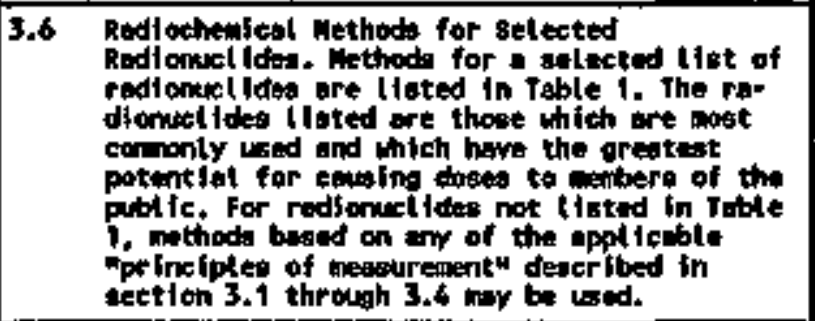 & & $Y=0$ & 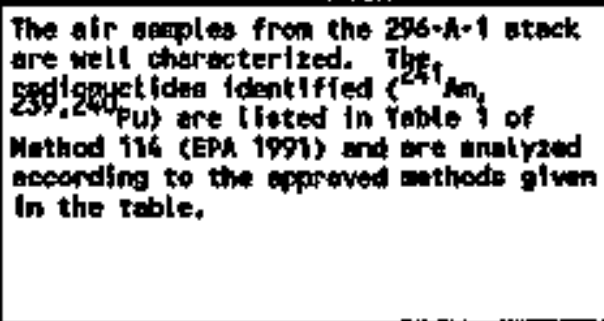 \\
\hline
\end{tabular}




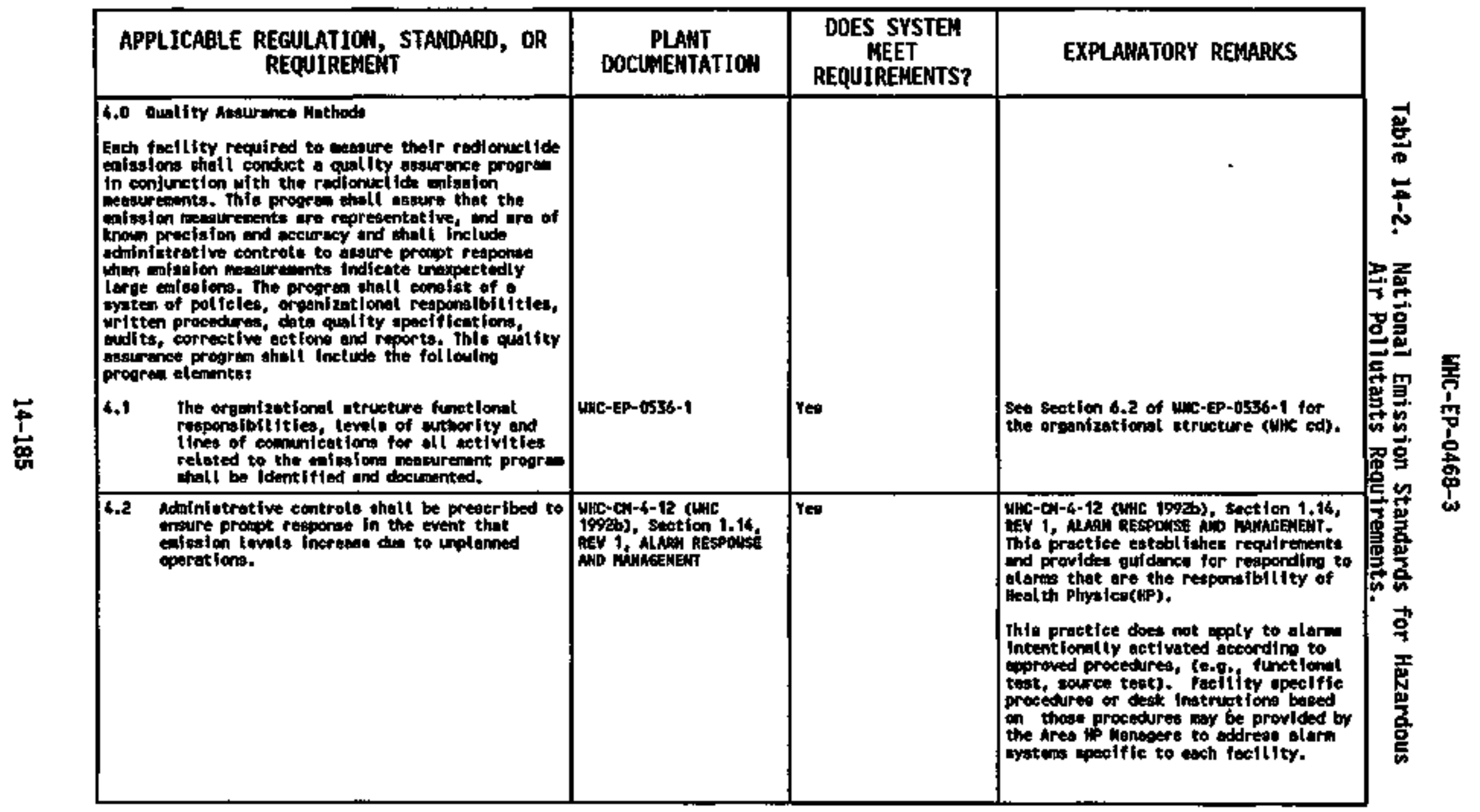




\begin{tabular}{|c|c|c|c|}
\hline $\begin{array}{l}\text { APPLICABLE REGULATIOH, STAHOARO, OR } \\
\text { REQUIREHEHT }\end{array}$ & $\begin{array}{c}\text { PLANT } \\
\text { DOCLNENTATION }\end{array}$ & $\begin{array}{l}\text { DOES SYSTEM } \\
\text { MEET } \\
\text { REQUIREMENTS? }\end{array}$ & EXPLANATORY REHARKS \\
\hline 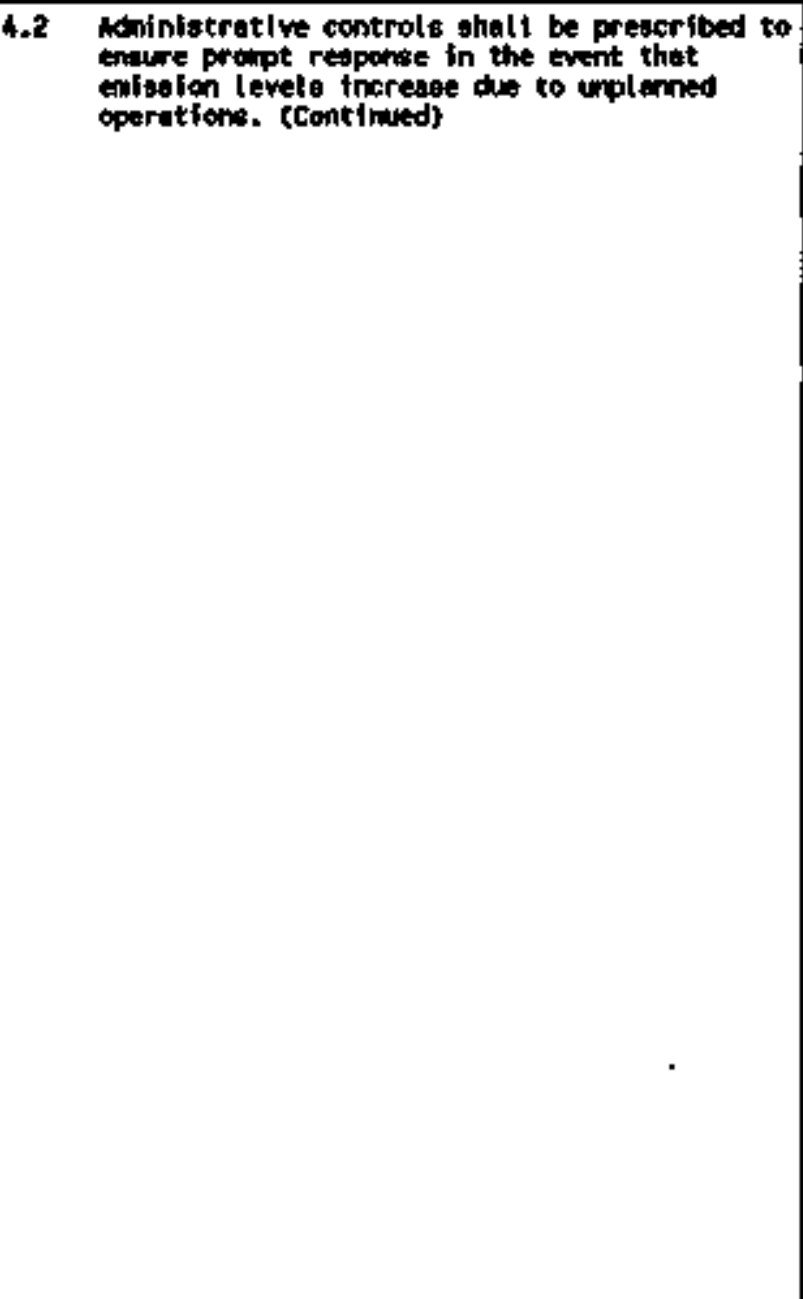 & 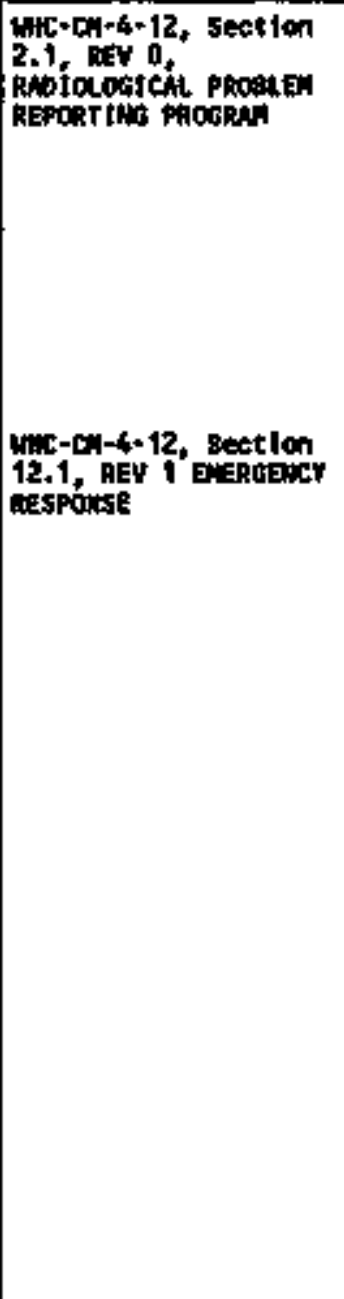 & $\begin{array}{l}\text { Yes } \\
\text { res }\end{array}$ & 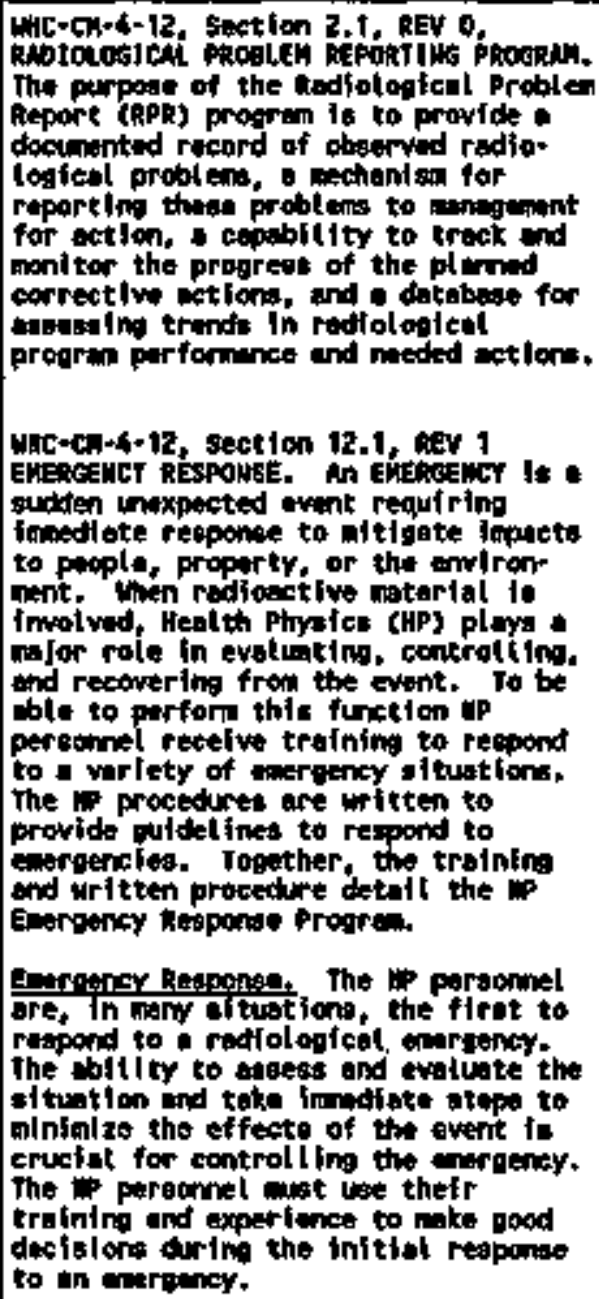 \\
\hline
\end{tabular}




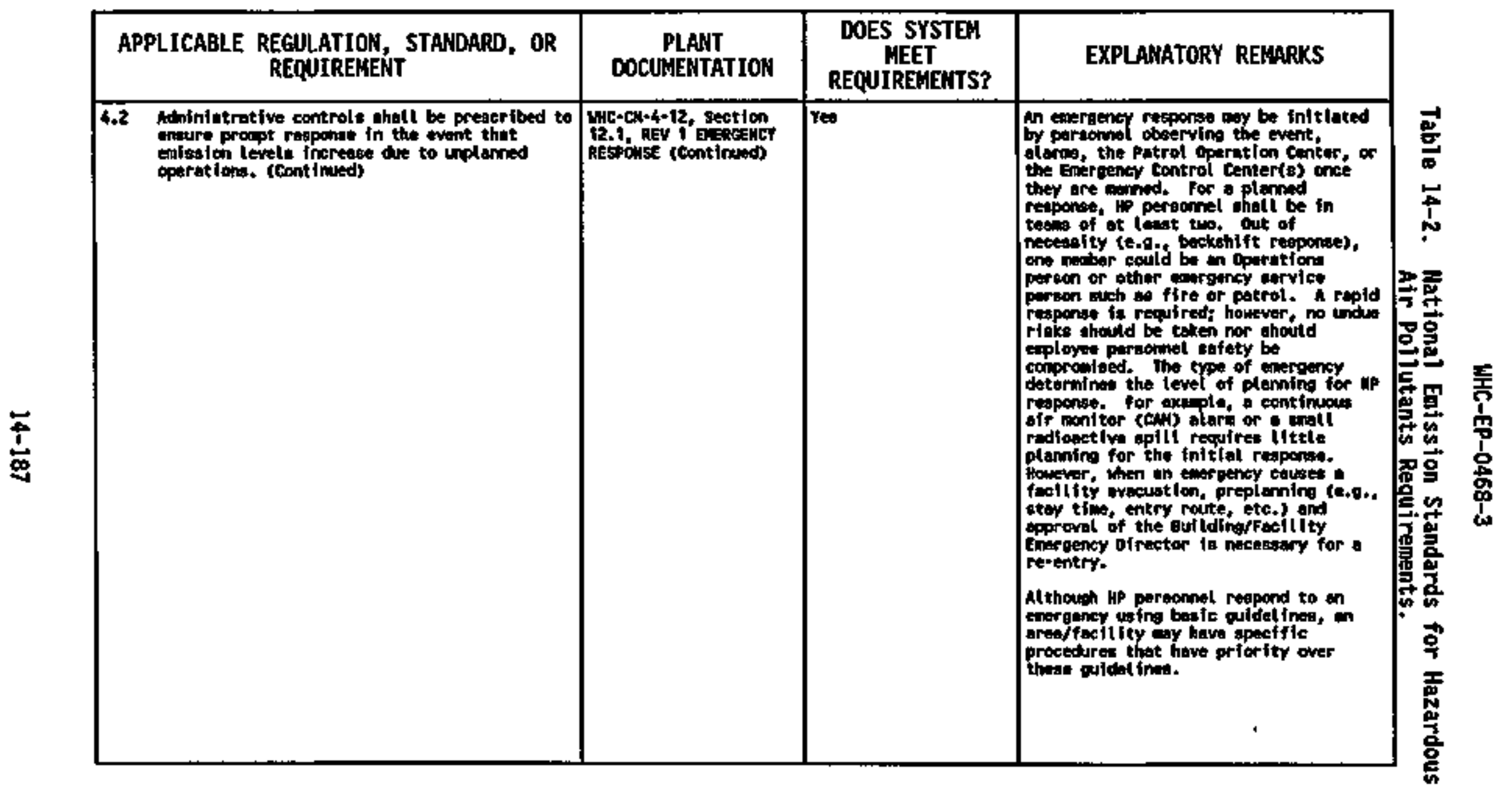




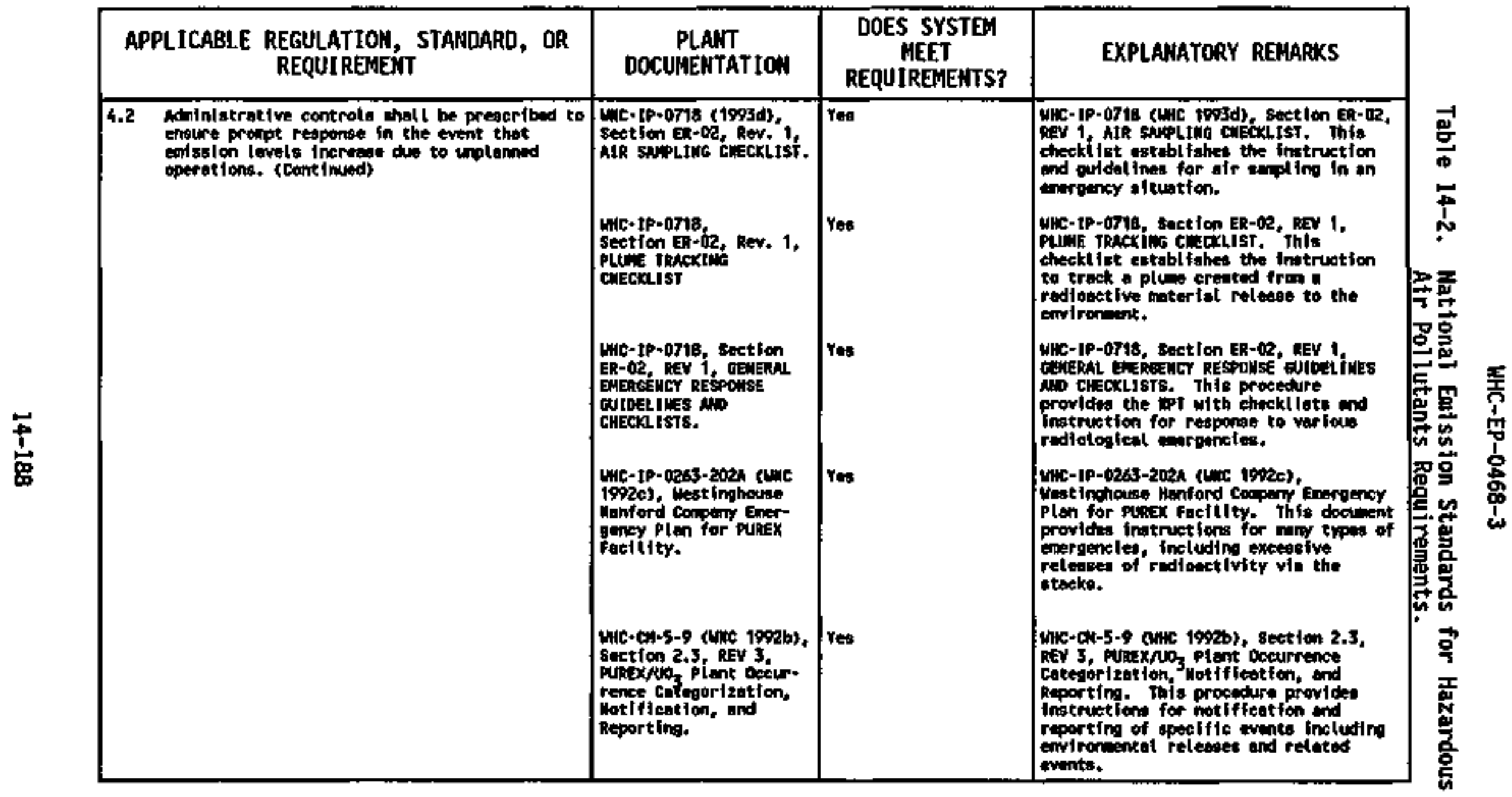




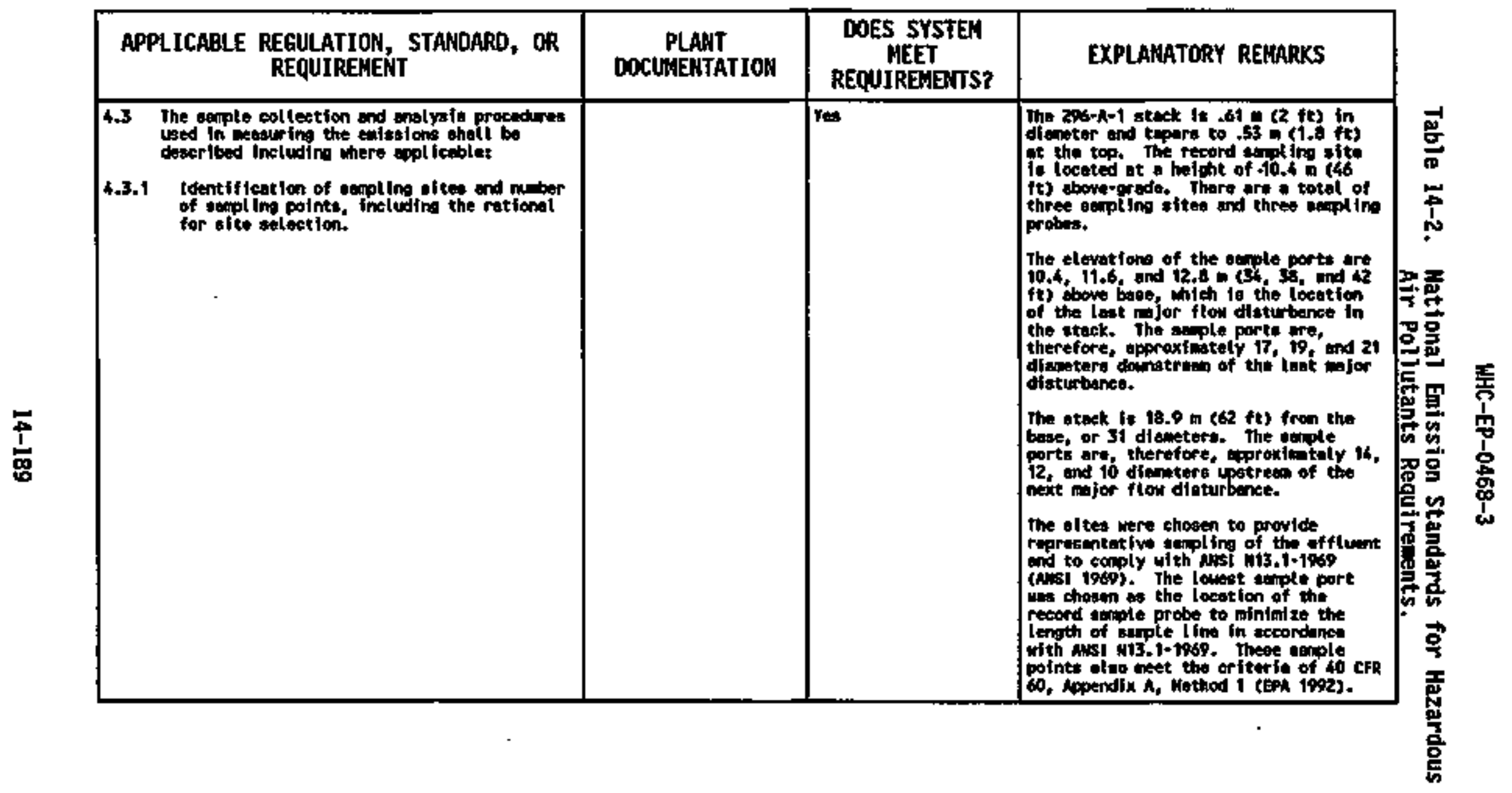




\begin{tabular}{|c|c|c|c|}
\hline $\begin{array}{l}\text { APPLICABLE REGULATION, STANBARD, OR } \\
\text { REQUIREMENT }\end{array}$ & $\begin{array}{l}\text { PLANT } \\
\text { DOCUMENTATION }\end{array}$ & $\begin{array}{l}\text { DOES SYSTEM } \\
\text { MEET } \\
\text { REQUIREMEHTS? }\end{array}$ & EXPLANATORY REMARKS \\
\hline 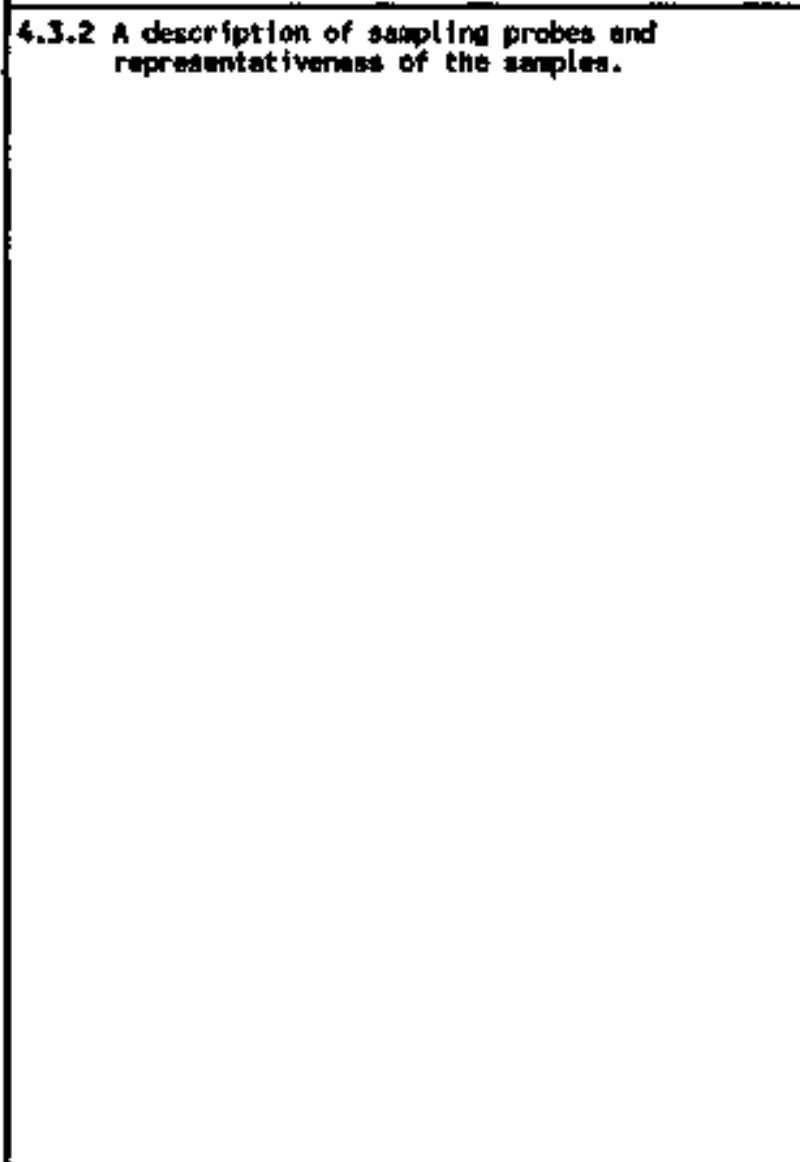 & & Yoo & 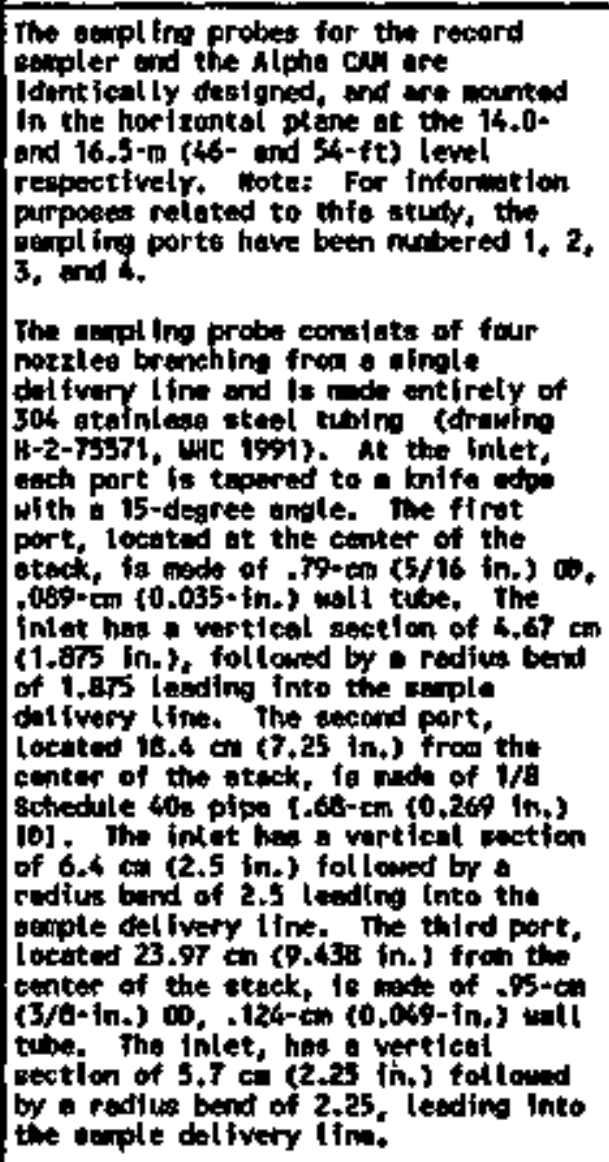 \\
\hline
\end{tabular}




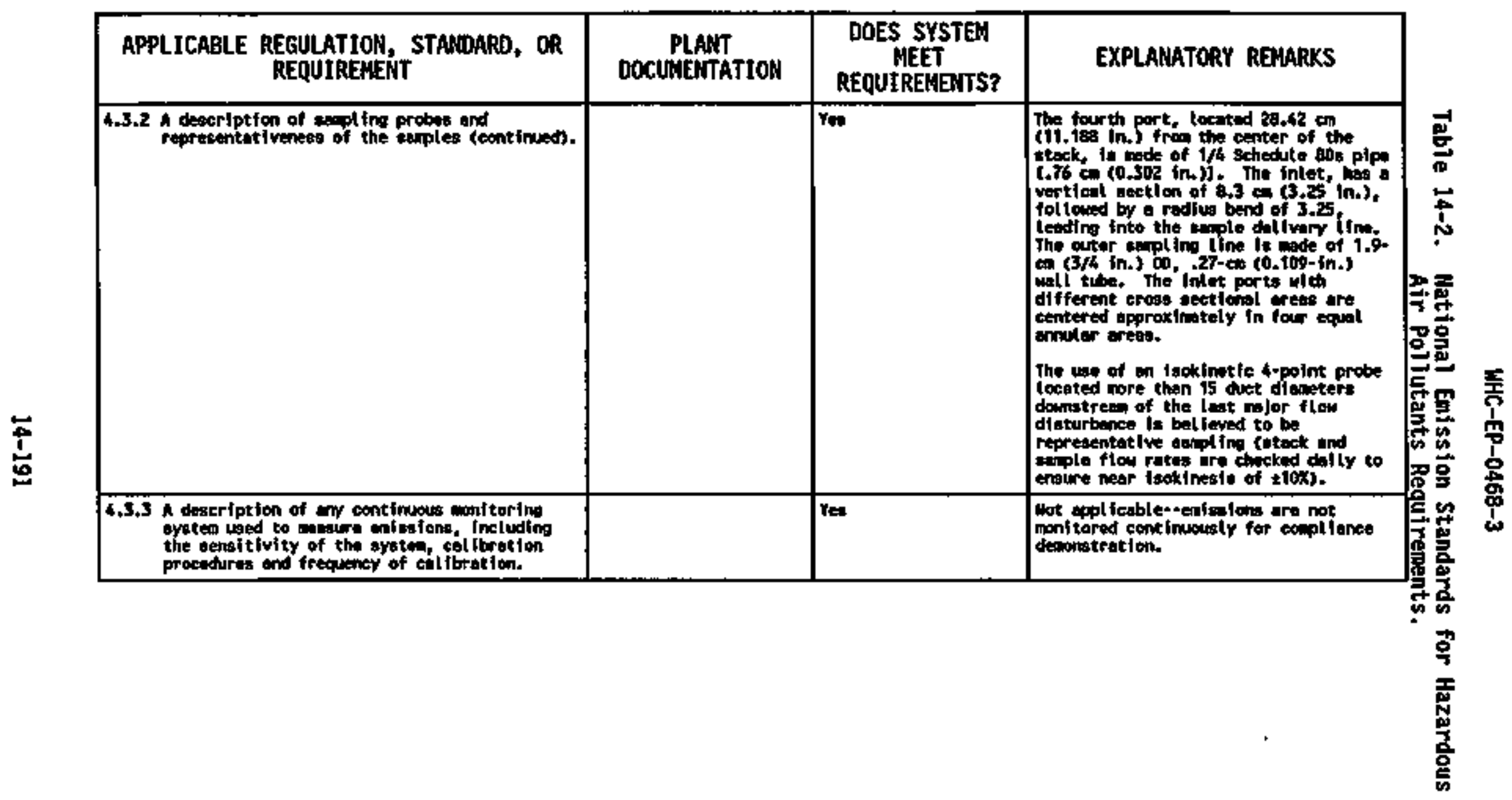




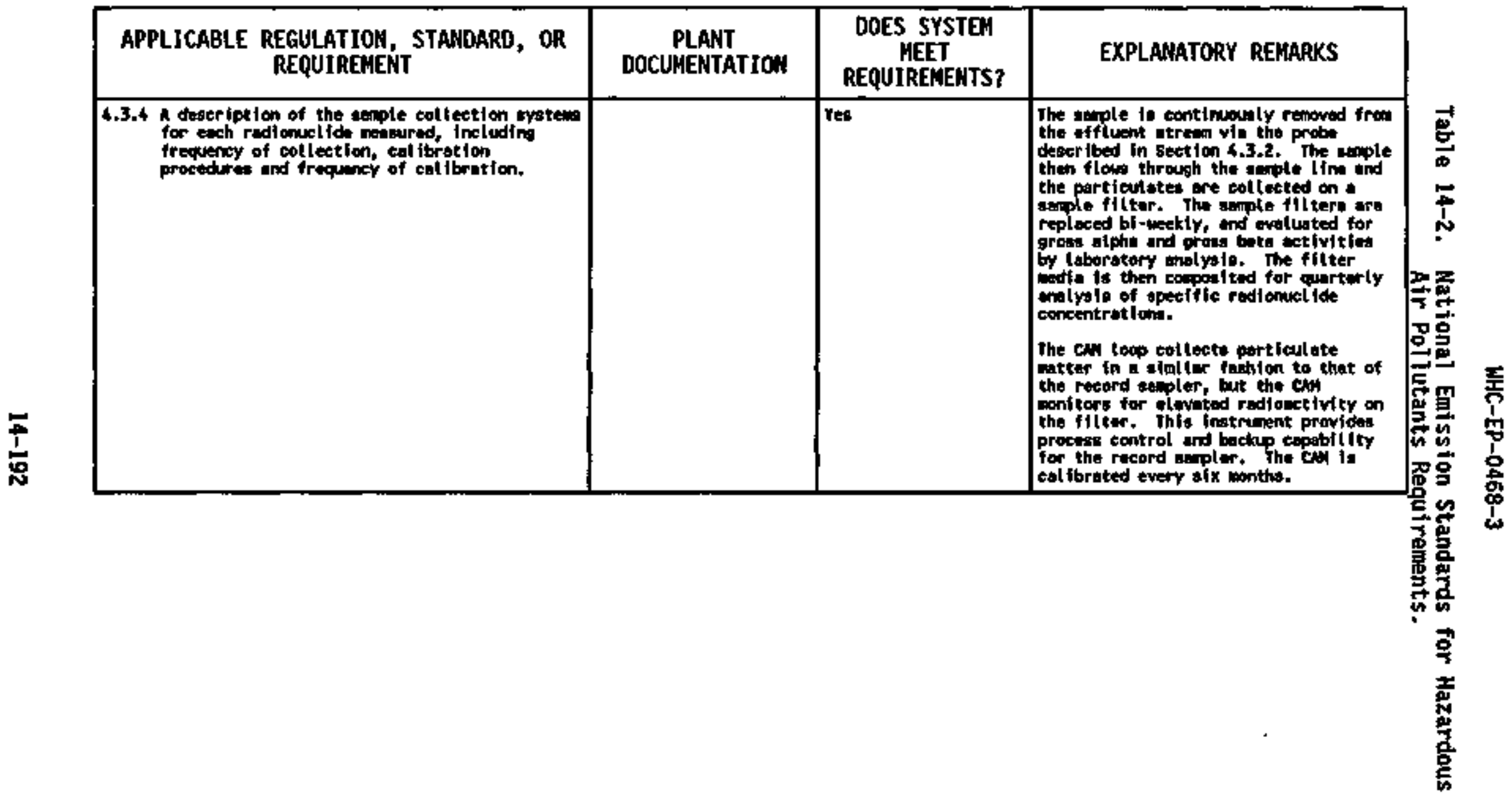




\begin{tabular}{|c|c|c|c|}
\hline $\begin{array}{l}\text { APPLICABLE REGULATION, STANDARD, OR } \\
\text { REQUIREMENT }\end{array}$ & $\begin{array}{l}\text { PLANT } \\
\text { DOCUMEMTATION }\end{array}$ & $\begin{array}{l}\text { COES SYSTEM } \\
\text { MEET } \\
\text { REQUIREMEKTS? }\end{array}$ & EXPLANATORY REYARKS \\
\hline 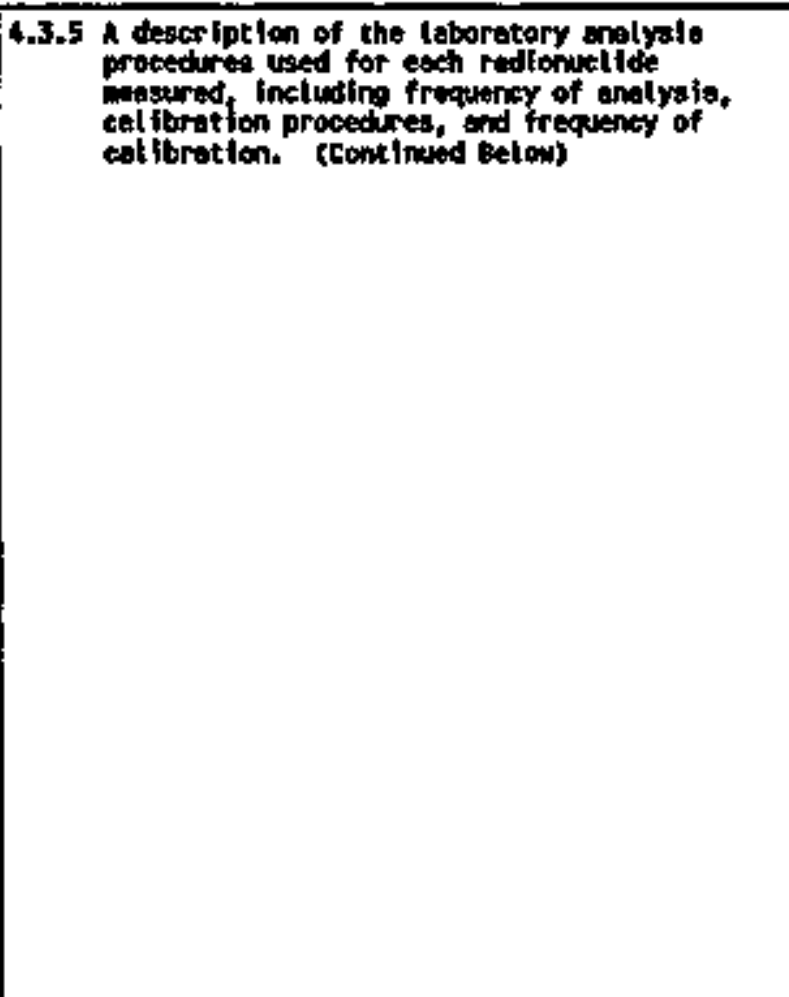 & & $p_{100}$ & 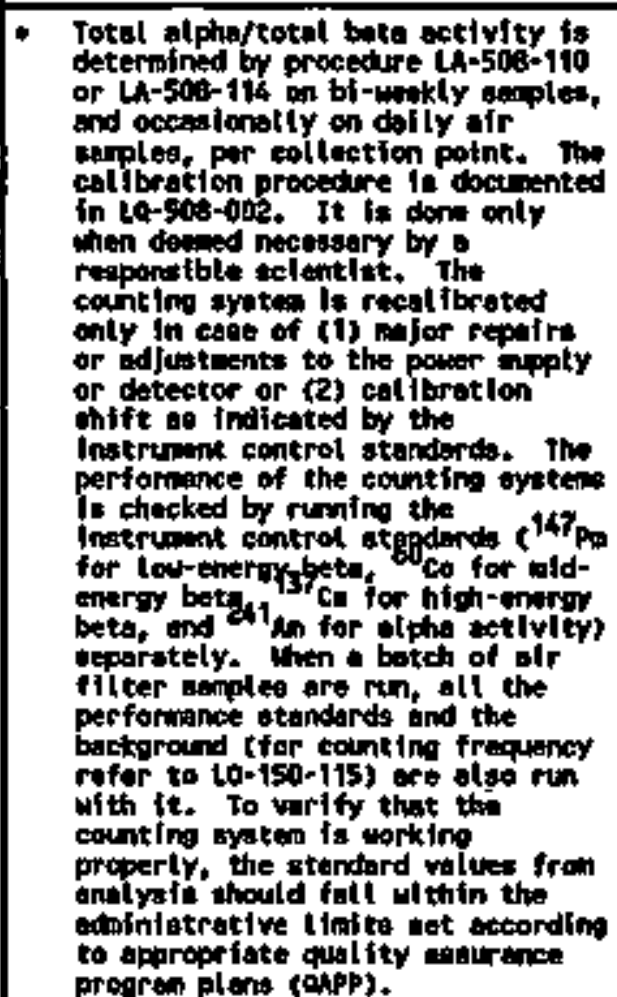 \\
\hline
\end{tabular}




\begin{tabular}{|c|c|c|c|}
\hline $\begin{array}{l}\text { APPLICABLE REGULATIOH, STAHDARD, OR } \\
\text { REQUIREHEMT }\end{array}$ & $\begin{array}{c}\text { PLANT } \\
\text { DOCLNAERTATION }\end{array}$ & $\begin{array}{l}\text { DOES SYSTEM } \\
\text { MEET } \\
\text { REQUIREMENTS? }\end{array}$ & EXPLANATORY REMARKS \\
\hline 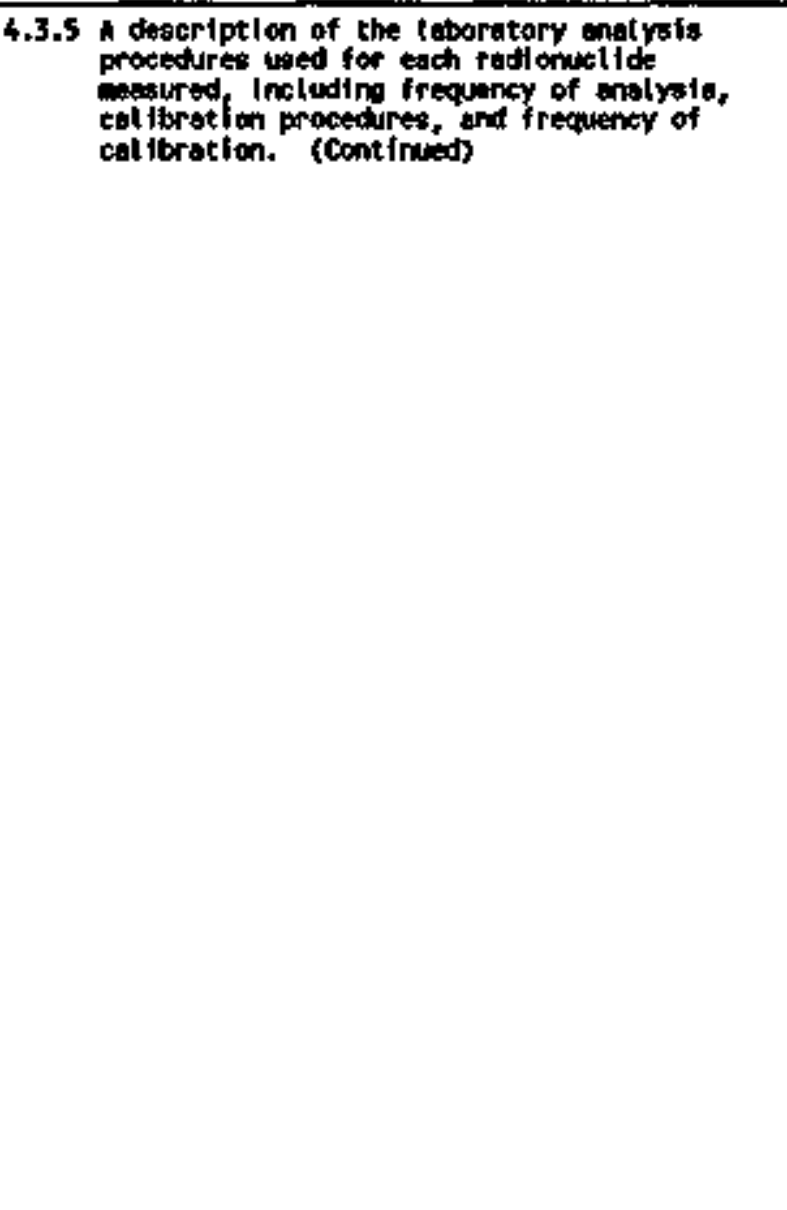 & & rese & 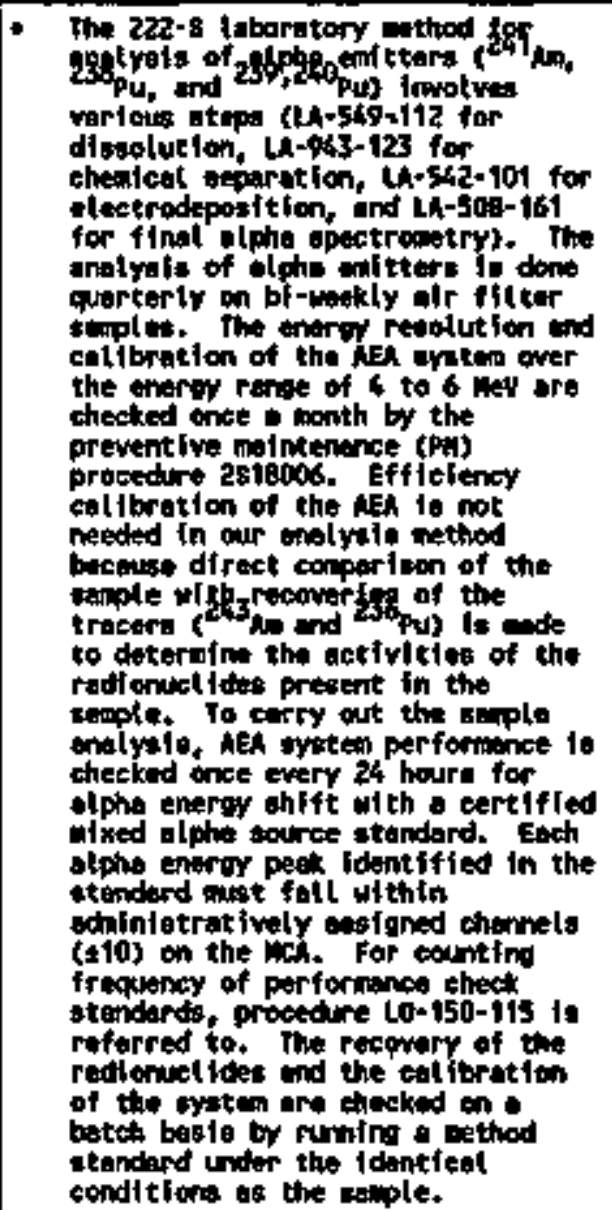 \\
\hline
\end{tabular}




\begin{tabular}{|c|c|c|c|}
\hline $\begin{array}{l}\text { APPLICABLE REGULATION, STANDARD, OR } \\
\text { REQUIREMEMT }\end{array}$ & $\begin{array}{c}\text { PLART } \\
\text { DOCUHENTATION }\end{array}$ & $\begin{array}{l}\text { DOES SYSTEM } \\
\text { MEET } \\
\text { REQUIREMEMTS? }\end{array}$ & EXPLANATORY REMARKS \\
\hline 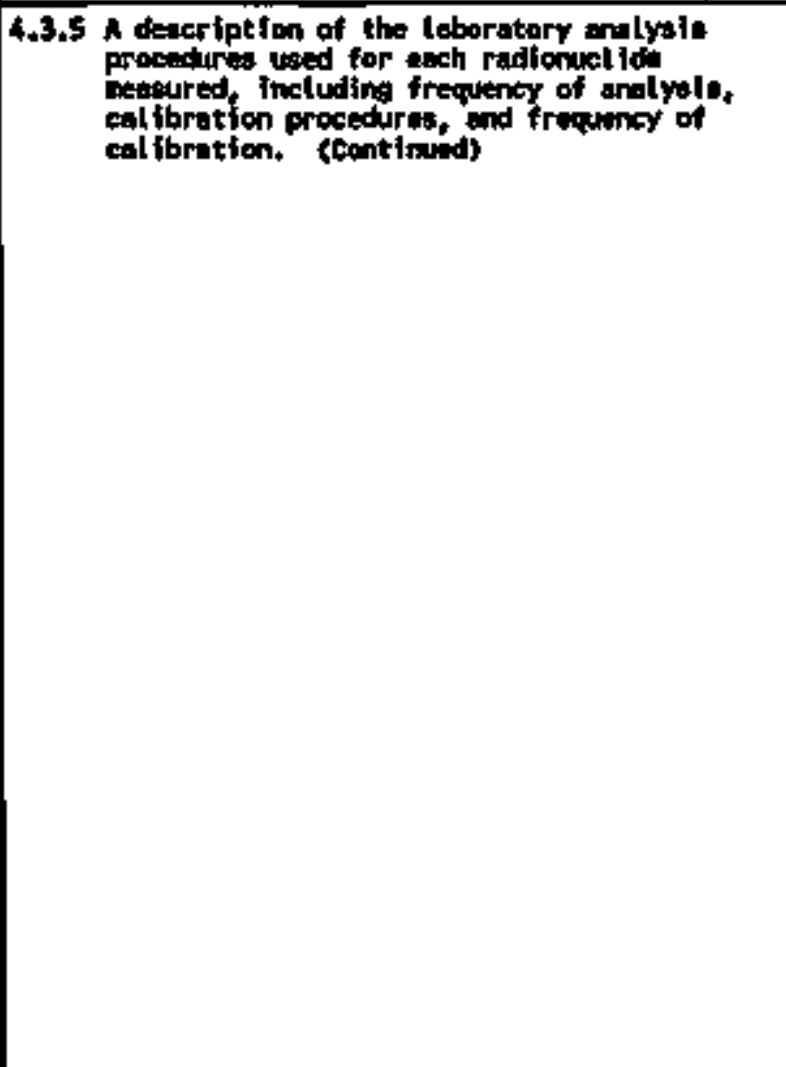 & & res & 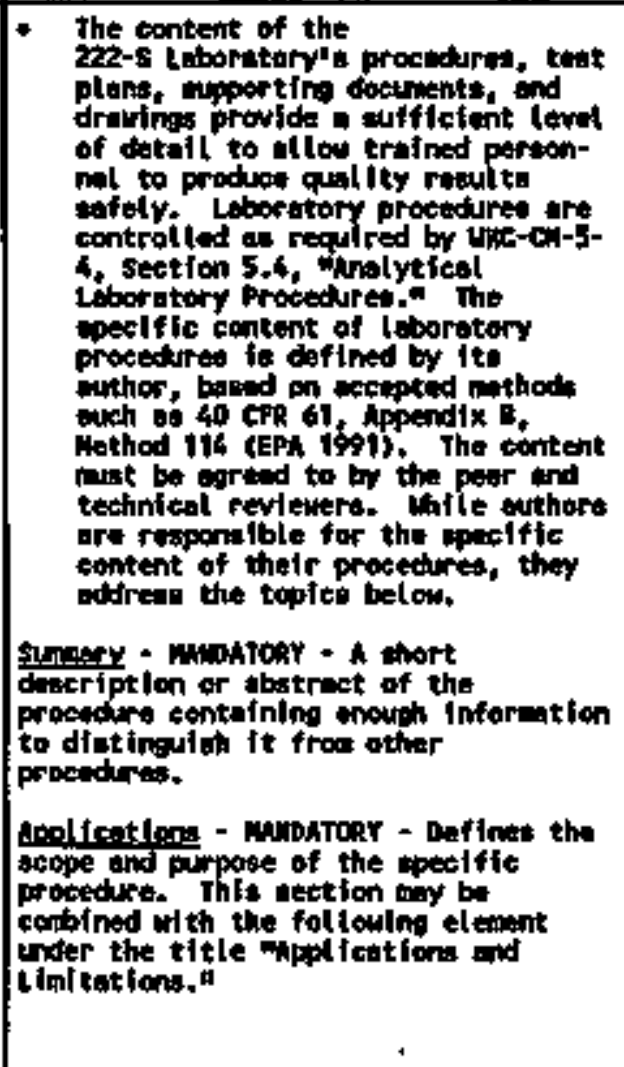 \\
\hline
\end{tabular}




\begin{tabular}{|c|c|c|c|}
\hline $\begin{array}{l}\text { APPLICABLE REGULATIOH, STANDARD, OR } \\
\text { RECUIREMERT }\end{array}$ & $\begin{array}{l}\text { PLANT } \\
\text { DOCUMENTATION }\end{array}$ & $\begin{array}{c}\text { DOES SYSTEM } \\
\text { MEET } \\
\text { REQUSREMENTS? }\end{array}$ & EXPLAMATORY REMARKS \\
\hline 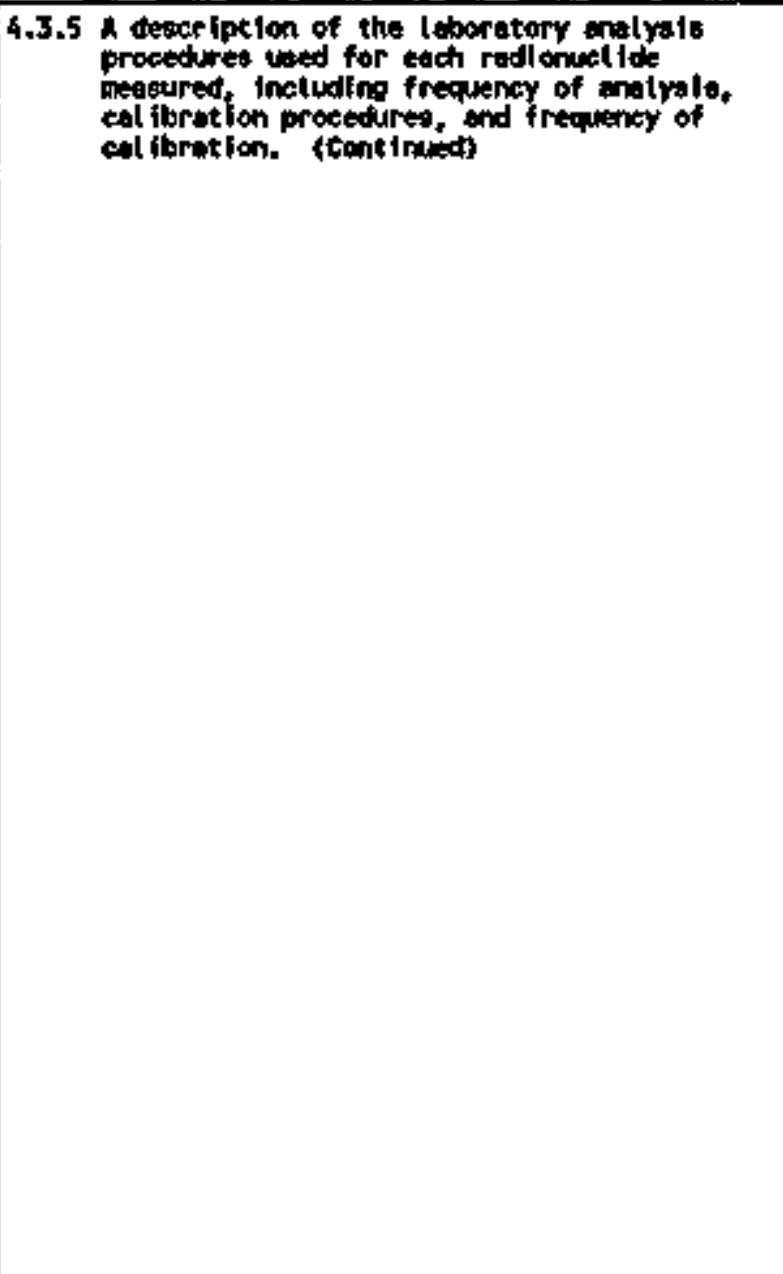 & & Yos & 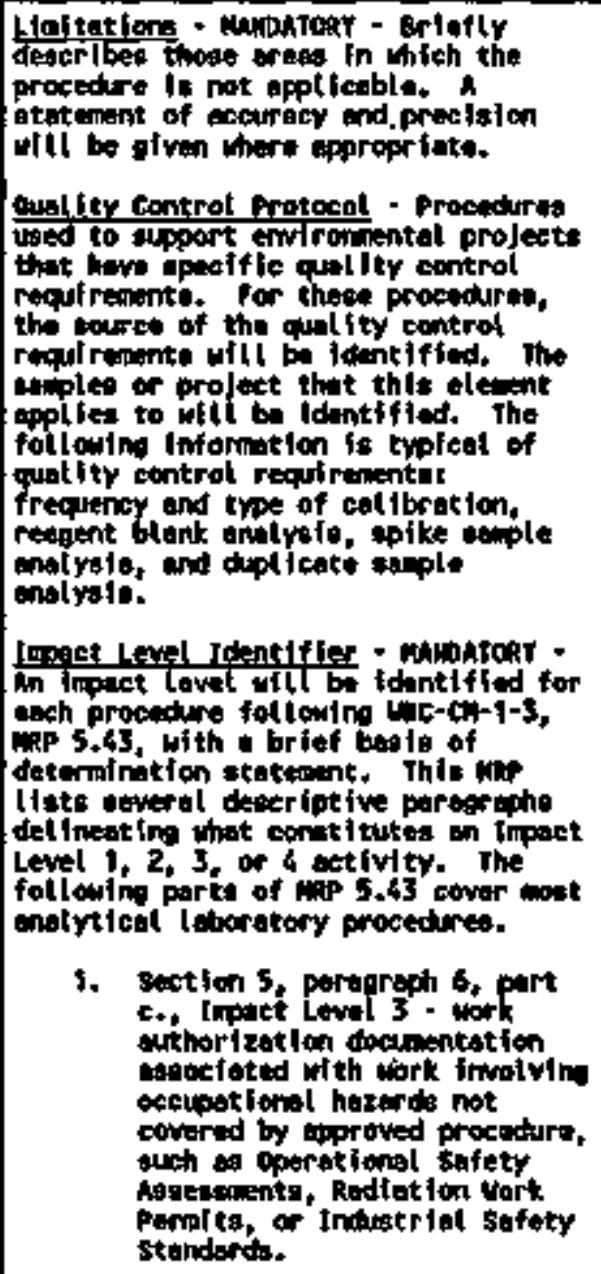 \\
\hline
\end{tabular}




\begin{tabular}{|c|c|c|c|}
\hline $\begin{array}{l}\text { APPLICABLE REGULATION, STANDARD, OR } \\
\text { REQUIREMENT }\end{array}$ & $\begin{array}{l}\text { PLANT } \\
\text { DOCUMENTATION }\end{array}$ & $\begin{array}{c}\text { DOES SYSTEM } \\
\text { MEET } \\
\text { REQUTREMENTS? }\end{array}$ & EXPLANATORY REMARKS \\
\hline 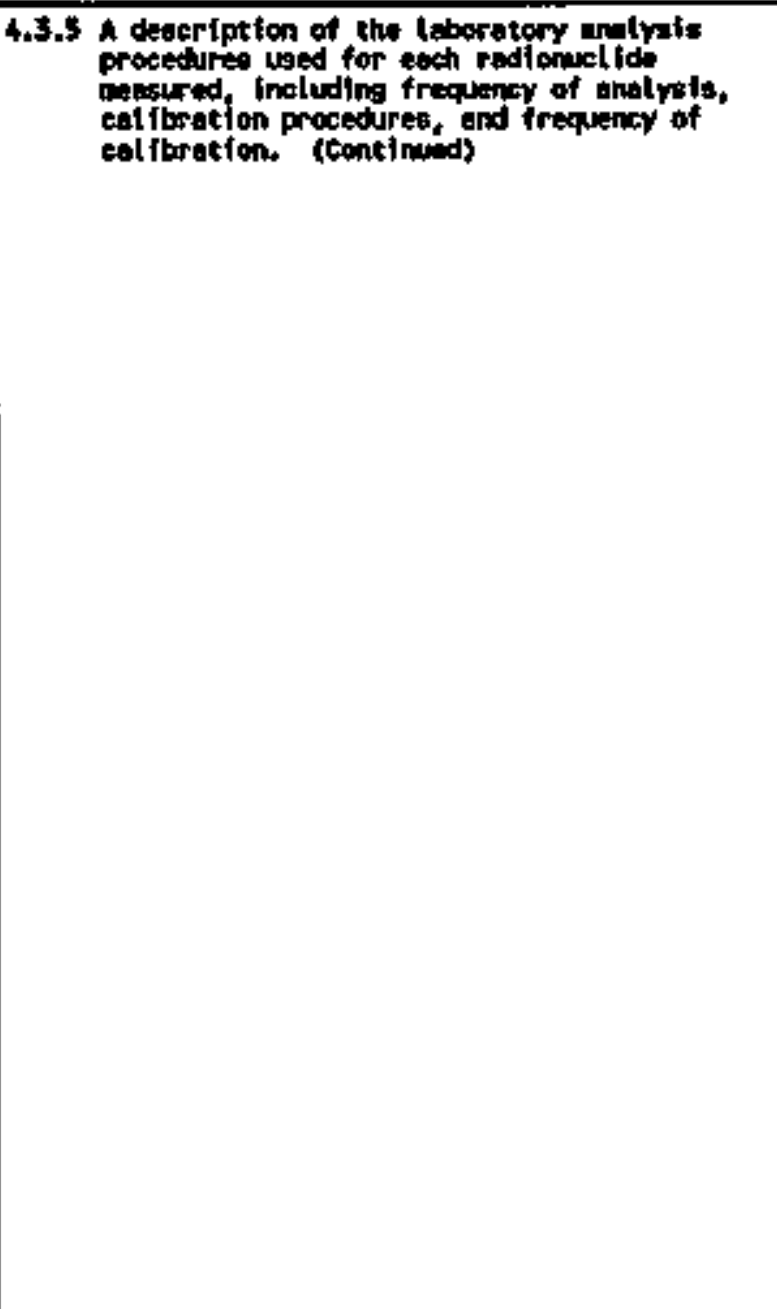 & & $r=$ & 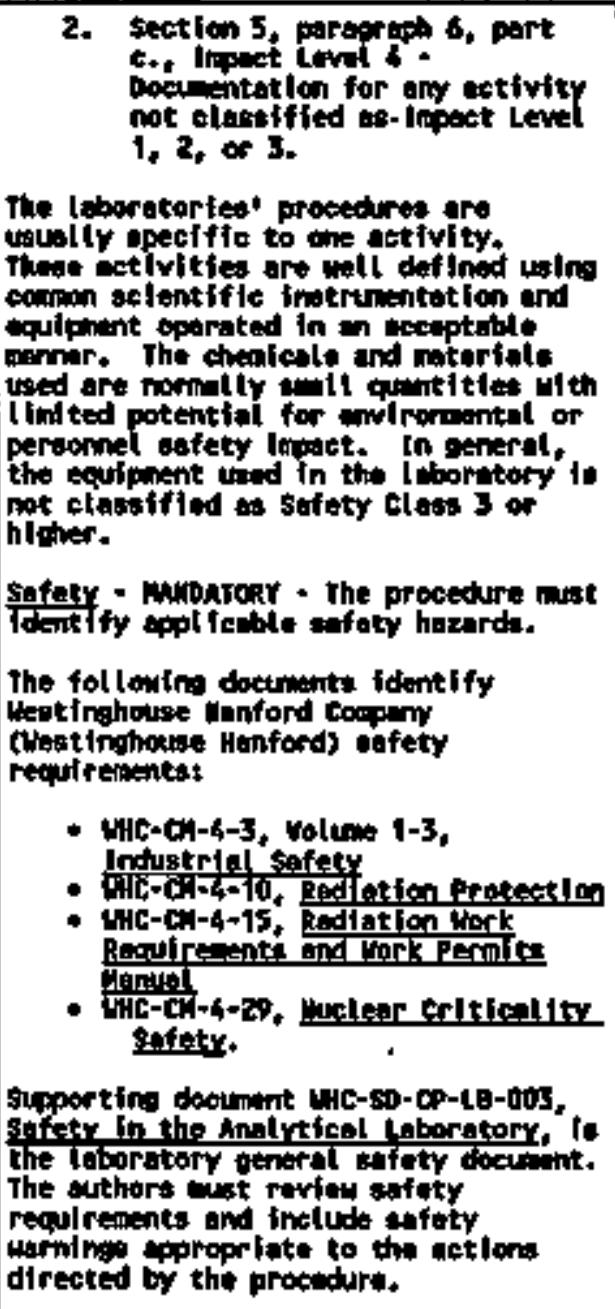 \\
\hline
\end{tabular}




\begin{tabular}{|c|c|c|c|}
\hline $\begin{array}{l}\text { APPLICABLE REGULATION, STANDARD, OR } \\
\text { REQUIREMEHT }\end{array}$ & $\begin{array}{l}\text { PLANT } \\
\text { DOCUMENTATION }\end{array}$ & $\begin{array}{c}\text { DOES SYSTEM } \\
\text { MEET } \\
\text { REQUIREMENTS? }\end{array}$ & EXPLANATORY REMARKS \\
\hline 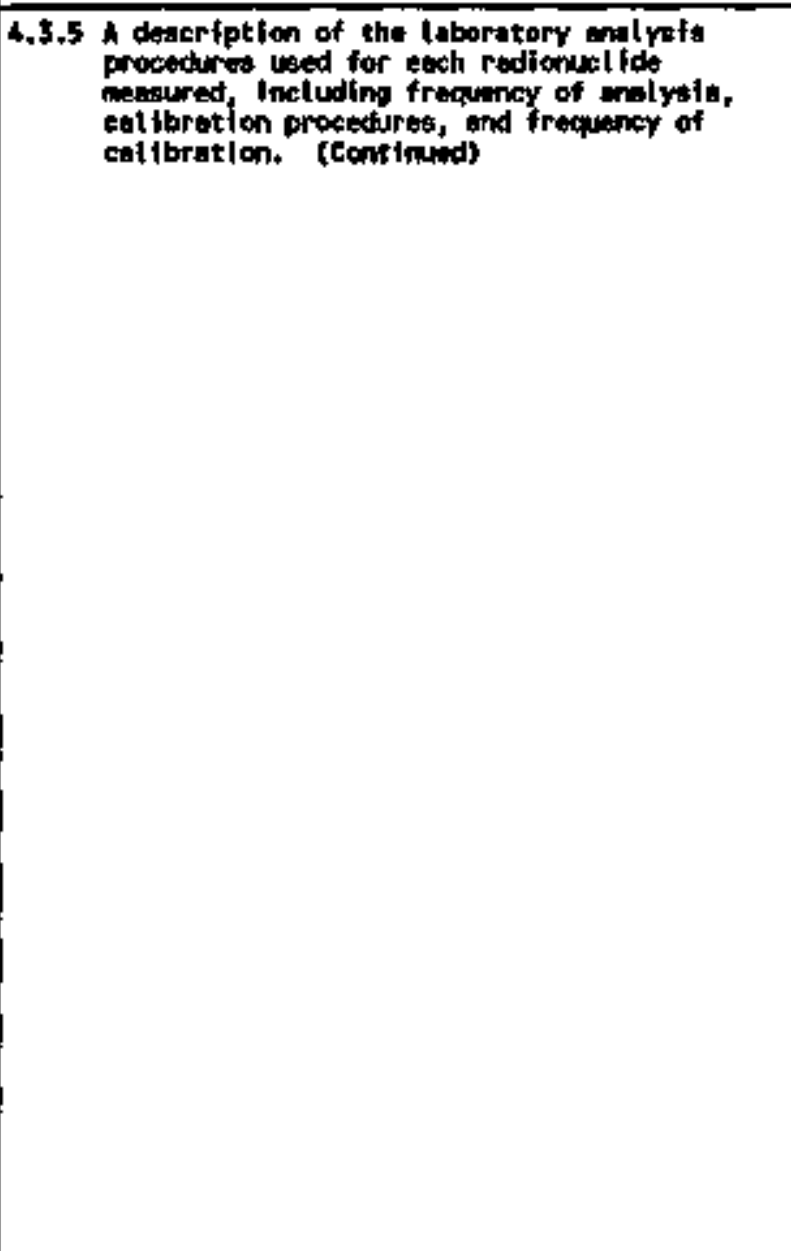 & & Yot & 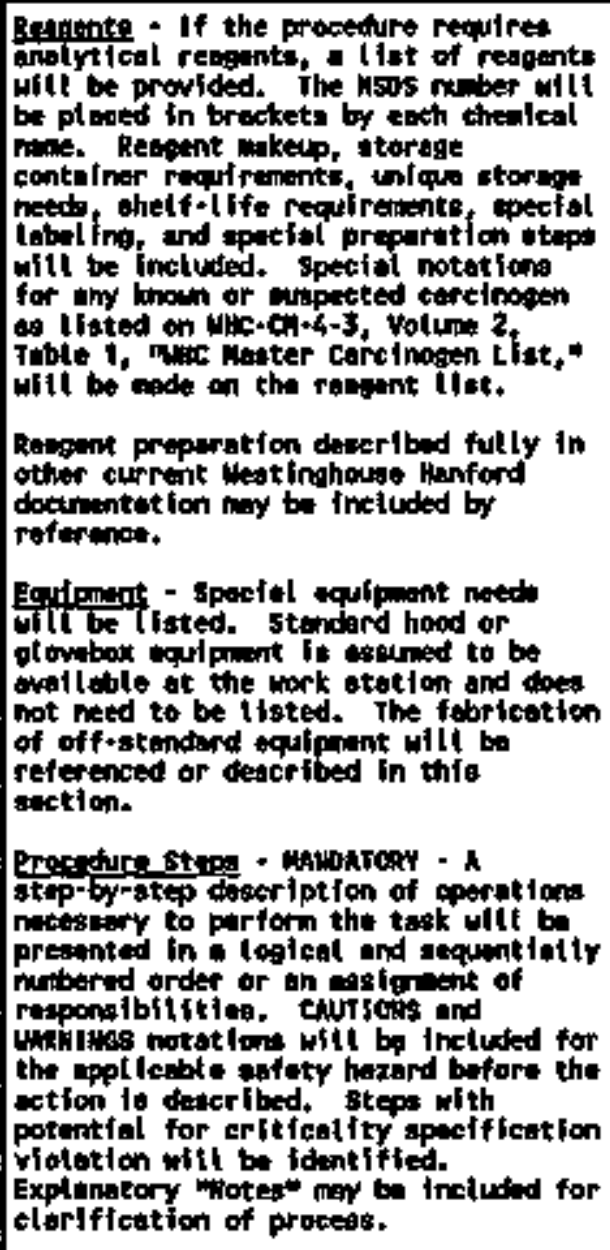 \\
\hline
\end{tabular}




\begin{tabular}{|c|c|c|c|}
\hline $\begin{array}{l}\text { APPLICABLE REGULATIOH, STANOARO, OR } \\
\text { REQUIREMEMT }\end{array}$ & $\begin{array}{c}\text { PLANT } \\
\text { DOCWNEATATION }\end{array}$ & $\begin{array}{c}\text { DOES SYSTEN } \\
\text { MEET } \\
\text { REQUIREMENTS? }\end{array}$ & EXPLANATORY REMARKS \\
\hline 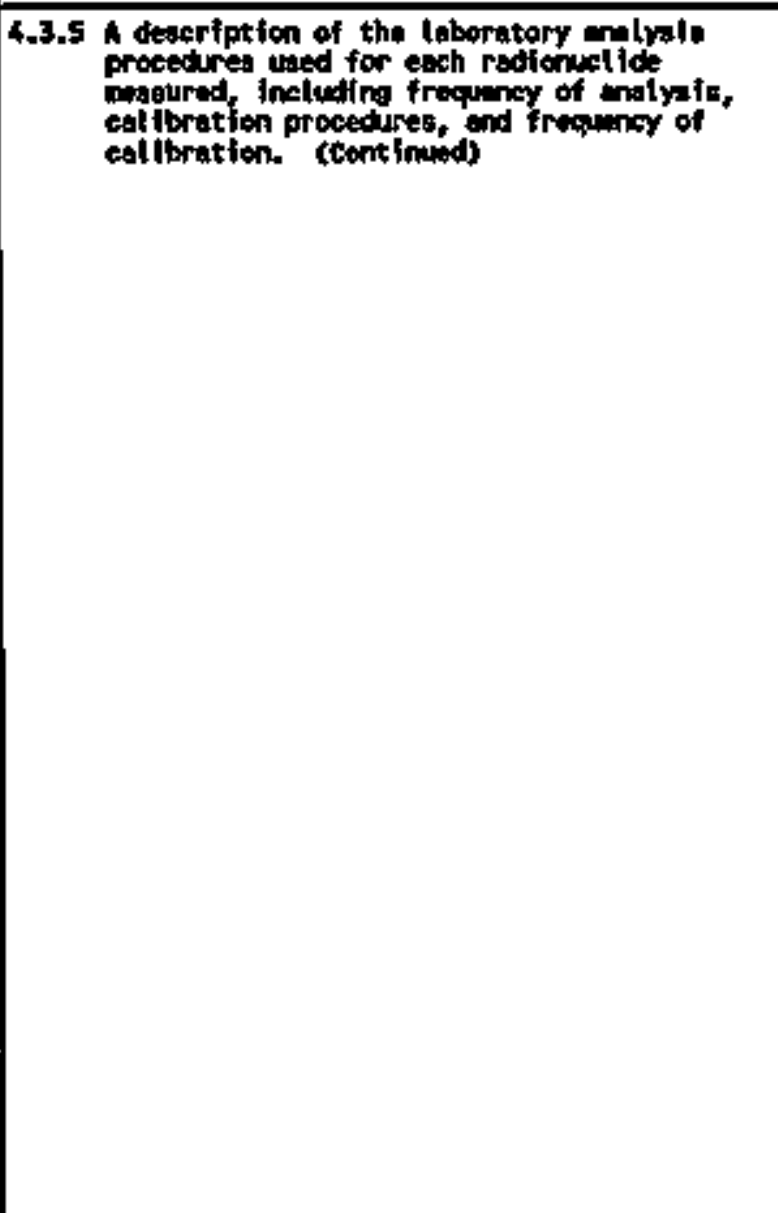 & & vet & 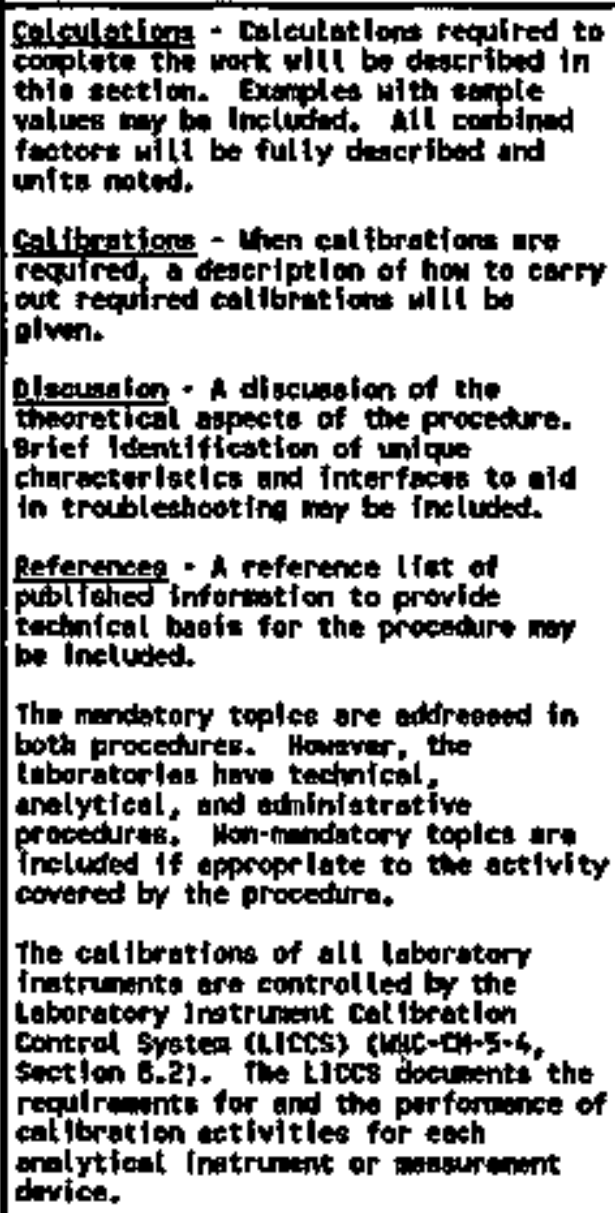 \\
\hline
\end{tabular}




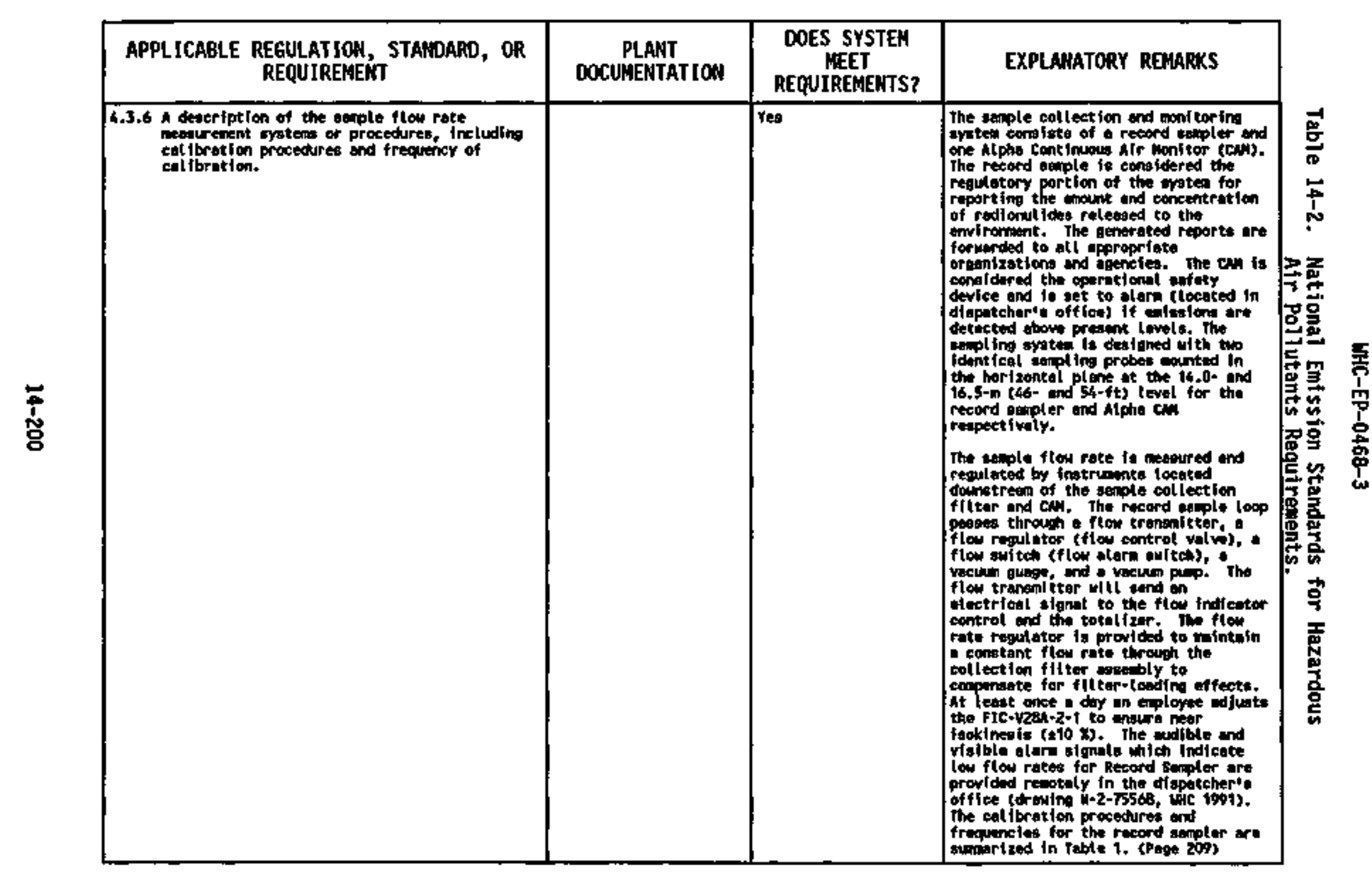




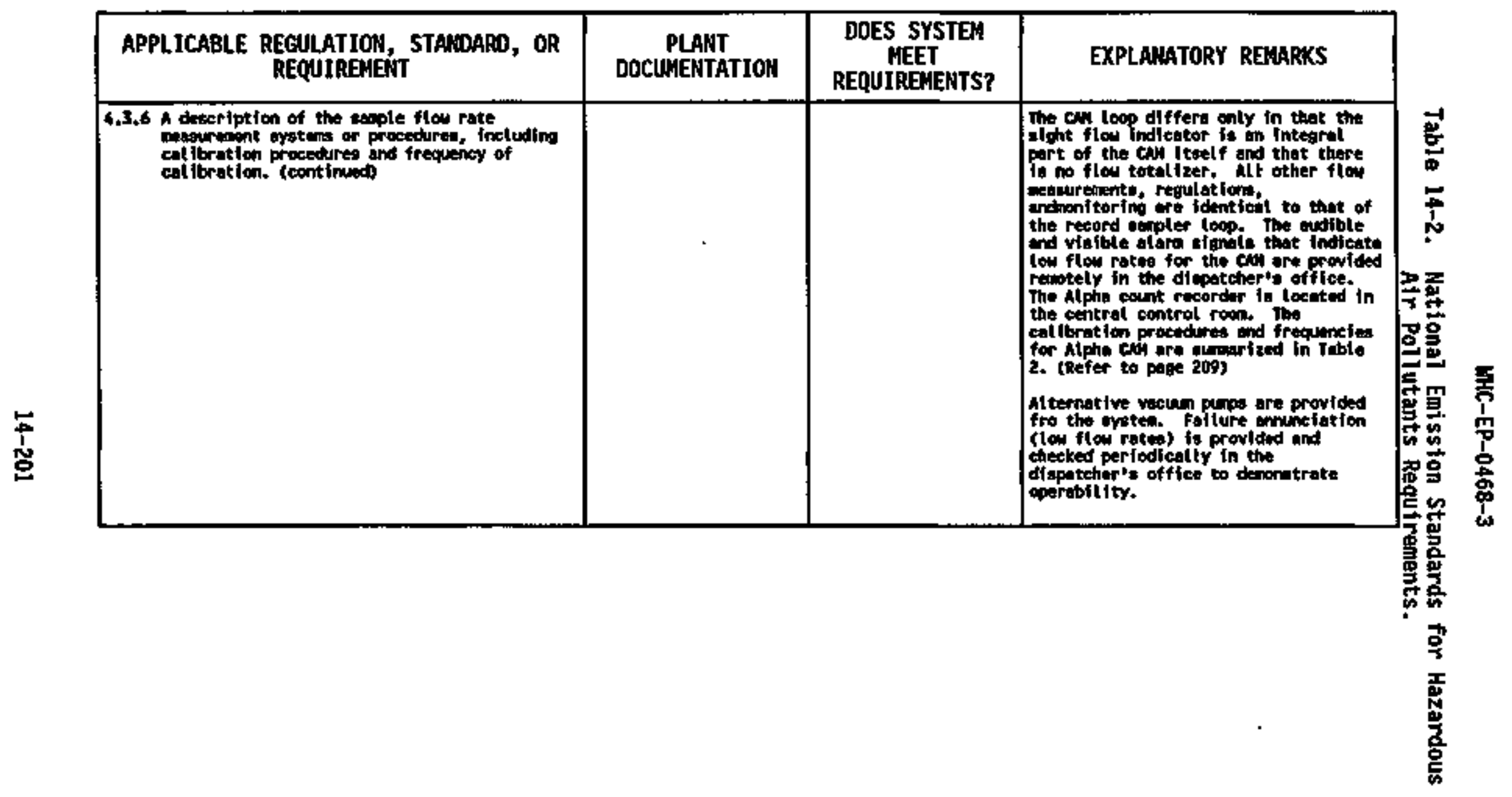




\begin{tabular}{|c|c|c|c|}
\hline $\begin{array}{l}\text { APPLICABLE REGULATION, STANDARD, OR } \\
\text { REQUIRENEHT }\end{array}$ & $\begin{array}{c}\text { PLANT } \\
\text { OOCUNENTATIOH }\end{array}$ & $\begin{array}{l}\text { DOES SYSTEN } \\
\text { NEET } \\
\text { REQUIREMEMTS? }\end{array}$ & EXPLANATORY REMARIKS \\
\hline 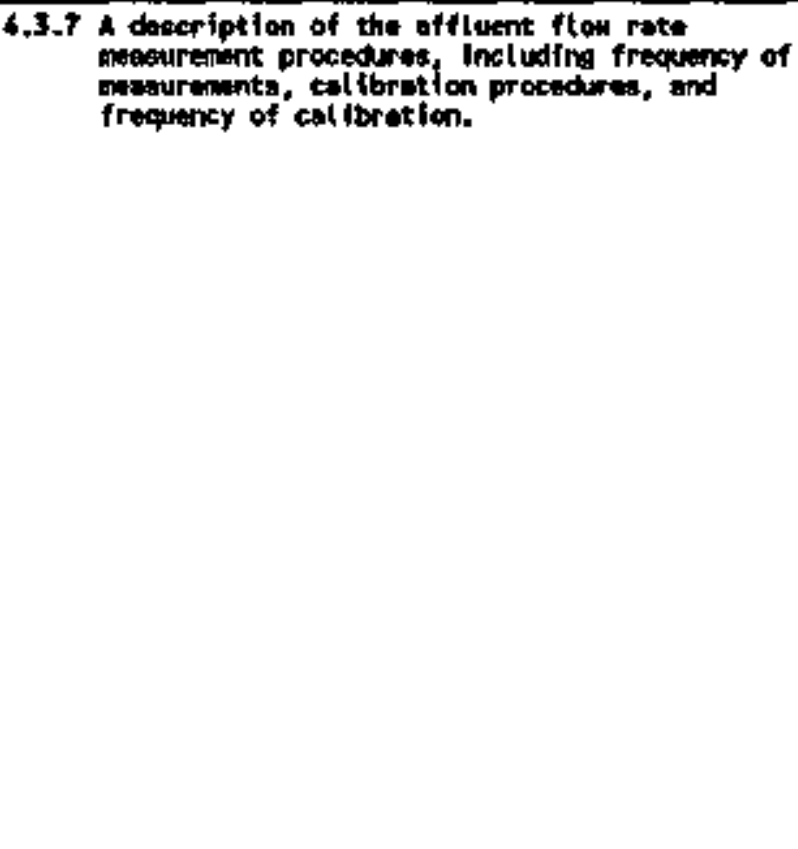 & & res & 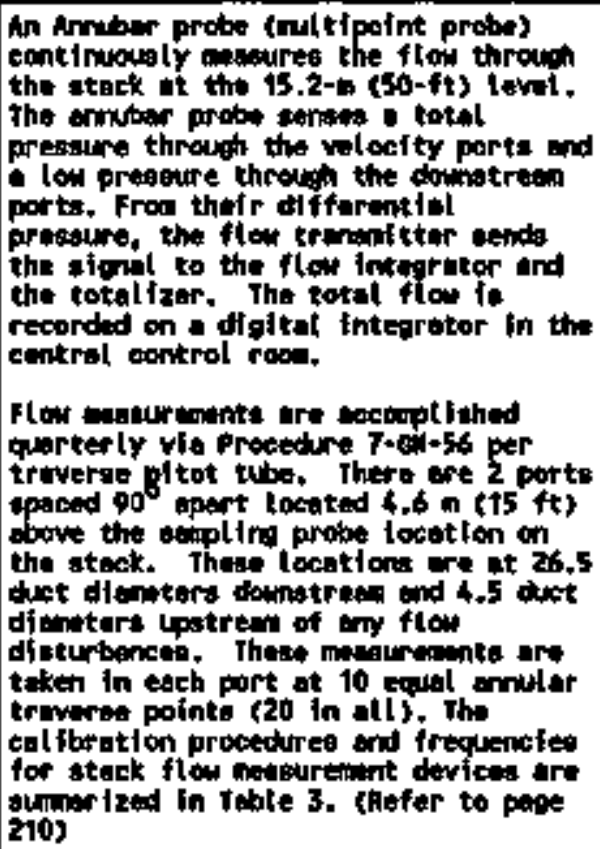 \\
\hline
\end{tabular}




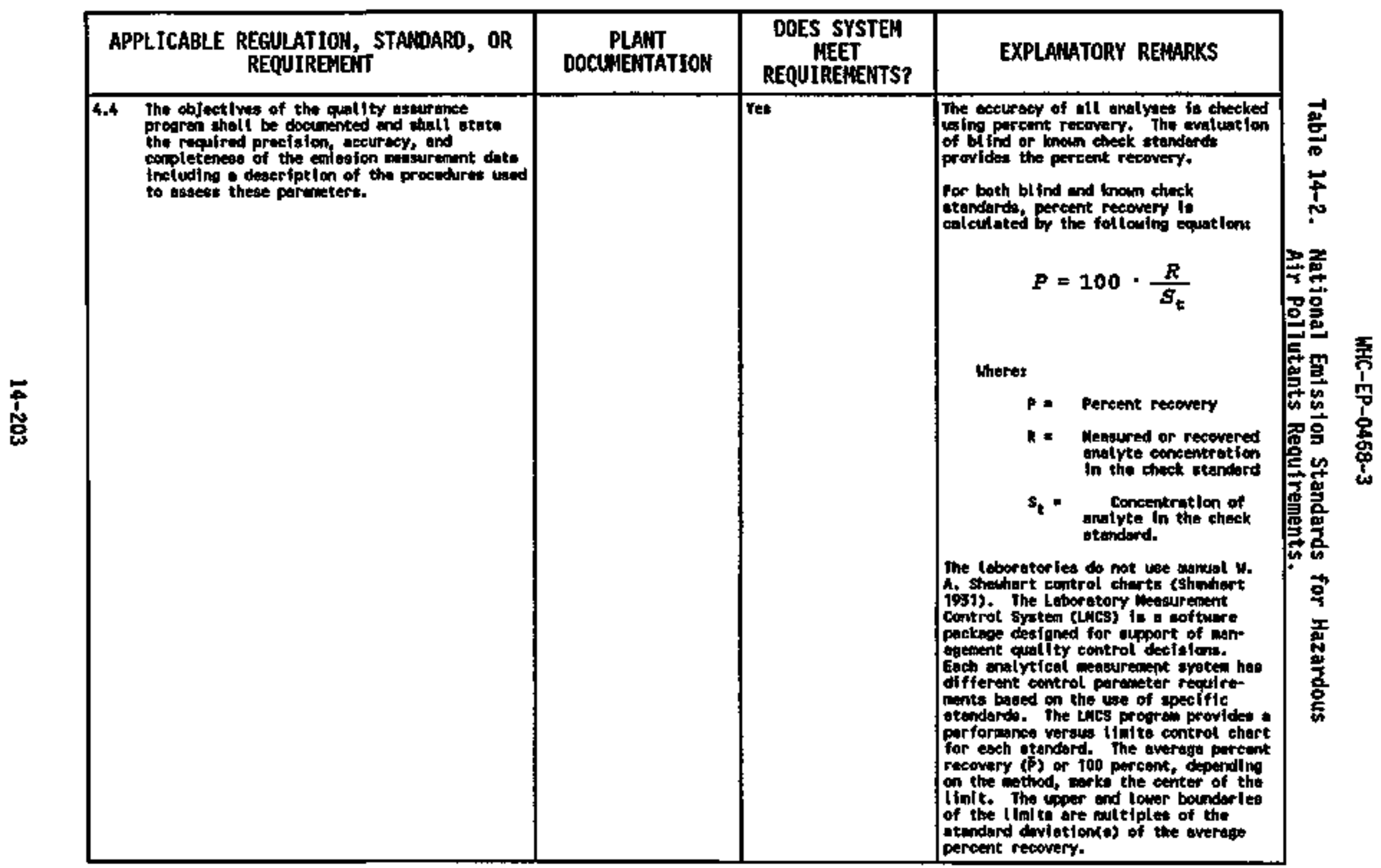




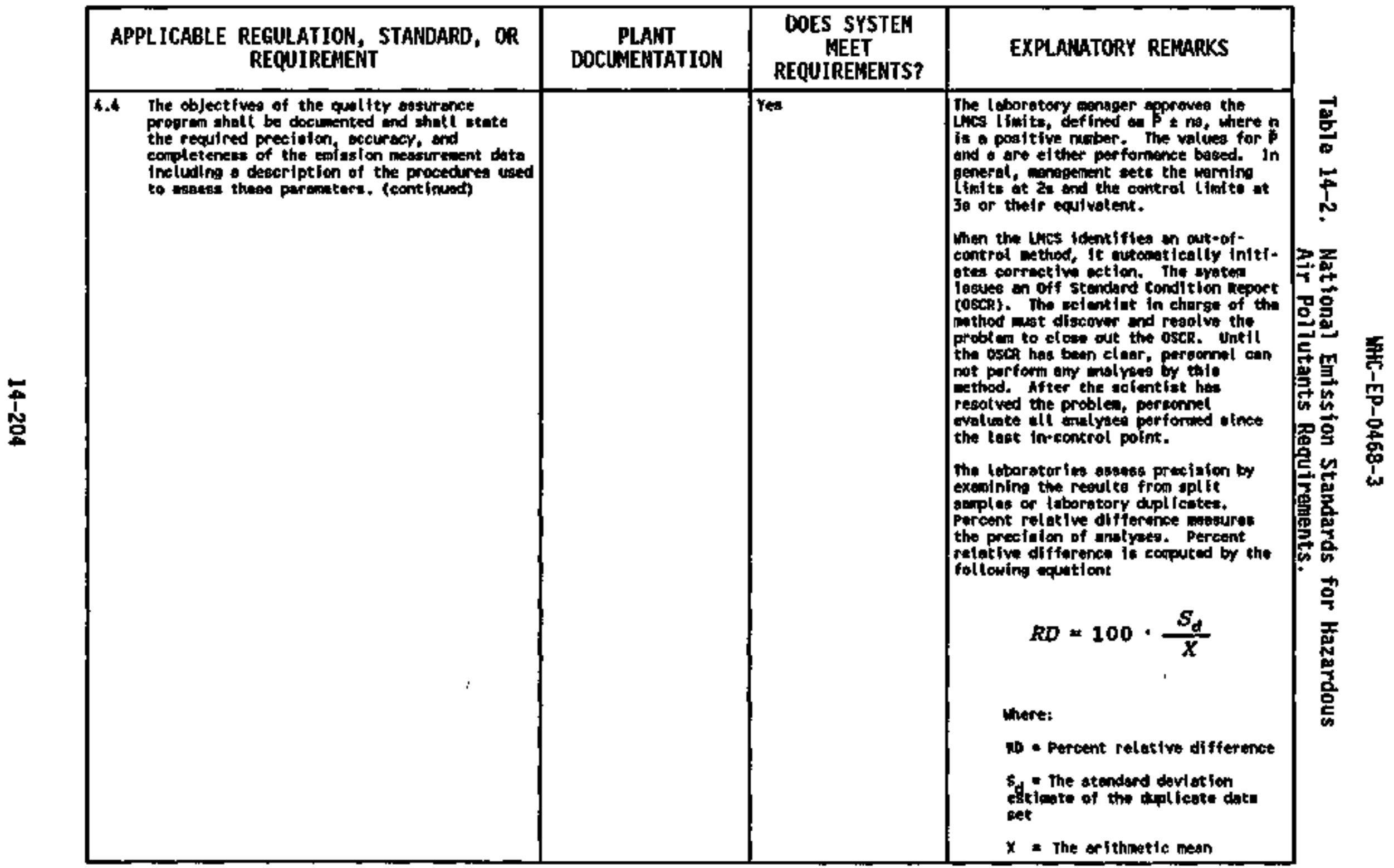




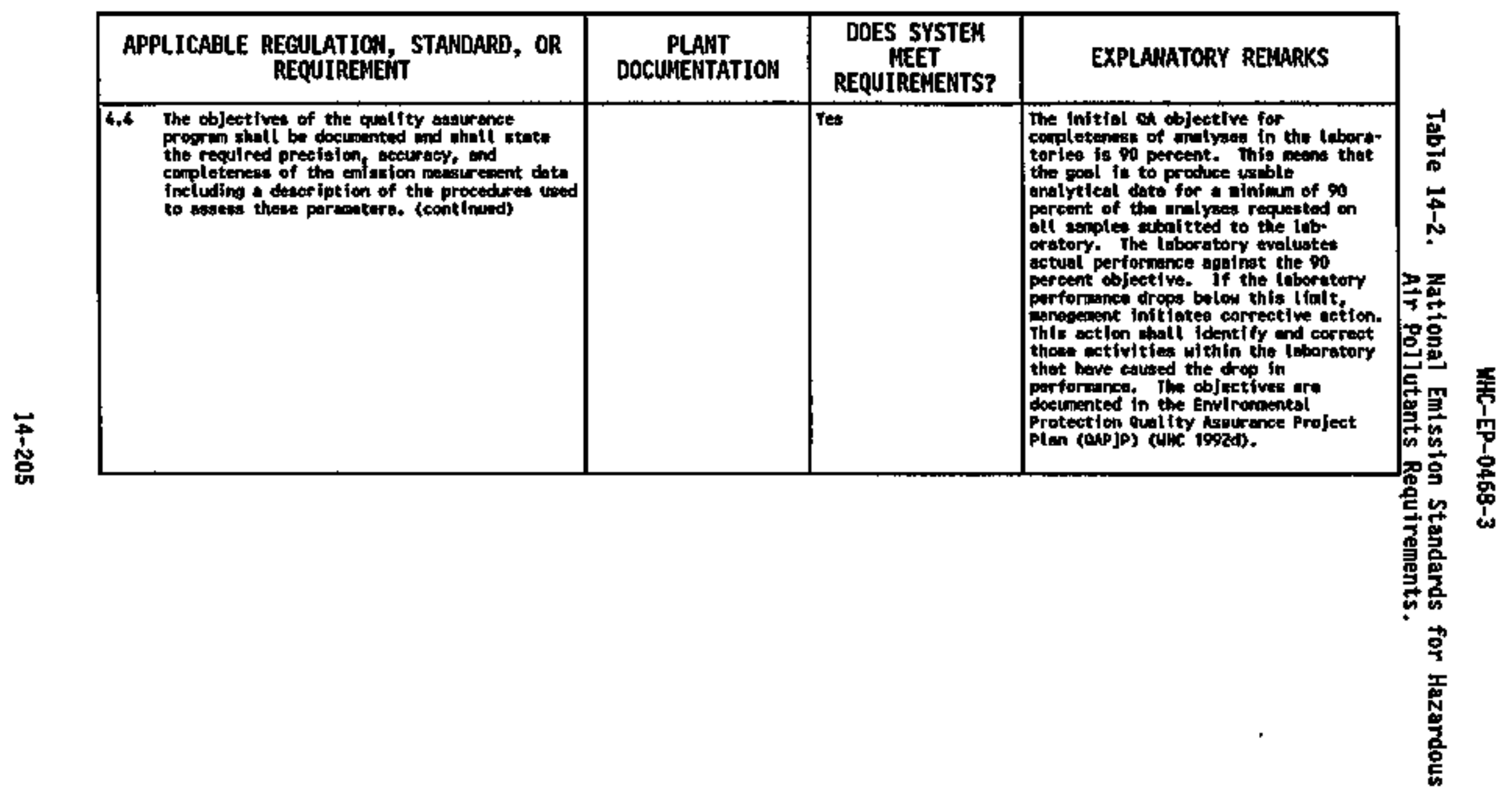




\begin{tabular}{|c|c|c|c|}
\hline $\begin{array}{l}\text { APPLICABLE REGULATION, STANDARD, OR } \\
\text { REQUIREMENT }\end{array}$ & $\begin{array}{l}\text { PLANT } \\
\text { DOCUMENTATIOH }\end{array}$ & $\begin{array}{c}\text { DOES SYSTEM } \\
\text { MEET } \\
\text { REQUIRENENTS? }\end{array}$ & EXPLAMATORY REMARKS \\
\hline 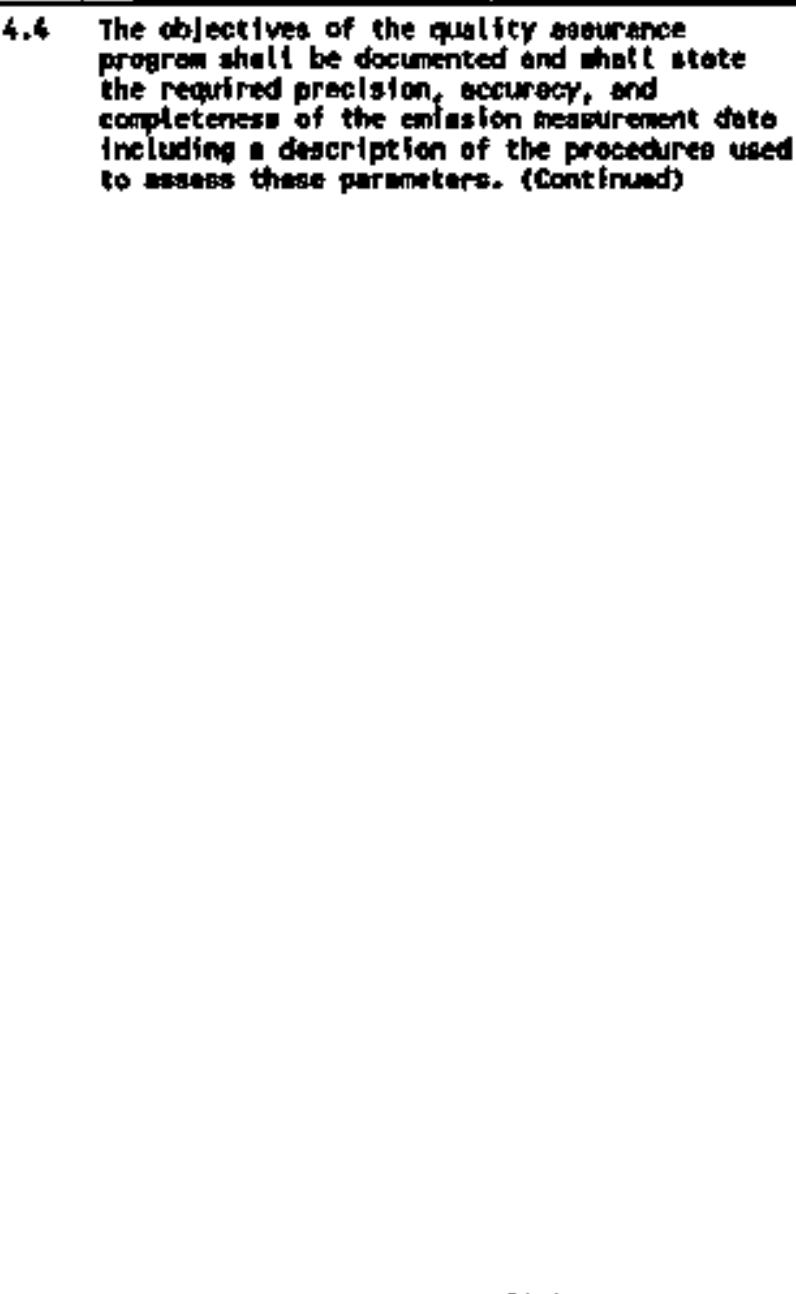 & & Tea & 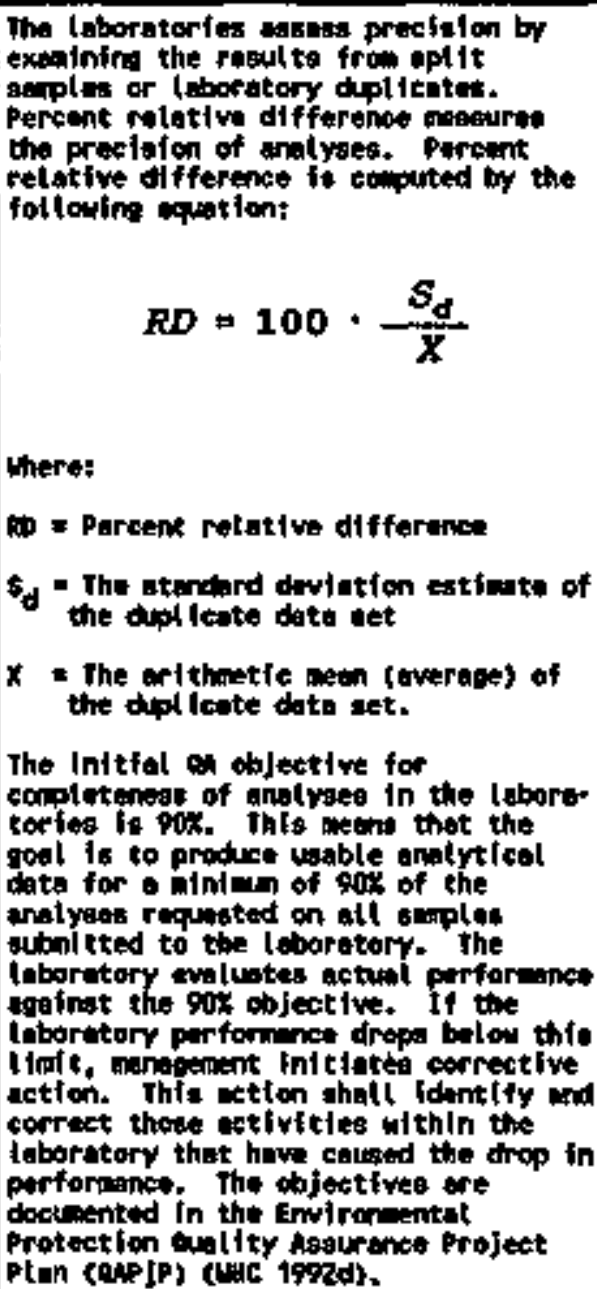 \\
\hline
\end{tabular}




\begin{tabular}{|c|c|c|c|}
\hline $\begin{array}{l}\text { APPLICABLE REGULATION, STANDARD, OR } \\
\text { REQNIREMERT }\end{array}$ & $\begin{array}{l}\text { PLANT } \\
\text { DOCLMENTATIOA }\end{array}$ & $\begin{array}{c}\text { DOES SYSTEM } \\
\text { MEET } \\
\text { REQUIREMENTS? }\end{array}$ & EXPLAILATORY REMARKS \\
\hline 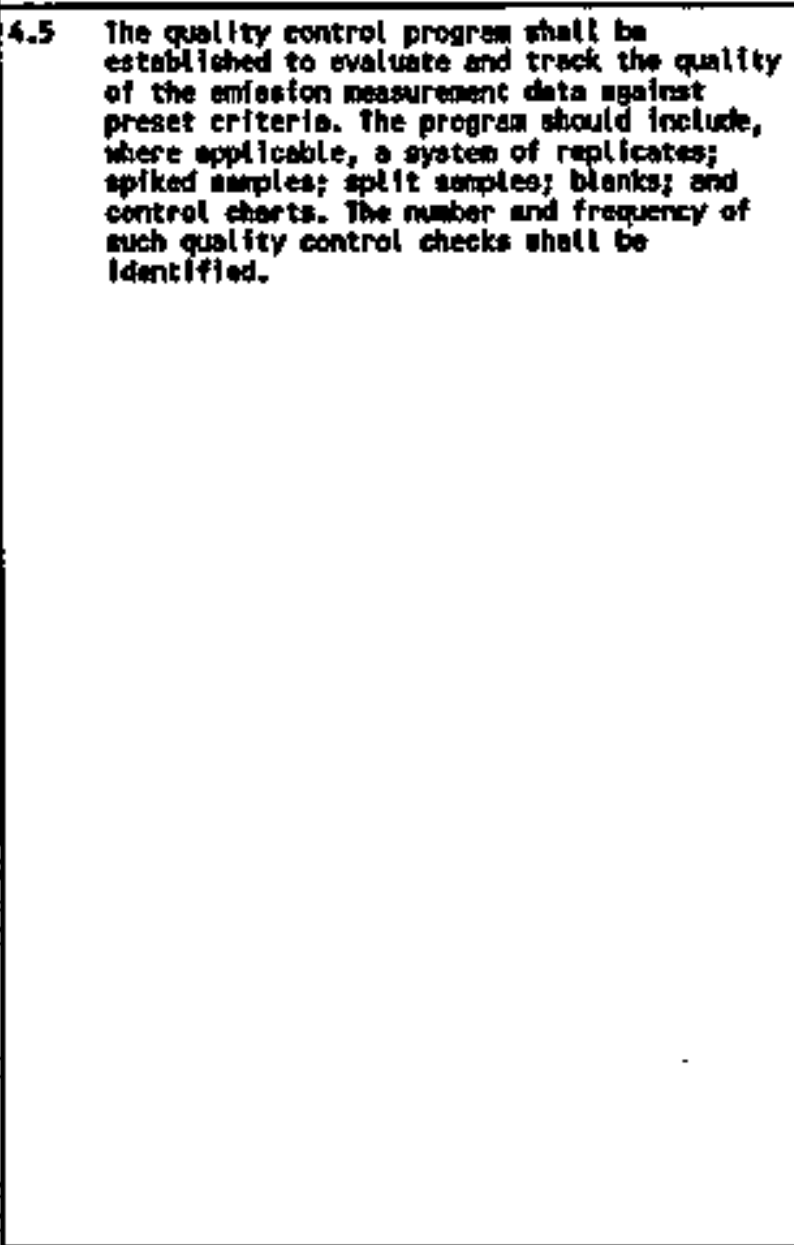 & & res & 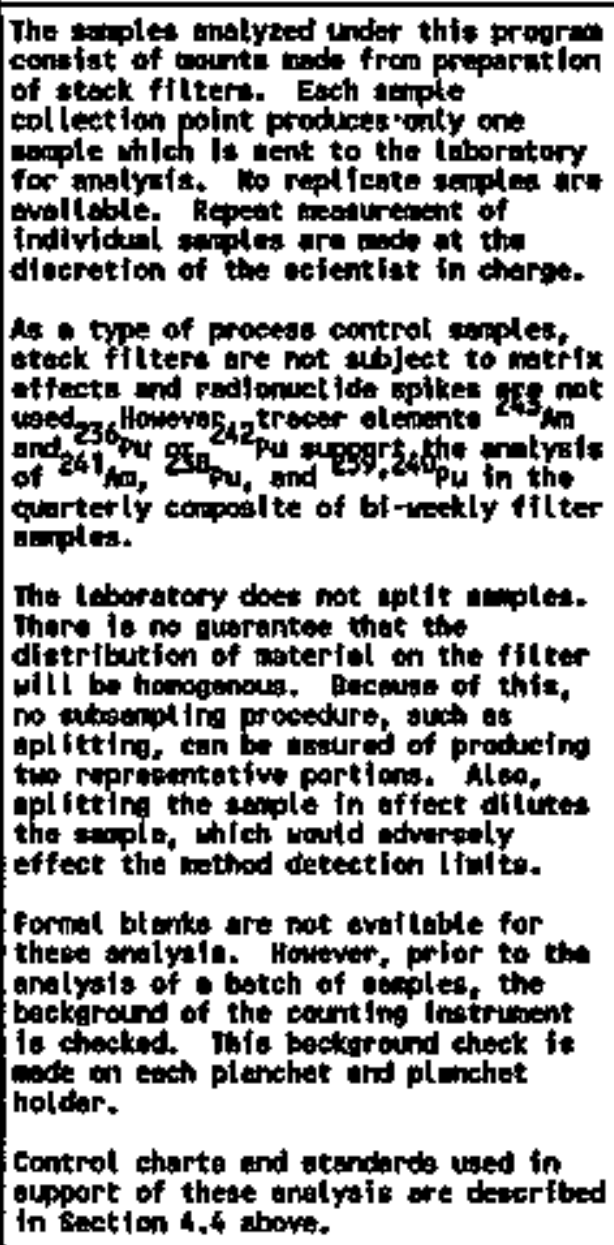 \\
\hline
\end{tabular}




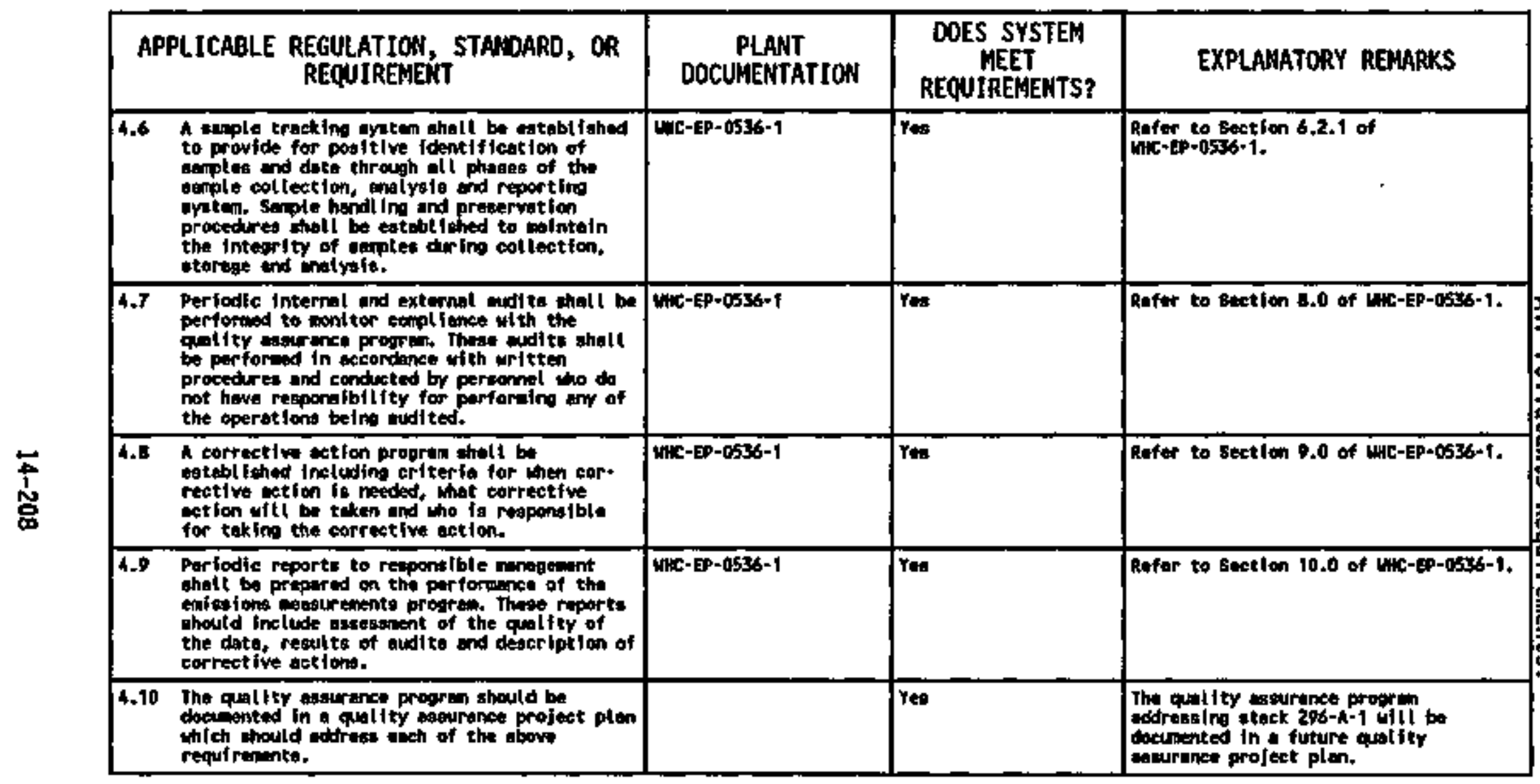


Table 1. Calibration Procedures and Frequencies for Record Sampler (Sample Flou heasurement Devices).

\begin{tabular}{|l|c|c|c|}
\hline \multicolumn{1}{|c|}{ Component } & Procedures & CBRS* & Frequency \\
\hline $\begin{array}{l}\text { Flow transnitter } \\
\text { (FT-V28A-2-1) }\end{array}$ & PSCP-6-153 & V28A2-2 & 6 month \\
$\begin{array}{l}\text { Flow alarm switch } \\
\text { (FAS-V28A-3-1) }\end{array}$ & PSCP-6-029 & V28A3-1 & 6 month \\
$\begin{array}{l}\text { Flow indicator control } \\
\text { (FIC-V28A-2-1) } \\
\begin{array}{l}\text { Flow integrator } \\
\text { (FQ-V28A-2-1) }\end{array}\end{array}$ & PSCP-4-059 & V28A2-5 & 12 month \\
\hline
\end{tabular}

* Computer Based Recall System

Table 2. Calibration Procedures and Frequencies for Alpha Continuous Air Monitor Sampler (Sample Flow Measurement Devices).

\begin{tabular}{|c|c|c|c|}
\hline \multicolumn{1}{|c|}{ Component } & Procedures & CBRS* & Frequency \\
\hline $\begin{array}{l}\text { Flow al arm switch } \\
\text { (FAS-Y29A-3-1) } \\
\begin{array}{l}\text { Cont inuous air } \\
\text { nonitor/rotaneter } \\
\text { (RAN-V29A-1-1) }\end{array}\end{array}$ & PSCP-6-029 & VS29A3-1 & 12 month \\
\hline
\end{tabular}

* Computar Based Recall Systam 
WHC-EP-0468-3

Table 3. Calibration Procedures and Frequencies for Stack flow Beasurement Devices.

\begin{tabular}{|l|c|c|c|}
\hline \multicolumn{1}{|c|}{ Component } & Procedures & CBR5* & Frequency \\
\hline $\begin{array}{l}\text { Flow transmitter } \\
\text { (FT-V21-10-1) }\end{array}$ & PSCP-6-032 & V2110-2 & 6 month \\
$\begin{array}{l}\text { Flow integrator } \\
\text { (FQ-V21-10-1) }\end{array}$ & PSCP-1-008 & V2110-8 & 6 month \\
$\begin{array}{l}\text { Flow al arm switch } \\
\text { (FAS-V21-10-1) }\end{array}$ & PSCP-4-001 & V2110-5 & 6 month \\
\hline
\end{tabular}

* Computer Based Recal] System 


\subsection{SURAARY AHD COICLUSIOHS}

\subsection{MOHITORIMB REQUEREMETS FOR AIR AHD LIQUTD EFFLUETS}

\subsubsection{Monitoring Requirenents for Radioactive Constituents in Afr Effiuents}

Continuous sampling and periodic laboratory analysis are required for Stacks 291-A-1 and 296-A-1. Specific requirements are described below.

15.1.1.1 Stack 291-A-1. Stack 291-A-1 will require cont fquous sampling for partfeulates, with analysis for total alpha, total beta, ${ }^{24}$ Am.

15.1.1.2 stack 296-A-1. Stack 296-A-1 will require cont /nuoys sampljigg for particulates, with analysis for total alpha, total beta, $24 \mathrm{Pu}$ and $24 \mathrm{Am}$.

15.1.1.3 Remaining stacks. The remaining stacks at the PUREX Plant will not require continuous sampling. However, it is advisable to maintain the existing air monttoring equipment in good working order.

\subsubsection{Monitoring Requireants for Radloactive Constituents in Liquid Effluent}

All operating 1iquid effluent waste streans will be continuously saupled and periodically analyzed for total alpha and total beta radiation.

\subsection{SAMPLING REQUIRENENTS FOR AIR AND LIQUID EFFLUENTS}

\subsubsection{Sanpling Requirements for Radioactive Constituents in Air Effluents}

Sampling requirements have been given in 15.1.1.

\subsubsection{Sampling Requirenents for Liquid Efftuents}

Composite and grab samples will be analyzed for radioactive, organic, and nonradioactive inorganic constituents. Composite samples will be collected and analyzed monthly. The sampling and analytical program is detailed in Section 7.2. 


\subsection{SYSTENS UPGRADES FOR AIR MONITORING AND LIQUID SAMPIHG}

\subsubsection{Systems Upgrades for Air Monitoring/Sampling}

15.3.1.1 Stack 291-A-1. The existing equipment at Stack 291-A-1 will not require a system 'upgrade to meet the sampling needs. Etther one of the existing isokinetic sampling systens installed at the $18 \mathrm{~m}$ and $22.5 \mathrm{~m}$ (60 ft or $74 \mathrm{ft}$ ) elevations appear to be adequate for ensuring a representative sample is collected.

15.3.1.2 Stack 296-A-3. The sampling system at Stack 296-A-1 will not require an upgrade to meet the sampling needs. The existing near-isokinetic syster appears to be adequate for collecting a representative sanple for $2 \%, 24 \mathrm{Pu}$ and $24 \mathrm{Am}$ analyses.

15.3.1.3 Remaining Stacks. No system upgrades are required for the remaining stacks at the PUREX Plant.

\subsubsection{Systems Upgrades for Liquild Sampling}

No system upgrades are required at this time. PUREX liquid effluent discharges to the SALDS will be based upon the criteria set forth in the state Waste Discharge Permit; acceptance criteria for the SALDS are currently under negotiations. A new CSL sampling and ana7ys is plan (SAP) will be written to reflect any changes or modifications to the existing sampling progran based upon the final permit discharge criteria. 
WHC-EP-0468-3

\subsection{ATTACHMENS}

\subsection{REFFR日ICES}

ANSI, 1969, Guide to Sanpling Airborme Radjoactive Naterials in a Nuclear Facilfty, ALSI N13.1. American National Standards Institute, Washington, D.C.

ANSI, 1974, Speciffeation and Perforwances of On-Site Instruwentation for Continuousiy Nonitoring Radioactivity in Effluents, American Nationa] Standards Instjtute, Washington, D.C.

CTean Afr Act, as amended, Pub7ic Law 95-95, 91 Stat. 685, 45 USC 7401.

CTean Air Act, as amended, Public Law 95-217, 92 Stat. 1566, 33 USC 1251.

Comprehensive Emvironmental Response, Compensation, and LJability Act of 1980, as amended, Public Law 96-510, 94 Stat. 2767, 42 USC 9601 et seg.

DOE, I983a, Enviromental Protection, Safety, and Health Protection Inforwation Reporting Requirewents, DOE Order 5484.1, U.S. Department of Energy, Hashington, D.C.

DOE, 1983b, Quality Assurance, DOE Order 5700.1A, U.S. Department of Energy, Washington D.C.

DOE, 1988, Radioactive Haste Hanagement, DOE Order 5820.2A, U.S. Departwent of Energy, Washington D.C.

DOE, 1989, Environmental Protection, Safety, and Health Protection Standands, DoE Order 5480.4, U.S. Department of Energy, Washington D.C.

DOE, 1990a, Radiation Protection of the Public and the Enviroment, DOE Order 5400.5, U.S. Departwent of Energy, Washington D.C.

DOE, 1991a, General Enviromaental Protection Program, DOE Order 5400.1, i. S. Departetent of Energy, Washington, D.C.

DOE, 1991b, Environmental ReguTatory Guide for Radiological Effiuent Honttoring and Environsental Surveillance, DOE/EH-DI73T, U.S. Department of Energy, Washington D.C.

DOE, 1991d, Quality Assurance, DOE Order 5700.6C, U.S. Department of Energy, Washington D.C.

DOE, 1993, Occurrence Reporting and Processing of Operations Information, DOE Order $\$ 000.38,0 . \$$. Department of Energy, Washington D.C.

DOE-RL, 1990, 216-8-3 Pond System Closure/Post C7osure P7an, DOE/RL-89-28, U.S. Department of Energy, Richland Field office, Richland, Washington. 
DOE-RL, 1991, Calendar Year 1990 Air Esissions Report for the Hanford Site, DOE/RL-91-10, U.S. Department of Energy, Richland Field Office, Richland, Washington.

OOE-RL, 1993, Calendar Year 1993 Air Enissions Report for the Hanford Site, DOE/RL-93-36, U.S. Department of Energy, Rtchland Field office, Richland, Washington.

Ecology, EPA, and DOE, 1989, Hanford Federal Facflity Agreement and Consent Order, as amended, Washington State Department of Ecology,

U.S. Environmental Protection Agency, U.S. Department of Energy, Olympia, Washington.

EPA, 1983, The National Pollutant Discharge El juination System, Title 40, Code of Federal Regulations, Part 122, U.5. Environmental Protection Agency, Washington, D.C.

EPA, 1985, Disposal of Spent Nuclear FueT, High-Level and Transuranic Aadjoactive Waste, Title 40, Code of Federal Regulations, Part 191, U.S. Environmenta1 Protection Agency, Washington, D.C.

EPA, 1986, Test Hethods for Evaluating Solid Naste, SH-846, 3rd Ed., U.S. Environmental Protection Agency, Washington, D.C.

EPA, 1987, Superfund Asendisents and Reauthorizations Act of I986 (SARA); Emergency PIanning and Notification, Title 40, Code of Federal Regulations, Part 355, U.S. Environnental Protection Agency, Washington, D.C.

EPA, 1988a, Standards Applicable to Generators or Hazardous Waste, Title 40, Code of Federal Regulations, Part 262, U.S. Environmental Protect ton Agency, Washington, D.C.

EPA, 1988b, Standards for Owners and Operators of Hazardous Waste Treatment, Storage, and Disposal Facilities, Tttle 40, Code of Federal Regulations, Part 264, as amended, U.S. Environmental Protection Agency, Washington, B.C.

EPA, 1988c, Interfw Status Standards for Owhers and Operators of Hazardous Waste Treatment, Storage, and Disposal Facilities, Title 40, Code of Federal Regulations, Part 265, as amended, U.S. Environmental Protection Agency, Washington, D.C.

EPA, 1989a, Identification and Listing of Hazardous Waste, Title 40, Code of Federal Regulations, Part 261.3, U.S. Environmental Protection Agency, Washington, D.C.

EPA, 1990a, Quality Assurance Hethods, Title 40, Code of Federal Regulations, Part 60, U.S. Enviromental Protection Agency, Washington, D.C.

EPA, 1990b, Effluent Gufdelines Standards, Title 40, Code of Federa] Regulations, Part 403-471, U.S. Environmental Protection Agency, Washingtor, D.C. 
EPA, 1991a, National Emission Standards for Hazardous Air Pollutants Requirements, Title 40, Code of Federal Regulations, Part 61, U.S. Environmental Protection Agency, Mashington, D.C.

EPA, 1991b, Designation, Reportable Quantities, and Notification, Title 40, Code of Federal Regulations, Part 302, U.S. Environmental Protection Agency, Washington, D.C.

EPA, 1991c, Approva? and Promulgation of Implementation Plans, Title 40, Code of Federal Regulations, Part 52, U.S. Environmental Protect ton Agency, Nashington, O.C.

EPA, 1991d, National Interim Prinary Drinking Nater Regulations, Title 40, Code of Federal Regulations, Part 141, U.S. Environmental Protection Agency, Washington, D.C.

EPA, 1991e, Subchapter N--Effluent Guidelines and Standards, Title 40, Code of Federal Regulations, 401-471, U.S. Environmenta] Protection Agency, Washington, D.C.

EPA, 1991f, Designation, Reportable Quantities, and Notffication, Title 40, Code of Federal Regulations, Part 261, U.S. Environmental Protection Agency, Hashington, D.C.

M1shko, G. J., 1990, 200 Area Treated Effluent Disposal Facillty (TEDF) Effiuent Acceptance Crfterla (Projects $\mathrm{W}$-049H and C-018H), Internal Mewo 86132-90-0Lf-007, Mestinghouse Hanford Company, Richiland, Mashington.

Napjer, B. A., R. A. Peloquín, O. L. Strenge, and J. V. Randse11, 1988, GEMII - The Hanford Environmental Radfation Dosinetry Sof tware Syster, PNL 6584, Vol. 1-3, Pacific Northwest Laboratory, Richland, Nashington.

PNL and MHC, 1989, Nemorandum of Understanding, Pacific Morthwest Laboratory and Westinghouse Hanford Company, Richland, Washington.

Resource Conservation and Recovery Act of 1976, as amended, Public Law 94-580, 90 Stat. 2795, 42 USC 6901 et seq.

Safe Drinking Water Act, as amended, 42 USO $300 \mathrm{f}$ et seq.

WAC, 1976, General Regulations for Air Pollution Sources, Washington Administrative Code 173-400, Washington State Department of Ecology, Olympla, Washington.

WAC, 1986, Ambient Air Qualfty Standards and Enisston Liofts for Radionuclides, WAC-173-480, Washington Administrative Code, Olympia, Mashington.

MAC 1987a, Water Quality Standards for Ground Water of the State of Washington, WAC-173-200, Washington Administrative Code, 0]ympia, Washington. 
WAC, 1988, National Pollutants Discharge Elipination Systen Permit, Washington Administrative Code 173-220, Washington State Department of Ecology, 01 ympla, Washington.

WAC, 1990, Submission of PIans and Reports for Construction of Wastewater Facilities, Washington Administrative Code 173-240, Washington State Department of Ecology, Olympia, Washington.

WAC, 1991a, Dangerous Waste Regulations, Code 173-303, Washington State Department of Ecology, Olympia, Washington.

WAC, 19g1b, Radiation Protection Air Emissions, Hashington Adainistrative Code Chapters 246-247, as anended, Washington State Department of Health, Dlyopia, Washington.

IAC, 1991c, Ambient Radionuc7ide, Mashington Adninistrattve Code 173-480, Washington State Department of Ecology, 01ympia, Washington.

WAC, 1991d, State Waste Discharge Peroit, Washington Aministrative Code 173-216, Washington State Department of Ecology, 01ympia, Washington.

WAC, 199le, Dangerous Waste Regulations, Washington Adwinistrative Code 173-303, Washington State Department of Ecology, Olympia, Washington.

WAC, 1991f, General Regulations of Air Pollution, Washington Administrative Code 173-400, Washington State Department of Ecology, Olympla, Washington.

WHC, 1988a, Eff7uent Nonitoring Plan PUREX Gaseous Effluents, as anended, SD-CP-EMP-004, Westinghouse Hanford Company, Richland, Washington.

WHC, 1988b, Analytical Lab Hood Exhaust Nonftor Flow Ojagran, as amended, H-2-92440, Westinghouse Hanford Company, Richland, Washington.

WHC, 1988c, DWG List/Engineering Flow Diagran PR Roow Stack Nonitor, as amended, H-2-75568, Westinghouse Hanford Company, Richland, Washington.

WHC, 1988d, Westinghouse Hanford Cowpany Environoental Survell Iance Annua? Report 200/600 Areas Calendar Year I987, as amended, WHC-EP-0145, R. E. Elder, G. W. Egert, A. R. Johnson, Westinghouse Hanford Company, Richl and, Washtngton.

WHC, 1989a, Analytical Cheofstry Services Laboratories Quality Assurance Plan, SD-CP-QAPP-001, G. B. Svancara and S. S. Moss, West inghouso Hanford Company, Richtand, Washington.

WHC, 1989b, Quality Assurance Project Plan for the Chenical Analysis of Highly Radioactive Mixed Waste Samples in Support of Environaental Activities on the Hanford Site, WHC-SD-QAPP-002, Westinghouse Hanford Company, Rich1 and, Washington.

WHC, 1989c, PUREX Sample Schedule, FSS-P-080-00002, West inghouse Hanford Company, Richland, Washington. 
WHC, 1989d, Identifying and Resolving Unreviewed Safety Question, WHC-CH-1-3, Hestinghouse Hanford Company, Richland, Washington.

WHC, 1989e, Emergency Plan, WHC-CH-4-1, Nestinghouse Hanford Company, Richland, Washington.

WHC, 1990a, Streat-Specific Reports, MHC-EP-0342, Addendum 2,.5, 12, 14, and 20, Westinghouse Hanford Company, Richland, Washington.

WHC, 1990b, DWG List/Engineering Flow Diagram, SCS Honitoring \& Diversion, as amended, H-2-75589, Westinghouse Hanford Company, Richland, Washington.

MHC, 1990c, East-West Sample Gallery Hood Exhaust Honitor Flow Diagram, as amended, H-2-92511, Nestinghouse Hanford Company, Richland, Washington.

WHC, 1990d, EGE/EGN Honitor Flow Diagram, as amended, H-2-93293, Westinghouse Hanford Company, Richland, Mashington.

WHC, 1990e, CWL IEFD Aqueous Of scharge Cooling Water Systew, as amended, H-2-74309, Mestinghouse Hanford Company, Richland, Washington.

WHC, 1990f, IEFD SCD Stean Condensate Sample Systeat, as awended, H-2-94372, Westinghouse Hanford Company, Richland, Mashington.

UHC, 1990g, PUREX Liquid Effluent Nonitoring Plan, as amended, WHC-SD-CP-EAP-006, Nestinghouse Hanford Company, Richland, Washington.

MHC, 1991a, Quality Assurance Prograd PJan for the Chestical Analysis of Environisental Samples, as amended, WHC-SD-CP-QAPP-003, Mestinghouse Hanford Company, Rich] and, Washington.

VHC, 1991b, Radiological Design, as amended, WHC-CH-4-9, Rev. 3, Nestinghouse Hanford Coupany, Richland, Washington.

HHC, 1991c, Airflow Capacity and Distribution Tests, as anended, Maintenance Engineering Services Haintenance Procedure 7-GN-56, Rev 3, Westinghouse Hanford Company, Richl and, Washington.

WHC, 1991d, Managewent Plan for Facility Effluent Monitoring Plan Activities, as amended, WHC-EP-0491, Nestinghouse Hanford Company, Richland, Washington.

WHC, 1992a, Quality Assurance Project PI an for Radioactive Airborne Elissions Data Compilation and Reporting, as amended, WHC-EP-0528, Westinghouse Hanford Company, Richland, Mashington.

MhC, 1992b, Liquid Effluent Sampling Quality Assurance Projoct Plan, as amended, WHC-SD-BM-QAPP-011, Mestinghouse Hanford Company, Richl and, Washington.

WHC, 1992c, Quality Assurance Project PJan for Facility Effluent Monitoring P1 an Activities, as amended, WHC-EP-0446, Rev. 1, West1nghouse Hanford Company, Richtand, Washington. 
WHC, 1992d, Operational Environmental Monftoring, as amended, WHC-CH-7-4, Westinghouse Hanford Company, Rjchland, Washington.

WHC, 1992e, PUREX CSL Sampling and Analysis Plan, as amended, WHC-SD-CP-PLH-013, Westinghouse Hanford Company, Richland, Washington.

WHC, 1992f, Environmental Releases for Calendar Year 1991, as-awended, WHC-EP-0527-1, Westinghouse Hanford Company, Richland, Washington.

UHC, 1992g, Laboratory Procedures, as amended, Westinghouse Hanford Company, Richiand, Washington.

- LA-220-103, Strontium-89, 90 and/or Stront fum-89 and 90 from Leachates of Soll, Vegetation, Air filters, and other Solid Samples

- LA-508-051, Alpha Energy Analysis using the Canberra Jupiter Systems

- LA-508-052, Gama Energy Analysis on the Canberra Juptter Systeit

- LA-508-110, Operation of the TenneTec LB-5500 Alpha/Beta Counting Systen

- LA-508-111, Operation of the TenneTec LB-1000 Alpha/Beta Detectors (9. 10, 11, and 12)

- LA-508-114, Operation of the gava products alpha beta counting system using $P C$ contro?

- LA-508-121, Operation of the Beckwan Lfquid Seint1]lation Counters

- LA-542-101, Electrodeposition of Actinfdes

- 1A-548-111, Preparation of Nounts for Lfquid Scintillation Counting

- LA-549-112, Dissolution of Versapor Type Fflers

- LA-613-111, Detersination of Pronethius-147 in Effluent Wastes Samples by Solvent Extraction and Liquid Scintillation Counting

- LA-925-107, Uraniug by Laser Induced Kinetfc Phosphorescence Analyzer

- LA-943-123, Separation of Pu and AN by Ion Exchange

- L0-150-115, Instrugent Standards Counting Frequency--222-S Counting ROOB

- 1Q-508-002, CaIibration Guidelines for Window Type Gas Flaw Alpha/Beta Proportional Counters

- LQ-508-003, CaIfbration of the Juptter Gansa Energy Analysis Systems

- LQ-508-005, Calibration of Beta Detector for $5 r-90$ and $\gamma-90$ 
- PM 2518006, Inspect and Test the A7pha Energy Analyzer System at 222-S Roow BIA (Jupiter Subsysten)

- LiC-SJ-CP-LB-003, Safety in the Analytical Laboratory

WHC, 1993a, Environgental Conplfance Hanual, WHC-CH-7-5, Rev 50, Westinghouse Hanford Company, Richland, Washington.

HiC, 1993b, PUREX/UO, Plant Administration, as amended, WHC-CH-5-9, Hestinghouse Hanforord Corpany, Richland, Washington.

WHC, 1993c, Analytical Chenistry Services Laboratories Operating Instructions, WHC-CW-5-4, Westinghouse Hanford Corpany, Richland, Mashington.

WHC, 1993d, Environuenta) Releases for Calendar Yoar 1992, WHC-EP-0527-2, Westinghouse Hanford Company, Richland, Washington.

WHC, 1993e, Quality Assurance Mamual, WHC-CH-4-2, Westinghouse Hanford Company, Richland, Hashington.

WHC, 1993f, Quality Assurance Plan for Radionuclide Airborne Eafssfons Honitoring, WHC-EP-0536, Rev, 1, Westinghouse Hanford Company, Richland, Washington.

Hic, 1993g, Environgental Investigations and Stte Characterization Nanual, as amended, WHC-CH-7-7, Westinghouse Hanford Company, Richland, Washington.

WHC, 1993h, Health Physics Procedures, KHC-IP-0718, Hestinghouse Hanford Company, Richland, Washington. 
WHC-EP-0468-3

REFERENCES to TABLE 14-2

ANSI, 1969, Guide to Sampling Airborne Radfoactive Naterials in a Nuclear Facility, AKSI N13.1, American National Standards Institute, Washington, D.C.

DOE, 1990, Radiation Protection of the Public and the Environment, DOE Order 5400.5, U.S. Department of Energy, Washington D.C.

EPA, 1991, Natfonal Emission Standards for Hazandous Air Pollutants Requirements, Title 40, Code of Federal Regulations, Part 61, U.S. Environmenta] Protectíon Agency, Washington, D.C.

EPA, 1992, "Standards of Performance for New Stationary Sources," Title 40 , Code of Federal Regulations, Part 60, U.S. Environmental Protection Agency, Nashington, D.C.

Napjer, B. A., R. A. Peloquin, D. L. Strenge, and J. V. Randse11, 1988, GENII- The Hanford Environmental Radiation Dosimetry Sof tware Systen, PNL. 6584, Vol. 1-3, Pacific Northrest Laboratory, Richland, Nashington.

RL, 1993, Calendar Year 1992 Radionuclide Air Emissions Report for the Hanford Site, D0E/RL-93-36, U.S. Department of Energy, Richland Field Office, Richi and, Washington.

WHC, 1990, Westinghouse Hanford Company Eff7uent Discharges and Solid Waste Nanagement Report for Calendar Year 1989: 200/600 Areas, WHC-EP-0141-2, Westinghouse Hanford Company, Richland, Washington.

WHC, 1991, Drawings, Westinghouse Hanford Company, Rich] and, Washington.

- H-2-75568, DWG List/Engineering Flow Diagram PR Roos Stack MON

- H-2-75570, ELEC/INSTH Plan Elevations \& OET PR Stack Monitoring

- H-2-75571, ELEC/INSTH Installation Details PR Room Stack Honitor

WHC, 1992a, Laboratory Procedures, Westinghouse Hanford Company, Richland, Washington.

- LA-218-112, Tritiulu analysis on Sillea gel by Liquid Scintillation Counting

- LA-220-103, Strontium-89, 90 and/or Strontium-89 and 90 from Leachates of Soil, Vegetation, Air Filters, and other Solid Samples

- LA-34B-101, Carbon-14 by Distilling and Liguid Seintillation Counting

- LA-50B-110, Operation of the Tennelec LB-5500 Alpha/Beta Counting Systers

- LA-508-111, Operation of the Tennelec LB-1000 Alpha/Beta Detectors $(9,10,11$, and 12$)$

- LA-508-114, Operation of the gama products atpha beta counting system using $P C$ control

- LA-508-121, Operation of the Beckman Liquid Scintillation Counters

- LA-548-111, Preparation of Mounts for Liquid Scintillation Counting

- UA-549-112, Dissolution of Versapor Type FIlers 
- LA-613-111, Determination of Promethium-147 in Effluent Wastes Samples by Solvent Extraction and Liquid Scintillation Counting

- LA-925-107, Urani ur by Laser Induced Kinetic Phosphorescence Analyzer

- LA-943-123, Separation of Pu and Aa by Ion Exchange,

- L0-150-115, Instrument Standards Counting Frequency--222-s counting Room

- LO-150-133, Processing Record Stack and Red Bordered Ekergency Air Samples

- LQ-508-002, Calibration Guidelines for Kindow Type Gas Flow Alpha/Beta Proportional Counters

- LQ-508-005, Celibration of Bete Detector for $\$ r-90$ and $\gamma-90$

- WHC-SB-CP-LB-003, Safety in the Analytical Laboratory

MHC, 1992b, Nanuals, Westinghouse Hanford Company, Richland, Washington.

- WHC-CH-1-3, Nanagement Requirements and Procedures

- WHC-CH-4-2, Quality Assurance Hanual

- $\mathrm{HHC}-\mathrm{CH} 4-4-3$, Industrial Safety

- $\mathrm{HHC}-\mathrm{CH} 4-4-10$, Radiation Protection

- WHC-CH-4-12, Health Physics Practices Manual

- WHC-CH-4-15, Radiation Work Requirements and Nork Permits Manual

- HHC-CM-4-29, Nuclear Criticality Safety

- $\quad$ HAC-CH-5-4, Anafytical Chemistry Services Laboratories - Operating Instructions

- WHC-CM-5-9, PUREX $/ \mathrm{WO}_{3}$ Plant Occurrence Categorization, Notification, and Reporting

WHC, 1992c, Westinghouse Hanford Company Emergency Plan for PUREX Facility, WHC-IP-0263-202A, Mestínghouse Hanford Campany, Richland, Washington.

WAC, 1992d, Quality Assurance Project Plan for Radfoactive Airborne Eufssions Data Compilation and Reporting, WHC-EP-0528, Mestinghouse Hanford Company, Richland, Yashington.

WAC, 1993a, Airflow Capacity and Distribution Tests, Facilities Maintenance support Services Maintenance Procedure 7-GH-56, Rev 2 Change A, Westinghouse Hanford Company, Richland, Mashington.

MHC, 1993b, Final Report on Fiscal Year 1992 Activities for the Enviromienta? Honitors Line-Loss $\$ t u d y$, MHC-EP-0680, Nestinghouse Hanford Company, Ríchi and, Vashington.

WAC, 1993c, Qualfty Assurance Progran Plan for Radfonuclide Airborne Enotssions Monitoring, WHC-EP-0536-1, Mestinghouse Hanford Company, Richtand, Washington.

WhC, 1993d, Health Physics Procedures Manual, WHC-IP-0718, Westinghouse Hanford Company, Richland, Nashington.

WAC, 1994a, Plutoniun-Uraniun Extraction PJant Product Respoval (296-A-1) Stack Potentfat Dose Deternfoation, HHC-SO-CP-TI-188, Nestinghouse Hanford Company, Richland, Mashington. 
WHC, 1994b, Determination of Effluent Flow for Large Stacks, Maintenance Engjneering Services Maintenance Procedure, PROC. MO. 1202, Westinghouse Hanford Company, Richiand, Washington.

WHC, 1994c, Laboratory Procedures, Westinghouse Kanford Company, Richiand, Washington.

- LA-508-161, ATpha Energy Ana7ysis using the Canberra Jupiter Systens

- LA-50B-162, Gamma Energy Analysis on the Canberra Jupiter Systen

- LA-542-101, Electrodeposition of Actinides

- L0-508-003, Calibration of the Jupiter Gasias Energy Analysis Systems 


\section{DISTRIBUTION}

Number of Conies

ONSITE

U.S. Department of Energy, Richland Operations Office

J. O. Bauer

A5- 15

3. B. Hall

A5-55

G. M. Bel1

A5-52

E. B. Dagan

R. G. Holt

S. D. Stites

A5-19

A5- 15

Pubilic Reading Room

A5-19

Al-65

6

Pacific Northwest Laboratory

T. O. Chikalla

P7-75

G. R. Hoenes

P7-78

R. E. Jaquish

D. L. Klages

R. K. Hoodruff

K1-30

P7-68

Technical Files

K6-13

$\mathrm{K} 1-\mathrm{I} 1$

29

West. Inqhouse Hanford Company

D. J. Carrell

L. P. Diediker (2)

H6-22

J. J. Barian

B. G. Erlandson

T. P. Frazier (5)

J. L. Geiger

E. H. Greager

K. A. Hadley

D. G. Hamrick

D. L. Johnson

R. E. Johnson

T1-30

H6-30

$\mathrm{H} 6-20$

$\mathrm{TI}-\mathbf{3 0}$

R3-01

A6-30

R3-56

S6-15

S6-19

J. Lohrasbi

T1-30

D. G. Ranade

S6-19

B2-16 
WHC-EP-0468-3

\section{DISTRIBOTION (cont inued)}

Number of Copies

ONSITE

Westinghouse Hanford Company (continued)

L. H. Yance

$\mathrm{H} 4-16$

D. D. Volkman

H4-25

D. L. Wiegand

S6-19

C. D. Wollam (2)

$\$ 6-19$

Central Ftles

Document Processing and

Distribution (2)

L8-04

Information Release Administration

(3)

L8-15

R1-05 